http://dx.doi.org/10.18778/7525-767-0

\title{
Polityka Szwajcarii wobec \\ Unii Europejskiej
}





\section{MICHAŁ TOMCZYK}

\section{Polityka Szwajcarii wobec \\ Unii Europejskiej}

ŁÓDZKIEGO 
Michał Tomczyk - Katedra Badań Niemcoznawczych, Uniwersytet Łódzki 91-131 Łódź, ul. Narutowicza 59a

\title{
RECENZENT
}

Dariusz Popławski

\section{REDAKTOR WYDAWNICTWA UŁ \\ Bogustaw Pielat}

\author{
SKŁAD I ŁAMANIE \\ $A G E N T P R$
}

PROJEKT OKŁADKI

Barbara Grzejszczak

Publikacja sfinansowana przez Ambasadę Szwajcarii w Polsce

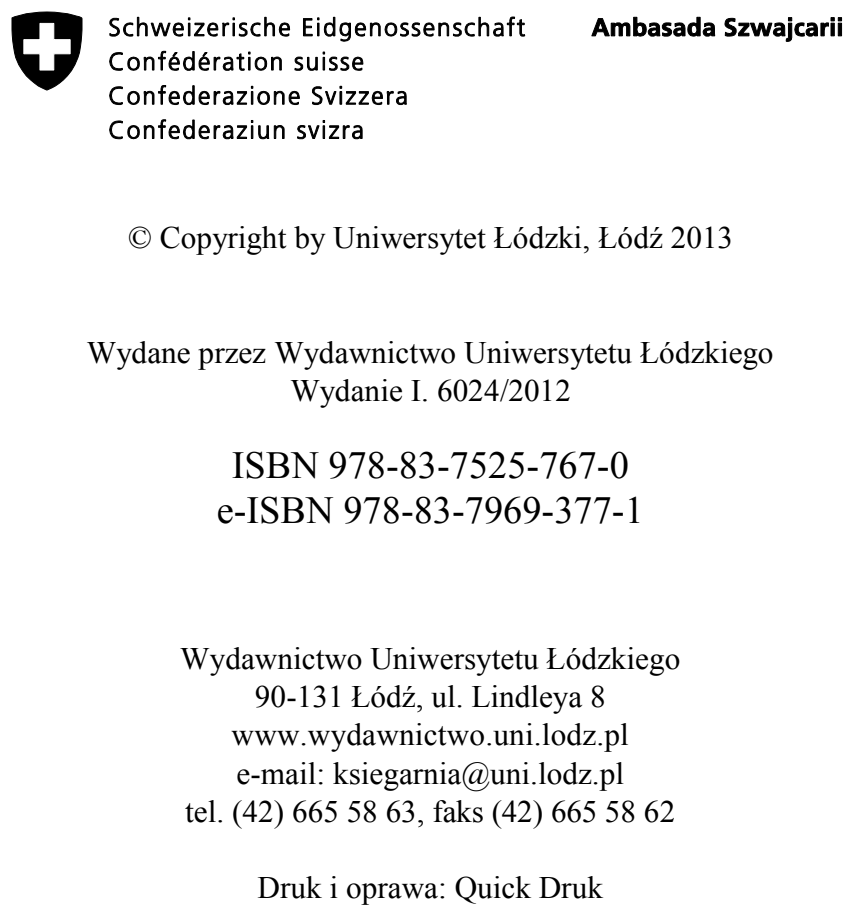




\section{SPIS TREŚCI}

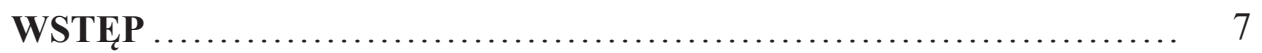

\section{ROZDZIAL I}

\section{UWARUNKOWANIA POLITYKI SZWAJCARII WOBEC UNII} EUROPEJSKIEJ ........................................... 13

1.1. Istota i zakres uwarunkowania polityki Szwajcarii ................ 13

1.2. Doktryna i tradycja polityki Szwajcarii ......................... 16

1.2.1. Neutralność w polityce zagranicznej Szwajcarii ............. 16

1.2.2. Polityka Szwajcarii wobec zjawisk integracyjnych .......... 21

1.3. System polityczny Szwajcarii ................................ 26

1.3.1. Specyfika ośrodków decyzji politycznej i procesu decyzyjnego .............................................. 27

1.3.2. Federalizm .......................................... 30

1.3.2.1. Wpływ kantonów na politykę zagraniczną związku .... 30

1.3.2.2. Relacje między związkiem a kantonami w perspektywie integracji z Unią Europejską. Raport EuRefKa ......... 36

1.3.2.3. Stanowisko kantonów wobec integracjiz Unią Europejską ........................................... 43

1.3.2.4. Stanowisko rządu wobec raportu EuRefKa ............ 45

1.3.3. Demokracja bezpośrednia ............................... 47

1.3.3.1. Demokracja bezpośrednia jako bariera integracyjna .... 47

1.3.3.2. Referendum obligatoryjne i fakultatywne w perspektywie integracji europejskiej ........................... 48

1.3.3.3. Proces decyzyjny .............................. 54

1.3.3.4. Demokracja bezpośrednia jako element przewagi w negocjacjach z Unią Europejską ....................... 55

1.4. Jakość i aktywność służb dyplomatycznych ...................... 58

1.5. Rola mediów w polityce zagranicznej Szwajcarii .................. 64

\section{ROZDZIAŁ II}

KONCEPCJA POLITYKI ZAGRANICZNEJ SZWAJCARII WOBEC UNII EUROPEJSKIEJ ........................................ 71

2.1. Krystalizacja głównych koncepcji politycznych ................ 71

2.1.1. Specyfika ośrodków decyzji politycznych ................ 77 
2.1.2. Koncepcje polityczne i decyzje społeczne ................ 78

2.2. Koncepcje ośrodków decyzji politycznych .................... 84

2.2.1. Unia Europjska w koncepcji ośrodków decyzyjnych na początku lat 90. XX w. .................................. 85

2.2.2. Członkostwo w Unii Europejskiej jako cel strategiczny ....... 90

2.2.3. Bilateralizm jako najbardziej optymalna forma współpracy z Unią Europejską ................................... 97

2.3. Koncepcje ośrodków opiniotwórczych ........................ 109

2.3.1. Organizacje pozarządowe wobec problemów europejskich ... 113

2.3.2. Stanowisko środowisk gospodarczych ................... 120

ROZDZIAL III

REALIZACJA POLITYKI SZWAJCARII WOBEC UNII EUROPEJSKIEJ .......................................................... 128

3.1. Ewolucja polityki Szwajcarii w stosunku do Unii Europejskiej ...... 128

3.1.1. Szwajcaria w obliczu zjawisk integracyjnych w Europie ....... 128

3.1.2. Nowa polityka wobec Unii Europejskiej ................... 133

3.2. Podstawy normatywne ................................... 153

3.2.1. Charakter umów .................................... 153

3.2.2. Uwarunkowania prawne ............................. 155

3.2.3. Uwarunkowania instytucjonalne ........................ 157

3.2.4. Praktyka i ocena podstaw normatywnych ................. 162

3.3. Umowy bilateralne ...................................... 165

ROZDZIAL IV

OCENA I PERSPEKTYWY POLITYKI SZWAJCARII WOBEC UNII EUROPEJSKIEJ .............................................. 207

4.1. Ocena polityki Szwajcarii wobec Unii Europejskiej ................ 207

4.1.1. Ekonomiczny wymiar polityki wobec Unii Europejskiej ...... 209

4.1.2. Polityczny wymiar współpracy ......................... 221

4.2. Perspektywy polityki Szwajcarii wobec Unii Europejskiej .......... 227

4.2.1. Kontynuacja polityki bilateralnej ......................... 229

4.2.2. Przystąpienie do Unii Europejskiej ........................ 237

4.2.2.1. Wymiar polityczny ............................. 237

4.2.2.2. Wymiar ekonomiczny ........................... 242

4.2.3. Alternatywne formy integracji ........................ 244

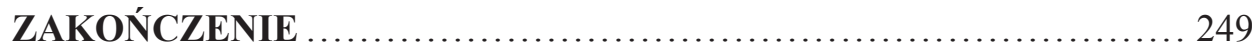

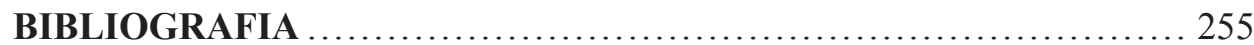

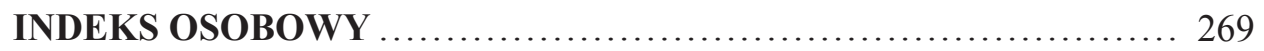




\section{WSTĘP}

Problematyka polityki Szwajcarii wobec Unii Europejskiej stanowi istotny element badań zjawiska postępującej integracji europejskiej. Szwajcaria, choć formalnie nie jest członkiem Unii Europejskiej, pozostaje w ścisłych z nią zależnościach. Zainicjowana na początku lat 90. ubiegłego wieku współpraca, głównie na płaszczyźnie gospodarczej, doprowadziła do wykształcenia szeregu bliskich powiązań, które sprawiły, iż Szwajcaria jest pod wieloma względami krajem bardziej zintegrowanym z Unią Europejską niż niejedno państwo członkowskie. W świetle uwarunkowań historycznych, ustrojowych i gospodarczych współpraca ta odznacza się szeregiem problemów, rzutujących na przyszłość rozwoju wzajemnych relacji. Obecnie Szwajcaria stoi przed dylematem określenia formy, a przede wszystkim granic, dalszej integracji. Decyzja ta uwzględniać musi szereg istotnych czynników zarówno wewnętrznych, jak i zewnętrznych, warunkujących relacje z Unią Europejską.

Głównym celem powstania niniejszej monografii jest więc analiza, w ujęciu problemowo-chronologicznym, polityki Szwajcarii wobec Unii Europejskiej wraz z jej najważniejszymi wyznacznikami i tendencjami ewolucyjnymi. Analizę przeprowadzono przy szczególnym uwzględnieniu czynników wewnętrznych, głównie politycznych i społecznych, które zaważyły na obecnym poziomie relacji pomiędzy Szwajcarią a UE. Największy nacisk położony został zatem na specyfikę ustroju politycznego, w tym federalizm, demokrację bezpośrednią oraz charakterystyczną dla Szwajcarii doktrynę polityki zagranicznej, opartą na neutralności wieczystej. Ponadto istotnym elementem jest analiza koncepcji głównych ośrodków opiniotwórczych zarówno rządowych, jak i pozarządowych. Całości dopełnia próba oceny dotychczasowej polityki wobec UE oraz prognozowania jej dalszego rozwoju. Za cezurę czasową przyjmuje się okres od początku lat 90. XX w., tj. od momentu rozpoczęcia intensywnych relacji Szwajcarii z EWG - UE.

Pierwszy rozdział poświęcony jest analizie uwarunkowań polityki Szwajcarii wobec Unii Europejskiej. Dokonano w nim próby wyodrębnienia tych czynników, które wpływają w decydującym stopniu na kształt wzajemnych relacji. W sposób szczególny uwzględnione zostały tutaj aspekty związane ze specyfiką ustrojową Szwajcarii, w tym przede wszystkim elementy składowe demokracji bezpośredniej i jej wpływ na proces decyzyjny. Ten ostatni poddany został analizie pod kątem oddziaływania i kompatybilności z procesami integracyjnymi. Dlatego niezwykle istotna jest próba oceny funkcjonowania ośrodków decyzyjnych, biorących udział w kreowaniu polityki zagranicznej na poziomie federalnym, a tak- 
że kantonalnym. Zgodnie z postanowieniami konstytucji Rada Związkowa (rząd szwajcarski), odgrywa główną rolę w kształtowaniu określonej strategii państwa w relacjach zewnętrznych. Stopniowo uwidacznia się jednak problem współpracy na tym polu z kantonami, tym bardziej że nowelizacja konstytucji z roku 1999 nadała im prawo do współkształtowania (Mitwirkung) tej polityki. Niestety aspiracje kantonów związane z ochroną własnych interesów politycznych nie idą w parze z faktycznymi możliwościami oddziaływania na władze związkowe. Rząd ma obowiązek zapoznania się ze stanowiskiem rządów kantonalnych. Ich opinie nie są jednak dla niego wiążące. Ponadto bieżąca realizacja polityki zagranicznej wobec UE sprowadza rolę kantonów do instytucji opiniujących wypracowane już porozumienia, nie dając im możliwości pełnego uczestniczenia w procesie jeszcze na etapie koncepcyjnym.

Bardzo istotnym elementem tej części monografii jest także próba odpowiedzi na pytanie, w jakim stopniu podstawowe elementy demokracji bezpośredniej, jak referendum oraz inicjatywa ludowa, wpływają na politykę zagraniczną Szwajcarii. Dotychczasowe analizy wskazują, iż demokracja bezpośrednia stanowi dość istotną przeszkodę w budowie obecnych i przyszłych relacji ze Wspólnotą. W konsekwencji może to doprowadzić do konieczności ograniczenia jej do poziomu pozwalającego na spójną realizację procesów integracyjnych i eliminację wszelkich barier, które mogą uwidocznić się po przystąpieniu Szwajcarii do struktur Unii Europejskiej. W przypadku przystąpienia do UE, system polityczny Szwajcarii może doprowadzić do uniemożliwienia transponowania unijnego prawa do szwajcarskiego porządku prawnego. W tej sytuacji rząd będzie zmuszony do przeprowadzenia reformy procesu decyzyjnego, w tym również ograniczenia oddziaływania demokracji bezpośredniej. Pogłębienie integracji może zatem w poważnym stopniu zaważyć na jej przyszłości. Wolno więc wysnuć wniosek, iż szwajcarski system polityczny, w tym demokracja bezpośrednia, okazują się nieefektywne i anachroniczne, przede wszystkim jednak nieadekwatne do problemów i wyzwań, jakie stoją przed Szwajcarią u progu wieku XXI.

Drugi rozdział książki poświęcony jest analizie koncepcji głównych ośrodków opiniotwórczych zarówno rządowych, jak i pozarządowych, zwłaszcza pod kątem ich oddziaływania na realizację polityki rządu wobec Unii Europejskiej. Fundamentalna koncepcja, dotycząca rozwoju relacji ze Wspólnotą zarówno ośrodków rządowych, jak i pozarządowych, pozostaje spójna w odniesieniu do podstawowego celu, jakim jest nawiązanie ściślejszej współpracy gospodarczej. Pozostałe kwestie, związane przede wszystkim z kształtem owej współpracy oraz stopniem integracji, niezmiennie dzielą opinię publiczną na dwa obozy - zwolenników i przeciwników włączenia Szwajcarii do struktur UE. Jest bowiem istotne, że aktualna strategia polityczna w postaci współpracy bilateralnej od dawna nie budzi większych kontrowersji. Świadczy o tym chociażby dość szerokie poparcie społeczne, uzyskane jeszcze na samym początku tej drogi, a więc w trakcie głosowania referendalnego, przeprowadzonego w maju $2000 \mathrm{r}$. 
Rozdział ten jest więc próbą prześledzenia ewolucji koncepcji polityki europejskiej rządu, która bez wątpienia na przestrzeni lat ulegała licznym modyfikacjom. Całość została zwieńczona wstępną ich oceną, głównie pod kątem prawdopodobieństwa ich realizacji. Ważne jest bowiem, na ile polityka rządu stanowi faktycznie urzeczywistnienie danej koncepcji politycznej, na ile zaś pozostaje wynikiem społecznego kompromisu, wymagającego nierzadko znacznych odstępstw od przyjętej na samym początku strategii politycznej.

Trzeci rozdział poświęcony został omówieniu realizacji polityki zagranicznej Szwajcarii wobec Unii Europejskiej. Analizie poddano genezę i ewolucję wzajemnych relacji, sięgając do początków współpracy, tj. układu o wolnym handlu, zawartym w roku 1972 z EWG. Data ta traktowana jest jako początek powolnego procesu integracyjnego, którego kontynuacją są obowiązujące obecnie umowy bilateralne. Rozpatrzone zostały również podstawy normatywne, tj. ramy instytucjonalne oraz prawne, w tym przede wszystkim dwa najważniejsze filary, czyli pakiety umów Bilaterale I oraz Bilaterale II, podpisane kolejno w 1999 oraz w 2004 r. Ze względu na ich wagę i złożoną problematykę nie sposób uniknąć szczegółowej analizy poszczególnych płaszczyzn, a więc obszarów tematycznych, które podlegają dwustronnym regulacjom. Należy zaznaczyć, iż konstrukcja prawna pierwszego pakietu przewiduje tzw. zasadę gilotyny, czyli regułę, wedle której wypowiedzenie nawet jednej umowy (z zawartych wówczas siedmiu) skutkuje anulowaniem wszystkich pozostałych. Wypada zatem odpowiedzieć na pytanie, w jakim stopniu tego typu uwarunkowania wpływają na stopień determinacji w zakresie wdrażania poszczególnych umów. Szczególną rolę w tym kontekście odgrywa porozumienie w sprawie swobodnego przepływu osób, ułatwiające podejmowanie pracy na terenie Szwajcarii przez obcokrajowców. Umowa ta wywołuje najwięcej emocji wśród opinii publicznej, stanowiąc zarazem poręczny oręż w walce politycznej pomiędzy zwolennikami a przeciwnikami integracji. Niniejszy rozdział służy również odpowiedzi na pytanie, w jakim stopniu koncepcja nakreślona w oficjalnych dokumentach strategicznych władz związkowych znajduje swoje odzwierciedlenie w praktyce.

Ostatni rozdział poświęcono próbie oceny dotychczasowej polityki Szwajcarii wobec Unii Europejskiej oraz nakreśleniu perspektyw dalszej współpracy. Wzięto tutaj pod uwagę przede wszystkie trzy scenariusze: włączenie Szwajcarii do UE, pozostanie poza strukturami Unii Europejskiej, jednakże przy założeniu kontynuacji współpracy na poziomie bilateralnym lub powrót do izolacjonizmu. Ten ostatni wariant wydaje się najmniej realny. Z kolei możliwość kontynuacji bilateralizmu rodzi pytanie dotyczące formy i stopnia integracji. Czy możemy mówić tutaj o prawdopodobieństwie podpisania kolejnych umów czy też w grę wchodzą inne formy współpracy, jak chociażby układ ramowy lub umowa o stowarzyszeniu? Analiza powyższych scenariuszy umożliwi odpowiedź na pytanie dotyczące skutków określonej polityki wobec UE dla systemu politycznego.

Sporo miejsca poświęcono również ocenie dotychczasowej współpracy pomiędzy Szwajcarią a Unią Europejską, przede wszystkim w kontekście pytania, 
czy obecne relacje ze Wspólnotą są efektem z góry przemyślanej strategii, czy też wynikają z konieczności przystosowania się do zachodzących zmian geopolitycznych? Ostatni rozdział jest zatem próbą bilansu dotychczasowej polityki Szwajcarii wobec Unii Europejskiej.

Literatura przedmiotu w aktualnym stanie nie jest wyczerpującym źródłem informacji w zakresie uwarunkowań polityki Szwajcarii w stosunku do UE, dostarczając nam wiedzy przede wszystkim na temat bieżącego stanu rozwoju relacji dwustronnych oraz informacji dotyczących ewolucji współpracy ze Wspólnotą Europejską. Brakuje jednak analizy czynników determinujących kształt polityki zagranicznej Szwajcarii w odniesieniu do Unii Europejskiej. Przedmiotem badań są najczęściej ogólne uwarunkowania, bez uwzględnienia szczególnego charakteru tych czynników, które mają decydujący wpływ na kształt relacji z UE. Uniemożliwia to tym samym wiarygodną ocenę przyjętej przez rząd szwajcarski strategii politycznej, a także jej dalszych perspektyw.

Polityka zagraniczna Szwajcarii, w ujęciu całościowym, była wielokrotnie przedmiotem licznych badań i analiz. Warto wspomnieć tutaj o pracach L. Goetschel, M. Bernath, D. Schwarz, Schweizerische Aussenpolitik. Grundlagen und Möglichkeiten, D. Ruloff, T. Bernauer, S. Bruno, P. Moser, A. Schnur, Globaler Wandel und Schweizerische Aussenpolitik. Informationsbeschaffung und Entscheidungsfindung czy nieco wcześniejszej, autorstwa A. Riklin, H. Haug, R. Probst, Neues Handbuch der Schweizerischen Aussenpolitik. Należy również przywołać książkę prof. Dariusza Popławskiego Szwajcarska polityka bezpieczeństwa, będącą obszerną analizą, opracowaną w ujęciu problemowo-chronologicznym, ewolucji polityki zagranicznej Szwajcarii, ze szczególnym uwzględnieniem kwestii budowy strategii bezpieczeństwa. Także literatura anglojęzyczna dostarcza nam kilku wartych uwagi prac, jako chociażby J.M. Gabriel, Swiss foreign policy, 1945-2002.

Przedmiotem licznych analiz i opracowań był również wpływ integracji europejskiej na system federalny Szwajcarii. Dostępne są liczne opracowania dotyczące ewentualnych następstw włączenia federacji do struktur UE. Należy chociażby wspomnieć o pracy T. Cottier, A.R. Kopse, Der Beitritt der Schweiz zur Europäischen Union, Brennpunkte und Auswirkungen. Szczególną wartością poznawczą cechują się analizy wpływu integracji na federacyjną organizację państwa, przygotowane przez grupę ekspercką EuRefKa (Europa - Reformen der Kantone). Szerszym aspektom ewentualnego włączenia Szwajcarii do Unii Europejskiej poświęcone jest zbiorowe opracowanie, pod redakcją C.H. Church, Switzerland and the European Union oraz wspominana już książka T. Cottier, A.R. Kopse, Der Beitritt der Schweiz zur Europäischen Union...

Trzeba wyraźnie podkreślić, że żadne z powyższych opracowań nie jest poświęcone kompleksowej analizie uwarunkowań, która dałaby odpowiedź na pytanie dotyczące faktycznych przesłanek polityki Szwajcarii wobec Unii Europejskiej. Wiele z nich cechuje dość selektywny dobór faktów, co w dużym 
stopniu upraszcza wizerunek polityki zagranicznej Szwajcarii oraz jej relacji z państwami UE.

Materiały do niniejszej pracy zebrane zostały dzięki kilkukrotnym pobytom w Szwajcarii. Zaowocowały one przeprowadzeniem kwerendy naukowej, obejmującej zbiory Zentralbibliothek Zürich, ETH-Bibliothek, a także biblioteki Europa Institut der Universität Zürich. Autor przeprowadził także kwerendę opracowań i analiz poświęconych problematyce europejskiej, opublikowanych przez Europa Institut der Universität Basel (seria Basler Schriften zur europäischen Integration), kwerendę artykułów dwóch największych dzienników ogólnokrajowych (za lata 2007-2010) - „Neue Zürcher Zeitung” oraz „Tagesanzeiger”. Analiza materiałów źródłowych oparta została na dokumentach, sprawozdaniach, raportach, a także innych materiałach zamieszczonych na stronach Ministerstwa Spraw Zagranicznych (Eidgenössisches Departement für auswärtige Angelegenheiten), Biura Integracyjnego (Integrationsbüro EDA/EVD), Ministerstwa Gospodarki (Eidgenössisches Volkswirtschaftsdepartement EVD), Federalnego Urzędu Statystycznego (Bundesamt für Statistik) oraz w bazie DoDiS (Diplomatische Dokumente der Schweiz). Cennych informacji dostarczają także „Biuletyny Urzędowe” („Amtliches Bulletin"), zawierające protokoły z obrad izb parlamentu związkowego. Drugi rozdział przygotowany został na podstawie dokumentów, publikacji, stanowisk zamieszczonych na stronach internetowych czołowych ośrodków opiniotwórczych oraz organizacji pozarządowych, zajmujących się tematyką integracji (Neue Europäische Bewegung Schweiz, Aktion für eine unabhängige und neutrale Schweiz, Economiesuisse, Avenir Suisse), a także materiałów, głównie oficjalnych stanowisk wobec problematyki europejskiej, zamieszczonych na stronach partii politycznych (SVP, CVP, FDP, SPS, Grüne Partei Schweiz). Autor powołuje się w swojej pracy również na opracowania politologiczne dotyczące polityki europejskiej rządu szwajcarskiego, publikowane m.in. przez Centrum Studiów nad Bezpieczeństwem (Center for Security Studies [CSS]) oraz Netzwerk Schweizerische Aussen- und Sicherheitspolitik (SSN), a także publikacje serii wydawniczej Swiss Political Science Review.

W sposób szczególny pragnę w tym miejscu podziękować mojemu opiekunowi naukowemu, a zarazem promotorowi pracy doktorskiej, na podstawie której przygotowana została niniejsza monografia - prof. dr. hab. Markowi Pietrasiowi za opiekę naukową oraz cenne uwagi i wskazówki dotyczące przygotowania koncepcji, a następnie jej realizacji, a także za pomoc w przygotowaniu publikacji do druku. Wyrażam również wdzięczność prof. dr. hab. Dariuszowi Popławskiemu, recenzentowi pracy, za wszelkie uwagi merytoryczne, dzięki którym monografia nabrała właściwego kształtu oraz prof. dr. hab. Krzysztofowi A. Kuczyńskiemu za wsparcie w rozwoju naukowym i umożliwienie prowadzenia badań przy kierowanej przez Niego jednostce. 



\section{ROZDZIAL I \\ UWARUNKOWANIA POLITYKI SZWAJCARII WOBEC UNII EUROPEJSKIEJ}

Polityka zagraniczna państwa wielokrotnie była już przedmiotem opracowań naukowych i nadal stanowi jeden z najistotniejszych tematów w dyskursie politologicznym, a także publicystycznym. Zarówno polski, jak i światowy dorobek piśmienniczy dostarcza nam wielu ciekawych analiz, które w różny sposób, niekiedy bardzo nowatorski, traktują o relacjach zewnętrznych poszczególnych państw. Polityka zagraniczna jest bowiem tym obszarem badawczym, który cechuje duża dynamika rozwoju. Pojawiają się nowe tendencje i elementy składowe, które jeszcze do niedawna nie istniały lub nie były przedmiotem głębszych rozważań. Rzeczywistość stawia nowe wyzwania i zmusza do redefinicji wcześniejszych ustaleń. Dobrym tego przykładem jest chociażby pojawienie się Unii Europejskiej jako pełnoprawnego uczestnika polityki międzynarodowej. W takim przypadku przyjęte schematy analizy relacji zewnętrznych mogą nie być wystarczające dla ukazania właściwego wymiaru, podstaw i koncepcji, jakie kryją się za określonymi postawami w stosunkach dwustronnych. Niektóre elementy składowe mogą okazać się nieistotne, inne z kolei kluczowe dla właściwego zrozumienia polityki zagranicznej danego państwa. Uwypuklenie tych drugich powinno być zatem wytyczną dla miarodajnej i efektywnej analizy.

\subsection{ISTOTA I ZARES UWARUNKOWANIA POLITYKI SZWAJCARII}

Punktem wyjścia analizy polityki zagranicznej Szwajcarii jest założenie przyjęte przez J. Kukułkę, mówiące o nieustannej interakcji pomiędzy polityką wewnętrzną a zewnętrzną ${ }^{1}$. Nie jest bowiem możliwe prowadzenie polityki zagranicznej w izolacji od interesów innych państw, tak samo jak w oderwaniu od środowiska wewnętrznego. W tym sensie istotne jest zatem określenie elementów składowych obydwu obszarów i właściwa kategoryzacja. Wydaje się, iż najbardziej odpowiednią terminologią jest wykorzystywany w pracach wspomnianego już J. Kukułki oraz R. Zięby termin „uwarunkowania” polityki zagranicznej.

${ }^{1}$ J. Kukułka, R. Zięba, Polityka zagraniczna państwa, Wydawnictwo Uniwersytetu Warszawskiego, Warszawa 1992, s. 24. 
Obejmuje on bowiem zarówno czynniki warunkujące, jak i sprawcze, a więc okoliczności, które sprzyjają podejmowaniu określonych działań bądź je determinują. $\mathrm{W}$ takim rozumieniu termin ten ma więc szerokie znaczenie.

Zaproponowany w pracach wyżej wymienionych badaczy podział uwarunkowań zewnętrznych i wewnętrznych na obiektywne oraz subiektywne wydaje się najbardziej przejrzysty, a więc również ułatwiający poznanie naukowe. Dla osiągnięcia celów niniejszej pracy warto pokusić się jednakże o bardziej autorską analizę, polegającą na wyborze tych uwarunkowań, które mają decydujące znaczenie i które w największym stopniu wyznaczają kierunki polityki zagranicznej Szwajcarii wobec UE. Należy mieć bowiem świadomość, o czym przekonuje R. Kuźniar, że wszystkie czynniki występują w specyficznym powiązaniu, innym dla każdego kraju i sytuacji ${ }^{2}$. Dodatkowo ,podlegają nieustannym zmianom w czasie"3. Jednym z założeń niniejszego opracowania jest więc przekonanie, iż strategia przyjęta przez rząd Szwajcarii w stosunkach z Unią Europejską jest wynikiem unikalnej konfiguracji różnych czynników - zarówno wewnętrznych, jak i zewnętrznych - która niekoniecznie ma zastosowanie wobec innych podmiotów. Nie chodzi tutaj o negację pewnych uwarunkowań, lecz przypisanie im zdecydowanie mniejszego znaczenia. $Z$ tego też powodu analiza wszystkich mogłaby niepotrzebnie zatrzeć właściwy kierunek badawczy, przyjęty w niniejszej pracy.

Badania relacji zewnętrznych państw skłaniają najczęściej do przyjęcia tezy o silnej polaryzacji polityki wewnętrznej, która zazwyczaj decyduje o przyjmowanej postawie i roli, jaką odgrywa dany podmiot na arenie międzynarodowej. Podobnie jest również w przypadku Szwajcarii, której system polityczny w ogromnym stopniu kształtuje politykę wobec UE. Należy tutaj podkreślić, że skala tego oddziaływania jest o wiele większa niż w relacjach z innymi partnerami. Co więcej, ma ona charakter statyczny, albowiem specyfika ośrodków decyzyjnych w Szwajcarii uniemożliwia nagłą destabilizację polityczną i redefinicję przyjętej wcześniej strategii. Kolektywna forma sprawowania władzy jest gwarancją stabilności rządów i niewielkiej wrażliwości większości parlamentarnej na zmiany.

Ogromne znaczenie ma również stopień demokratyzacji życia politycznego w Szwajcarii. Państwo, będące symbolem sprawnie funkcjonującej demokracji bezpośredniej i w pełni wykorzystujące jej atuty, nie jest jednak w stanie ustrzec się negatywnych konsekwencji takiego systemu. Możliwość silnego oddziaływania społeczeństwa na proces decyzyjny odczuwalna jest również w obszarze polityki zagranicznej. Populizm i powiązana z nim subiektywnie pojmowana racja stanu są w tym przypadku czynnikami silnie wpływającymi na relacje zewnętrzne, szczególnie w sytuacjach, w których realizacja polityki zagranicznej jest ściśle związana z różnymi procesami legislacyjnymi. Z taką sytuacją mamy do czy-

${ }^{2}$ E. Haliżak, R. Kuźniar, Stosunki międzynarodowe. Geneza, struktura, dynamika, Wydawnictwa Uniwersytetu Warszawskiego, Warszawa 2001, s. 115.

${ }^{3}$ Ibidem. 
nienia właśnie w przypadku współpracy z Unią Europejską. Kwestia ta zostanie dokładniej omówiona w dalszej części niniejszego rozdziału. Demokracja bezpośrednia komplikuje zatem politykę zagraniczną. Zmusza przy tym do głębszego przeanalizowania tego uwarunkowania, tym bardziej że nierozerwalnie łączy się ono z innymi, takimi jak percepcja środowiska międzynarodowego, postawy społeczne wobec innych państw, tożsamość narodowa czy kulturowa.

Warto w tym miejscu zauważyć, że powyższe czynniki są silnie motywowane historycznie. Określone postawy społeczne kształtowane są przez tradycje i doświadczenia narodowe oraz stereotypy widzenia świata. Istotny jest zatem sposób analizowania wybranych uwarunkowań. Wydaje się, iż pomocna może być metodologia zaproponowana przez Jamesa N. Rosenau, zakładająca trzy sposoby analizy - wertykalną, horyzontalną i diagonalną ${ }^{4}$ Z Właszcza ta ostatnia, będąca wypadkową dwóch pierwszych, wydaje się właściwa, ponieważ pozwala na przeanalizowanie różnych przesłanek, także w ujęciu ewolucyjnym.

Wracając do kwestii współzależności pomiędzy polityką zagraniczną a wewnętrzną należy zwrócić uwagę na trzy płaszczyzny, w ramach których dochodzi do ścierania się obu środowisk. Wspomina o nich J. Kukułka ${ }^{5}$. Pierwsza to aspekt ludzki, a więc wszystkie czynniki kulturowe, ideologie, koncepcje polityczne, cechy etniczne i demograficzne. Im bardziej społeczeństwo jest wykształcone i zróżnicowane kulturowo, tym większa jest siła oddziaływania na relacje zewnętrzne i odwrotnie, zwłaszcza jeżeli przyjmiemy, podążając za J. Kukułką, że kultura jest wyrazem tożsamości narodowej. W przypadku Szwajcarii ma to istotne znaczenie ponieważ zarówno zróżnicowanie kulturowe, jak i poziom wykształcenia, motywowany zamożnością obywateli, pozostaje wysoki. Jeżeli więc podziały te nie wpłynęły jak dotąd negatywnie na dezintegrację państwa, to przyjąć należy, iż stanowią elementy wzmacniające politykę zagraniczną, tzn. zapewniają stabilne zaplecze do utrzymywania konsekwentnych i przewidywalnych relacji międzynarodowych.

Druga to aspekt fizyczny bądź materialny, a więc geopolityka, poziom rozwoju gospodarczego i naukowo-technicznego. W tym obszarze można zdecydowanie odrzucić teorię determinizmu geograficznego, o czym świadczy chociażby położenie Szwajcarii w centrum Europy, które od lat nie idzie w parze z jej powiązaniami politycznymi. Bezwzględnie jednak poziom rozwoju i zamożności ma bezpośrednie „,przełożenie” na kształt polityki zagranicznej. Szwajcaria, jako państwo o jednym z najwyższych w Europie wskaźników PKB w przeliczeniu na jednego mieszkańca, może mieć poczucie zdecydowanie większej niezależności gospodarczej i silniejszej pozycji na arenie międzynarodowej. Dysponuje więc istotną kartą przetargową, umożliwiającą stawianie partnerom określonych

${ }^{4}$ J.N. Rosenau, The Scientific Study of Foreign Policy, Nicholas Pub Co., London 1980, s. $320-321$.

${ }^{5}$ J. Kukułka, R. Zięba, op. cit., s. 28-30. 
warunków współpracy. $Z$ drugiej strony procesy globalizacyjne zmuszają do poszukiwania nowych form gospodarowania, opartych niekiedy na bardzo ścisłych powiązaniach nie tylko gospodarczych, ale i politycznych. Często wiąże się to ze świadomym samoograniczeniem wykonywania praw wynikających z suwerenności.

Trzeci aspekt to sfera instytucjonalna. Chodzi tutaj o jakość i aktywność służb dyplomatycznych, zasięg powiązań międzynarodowych czy też obowiązujące uwarunkowania prawne. Jak słusznie zauważa J. Kukułka, wszystkie wymienione wyżej aspekty współzależności są ściśle powiązane z bieżącą koniunkturą życia międzynarodowego. Kryzysy i napięcia wzmacniają znaczenie czynników polityczno-strategicznych. Z kolei w okresie stabilizacji większą wagę przykłada się do kwestii gospodarczych. W przypadku Szwajcarii mamy do czynienia z wyraźnie silniejszym znaczeniem tych drugich.

Przyjęta koncepcja pracy zakłada zatem przegląd poszczególnych płaszczyzn występowania współzależności pomiędzy polityką wewnętrzną a zewnętrzną oraz subiektywny wybór tych uwarunkowań, które w największym stopniu determinują kształt relacji miedzy UE a Szwajcarią. Za kluczowe uznano elementy systemu politycznego, ze szczególnym uwzględnieniem federalizmu oraz demokracji bezpośredniej. W tym kontekście istotna jest również specyfika procesu decyzyjnego. Doktryna polityki zagranicznej Szwajcarii zawiera w sobie koncepcję neutralności oraz unikalny sposób pojmowania własnej roli i pozycji na arenie międzynarodowej, silnie powiązanej z tożsamością kulturową i pamięcią historyczną. Na uwagę zasługuje również rola mediów, które w perspektywie oddziaływania na opinię publiczną pełnią wyjątkową funkcję w kreowaniu określonych postaw, odzwierciedlanych następnie w procesie decyzyjnym. Ostatnim, lecz nie mniej istotnym, elementem jest etap realizacji polityki zagranicznej. Warto zatem przyjrzeć się bliżej funkcjonowaniu szwajcarskiej dyplomacji.

\subsection{DOKTRYNA I TRADYCJA POLITYKI SZWAJCARII}

\subsubsection{NEUTRALNOŚĆ W POLITYCE ZAGRANICZNEJ SZWAJCARII}

Polityka zagraniczna zajmowała w Szwajcarii, na tle innych państw, dość szczególne miejsce, determinowane przede wszystkim przez dwie najważniejsze wartości - neutralność i suwerenność państwa. Wartości te przyświecały twórcom konstytucji Związku z roku 1848. Zgodnie z przyjętą wówczas zasadą neutralności państwa, która pełniła funkcję zarówno celu, jak i narzędzia polityki zagranicznej kraju, gwarantować miała ona jego bezpieczeństwo i integralność terytorialną. Tradycyjna koncepcja polityki zagranicznej nie odbiegała zatem od ówcześnie praktykowanych standardów, uznających równowagę sił i sojusze za najwłaściwszy środek zapewnienia stabilizacji i bezpieczeństwa, z taką jednak 
różnicą, iż w przypadku Szwajcarii sojusze zastąpiono wieczystą neutralnością. Od tego momentu polityka zagraniczna nabrała charakteru defensywnego, z czasem zwanego konserwatywnym, a powściągliwość i dystansowanie się wobec wydarzeń na arenie międzynarodowej okazały się jej podstawowymi wyznacznikami. W tym sensie słuszne wydaje się stwierdzenie, ukute pierwotnie dla scharakteryzowania polityki zagranicznej Szwecji w okresie powojennym, że polityka zagraniczna Szwajcarii polegała na nieprowadzeniu polityki zagranicznej w ogó$1 \mathrm{e}^{6}$. Cechowała ją wówczas przede wszystkim pewna schematyczność działania, która zresztą odpowiadała ówczesnym realiom, w tym przede wszystkim dynamice wydarzeń i konieczności reagowania na pojawiające się problemy w relacjach $\mathrm{z}$ innymi państwami.

Doświadczenia obu wojen światowych, z których Szwajcaria wyszła nie tylko niemal nietknięta, lecz nawet wzmocniona gospodarczo, zdawały się potwierdzać słuszność obranej strategii. Nieuczestniczenie w sporach międzynarodowych okazało się w tym czasie najbardziej skuteczną metodą na przetrwanie wojennej zawieruchy. Na ile Szwajcaria zawdzięcza to przyjętej doktrynie neutralności, a na ile innym politycznym, geograficznym i gospodarczym uwarunkowaniom, pozostaje kwestią odrębnych dywagacji. Wystarczy chociażby dla porównania przytoczyć przypadek Belgii, której neutralność pogwałcona została przez Niemcy jeszcze w trakcie I wojny światowej. Faktem jest jednak, że bezstronność w czasach konfliktu stanowić może jeden z czynników, nawet jeżeli nie decydujący, które zmniejszają ryzyko wciągnięcia państwa w wojnę.

Doświadczenia wojenne utrwaliły zatem wizerunek Szwajcarii jako państwa wieczyście neutralnego, co skrzętnie wykorzystywano do osiągania celów politycznych i gospodarczych, o czym szerzej mowa będzie w dalszej części. W pierwszej kolejności neutralność posłużyła jednak do podreperowania, nadszarpniętej poprzez kontrowersyjną politykę współpracy z III Rzeszą, reputacji. Paradoksalnie, to właśnie ta, do pewnego stopnia pozorna, neutralność Szwajcarii w trakcie II wojny światowej stała się źródłem licznych kontrowersji i nieprzychylnych opinii, kierowanych pod jej adresem tuż po wojnie. Rząd Szwajcarii promował zatem nowy wizerunek państwa jako bezstronnego uczestnika międzynarodowych wydarzeń, oferującego pomoc w rozwiązywaniu sporów i konfliktów. Genewa stała się stolicą światowej dyplomacji, podejmowano tu kluczowe porozumienia, decydujące o bezpieczeństwie i pokojowym wspólistnieniu? Szwajcaria, oferując państwom pakiet tzw. dobrych usług8, stała się symbolem

${ }^{6}$ P. Andrzejewski, Neutralność w polityce zagranicznej Finlandii i Szwecji, Państwowe Wydawnictwo Naukowe, Warszawa 1988, s. 56.

${ }^{7} \mathrm{~W}$ Genewie mieści się jedna z siedzib ONZ, tutaj m.in. odbyła się II faza negocjacji KBWE w latach 1973-1975 (negocjacje eksperckie).

${ }^{8}$ Zgodnie z definicją zawartą w Karcie Narodów Zjednoczonych do tzw. dobrych usług zaliczamy: rokowania, pośrednictwo, ugodowe załatwianie sporów, reprezentowanie interesów innych państw. Doświadczenia szwajcarskie w tym zakresie mają bardzo bogatą tradycję i sięgają końca 
dialogu międzynarodowego, mediacji i pokojowego rozwiązywania konfliktów, a jej niezbyt chlubna przeszłość wojenna powoli odchodziła w niepamięć. W ten sposób kontynuowano tradycję zapoczątkowaną przez działalność Ligi Narodów, której siedziba znajdowała się przed wojną również w Genewie.

Polityka zagraniczna Szwajcarii, oparta na zasadzie bezstronności, doskonale sprawdzała się w powojennej rzeczywistości, naznaczonej dwubiegunowym podziałem sił. Raz wypracowana strategia kontynuowana była z powodzeniem aż do końca lat 80. XX w., czyli do rozpadu systemu bipolarnego. Przyjęta przez rząd Szwajcarii polityka oparta była na formule opracowanej przez Rudolfa Bindschedlera - doradcy prawnego Ministerstwa Spraw Zagranicznych, który dokonał próby zdefiniowania polityki neutralności, nadania jej ściśle określonych ram i umieścił ją w centralnym punkcie dyplomacji Szwajcarii ${ }^{9}$. Według opracowanej przez niego koncepcji Szwajcaria, jako państwo neutralne, nie mogła być członkiem międzynarodowych organizacji o charakterze politycznym bądź gospodarczym, włączając $w$ to również unie celne oraz wszelkie układy zbiorowego bezpieczeństwa ${ }^{10}$. Zasadność nieuczestniczenia w sojuszach o charakterze wojskowym pozostawała bezdyskusyjna. Inaczej jednak kształtowała się sprawa bliższych powiązań gospodarczych, uznanych przez Bindschedlera za potencjalne źródło uzależnienia ekonomicznego Szwajcarii, stojącego w sprzeczności z zasadami, którymi powinno się kierować państwo neutralne. Rzeczywistość pokazała jednak, iż dystansowanie się od tego rodzaju powiązań jest w praktyce niemożliwe. $Z$ czasem dokonano zatem pewnych modyfikacji, dopuszczających przystąpienie Szwajcarii do unii celnych, przewidujących wyłącznie eliminowanie barier $w$ handlu ${ }^{11}$. Szwajcaria, choć pozostająca oficjalnie nadal poza strukturami ONZ, stała się również aktywnym członkiem wielu wyspecjalizowanych organizacji, przewyższając swoją aktywnością niejednego stałego członka Zgromadzenia Ogólnego. W ten sposób dokonano jasnego podziału pomiędzy organizacjami o charakterze politycznym i technicznym, przyznając rzecz jasna prymat tym ostatnim.

Tradycyjna koncepcja polityki zagranicznej Szwajcarii nawiązywała również do sformułowanej w roku 1947 doktryny Petitpierre'a, wyznaczającej cztery

XV w. Zob. więcej: R. Probst, Die Schweiz und die „guten Dienste”, [w:] A. Riklin, H. Haug, R. Probst, Neues Handbuch der schweizerischen Aussenpolitik, Haupt Verlag, Bern-Stuttgart-Wien 1992; D. Trachsler, Gute Dienste - Mythen, Fakten, Perspektiven, Bulletin 2004 der schweizerischen Sicherheitspolitik. Dokument dostępny na stronie www.eda.admin.ch (10.09.2009).

${ }^{9}$ W roku 1954 opublikowano oficjalną koncepcję neutralności, zwaną później doktryną Bindschedlera. Treść dokumentu dostępna jest w bazie DoDiS (Diplomatische Dokumente der Schweiz), pod adresem: http://www.dodis.bar.admin.ch/dodis/dodis;jsessionid=f43038f7021d4c86e458?XE7lhitk5AZh7Dfw9OYVZZzghtrLw7sN7xvmXB5111 irfjtWjzj7ogT7P4OQr2JQy9Qemj0KNJEQOhR9qYpv45a; dodis.ch/9565 (16.09.2009).

${ }^{10}$ Zob. D. Schindler, Dokumente zur schweizerischen Neutralität seit 1945: Geschichte und Stellungnahme der schweizerische Neutralität seit 1945-1983, Bern-Stuttgart 1984.

11 Zgodnie $\mathrm{z}$ nową interpretacją doktryny Bindschedlera Szwajcaria była członkiem założycielem EFTA od roku 1961, a także podpisała układ o wolnym handlu z EWG w roku 1972. 
zasady gwarantujące bezpieczeństwo państwa i utrzymanie jego wiarygodności na arenie międzynarodowej. Do neutralności dodano zatem pojęcie solidarności, uniwersalności i dyspozycyjności. Solidarność odwoływała się do konieczności wspólnej odbudowy powojennej Europy, co wpisywało się we wspomniane już wyżej zabiegi na rzecz polepszenia wizerunku Szwajcarii. Zasada ta stała się ponadto symbolem prób przezwyciężenia izolacji politycznej, będącej naturalnym efektem realizacji koncepcji neutralności. Uniwersalność oznaczała z kolei dążenie do utrzymania równowagi w sferze dyplomatycznej, pomiędzy dwoma blokami, odpierając tym samym, przynajmniej pozornie, zarzut faworyzowania jednej ze stron. Należy przy tym bowiem zauważyć, że Szwajcaria ideologicznie związana była bliżej ze światem Zachodu. Miało to swoje naturalne odzwierciedlenie również w poziomie powiązań gospodarczych, pomimo licznych zabiegów na rzecz ich intensyfikacji z Europą Wschodnią ${ }^{12}$. Zasada dyspozycyjności związana była z gotowością do świadczenia wspomnianych już wyżej tzw. dobrych usług zarówno na terytorium własnym, jak i państw trzecich. Był to istotny element wzmacniający zaufanie wobec Szwajcarii. Zasada Petitpierre'a legła u podstaw tzw. aktywnej neutralności, zakładającej aktywną działalność w sferze polityki międzynarodowej, jednakże w ramach zobowiązań wynikających z zasady bezstronności. Aktywna neutralność oznaczała zatem wszelkie działania na rzecz rozwoju pokoju i międzynarodowej stabilizacji. W literaturze fachowej przyjęły one nazwę działań wyprzedzających (Vorwirkungen), będących uzupełnieniem obowiązków wtórnych państwa neutralnego, przyjętych w prawie międzynarodowym ${ }^{13}$. Obok działalności negocjacyjno-pośredniczącej zaliczamy do nich rozbudowaną działalność humanitarną oraz udział w misjach pokojowych. Jednak, jak zauważa Dariusz Popławski, z czterech opisanych wyżej zasad, tylko neutralność znalazła swoje miejsce $\mathrm{w}$ tekście konstytucji ${ }^{14}$. Pozostałe stanowią jedynie element równoważący, pozwalający na nieco szerszą interpretację dość zawężonej strategii politycznej, podyktowanej doktryną Bindschedlera. Występują one raczej na poziomie dyskursu politycznego, niż w formie formalnoprawnych uregulowań. Stanowią pewien wyznacznik strategii politycznej, który przewija się w późniejszych dokumentach, dotyczących polityki zagranicznej bądź bezpieczeństwa.

${ }^{12}$ Od lat 70. XX w. stopniowo intensyfikowano kontakty gospodarcze z ZSRR. W 1978 r. podpisano układ o współpracy gospodarczej, przemysłowej i naukowo-technicznej. W przeważającej większości (ok. 85\%) eksport z ZSRR dotyczył dostaw surowców energetycznych. Kontakty gospodarcze z Europą Wschodnią nie należały jednak do priorytetowych kierunków polityki rządu, najważniejszymi elementami pozostała współpraca z EFTA, EWG oraz wielostronne umowy w ramach GATT.

${ }^{13}$ Zob. D. Popławski, Neutralność i polityka neutralności, [w:] Historia. Polityka. Stosunki Międzynarodowe. Księga Jubileuszowa na 65-lecie Profesora Józefa Kukutki, Warszawa 1999, s. 238.

${ }^{14}$ D. Popławski, Szwajcarska polityka bezpieczeństwa, Warszawa 2007, s. 78. 
Dobrym tego przykładem jest koncepcja powszechnej obrony, przyjęta przez rząd w roku 1973, będąca pierwszym oficjalnym dokumentem dotyczącym polityki bezpieczeństwa Federacji Szwajcarskiej. Dokument ten stanowi punkt zwrotny w dotychczasowych strategiach polityczno-wojskowych, opierających się jedynie na biernej obronie państwa w przypadku konfliktu. Koncepcja z roku 1973 zakładała realizację tzw. podwójnej strategii. Polegała ona na jednoczesnym podejmowaniu działań o charakterze wojskowym i dyplomatycznym. Uznano zatem, iż tradycyjna strategia, opierająca obronę państwa na zasadzie tzw. odstraszania ${ }^{15}$ utraciła, w nowej rzeczywistości międzynarodowej, swoją pierwotną skuteczność. W celu właściwego zapewnienia bezpieczeństwa państwa wskazane jest podejmowanie tych działań, które pozwolą na zażegnanie groźby konfliktu jeszcze w jego początkowej fazie. Chodziło zatem o zastosowanie środków dyplomatycznych i politycznych. W pewnym sensie dopuszczano tutaj również instrumenty natury gospodarczej czy też stricte finansowej, jak np. pomoc rozwojowa dla państw rozwijających się. Początkowo oferowana ona była krajom europejskim, z czasem rozszerzona została również na państwa trzeciego świata. Rząd Szwajcarii przeznaczał ogromne sumy pieniędzy, często w formie bezzwrotnych pożyczek, na wsparcie rozwoju biedniejszych państw. Istotnym celem tej polityki, jak zauważa Laurent Goetschel, była także chęć wyrównania poziomów sfery socjalnej, w celu ograniczenia liczby imigrantów, dla których Szwajcaria była nierzadko jednym $z$ atrakcyjniejszych państw ${ }^{16}$, tym bardziej że według obowiązujących do dzisiaj przepisów o azyl starać się można we wszystkich placówkach dyplomatycznych Szwajcarii na świecie ${ }^{17}$.

Punktem wyjścia strategii powojennej polityki zagranicznej pozostawała zatem neutralność zarówno w sferze politycznej, jak i gospodarczej. Traktowana była jako gwarant zachowania bezpieczeństwa i suwerenności Szwajcarii. Warto zwrócić uwagę na fakt, że element ten zakotwiczony był głęboko w świadomości historycznej obywateli, pełniąc funkcję elementu spajającego pewną heterogeniczność narodu szwajcarskiego, o czym mowa będzie jeszcze w dalszej części niniejszego rozdziału. Wart podkreślenia jest fakt, że przez lata polityka zagraniczna, przynajmniej w porównaniu z państwami ościennymi, odgrywała rolę raczej marginalną, oddając prym polityce wewnętrznej. Te dwie sfery były ponadto traktowane oddzielnie jako dwa, nie wpływające na siebie, byty. Miało to swoje odzwierciedlenie, tak na poziomie instytucjonalnym, jak i intelektualnym, o czym świadczyć może chociażby

\footnotetext{
${ }^{15}$ Strategia polegała na rozbudowanym systemie obrony, opartym na ścisłej współpracy cywilno-wojskowej, pozwalającym na długotrwały opór na własnym terytorium, w sytuacji bezpośredniej agresji. Według autorów tej koncepcji straty poniesione przez agresora przewyższać miały korzyści wynikające z okupacji kraju. Ucieleśnieniem tej strategii była tzw. Reduta Narodowa, tj. system silnych fortyfikacji, zbudowanych w centralnej części Szwajcarii.

${ }^{16}$ L. Goetschel, Wie Aussenpolitik zunehmend politisch wird, „Rote Revue. Zeitschrift für Politik, Wirtschaft und Kultur" 2007, Nr. 4, s. 9.

${ }^{17}$ Asylgesuche im Ausland stoppen, „Neue Zürcher Zeitung”, 3. September 2009.
} 
brak długofalowych strategii, opartych na głębszych analizach politycznych. Wiąże się z tym także, co podkreślane jest w literaturze przedmiotu, brak zdolności dynamicznego reagowania na zjawiska zachodzące na arenie międzynarodowej ${ }^{18}$. Uważano jednak, że polityka oparta na maksymie bezstronności jest w stanie, w najlepszym stopniu, zabezpieczyć interesy małego i niewiele znaczącego w Europie państwa. Co istotne, przyjęta strategia minimalizowała groźbę braku społecznej legitymizacji, co w warunkach demokracji bezpośredniej pozostaje niezwykle ważnym czynnikiem. Bardzo często spotkać się można z określeniem polityki zewnętrznej Szwajcarii jako mało ambicjonalnej, ograniczonej jedynie do zachowania bezpieczeństwa i gospodarczej stabilizacji. W pewnym stopniu podyktowane było to uwarunkowaniami wewnętrznymi, z których dwa - federalizm oraz demokracja bezpośrednia, odgrywały od zawsze, obok neutralności, kluczową rolę.

Istotny jest w tym względzie syndrom „odosobnionego przypadku” (Sonderfall) Szwajcarii, który bardzo często przewija się w dyskursie naukowym i politycznym. Jest to pewne, zakorzenione głęboko w mentalności Szwajcarów, poczucie własnej odrębności zarówno kulturowej, jak i politycznej, usprawiedliwiające niejaką alienację państwa i jego stosunek wobec otaczającej rzeczywistości. Do pewnego stopnia starano się wykorzystywać tę „wyjątkowość” jako atrybut służący osiągnięciu własnych celów, tak jak stało się to w przypadku próby wytłumaczenia negatywnego stosunku wobec głębszej integracji europejskiej. Z czasem jednak teza o wyjątkowości Szwajcarii traciła na znaczeniu, w ślad za czym zamiast Sonderfall pojawiały się coraz częściej głosy nawołujące do konieczności przeprowadzenia szerokich reform politycznych, adaptujących nieefektywny system państwowy do nowej rzeczywistości geopolitycznej ${ }^{19}$.

\subsubsection{POLITYKA SZWAJCARII WOBEC ZJAWISK INTEGRACYJNYCH}

Upadek bloku wschodniego i rozpad systemu bipolarnego zmusił rząd w Bernie do przewartościowania swojej dotychczasowej polityki. Okazało się bowiem, iż nowe wyzwania wymagają podejmowania bardziej elastycznych działań, do czego ani instytucjonalnie, ani koncepcyjnie Szwajcaria nie była przygotowana. Należało wypracować nową strategię, która odpowiadałaby obecnym problemom zarówno na płaszczyźnie politycznej, jak i społecznej, ponieważ w zmienionej rzeczywistości dotychczas odseparowywane sfery polityki wewnętrznej i zewnętrznej zaczęły wzajemnie na siebie oddziaływać.

${ }^{18}$ Zob. krytyczne uwagi pod adresem procesu decyzyjnego i efektywności działania szwajcarskiej dyplomacji D. Ruloff, T. Bernauer, S. Bruno, P. Moser, A. Schnur, Globaler Wandel und Schweizerische Aussenpolitik. Informationsbeschaffung und Entscheidungsfindung, Studie im Rahmen des NFP „Aussenpolitik”, Bern 1999, s. 10.

${ }^{19}$ Debacie tej poświęcona jest ciekawa praca S. Borner, A. Brunetti, T. Straubhaar, Schweiz AG. Vom Sonderfall zum Sanierungsfall?, Verlag Neue Zürcher Zeitung, Zürich 1990. 
Pierwszym krokiem, który legł u podstaw pozimnowojennej strategii politycznej, był rządowy Raport na temat polityki zagranicznej $w$ latach 90., opublikowany w roku 1993 (dalej jako Raport 1993) ${ }^{20}$. Dokument ten wyznaczał zupełnie nowe cele i środki szwajcarskiej polityki zagranicznej, zastępując jednotorową politykę niezależności systemem pięciu celów. Składały się nań21:

- wspieranie pokoju i bezpieczeństwa;

- popieranie praw człowieka, demokracji i państwa prawa;

- popieranie dobrobytu;

- redukcja społecznych przeciwieństw;

- ochrona naturalnych podstaw egzystencji.

Powyższe cele winny być osiągnięte na drodze szerszej współpracy międzynarodowej, opartej na solidarności, bezpieczeństwie zbiorowym i integracji europejskiej. Neutralność pozostaje przy tym ważnym czynnikiem, lecz nie o charakterze dominującym. Wskazuje się tutaj raczej na konieczność jej adaptacji do nowo określonych środków polityki zagranicznej. Sformułowano w ten sposób nową wykładnię doktryny Bindschedlera, wedle której neutralność przestaje zajmować centralną pozycję, ograniczając ją jedynie do tzw. wojskowego jądra22. Oznaczało to w praktyce powrót do zasad neutralności kwalifikowanej, a więc wykładni, wedle której udział w sankcjach gospodarczych jest do pogodzenia z prawem państwa neutralnego. Co więcej, neutralność pozostaje także w zgodzie z członkostwem w wielu organizacjach międzynarodowych, jak np. ONZ, EOG czy udziałem w Programie Partnerstwa dla Pokoju NATO, do którego Szwajcaria przystąpiła w roku 1996. Przede wszystkim jednak otwierała ona nowy obszar do dyskusji wokół członkostwa Szwajcarii we Wspólnocie. Jak zauważa J.M Gabriel, doktryna neutralności stała się zatem instrumentem doraźnym, stosowanym „,w razie konieczności", a więc w przypadku utraty zaufania wobec innych instrumentów zapewnienia bezpieczeństwa, jak choćby współpracy z NATO lub działań na forum ONZ ${ }^{23}$.

Z duchem Raportu 1993 współbrzmi również praktykowane z powodzeniem przez rząd w Bernie dualistyczne podejście do konfliktu zbrojnego, zakładające podział na wojnę w klasycznym rozumieniu oraz w rozumieniu Karty Narodów Zjednoczonych. Zgodnie z tą wykładnią prawa i obowiązki państwa neutralnego przestają mieć zastosowanie wobec konfliktu, w którym zaangażowane jest

${ }^{20}$ Bericht über die Aussenpolitik der Schweiz in der 90er Jahren vom 29. November 1993, EDMZ, Bern 1993.

${ }^{21}$ Ibidem, s. 5-6.

${ }^{22}$ J.M. Gabriel wskazuje jednak przy tym na pewną niefortunność zastosowanego w dokumencie wobec neutralności określenia kompatybilność (Kompatibilität), pozwalającą na uwypuklenie znaczenia dawnej doktryny w nowo przyjętej strategii. Zob. J.M. Gabriel, Sackgasse Neutralität, Hochschulverlag, Zürich 1997, s. 151-156.

${ }^{23}$ J.M. Gabriel, Neutralität für den Notfall. Der Bericht des Bundesrates zur Aussenpolitik der Schweiz in den 90er Jahren, „Swiss Political Science Review”1995, Nr. 1 (2-3), s. 161-190; J.M. Gabriel, J.A. Fanzun, Swiss Foreign Policy: An Overview, Center for International Studies, Beiträge Nr. 43, Zürich 2003, s. 6. 
ONZ, wychodząc z założenia, że w tym przypadku nie mamy do czynienia z konfrontacją wojenną między państwami w rozumieniu konwencji haskiej z $1907 \mathrm{r}^{24}$ Podkreśla się, iż rezolucje Rady Bezpieczeństwa ONZ, zastosowane przeciwko łamiącemu prawo lub zakłócającemu pokój, mają funkcję pokojową, a więc zgodną z istotą i duchem neutralności.

Praktyka polityczna obnażyła jednak niekonsekwentność w realizacji powyższej strategii. Typowym tego przykładem jest operacja NATO w Kosowie w roku 1999. Pomimo braku rezolucji ONZ rząd szwajcarski zdecydował się na przyłączenie do sankcji dotyczących dostaw broni do Jugosławii, dając do zrozumienia, że nie traktuje tego konfliktu według klasycznych norm. Chwilę później odmówił jednak włączenia się do ustanowionego przez UE embarga na dostawy ropy oraz zamknął przestrzeń powietrzną dla samolotów bojowych NATO, biorących udział w działaniach wojennych. Kolejny Raport z $2000 r$. podejmuje próbę wyjaśnienia powyższej niekonsekwencji w działaniach rządu, nie rozwiewa jednak wszystkich wątpliwości. Jak zauważa D. Popławski pewnym wytłumaczeniem polityki władz szwajcarskich może być fakt, iż czym innym jest przyłączenie do działań spełniających funkcję pokojową, tj. uniemożliwienie dostawy broni do państw objętych konfliktem, a czym innym udostępnienie de facto własnego terytorium do działań wojennych ${ }^{25}$, tym bardziej że, jak wcześniej wspomniano, brakowało w tym przypadku właściwej rezolucji ONZ.

Strategia, przyjęta przez rząd w roku 1993, znalazła również swoje odzwierciedlenie w konstytucji z roku $1999^{26}$. W części dotyczącej stosunków zewnętrznych odnaleźć możemy słowa o dążeniu Związku do obrony niezależności i dobrobytu Szwajcarii oraz łagodzenia biedy na świecie i wsparcia dla demokracji, a także pokojowego współistnienia.

Jak już wcześniej wspomniano Raport 1993 pozwolił również na otwarcie nowej karty w stosunkach Szwajcarii z Unią Europejską, określając integrację jako jeden ze środków polityki zagranicznej, dopuszczając tym samym do podjęcia takich działań, które jeszcze przed kilkoma laty, ze względu na niekompatybilność z doktryną neutralności, wydawały się niemożliwe do zaakceptowania. Stały również w sprzeczności z tzw. rządową „strategią trzech filarów”27. Opierała ona politykę gospodarczą Szwajcarii na aktywnej kooperacji w ramach EFTA, zawarciu układu o wolnym handlu z EWG oraz multilateralnej współpracy w strukturach GATT. Nie przewidywano tutaj zatem ściślejszej integracji ze Wspólnotą, tym bardziej że ta, w oczach wielu decydentów i społeczeństwa szwajcarskiego, była, jak zauważa Alois Riklin, efektem zimnowojennych antagonizmów na linii

${ }^{24}$ Por. D. Popławski, Szwajcarska polityka bezpieczeństwa ..., s. 178-180.

${ }^{25}$ Ibidem, s. 223.

${ }^{26}$ Art. 54, par. 2, Schweizerische Bundesverfassung.

${ }^{27}$ Strategia opracowana została przez Federalny Urząd Gospodarki Zagranicznej (Bundesamt für Aussenwirtschaft, BAWI), przekształcony w roku 1999 na Sekretariat Ekonomiczny (Staatssekretariat für Wirtschaft). 
Wschód-Zachód. Przewidywano rychłą jej dezintegrację, której początek miał nastąpić wraz z upadkiem muru berlińskiego ${ }^{28}$. Jako ciekawostkę warto dodać, że według sowieckiej propagandy tamtego okresu EWG stanowiło ekonomiczne zaplecze NATO. Współpraca państwa neutralnego ze Wspólnotą musiała spotkać się z ostrą krytyką ze strony państw bloku wschodniego, podważając tym samym jego wiarygodność w oczach międzynarodowej opinii publicznej.

Analizując motywy, dla których rząd Szwajcarii zabiegał o współpracę ze Wspólnotą, wskazać należy na trzy najważniejsze czynniki. Pierwszy z nich, najbardziej oczywisty, odnosi się do chęci zapewnienia odpowiedniego rozwoju gospodarczego. Jak wiadomo Szwajcaria jest państwem małym, pozbawionym bogactw naturalnych, zależnym surowcowo od dostaw zagranicznych, a przy tym z niewielkim rynkiem wewnętrznym. Zapewnienie właściwego rozwoju ekonomicznego nie może odbywać się w warunkach autarkii gospodarczej, czego efektem byłaby restrykcyjna realizacja doktryny Bindschedlera. Rząd w Bernie zmuszony był podjąć działania mające na celu nie tylko ułatwienie dostępu do zagranicznych rynków poprzez likwidację barier w handlu. Warto zwrócić uwagę na fakt, że spora część dużych szwajcarskich przedsiębiorstw radziła sobie doskonale jeszcze przed podpisaniem pierwszych regulacji z EWG. Współpraca ze Wspólnotą była jednak sposobem na obronę przeciwko protekcjonistycznej polityce gospodarczej, stosowanej przez EWG, a działającej na niekorzyść państw, niebędących jej członkami. Polityce, która zaostrzała się wraz z intensyfikacją integracji. Wielkie nadzieje pokładano początkowo we współpracy z krajami EFTA. Dość szybko udało się doprowadzić do zniesienia barier celnych, co przełożyło się na wzrost obrotów handlowych ${ }^{29}$. Od samego początku tworzenia stref wolnego handlu było jednak jasne, iż współpraca oparta wyłącznie na zniesieniu barier handlowych nie rozwiązuje wszystkich problemów. Bardzo szybko zaczęli zauważać to inni członkowie EFTA, decydując się, już pod koniec lat 60., na nawiązanie ściślejszej współpracy z Europejską Wspólnotą Gospodarczą.

Drugi czynnik wynikał ze słabnącej pozycji EFTA na arenie międzynarodowej. Jeszcze pod koniec lat 80. sądzono, że współpracę z EWG będzie można nawiązać poprzez podpisanie stosownych układów na poziomie instytucjonalnym, tj. bezpośrednio pomiędzy EFTA a Wspólnotą. Takie rozwiązanie byłoby zdecydowanie najkorzystniejsze z punktu widzenia Szwajcarii, nie tylko z uwagi na możliwość wyeliminowania kontrowersji wokół doktryny neutralności, lecz również ze względu na wzmocnienie pozycji tego państwa w trakcie ewentualnych rokowań nad formą i treścią układów. Szybko okazało się jednakże, iż tego typu rozwiązanie nie jest możliwe. Główną przeszkodą było słabnące znaczenie Stowarzyszenia oraz jego niewydolność negocjacyjna. W tej sytuacji istniała obawa,

\footnotetext{
${ }^{28}$ A. Riklin, H. Haug, R. Probst, op. cit., s. 206-207.

${ }^{29} \mathrm{Na}$ skutek zniesienia barier celnych w roku 1967 kraje strefy EFTA stały się najważniejszym partnerem handlowym Szwajcarii.
} 
skądinąd słuszna, że osłabienie EFTA oznacza dla Szwajcarii izolację polityczną. Rząd w Bernie doskonale zdawał sobie sprawę z faktu, że wariant „samotnej twierdzy" jest na dłuższą metę niemożliwy do realizacji i wcześniej czy później Szwajcaria będzie zmuszona do nawiązania ściślejszej współpracy ze Wspólnotą.

Dochodzi do tego również trzeci aspekt, o którym warto wspomnieć, choć na tle wcześniejszych ma on zdecydowanie mniejsze znaczenie. Chodzi mianowicie o aspekt kulturowy. W dobie silnych zjawisk integracyjnych zarówno na polu politycznym, jak i gospodarczym, nie bez znaczenia pozostaje kwestia przynależności do określonej wspólnoty historycznej oraz kulturowej, i, co za tym idzie, świadomość wspólnych korzeni tudzież wielowiekowego dziedzictwa. Szwajcaria jako państwo zlokalizowane niemal w centrum Europy, paradoksalnie, zagrożona jest $\mathrm{w}$ takim samym stopniu utratą silnych więzi kulturowych $\mathrm{z}$ resztą kontynentu, jak państwa położone na jej peryferiach. Obserwując debatę związaną z tym tematem, bardzo często spotkać się można z opiniami mówiącymi o silnej obawie przed określeniem Szwajcarii jako kulturowego kopciuszka Europy ${ }^{30}$. Integracja europejska daje zatem nadzieję na swobodny dostęp do tej sfery, która gwarantuje rozwój nie tylko gospodarczy, lecz również duchowy, oddziałując na wzmacnianie więzi z innymi państwami w Europie.

Wydaje się zatem, że rząd w Bernie zaczął zdawać sobie sprawę z szerszego kontekstu integracji, której nie można traktować w kategoriach czysto instytucjonalnych. Chęć zawarcia pragmatycznych układów handlowych zastąpiona została z czasem dążeniem do nawiązania współpracy na nowych płaszczyznach, pozwalających na pełnoprawne włączenie Szwajcarii do europejskiej rodziny, a, co za tym idzie, oddalenie groźby politycznej, gospodarczej i kulturowej izolacji. Na samym początku lat 90 . wydawało się, iż przystąpienie do Wspólnoty, podobnie jak w przypadku innych państw neutralnych, takich jak Austria czy Szwecja, nastąpi w możliwej do określenia przyszłości, biorąc przy tym pod uwagę zarówno obowiązującą doktrynę polityczną, jak i nastroje społeczeństwa szwajcarskiego, a dodać należy, iż to ostatnie zdawało się nie podzielać opinii kół rządzących. Zakończone fiaskiem próby włączenia Szwajcarii do struktur Europejskiego Obszaru Gospodarczego ${ }^{31}$ przekreśliły jednak szanse na szybką integrację z krystalizującą się wówczas Unią Europejską. Oznaczało to rozpoczęcie długiego, trwającego do dzisiaj, procesu stopniowej integracji ze Wspólnotą, której ostateczny finał pozostaje nadal trudny do przewidzenia.

Podsumowując, od początku lat 90. zauważyć można stopniowy proces wzmacniania znaczenia polityki europejskiej jako jednego z najważniejszych filarów polityki zagranicznej rządu. Ma to oczywisty związek ze zmianami, jakie

${ }^{30}$ M. Schenker, EG als Chance. Die Schweiz am europäischen Scheideweg, Werd Verlag, Zürich 1991, s. 21.

${ }^{31}$ Przeprowadzone w roku 1992 referendum zakończyło się odrzuceniem przez społeczeństwo wniosku o przystąpienie do Europejskiego Obszaru Gospodarczego. 
zaszły na przełomie lat 1989/1990, czego konsekwencją była intensyfikacja integracji europejskiej, lecz również problem wzrastającego oddziaływania polityki zewnętrznej na wewnętrzną i odwrotnie. Niosło to za sobą konieczność rewizji dotychczasowej strategii politycznej w postaci wypracowania wielokierunkowych działań, które w sposób kompleksowy zabezpieczałyby interesy Szwajcarii. W tym kontekście możemy mówić o przejściu od polityki koegzystencjii2, będącej domeną lat powojennych, do polityki kooperacji, a więc otwarcia władz Szwajcarii na szerszą współpracę międzynarodową. Unia Europejska stała się naturalnym i najważniejszym partnerem dla Szwajcarii. Istotny był tutaj nie tylko aspekt geograficzny czy gospodarczy ${ }^{33}$, lecz także poczucie pewnej więzi, opartej na spójnych celach i przyjętych strategiach rozwoju. Dotyczy to również wsparcia i promocji pokoju oraz praw człowieka. Wartości, które stały się podstawą funkcjonowania Wspólnoty i które w polityce państwa neutralnego odgrywają niezwykle istotną rolę 34 .

\subsection{SYSTEM POLITYCZNY SZWAJCARII}

Polityka zagraniczna Szwajcarii, w tym również wobec Unii Europejskiej, determinowana jest przez szereg uwarunkowań wewnętrznych, które charakterystyczne są wyłącznie dla tego państwa. Najczęściej wskazuje się tutaj na aspekt wielokulturowości. Faktycznie, żadne inne państwo w Europie nie tworzy takiej mieszanki języków, dialektów, zwyczajów czy wyznań religijnych. Oczywiście nie pozostaje to bez wpływu na kształt relacji wewnętrznych, które w warunkach silnie zakorzenionej demokracji bezpośredniej niezwykle istotnie oddziaływują także na rozwój stosunków zewnętrznych. Unikalność Szwajcarii polega jednak również na wyją̧tkowości jej systemu politycznego. Nie znaczy to oczywiście, iż nie można doszukiwać się pewnych podobieństw z innymi państwami o zbieżnej specyfice społeczno-politycznej, jak chociażby Belgia czy Niemcy. Dodatkowe uwarunkowania, właściwe jedynie systemowi ustrojowemu Szwajcarii, sprawiają jednak, że stanowi ona na tle innych państw przypadek szczególny.

Po pierwsze, mamy tutaj do czynienia z unikalnym systemem sprawowania władzy opartym na zasadzie kolegialności. Rząd, czyli Radę Związkową, tworzy siedmioosobowe gremium, złożone z przedstawicieli głównych partii politycznych. Oznacza to konieczność podejmowania działań na drodze kompromisu, co,

${ }^{32}$ Zob. D. Thürer, Aussenpolitische Aspekte der künftigen Beziehung zur Europäischen Gemeinschaft, [w:] A. Riklin, H. Haug, R. Probst, op. cit., s. 534.

${ }^{33}$ Zob. L. Goetschel, M. Bernath, D. Schwarz, Schweizerische Aussenpolitik. Grundlagen und Möglichkeiten, Verlag Neue Zürcher Zeitung, Zürich 2002, s. 166-172.

${ }^{34} \mathrm{O}$ zbieżności celów i strategii rozwoju zob. Raport 1993 oraz raport z roku 1999 dotyczący integracji europejskiej: Schweiz-Europäische Union: Integrationsbericht 1999, EDMZ, Bern 1999, s. 207. 
niestety, nie pozostaje bez wpływu na skuteczność i efektywność jego funkcjonowania, także w obszarze polityki zagranicznej. Po drugie, pozycja parlamentu w stosunku do Rady Związkowej jest zdecydowanie słabsza, a jego rola, o czym będzie mowa później, została w dużym stopniu zmarginalizowana. Po trzecie, istotna jest również specyfika procesu decyzyjnego, opartego na społecznym konsensusie i dużym znaczeniu pozaparlamentarnych negocjacji. Analizę uwarunkowań uzupełnić należy o ocenę wpływu świadomości kulturowej i politycznej obywateli, a także elit rządzących, oddziałującą bez wątpienia na stopień relacji międzynarodowych.

\subsubsection{SPECYFIKA OŚRODKÓW DECYZJI POLITYCZNEJ I PROCESU DECYZYJNEGO}

Początki państwowości Szwajcarii sięgają roku 1291, a więc momentu, w którym zjednoczenie trzech pierwszych kantonów - Uri, Schwyz i Unterwalden, stworzyło podwalinę przyszłego rozwoju Związku. Z biegiem czasu dołączały do niego kolejne kantony, formując, mniej więcej do połowy wieku XVI, kształt i zakres terytorialny dzisiejszej Szwajcarii. Najważniejszym dokumentem nowożytnej historii tego państwa jest konstytucja z roku 1848, ustanawiająca federację dwudziestu, zróżnicowanych językowo i kulturowo, kantonów. Istotny jest przy tym fakt, że w tekście konstytucji mowa jest nie o narodzie szwajcarskim, lecz o ludności kantonów (Völker der Bund), co świadczy o pewnej specyfice społeczno-politycznej państwa. Szwajcaria nie jest monolitem państwowym, lecz państwem powstałym na gruncie wspólnych wartości i dążeń jego mieszkańców, a także poczucia pewnej więzi, pomimo oczywistych różnic językowych i kulturowych. Możemy zatem pokusić się o określenie Szwajcarii jako wspólnoty ideowej, opartej jednakże na sztywnych, instytucjonalnych podstawach. Ogniwem spajającym państwo są takie wartości, jak niezależność i suwerenność, a także zasada sprawiedliwego podziału władzy, oparta na poszanowaniu interesów wszystkich stron. W ten sposób narodził się pierwszy z trzech najważniejszych filarów szwajcarskiej państwowości - federalizm. Stanowił on podstawę decentralizacji państwa, zapewniającej poszczególnym jednostkom składowym - kantonom - dość szeroką autonomię w zakresie sprawowania władzy na swoim terytorium, a jednocześnie dawał im możliwość współdecydowania w sprawach dotyczących całego Związku. Chęć zapewnienia proporcjonalnego podziału władzy i podejmowania decyzji na drodze ogólnonarodowego konsensusu ma swoje odzwierciedlenie w kolejnym filarze sytemu ustrojowego - demokracji bezpośredniej. Obecna jest ona zarówno na najniższym szczeblu administracyjnym, na poziomie gminy, jak i najwyższym - centralnym. Całość spaja neutralność, będąca pojęciem odnoszącym się nie tylko do relacji zewnętrznych, lecz również do stosunków wewnętrznych, a więc przejawiająca się w dążeniu, poprzez dialog 
i kompromis, do unikania i łagodzenia ewentualnych konfliktów pomiędzy poszczególnymi kantonami w ramach procesu decyzyjnego ${ }^{35}$.

Polityka zagraniczna prowadzona jest na szczeblu centralnym. Zgodnie $\mathrm{z}$ postanowieniami konstytucji ${ }^{36}$ relacje zewnętrzne pozostają w gestii Związku, a więc władz w Bernie. Kłóci się to zresztą z tradycyjnymi dążeniami decentralizacyjnymi ${ }^{37}$. Niemniej jednak podział kompetencji ma tutaj charakter wertykalny, podobnie jak w innych państwach federalnych, takich jak Niemcy lub Austria ${ }^{38}$. Zadania Rady Związkowej w tym zakresie określone są szczegółowo w konstytucji ${ }^{39}$. Reprezentuje ona zatem państwo na zewnątrz i określa cele oraz środki polityki zagranicznej Szwajcarii. Należy w tym miejscu podkreślić, iż relacje zewnętrzne nie są kreowane wyłącznie przez jeden Departament (szwajcarski odpowiednik Ministerstwa). Wszystkie decyzje dotyczące zarządzania państwem, w tym również w obszarze polityki zagranicznej, podejmowane są wspólnie przez wszystkich członków Rady Związkowej. Oczywiście na poziomie strategicznym, a nie operacyjnym. Ponadto rząd podpisuje i ratyfikuje umowy międzynarodowe i przedstawia je parlamentowi do zatwierdzenia. Co ważne, jeżeli wymaga tego interes narodowy, ma prawo do wydawania dekretów i rozporządzeń bez jego zgody. Rząd nie jest odpowiedzialny przed parlamentem, w związku z czym nie ma możliwości jego zdymisjonowania poprzez votum parlamentarne. Rola Zgromadzenia Narodowego w kreowaniu polityki zagranicznej jest więc niezwykle ograniczona. Konstytucja wyposaża parlament jedynie w funkcje nadzorcze.

W przypadku realizacji tradycyjnej polityki zagranicznej, która, o czym mowa była wyżej, miała dość ograniczony charakter, dominująca pozycja rządu nie stanowiła większego problemu. Główne zadania parlamentu sprowadzały się do ogólnych zagadnień, jak prawa człowieka lub uznanie innych państw. Reszta pozostawiona była Radzie Związkowej. Jednakże w przypadku realizacji polityki europejskiej, której oddziaływanie na sferę wewnętrzną ma charakter niemal bezpośredni, marginalizacja funkcji parlamentu nabrała rangi poważnego problemu politycznego i konstytucjonalnego. Pewną próbą uregulowania tej kwestii była ustawa o podziale kompetencyjnym z roku 1992, która precyzuje współdziałanie obu izb parlamentu w kreowaniu polityki zagranicznej Związku. Zgodnie z powyższym dokumentem odbywa się ono poprzez stałe komisje parlamentarne, pełniące funkcje informacyjne i doradcze ${ }^{40}$. Ich postanowienia nie mają jednakże

${ }^{35}$ Zobacz więcej nt. neutralności skierowanej do wewnątrz: D. Popławski, Szwajcarska polityka bezpieczeństwa..., s. 47-50.

${ }^{36}$ Bundesverfassung der Schweizerischen Eidgenossenschaft vom 18. April 1999 (Stand am 11. März 2012), Art. 54, źródło: http://www.admin.ch/ch/d/sr/101/index.html.

${ }^{37}$ W. Linder, Schweizerische Demokratie: Institutionen - Prozesse - Perspektive, Bern 1999, s. 136.

${ }^{38}$ L. Goetschel. M. Bernath, D. Schwarz, op. cit., s. 60.

${ }^{39}$ Art. 180 i 184, BV.

${ }^{40}$ Kompleksową analizę funkcjonowania komisji parlamentarnych zawiera praca R. Lüthi, Die Legislativkommissionen der Schweizerischen Bundesversammlung: Institutionelle Veränderung und das Verhalten von Parlamentsmitgliedern, Paul Haupt Verlag, Bern 1997. 
dla rządu charakteru wiążącego. Ich znaczenie jest więc marginalne. Co więcej, zgodnie z art. 166 konstytucji, zawarcie niektórych umów międzynarodowych nie wymaga nawet zatwierdzenia przez parlament ${ }^{41}$. Według opinii wielu politologów właściwym celem powyższych regulacji jest raczej sprowokowanie do intensywniejszego dialogu niż kwestionowanie dotychczasowego podziału kompetencyjnego ${ }^{42}$.

W perspektywie integracji europejskiej pozycja parlamentu i jego oddziaływanie na politykę rządu stanowią istotny element dyskusji nad instytucjonalną gotowością do członkostwa Szwajcarii w Unii Europejskiej. Postuluje się tutaj stworzenie stałych komisji parlamentarnych, zajmujących się wyłącznie problematyką europejską. Winny być one wyposażone w silniejsze kompetencje, w tym możliwość wydawania wiążących dla rządu opinii. Ten z kolei powinien być konstytucyjnie zobowiązany do informowania parlamentu lub specjalnych komisji o swojej polityce europejskiej. Tego typu reformy zapewne wpłynęłyby pozytywnie na przejrzystość działań rządu, eliminując również problem postępującej centralizacji władzy. Z drugiej strony, wzmocnienie roli parlamentu, a tym samym wydłużenie procesu podejmowania decyzji politycznych, wpłynie niekorzystnie na efektywność działań rządu, które już teraz spotykają się z narastającą krytyką.

Sprawność procesu decyzyjnego jest szczególnie istotna w przypadku polityki europejskiej. Decyzje zapadające w Brukseli wymagają niekiedy szybkiej i zdecydowanej reakcji ze strony władz Szwajcarii. Współpraca ta ma bowiem charakter dynamiczny, o czym mowa będzie jeszcze w dalszych partiach tekstu. W tej sytuacji parlament mógłby stać się areną politycznych rozgrywek i przepychanek, w efekcie których problemy europejskie byłyby kartą przetargową w realizacji partyjnych interesów. Doskonale widać to na przykładzie dyskusji wokół doktryny neutralności. Poszczególne partie często traktują ją w sposób przedmiotowy, dowodząc za jej pomocą słuszności postulatu większej aktywności międzynarodowej lub wykorzystując ją jako argument przemawiający za polityczną biernością. Analogiczny spór mógłby paraliżować dynamikę działań w sferze polityki europejskiej, a to z kolei wpłynęłoby negatywnie na pozycję Szwajcarii w relacjach z Unią Europejską.

${ }^{41}$ Bundesrat podpisuje umowy międzynarodowe bez zgody parlamentu, jeżeli: nie nakładają one na Szwajcarię nowych zobowiązań ani nie doprowadzają do anulowania wcześniejszych, mają charakter uzupełniający, służąc wdrażaniu uprzednio zatwierdzonych przez parlament umów, dotyczą spraw techniczno-administracyjnych i nie pociągają za sobą dużych nakładów finansowych, odnoszą się do spraw leżących wyłącznie w kompetencji rządu.

${ }^{42}$ Tego typu opinia zawarta jest w pracy L. Wildhaber, Aussenpolitische Kompetenzordnung im schweizerischen Bundesstaat, [w:] A. Riklin, H. Haug, R. Probst, op. cit., s. 135. 


\subsubsection{FEDERALIZM}

\subsubsection{WPŁYW KANTONÓW NA POLITYKĘ ZAGRANICZNĄ ZWIĄZKU}

Realizacja polityki europejskiej jest w przypadku Szwajcarii procesem złożonym, rodzącym wiele komplikacji i kontrowersji. Poza zasygnalizowanymi już kwestiami związanymi ze specyfiką pracy rządu oraz głównych instytucji szczebla centralnego, warto poświęcić tu nieco więcej uwagi problemom ustroju federacyjnego. Federalizm jest bowiem jednym z tych czynników, które nie tylko w sposób wymierny wpływają na kształt obecnych relacji ze Wspólnotą, ale przedstawiany jest często jako jeden z elementów utrudniających całkowitą integrację z UE.

Jak już wcześniej wspomniano, konstytucja nadaje władzom federalnym szczególną pozycję w kreowaniu polityki zagranicznej Związku. Nie oznacza to jednak, że rząd podejmuje decyzje w sposób autonomiczny. Skuteczność realizacji nakreślonej przez Radę Związkową strategii odbywa się na drodze ścisłej współpracy ze wszystkim kantonami. Współpraca ta jest zresztą elementem zapisanym bezpośrednio w konstytucji Związku z roku $1999^{43}$.

Polityka europejska otworzyła nowy rozdział w relacjach pomiędzy władzami federalnymi i kantonalnymi. Z jednej strony wymusza na nich ścisłą współpracę, z drugiej generuje na tym tle wiele niejasności i pretensji. Przede wszystkim jednak uwidacznia kamuflowane do tej pory problemy we wzajemnych relacjach. Integracja ze Wspólnotą, nawet na poziomie układów bilateralnych, oznacza ujednolicenie wspólnej polityki w tych obszarach, które dotychczas leżały wyłącznie w gestii władz kantonalnych lub gminnych. Rodzi to szereg problemów kompetencyjnych, możliwych do rozwiązania jedynie na drodze głębszych reform.

System polityczny współczesnej Szwajcarii opiera się na federacji 26 kantonów, z których każdy cieszy się szeroką autonomią w zakresie polityki wewnętrznej. Jest on efektem przemian społeczno-politycznych, będących konsekwencją konfliktu wewnętrznego pomiędzy konserwatywnymi kantonami katolickimi a radykalnymi protestanckimi. Spór, którego punktem kulminacyjnym było opracowanie nowej konstytucji związkowej w roku 1848, dotyczył zmian kształtu porządku politycznego i podziału kompetencji ustawodawczych i wykonawczych pomiędzy władzą centralną a kantonami i gminami. Chodziło o stworzenie systemu, który byłby wypadkową dwóch, całkowicie odrzucanych struktur - państwa unitarnego i konfederacji. Wypracowana na drodze społecznego kompromisu konstytucja przekazywała władzy centralnej część kompetencji, pozostawiając jednak obszary najbliższe obywatelom oraz te, wymagające uwzględnienia regionalnej bądź lokalnej specyfiki, w gestii kantonów i gmin. W ten sposób stworzono system odwołujący się do historii i tradycji szwajcarskiej samorządności, unikając przy tym takiego modelu państwa, który oparty byłby na całkowitej decentraliza-

\footnotetext{
${ }^{43}$ Art. 54 par. 3 oraz art. 55 konstytucji.
} 
cji władzy. Konstytucja z roku 1848 zapewniała kantonom dość rozległą władzę wykonawczą, a dodatkowo istotny udział w procesie decyzyjnym federacji. Takie zagadnienia, jak system podatkowy, edukacja czy służba zdrowia regulowane są na poziomie kantonalnym lub gminnym. Wyłączna władza ustawodawcza federacji ogranicza się jedynie do kluczowych obszarów, związanych m.in. ze sprawami zagranicznymi, obroną narodową czy polityką monetarną. Ponadto kantony zobowiązane są do wdrażania prawa federalnego. Mają jednak w tym względzie pewną swobodę, która pozwala na uniknięcie konfliktów z kantonalnym prawodawstwem. W celu eliminacji ewentualnych nieporozumień czy komplikacji stworzono system wzajemnych konsultacji i informacji, zapewniający kantonom współudział w tworzeniu federalnego prawa ${ }^{44}$.

Z czasem system ten uległ przewartościowaniu, polegającemu na przesunięciu części kompetencji w kierunku federacji. Od pewnego czasu zauważyć możemy proces centralizacji władzy, który z jednej strony sprzyja procesowi decyzyjnemu, lecz z drugiej osłabia pozycję kantonów, doprowadzając do oczywistych tarć i nieporozumień pomiędzy władzą federalną i kantonalną. Związane jest to przede wszystkim z nowymi zjawiskami społeczno-politycznymi na świecie, takimi jak globalizacja czy integracja europejska, które wymuszają na biorących w nich udział podmiotach rewizję dotychczasowych strategii politycznych, a nawet, jak to dzieje się w przypadku Szwajcarii, adaptację własnego systemu prawnego i politycznego. Bardzo dobrym tego przykładem jest właśnie obszar polityki zagranicznej, będącej aż do początku lat 90 . XX w. wyłącznym obszarem kompetencyjnym władz federalnych. Podział ten wynikał nie tylko z postanowień zawartych w konstytucji, lecz również z ówczesnej sytuacji geopolitycznej, a także statusu neutralności Szwajcarii, oznaczającego w konsekwencji ograniczenie aktywności na arenie międzynarodowej. Taki wymiar polityki zagranicznej mógł być skutecznie realizowany wyłącznie przez władze federalne i nie wymagał szczególnego współudziału kantonów czy gmin, które zresztą dysponowały kompetencjami w zakresie prowadzenia własnej, tzw. małej polityki zagranicznej. Sprowadzała się ona do zawierania umów zagranicznych na szczeblu regionalnym, a więc ze zbliżonymi kompetencyjnie podmiotami, jak niemieckie landy czy austriackie regiony ${ }^{45}$. Układy o wolnym handlu, polegające na zniesieniu ceł, nie niosły za sobą żadnych dodatkowych zobowiązań wobec poszczególnych kantonów. Postanowienia zawierane $\mathrm{w}$ ramach unii celnych mogły być z powodzeniem realizowane na szczeblu federalnym, zgodnie z przyjętym podziałem kompetencji między federacją a kantonami.

Sytuacja uległa zmianie po upadku systemu bipolarnego. Nowa rzeczywistość geopolityczna dała impuls do intensyfikacji działań na rzecz integracji eu-

${ }^{44}$ Zob. więcej W. Linder, Demokracja szwajcarska. Rozwiązywanie konfliktów w społeczeństwie wielokulturowym, Wydawnictwo Wyższej Szkoły Pedagogicznej, Rzeszów 1996, s. 73.

${ }^{45}$ L. Goetschel, M. Bernath, D. Schwarz, op. cit., s. 63. 
ropejskiej, na płaszczyźnie gospodarczej, a także społeczno-politycznej. Próba włączenia Szwajcarii do Europejskiego Obszaru Gospodarczego, a następnie rokowania w sprawie układów bilateralnych nadały polityce zagranicznej nowy wymiar. Procesy integracyjne doprowadziły do intensyfikacji współpracy również w tych obszarach, które do tej pory, przynajmniej w rozumieniu klasycznym, nie były jej elementem składowym. Innymi słowy, polityka zagraniczna rządu federalnego zaczynała dotykać tych tematów, którymi zajmowały się do niedawna wyłącznie kantony. Dochodziło zatem do sytuacji, w której federacja, realizując przynależny jej obszar kompetencyjny, naruszała tym samym autonomię kantonów. Problemem w tym przypadku był brak faktycznego wpływu tych ostatnich na politykę zagraniczną w stopniu gwarantującym ochronę ich interesów. Powyższe zjawisko nie dotyczyło zresztą jedynie polityki europejskiej. Do analogicznych tarć dochodziło chociażby w przypadku aktywności Szwajcarii w ramach Światowej Organizacji Handlu. Chodziło zatem o uniknięcie sytuacji, w której cały ciężar, w tym przede wszystkim finansowy, wdrażania wypracowanych na szczeblu międzynarodowym porozumień, ponosiłyby kantony ${ }^{46}$. Konieczna była zatem weryfikacja dotychczasowego podziału kompetencyjnego pomiędzy federacją a kantonami.

Jeszcze w trakcie dyskusji nad włączeniem Szwajcarii do EOG stało się jasne, że rola kantonów wymaga wzmocnienia do poziomu, który gwarantowałby im równoprawny udział w kształtowaniu polityki zagranicznej państwa. Kwestia ta była niezwykle istotna zwłaszcza w perspektywie rozpoczęcia rozmów w sprawie umów bilateralnych z UE. Intencją kantonów było uzyskanie pozycji, która byłaby zagwarantowana konstytucyjnie ${ }^{47}$. Kantony dążyły również do utworzenia jednolitego organu, który reprezentowałby ich interesy, stanowiąc swego rodzaju łącznik pomiędzy władzą federalną a kantonalną. System polityczny Szwajcarii dopuszcza co prawda udział przedstawicieli kantonów w procesie decyzyjnym poprzez jedną z izb parlamentu - Radę Kantonalną (Ständerat). Członkowie Rady wybierani są jednak w powszechnych wyborach, co oznacza, iż nie reprezentują regionalnych rządów i tym samym nie są związani żadnymi instrukcjami ${ }^{48}$. Można zatem skonstatować, że znaczenie Rady Kantonalnej, jako reprezentanta kantonów, ma wymiar raczej symboliczny, wynikający z tradycji i historycznych zaszłości ${ }^{49}$. Doszło więc do paradoksalnej sytuacji, w której kantony, mające kluczowe znaczenie $\mathrm{w}$ wypełnianiu postanowień międzynarodowych porozumień,

\footnotetext{
${ }^{46}$ Federacja odpowiedzialna jest głównie za ustawodawstwo i partycypuje jedynie w niewielkim stopniu w kosztach wdrażania ustaw.

${ }^{47}$ L. Bösch, Mitwirkung der Kantone in der Europapolitik: Strategie und Standortbestimmung, [w:] P. Barblan, A. Koeller, R. Oppenheim, Die Stellung der Schweiz in Europa, Forum Helveticum, Menziken 2007, s. 35.

${ }^{48}$ Według art. 161 ust. 1 konstytucji z 1999 r.

${ }^{49}$ Pierwowzorem dzisiejszej Rady były tzw. Tagsatzung - zgromadzenia reprezentantów władz kantonalnych.
} 
nie dysponowały żadnymi możliwościami akcentowania własnych interesów, a ich pozycja ograniczała się jedynie do obowiązku realizacji zaciągniętych przez władze federalne zobowiązań.

W perspektywie dalszego rozwoju współpracy dwustronnej z Unią Europejską rozgorzała dyskusja nad kompatybilnością szwajcarskiego federalizmu z postępującym procesem integracyjnym. Należało odpowiedzieć na pytanie, na ile elementy składowe tego systemu wykazują wystarczające możliwości adaptacyjne. Główny nacisk kładziono przy tym na czynniki mające największy wpływ na kształt procesu decyzyjnego w Szwajcarii, tj. demokrację bezpośrednią wraz z jej najważniejszą formą, czyli referendum oraz rolę i pozycję kantonów. Pierwszy wspomniany element, choć niezwykle istotny, zepchnięty został na dalszy plan. Wobec konieczności rezygnacji, przynajmniej czasowej, z pełnego członkostwa we Wspólnocie, problem demokracji bezpośredniej, jako ewentualnej bariery w integracji, nie wydawał się palący i w toku naukowego czy też politycznego dyskursu nie odgrywał decydującej roli ${ }^{50}$. Powoływano się tutaj na doktrynę bezpieczeństwa Szwajcarii, która pomimo kolejnych modyfikacji, z roku 1973 oraz $1988^{51}$, bazowała nadal na statusie neutralności, odrzucającej możliwość członkostwa w organizacjach międzynarodowych o charakterze ponadnarodowym. Zgoła odmienną funkcję w powyższej dyskusji pełniła kwestia faktycznej roli kantonów jako podmiotów, które w dobie nowej polityki europejskiej miały przecież mieć decydujące znaczenie.

$\mathrm{Na}$ wprowadzenie pewnych rozwiązań konstytucjonalnych nie zdecydowano się od razu. Pierwszym krokiem, mającym wzmocnić pozycję kantonów poprzez ich aktywny udział w kreowaniu polityki zagranicznej, było stworzenie jednolitego organu, o charakterze informacyjno-konsultacyjnym. Konferencja Rządów Kantonalnych (Konferenz der Kantonsregierung), w skrócie KdK, powstała w roku 1993, a więc wkrótce po nieudanej próbie włączenia Szwajcarii do Europejskiego Obszaru Gospodarczego. Głównym celem tego organu było stworzenie przedstawicielstwa wszystkich kantonów, spójnie reprezentującego interesy wszystkich władz regionalnych i współdecydującego o polityce Związku ${ }^{52}$. Co ważne, KdK nie jest instrumentem przeznaczonym wyłącznie do realizacji polityki europejskiej, lecz bardziej instytucją nacisku czy też oddziaływania na te obszary, które z punktu widzenia interesów kantonów mają dla nich kluczowe znaczenie. Należy wskazać przy tym na jeden z najważniejszych wyznaczników,

${ }^{50}$ Por. R.E. Germann, Die Europatauglichkeit der direktdemokratischen Institutionen der Schweiz, „Schweizerisches Jahrbuch für politische Wissenschaft” 1991, s. 257-269; B. Kaufmann, G. Kreis, A. Gross, Direkte Demokratie und europäischen Integration. Die Handlungsspielräume der Schweiz, „Baslerschriften zur europäischen Integration” [Europainstitut der Universität Basel, Basel] 2005, Nr. 75.

${ }^{51}$ Zob. D. Popławski, Szwajcarska polityka bezpieczeństwa..., s. 134-144.

${ }^{52}$ B. Münger, Die Konferenz der Kantonsregierungen, [w:] D. Freiburghaus, Die Kantone und Europa, Bern 1994, s. 249. 
świadczących o precedensowym charakterze KdK, a więc na jego skład osobowy. W obradach Konferencji biorą udział przedstawiciele rządów kantonalnych, co gwarantuje, iż decyzje, które zapadają większością 18 głosów (każdy kanton ma jeden głos), są prawdziwym odzwierciedleniem faktycznych stanowisk kantonów, odpowiadających ich prawdziwym interesom ${ }^{53}$. Zgodnie z postanowieniami zawartymi w konstytucji, o której będzie jeszcze mowa później, władze federalne mają obowiązek konsultowania swych decyzji z KdK. Wypracowane przez Konferencję stanowisko, w kwestiach o szczególnym dla nich znaczeniu, ma dla Związku charakter wiążący ${ }^{54}$.

W toku rozmów prowadzonych pomiędzy KdK a Radą Związkową podjęto również decyzję o wzmocnieniu wzajemnego przepływu informacji poprzez powołanie specjalnych przedstawicieli kantonów, funkcjonujących bezpośrednio przy Departamentach Związkowych. Od października roku 1994 stworzono dodatkowe etaty w Biurze Integracyjnym (Integrationsbüro EDA/EVD), w Departamencie Sprawiedliwości i Policji (EJPD - Eidgenössisches Justiz- und Polizeidepartement) oraz przy szwajcarskiej misji w Brukseli. Osoby zatrudnione na tych stanowiskach mają za zadanie usprawniać przepływ informacji pomiędzy władzami kantonalnymi i federalnymi. Zadaniem przedstawicieli kantonów jest informowanie nie tylko o podjętych przez Związek decyzjach, lecz również o zamiarach, obranej strategii czy głównych kierunkach polityki rządu, np. wobec instytucji Unii Europejskiej. Istotnym elementem wzmacniającym pozycję kantonów jest także możliwość udziału eksperta delegowanego z ramienia KdK w oficjalnych delegacjach Związku. Dzięki temu kantony mają własnego przedstawiciela, biorącego udział w rokowaniach ze stroną unijną w ramach tak istotnych obszarów, jak transport powietrzny i lądowy, swoboda przepływu osób czy system podatkowy. Doświadczenia i efekty tej formy współpracy okazały się dla obu stron niezwykle cenne, co znalazło odzwierciedlenie w dokumencie podsumowującym zawarcie pierwszego pakietu Bilaterale I, opublikowanego w roku 1999 przez Radę Związkową 55.

Decyzje podjęte przez władze federalne były bardzo istotnym krokiem na rzecz nie tylko wyraźniejszego zaznaczenia roli kantonów, lecz zarazem ważnym elementem spajającym system federacyjny, który w perspektywie nowych wyzwań integracyjnych stanął w obliczu poważnego problemu kompetencyjnego. Utworzenie

${ }^{53} \mathrm{~W}$ toku dyskusji nad formułą pracy KdK, w kontekście ewentualnych reform mających na celu zwiększenie jej efektywności, wysunięto wniosek, aby decyzje zapadały większością 14 kantonów, zamieszkanych przynajmniej w połowie przez obywateli Szwajcarii.

${ }^{54}$ Zob. stanowisko kantonów wobec układów bilateralnych: Erläuterung zu den Bilateralen Abkommen II, Konferenz der Kantonsregierungen, 2004 lub Zusatzprotokoll Personenfreizügigkeitsabkommen, Konferenz der Kantonsregierungen, 2004. Dokumenty dostępne online: http:// www.kdk.ch/int/kdk/de/wissen/bilatabk.html (25.06.2009).

${ }^{55}$ Botschaft des Bundesrates zur Genehmigung der sektoriellen Abkommen zwischen der Schweiz und der EG, Bern 1999, BBI Nr. 34, 6144-6145. 
KdK oraz powołanie stałych przedstawicieli kantonów w organach związkowych nie oznaczało jednak całkowitego wyeliminowania wątpliwości związanych z faktycznymi możliwościami adaptacyjnymi federalizmu Szwajcarii. Postępująca integracja europejska, w tym ewentualne członkostwo we Wspólnocie, prowokowały kolejne problemy, które wymagały szerszych, systemowych rozwiązań.

W czerwcu 2012 r. podjęto decyzję o utworzeniu Komitetu Sterującego jako stałego organu wymiany informacji między Związkiem a Kantonami ${ }^{56}$. Główną ideą jego powołania było wzmocnienie współpracy celem podejmowania wspólnych, uwzględniających interesy obu stron, decyzji dotyczących szeroko rozumianej polityki europejskiej. Jest to również element realizacji praw i obowiązków wynikających z zapisów konstytucyjnych. W skład Komitetu Sterującego wchodzą przedstawiciele KdK, w tym przewodniczący Konferencji. Stronę rządową reprezentują szefowie resortu spraw zagranicznych oraz gospodarki. Komitet obraduje w regularnych odstępach, nie rzadziej jednak niż raz na dwa miesiące.

Jak już wcześniej wspomniano, jedną z podstawowych cech federalizmu Szwajcarii jest ścisły podział kompetencji pomiędzy władzą federalną i kantonalną. Warto jednakże zauważyć, iż federalizm, jako najważniejszy element ustroju politycznego państwa, nie jest zapisany explicite w konstytucji, lecz znajduje swoje odzwierciedlenie w treści poszczególnych artykułów. Przykładowo, część poświęcona prowadzeniu polityki zagranicznej jasno określa kompetencje Związku i kantonów, przyznając w tym obszarze władzom federalnym rolę nadrzędną. Nowelizacja konstytucji z roku 1999 wzmocniła jednakże w tym względzie pozycję kantonów. W przeciwieństwie do poprzedniej ustawy zasadniczej z roku 1874 kantony zyskały możliwość współdecydowania lub przynajmniej wyraźnego oddziaływania na decyzje polityczne Związku. W tym kontekście szczególnie istotna jest rola informacyjna i konsultacyjna. Władze federalne mają konstytucyjny obowiązek uwzględnienia stanowiska kantonów w sprawach mieszczących się w ramach ich obszarów kompetencyjnych lub dotykających ich , ,istotnych interesów"s7.

Na tym jednakże nie kończą się formalne instrumenty wpływania kantonów na politykę zagraniczną Związku, choć przyznać należy, że pozostałe mają charakter raczej wtórny, a ich faktyczne oddziaływanie wydaje się dość ograniczone. Bardzo dobrym tego przykładem jest inicjatywa kantonalna, dająca możliwość przedstawienia parlamentowi propozycji własnej uchwały. Instrument ten stosowany jest najczęściej bezpośrednio przed etapem międzynarodowych negocjacji, w celu zwrócenia uwagi Związku na potrzeby poszczególnych regionów czy też

${ }^{56}$ Bund und Kantone unterzeichnen Vereinbarung zum Europadialog, Medienmitteilung EDA/ EVD, Bern 05.06.2012.

${ }^{57}$ Art. 55 Bundesverfassung, cyt. za: B. Tornay, I. Renfer, A. Auer, Die Kantone zwischen EU-Beitritt und bilateralen Weg: Direkte Demokratie, Mitwirkung an der Europapolitik und Umsetzung, [w:] Konferenz der Kantonsregierungen (Hrsg.) Zwischen EU-Beitritt und bilateralem Weg: Überlegungen und Reformbedarf aus kantonaler Sicht, Schulthess, Zurich-Basel-Genf 2006, s. 252. 
swoistego zamanifestowania własnych interesów. Należy przy tym zwrócić uwagę na fakt, iż ze względu na niewiążący charakter takiego projektu, taki sposób oddziaływania kantonów jest raczej mało skuteczny. Kolejnym instrumentem są konsultacje społeczne (Vernehmlassungsverfahren), stosowane zarówno w przypadku ustaw krajowych, jak i międzynarodowych. Słabością tego procesu jest niestety fakt, że w przeciwieństwie do ustaw krajowych projekt porozumienia kierowany jest do konsultacji dopiero po uzgodnieniu jego treści przez umawiające się strony. Oznacza to, iż kantony nie mają w tym przypadku faktycznego wpływu na ostateczny kształt porozumienia.

Należy jednak zauważyć, że normy prawne, będące konsekwencją międzynarodowych porozumień, wdrażane są na poziomie kantonalnym z uwzględnieniem lokalnego prawa, w tym przede wszystkim kantonalnej konstytucji. Daje to zatem pewną swobodę interpretacyjną, pozwalającą niekiedy na zastosowanie określonych instrumentów, chroniących interesy poszczególnych kantonów.

Minione lata pokazały na ile instrumenty, którymi dysponują władze kantonalne, pozwalają na wypracowanie własnej strategii politycznej, gwarantującej ochronę interesów i pozycji kantonów w ramach federacji. Najlepszym sprawdzianem tych możliwości był okres negocjacji ze stroną unijną pierwszego pakietu układów bilateralnych, zwanych Bilaterale I. Współpraca dwustronna z UE była także testem skuteczności $\mathrm{KdK}^{58}$. Efekty podjętych działań należy oceniać pozytywnie. Kantony dowiodły, że mogą być traktowane jako równorzędny partner, potrafiący szybko i sprawnie formułować własne postulaty, mając przy tym na uwadze interesy nie tylko własne, lecz również całego Związku ${ }^{59}$. Właśnie ta jednomyślność przyczyniła się zapewne do uzyskania przez Szwajcarię bardzo korzystnych warunków, na jakich opiera się współpraca bilateralna ze Wspólnotą.

\subsubsection{RELACJE MIĘDZY ZWIĄZKIEM A KANTONAMI W PERSPEKTYWIE INTEGRACJI Z UNIĄ EUROPEJSKĄ. RAPORT EUREFKA}

W dokumencie podsumowującym podpisanie drugiego pakietu porozumień wskazuje się na elementy, które w przyszłości zapewniłyby wzmocnienie działań KdK w zakresie współdziałania i współdecydowania kantonów w polityce zagranicznej Związku ${ }^{60}$. Powyższe wnioski nie były zresztą jedynymi, które niosły ze sobą postulaty przeprowadzenia rewizji podstaw prawnych, na których opiera się proces decyzyjny, głównie w kontekście realizacji polityki zagranicznej. Pod wpływem dyskusji nad inicjatywą „Tak dla Europy” ( Ja zu Europa $)^{61}$, będącą

${ }^{58}$ B. Tornay, I. Renfer, A. Auer, op. cit., s. 255.

${ }^{59}$ Ibidem.

${ }^{60}$ Botschaft zur Genehmigung der bilateralen Abkommen zwischen der Schweiz und der Europäischen Union vom 1. Oktober 2004, BBI, 2004, Nr. 44, s. 5623.

${ }^{61}$ Inicjatorem kampanii na rzecz włączenia Szwajcarii do UE był Neue Europäische Bewegung Schweiz, zob. www.europa.ch. 
próbą przyspieszenia członkostwa Szwajcarii w UE, Zgromadzenie Plenarne KdK podjęło decyzję o powołaniu specjalnej grupy eksperckiej Europa - Reformen der Kantone (EuRefKa). Jej zadaniem było wypracowanie nowej strategii politycznej dla kantonów wraz z propozycją reformy wewnętrznego porządku prawnego, który umożliwiałby lepsze przystosowanie do wymogów integracji europejskiej. Prace rozpoczęte jeszcze w roku 1999 zaowocowały stworzeniem, w ciągu dwóch lat, pierwszego raportu, analizującego podział kompetencyjny pomiędzy kantonami a Związkiem, doświadczenia ze współpracy w ramach realizacji polityki europejskiej oraz wpływ członkostwa na politykę fiskalną i wymiar sprawiedliwości W regionach ${ }^{62}$. Wkrótce po jego opublikowaniu podjęto decyzję o konieczności przygotowania jednolitego dokumentu strategicznego, który byłby pierwszym oficjalnym dokumentem prezentującym wspólne stanowisko kantonów wobec procesów integracyjnych. Ostatecznie został on przyjęty przez Zgromadzenie Plenarne KdK w dniu 12 marca 2004 r. Główne postulaty dotyczyły konieczności przyjęcia przez wszystkie kantony jednolitej strategii politycznej. Przeważały przy tym głosy podważające słuszność kontynuacji współpracy na drodze bilateralnej.

Strategie EuRefKa opracowywane są na podstawie analizy najważniejszych problemów, przed jakimi stoi Szwajcaria w perspektywie dalszej integracji europejskiej. Należy bowiem wyróżnić dwa możliwe warianty rozwoju współpracy. Jeden z nich zakłada rozszerzenie układów bilateralnych na nowe obszary, drugi zaś przewiduje akcesję Szwajcarii do struktur Wspólnoty. Należy zauważyć, iż zarówno pierwszy, jak i drugi wariant niesie za sobą określone problemy. Integracja europejska, bez względu na jej ostateczną formę, oparta jest nie na umowach międzynarodowych, lecz na tworzeniu wspólnego dorobku prawnego. Oznacza to konieczność transponowania Aquis communitaire do własnego porządku prawnego. W przypadku Szwajcarii będzie się to odbywać przede wszystkim na poziomie kantonalnym. Jeżeli zatem władze w Bernie podejmą decyzję o pełnej integracji, wpływ organów federacji na proces decyzyjny w ramach Wspólnoty przybierze charakter raczej symboliczny. Członkostwo Szwajcarii w UE doprowadzić może do drastycznego ograniczenia tych funkcji, które uznawane są za kluczowy element federalizmu Szwajcarii, czyli demokracji bezpośredniej. Liczne analizy naukowe wskazują na problem niekompatybilności obecnych struktur federacyjnych $\mathrm{z}$ procesem decyzyjnym $\mathrm{w}$ ramach $\mathrm{UE}^{63}$. Trudno się $\mathrm{z}$ tym nie zgodzić. W praktyce bowiem funkcjonowanie takich elementów demokracji bezpośredniej, jak referendum, nie będzie możliwe, przynajmniej w takiej formie, w jakiej funkcjonuje ono obecnie. Należy zatem, co postuluje zresztą raport EuRefKa, wypracować nową strategię, która wzmocniłaby rolę kantonów

${ }^{62}$ Powyższe wnioski opublikowane zostały w raporcie Die Kantone vor der Harausforderung eines EU-Beitritts, Bericht der Arbeitsgruppe „Europa-Reformen der Kantone”, Zürich 2001.

${ }^{63}$ Zob. J. Steiner, Continental Integration and Swiss Federalism: a New Openness to Europe?, [w:] H. Lazar, H. Telford, R.L. Watts, The Impact of Global and Regional Integration on Federal Systems, McGill-Queen's University Press, Montreal 2003. 
zarówno w przypadku członkostwa Szwajcarii w UE, jak i dalszej intensyfikacji współpracy bilateralnej. Warto przy tym skorzystać z doświadczenia tych państw europejskich, które ze względu na zbliżoną strukturę wewnętrzną borykały się z podobnymi problemami. Dobrym przykładem są tutaj inne państwa niemieckojęzyczne - Austria oraz Niemcy ${ }^{64}$. Oba zdecydowały się na nowelizację ustawy konstytucyjnej na początku lat 90., a więc w przypadku Austrii jeszcze przed członkostwem w UE. Różnice te dotyczą zresztą nie tylko aspektów integracyjnych, lecz obecne są już na poziomie zwykłych relacji zewnętrznych. Rząd Niemiec zobowiązany jest przykładowo do przedstawienia landom projektu umowy międzynarodowej jeszcze przed jej parafowaniem przez obie strony, a więc znacznie wcześniej niż odbywa się to w przypadku Szwajcarii. Na tym jednak nie koniec. Przede wszystkim wzmocniono pozycję regionów poprzez udział ich przedstawicieli we wszystkich ważniejszych organach biorących udział w procesie decyzyjnym zarówno na poziomie krajowym, jak i wspólnotowym. Szczególnie dobrze widoczne jest to w odniesieniu do Niemiec, gdzie poszczególne landy mają biura regionalne w Brukseli, zatrudniające często po kilkaset osób i stanowiące doskonałą platformę lobbingu na rzecz własnego regionu ${ }^{65}$. Paradoksalnie możemy w tym przypadku mówić nawet o zjawisku konkurowania pomiędzy landami. Szczególnie istotne jest to w aspekcie gospodarczym. W Brukseli zapada bowiem wiele istotnych decyzji, wpływających bezpośrednio na rozwój ekonomiczny państw członkowskich. Warto również wspomnieć o ekspertach, delegowanych przez władze poszczególnych landów do udziału w komisjach lub grupach roboczych, powoływanych na szczeblu UE.

Konstytucja z roku 1999, pomimo cennych modyfikacji, nie zabezpiecza zatem w wystarczającym stopniu interesów kantonów. Jean François Aubert, we wspomniany wyżej raporcie z roku 2001, zwraca uwagę na słabość interpretacyjną pewnych zapisów, które, w miarę postępującej współpracy z UE, tracą swoje pierwotne znaczenie ${ }^{66}$. Widoczne jest to chociażby w artykule 55, mówiącym o współdziałaniu kantonów w procesie decyzyjnym, dotyczącym ich istotnych (,wesentlichen") interesów. Zdaniem Auberta, problemem jest właśnie to ostanie sformułowanie, które dopuszcza zbyt duży margines interpretacyjny. Niekiedy trudno bowiem jasno określić wagę danego obszaru tematycznego. Należy przy tym zwrócić uwagę na fakt, że w wielu przypadkach mamy do czynienia z sytuacją, w której wdrażanie postanowień jednej umowy czy też implementowa-

${ }^{64}$ Por. R.J. Schweitzer, S.C. Brunner, Die Mitwirkung der Bundesländer an EU-Vorhaben in der Bundesrepublik Deutschland und in Österreich, Schweizer Schriften zur Europäischen Integration Nr. 14, Bern-Zürich 1998.

${ }^{65}$ Największe biuro regionalne, liczące ok. 50 pracowników, ma obecnie Bawaria.

${ }^{66}$ J.F Aubert, Mitwirkung der Kantone an der europäischen Politik im Falle eines Beitritts der Schweizerischen Eidgenossenschaft zur Europäischen Union, [w:] Konferenz der Kantonsregierung (Hrsg.), Die Kantone vor der Herausforderung eines EU-Beitritts, Bericht der Arbeitsgruppe „Europa-Reformen der Kantone”, Zürich 2001, s. 175. 
nie porządku prawnego $\mathrm{w}$ danym obszarze wiąże się z koniecznością szerszych modyfikacji prawnych, nieobjętych postanowieniami dwustronnego porozumienia. Dzieje się tak w przypadku chociażby sektora energetycznego, ściśle powiązanego z ochroną środowiska. Oddzielenie tych dwóch aspektów okazuje się w praktyce niezwykle trudne czy wręcz niemożliwe do spełnienia. Biorąc powyższe pod uwagę, autorzy raportu proponują zmodyfikowanie przedmiotowego zapisu, nadając funkcjom konsultacyjnym i informacyjnym kantonów charakter obligatoryjny, bez względu na zakres tematyczny. Podobna zasada stosowana jest w Austrii oraz w Niemczech.

Wprowadzenie powyższych poprawek, nadających artykułowi 55 nieco bardziej restrykcyjny charakter, może jednak znacząco obniżyć zdolności negocjacyjne Związku. W niektórych sytuacjach, wymagających nie tylko dynamicznych, lecz przede wszystkim elastycznych postaw negocjacyjnych, konieczność każdorazowego uwzględniania stanowiska kantonów może wpłynąć negatywnie na ostateczny efekt rokowań. Jak proponuje Aubert, należałoby wprowadzić obowiązek konsultacji, z zastrzeżeniem jednakże, iż nie będzie on dotyczył spraw „leżących w interesie narodowym"67. Byłoby to szczególnie istotne w przypadku kontynuowania drogi bilateralnej. Praktyka pokazuje bowiem, że współpraca dwustronna coraz częściej odnosi się do obszarów mieszczących się w granicach kompetencyjnych kantonów. Takie obszary tematyczne, jak edukacja, bezpieczeństwo, prawo azylowe czy imigracyjne, swoboda przepływu osób lub realizacja układów Schengen/Dublin tylko w niewielkim stopniu zależne są od władz federalnych. Układy bilateralne wymuszają zatem przyjmowanie zewnętrznego porządku prawnego oraz realizację polityki, która bardzo często godzi w interesy kantonów lub jest w praktyce niesłychanie trudna do zrealizowania. Należy pamiętać, że każdy kanton ma własną konstytucję i odrębne ustawodawstwo, nie wspominając już o systemie edukacyjnym, podatkowym czy socjalnym. Trudno zatem wprowadzać odgórne regulacje, nie uwzględniając przy tym specyfiki regionalnej i bez udziału organów, które za wdrażanie tychże odpowiadają. Można zatem wysnuć wniosek, że współpraca dwustronna prowadzi, paradoksalnie, do większego uzależnienia Szwajcarii od UE. Pomimo ogólnie pozytywnych aspektów dotychczasowej współpracy, coraz częściej dochodzi do spięć i konfliktów. Dotyczy to zwłaszcza sfery finansowej, będącej typowo newralgicznym obszarem. Szwajcaria jako państwo, które zawdzięcza swoją pozycję ekonomiczną dobrze rozbudowanemu systemowi fiskalnemu oraz usługom bankowym, jest szczególnie wrażliwa na wszelkie próby ograniczenia autonomii w tym zakresie. Typowym przykładem może być, toczący się od dłuższego czasu, spór w sprawie wysokości kantonalnych podatków, ograniczających, zdaniem Brukseli, swobodę konkurencji. Unia Europejska powołuje się przy tym na Uklad o Wolnym Handlu,

${ }^{67}$ J.F. Aubert, op. cit., s. 176. 
zawarty pomiędzy Szwajcarią a EWG jeszcze w roku $1972^{68}$. Pomimo, skądinąd słusznych, argumentów Berna, podważających zasadność unijnych roszczeń, należy oczekiwać, iż w najbliższym czasie konflikt ten nie zostanie zażegnany.

Raport EuRefKa wskazuje na konieczność przeprowadzenia pewnych reform i wyznaczenia przy tym nowych strategii działania. Osiąganie celów politycznych, określonych przez rządy poszczególnych kantonów, będzie możliwe jedynie poprzez zastosowanie jednego z czterech możliwych scenariuszy. Jean F. Aubert wymienia wśród nich konieczność wypracowania nowych metod w ramach Rady Kantonów, przy zachowaniu przy tym jej obecnego kształtu, zmodyfikowania Rady Kantonów lub KdK bądź też stworzenia zupełnie nowego organu przedstawicielskiego. Ten ostatni wariant wydaje się jednak najmniej realny. Tworzenie dodatkowego organizmu, który, po pierwsze, organizacyjnie musiałby być bardzo zbliżony do już istniejących, a po drugie, odbierałby im część kompetencji, jest działaniem zbędnym. Należałoby raczej wykorzystać dotychczasowe doświadczenie, uzyskane w drodze współpracy bilateralnej z UE, w celu przeprowadzenia jedynie pewnych modyfikacji w ramach już istniejących struktur. Tutaj również można by wzorować się na doświadczeniach niemieckich. Modyfikacja Rady Kantonów (Ständerat) w kierunku zbliżonym do Bundesratu zapewne stanowiłaby jedno z rozwiązań. Chodziłoby głównie o nadanie Radzie silniejszych cech przedstawicielskich poprzez zmianę jej składu osobowego, który pozwalałby na wprowadzenie do parlamentu reprezentantów władz kantonalnych. Jeżeli jednak stosunek liczby deputowanych do poszczególnych kantonów pozostawimy na obecnym poziomie, mielibyśmy do czynienia z problemem zachowania właściwej proporcji pomiędzy kantonami. Jak wiadomo, kantony różnią się między sobą liczbą mieszkańców. Rozbieżności w tym względzie są znaczne. W samej tylko stolicy kraju - Bernie mieszka kilkanaście razy więcej osób niż w całym kantonie Appenzell. Teoretycznie zatem takie kantony, jak Zürich czy Winterthur winny mieć w parlamencie większą liczbę reprezentantów. Fakt ten sprawia, że mielibyśmy do czynienia z niedoreprezentowaniem znacznej części obywateli. Zjawisko to nie byłoby, co prawda, niczym nowym. Problem ten pojawia się chociażby przy okazji każdego referendum, w którym bierze się pod uwagę większość głosów obywateli i zarazem kantonów ${ }^{69}$. Bardzo często mamy tutaj do czynienia z sytuacją, w której mniejszość blokuje wolę większości, albowiem małe kantony mają w tym przypadku taką samą wagę jak te o znacznie wyższym wskaźniku zaludnienia. Poza tym, liczba reprezentantów w obecnej Radzie Kantonów rów-

${ }^{68}$ Zob. Steuerkontroverse, Medienmitteilung, Integrationsbüro EDA/EVD, 2007. Dokument dostępny online: http://www.europa.admin.ch/themen/00499/00503/00567/index.html?lang=de (25.06.2009); Der Steuerstreit mit der EU wird bald konkret, „Neue Zürcher Zeitung”, 22. Januar 2008.

${ }^{69}$ Jest to tzw. zasada podwójnej większości, wymagana przy wprowadzaniu poprawek do konstytucji bądź próbie włączenia Szwajcarii do organizacji o charakterze ponadnarodowym. Zob. W. Linder, op. cit., s. 120. 
nież wskazuje na pewną nierównowagę. Rada składa się z 46 deputowanych, po dwóch z każdego kantonu i po jednym z tzw. półkantonu ${ }^{70}$. Stan osobowy izby nie jest jednak dużym problemem, ze względu na dość ograniczone kompetencje, a przede wszystkim fakt, iż nie zasiadają w niej reprezentanci władz kantonalnych. Członkowie Rady, wybierani w wyborach powszechnych, reprezentują najczęściej określone grupy interesu, np. bankierów lub rolników ${ }^{71}$. Wynika to zresztą z doświadczeń historycznych. Rada była zazwyczaj odzwierciedleniem aktualnych podziałów społecznych i służyła z reguły do osiągania korzyści przez różne polityczne siły, w zależności od liczby posiadanych w niej miejsc. Do tego dodać należy, że głosy deputowanych nie są oddawane en bloc, co oznacza, że reprezentanci tego samego kantonu mogą w danej sprawie głosować zupełnie odmiennie. Niemniej jednak w przypadku zmiany charakteru Rady i jej funkcji należałoby zrewidować również system podziału głosów. Można się w tym przypadku odnieść także do niemieckiego Bundesratu, w którym poszczególne kraje federalne mają od trzech do sześciu reprezentantów.

Osobnym zagadnieniem pozostaje zakres posiadanych kompetencji. Wskazuje się tutaj na dwa główne problemy. Po pierwsze, Rada Kantonów nie sprawuje priorytetowego nadzoru nad wykonywaniem ustaw federalnych. Po drugie, odnosząc się bezpośrednio do poruszanych w niniejszej pracy zagadnień, współdziałanie Rady w zakresie realizacji polityki zagranicznej ma również bardzo ograniczony charakter. Rząd jest co prawda zobowiązany do poddania projektu umowy międzynarodowej pod głosowanie obu izbom parlamentu, jeszcze przed jej ostateczną ratyfikacją. Niemniej jednak zgoda na ratyfikację nie ma charakteru wiążącego, a jest bardziej przyzwoleniem na jej dokonanie. Ostateczną decyzję podejmuje zawsze rząd, który może w każdej chwili zrezygnować z ratyfikacji umowy. Wyjątek stanowią jedynie porozumienia zawierane w ramach Międzynarodowej Organizacji Pracy ${ }^{72}$. Udział obu izb parlamentu ma więc tutaj charakter bierny, ograniczają się jedynie do akceptowania umowy bez rzeczywistego wpływu na jej kształt. Ponadto należy zwrócić uwagę na fakt, że istnieje szereg umów, których zawarcie nie wymaga zgody parlamentu. Nie należą do nich, co prawda, umowy bilateralne z UE, gdyż te z zasady narzucają Szwajcarii szereg zobowiązań. Istnieje jednak część umów, których podpisanie służy realizacji wcześniej przyjętych, zgodnie z zasadą, że raz określony cel nie wymaga cyklicznej weryfikacji.

Według artykułu 150 ust. I konstytucji członkowie Rady Narodowej są reprezentantami Narodu, członkowie Rady Kantonalnej zaś przedstawicielami

${ }^{70}$ Statut tzw. półkantonu mają: Appenzell Innerrhoden, Appenzell Außerrhoden, Basel-Stadt, Basel-Landt, Obwalden, Nidwalden. Wynika to z zaszłości historycznych i podziałów w ramach dawnych, pełnych kantonów.

${ }^{71}$ System wyborczy zależy od przyjętych w danym kantonie zasad. Zazwyczaj jest to system większościowy. W przeszłości członkowie Rady wybierani byli przez parlamenty kantonalne.

72 J.F. Aubert, Parlament a Zgromadzenie Federalne, [w:] Parlament Szwajcarii, Wydawnictwo Sejmowe, Warszawa 2000, s. 36. 
Kantonów. Chodzi tutaj o wyraźne rozgraniczenie znaczenia obu Izb. Należałoby jednak zastanowić się nad faktyczną różnicą pomiędzy obydwoma Izbami, jeżeli deputowani zarówno jednej, jak i drugiej, z zasady mają obowiązek działania w interesie Związku i reprezentowania interesów własnych wyborców. Analizując dalej, posłowie zasiadający w Radzie Narodowej wybierani są przez mieszkańców danego kantonu. Reprezentując ich interesy, reprezentują, przynajmniej pośrednio, interesy Kantonu, z którego zostali wybrani. Identycznie jest w przypadku deputowanych do Rady Kantonalnej. Osoby w niej zasiadające siłą rzeczy w większym stopniu reprezentują interesy własnych wyborców czy też określonych grup społecznych, a jedynie w pośredni sposób Kantonów.

Widać zatem wyraźnie, iż polityka europejska stawia nowe wyzwania i zmusza do przeprowadzenia poważnych modyfikacji w zakresie funkcjonowania Rady Kantonalnej. W dyskursie politologicznym pojawia się najczęściej propozycja stworzenia gremium, w skład którego wchodziliby przedstawiciele władz poszczególnych kantonów, a nie ich reprezentanci, wybierani w drodze wyborów powszechnych. Dobrym rozwiązaniem mógłby okazać się wybór reprezentantów przez parlamenty kantonalne lub, jak to dzieje się w przypadku KdK, przez władze danego Kantonu. Osobnym problemem byłaby kwestia ustalenia kompetencji tak zmodyfikowanej struktury, oczywiście w celu nadania jej szerszych funkcji i wzmocnienia pozycji w procesie legislacyjnym. Powołując się na cytowanego już J.F. Auberta ${ }^{73}$, należałoby również w tym miejscu postawić pytanie, czy ewentualne zmiany powinny uwzględniać potrzebę zachowania zasady równości głosów, bez względu na rozmiar kantonu oraz czy obie izby parlamentu powinny dysponować podobnymi kompetencjami? Z uwagi na brak miejsca w niniejszej pracy dla tego typu rozważań zostawmy postawione tu pytania bez odpowiedzi.

Wróćmy natomiast do problemu funkcjonowania $\mathrm{KdK}$ w warunkach postępującej integracji z Unią Europejską ${ }^{74}$. Konferencja Rządów Kantonalnych jest organem wyjątkowym, który poza funkcją konsultacyjno-reprezentacyjną nie ma żadnych dodatkowych kompetencji o charakterze ustawodawczym bądź kontrolnym. Oczywiście jego rola, jako organu reprezentującego interesy kantonów, jest niepodważalna. Obiektywna ocena funkcjonowania KdK wymaga jednak dokładniejszej analizy.

Biorąc pod uwagę specyfikę demokracji Szwajcarii, jedną z podstawowych wad KdK jest niski poziom udziału obywateli w procesie decyzyjnym. Z jednej strony zapewniona jest dzięki temu wysoka sprawność formułowania stanowiska. Z drugiej jednak pomija się najważniejsze elementy, na których oparta jest demokracja w Szwajcarii, a więc bezpośredni udział obywateli w procesie decyzyjnym w postaci referendum lub chociażby pośredni, poprzez parlament kantonalny. Najczęstszym zarzutem stawianym pod adresem KdK jest zatem brak społecznej legitymizacji. Warto zwrócić przy tym również uwagę na niski poziom

${ }^{73}$ J.F Aubert, Mitwirkung der Kantone..., s. 192.

${ }^{74}$ Zob. A. Auer, Neue Partnerschaft im schweizerischen Bundesstaat, [w:] Die Schweiz, „Neue Helvetische Gesellschaft" 1997/1998, s. 137-150. 
oddziaływania parlamentów kantonalnych na funkcjonowanie Konferencji. Parlamenty nie są w stanie wpływać w żaden sposób na stanowisko członków KdK. Z kolei ci nie są zobligowani do wcześniejszego poinformowania parlamentów kantonalnych o stanowisku władz kantonu, jakie zostanie przedstawione na forum $\mathrm{KdK}$. Jednym z rozwiązań tego problemu, przedstawianym we wspomnianej już analizie EuRefKa, jest postulat przeprowadzania okresowych posiedzeń parlamentu, dotyczących tematów, które poruszane są aktualnie na forum Konferencji. Wnioski z posiedzeń, w postaci uchwał bądź instrukcji, mogłyby być następnie przekazywane do KdK, mając oczywiście charakter wiążący.

\subsubsection{STANOWISKO KANTONÓW WOBEC INTEGRACJI Z UNIĄ EUROPEJSKĄ}

Rozwój współpracy z UE, w tym również w perspektywie jej rozszerzenia na nowe państwa - Bułgarię i Rumunię, stał się podstawą do wypracowania nowego stanowiska rządów kantonalnych wobec polityki europejskiej Szwajcarii. Wnioski zawarte w dokumencie, przyjętym w marcu 2007 r., opierały się na założeniu, iż ochrona interesów Kantonów wymaga wypracowania jednolitej strategii i wspólnego działania. Strategia ta winna uwzględniać uwarunkowania wewnątrzpolityczne oraz bieżącą sytuację międzynarodową. Ta ostatnia jest obecnie dla Szwajcarii bardzo korzystna, albowiem Unia przechodzi etap refleksji nad własną przyszłością. Stwarza to warunki sprzyjające zredefiniowaniu relacji dwustronnych z państwami niebędącymi członkami Wspólnoty, w tym także ze Szwajcarią. Przyjęta przez kantony strategia zakłada, że układy bilateralne nie mogą być uznawane za docelową formę integracji z UE. Dotychczasowa współpraca nie zaspokaja potrzeb i oczekiwań obu stron, a jej dalszy rozwój osłabia pozycję kantonów i godzi w ich interesy. Sytuacja wymaga dokładnej analizy stanu obecnej współpracy oraz oddziaływań układów bilateralnych w szerszym kontekście. Umożliwi to zawarcie nowych układów, które jednakże w większym stopniu będą uwzględniać specyfikę szwajcarskiego systemu politycznego i zagwarantują kantonom możliwość zajęcia należnej im pozycji. Bardzo istotnym zapisem w przedmiotowym dokumencie jest potwierdzenie możliwości pełnego członkostwa Szwajcarii w UE. Kantony zaznaczają, co prawda, iż w najbliższym czasie nie ma na to szans zarówno ze względu na uwarunkowania wewnętrzne, jak i zewnętrze. Niemniej jednak opcja pełnej integracji z UE nie jest odrzucana i jako taka powinna być rozważana, jeżeli tylko okaże się korzystna politycznie i gospodarczo. Sceptycznie natomiast ocenia się inne formy współpracy, jak chociażby układy ramowe ${ }^{75}$.

\footnotetext{
${ }^{75}$ W wywiadzie dla „Neue Zürcher Zeitung”, ze stycznia 2008 r., Micheline Calmy-Rey, szefowa dyplomacji Szwajcarii, wspomniała o potrzebie rozszerzenia współpracy bilateralnej o kolejne obszary tematyczne oraz o zawarciu układu ramowego, który ułatwiałby kontrolę i monitoring zawartych porozumień. Zob. Eine neue Vision für das Verhältnis zur EU, „Neue Zürcher Zeitung”, Januar 2008.
} 
Kantony potwierdzają również konieczność przeprowadzenia wewnętrznych reform. Punkt ten traktowany jest jako element niezbędny w dalszym rozwoju polityki europejskiej. Celem nadrzędnym przyszłych reform winna być ochrona podstawowych wartości federalizmu Szwajcarii. Istotne jest przy tym, aby wszelkie zmiany wprowadzane były stopniowo, tak by ich efekty były stale analizowane, a wnioski uwzględniane przy wprowadzaniu kolejnych. Co ważne, określone decyzje polityczne należy podejmować już teraz, w celu uniknięcia nacisków ze strony Brukseli. Innymi słowy, reformy winny mieć charakter autonomiczny, a najlepiej również oddolny, tj. inicjowany przez kantony. Taki kierunek najlepiej odpowiadałby potrzebom kantonów, a przeprowadzone zmiany miałyby największą szansę powodzenia.

Warto przy tej okazji zwrócić uwagę na aspekt finansowy. Jak wspomniano wyżej, kantony ponoszą główne koszty wdrażania międzynarodowych porozumień. W przeszłości nie stanowiło to większego problemu, albowiem ich charakter sprawiał, że znalezienie dodatkowych środków w budżecie kantonów nie było konieczne. Szwajcaria jako państwo neutralne nie była zresztą zainteresowana podpisaniem takich umów, które ograniczałyby w jakiś sposób jej suwerenność i nakładały dodatkowe zobowiązania. Integracja europejska nadała jednak relacjom międzynarodowym nowy wymiar, nie tylko w aspekcie politycznym, lecz również ekonomicznym. Ceną integracji jest m.in. konieczność zwiększenia nakładów finansowych, chociażby w celu wprowadzenia zasad jednolitego rynku bądź też harmonizacji prawa. Szwajcaria nie jest, co prawda, członkiem Wspólnoty, co zwalnia ją z obowiązku finansowania wspólnego budżetu, jednak konstrukcja układów bilateralnych przewiduje wprowadzanie szeregu nowych regulacji, co oznacza dodatkowe koszty. Sytuację kantonów pogarsza fakt, iż Unia wymusza na nich takie decyzje, które mogą doprowadzić do znacznego ograniczenia wpływów budżetowych. Doskonałym przykładem jest tu spór wokół polityki fiskalnej kantonów, która gwarantuje szczególnie korzystne warunki do lokowania biznesu. Bardzo często wysuwany jest więc pod adresem kantonów zarzut kreowania na swym terenie rajów podatkowych, co w oczywisty sposób godzi w interesy państw UE. Mamy zatem sytuację, w której z jednej strony oczekuje się od kantonów, że te pokryją koszty finansowe integracji, z drugiej natomiast zmusza się je do prowadzenia niekorzystnej polityki fiskalnej. Postulowane przez kantony i władze federalne reformy winny uwzględniać konieczność pewnych modyfikacji również i w tym obszarze.

Oceniając powyższe spostrzeżenia należy zwrócić szczególną uwagę na otwartość władz kantonalnych wobec perspektywy pełnej integracji z UE. Jest to tym bardziej ciekawe, że stanowisko to, przyjęte przecież jednogłośnie przez wszystkie kantony, zaakceptowane zostało nawet przez te najbardziej konserwatywne. Integracja europejska, a wcześniej inne formy tzw. nowego otwarcia Szwajcarii na współpracę międzynarodową, od zawsze dzieliła szwajcarskie społeczeństwo. Podział ten przebiegał początkowo pomiędzy niemieckojęzycznymi 
a francuskojęzycznymi kantonami, przy czym te ostatnie wykazywały zawsze znacznie większą otwartość ${ }^{76}$. Obecnie nastawienie społeczeństwa zależne jest bardziej od statusu materialnego czy poziomu wykształcenia. Coraz mniejsze znaczenie ma tutaj pochodzenie, choć mieszkańcy aglomeracji wiejskich nadal wykazują o wiele większy sceptycyzm niż ich sąsiedzi z terenów zurbanizowanych i gospodarczo lepiej rozwiniętych ${ }^{77}$. Szczególny przypadek stanowi kanton Tessin, jednakże niechęć wobec integracji ma tutaj szerszy kontekst ${ }^{78}$. Wolno zatem postawić tezę, że kantony stały się niejako motorem integracji, co jeszcze kilka lat temu można było powiedzieć wyłącznie o władzach federalnych. Oczywiście podkreśla się potrzebę przeprowadzenia niezbędnych reform, nie zmienia to jednak faktu wyraźnego ciążenia kantonów w kierunku intensyfikacji współpracy z UE.

\subsubsection{STANOWISKO RZĄDU WOBEC RAPORTU EUREFKA}

W odpowiedzi na stanowisko kantonów oraz przedstawione wcześniej analizy EuRefKa, rząd federalny przedstawił w roku 2007 własny komunikat ${ }^{79}$. Mowa w nim m.in. o konieczności rewizji podziału kompetencji pomiędzy kantonami a federacją, z zaznaczeniem jednakże, że kantonom należy pozostawić w tym względzie wiodącą rolę. Chodzi o realizację założenia, iż decyzje powinny być podejmowane na najniższym szczeblu, a więc najbliżej obywatela. Jest to zresztą cecha charakterystyczna federalizmu Szwajcarii, która zakorzeniona jest głęboko w tradycji i mentalności obywateli tego kraju. Stąd też bierze się niezwykle istotna rola gmin, cieszących się dość szerokimi kompetencjami. Dobrym odzwierciedleniem istoty tego zjawiska jest fakt, że każdy Szwajcar jest w pierwszej kolejności obywatelem gminy, następnie kantonu, a dopiero na końcu federacji ${ }^{80}$. Rząd federalny odnosi się w swoim komunikacie również do kwestii współdziałania kantonów w realizacji polityki zagranicznej Związku. Podkreśla, że konieczne jest $\mathrm{w}$ tym względzie nadanie już istniejącym organom, jak KdK, większej legitymizacji, tak aby wyraźny był wpływ obywateli na podejmowane decyzje.

${ }^{76}$ Podział ten zapoczątkowany został jeszcze w okresie I wojny światowej, przeszedł do historii pod nazwą Röstigraben. Nazwa pochodzi od tradycyjnego dania, wywodzącego się z kuchni kantonów niemieckojęzycznych.

${ }^{77}$ Zob. analiza instytutu Gfs. Bern, dotycząca wyników głosowania nad rozszerzeniem swobody przepływu osób na Bułgarię i Rumunię z dnia 8 lutego 2009 r. Analiza dostępna online: http:// www.polittrends.ch/abstimmungen/abstimmungsanalysen/vox-analysen/2009-02-08_VoxD.pdf (26.06.2009).

${ }^{78}$ Zob. artykuły w „Neue Zürcher Zeitung”: Das Tessin - wegen Italien ein Sonderfall, 10. Februar 2009; Das Tessin schert aus, 9. Februar 2009.

${ }^{79}$ Bericht des Bundesrates zu den Auswirkungen verschiedener europapolitischer Instrumente auf den Föderalismus in der Schweiz, BB1 20075907.

${ }^{80}$ W. Linder, op. cit., s. 75. 
Jednym z najważniejszych elementów stanowiska jest jednak konieczność zagwarantowania właściwego przepływu informacji pomiędzy kantonem a federacją. Słuszna wydaje się propozycja władz federalnych przewidująca podpisanie dodatkowej umowy ramowej. W ten sposób obowiązek wzajemnych konsultacji zyskałby charakter formalno-prawny ${ }^{81}$. Rozważa się również wprowadzenie dodatkowych przedstawicieli kantonów do organów federalnych, tak jak stało się to już w przypadku Biura Integracyjnego lub Departamentu Sprawiedliwości (EJPD). W tym kontekście istotny jest też wzrost tzw. świadomości europejskiej. Ważne jest bowiem, aby kantony, poza możliwością przedstawiania Związkowi własnego stanowiska, wyposażone były w konkretną wiedzę na temat procesów zachodzących w ramach Wspólnoty. Pozwoli to na lepsze zrozumienie polityki UE wobec państw trzecich i być może umożliwi uniknięcie wielu nieporozumień we wzajemnych relacjach.

Reasumując, należałoby zadać pytanie, kiedy i w jakim stopniu obecny system federalny Szwajcarii ulegnie przewartościowaniu. Już teraz pojawiają się głosy, że członkostwo w Unii doprowadzić może do gruntownej rewizji federalizmu, sprowadzając go do wymiaru zbliżonego do systemów Niemiec bądź Austrii. Nie musi to oczywiście oznaczać politycznego paraliżu, jednak nie należy liczyć, by tego typu zmiany spotkały się ze szczególną akceptacją społeczeństwa. Co więcej, próba przeprowadzania reform, które stanowiłyby zagrożenie dla federalizmu i demokracji bezpośredniej, będących kręgosłupem systemu politycznego Związku, zapewne zakończyłaby się niepowodzeniem. Czy wobec tego członkostwo Szwajcarii w strukturach UE jest w ogóle możliwe? Ciekawą tezę przedstawił Dieter Freiburghaus, uznając, iż niezdolność federalizmu Szwajcarii do przeprowadzenia wewnętrznych reform uniemożliwia pełną integrację ${ }^{82}$. Dla jej uzasadnienia przytacza on kilka interesujących argumentów. Zwraca uwagę, że od momentu ustanowienia federacji, tj. od roku 1848, aż do czasów obecnych, podstawy jej funkcjonowania nie uległy zmianie. Jedyną różnicą jest liczba kantonów, która wzrosła z 22 do 26. Rzeczywistość międzynarodowa wymusza rewizję dotychczasowego podziału kompetencyjnego. Kantony muszą zmierzyć się z nowymi wyzwaniami i problemami. Nadal jednak dysponują tymi samymi instrumentami i organami władzy. Świadczy to o ogromnym przywiązaniu społeczeństwa szwajcarskiego do tradycyjnych struktur i najważniejszych dla nich wartości, jak chociażby demokracji bezpośredniej. Obecny dyskurs nad przyszłością federacji niemal zawsze sprowadza się właśnie do tego problemu. Punktem odniesienia w dyskusji nad funkcjonowaniem państwa jest konieczność zagwarantowania obywatelom odpowiedniego wpływu na procesy decyzyjne, zachodzące na szczeblu federalnym, kantonalnym oraz gminnym.

\footnotetext{
${ }^{81}$ Föderalismusbericht, Integrationsbüro EDA/EVD, Juni 2007, s. 2.

${ }^{82}$ D. Freiburghaus, Föderalismus, de quois's a git-il? Grundlagen und Reformbestrebungen im schweizerischen Föderalismus, [w:] P. Barblan, A. Keller, R. Oppenheim, op. cit., s. 42.
} 


\subsubsection{DEMOKRACJA BEZPOŚREDNIA}

\subsubsection{DEMOKRACJA BEZPOŚREDNIA JAKO BARIERA INTEGRACYJNA}

Powyższe uwarunkowania skłaniają do przeanalizowania problemu demokracji bezpośredniej jako kolejnego czynnika mającego bezpośredni wpływ na kształt polityki Szwajcarii wobec Unii Europejskiej. Trudno bowiem pominąć element, będący podstawą systemu politycznego tego państwa, a jednocześnie najstarszą formą sprawowania władzy. Należy zwrócić uwagę na fakt, że demokracja bezpośrednia, a więc możliwość podejmowania wspólnych decyzji przez wszystkich obywateli, narodziła się wśród małych społeczności wiejskich. Każdy mieszkaniec gminy, płci męskiej, miał prawo wzięcia udziału w lokalnym głosowaniu, a tym samym wyrażenia własnej opinii dotyczącej omawianego problemu. Dopiero w trakcie rozwoju państwowości Szwajcarii, w szczególności od roku 1848 , ta forma sprawowania rządów została zaadaptowana na potrzeby całego Związku. Należy jednakże dodać, że w opinii niektórych politologów źródeł demokracji bezpośredniej trzeba doszukiwać się w okresie dominacji napoleońskiej ${ }^{83}$. Faktem jest jednakże, o czym przypomina Jürg Steiner, że idea zbiorowej partycypacji w sprawowaniu władzy jest silnie zakorzeniona w szwajcarskiej tradycji ${ }^{84}$. Demokracja bezpośrednia, w różnej formie, począwszy od głosowań obligatoryjnych i fakultatywnych, na inicjatywie powszechnej kończąc, obecna jest na każdym szczeblu administracyjnym zarówno gminnym, kantonalnym, jak i federalnym. Jest to niezwykle istotne, albowiem demokracja bezpośrednia pozostaje integralnym elementem systemu politycznego Szwajcarii. Integracja europejska stanowi dlań zupełnie nowe wyzwanie, oznaczające konieczność zaadaptowania tej formy demokracji do uwarunkowań politycznych Wspólnoty. Jako mało realną natomiast traktować należy opcję jej całkowitego wyeliminowania, nawet w perspektywie pełnego członkostwa.

$\mathrm{W}$ analizie demokracji bezpośredniej, jako jednego z głównych czynników wpływających na relacje Szwajcarii z UE, wskazać wypada, że konstytucja federacji nie przewiduje osobnych regulacji w stosunku do polityki wewnętrznej i zewnętrznej. Oznacza to, iż reguły dotyczące udziału obywateli w procesie decyzyjnym są takie same dla obu obszarów. Demokracja bezpośrednia w równym stopniu oddziałuje zatem na krajowe ustawodawstwo oraz międzynarodowe regulacje prawne, w tym przede wszystkim na te, które dotyczą administracji federalnej i kantonalnej. Możemy zatem skonstatować, że polityka Szwajcarii wobec Unii Europejskiej wymaga ciągłego uwzględniania uwarunkowań wewnątrzpolitycznych, związanych z oddziaływaniem demokracji bezpośredniej. Obecna jest ona bowiem na każdym etapie legislacyjnym zarówno lokalnym, jak i federalnym.

${ }^{83}$ A. Kölz, Neuere schweizerische Verfassungsgeschichte, Stämpfli, Bern 1992, s. 615-620.

${ }^{84}$ J. Steiner, Demokracje europejskie, WSP, Rzeszów 1993, s. 239-240. 


\subsubsection{REFERENDUM OBLIGATORYJNE I FAKULTATYWNE W PERSPEKTYWIE INTEGRACJI EUROPEJSKIEJ}

Obywatele mają prawo wyrażania decydującej opinii w kwestiach będących przedmiotem obrad parlamentów kantonalnych oraz związkowego. Odbywa się to w formie referendum powszechnego. Wyróżniamy tutaj dwa rodzaje głosowań - obligatoryjne oraz fakultatywne. Do referendum obligatoryjnego, na szczeblu federalnym, dochodzi przy okazji poprawek konstytucyjnych lub ważnych traktatów międzynarodowych. W przypadku tych ostatnich „suweren”, a więc ogół posiadających prawo wyborcze obywateli, wypowiada się w sprawie przyłączenia Szwajcarii do organizacji zbiorowego bezpieczeństwa (np. NATO) lub tzw. organizacji o charakterze supranarodowym. W rozumieniu szwajcarskiego prawodawstwa zalicza się do nich Unia Europejska. W obu powyższych przypadkach wymagana jest podwójna większość głosów. Oznacza to, że projekt zostanie przyjęty pod warunkiem, iż zagłosuje za nim ponad połowa obywateli w większości kantonów $^{85}$. Zapis ten wskazywany jest zresztą jako jedna z głównych przeszkód na drodze do pełnej integracji ze Wspólnotą. Referendum fakultatywne, niewymagające podwójnej większości, odbywa się dość często zarówno na poziomie lokalnym, jak i regionalnym czy federalnym. Szacuje się, że suweren wypowiada się rocznie średnio w ponad 20 kwestiach, co określić można jako wynik dość imponujący ${ }^{86}$. Na poziomie federalnym odnosi się ono do zwykłego ustawodawstwa, pod warunkiem, iż w ciągu 90 dni zostanie zebranych 50000 podpisów. Podobnie jest w przypadku głosowań kantonalnych, choć w kilku regionach nowe projekty ustaw wymagają niekiedy obligatoryjnego referendum. Dopełnieniem demokracji bezpośredniej jest inicjatywa powszechna, polegająca na zgłoszeniu poprawki konstytucyjnej, propozycji zmiany lub zniesienia istniejących zarządzeń. Formalny wniosek składany jest pod warunkiem zebrania 100000 podpisów. Staje się on przedmiotem debaty na forum Rady Związkowej i parlamentu, a jej wynikiem może być formalna kontrpropozycja. Oba wnioski poddawane są wówczas głosowaniu powszechnemu. Podobnie jak w przypadku referendum obligatoryjnego wymagana jest tutaj podwójna większość. Warto dodać, że demokracja bezpośrednia, w postaci referendum oraz inicjatywy powszechnej, na szczeblu federalnym wprowadzona została w celu ograniczenia prerogatyw władzy centralnej. Jest ona również odzwierciedleniem tendencji decentralistycznych.

Z punktu widzenia tematyki niniejszej monografii szczególnego znaczenia nabiera prawo do przeprowadzenia referendum fakultatywnego w odniesieniu m.in. do umów międzypaństwowych. Konstytucja wyraźne określa rodzaje

${ }^{85}$ Większość w kantonie traktowana jest jako jeden głos, w półkantonie jako pół głosu. Oznacza to, iż aby projekt został przyjęty musi uzyskać minimum 12 głosów. Wynik remisowy traktowany jest jako odrzucenie propozycji.

${ }^{86}$ W. Linder, op. cit., s. 149. 
umów, które mogą podlegać zakwestionowaniu przez obywateli ${ }^{87}$. Należą do nich umowy bezterminowe lub te, które przewidują przystąpienie do organizacji międzynarodowej. Konstytucja zalicza do tego grona również takie projekty, których realizacja pociągnie za sobą multilateralną standaryzację prawa (multilarelare Rechtsvereinheitlichung). Zawarta w ustawie zasadniczej definicja uznawana jest za dość szeroką, pozostawiającą spory margines interpretacji. Do roku 1994 jedynie 4 projekty ze 119 poddane zostały głosowaniu ${ }^{88}$. Jest to wynik mogący świadczyć o szerokiej akceptacji społecznej dla polityki zagranicznej rządu lub też o nikłym zainteresowaniu obywateli tą sferą działań administracji rządowej. Od roku 2003 wprowadzono poprawkę do konstytucji rozszerzającą zakres umów, które mogą zostać poddane pod głosowanie fakultatywne. Nowa ustawa uwzględnia także umowy zawierające istotne regulacje prawne lub wymagające stosownego rozporządzenia $w$ prawie związkowym ${ }^{89}$. Powyższa definicja nie rozwiała jednak wielu wątpliwości. W ciągu dwóch pierwszych lat obowiązywania nowych regulacji Rada Związkowa przygotowała 20 umów, które oceniane były przez parlament pod kątem konieczności poddania ich pod głosowanie fakultatywne ${ }^{90}$. Uznano, iż jedynie 12 z nich spełnia wymogi zawarte w ustawie zasadniczej. Najwięcej kontrowersji budzi stwierdzenie mówiące o istotnym znaczeniu prawnym umowy. Trudno bowiem określić, czy należy w tym wypadku stosować wyłącznie prawną wykładnię, czy też kierować się politycznym znaczeniem międzynarodowego porozumienia.

W literaturze przedmiotu bardzo często spotkać można stwierdzenie, że integracja europejska stanowi zagrożenie dla dalszego funkcjonowania demokracji bezpośredniej, przynajmniej w jej obecnym kształcie. Warto jednakże nieco odwrócić powyższą tezę w celu przeanalizowania jej aktualnego wpływu na rozwój relacji z Unią Europejską. Czy zatem demokracja bezpośrednia stanowi poważną barierę na drodze do integracji? Jeszcze na początku lat 90. stało się jasne, że jedną z najpoważniejszych przeszkód włączenia Szwajcarii do struktur Wspólnoty pozostaje referendum obligatoryjne, czyli jedno z najważniejszych instrumentów demokracji bezpośredniej. Zgodnie z obowiązującymi regulacjami ostateczne przystąpienie do UE zależeć będzie przede wszystkim od decyzji samych obywateli, albowiem tego typu wniosek musi być zaakceptowany w referendum. Oczywiście sam fakt poddania go pod głosowanie nie musi oznaczać klęski. Podobna sytuacja występuje przecież również w innych państwach, których obywatele mają prawo do zadecydowania o ewentualnej przynależności ich państwa do ponadnarodowej organizacji. Jednak w przypadku Szwajcarii prawdopodobieństwo odrzucenia wniosku jest o wiele większe, przede wszystkim ze względu na konieczność uzyskania wspomnianej już wyżej tzw. podwójnej większości.

\footnotetext{
${ }^{87}$ Bundesverfassung der Schweizerischen Eidgenossenschaft vom 18. April 1999..., art. 141.

${ }^{88}$ L. Goetschel. M. Bernath, D. Schwarz, op. cit., s. 72.

${ }^{89}$ Art. 141 Abs. 1 Bst. d Ziff. 3 BV.

${ }^{90}$ Bundeskanzlei, „Verwaltungspraxis der Bundesbehörden” 2005, Nr. 69/75, s. 1.
} 
Wymóg ten był jednym z powodów, dla których rząd Szwajcarii zrezygnował ze strategii nastawionej na członkostwo w UE na rzecz rozpoczęcia współpracy bilateralnej, będącej jedynym sposobem uniknięcia kłopotliwego referendum obligatoryjnego. Podstawowym problemem tej formy demokracji jest zjawisko niereprezentacyjności. Oznacza ono w skrócie, iż negatywnie nastawiona mniejszość jest w stanie skutecznie torpedować wolę większości. Podstawowa reguła, jaka przyświecała twórcom demokracji, polegała na sprawiedliwym podziale głosów pomiędzy wszystkich obywateli, zgodnie z regułą ,jeden człowiek - jeden głos". W czasach, gdy ustanawiano podstawy obecnego systemu politycznego Szwajcarii, stopień zaludnienia poszczególnych kantonów był w całym państwie na podobnym poziomie. Oznaczało to porównywalną liczbę obywateli we wszystkich regionach, a co za tym idzie podobną wagę głosów. Zróżnicowany stopień rozwoju gospodarczego kantonów i wewnętrzne migracje ludności w ciągu ponad 150 lat istnienia Związku zaważyły na istnieniu dziś ogromnych różnic w liczbie ludności poszczególnych regionów. W efekcie zaludnienie kantonu Appenzell Innerrhoden sięga zaledwie nieco ponad 1\% wszystkich mieszkańców kantonu Zürich. Reguły ważenia głosów nie uległy przy tym przez cały ten czas żadnym zmianom.

W trakcie głosowań obligatoryjnych mamy zatem do czynienia z sytuacją, w której wynik głosowania w kantonach słabo zaludnionych ma taką samą wartość jak w tych, mogących się poszczycić o wiele wyższymi wskaźnikami. Stanowi to o słabości tego rodzaju instrumentów demokracji bezpośredniej. Oczywiście podczas głosowań nad niebudzącą większych kontrowersji poprawką do konstytucji referendum obligatoryjne nie stanowi większej przeszkody. Sprawa nabiera jednak zupełnie innego wymiaru w przypadku polityki europejskiej. Społeczne uwarunkowania mają decydujące znaczenie. Okazuje się bowiem, że największy odsetek eurosceptyków odnaleźć można w słabo zaludnionych kantonach. Relatywnie niski poziom rozwoju gospodarczego sprawił, iż zamieszkująca te tereny ludność odznacza się dość konserwatywnymi poglądami, a co za tym idzie, dużym przywiązaniem do tradycyjnych wartości i niechęcią wobec politycznych przemian. Reimund E. Germann w opublikowanych przez siebie badaniach przedstawił procentowy udział głosów na „nie”, które są w stanie zablokować wolę większości ${ }^{91}$. W roku 1880 odsetek ten był największy i wynosił 11,2\%. Na początku lat 90. XX w. liczba ta zmniejszyła się do zaledwie 9\%. Wynik ten budzi zatem uzasadnione obawy zwolenników szybkiej integracji ze Wspólnotą. Warto dodać do tego niski poziom partycypacji w głosowaniach. Zazwyczaj frekwencja oscyluje w granicach 40-50\%. Oczywiście liczba ta wzrasta przy bardziej kontrowersyjnych problemach. Dobrym tego przykładem było głosowanie nad wnioskiem o włączenie Szwajcarii do Europejskiego Obszaru Gospodarczego.

${ }^{91}$ R.E. Germann, op. cit., s. 262. 
Do urn poszło wówczas $78,8 \%$ uprawnionych ${ }^{92}$. Można zatem oczekiwać, że w przypadku referendum dotyczącego przystąpienia do UE frekwencja znacznie się podniesie. Należy liczyć się jednak z dość powszechnym, również w innych państwach, zjawiskiem, polegającym na niskiej partycypacji osób o raczej postępowych poglądach, a więc otwartych na integrację europejską. Osoby konserwatywne, które z reguły odczuwają większe obawy przed zmianami, są w tym względzie znacznie bardziej zdyscyplinowane. Może się zatem zdarzyć, iż pomimo relatywnie wysokiej frekwencji, przeważać będą głosy negatywne i to one zadecydują o ostatecznym wyniku głosowania, pomimo że w ogólnym rozrachunku eurosceptycy należeć będą do mniejszości. Dotychczasowe głosowania w sprawie przystąpienia do Organizacji Narodów Zjednoczonych w roku 1986 oraz Europejskiego Obszaru Gospodarczego pokazują dobitnie, że tego typu sytuacje nie należą do rzadkości. Przyglądając się zresztą wynikom wszystkich głosowań związanych z polityką europejską od roku 1972 do 2009 zauważyć można, że w przeważającej liczbie przypadków większość kantonów opowiedziała się przeciwko, nawet jeżeli w ogólnym rozrachunku wniosek został przyjęty ze względu na procentowo większy odsetek obywateli głosujących na „tak”.

W ramach wspomnianego już wyżej Narodowego Programu Badawczego (NFP 42), dotyczącego polityki zagranicznej, przedstawiono obszerny raport zawierający analizę problemu demokracji bezpośredniej w perspektywie intensyfikacji współpracy z UE ${ }^{93}$. Autorzy dokumentu wychodzą z założenia, że jedną z głównych przeszkód na drodze zbliżenia ze Wspólnotą jest system polityczny Szwajcarii. System, którego, wydawać by się mogło, najważniejsza zdobycz demokracja bezpośrednia - pozostaje największym hamulcem integracji. Okazuje się bowiem, iż referendum, będące przecież ucieleśnieniem zasady społecznego legitymizmu, bardzo często staje się instrumentem walki politycznej oraz politycznego szantażu. To, co w teorii wydaje się niemal idealne, w praktyce przynosić może wręcz odwrotny skutek. Autorzy raportu przypominają o niebezpiecznej tendencji do dominowania mniejszości nad wolą większości obywateli. Główne przyczyny takiej sytuacji opisane zostały powyżej. Warto jednak zwrócić uwagę na jeszcze jeden problem, o którym wspominają autorzy raportu. Przeprowadzone przez nich badania wykazały, iż znaczna część uprawnionych do głosowania nie jest w wystarczającym stopniu poinformowana w sprawach będących przedmiotem referendum. Jak pokazują badania przeprowadzone przez Grunera i Hertiga, wiele osób nie jest nawet świadomych tematyki referendum ${ }^{94}$. $Z$ ankiety przeprowadzonej pod koniec lat 70 . wynikało, iż $2 / 3$ respondentów nie potrafiło powtórzyć treści pytania referendalnego. Decyzje podejmowane bezpośrednio przy urnie nie

\footnotetext{
${ }^{92}$ Był to najwyższy wskaźnik od roku 1947.

${ }^{93}$ A. Brunetti, M. Jaggi, R. Weder, Öffnung der Schweiz: Verteilungswirkungen, Kompensation und mögliche Strategien, NFP 42 Synthesis 7, Bern 1999.

${ }^{94}$ E. Gruner, H. Hertig, Das Stimmbürger und neue Politik, Haupt Verlag, Bern 1983.
} 
mają w takiej sytuacji charakteru obiektywnego, a ostateczne wyniki zniekształcają faktyczny obraz rzeczywistości. Duży odsetek obywateli głosuje wbrew swoim dotychczasowym przekonaniom lub też nie robi tego wcale. Istotne znaczenie ma przy tym siła oddziaływania kampanii wyborczej. Bardzo często jest ona źle prowadzona i polega na prezentowaniu wyselekcjonowanych informacji. Co ciekawe, niekorzystny system ważenia głosów sprawia, że zdecydowanie łatwiej, a przede wszystkim taniej, jest przeprowadzić udaną kampanię w kantonach gospodarczo słabiej rozwiniętych i bardziej konserwatywnych. W ten sposób, relatywnie niedużym wysiłkiem, można doprowadzić do zablokowania przedłożonego w referendum projektu. Ostateczny wynik głosowania uzależniony jest często od właściwych działań informacyjnych rządu. Referendum w sprawie Europejskiego Obszaru Gospodarczego pokazało dobitnie, że niewystarczające zabiegi administracji centralnej mogą się walnie przyczynić do niekorzystnego wyniku wyborów. Oczywiście w tym konkretnym przypadku mieliśmy do czynienia nie tyle z brakiem określonych działań, ile raczej z niewłaściwym ich ukierunkowaniem. Parlament Szwajcarii udzielił zgody na kredyt w wysokości 6 milionów franków celem przeprowadzenia odpowiedniej kampanii informacyjnej przed planowanym głosowaniem w sprawie EOG. Biorąc pod uwagę wyniki referendum uznać możemy, że nie odniosła ona zamierzonego skutku. W roku 1994 opublikowana została obszerna analiza L. Goetschel, oceniająca kampanię, a przede wszystkim wskazująca na przyczyny jej niepowodzenia ${ }^{95}$. Do najważniejszych autorka zalicza niewłaściwą formę przekazu, znaczne opóźnienia w jej rozpoczęciu oraz brak jednomyślności w łonie rządu. Ponadto, na co zwraca uwagę Goetschel, nie zdecydowano się na przesunięcie terminu głosowania celem przedłużenia kampanii i zwiększenia szans na przyjęcie wniosku przez społeczeństwo. Jak zauważa Germann, nacisk ze strony państwa EFTA, w tym przede wszystkim Szwecji, odgrywał tutaj niemałą rolę ${ }^{96}$.

Polityka europejska pokazała, jak wrażliwe i podatne na manipulacje są najważniejsze instrumenty demokracji bezpośredniej. Wystarczy wskazać na podstawowe motywy, jakimi kieruje się przeciętny wyborca. Wiele osób podejmuje przecież decyzję wyłącznie na podstawie sugestii zawartych w spotach reklamowych lub billboardach, których treść bardzo często określić możemy jako populistyczną. Integracja europejska jest doskonałym tłem dla tego typu działań. Dostarcza bowiem najwięcej kontrowersyjnych i podatnych na populistyczną demagogię tematów. Najczęściej spotkać można tu utarte slogany i odwoływania do podstawowych wartości, związanych z bezpieczeństwem oraz gospodarczą

${ }^{95}$ Zob. L. Goetschel, Zwischen Effizienz und Akzeptanz. Die Information der Schweizer Behörden im Hinblick auf die Volksabstimmung über den EWR-Vertrag vom 6. Dezember 1992, Haupt Verlag, Bern 1994.

${ }^{96}$ R.E. Germann, Staatsreform. Der Übergang zur Konkurrenzdemokratie, Haupt Verlag, Bern 1994, s. 163. 
i polityczną stabilnością ${ }^{97}$. Swego czasu szerokim echem, nie tylko w samej Szwajcarii, lecz również w innych państwach ${ }^{98}$, odbiła się kontrowersyjna kampania konserwatywnej partii ludowej SVP, zorganizowana w roku $2007 \mathrm{w}$ ramach inicjatywy przewidującej przymusową deportację cudzoziemców skazanych za ciężkie przestępstwa popełnione w Szwajcarii ${ }^{99}$. Jeden z plakatów przedstawiał kilka białych owiec na tle szwajcarskiej flagi, które kopniakiem wyrzucają ze swojego pola czarną owcę. Miał być to symbol podjęcia zdecydowanych działań na rzecz zapewnienia bezpieczeństwa. Kampanię, choć kontrowersyjną, można uznać za skuteczną, czego najlepszym dowodem jest zebranie 200000 podpisów pod inicjatywą. Główną przyczyną jej sukcesu był fakt, że, po pierwsze, odwoływała się do powszechnej, choć ukrywanej, niechęci lub przynajmniej braku zaufania wobec osób odmiennej narodowości. Szwajcaria jest zresztą pod tym względem wyjątkowa, ponieważ niemal $20 \%$ osób mieszkańców to cudzoziemcy. Sytuacja ta sprawia, iż tolerancja i poszanowanie wobec różnych kultur jest dla wielu Szwajcarów niemal podstawową wartością. Jest to także związane z historią i specyfiką społeczno-polityczną państwa, powstałego przecież na drodze łączenia, niekiedy odmiennych kulturowo i językowo obszarów. Nie oznacza to jednakże, iż odczucia, tkwiące głęboko w świadomości, a skrywane przez lata pod zasłoną tolerancji i neutralności, są obce mieszkańcom Szwajcarii. Najlepszym tego dowodem jest popularność skrajnie prawicowej i konserwatywnej SVP, która od roku 2003 cieszy się silną pozycją w parlamencie Szwajcarii, a czołowa postać tego ugrupowania - Christoph Blocher, jak żaden inny polityk, potrafił swoimi kontrowersyjnymi, lecz otwarcie przedstawianymi, opiniami spolaryzować szwajcarskie społeczeństwo. Po drugie, kampania SVP podejmowała bliską i niezwykle wrażliwą tematykę. Poczucie bezpieczeństwa jest przecież jedną z najważniejszych wartości. Badania empiryczne pokazują, że wyborcy z natury rzeczy pozostają nieufni wobec zmian. Utrzymanie status quo staje się wówczas najbardziej naturalnym wyborem. Potwierdzają to również badania wykonane w ramach NFP 42. Zdaniem Kriesi argumenty przeciwników integracji zazwyczaj zdecydowanie lepiej pokrywają się z motywami, którymi kierują się głosujący na „nie”, niż argumenty zwolenników z wartościami, które przyświecają głosującym na „tak" $"$.

${ }^{97} \mathrm{Na}$ temat politycznej manipulacji i znaczenia kampanii wyborczej w perspektywie referendum zob.: G. Schneider, C. Hess, Die innenpolitische Manipulation der Aussenpolitik: Die Logik von Ratifikationsdebatten in der direkten Demokratie, „Swiss Political Science Review” 1995, Nr. $1(2-3)$, s. 91-110.

${ }^{98}$ Komentarze pojawiły się m.in. w „New York Times” oraz niemieckim „Stern Magazin”.

${ }^{99}$ Inicjatywa SVP uznana została za sprzeczną z prawami człowieka. Zob. stanowisko szwajcarskiej organizacji pomocy uchodźcom: Änderungen im Ausländergesetz (Indirekter Gegenvorschlag zur Ausschaffungsinitiative). Stellungnahme der Schweizerischen Flüchtlingshilfe, Bern 2009. Dokument dostępny na stronie www.fluchtlingshilfe.ch (03.10.2009).

${ }^{100}$ Zob. H. Kriesi, P. Sciarini, L. Marquis, Démocratie directe et politique extérieure: étude de la formation des attitudes en votation populaire, Bern 2000. 


\subsubsection{PROCES DECYZYJNY}

Specyfika systemu politycznego Szwajcarii urasta zatem do rangi problemu wprost proporcjonalnie do stopnia integracji europejskiej. Jak wiadomo, państwa UE nie borykają się, przynajmniej w tak dużym stopniu, z problemem oddziaływania demokracji bezpośredniej na proces legislacyjny. W przypadku Szwajcarii niemal każda nowa ustawa, nawet jeżeli nie pociąga za sobą zmian w konstytucji, musi liczyć się z możliwością społecznej weryfikacji. Tworzenie prawa na gruncie krajowym jest nieco łatwiejsze, albowiem specjalnie stworzony instrument w postaci społecznych konsultacji (Vernehmlassungsverfahren) pozwala, jeszcze na etapie konsultacji parlamentarnych, wyeliminować z ustawy najbardziej sporne elementy. Tak opracowany projekt trafia pod obrady parlamentu, a dopiero później przedstawiany jest opinii publicznej. Dzięki temu ryzyko zakwestionowania ustawy na drodze referendum fakultatywnego pozostaje relatywnie niewielkie. W latach 1848-1990 na 1506 projektów jedynie 103 poddane zostały pod głosowanie ${ }^{101}$. Inaczej sytuacja wygląda w przypadku prawodawstwa UE, gdzie znaczna liczba aktów prawnych, w postaci rozporządzeń, dyrektyw, opinii lub zaleceń, tworzona jest w Brukseli. Państwa członkowskie są następnie zobowiązane do transponowania ich do własnego porządku prawnego. Wyjątek stanowi rozporządzenie, które zgodnie z unijnym prawem jest bezpośrednio stosowalne. Oczywiście każde państwo członkowskie pozostawia sobie pewien margines interpretacyjny, pozwalający na dostosowanie treści danego aktu prawnego do specyfiki krajowego prawodawstwa. Jest tu więc miejsce na uwzględnienie rodzimych uwarunkowań prawnych. Bezwzględnie jednak musi zostać zachowany podstawowy cel aktu prawnego tak, aby utrzymać jednorodność ustawodawstwa na całym obszarze Unii Europejskiej. W tym miejscu pojawia się zatem podstawowy problem. W przeciwieństwie do innych państw, w Szwajcarii proces legislacyjny przewiduje możliwość odrzucenia ustawy przez społeczeństwo. Może to zatem doprowadzić do sytuacji, w której znaczna część niepopularnych społecznie regulacji prawnych zostanie odrzucona w drodze fakultatywnego referendum. Warto zaznaczyć, że władze federalne będą w takim przypadku bezsilne, albowiem znaczna część ustaw wdrażanych jest na poziomie kantonalnym. Sprawę komplikuje fakt, że konsultacje społeczne, będące właściwie jedynym instrumentem zapobiegawczym, staną się na tym etapie bezużyteczne. Społeczeństwo będzie postawione w zasadzie przed faktem dokonanym, a ewentualne poprawki, zgłaszane przez partie polityczne czy inne grupy interesu, będzie znacznie trudniej uwzględnić. W tej sytuacji rząd szwajcarski będzie zmuszony do zastosowania szerszego rozwiązania systemowego, którego efektem może być ograniczenie znaczenia demokracji bezpośredniej w procesie legislacyjnym. Zapewne wzbudzi to uzasadnione kontrowersje i społeczny opór.

${ }^{101}$ Zob. H.P. Hertig, Volksabstimmungen, [w:] Handbuch Politisches System der Schweiz, Band II, Bern 1984, cyt. za: W. Linder, op. cit., s. 155. 
W związku z powyższym należy również wziąć pod uwagę inny problem, a mianowicie możliwość odrzucenia „unijnego” projektu ustawy przez społeczeństwo w drodze fakultatywnego referendum. Być może rząd będzie musiał sprostać zjawisku permanentnej blokady nowych ustaw, stanowiącej wyraz społecznego sprzeciwu wobec ujednolicania prawodawstwa, bez możliwości bezpośredniego udziału suwerena $\mathrm{w}$ tworzeniu nowego prawa. Oczywiście w takim przypadku Szwajcaria będzie musiała liczyć się z możliwością postawienia jej przed Europejskim Trybunałem Sprawiedliwości. Jednak, jak wskazuje praktyka, do tej pory jedynie czterokrotnie nałożono na państwo członkowskie sankcje za niewłaściwe wdrażanie unijnego prawa. Można zatem wyciągnąć wniosek, iż prawdopodobieństwo zaistnienia poważnej kolizji prawnej, skutkującej bolesnymi dla Szwajcarii sankcjami, pozostaje niewielkie.

Przy tej okazji warto zwrócić uwagę na inny jeszcze aspekt. Już przy okazji prób włączenia Szwajcarii do Europejskiego Obszaru Gospodarczego rząd w Bernie zwracał uwagę na duży stopień kompatybilności prawodawstwa Szwajcarii ze wspólnotowym. Okazuje się bowiem, iż wiele regulacji prawnych pozostaje zbieżnych z tymi, obowiązującymi w państwach UE. Część z nich, tak jak np. wymogi dotyczące ochrony środowiska, są nawet bardziej restrykcyjne, stanowiąc, jak niektórzy oceniają, wzór dla Wspólnoty. Dzieje się tak dlatego, że przez lata zachodził w prawodawstwie Szwajcarii proces nazywany ,autonomicznym dostosowaniem" (autonomie Nachvollzug). Ocenia się, iż niemal w $85 \%$ cechuje go eurokompatybilność ${ }^{102}$. Fakt ten sprawia, że do pewnego stopnia, nawet w perspektywie przystąpienia do UE, Szwajcaria nie będzie musiała adaptować acquis communautaire do własnego porządku prawnego. Jedynie niewielka część aktów prawnych, o czym wspomina rządowy raport z roku 1999, zawiera normy, które odznaczają się niekompatybilnością z prawem UE ${ }^{103}$. Większość z nich została zatem przyjęta przez szwajcarskie społeczeństwo na długo przez rozpoczęciem faktycznej integracji. Jest to niezwykle istotne, albowiem eliminuje wiele niepotrzebnych komplikacji natury legislacyjnej.

\subsubsection{DEMOKRACJA BEZPOŚREDNIA JAKO ELEMENT PRZEWAGI W NEGOCJACJACH Z UNIĄ EUROPEJSKĄ}

Poza opisanymi wyżej, raczej negatywnymi konsekwencjami specyfiki szwajcarskiego systemu politycznego, należy wspomnieć o innym aspekcie demokracji bezpośredniej, który pod pewnymi względami może działać na korzyść Szwajcarii w trakcie rokowań z UE. Wiadomo bowiem, iż konieczność uwzględnienia bezpośredniego współuczestnictwa obywateli w procesie decyzyjnym wy-

${ }^{102}$ S. Kux, Zwischen Isolation und autonomer Anpassung: Die Schweiz im integrationspolitischen Abseits?, ZEI Disscusion Paper of the Center for European Integration Studies C3/1998, Rheinische Friedrich Wilhelms-Universität, Bonn 1998, s. 10.

${ }^{103}$ Schweiz-Europäische Union: Integrationsbericht 1999... 
musza na obu stronach swoistą powściągliwość w procesie negocjacyjnym. Unia Europejska musi bowiem zdawać sobie sprawę z obiektywnych ograniczeń stojących przez rządem Szwajcarii. Jest przecież oczywiste, że do pewnego stopnia stanowisko Rady Związkowej nie zależy wyłącznie od subiektywnie określanych celów politycznych i metod ich osiągania, lecz od obiektywnych czynników, podyktowanych nastrojami społecznymi. Najlepszym tego przykładem jest chociażby próba włączenia Szwajcarii do Europejskiego Obszaru Gospodarczego. Polityka rządu bardzo szybko została wówczas negatywnie zweryfikowana przez społeczeństwo. Często mamy zatem do czynienia z sytuacją, w której partner rozmów, w tym przypadku UE, jest niejako zmuszony do pewnych ustępstw na rzecz Szwajcarii. Dzięki temu wypracowany wspólnie kompromis ma więcej szans na uzyskanie społecznej legitymizacji w przypadku konieczności poddania go pod referendum. Dobrym tego przykładem jest układ o swobodzie przepływu osób, zawarty w roku 1999. Zgodnie z przyjętymi regulacjami Szwajcaria uzyskała bardzo korzystne okresy przejściowe na otwarcie rodzimego rynku pracy dla obywateli unijnych. W odniesieniu do nowych państw UE wprowadzono również tzw. kontyngenty ilościowe, które stanowią skuteczną ochronę przed socjalnym dumpingiem ${ }^{104}$. Był to celowy $i$, wydaje się, niezbędny zabieg, który dopomógł rządowi przekonać społeczeństwo do podjęcia odważnego kroku w relacjach ze Wspólnotą. Oczywiście wiązało się to również z pewnym ryzykiem. Bruksela, świadoma zagrożenia, doprowadziła do związania pierwszego pakietu umów tzw. zasadą gilotyny. W myśl tej zasady odrzucenie jednej umowy, pociąga za sobą anulowanie wszystkich pozostałych. Okazało się to niezwykle skutecznym instrumentem zapobiegawczym. Zasada gilotyny zdała egzamin nie tylko przy okazji głosowania z roku 2000, umożliwiając wejście w życie pierwszego pakietu porozumień w styczniu roku 2001. Również kolejne głosowania dotyczące rozszerzenia swobody przepływu osób na nowe państwa unijne z roku 2005 oraz 2009 potwierdziły jej skuteczność ${ }^{105}$. Czas pokaże, czy również w przyszłości Szwajcaria, biorąc pod uwagę szczególne znaczenie demokracji bezpośredniej, będzie mogła liczyć na taryfę ulgową w trakcie negocjacji nad kolejnym pakietem umów. Już teraz pojawiają się jednak symptomy, które świadczą o coraz mniejszej pobłażliwości ze strony Brukseli. Być może już wkrótce referendum przestanie być problemem obu stron, a stanie się wyłącznie bolączką władz Szwajcarii.

${ }^{104}$ Limity zostały zniesione w roku 2007 dla obywateli tzw. starej piętnastki. Dla pozostałych krajów ograniczenia mają obowiązywać maksymalnie do roku 2019 (włączając w to specjalną trzyletnią klauzulę ochronną).

105 Szwajcarzy opowiedzieli się wówczas za otwarciem rynku pracy, oczywiście przy uwzględnieniu okresów przejściowych oraz kontyngentów ilościowych dla obywateli krajów, które od roku 2004 stały się członkami UE, z wyjątkiem Malty i Cypru (tj. Polski, Czech, Słowacji, Węgier, Litwy, Łotwy, Estonii i Słowenii). Wobec obywateli Malty i Cypru obowiązują takie same regulacje, jak dla obywateli krajów starej piętnastki. Podobne głosowanie przeprowadzono w roku 2009 w odniesieniu do Bułgarii i Rumunii. 
Omawiając problem oddziaływania form demokracji bezpośredniej na politykę Szwajcarii wobec Unii Europejskiej warto zwrócić uwagę na jeszcze jeden aspekt. Chodzi mianowicie o miejsce, jakie zajmuje polityka zagraniczna w życiu społecznym obywateli. W przypadku państw, których system polityczny nie przewiduje bezpośredniej partycypacji społeczeństwa $\mathrm{w}$ procesie decyzyjnym, poziom zainteresowania polityką zagraniczną nie ma większego znaczenia. W Szwajcarii jest to jednak niezwykle istotny czynnik, który śmiało zaliczyć możemy do ważnych uwarunkowań jej polityki zagranicznej. Jeszcze w czasie poprzedzającym nawiązanie ściślejszych relacji ze Wspólnotą, a więc w okresie zdominowanym przez bipolarny podział świata, poziom zainteresowania społecznego relacjami zewnętrznymi był wprost proporcjonalny do zaangażowania Szwajcarii na arenie międzynarodowej. Obecność polityki zagranicznej w debacie publicznej była relatywnie niewielka, a neutralność polityczna stanowiła odzwierciedlenie nastrojów społecznych. Większość spraw związanych z realizacją współpracy międzynarodowej była niemal wyłączną domeną rządu, rzadko weryfikowaną przez społeczeństwo. Wyjątek stanowiły jedynie te decyzje, które wymagały przeprowadzenia obligatoryjnego referendum. Dotyczyło to przykładowo włączenia Szwajcarii do takich organizacji, jak Liga Narodów czy ONZ. W pozostałych przypadkach instrumenty demokracji bezpośredniej nie znajdowały zastosowania $\mathrm{w}$ obszarze polityki zagranicznej. W związku z powyższym odnotować możemy również mniejszą aktywność mediów, będących przecież podstawowym środkiem przekazu i źródłem informacji na temat pracy rządu i relacji z innymi krajami.

Sytuacja uległa zmianie po zakończeniu zimnej wojny i upadku bloku wschodniego. Procesy integracyjne przyczyniły się do wzrostu obecności polityki zagranicznej w debacie publicznej. Działania rządu w tej materii coraz częściej uwzględniać musiały nastroje społeczne, tym bardziej że zmiana konstytucji w 1999 r. wzmocniła znaczenie demokracji bezpośredniej. Oczywiście kluczową rolę odgrywała nadal egzekutywa, w mniejszym stopniu parlament. Co ciekawe, według opublikowanego w roku 2000 raportu, w większości przypadków rząd nie bierze bezpośredniego udziału w realizowaniu polityki courant normal ${ }^{106}$. Odpowiedzialne są za to poszczególne Departamenty i ich dyrektorzy. Jedynie $\mathrm{w}$ trudnych politycznie przypadkach, związanych z silniejszą presją wewnątrzkrajową czy międzynarodową, członkowie Rady Związkowej angażują się osobiście. Niemniej jednak zjawiska zachodzące na arenie międzynarodowej wymuszały coraz większą partycypację obywateli w życiu politycznym. Polityka zagraniczna zaczęła odgrywać coraz większą rolę. Niestety, w ślad za tymi zmianami nie szły przemiany instytucjonalne. Utarte przyzwyczajenia i zasady sprawiły, że poziom zainteresowania społeczeństwa polityką zagraniczną pozostawał na relatywnie

${ }^{106}$ U. Klöti, U. Serdült, T. Widmer, Aussenpolitik von innen: Entscheidungsprozesse der schweizerischen Aussenpolitik in den achtziger und neunziger Jahren, NFP 42 Synthesis 51, Bern 2000, s. 12. 
niskim poziomie, pomimo iż władze coraz częściej zmuszane były do odwoływania się do woli suwerena. Tak było chociażby przy okazji włączenia Szwajcarii do Międzynarodowego Funduszu Walutowego i Banku Światowego. To właśnie decyzja społeczeństwa, a nie rządu, zadecydowała o rozpoczęciu współpracy bilateralnej z UE. Należałoby zatem oczekiwać, że jakość debaty publicznej i - co za tym idzie - wiedzy obywateli na temat relacji zewnętrznych, osiągnie nieporównywalnie wyższy poziom niż w okresie zimnej wojny, zdominowanej przez doktrynę neutralności. Analizy przeprowadzone w ramach Narodowego Programu Badawczego NFP przedstawiają jednak zupełnie inny obraz rzeczywistości. Okazuje się bowiem, iż zainteresowanie i wiedza obywateli, dotyczące polityki zagranicznej, są znacznie niższe od oczekiwanej w przypadku społeczeństw wyposażonych w instrumenty bezpośredniej partycypacji politycznej. Wyrażanie własnego zdania odnośnie do kwestii mających niekiedy kolosalne znaczenie dla ochrony interesów państwa oraz jego roli na arenie międzynarodowej, w tym również dla postrzegania przez innych aktorów wymaga przecież szczególnej wiedzy. Wiedzy, która pozwoliłaby na obiektywną ocenę poruszanych w trakcie referendum kwestii, a tym samym świadome podejmowanie związanych z nią decyzji. Jako przyczyny niezadowalającego poziomu wiedzy wskazać należy dwa podstawowe czynniki. Po pierwsze, jak wskazują ustalenia wspomnianego już raportu, aż 40\% kwestii związanych z realizacją polityki zagranicznej nie wychodzi poza sferę działania rządu, tzn. stosowne informacje nie są publikowane w żadnych urzędowych biuletynach, a co za tym idzie społeczeństwo nie ma właściwie żadnego do nich dostępu ${ }^{107}$. W praktyce upubliczniane są najczęściej jedynie te sprawy, które trafiają do parlamentu i są przedmiotem obrad specjalnych komisji. Skutkiem tego do konsultacji społecznych kierowana jest tylko niewielka część projektów. Według przeprowadzonych badań, w latach 1992-1997 zaledwie ok. 10\% wszystkich konsultacji poświęconych było kwestiom związanym z polityką zewnętrzną ${ }^{108}$. Po drugie, bardzo wiele informacji nie trafia do mediów, będących podstawowym źródłem wiedzy lub też trafia tam ze zbyt dużym opóźnieniem.

\subsection{JAKOŚĆ I AKTYWNOŚĆ SŁUŻB DYPLOMATYCZNYCH}

Jak już wcześniej wspomniano, główne decyzje polityczne podejmowane przez Radę Związkową są następnie realizowane przez poszczególne Departamenty. W przypadku polityki zagranicznej podstawowym, lecz nie jedynym, organem działań operacyjnych jest Departament Spraw Zagranicznych (Eidgenössisches Departement für auswärtige Angelegenheiten, EDA). Pełni on niejako funkcję koordynatora działań zagranicznych, podejmowanych przez inne resor-

\footnotetext{
${ }^{107}$ Ibidem.

${ }^{108}$ Ibidem, s. 13.
} 
ty. Instytucja ta przeszła na przestrzeni ostatnich stu lat diametralną przemianę. Jeszcze na początku wieku XX EDA zatrudniała jedynie kilkudziesięciu urzędników, kierowanych, niejako przy okazji, przez aktualnego przewodniczącego Rady Związkowej. Warto dodać, iż funkcja ta każdego roku pełniona była przez innego członka Rady, co w oczywisty sposób odbijało się na jej działaniu, a zwłaszcza efektywności podejmowanych poczynań. W miarę przenoszenia punktu ciężkości na sprawy zewnętrzne Departament stopniowo się rozrastał. W różnych strukturach EDA zatrudnionych jest obecnie ok. 2700 pracowników ${ }^{109}$. Pod względem strukturalnym Departament podzielony jest na trzy piony: polityczny (die Politische Direktion), prawa międzynarodowego (Direktion für Völkerrecht) oraz rozwoju i współpracy (Direktion für Entwicklung und Zusammenarbeit).

W ramach pierwszego pionu powołano do życia, w roku 1961, Biuro Integracyjne (Integrationsbüro), zajmujące się wyłącznie tematyką europejską, tj. rozwojem stosunków z EFTA oraz ze Wspólnotą (wcześniej EWG, obecnie z Unią Europejską). Warto dodać, że Biuro jest instytucją funkcjonującą na pograniczu dwóch Departamentów, włączając w to Departament Gospodarczy. Jego głównym celem jest monitorowanie procesu integracji oraz analiza wywieranego wpływu na Szwajcarię. Biuro pełni ponadto funkcje doradcze wobec Rady Związkowej oraz, w porozumieniu z innymi agencjami, kieruje procesem negocjacji z UE ${ }^{110}$. Rola Biura Integracyjnego wzrosła przede wszystkim po decyzji rządu o rozpoczęciu współpracy ze Wspólnotą na drodze bilateralnej, czyli od roku 1993. Od tego momentu Biuro odpowiedzialne jest za formułowanie, w imieniu Rady Związkowej, oficjalnego stanowiska rządu w kwestiach będących przedmiotem dwustronnych rokowań. Organ ten jest także głównym źródłem informacji dla opinii publicznej na temat polityki europejskiej oraz integracji z UE. Biuro Integracyjne, pomimo istotnych kompetencji i szerokiego wachlarza zadań, zatrudnia relatywnie niewielką liczbę osób. Według stanu z sierpnia 2009 r. liczy 33 pracowników. Priorytetowe kierunki działań Biura określone zostały w rządowym raporcie z 2006 r. Do najważniejszych obecnie zadań należy kontynuacja prac nad nowym pakietem porozumień dwustronnych oraz nadzór nad ich prawidłowym wdrażaniem.

Warto w tym miejscu wspomnieć o innych instytucjach, które biorą udział w kształtowaniu i realizacji polityki europejskiej rządu. Departament Spraw Zagranicznych nie jest jedynym ciałem odpowiadającym za relacje zewnętrzne, choć na pewno pełni on funkcje koordynujące ${ }^{111}$. Istotne jest jednak, że podstawowy obszar współpracy z Unią Europejską, a więc kwestie gospodarcze, pozostaje domeną Departamentu Gospodarczego, odpowiedzialnego w głównej mierze za re-

${ }^{109}$ L. Goetschel. M. Bernath, D. Schwarz, op. cit., s. 68.

${ }^{110}$ Im Kern der Schweizer Europapolitik, Integrationsbüro EDA/EVD, August 2009, s. 2.

${ }^{111}$ Organisationsverordnung für das Eidgenössische Departement für auswärtige Angelegenheiten vom 29. März 2000, s. 1. Dokument dostępny na stronie http://www.admin. $\mathrm{ch} / \mathrm{ch} / \mathrm{d} / \mathrm{sr} / 1 / 172.211 .1 . d e . p d f(21.09 .2009)$. 
prezentowanie i ochronę interesów Szwajcarii za granicą. Podobnie jest z innymi resortami, które ponoszą współodpowiedzialność za rozwój relacji zewnętrznych, oczywiście w kompetencyjnie przynależnych im obszarach. Oznacza to, iż obecnie niemal każdy Departament zdolny jest do reprezentowania interesów Szwajcarii na zewnątrz. Przykładowo w pertraktacjach z rządem USA dotyczących głośnej sprawy ujawnienia informacji na temat kont obywateli amerykańskich, którzy, unikając podatków, lokowali swoje pieniądze w szwajcarskich bankach, brali udział szefowie trzech Departamentów ${ }^{112}$. Sytuacja ta sprzyja rozwojowi współpracy międzyresortowej, lecz stawia również spore wymagania w zakresie koordynacji działań. Niestety czasami odbija się to negatywnie na efektywności polityki zagranicznej Szwajcarii.

W roku 1999 opublikowano wyniki Narodowego Programu Badawczego, analizującego podstawy i możliwości szwajcarskiej polityki zagranicznej ${ }^{113}$. Jego częścią jest raport poświęcony działaniu aparatu decyzyjnego w perspektywie spektakularnych zmian międzynarodowego kontekstu politycznego, wywołanych wydarzeniami lat 1989/1990. Raport jest próbą wskazania jakościowych deficytów funkcjonowania ośrodków decyzyjnych i problemów, z jakimi będzie trzeba się zmierzyć w najbliższej przyszłości. Punktem wyjścia są tutaj cztery najważniejsze wydarzenia wskazanego wyżej okresu - zjednoczenie Niemiec, rozpad ZSRR, wojna w Zatoce Perskiej, a także proces integracyjny w Europie, przede wszystkim w perspektywie przekształcania struktur EWG i tworzenia Unii Europejskiej.

Okres ten wybrano ze względu na wyjątkowy charakter przemian, wymagających rewizji dotychczasowej strategii politycznej. Rząd Szwajcarii skonfrontowany został z zupełnie nowymi problemami polityki międzynarodowej. Ich rozwiązanie wymagało podejmowania dynamicznych działań, opartych na prawidłowej analizie bieżących wydarzeń. Wszystkie, z wyjątkiem zjednoczenia Niemiec, wiązały się z koniecznością formułowania określonego, niekiedy kontrowersyjnego, stanowiska. Problemem było chociażby uznanie państw powstałych w wyniku rozpadu Związku Radzieckiego czy udział w sankcjach gospodarczych i militarnych wymierzonych przeciwko Irakowi. Rząd w Bernie musiał zmierzyć się również z problemem integracji europejskiej, mającej bezpośredni wpływ na cały system polityczny państwa. Aparat decyzyjny przeszedł tę próbę, z wyjątkiem głosowania w sprawie przystąpienia do Europejskiego Obszaru Gospodarczego, zwycięsko. Nie świadczy to jednak, zdaniem autorów raportu, iż ośrodki decyzji politycznych funkcjonują bez zarzutu ${ }^{114}$. Wręcz przeciwnie, w wielu przypadkach decyzje podejmowane były bez przeprowadzenia właściwych analiz, które pozwalałyby chociażby na opracowanie różnych scenariuszy rozwoju. Świadczy to o niedostatecznym poziomie prognozowania politycznego, a w związku z tym

\footnotetext{
${ }^{112}$ Departament Finansów, Spraw Zagranicznych oraz Policji i Wymiaru Sprawiedliwości.

${ }^{113}$ D. Ruloff, T. Bernauer, S. Bruno, P. Moser, A. Schnur, op. cit.

${ }^{114}$ Ibidem, s. 8.
} 
o pewnych niedostatkach jakościowych i funkcjonalnych głównych decydentów polityki zagranicznej Szwajcarii.

Zdaniem autorów omawianego powyżej raportu polityka zagraniczna Szwajcarii oparta jest na określonych, dość wąskich schematach, które nie zawsze są dostosowane do aktualnych wydarzeń. Można zatem odnieść wrażenie, że w wielu przypadkach podejmowane decyzje nie były częścią długofalowej strategii, lecz miały charakter doraźny, pragmatyczny, służący rozwiązaniu bieżących problemów. Wiąże się z tym zarzut braku głębszych koncepcji politycznych. Poszczególne sytuacje czy też wydarzenia traktowane były w sposób jednostkowy, bez uwzględnienia szerszego kontekstu geopolitycznego. Rząd koncentrował się przede wszystkim na rozwiązaniu zagadnień bezpośrednio wpływających na bezpieczeństwo lub interes gospodarczy Szwajcarii. Niemałą rolę odgrywały przy tym placówki zagraniczne, odpowiedzialne, bodaj w największych stopniu, za dostarczenie wyczerpujących informacji i analiz. Raport określał zatem politykę rządu jako zbyt konserwatywną, nastawioną na rozwiązywanie różnych problemów za pomocą tego samego, pragmatycznego wzorca ${ }^{115}$.

Autorzy raportu koncentrują się również na analizie samego procesu decyzyjnego i na formułowaniu stanowiska przez rząd. Wyłania się z niej niezbyt korzystny obraz. Przede wszystkim wskazano na słabości w funkcjonowaniu samej Rady Związkowej, która, według nich, sama w sobie nie jest predestynowana do szybkiego reagowania na zmiany zachodzące $\mathrm{w}$ polityce międzynarodowej. Źródeł tego problemu upatrywać można zarówno w zapisach konstytucyjnych, jak i bezpośrednio na poziomie organizacyjnym. Niezwykle istotnym czynnikiem jest sam charakter Rady, będącej siedmioosobowym gremium, w ramach którego wszelkie decyzje, przede wszystkim z powodu braku wyraźnego przywództwa, podejmowane są w sposób kolegialny. Odbija się to na dynamiczności i efektywności jej działań. Do tego dochodzi problem referendum, będącego w wielu przypadkach czynnikiem ograniczającym i zmuszającym rząd do podejmowania działań w sposób schematyczny. Każda decyzja, wychodząca poza utarte reguły, narażona jest na kontestację ze strony społeczeństwa, wyposażonego w niezwykle skuteczną broń w postaci referendum opcjonalnego. Do tego dochodzi problem przepływu informacji w ramach samej Rady. Autorzy raportu wskazują tutaj przykładowo na wręcz patologiczne deficyty we właściwym poziomie wzajemnego informowania o postępie w negocjacjach dotyczących przystąpienia do Europejskiego Obszaru Gospodarczego. Konsekwencją deficytów informacyjnych są z kolei tarcia polityczne wewnątrz rządu.

Autorzy raportu poświęcają również trochę uwagi poziomowi przepływu informacji na innych szczeblach administracji państwowej. Bardzo ważnym elementem pracy Departamentu Spraw Zagranicznych jest właściwa współpraca pomiędzy Sekretariatem Politycznym (Politisches Sekretariat) a Wydziałem

115 Ibidem, s. 9. 
Politycznym (Politische Abteilung). Funkcjonowanie obu jednostek uzależnione jest od wzajemnego przepływu informacji. Według przygotowanej koncepcji Sekretariat Polityczny odpowiedzialny jest za opracowywanie analiz i raportów, na podstawie których Wydział Polityczny podejmuje operacyjne działania. Sekretariat pełni zatem funkcje think tanku, zbierającego i przetwarzającego informacje, które stają się podstawą konkretnych decyzji, będących częścią, przynajmniej $\mathrm{w}$ założeniu, szerszych strategii politycznych ${ }^{116}$. Autorzy raportu wskazują jednakże, że w praktyce powyższy podział kompetencyjny ulega zatarciu. Bardzo często dochodzi do zjawiska swoistej izolacji Sekretariatu, co przekłada się na niewłaściwy poziom przepływu informacji.

Właściwe funkcjonowanie Departamentu Spraw Zagranicznych zależne jest również od współpracy pomiędzy centralą a szwajcarskimi placówkami dyplomatycznymi za granicą. Ambasady odpowiedzialne są za dostarczanie najświeższych i najbardziej kompetentnych informacji, płynących z danego regionu. Jest to tym istotniejsze, że w przeciwieństwie do innych komórek funkcjonujących z dala od źródła wydarzeń, są one w stanie ocenić właściwy nastrój i intencje innych państw w stosunku do określonego problemu. Placówki dyplomatyczne pełnią również funkcję pierwszych weryfikatorów informacji, podejmując decyzje o wadze danego wydarzenia z punktu widzenia interesów Szwajcarii. Ewentualne błędy popełniane na tym etapie mają niezwykle istotnych wpływ na dalszy proces podejmowania decyzji, już na poziomie centralnym. Twórcy raportu wskazują, że informacje przesyłane przez pracowników ambasad tworzone są bardzo często wyłącznie na podstawie lektury prasy ${ }^{117}$. Odbywa się to, niestety, kosztem głębszych analiz problemowych, w tym przede wszystkim prób politycznego prognozowania. W przypadku niektórych zjawisk polityki międzynarodowej, takich jak chociażby integracja europejska, pogłębiona analiza problemowa zapewne stanowiłaby istotną pomoc przy prowadzeniu bilateralnych negocjacji ze Wspólnotą. Wydaje się bowiem, iż nie tylko oficjalne stanowisko partnera, lecz również zrozumienie szerszego kontekstu politycznego czy też przesłanek stojących za decyzjami Brukseli mogą mieć istotny wpływ na rozwiązanie wielu kontrowersyjnych kwestii. Dobrym tego przykładem jest spór dotyczący systemu podatkowego, prowadzony od dłuższego czasu pomiędzy Bernem a Brukselą ${ }^{118}$.

Przyczyn powyższego problemu upatrywać należy przede wszystkim w niedostatkach kadrowych, ale istotna jest przy tym również mentalność poszczególnych pracowników, niechętnych podejmowaniu odważnych analiz, zmierzających do opracowania możliwych scenariuszy i określonych strategii działania.

Powyższe uwarunkowania przedstawiają raczej negatywny obraz funkcjonowania szwajcarskiej dyplomacji. Trzeba jednak zaznaczyć, że raport sporządzony był na podstawie analizy wyjątkowego okresu, a więc część zasygnalizowanych

\footnotetext{
${ }^{116}$ Ibidem, s. 13.

${ }^{117}$ Ibidem, s. 14.

${ }^{118}$ Więcej na temat sporu w rozdziale poświęconym realizacji polityki wobec UE.
} 
w nim problemów na pewno uległa dezaktualizacji. Warto przy tym skupić uwagę na tych elementach, które w perspektywie zagadnień, będących przedmiotem niniejszego opracowania, wydają się nadal aktualne.

W latach 2003-2011, a zatem w okresie wdrażania zawieranych z UE umów, na czele resortu spraw zagranicznych stała Micheline Calmy-Rey ${ }^{119}$. Dość długi okres kadencji świadczy zapewne o jej ugruntowanej pozycji w Razie Związkowej. Polityka Calmy-Rey była jednak nierzadko obiektem krytyki, także ze strony partyjnych kolegów. Uważano, iż zbyt często podejmuje decyzje bez konsultacji z resztą rządu, co w konsekwencji stawia niejednokrotnie Radę w niezręcznych sytuacjach ${ }^{120}$. W polityce europejskiej zarzucano jej też zbytnią bierność. W przeciwieństwie do swoich poprzedników za priorytet uznała działanie na rzecz obrony praw człowieka i pośrednictwo w rozwiązywaniu konfliktów. Według wielu komentatorów jej poczynania, przede wszystkim zaś pewna chaotyczność w działaniu, spowodowały, że na tle innych członków Rady Związkowej sprawiała wrażenie osamotnionej ${ }^{121}$. W polityce europejskiej była zwolennikiem raczej ostrożnego zbliżenia z UE, choć to za jej kadencji przyjęto dokument uznający przystąpienie do Unii Europejskiej za jeden z możliwych wariantów rozwoju dalszych relacji ze Wspólnotą ${ }^{122}$. Niemniej jednak w najbliższym czasie nie należy spodziewać się zasadniczych zmian w dotychczasowej polityce. Micheline Calmy-Rey w udzielanych wywiadach wielokrotnie potwierdzała chęć kontynuacji współpracy bilateralnej, której przypieczętowaniem, zdaniem szefowej dyplomacji, winna być umowa ramowa ${ }^{123}$. W oczach opinii publicznej nie uchodziła za euroentuzjastkę, czego nie można było powiedzieć o jej poprzedniku - Josephe Deissie ${ }^{124}$.

Oceniając politykę Micheline Calmy-Rey trudno oprzeć się wrażeniu, że wiele jej decyzji determinowanych było przez samą specyfikę działania Rady Związkowej. Opiera się ono na wzajemnej współpracy, co w warunkach partyjnej heterogeniczności nie jest zapewne sprawą łatwą. Osobiste poglądy, a także zobowiązania wobec własnej partii czy też wyborców, odgrywają tutaj niezwykle istotną rolę. Dodać należy do tego kwestię reprezentowania interesów własnego

${ }^{119}$ Od 1 stycznia 2012 r. szefem resortu jest Didier Burkhalter.

${ }^{120}$ Dobrym przykładem jest sprawa uznania niepodległości Kosova jeszcze przed wydaniem oficjalnego komunikatu przez rząd szwajcarski lub krytykowana przez innych członków Rady Związkowej jej aktywność w trakcie konfliktu rosyjsko-gruzińskiego.

${ }^{121}$ Wie schlecht ist dieser Bundesrat wirklich?, „Tagesanzeiger”, 5 Mai 2009.

${ }^{122}$ Raport rządu dot. polityki europejskiej Europabericht 2006, dostępny na stronie: www.admin.ch/ch/d/ff/2006/6815.pdf (25.09.2009). Szczegółowo omówiony w rozdziale drugim niniejszej pracy.

${ }^{123}$ Zob. wielokrotne wypowiedzi na temat polityki wobec EU: Wir lösen Steuerstreit, „St. Galler Tagblatt”, 9. Februar 2009; Der Kampf um die Schweizer Europapolitik ist neu lanciert, „Neue Zürcher Zeitung”, 20. Januar 2008; Wir sind keine Insel in der EU, „Focus” 2003, Nr. 42, s. 266.

${ }^{124}$ Neutralität bedeutet nicht, möglichst ruhig zu bleiben, „Basler Zeitung”, 28./29. August 2004, Nr. 201, s. 3. 
okręgu wyborczego, a więc kantonu. Pochodzenie członków Rady, w rozumieniu obszaru językowego, z którego pochodzą, ma również duże znaczenie. Powszechnie znana jest większa otwartość na współpracę ze Wspólnotą polityków wywodzących się z francuskojęzycznych kantonów i eurosceptycyzm ich niemieckojęzycznych kolegów. Nie dziwi zatem, że polityka szefowej dyplomacji Szwajcarii, wychodząca niekiedy poza utarte schematy, spotykała się często z krytyką partyjnych kolegów lub członków rządu. Spora część społeczeństwa popierała jednak pracę Micheline Calmy-Rey, ceniąc ją przede wszystkim za otwartość i pewną spontaniczność w działaniu, a jednocześnie przywiązanie do podstawowych wartości, takich jak suwerenność i neutralizm.

Warto również wspomnieć o coraz liczniejszych postulatach zreformowania EDA, jakie pojawiają się najczęściej w kontekście zmian w funkcjonowaniu Rady Związkowej. Należy podkreślić, że jej struktura i sposób funkcjonowania nie uległy zmianie od roku 1848, a więc od momentu uchwalenia pierwszej konstytucji Związku. Jedna z propozycji zakłada wydłużenie kadencji przewodniczącego Rady Związkowej wraz z przyporządkowaniem mu funkcji szefa szwajcarskiej dyplomacji. Taka reforma sprzyjałaby zapewne utrzymywaniu długofalowej strategii politycznej i lepszej koordynacji działan, podejmowanych wobec partnerów zewnętrznych. Oczywiście przy założeniu, iż taka zmiana pociągnie za sobą wzmocnienie, w sposób wymierny, pozycji przewodniczącego Rady.

\subsection{Rola mediów w polityce zagranicznej Szwajcarii}

Specyfika funkcjonowania mediów, będących najważniejszym instrumentem kształtowania opinii publicznej, pozwala nam zaliczyć je do istotnych uwarunkowań polityki zagranicznej, przede wszystkim w kontekście ich oddziaływania na demokrację bezpośrednią, a co za tym idzie na proces decyzyjny. Problem ten był zresztą przedmiotem szerszych analiz w ramach wspomnianego już Narodowego Programu Badawczego NFP 42, dotyczącego podstaw i możliwości prowadzenia polityki zagranicznej Szwajcariii ${ }^{125}$. Głównie chodzi o te funkcje szwajcarskich mediów, które przekładają się m.in. na relacje z Unią Europejską. Okazuje się bowiem, że choć polityka zagraniczna nie znajduje się w centralnym punkcie zainteresowania (według badań NFP polityka zagraniczna zajmuje piątą lokatę $\mathrm{w}$ hierarchii ważności), środowisko dziennikarskie określić można jako przyjazne otwarciu Szwajcarii na współpracę międzynarodową, w tym również na integrację ze Wspólnotą. Nie znaczy to oczywiście, że wszelkie wydarzenia relacjonowane są w sposób jednostronny. Niemniej jednak, jak wskazują sondaże, ok. 80\% dziennikarzy popiera współpracę z UE, co w sposób oczywisty przekłada się na

${ }^{125}$ H. Bonfadelli, R. Blum, Helvetisches Stiefkind: die Rolle der Massenmedien bei der Vermittlung schweizerischer Aussenpolitik, NFP Synthesis 28, Bern 2000. 
formę i wyraz przekazu kierowanego do opinii publicznej ${ }^{126}$. Oczywiście w przypadku mediów mamy do czynienia z pewnymi podziałami światopoglądowymi, które determinują, także w zależności od zróżnicowania językowego, mniejszy lub większy euroentuzjazm. Francuskie tytuły prasowe będą zatem zdecydowanie bardziej otwarte na współpracę europejską niż przeciętne dzienniki niemieckojęzyczne. Najbardziej istotny jest jednak fakt, że spośród wszystkich tematów zagranicznych, to właśnie Europie poświęca się zdecydowanie najwięcej miejsca. Badania wskazują, iż wydarzenia związane ze Starym Kontynentem zajmują w opinii dziennikarzy priorytetowe miejsce. Wśród nich największym zainteresowaniem cieszą się relacje bilateralne z Unią Europejską. Jest to niezwykle pozytywny sygnał, wpływający dodatnio na poziom wiedzy obywateli w kontekście spraw europejskich, tym bardziej że w ostatnim czasie są one dość często eksploatowane, chociażby przy okazji obligatoryjnych i fakultatywnych głosowań referendalnych. W pracy mediów brakuje jednakże szerszej analizy problemu. Przeglądając dzienniki lub słuchając sprawozdań radiowo-telewizyjnych zauważyć można tendencję ograniczania się do relacjonowania wydarzeń, przy unikaniu przy tym autorskich komentarzy lub choćby próby interpretacji szerszego tła politycznego ${ }^{127}$. Jedynie duże tytuły, jak „Neue Zürcher Zeitung”, poświęcają głębszej analizie nieco więcej miejsca. Wspomniany dziennik jest zresztą liderem, na którego powołują się nie tylko lokalne media, lecz również prasa zagraniczna. Jest to o tyle istotne, że wiele komentarzy i opinii nie trafia do czytelników mniejszych gazet. Warto zaznaczyć, że w całej Szwajcarii wydawanych jest około 200 tytułów prasowych. Większość z nich, bo ok. 70\%, ma nakłady niższe niż 15000 egzemplarzy. Odsetek czytelników pozbawionych poważniejszych analiz prasowych, pozwalających na wykrystalizowanie własnych opinii, nie jest może przeważający, lecz na pewno wart odnotowania.

Należałoby zatem odpowiedzieć na pytanie, w jakim stopniu czołowe media kształtują poglądy opinii publicznej w Szwajcarii i w jakim stopniu przekłada się to na funkcjonowanie podstawowych mechanizmów demokracji bezpośredniej? Interesującą tezę wysnuć można $\mathrm{z}$ danych przedstawionych we wspomnianej już pracy badawczej. Okazuje się, iż głównym źródłem informacji są komunikaty prasowe Departamentu Spraw Zagranicznych (EDA) ${ }^{128}$. Większość mediów czerpie wiedzę na temat działań rządu i całego resortu z materiałów opracowanych przez EDA lub organizowanych co pewien czas konferencji prasowych. Otrzymywane tą drogą informacje są następnie stosownie przerabiane i na ich podstawie tworzy się kolejne artykuły, relacje, opinie oraz analizy. Często mamy wówczas do czynienia ze zjawiskiem multiplikacji. Średnio na podstawie jednej informacji przekazanej mediom przez resort powstają cztery artykuły ${ }^{129}$. Wielokrotnie mate-

\footnotetext{
${ }^{126}$ Ibidem, s. 9.

${ }^{127}$ Ibidem, s. 11.

${ }^{128}$ Ibidem, s. 10.

${ }^{129}$ Ibidem, s. 15.
} 
riał opracowany przez EDA jest bez zmian przedrukowywany w prasie, tak jak dzieje się to w przypadku „Neue Zürcher Zeitung”. W kontekście powoływania się mediów na źródła z Departamentu Spraw Zagranicznych zauważyć możemy typową dla Szwajcarii tendencję. Również i tutaj rysują się pewne podziały pomiędzy mediami francusko- i niemieckojęzycznymi. Te ostatnie zdecydowanie częściej opierają się na źródłach rządowych. Być może przyczyn tego stanu należy upatrywać w generalnie mniejszym zainteresowaniu mediów z zachodnich kantonów polityką zagraniczną. Do spraw krajowych podchodzi się ze zdecydowanie większą atencją. Niemniej jednak EDA odgrywa pierwszoplanową rolę jako animator agendy tematycznej, która zajmują się następnie szwajcarskie media. Oczywiście, w przeciwieństwie do źródeł rządowych prasa znacznie chętniej podejmuje wątki niezwiązane wyłącznie z sukcesami resortu. Chętnie uwypuklane są porażki polityczne, a osoby na kluczowych stanowiskach często stają się obiektem krytyki. Nie zmienia to faktu, że w wielu przypadkach media wykazują się relatywnie niewielką kreatywnością, a przede wszystkim brakiem długofalowej koncepcji politycznej. Przykładowo, komentarze zamieszczane w najbardziej opiniotwórczej gazecie „Neue Zürcher Zeitung” zazwyczaj odzwierciedlają jedynie stanowisko rządu.

W tym sensie trudno mówić o wyjątkowej roli mediów jako kreatora opinii. Autorzy przytoczonego powyżej raportu wskazują jako tego przyczynę pewne zapóźnienia instytucjonalne i mentalne szwajcarskich mediów, które nie nadążyły za nowymi wyzwaniami postzimnowojennej rzeczywistości. Tradycyjna koncepcja roli i funkcjonowania mediów traci na aktualności wobec specyfiki bieżących wydarzeń. Przede wszystkim chodzi o gwałtowny wzrost liczby tematów i problemów polityki międzynarodowej, które należy nie tylko zrelacjonować, lecz również przeanalizować i w odpowiedni sposób skomentować. Media pozostają głównym przekaźnikiem informacji na temat otaczającego świata i procesów politycznych oraz społecznych zachodzących w kraju i za granicą. Jeżeli wykazują postawę zachowawczą, duże przywiązanie do tradycji, podstawowych wartości i utartych schematów, to właśnie taki obraz i takie wzorce przekazywane są społeczeństwu. W konsekwencji obywatele wykazują zdecydowanie większy oportunizm i niechęć do jakichkolwiek zmian. Doskonałym tego przykładem jest niezwykła stabilizacja sceny politycznej Szwajcarii, która utrzymywana była w niemal niezmiennych proporcjach przez blisko połowę ubiegłego stulecia ${ }^{130}$. Innym dobrym przykładem jest również polityka wobec UE, determinowana przez społeczeństwo nastawione zdecydowanie bardziej sceptycznie, w porównaniu z innymi państwami europejskimi. Przekłada się to oczywiście na wyniki gło-

130 Tzw. Zauberformel polegała na sztywnym podziale stanowisk w Radzie Związkowej pomiędzy CVP, FDP, SP oraz SVP. Każda z partii, z wyjątkiem SVP, miała po dwóch reprezentantów w rządzie. Reguła funkcjonowała od roku 1959 i przetrwała aż do 2003 r., kiedy to ludowcy, po korzystnych dla nich wynikach wyborów parlamentarnych, uzyskali dodatkowe miejsce w Radzie kosztem CVP. Zob. A.F. Reber, Der Weg zur Zauberformel, Lang, Bern 1976; E. Rüegg, Regierbarkeit durch Konkordanz?, Zürich 1985. 
sowań referendalnych, dotyczących nie tylko spraw bezpośrednio związanych z polityką zagraniczną, lecz również tych, które w sposób pośredni wpłynąć mogą na jej efektywność. Obywatele zdają sobie sprawę z potrzeby przeprowadzenia wielu reform w celu wzmocnienia skuteczności politycznej Szwajcarii w relacjach zewnętrznych. Świadczą o tym chociażby takie problemy, jak spór z UE na tle polityki fiskalnej, kwestia tajemnicy bankowej lub ciągnący się od dłuższego czasu konflikt dyplomatyczny z Libią ${ }^{131}$. Pomimo to obywatele pozostają nieufni wobec większych zmian instytucjonalnych, szczególnie jeżeli miałyby być efektem oddziaływania albo wręcz presji ze strony czynników zewnętrznych. Stąd też ogromna niechęć do zmian wynikających z konieczności adaptacji systemu politycznego do standardów i wymogów UE. Choćby z tego względu poruszone w niniejszym rozdziale problemy, z przyczyn obiektywnych, do których zaliczamy znaczenie i siłę demokracji bezpośredniej, uznać można za nierozwiązywalne w najbliższej przyszłości. Zapewne będą one nadal rzutować na kształt relacji wzajemnych ze Wspólnotą. Mamy zatem do czynienia z pewnym paradoksem. Z jednej strony, jak pokazują przytoczone powyżej badania, media w Szwajcarii generalnie uznać wypada za postępowe, tj. otwarte na integrację, a przynajmniej popierające politykę bilateralną rządu. Z drugiej strony, środki masowego przekazu należą do tych instytucji, które kultywują tradycyjny światopogląd, oparty na neutralności i demokracji bezpośredniej. Wartości te, których być może nie powinno się zaliczać do przeszkód na drodze do integracji, są na pewno istotnym czynnikiem spowalniającym.

Warto przy tej okazji poświęcić nieco miejsca na omówienie funkcjonowania i oddziaływania środków masowego przekazu w Szwajcarii. Swoista unikalność mediów wynika przede wszystkim z podziału językowego. Pomiędzy poszczególnymi tytułami prasowymi zauważyć możemy wiele różnic związanych ze sposobem relacjonowania najważniejszych informacji. Wpływają na to odmienności kulturowe i światopoglądowe pomiędzy kantonami niemiecko-, francuskoi włoskojęzycznymi. Ze względu na dysproporcje ludnościowe i terytorialne, a przede wszystkim fakt, iż centrum wydarzeń politycznych usytuowane jest w kantonie niemieckojęzycznym, siłą rzeczy właśnie w tych kantonach wydawanych jest najwięcej tytułów prasowych. Dzienniki takie, jak „Neue Zürcher Zeitung” czy „Tagesanzeiger” należą do najbardziej poczytnych i opiniotwórczych gazet. Trzeba również nadmienić, że zarówno telewizja, jak i radio zdecydowanie najlepiej rozwinięte są we wschodnich kantonach. Wszystko to sprawia, że analizując wpływ mediów na kształtowanie opinii publicznej wypada wziąć pod uwagę zakres ich oddziaływania, tj. liczbę odbiorców poszczególnych tytułów prasowych lub telewizji. Jest rzeczą naturalną, że otwartość lub konserwatyzm polityczny kantonów niemieckojęzycznych jest w ogromnej mierze efektem

${ }^{131}$ Dossier nt. kryzysu szwajcarsko-libijskiego na stronach internetowych „Neue Zürcher Zeitung": http://www.nzz.ch/hintergrund/dossiers/libyen_-_schweiz_dossier_2.46474 (15.10.2010). 
działania środków masowego przekazu. Określony punkt widzenia prasy niemieckojęzycznej, odmienny od tego, który prezentowany jest w kantonach francuskolub włoskojęzycznych, a nie należy to do rzadkości, ma swoje odzwierciedlenie w podziale światopoglądowym, przebiegającym wzdłuż granic poszczególnych kantonów. W przeszłości znane były przypadki silnych podziałów, bynajmniej niezwiązanych ze statusem społecznym bądź wykształceniem, lecz z pochodzeniem i językiem. Zjawisko to, zwane Röstigraben ${ }^{132}$, stało się źródłem wielu napięć, a nawet niepokojów społecznych, które nasiliły się przede wszystkim w okresie I wojny światowej ${ }^{133}$. Od tego czasu podział ten, choć o zdecydowanie mniejszym natężeniu, pozostaje nadal zauważalny, chociażby przy okazji publicznych debat lub w analizach sondażowych. Tutaj ponownie można odwołać się do polityki europejskiej. Wyniki głosowań referendalnych wskazują na niezwykle tendencyjny rozkład głosów, świadczący o znacznie większym stopniu euroentuzjazmu wśród obywateli kantonów francuskojęzycznych. Oczywiście z czasem podział ten stopniowo zanika, przede wszystkim na rzecz różnic związanych z wykształceniem lub statusem materialnym, w tym także z tradycyjnym już podziałem wieś - miasto.

$* * *$

Biorąc pod uwagę złożoność wszystkich omówionych w niniejszym rozdziale uwarunkowań można śmiało postawić tezę, że to właśnie one zadecydowały w największym stopniu o kształcie polityki europejskiej Szwajcarii. Wydaje się, że swoista unikalność systemu politycznego, z jego głównymi przywarami w postaci demokracji bezpośredniej oraz federalizmu, stanowi o szczególnym przypadku (Sonderfall) tego państwa, które wbrew ogólnoeuropejskim tendencjom skutecznie opiera się integracji, przynajmniej w kształcie zaproponowanym przez Traktat z Maastricht, a realizowanym przez większość państw europejskich. Polityka ta doprowadziła do pozornego osamotnienia Szwajcarii, będącej wyspą na politycznej mapie Europy. Pozornego, albowiem faktyczne zjawiska integracyjne są niepodważalne, choć ramy instytucjonalne i prawne zdecydowanie odbiegają od powszechnie przyjętych standardów. Uwarunkowania polityczne, społeczne, kulturowe oraz historyczne zdają się mieć największy wpływ na politykę rządu wobec Wspólnoty. Pozostaje jednak jeszcze jeden aspekt, który stanowi istotną dla nich przeciwwagę. Jest nim czynnik gospodarczy. Przez niemal cały wiek XX Szwajcaria z powodzeniem realizowała własne interesy ekonomiczne, pozostając z dala od ścisłych związków ze Wspólnotą. Nie ulega jednak wątpliwości, iż zawdzięczała to w głównej mierze swoim doświadczeniom wojennym. Nie tylko przetrwała ten trudny okres niemal nietknięta, lecz nawet wyszła z niego wzmocniona. Niektóre sektory gospodarki, jak usługi bankowe czy prze-

${ }^{132}$ Określenie to pochodzi od nazwy tradycyjnego dania kuchni wywodzącej się z kantonów niemieckojęzycznych - Rösti.

${ }^{133}$ Zob. A. Porębski, Wielokulturowość Szwajcarii, Wydawnictwo Uniwersytetu Jagiellońskiego, Kraków 2009, s. 158-162. 
mysł zbrojeniowy, przeżywały ogromny rozkwit. Dzięki temu waluta szwajcarska stała się jedną z najsilniejszych na świecie, obok dolara amerykańskiego ${ }^{134}$. Skuteczna, choć kontrowersyjna, polityka walutowa zapewniła Szwajcarii szczególną pozycję gospodarczą. Dopiero utworzenie Europejskiej Wspólnoty Węgla i Stali, a następnie powołanie do życia Europejskiej Wspólnoty Gospodarczej zmusiło rząd szwajcarski do pewnych refleksji. Niemniej jednak przez bardzo długi czas układy w ramach GATT oraz EFTA gwarantowały Szwajcarii rozwój gospodarczy na satysfakcjonującym poziomie. Pod względem dochodów na jednego mieszkańca państwo to należało i wciąż należy do światowej czołówki. Szwajcaria, dzięki zrównoważonemu budżetowi i ogromnym rezerwom budżetowym, postawiła na rozwój sektora badawczo-rozwojowego. Poziom innowacyjności szwajcarskich przedsiębiorstw należy obecnie do najwyższych na świecie. Koncerny farmaceutyczne czy chemiczne zatrudniają dziś setki tysięcy osób w kraju i za granicą. Ocenia się, że szwajcarski sektor prywatny stworzył ponad 700000 miejsc pracy w samej tylko Unii Europejskiej. Na całym świecie firmy te zatrudniają ponad milion osób. Szwajcaria budowała silną pozycję gospodarczą przez cały wiek XX, znajdując się, przynajmniej teoretycznie, poza sztywnymi strukturami integracyjnymi.

Abstrahując od wspomnianych już uwarunkowań historycznych, gospodarka szwajcarska zawdzięcza swoją siłę trafnej polityce gospodarczej i politycznej rządu. Europejskie i światowe rynki ulegały jednak ciągłym zmianom. Procesy globalizacyjne i integracyjne zadecydowały o konieczności zredefiniowania głównych strategii politycznych. Szwajcaria przez długi okres opierała się tym procesom. Przede wszystkim dlatego, iż było ją na to po prostu stać. Pozostawanie kopciuszkiem Europy, poza utratą politycznego prestiżu, nie odbijało się negatywnie na płaszczyźnie gospodarczej. Jak wiadomo, decydujący wpływ na nastroje obywateli mają warunki ekonomiczne, a te przez ostatnie dziesięciolecia były wyjątkowo korzystne. Rozwój gwarantował zatem rządowi społeczną legitymizację dla prowadzonych działań. Oznaczało to tym samym, że polityka ochrony suwerenności i neutralności zdominowała życie polityczne kraju. Rozpad bloku wschodniego i intensyfikacja integracji paradoksalnie doprowadziły do osamotnienia Szwajcarii. Należało znaleźć nową płaszczyznę współpracy, która gwarantowałaby ochronę interesów ekonomicznych, przy zachowaniu jednakże najważniejszych uwarunkowań politycznych oraz kulturowej tożsamości. Chodziło zatem o znalezienie właściwej formuły, pozwalającej rządowi na realizację dawno wytyczonych zadań, przy jednocześnie dużym poparciu społecznym. W warunkach demokracji bezpośredniej i silnego wpływu obywateli na procesy decyzyjne i legislacyjne jest to aspekt szczególnie istotny.

System polityczny Szwajcarii, do tej pory uznawany za ucieleśnienie prawdziwej idei społecznej równości i partycypacji w sprawowaniu władzy, stał się przedmiotem licznych analiz naukowych, uznających obecny jego kształt za ana-

${ }^{134}$ Przez długi czas po zakończeniu II wojny światowej były to jedyne wymienialne waluty. 
chroniczny i nieefektywny. Przede wszystkim jednak nieadekwatny w stosunku do problemów i wyzwań, jakie stoją przed Szwajcarią u progu XXI w. Podobnie szwajcarski federalizm, stawiany do niedawna za wzór dla jednoczącej się Europy, obecnie coraz częściej oceniany jest w kontekście konieczności reformy systemu, zwłaszcza w perspektywie integracji europejskiej. Można zatem pokusić się o stwierdzenie, iż tradycyjne uwarunkowania polityki zagranicznej Szwajcarii uzyskują, w odniesieniu do relacji z Unią Europejską, zupełnie nowy wymiar. 


\section{ROZDZIAL II \\ KONCEPCJA POLITYKI ZAGRANICZNEJ SZWAJCARII WOBEC UNII EUROPEJSKIEJ}

Fundamentalna koncepcja dotycząca rozwoju relacji wobec UE - zarówno po stronie ośrodków rządowych, jak i pozarządowych - pozostaje spójna w odniesieniu do podstawowego celu, jakim jest nawiązanie ściślejszej współpracy gospodarczej ze Wspólnotą. Pozostałe kwestie, związane głównie z kształtem owej współpracy oraz stopniem integracji, niezmiennie dzielą opinię publiczną na dwa obozy - zwolenników i przeciwników włączenia Szwajcarii do struktur UE. Jest bowiem istotne, że aktualna strategia polityczna, w postaci współpracy bilateralnej, od dawna nie budzi większych kontrowersji. Świadczy o tym chociażby dość duże poparcie społeczne uzyskane na samym początku tej drogi, a więc w trakcie głosowania referendalnego, przeprowadzonego w maju roku $2000^{1}$.

Niniejszy rozdział poświęcony jest przedstawieniu koncepcji polityki europejskiej politycznych ośrodków decyzyjnych oraz opiniotwórczych. Scharakteryzowana zostanie również pokrótce ich specyfika, programy, a także stanowiska wobec kluczowych zagadnień w relacjach między Szwajcarią a Unią Europejską. Na ich podstawie wyciągnięte zostaną podstawowe wnioski dotyczące źródeł określonych tendencji ewolucyjnych, ich charakteru oraz implikacji w stosunku do obecnego i przyszłego kształtu polityki zagranicznej Szwajcarii.

\subsection{KRYSTALIZACJA GLÓWNYCH KONCEPCJI POLITYCZNYCH}

Przy omawianiu najważniejszych koncepcji politycznych warto na wstępie poświęcić nieco miejsca na omówienie tendencji ewolucyjnych oraz ich wpływu na opinię publiczną. Chodzi tutaj także o przedstawienie pewnych interakcji, które sprawiają, że określona koncepcja ośrodków decyzyjnych może ulec, i faktycznie nierzadko ulega, przewartościowaniu. Nie można bowiem omawiać strategii działania aparatu państwowego bez uwzględnienia różnych grup nacisku. Warto także zaznaczyć, iż niektóre koncepcje nie są ostatecznie realizowane. Pozostają jedynie na papierze, ale stanowią cenny element w badaniach politologicznych. Słusznie zauważa J. Kukułka, że należy dokonać tutaj wyraźnego rozgraniczenia

\footnotetext{
${ }^{1}$ Umowy poparło wówczas $67 \%$ głosujących.
} 
pomiędzy „chciejstwem”, a więc pewną koncepcją, od rzeczywistości, czyli jej realizacji ${ }^{2}$.

Po dość przykrych doświadczeniach związanych ze wspomnianymi już głosowaniami dotyczącymi przystąpienia Szwajcarii do Europejskiego Obszaru Gospodarczego każda inna forma współpracy, eliminująca groźbę członkostwa w UE, mogła liczyć na poparcie społeczeństwa. Bardzo szybko zawiązała się nieformalna koalicja zwolenników otwarcia Szwajcarii na Wspólnotę, złożona zarówno z ośrodków decyzyjnych, w tym niemal wszystkich obecnych w parlamencie partii, jak i środowisk gospodarczych oraz partnerów społecznych, a więc związków zawodowych, stowarzyszeń i innych pozarządowych organizacji. Na przeciwległym biegunie uplasowały się obozy polityczne, reprezentujące parlamentarną mniejszość oraz skrajnie prawicowe ugrupowania, wśród których zdecydowanie najliczniejszą grupę stanowi AUNS - Aktion für Unabhängige und Neutrale Schweiz (Kampania na rzecz Niezależnej i Neutralnej Szwajcarii). Co ciekawe, w praktyce żaden z powyższych obozów nie charakteryzuje się całkowicie spójnym stanowiskiem, o czym będzie mowa w dalszej części niniejszego rozdziału.

Już z wstępnej analizy obu ośrodków widać wyraźnie, iż ugrupowania popierające ściślejszą współpracę ze Wspólnotą mają pewną przewagę nad eurosceptykami. Ta nieformalna koalicja reprezentowana jest przez zdecydowaną większość wszystkich ośrodków opiniotwórczych zarówno rządowych, jak i pozarządowych. Szczególnie istotna jest obecność w tym obozie środowisk gospodarczych, tj. stowarzyszeń reprezentujących interesy szwajcarskich pracodawców (izby handlowo-przemysłowe), a także związków zawodowych. Sektor prywatny zapewnia cenne wsparcie merytoryczne oraz, co nie mniej istotne, finansowe każdej kampanii referendalnej, w wymierny sposób przyczyniając się do pozytywnych jej wyników. Dzięki takiej konstelacji rząd ma zapewnione silne poparcie dla swoich działań, co umożliwia skuteczne forsowanie własnych koncepcji politycznych. Pamiętając o instrumentach demokracji bezpośredniej i możliwości podważenia ich $\mathrm{w}$ drodze referendum fakultatywnego należy podkreślić, że jest to niezwykle ważny element. Powodem tak konsekwentnego poparcia ze strony kół gospodarczych są względy czysto merytoryczne, rzadziej polityczne czy też ideowe. Należy bowiem zauważyć, że umowy bilateralne służą poprawie współpracy gospodarczej, eliminują bariery w handlu, ujednolicają przepisy prawne, a przede wszystkim zapewniają dostęp do ogromnego unijnego rynku, grupującego ok. 450 milionową rzeszę konsumentów. Bez tego Szwajcaria byłaby skazana na gospodarczą alienację, która niezwykle niekorzystnie odbiłaby się na niemal wszystkich, nastawionych proeksportowo, sektorach szwajcarskiej gospodarki.

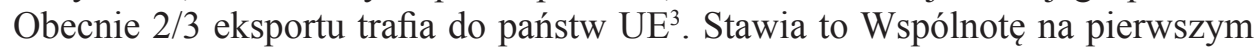

${ }^{2}$ J. Kukułka, R. Zięba, Polityka zagraniczna państwa, Wydawnictwo Uniwersytetu Warszawskiego, Warszawa 1992, s. 24.

${ }^{3}$ Według danych Integrationsbüro EDA/EVD w roku 1999, a więc w momencie podpisywania pierwszego pakietu umów bilateralnych, $62,2 \%$ produkcji przeznaczonej na eksport trafiało do państw UE. Z kolei import to 79,7\%. Źródło: Integrationsbüro EDA/EVD. 
miejscu wśród partnerów gospodarczych Szwajcarii. Niepodważalne korzyści ekonomiczne, jakie niosą ze sobą umowy bilateralne, skłaniają zatem szwajcarskie przedsiębiorstwa do poparcia działań rządu i aktywnego włączenia się do promowania ściślejszej współpracy z UE. Co ciekawe, są one nawet skłonne do licznych ustępstw, m.in. wobec związków zawodowych, celem wypracowania ogólnego konsensusu. Jest to szczególnie istotne jeszcze w fazie przedparlamentarnych konsultacji społecznych. Dzięki temu beneficjentami końcowymi umów bilateralnych są nie tylko szwajcarskie przedsiębiorstwa, lecz również przeciętni obywatele, którzy w sposób bezpośredni oraz pośredni, np. dzięki określonym instrumentom ochronnym, czerpią korzyści ze współpracy z UE.

Bez względu na dynamikę i efektywność wsparcia ze strony partnerów zewnętrznych, rządowe ośrodki opiniotwórcze wykazywały i nadal wykazują dość dużą determinację w propagowaniu idei współpracy bilateralnej ze Wspólnotą. Wpływ na to miały zapewne przykre doświadczenia z początku lat 90., kiedy to bierność rządu w kluczowych aspektach polityki europejskiej zmusiła go do przewartościowania obowiązującej dotychczas strategii. Od tego momentu podstawowym celem działań władz Szwajcarii było przekonanie opinii publicznej do poparcia drogi bilateralnej, głównie poprzez zaspokojenie potrzeb głównych interesariuszy oraz rozwianie obaw poszczególnych partnerów społecznych i środowisk gospodarczych, związanych z tzw. nowym otwarciem w polityce europejskiej. Największe kontrowersje wzbudzały umowy dotyczące swobody przepływu osób oraz związane z transportem drogowym. Te dwa punkty, stanowiące niejako trzon pierwszego pakietu porozumień bilateralnych, były przedmiotem nie tylko intensywnych negocjacji ze stroną unijną, lecz przede wszystkim wewnętrznych konsultacji społecznych. Chodziło o to, aby wypracować kompromis satysfakcjonujący wszystkie zainteresowane strony. Ze względu na istotne kontrowersje, jakie wiązały się z tymi tematami, eurosceptycy chętnie wykorzystywali je w debacie politycznej. Podnoszono argumenty związane $\mathrm{z}$ utratą miejsc pracy, dumpingiem socjalnym, spowodowanym napływem taniej siły roboczej oraz znacznym obciążeniem szwajcarskiego systemu socjalnego. Lista zarzutów była zresztą dłuższa, ale te przytoczone powyżej pojawiały się zdecydowanie najczęściej ${ }^{4}$. W późniejszym okresie tematem przewodnim debaty okołoeuropejskiej była groźba utraty suwerenności, ograniczenia autonomii ustawodawczej oraz osłabienia pozycji Szwajcarii wobec UE. Do tego należy dodać obawy związane ze specyfiką systemu politycznego Szwajcarii, tj. podstawowymi atrybutami demokracji bezpośredniej, a także z przyszłością systemu federalnego w warunkach ściślejszej integracji ze Wspólnotą. Trzeba jednak zaznaczyć, że argumenty

${ }^{4}$ Zob. ciekawą analizę kampanii referendalnej, dotyczącej głosowania nad pierwszym pakietem umów bilateralnych: T. Oberer, Die innenpolitische Genehmigung der bilateralen Verträge Schweiz-UE: Wende oder Ausnahmen bei Aussenpolitischen Vorlagen?, Baslerschriften zur europäischen Integration, Nr. 52/53, Basel 2001, s. 43. W wyniku przeprowadzonych analiz Oberer wskazał na kwestie związane ze swobodą przepływu osób oraz transportem lądowym jako najczęściej pojawiające się tematy w trakcie debaty publicznej. 
te miały charakter niejako wtórny, tj. były wynikiem doświadczeń z realizacji współpracy bilateralnej. Nie oznacza to również, iż problemy związane bardziej ze sferą gospodarczą zostały całkowicie zażegnane, o czym świadczyć może chociażby dość emocjonalna kampania w sprawie głosowania nad rozszerzeniem swobody przepływu osób na Bułgarię i Rumunię . Ostateczny wynik referendum, który ze względu na tzw. klauzulę gilotyny zaważyć mógł na przyszłości relacji pomiędzy Szwajcarią a Unią Europejską, okazał się co prawda pozytywny, ale przewaga głosów była relatywnie niewielka ${ }^{6}$. Oznacza to, że społeczeństwo nie jest do końca pewne ostatecznego wpływu integracji na gospodarkę Szwajcarii bądź też obawia się efektów pobocznych, niezwiązanych bezpośrednio ze sferą ekonomiczną, ale będących jej wypadkową, tj. różnych patologii społecznych, takich jak wzrost bezrobocia, przestępczości czy obciążeń socjalnych. Co ciekawe, obawy te nie mogły być motywowane negatywnymi doświadczeniami. Publikowane w tym okresie dane statystyczne jednoznacznie świadczyły o pozytywnym bilansie ekonomicznym, uzyskanym dzięki otwarciu rodzimego rynku pracy. Można więc pokusić się o stwierdzenie, że poczucie zagrożenia jest bardziej wynikiem złożonych uwarunkowań społecznych i świadomościowych, będących mieszanką doświadczeń historycznych, kulturowych, a także tożsamości narodowej oraz postępującego poczucia wyobcowania we własnym państwie, w którym ponad $20 \%$ mieszkańców to obcokrajowcy.

$\mathrm{Z}$ uwagi na fakt, że zarówno wśród ośrodków decyzyjnych, jak i opiniotwórczych znaleźć można przeciwników i zwolenników nowego otwarcia w polityce Szwajcarii wobec UE, warto dokonać na wstępie ich klasyfikacji. Poniższe tabele (tab. 2.1, 2.2) uwzględniają podmioty, które ze względu na dotychczasową aktywność czy siłę oddziaływania wydają się najważniejsze z punktu widzenia tematyki niniejszego rozdziału. Należy zauważyć, iż przyporządkowanie danego ośrodka do poszczególnych grup wydaje się miejscami bardzo trudne, albowiem - jak już wspomniano - znakomita większość z nich odnosi się do kwestii europejskich w sposób dwuznaczny, tj. popiera integrację, ale tylko na określonych warunkach i w ograniczonym wymiarze. Podziału dokonano zatem w sposób w miarę możliwości obiektywny, biorąc pod uwagę oficjalne stanowiska zawarte w dokumentach programowych oraz wypowiedziach głównych aktorów. Warto tu dodać, że media, choć oficjalnie zajmują stanowisko neutralne, w większości sprzyjają integracji. Opinie związane z polityką europejską, które przekazywane są za pośrednictwem najbardziej poczytnych tytułów prasowych, zostaną omówione w podrozdziale 4 .

${ }^{5} \mathrm{Na}$ szczególną uwagę zasługują argumenty ugrupowań prawicowych, w tym przede wszystkim SVP oraz AUNS. Zob. Kampagnen-Vielfalt zur Personenfreizügigkeit, „Die Neue Zürcher Zeitung", 14. Januar 2009 oraz strony internetowe: www.bilaterale.ch, www.auns.ch, www.blocher.ch.

${ }^{6}$ Za kontynuacją oraz rozszerzeniem swobody przepływu osób na Bułgarię oraz Rumunię zagłosowało $59,6 \%$ obywateli przy relatywnie niewielkiej, jak na Szwajcarię, frekwencji, wynoszącej 50,9\%. 
Ugrupowania euroentuzjastyczne

\begin{tabular}{|l|l|}
\hline \multicolumn{1}{|c|}{ Nazwa } & \multicolumn{1}{c|}{ Rodzaj } \\
\hline Sozialdemokratische Partei & partia polityczna \\
\hline Freisinnig-Demokratische Partei & partia polityczna \\
\hline Grüne Partei der Schweiz & partia polityczna \\
\hline Christlichdemokratische Partei & partia polityczna \\
\hline Neue Europäische Bewegung Schweiz & partia polityczna \\
\hline Economiesuisse & zrzeszenie \\
\hline Debei-bleiben.ch & NGO \\
\hline Schweizerische Gewerbeverband & zrzeszenie \\
\hline
\end{tabular}

Źródło: oprac. własne.

Tabela 2.2

Ugrupowania eurosceptyczne

\begin{tabular}{|l|l|}
\hline \multicolumn{1}{|c|}{ Nazwa } & \multicolumn{1}{c|}{ Rodzaj } \\
\hline Schweizerische Volkspartei & partia polityczna \\
\hline Schweizer Demokraten & partia polityczna \\
\hline Freiheitspartei Schweiz & partia polityczna \\
\hline Lega dei Ticinesi & partia polityczna \\
\hline Aktion für unabhängige und neutrale Schweiz & NGO \\
\hline Young4Fun & NGO \\
\hline
\end{tabular}

Źródło: oprac. własne.

Powyższe zestawienia pokazują, że główne partie, które zaliczyć można do obozu euroentuzjastów, stanowią nie tylko największą siłę w parlamencie, ale również tworzą większość w Radzie Związkowej. Jedyną przeciwwagę stanowi dla nich ludowo-konserwatywna SVP, która jednakże, ze względu na zaledwie jedno miejsce w siedmioosobowym gremium, jest zbyt słaba, aby skutecznie przeforsować własne stanowisko ${ }^{7}$. Często można się spotkać z opinią, że paraliż decyzyjny Rady i jej nieefektywność w polityce krajowej i międzynarodowej jest skutkiem działań ludowców. Nie ulega jednak wątpliwości, że także pozostałe

${ }^{7}$ Dzięki sukcesowi wyborczemu z roku 2003 SVP dysponowała dwoma miejscami w Radzie Związkowej, przerywając tym samym tzw. magiczną formułę, trwającą nieprzerwanie od 1959 r. Z powodu konfliktu wewnętrznego doszło jednak w łonie partii do rozłamu, w efekcie czego wyodrębniło się nowe ugrupowanie, którego członkiem została m.in. Eveline Widmer-Schlumpf, dotychczasowa członkini Rady Związkowej z ramienia SVP. Tym samym ludowcy utracili jednego przedstawiciela w rządzie. 
partie, jak CVP czy FDP, wykazują wzrastający poziom sceptycyzmu bądź raczej racjonalizmu wobec integracji europejskiej niż przed laty. Problem tkwi zatem raczej nie tyle w składzie Rady, co w jej ogólnym sposobie funkcjonowania.

Do tego dodać należy jeszcze jeden istotny czynnik. Otóż obóz zwolenników ścisłej współpracy z UE tworzy zwartą PR-owo grupę. Składa się zarówno z ośrodków rządowych, partii politycznych, organizacji pozarządowych, jak i różnych grup interesu. Razem stanowią zwarty ideowo front, konsekwentnie dążący do przestawienia kraju na proeuropejskie tory. Oczywiście zauważyć można w ich programach czy też wizjach politycznych pewne różnice. Takie ugrupowania, jak Neue Europäische Bewegung Schweiz opowiadają się za natychmiastowym włączeniem Szwajcarii do struktur UE. Inne reprezentują postawę bardziej umiarkowaną, dążąc do zacieśnienia współpracy, ale na poziomie bilateralnym. Niemniej jednak $\mathrm{w}$ tematach europejskich zajmują zawsze spójne stanowisko, w przeciwieństwie do obozu konserwatystów. Dobrym tego przykładem jest chociażby głosowanie z roku 2000, kiedy to AUNS, który, głównie pod wpływem niejednoznacznego stanowiska czołowego działacza - Christopha Blochera, zajął bierną postawę, odmawiając udziału w kampanii na rzecz odrzucenia pierwszego pakietu umów bilateralnych. Decyzja ta osłabiła wizerunek ugrupowań konserwatywno-prawicowych, przyczyniając się tym samym do uzyskania przez nie bardzo kiepskich wyników w trakcie referendum. Także w ramach SVP, o której będzie jeszcze mowa, zauważyć można liczne „zgrzyty” w odniesieniu do kwestii europejskich. W konsekwencji takiego zjawiska obywatele otrzymują niespójne komunikaty, wysyłane przez poszczególnych polityków tej partii.

Na komentarz zasługuje również nastawienie obywateli, a przede wszystkim ich podatność na wpływy różnych ośrodków opiniotwórczych. Szerzej problem ten zostanie omówiony w dalszej części tekstu. Otóż dane dotyczące liczby zwolenników oraz przeciwników integracji świadczą o relatywnie stałych ich proporcjach. Oczywiście liczby te ulegają zmianie, jednak jeżeli przyjrzymy się poszczególnym wartościom na początku i na końcu całego rozpatrywanego okresu, zauważyć można zasadniczy podział oscylujący zazwyczaj w granicach 50 na 50 . Oznacza to, iż fluktuacja pomiędzy obozami jest niewielka. Prawdopodobieństwo zmiany stanowiska euroentuzjasty jest bardzo małe. Podobnie wygląda sytuacja w obozie konserwatywnym. Ciężko zatem jednoznacznie określić, co tak naprawdę wpływa na zmianę nastawienia obywateli wobec problemu europejskiego.

Jednym z takich czynników może być celna kampania polityczna. Pod tym względem zdecydowanie lepiej wypada rząd i generalnie rzecz biorąc środowiska proeuropejskie. Mogą one bez trudu posługiwać się twardymi wskaźnikami statystycznymi, które na ogół pozwalają na przychylną ocenę bilansu dotychczasowej współpracy ${ }^{8}$. Pomimo trwającego wówczas kryzysu na rynkach finansowych,

${ }^{8}$ To one przesądziły o sukcesie głosowania w sprawie rozszerzenia swobody przepływu osób na Bułgarię i Rumunię. Obywatele nie czuli, pomimo silnej propagandy kół prawicowych, zagrożenia dla własnych miejsc pracy w efekcie napływu tzw. taniej siły roboczej. 
w latach 2008-2009 gospodarka szwajcarska radziła sobie dość dobrze, choć, co należy podkreślić, pierwsze oznaki nadchodzącej recesji były już widoczne. Być może wyniki referendum byłyby inne, gdyby zostało ono przeprowadzone pod koniec roku 2009, kiedy to wartość PKB była ujemna, a poziom bezrobocia sięgnął niemal 4\%, co jak na warunki szwajcarskie jest wysokim wskaźnikiem?

$\mathrm{Z}$ kolei podstawowym argumentem przeciwników integracji pozostaje kwestia suwerenności i niezależności Szwajcarii. Z tym wiąże się ściśle problem systemu politycznego, tj. zasad demokracji bezpośredniej, a także doktryna neutralności. Wartości te stanowią rdzeń tradycji i historii rozwoju państwowości szwajcarskiej, sprawiają, że w społeczeństwie silne jest poczucie odrębności kulturowej, która czyni Szwajcarię ,,samotną wyspą na mapie Europy”. Jest to jednak wybór świadomy, z którego Szwajcarzy pozostają niezmiennie dumni. Nic więc dziwnego, iż spośród wielu tematów podejmowanych w debacie politycznej, powyższe argumenty zapewniają przeciwnikom integracji niezwykle silne wsparcie.

\subsubsection{SPECYFIKA OŚRODKÓW DECYZJI POLITYCZNYCH}

Przyglądając się debacie europejskiej, a w szczególności koncepcji reprezentowanej przez ośrodki decyzyjne, można mieć odczucie pewnej dezorientacji. Wynika ona ze swoistych cech szwajcarskiego systemu parlamentarnego oraz określonej kultury politycznej. Różnice światopoglądowe przebiegają tutaj nie tylko horyzontalnie, tj. wzdłuż podziałów partyjnych, lecz również wertykalnie, a więc według miejsca w strukturze decyzyjnej. Najłatwiej wyjaśnić ten fenomen na przykładzie Rady Związkowej, którą - przynajmniej teoretycznie - winno cechować jednolite stanowisko wobec kluczowych problemów polityki międzynarodowej. Należy jednak pamiętać, że członkowie rządu Szwajcarii nie tworzą w parlamencie ugrupowania koalicyjnego. Pochodzą oni z odmiennych środowisk politycznych, różniących się między sobą w zasadniczych punktach programowych. Różnice światopoglądowe, przynajmniej na czas sprawowania tak wysokiego urzędu, muszą jednakże ustąpić miejsca celom nadrzędnym, jakim jest efektywne sprawowanie władzy. Wypracowana od lat zasada społecznego konsensusu wymusza zatem na członkach rządu konieczność podejmowania wspólnych decyzji, nierzadko wbrew poglądom reszty ugrupowania politycznego. Bardzo często dochodzi do sytuacji, w której członkowie Rady zajmują różne stanowiska na forum publicznym, w zależności od charakteru własnego wystąpienia - reprezentując partię lub rząd. Typowym przykładem tego rodzaju dualizmu jest postawa czołowego polityka obozu eurosceptyków - Christopha Blochera, który w trakcie zasiadania w Radzie Związkowej nie stronił od mocnych wystąpień

\footnotetext{
${ }^{9} \mathrm{~W}$ czerwcu 2009 r. PKB było ujemne i wynosiło -2,7\%. Średni poziom bezrobocia oscylował w granicach 3\%, a nawet mniej. Przykładowo w roku 2001 wynosił on zaledwie 1,7\%. Dane według Bundesamt für Statistik.
} 
antyunijnych. Trzeba pamiętać, że jego kadencja przypadała na okres negocjacji i podpisania drugiego pakietu umów bilateralnych ${ }^{10}$. U postronnego obserwatora sytuacja ta może wywołać zdziwienie, jednak dla obywateli Szwajcarii jest to całkiem normalne zjawisko. Według badań „Europa-Barometer”, przeprowadzonych w roku 2004 przez instytut $g f s$. Bern, 61\% respondentów było zdania, iż członek Rady Związkowej ma pełne prawo do prezentowania własnej, subiektywnej opinii, zwłaszcza jeżeli podyktowane jest to troską o dobro własnego państwa ${ }^{11}$. Ma to swoje źródła w uwarunkowaniach historycznych. Specyfika szwajcarskiego systemu politycznego wymusza wypracowywanie kompromisów niemal na każdym szczeblu procesu decyzyjnego, począwszy od gmin, a skończywszy na poziomie federalnym. Dotyczy to również Rady Związkowej.

\subsubsection{KONCEPCJE POLITYCZNE I DECYZJE SPOLECZNE}

Warto podkreślić, że specyfika kultury politycznej Szwajcarii wpływa niekorzystnie na percepcję samego rządu i możliwość kreowania przezeń określonych opinii i nastrojów wśród społeczeństwa. Być może właśnie ten fakt sprawia, że, jak wykazały badania opublikowane w roku 1998, stanowisko Rady Związkowej w kwestiach politycznych ma decydujące znaczenie dla jedynie $16,5 \%$ obywate${ }_{1}{ }^{12}$. Należy pamiętać, iż w przypadku każdego głosowania referendalnego władze federalne mają obowiązek przekazania własnego stanowiska wobec przedmiotowej sprawy ${ }^{13}$. Dzieje się tak zarówno w odniesieniu do inicjatyw ustawodawczych, zgłoszonych przez rząd oraz parlament, jak i projektów obywatelskich. Zapewnia to Radzie Związkowej możliwość poinformowania społeczeństwa o merytoryce i ewentualnych efektach danej ustawy bądź poprawki konstytucyjnej, i zachęcenia przy tym do jej poparcia lub odrzucenia. W praktyce jednak zabiegi rządu nie zawsze okazują się skuteczne. Bardzo często stanowisko Rady nie jest podzielane przez większość społeczeństwa. Dobrym tego przykładem jest chociażby głosowanie w sprawie konstytucyjnego zakazu budowy minaretów na terytorium Szwajcarii ${ }^{14}$. W tym przypadku suweren okazał się nie podzielać stanowiska ani rządu, ani parlamentu. Za przyjęciem inicjatywy opowiedziało się

${ }^{10}$ Christoph Blocher był członkiem Rady Związkowej w latach 2004-2007, w którym to okresie objął tekę ministra sprawiedliwości.

${ }^{11}$ C. Longchamp, Die Stärkung des bilateralen Weges. Hauptergebnisse aus dem neuesten Bericht zum Europa-Barometer Schweiz, Winter 2004, Bern 2004, s. 5.

${ }^{12}$ Zob. A. Trechsel, P. Sciarini, Direct Democracy in Switzerland: Do elites matter?, „European Journal of Political Research" 1998, t. XXXIII, No 1, s. 99-124.

${ }^{13}$ Na przykład: Volksabstimmung vom 8. Februar 2009. Erläuterungen des Bundesrates. Dokumentdostępnynastronie:http://www.ch.ch/abstimmungen_und_wahlen/01253/01265/01299/01797/ index.html?lang=de $(02.10 .2010)$.

${ }^{14}$ M. Tomczyk, Dlaczego Szwajcarzy zagłosowali za zakazem budowy minaretów?, „Kurier Dyplomatyczny" 2009, listopad-grudzień, nr 1, s. 10-13. 
wówczas 57,5\% obywateli. Nie oznacza to oczywiście, iżby Rada Związkowa utraciła pewien rodzaj autorytetu, choć faktycznie jego poziom zdaje się od kilku lat nieco obniżać.

Według badań Grunera i Hertiga, opublikowanych w pierwszej połowie lat 80. wieku XX, zdecydowana większość obywateli, bo ok. $60 \%$, znała poglądy władz oraz polityków i najczęściej się z nimi utożsamiała ${ }^{15}$. Poziom zaufania do elity politycznej był zatem znacznie wyższy, ale i złożoność spraw, które wymagały zasięgnięcia opinii suwerena była dosyć ograniczona. Warto zauważyć, iż jeszcze w okresie bipolarnego podziału świata polityka zagraniczna odgrywała rolę raczej marginalną. Na 555 głosowań, przypadających na lata 1848-2009, jedynie 27 dotyczyło spraw zagranicznych ${ }^{16}$. Dopiero po upadku bloku wschodniego liczba problemów związanych z tym obszarem gwałtownie wzrosła, głównie za sprawą integracji europejskiej oraz zjawisk, będących konsekwencją postępującej globalizacji. Do lat 90. ubiegłego wieku obywatele głosowali najczęściej zgodnie z sugestią władz federalnych lub rekomendacją własnej partii, której przedstawiciel zasiadał w Radzie Związkowej ${ }^{17}$. Jak wskazują badania Grunera i Hertiga podjęcie ostatecznej decyzji motywowane było nie tyle znajomością merytoryki danej sprawy i własnymi przekonaniami, ile reakcją na proste propagandowe slogany. Świadczy to oczywiście o pewnej podatności społeczeństwa na sugestie płynące ze strony polityków, ale również o dużym zaufaniu do elit politycznych. Jest to zresztą jedna z głównych cech szwajcarskiej demokracji. W systemie, w którym stopień partycypacji obywateli w sprawowaniu władzy jest tak duży, poziom znajomości poszczególnych tematów siłą rzeczy musi być ograniczony. Jeżeli zliczylibyśmy wszystkie kwestie, w których społeczeństwo musi wyrazić swoją opinię zarówno na poziomie lokalnym, jak i federalnym, to liczba ta oscylowałaby między 20 a $30 \mathrm{w}$ ujęciu rocznym. Nie jest zatem możliwe, aby obywatele obeznani byli ze wszystkimi propozycjami, zwłaszcza od strony merytorycznej. Konieczne jest więc określone zaufanie do rządzących. Wyborcy muszą być przeświadczeni o tym, iż przekaz płynący ze strony polityków nie jest jedynie pustym, populistycznym sloganem, choć oczywiście zarówno dawniej, jak i obecnie, istotną rolę odgrywa poziom intensywności agitacji politycznej.

Skąd więc relatywnie duże zaufanie do koncepcji politycznych rządu? Kluczem do zrozumienia specyfiki procesu decyzyjnego w Szwajcarii jest świadomość, że został on tak skonstruowany, aby pogodzić interesy wszystkich zainteresowanych stron. Stąd szczególne miejsce wspomnianych w pierwszym rozdziale konsultacji społecznych. Dzięki nim obywatele mają pewność, że na etapie po-

${ }^{15}$ E. Gruner, H. Hertig, Das Stimmbürger und neue Politik, Haupt Verlag, Bern 1983.

${ }^{16}$ Zestawienie dostępne na stronie http://www.swissvotes.ch/votes/statistic/ (02.01.2010).

${ }^{17}$ Jak zauważa T. Oberer, op. cit., s. 30 propozycje związane z polityką zagraniczna znacznie rzadziej odrzucane są przez społeczeństwo w trakcie referendum fakultatywnego. Zob. P. Sciarini, La formulation de la decision, [w:] U. Klöti, Handbuch der Schweizer Politik, Verlag NZZ, Zürich 1999 , s. 589-649. 
dejmowania przez nich ostatecznej decyzji, propozycja, nad którą głosują, jest efektem stanowiska wypracowanego wspólnie przez różne grupy interesu. Innymi słowy społeczeństwo musi zaufać swoim politykom, iż to co robią i do czego namawiają wyborców ma sens i jest zgodne z ich ogólnymi poglądami. Jest to element konieczny do tego, aby system demokracji bezpośredniej w miarę sprawnie funkcjonował.

W dobie cyfryzacji mediów, a tym samym coraz łatwiejszego i tańszego dostępu do środków masowego przekazu, komunikat głównych ośrodków politycznych, w tym rządowych, ulega znacznemu osłabieniu. Coraz większą rolę odgrywają małe partie i ruchy zorganizowane wobec określonej, często nośnej medialnie kwestii. Nierzadko kreują one zagadnienia mające na celu zwiększenie własnej popularności, traktując wrażliwe społecznie tematy jako trampolinę do sukcesu wyborczego w nadchodzących wyborach. W ten sposób główne partie, wchodzące w skład rządu, utraciły pewien rodzaj monopolu informacyjnego, którym do niedawna się cieszyły. Obywatele przestali ufać rządzącym lub przynajmniej zaczęli weryfikować ich komunikaty. Nie chodzi o to, że dawniej tego typu zjawiska nie występowały. Również i w przeszłości niewielkie ugrupowania politycznie, dzięki konsekwentnie prowadzonej kampanii, z czasem zyskiwały na popularności ${ }^{18}$. Należy jednak zauważyć, że w dobie rozwoju Internetu prowadzenie politycznej agitacji jest po prostu o wiele łatwiejsze. W ten sposób podstawowe instrumenty demokracji bezpośredniej, jakim są referendum oraz inicjatywa, stały się narzędziem w walce o polityczną egzystencję. Jak zauważa W. Linder, odbywa się to bardzo często poprzez zgłaszanie problemów nieistniejących, czyli takich, które nastawione są nie na rozwiązanie określonego zagadnienia poprzez uzyskanie większości głosów, lecz bardziej na zwrócenie na siebie uwagi ${ }^{19}$. Dzięki odpowiednim środkom finansowym oraz odrobinie konsekwencji określone grupy interesu są w stanie zebrać wymaganą liczbę 50 lub 100000 podpisów, potrzebną do przeprowadzenia referendum. Nierzadko odbywa się to dzięki pomocy specjalnie wynajętych do tego firm, które za określonym wynagrodzeniem są w stanie zgromadzić ich odpowiednią liczbę. W. Linder przedstawia ten mechanizm na przykładzie Szwajcarskich Demokratów, którzy dzięki konsekwentnemu poruszaniu problemu liczby cudzoziemców w Szwajcarii, zapewniali sobie stałe miejsce w świadomości wyborców ${ }^{20}$.

Nie ulega zatem wątpliwości, iż tego typu kampanie zmuszają obywateli do pewnych refleksji. Czasem niewielkie ugrupowania lub zrzeszenia o charakterze politycznym doprowadzają do obniżenia poziomu zaufania do rządzących. Odbywa się to najczęściej poprzez stosowanie demagogii i populistycznych haseł, które łatwo zdobywają zwolenników. Dzieje się tak również w przypadku kwestii

${ }^{18}$ Tak było w przypadku chociażby SVP.

${ }^{19}$ W. Linder, Demokracja szwajcarska. Rozwiazywanie konfliktów w społeczeństwie wielokulturowym, Wydawnictwo Wyższej Szkoły Pedagogicznej, Rzeszów 1996, s. 163.

${ }^{20}$ Ibidem. 
związanych z polityką europejską. Także i tutaj władze federalne muszą uwzględniać mechanizmy demokracji bezpośredniej, które bardzo często odgrywają rolę „hamulcową”, utrudniając możliwości negocjacyjne z UE. Rządzący nie są w stanie wypracować określonych korzyści kosztem pewnych ustępstw na rzecz Wspólnoty, mając świadomość dużego prawdopodobieństwa wykorzystania tych argumentów w opisanym powyżej mechanizmie. W konsekwencji oznacza to stagnację i osłabienie stanowiska Szwajcarii w negocjacjach z Unią Europejską.

Upowszechnienie środków masowego przekazu przyczyniło się zatem do obniżenia zdolności opiniotwórczych ośrodków rządowych, a w konsekwencji utrudniło prowadzenie skutecznej i „samodzielnej” polityki zewnętrznej. Według przeprowadzanych regularnie sondaży zaufanie obywateli wobec bilateralnej polityki rządu jest dość wysokie, choć, co ciekawe, nie tak wysokie jak w drugiej połowie lat 90. Intensywna kampania informacyjna władz federalnych, prowadzona w okresie negocjacji pierwszego pakietu umów, wpłynęła bardzo korzystnie na jej społeczny odbiór. Zdecydowana większość obywateli, bo aż $85 \%$, potrafiła odpowiedzieć na podstawowe pytania z nimi związane ${ }^{21}$. Rządowi udało się dzięki temu nie tylko zwiększyć poziom wiedzy obywateli, ale również przeciągnąć na swoją stronę część dotychczasowych sceptyków. Jak wykazują badania, jeszcze pod koniec lat 90. za przystąpieniem Szwajcarii do UE zagłosowałoby 53\% obywateli, podczas gdy w połowie roku 2004 tego samego zdania było zaledwie 39\% respondentów. Widzimy zatem, że po podpisaniu drugiego pakietu umów poparcie społeczne dla integracji zmalało, co było jednak głównie wynikiem akceptacji bieżącego poziomu współpracy.

Oczywiście polityka rządu, nastawiona na współpracę bilateralną, cieszy się nadal największym poparciem. Potwierdzają to m.in. wspomniane już wcześniej wyniki sondaży „Europa-Barometru”. Nie ulega jednak wątpliwości, że od momentu aktywizacji środowisk konserwatywnych i antyunijnych, systematycznie rośnie odsetek eurosceptyków. Wszystko to sprawia, iż pierwotna strategia rządu, jaką było jedynie odsunięcie w czasie perspektywy przystąpienia Szwajcarii do UE, staje się obecnie opcją niemal nieosiągalną. Warte przytoczenia są wyniki kolejnego sondażu $g f s$. Bern, tym razem przeprowadzonego w roku $2005^{22}$. Opcja włączenia Szwajcarii do struktur UE okazała się wówczas najmniej popularna aż $64 \%$ obywateli opowiedziało się przeciwko niej. Wariant członkostwa w UE uznało za możliwy jedynie 32\% respondentów. Można zatem wnioskować, że polityka europejska rządu będzie musiała liczyć się z coraz większą kontrolą i weryfikacją ze strony obywateli. Zwiększy to presję polityczną i być może przyczyni się do pogłębienia podziałów wewnątrz Rady Związkowej, ograniczając jeszcze bardziej zdolności decyzyjne szwajcarskiego rządu.

${ }^{21}$ Warto dodać, iż odsetek ten uległ niewielkiemu zmniejszeniu po podpisaniu drugiego pakietu.

${ }^{22}$ C. Longchamp, Offen auf die Zukunft zugehen. Hauptergebnisse aus dem neuesten Bericht zum Europa-Barometer Schweiz, Winter 2005, Bern 2005. 
Do niedawna nastroje opinii publicznej kształtowały się według dość prostych schematów. Poglądy obywateli, dotyczące zarówno spraw krajowych, jak i zagranicznych, były charakterystyczne dla danej grupy językowej. Podziały przebiegały zatem wzdłuż granic kantonów według znanej, przynajmniej od początków wieku XX, zasady: konserwatywne kantony niemieckojęzyczne oraz bardziej liberalne francusko- i włoskojęzyczne. Zasada ta odnosiła się niemal do wszystkich poważniejszych problemów światopoglądowych, włączając w to również główne zagadnienia polityki międzynarodowej, tj. współpracę $\mathrm{z}$ organizacjami międzynarodowymi, w tym także z Unią Europejską. Jeszcze w trakcie głosowania nad wnioskiem akcesyjnym w sprawie Europejskiego Obszaru Gospodarczego, francuskojęzyczne kantony wyraziły poparcie dla proeuropejskiej polityki rządu. W kantonie Neuenburg odsetek głosów ,za” wyniósł $80 \%{ }^{23}$. Z czasem jednak tradycyjne podziały uległy stopniowemu zatarciu. Linia demarkacyjna przestała przebiegać wzdłuż określonych kantonów, lecz raczej z uwagi na mniejsze bądź silniejsze zurbanizowanie terenów, a więc obszarów zamieszkanych przez konserwatywną lub liberalną większość. Również wiek przestał odgrywać decydującą rolę, o czym może świadczyć chociażby fakt, że wśród eurosceptyków pojawia się coraz więcej młodych osób ${ }^{24}$. Ciekawe wnioski można wysnuć na podstawie wyników ostatniego głosowania w sprawie kontynuacji oraz rozszerzenia swobody przepływu osób na Bułgarię i Rumunię. Jak się okazało, poglądy mieszkańców obszarów miejskich i wiejskich były w zasadzie zbieżne. Obie grupy opowiedziały się za otwarciem rodzimego rynku pracy. Różnice pomiędzy poszczególnymi obszarami wynoszą zaledwie $8 \%{ }^{25}$. Interesujące konkluzje przynosi również porównanie wyników pomiędzy kantonami. Okazuje się, że wynik negatywny odnotowano jedynie w kilku kantonach niemieckojęzycznych. Co ciekawe, największy odsetek eurosceptyków zanotowano jednak w kantonie włoskojęczynym - Tessin. Ale, co podkreślają komentatorzy, w tym przypadku chodziło nie tyle o sprzeciw wobec integracji, ile o zamanifestowanie swoich obaw. Mieszkańcy kantonu chcieli pokazać władzom federalnym, że istotne problemy, związane z rynkiem pracy i asymilacją obcokrajowców, są przez nie pomijane lub lekceważone ${ }^{26}$. Trudno zatem uznać rezultat powyższego głosowania za trwałą tendencję. Przeciwnie, przeprowadzone po nim badania wskazują, iż zjawisko, które przeszło do historii pod nazwą Röstigraben, zaczyna wyraźnie zanikać.

Wydaje się więc, że aktualne opinie i stanowiska przeciętnych obywateli w sprawie polityki europejskiej kształtowane są w głównej mierze przez czyn-

${ }^{23}$ Statystyczne zestawienie dostępne jest na stronie Kancelarii Związkowej: http://www.ad$\mathrm{min} . \mathrm{ch} / \mathrm{ch} / \mathrm{d} / /$ pore/va/19921206/index.html (03.01.2010).

${ }^{24}$ Zob. artykuł dotyczący rosnącego sceptycyzmu wobec Unii Europejskiej wśród młodych ludzi: Bei den Jungen wächst die Skepsis gegenüber der EU, „20Minuten”, 13. Mai 2009.

${ }^{25}$ Dane według Związkowego Urzędu Statystycznego, dostępne pod adresem: www.bfs.admin.ch (03.01.2010).

${ }^{26}$ Zob. artykuły prasowe: Das Tessin - wegen Italien ein Sonderfall oraz Entspanntere Stimmung im ländlichen Raum, „Die Neue Zürcher Zeitung”, 10. Februar 2009. 
niki obiektywne, takie jak chociażby wymierne efekty dotychczasowej współpracy, oraz subiektywne, determinowane w znacznym stopniu poprzez ośrodki opiniotwórcze - rządowe i pozarządowe. Duże znaczenie mają czynniki ekonomiczno-materialne, tj. poziom zamożności oraz źródła utrzymania. Nie ulega wątpliwości, że osoby zatrudnione w niektórych sektorach gospodarki mogą się czuć zagrożone lub przynajmniej wykazywać większą nieufność w odniesieniu do ostatecznych efektów integracji ze Wspólnotą ${ }^{27}$. Interesujący jest jednak fakt, że przedstawiciele sektorów szczególnie wrażliwych, jak chociażby rolnictwa, zaczynają dostrzegać pewne korzyści wynikające z wprowadzenia swobody przepływu towarów lub otwarcia rynków pracy. Jeszcze niedawno grupa ta stanowiła podstawę obozu eurosceptyków. Nastroje ulegają jednak stopniowej zmianie, o czym świadczy chociażby fakt, że w referendum z lutego 2009 r. (dotyczące otwarcia rynków pracy dla obywateli Bułgarii i Rumunii) na „tak” wypowiedziało się 51,3\% mieszkańców terenów wiejskich, zatrudnionych w przeważającej większości w sektorze rolno-spożywczym. Pozostałe determinanty, takie jak wykształcenie, wiek lub miejsce zamieszkania mają obecnie drugorzędne znaczenie.

Oczywiście bardzo istotną rolę odgrywa sama kampania, tzn. jej przebieg, poziom intensywności, rodzaj użytych środków bądź kanałów przekazu. Ogólna tendencja jest typowa - im dłużej dana agitacja polityczna jest prowadzona, tym poziom jej skuteczności jest wyższy. Tym samym większe są szanse, że określona koncepcja ośrodków decyzyjnych uzyska społeczne poparcie. Nic więc dziwnego, że ośrodki gospodarcze, w tym głównie zrzeszenie Economiesuisse, zdecydowały się na rozpoczęcie kampanii w sprawie przyjęcia pierwszego pakietu porozumień jeszcze w roku 1995, a więc na cztery lata przed formalnym jego podpisaniem oraz pięć przed głosowaniem referendalnym w tej sprawie. Decyzja ta była możliwa dzięki pokaźnym środkom finansowym, umożliwiającym pokrycie kosztów długoletniej kampanii. Oficjalne dane nie są znane, choć ocenia się, iż tylko w sprawie Bilaterale I nakłady finansowe sięgnęły od 5 do 10 milionów franków ${ }^{28}$. Warto dodać, że zarówno rząd, jak i ugrupowania opozycyjne nie były w stanie przeprowadzić w tym czasie podobnej akcji. Biuro Integracyjne (Integrationsbüro) dysponowało co prawda zwiększonym budżetem, ale nie zdecydowano się ostatecznie na zaciągnięcie dodatkowego kredytu w celu sfinansowania kampanii. Decyzję tę motywowano oficjalnie przeświadczeniem, że poziom wiedzy społeczeństwa na temat UE jest wystarczający, a przynajmniej dużo wyższy w porównaniu z okresem 1992-199329. Długoletnia kampania informacyjna

${ }^{27} \mathrm{Na}$ temat zagrożonych sektorów zob. Alleingang - Bilaterale Verträge - EU Beitritt. Implikationen für die Schweizer Wirtschaft und den Finanzplatz Schweiz, „UBS Group Economic Research Studies", April 2000, s. 17.

${ }^{28}$ T. Oberer, op. cit., s. 23.

29 Jak zauważa Oberer (op. cit., s. 26) na decyzję rządu wpłynął również fakt, iż prawdopodobieństwo odrzucenia układów bilateralnych było relatywnie duże, ze względu na brak konieczności uzyskania w głosowaniu tzw. podwójnej większości, tj. kantonów i obywateli. 
przynosi oczekiwane rezultaty. Jak pokazują analizy VOX-u zdecydowana większość respondentów, bo ok. $60 \%$, podejmuje decyzję na długo przed ostatecznym terminem głosowania ${ }^{30}$. Zaledwie $22 \%$ z nich podejmuje ją w ostatniej chwili.

\subsection{KONCEPCJE OŚRODKÓW DECYZJI POLITYCZNYCH}

Przed przystąpieniem do analizy koncepcji politycznych ośrodków decyzyjnych warto pokusić się o pewną dygresję. Ze względu na złożoność procesu decyzyjnego w warunkach szwajcarskich należałoby zastanowić się nad faktyczną realizacją opracowanych koncepcji politycznych rządu. Nie ulega bowiem wątpliwości, iż ze względu na funkcjonowanie mechanizmu konsultacji społecznych, będących niezwykle istotnym elementem etapu przedparlamentarnego, przyjęta przez rząd propozycja może, w toku prowadzonych dyskusji, ulec znacznym modyfikacjom. Należałoby zatem zastanowić się, na ile obecna polityka rządu jest faktycznie efektem realizacji danej koncepcji politycznej, a na ile wynikiem społecznego kompromisu? Dalsza część niniejszego podrozdziału rzuci nieco więcej światła na tę kwestię.

Główne wnioski dotyczące stanowiska rządu wobec kwestii europejskich zostały przeanalizowane na podstawie szeregu dokumentów, tj. raportów i sprawozdań poruszających kwestie polityki zagranicznej, a także na podstawie wypowiedzi członków Rady Związkowej i czołowych polityków tych partii, które mają swoich reprezentantów w rządzie.

Poniższa tabela (tab. 2.3) zawiera zestawienie podstawowych dokumentów odnoszących się do polityki zagranicznej rządu, w tym również wobec Unii Europejskiej. Jako cezurę czasową przyjęto rok 1992, tj. moment, w którym problematyka europejska zaczęła zajmować priorytetowe miejsce. Jednocześnie jest to data podpisania Traktatu z Maastricht, będącego podstawą dzisiejszej UE.

Lektura powyższych danych dostarcza wiedzy na temat ewolucji koncepcji polityki zagranicznej władz szwajcarskich wobec Unii Europejskiej. Opierając się na wnioskach, o których mowa będzie poniżej, można pokusić się o wyróżnienie trzech głównych etapów, charakteryzujących się nieco odmienną strategią polityczną. Każdy z nich cechuje też jednak jeden element wspólny, a mianowicie pewna asekuracyjność oraz rezygnacja z prezentowania śmiałych wizji czy koncepcji rozwoju dalszych relacji z UE. Można odnieść wręcz wrażenie, iż rząd celowo unika odważnych sformułowań, aby tym samym nie narazić się na ostrą krytykę ze strony różnych grup interesów, a przede wszystkim zachować kompromis w podejmowaniu wszelkich decyzji politycznych.

${ }^{30}$ Zob. H. Hirter, Analyse der eidgenössischen Abstimmungen vom 21. Mai 2000, VOX Nr. 70, GfS-Forschungsinstitut und Institut für Politikwissenschaft Universität Bern, Bern 2000. Streszczenie analizy dostępne na stronie: http://www.polittrends.ch/abstimmungen/abstimmungsanalysen/vox-analysen/002105d.html (04.01.2010). 
Tabela 2.3

Najważniejsze dokumenty rządowe dotyczące problematyki europejskiej

\begin{tabular}{|l|c|}
\hline \multicolumn{1}{|c|}{ Dokument } & $\begin{array}{c}\text { Data } \\
\text { opublikowania }\end{array}$ \\
\hline Bericht über einen Beitritt der Schweiz zur Europäischen Gemeinschaft & 18.05 .1992 \\
\hline Bericht über die Aussenpolitik der Schweiz in den 90er Jahren & 29.11 .1993 \\
\hline Schweiz-Europäische Union: Integrationsbericht 1999 & 03.02 .1999 \\
\hline Europabericht 2006 & 28.06 .2006 \\
\hline $\begin{array}{l}\text { Bericht des Bundesrates zu den Auswirkungen verschiedener europapoliti- } \\
\text { scher Instrumente auf den Föderalismus in der Schweiz }\end{array}$ & 15.06 .2007 \\
\hline Aussenpolitischer Bericht 2009 & 02.09 .2009 \\
\hline $\begin{array}{l}\text { Bericht des Bundesrates über die Evaluation der schweizerischen Europa- } \\
\text { politik }\end{array}$ & 17.09 .2010 \\
\hline
\end{tabular}

Źródło: oprac. własne.

\subsubsection{UNIA EUROPJSKA W KONCEPCJI OŚRODKÓW DECYZYJNYCH NA POCZĄTKU LAT 90. XX W.}

Pierwszy dokument, zatytułowany Bericht über einen Beitritt der Schweiz zur Europäischen Gemeinschaft (Raport na temat przystapienia Szwajcarii do Wspólnoty Europejskiej), opublikowany został przez Radę Związkową w roku $1992^{31}$. Stanowi on podstawowy dokument wyznaczający strategię rozwoju relacji pomiędzy Szwajcarią a Unią Europejską. Należy pamiętać, iż opublikowany został w maju, a więc jeszcze przed głosowaniem w sprawie włączenia Szwajcarii do Europejskiego Obszaru Gospodarczego, czyli momentem przełomowym dla relacji pomiędzy Szwajcarią a UE. W odróżnieniu od późniejszych dokumentów stanowisko władz przekazane jest w sposób klarowny i nie pozostawiający wątpliwości co do wizji rozwoju współpracy z UE. Zaraz na wstępie dokumentu odnaleźć można jasno określony cel w polityce integracyjnej rządu, jakim jest przystąpienie do Wspólnoty Europejskiej. Wskazuje się, że decyzja ta jest naturalnym następstwem rozwoju wzajemnych relacji, zapoczątkowanych jeszcze w latach 70. XX w., dzięki zawarciu Umowy o Wolnym Handlu z EWG. W nowej sytuacji geopolitycznej Szwajcaria jest świadoma konieczności otwarcia nowego etapu w stosunkach ze Wspólnotą, które będą przede wszystkim odpowiadać współ-

${ }^{31}$ Bericht über einen Beitritt der Schweiz zur Europäischen Gemeinschaft, BB1 1992 III 1185 (Bern 1992). Dokument stanowi kontynuację wcześniejszych sprawozdań dotyczących stanowiska Szwajcarii wobec integracji europejskiej. Zob.: Bericht vom 24. August 1988 über die Stellung der Schweiz im europäischen Integrationsprozess, BBl 1988 III 370 oraz Informationsbericht vom 26. November 1990 über die Stellung der Schweiz im europäischen Integrationsprozess (nieopublikowany). 
czesnym wyzwaniom. Jednocześnie rząd Szwajcarii wyraża przekonanie, iż integracja europejska jest nie tylko szansą na zagwarantowanie lepszych warunków gospodarczego rozwoju, lecz również zapewnia Szwajcarii możliwość wniesienia określonego wkładu w rozwój gospodarczy i społeczny Europy.

Pierwszym etapem integracji jest dla rządu przystąpienie do Europejskiego Obszaru Gospodarczego, co traktuje się jako wstępny krok na drodze do członkostwa we Wspólnocie Europejskiej. Cel ten, o czym wspomina się zaraz na początku raportu, określony został oficjalnie przez Radę Związkową w dniu 19 października 1991 r. Omawiany dokument nie jest więc próbą wskazania argumentów przemawiających za intensyfikacją współpracy gospodarczej. Poświęcony temu był zresztą inny raport ${ }^{32}$. Autorzy skupiają się bardziej na przedstawieniu ekonomicznych i społecznych skutków tej współpracy, próbując w ten sposób sprostać oczekiwaniom parlamentu, kantonów oraz partnerów europejskich. Rząd nie unika tym samym społecznej debaty, wręcz przeciwnie. Powyższy raport traktuje jako zachętę do dalszej dyskusji, mając jednocześnie nadzieję, że pozwoli ona na uzyskanie wsparcia dla własnej koncepcji politycznej. Całość dokumentu składa się z dziesięciu rozdziałów. Trzy pierwsze poświęcone są przedstawieniu podstaw decyzyjnych dotyczących przystąpienia do Wspólnoty Europejskiej. Kolejny rozdział jest próbą zajęcia stanowiska wobec roli Szwajcarii w ramach Wspólnoty. Natomiast następne poświęcone zostały analizie gospodarczych, instytucjonalnych oraz politycznych skutków członkostwa.

Od samego początku rząd świadom był konieczności zagwarantowania Szwajcarii możliwości współdecydowania w kwestiach europejskich. Chodziło o to, aby uniknąć tzw. biernej integracji, czyli włączenia do Wspólnoty na ograniczonych zasadach, uniemożliwiających realne oddziaływanie na kształt tego procesu. Jeszcze w pierwszym raporcie z roku $1988^{33}$, dotyczącym stanowiska Szwajcarii wobec integracji europejskiej, przystąpienie do Wspólnoty Europejskiej uznano za jedną z najważniejszych opcji politycznych. Rząd nie składał wówczas żadnych konkretnych deklaracji, prawdopodobnie m.in. ze względu na wciąż aktualną doktrynę neutralności, która w największym stopniu determinowała politykę zagraniczną. Niemniej jednak pojawiają się już wtedy pierwsze uwagi na temat zagwarantowania możliwości oddziaływania na proces integracyjny. Rząd zdawał sobie doskonale sprawę z faktu, że stanie z boku może mieć dla Szwajcarii przykre konsekwencje. Kolejny raport, z roku 1990, jedynie potwierdził to stanowisko ${ }^{34}$. Mowa w nim o konieczności dynamicznego reagowania na zmiany zachodzące w Europie, a także o gotowości do rezygnacji z obowiązującego dotychczas modelu integracji pragmatycznej, czyli nastawionej na realizację bieżących interesów i zaspokajania potrzeb, głównie o charakterze

${ }^{32}$ Botschaft zur Genehmigung des Abkommens über den Europäischen Wirtschaftsraum vom 18. Mai 1992, Bern 1992. Dokument dostępny na stronie archiwum państwowego: www.bar.admin.ch.

${ }^{33}$ Bericht vom 24. August $1988 \ldots$

${ }^{34}$ Informationsbericht vom 26. November 1990... 
gospodarczym. Podstawową przesłanką zredefiniowania dotychczasowej strategii politycznej była sytuacja, w której zjawiska integracyjne coraz bardziej oddziaływałyby na Szwajcarię, a tym samym niejako zmuszały to podjęcia aktywnych działań na rzecz zabezpieczenia własnych interesów.

Jak już wcześniej wspomniano, raport z roku 1992 stanowi próbę uzasadnienia nowej koncepcji politycznej wobec integracji europejskiej. Po pierwsze, decyzja władz miała charakter strategiczny. Było bowiem wówczas jasne, że w najbliższym czasie Austria, Szwecja i Finlandia podejmą decyzję o rozpoczęciu rozmów w sprawie przystąpienia do EWG. Nadchodzący rok uznawano zatem za przełomowy, nie tylko ze względu na decyzję państw EFTA, oznaczającą poważne osłabienie tej organizacji, lecz również z uwagi na potencjalnie słabszą, przyszłą pozycję Szwajcarii w rokowaniach akcesyjnych ze Wspólnotą. Nie ulegało wątpliwości, iż Berno, poprzez akces neutralnej Austrii, może utracić wiele poważnych argumentów negocjacyjnych. Oba kraje łączyła nie tylko doktryna neutralności, lecz również podobna specyfika systemu politycznego (chociażby federalizm) ${ }^{35}$. Istniało zatem uzasadnione przypuszczenie, że problemy sygnalizowane przez Austrię jeszcze na etapie negocjacji, zostaną rozwiązane, a to oznaczałoby w konsekwencji, że część postulatów wnoszonych w późniejszym czasie przez rząd Szwajcarii dawno utraciłaby aktualność. Przyszłość pokazała zresztą, jak duże znaczenie, w kontekście problemu pogodzenia neutralności z członkostwem w UE, miała decyzja o przystąpieniu Austrii, a także Szwecji i Finlandii ${ }^{36}$.

Po drugie, decyzja rządu podyktowana była odbyciem szczytu w Maastricht w grudniu 1991 r., którego efektem było podpisanie najważniejszego dla przyszłości UE traktatu. Władze w Bernie uznały, że jest to najlepszy moment, aby dzięki decyzji o włączeniu Szwajcarii zagwarantować sobie możliwość współkształtowania tej organizacji, zwłaszcza $\mathrm{w}$ tych aspektach, które nie zostały jeszcze całkowicie zdefiniowane ${ }^{37}$. Po trzecie, rząd zwracał uwagę na zbliżające się rozszerzenie Wspólnoty o Austrię, Finlandię i Szwecję. Zakładano, że naturalną konsekwencją tej decyzji będzie konieczność przeanalizowania możliwości kolejnego rozszerzenia, głównie w aspekcie instytucjonalnym ${ }^{38}$. W związku z powyższym pojawiały się uzasadnione obawy, iż nie będzie to możliwe bez przeprowadzenia koniecznych reform. Przedłużający się proces instytucjonalnego dostosowania organizacji do nowych warunków mógł poważnie opóźnić możliwość przyjęcia kolejnych członków. Rząd w Bernie obawiał się zatem, że jeżeli Szwajcaria nie zdecyduje się na przyłączenie do Wspólnoty w „obecnej rundzie”,

${ }^{35}$ Co ciekawe, szwajcarski wniosek akcesyjny nie zawierał, w przeciwieństwie do austriackiego, zastrzeżeń dotyczących neutralności.

${ }^{36}$ Wszystkie te kraje prowadziły politykę neutralności. Zob. więcej: P. Andrzejewski, Neutralność w polityce zagranicznej Finlandii i Szwecji, Państwowe Wydawnictwo Naukowe, Warszawa 1988 oraz D. Popławski, Austriacka polityka neutralności 1955-1995, Warszawa 1995.

${ }^{37}$ Bericht über einen Beitritt..., s. 7.

${ }^{38}$ Chodziło o zachowanie efektywności procesu decyzyjnego w ramach poszerzonej Wspólnoty. 
na kolejną przyjdzie jej poczekać kilka ładnych lat. Tym samym na możliwość współdecydowania o politycznym kształcie tej organizacji będzie już za późno.

Raport wskazuje również na aspekty wewnątrzpaństwowe, które zadecydowały o ówczesnym złożeniu wniosku w sprawie przystąpienia do Wspólnoty Europejskiej. Intencją władz było nadanie głosowaniu w sprawie EOG pełnej transparentności, tj. wysłanie do społeczeństwa jasnego komunikatu o intencjach i strategii rządu na najbliższe lata. Tym samym obywatele głosując za włączeniem Szwajcarii do EOG mieli mieć pełną świadomość, iż jest to pierwszy etap na drodze do pełnej integracji, dając jednocześnie rządowi zielone światło. Chciano przy tym zapobiec niekorzystnemu odbiorowi takiej polityki przez społeczeństwo. Po pierwsze, obywatele mogliby się obawiać, iż wynik referendum, nawet jeżeli okaże się pozytywny, ale nieprzeważający, może wpłynąć na odroczenie decyzji dotyczącej złożenia wniosku akcesyjnego. Oznaczałoby to zgodę na przedłużenie okresu przejściowego, tj. członkostwa w EOG, które jednakże nie rozwiązuje wielu problemów i nie zabezpiecza w wystarczającym stopniu interesów Szwajcarii. Z drugiej strony część obywateli, niepopierająca integracji ze Wspólnotą, mogłaby czuć się oszukana, nie znając prawdziwych pobudek, którymi kierował się rząd składając wniosek o włączenie do Europejskiego Obszaru Gospodarczego. Jednocześnie w omawianym raporcie władze zastrzegały, że decyzja w sprawie przystąpienia do Wspólnoty nie jest ostateczna, albowiem tę podejmują zawsze sami obywatele $\mathrm{w}$ drodze referendum.

Istotnym elementem omawianego dokumentu jest również wskazanie zasadniczych różnic pomiędzy opcją włączenia Szwajcarii do EOG a pełną integracją. Co ważne, oba etapy postrzegane są w sposób komplementarny. EOG traktuje się tutaj jako swoistą poczekalnię, która odgrywa jednak bardzo istotną rolę - przygotowuje Szwajcarię pod względem społecznym, prawnym i instytucjonalnym do pełnego członkostwa we Wspólnocie. Przystąpienie do Europejskiego Obszaru Gospodarczego oznacza konieczność ujednolicenia określonych podstaw prawnych, a więc przyjęcia przynajmniej części acquis communautaire. EOG stwarza zatem warunki ramowe przyszłej integracji. Nie bez znaczenia pozostaje także kwestia budowy zaufania i właściwego wizerunku Szwajcarii w Europie.

Przedstawiony w raporcie punkt widzenia władz Szwajcarii na kwestie europejskie wydaje się zatem mieć silne podstawy merytoryczne. Bez wątpienia decyzja ta była dużym wyzwaniem dla tego państwa. Biorąc jednak pod uwagę ówczesną sytuację geopolityczną, wydawała się zdecydowanie najlepszym wyjściem. Rząd chciał wykorzystać przy tym szansę, która pojawiła się wówczas, a mianowicie możliwość realnego współkształtowania integracji europejskiej. Była to zatem okazja do świadomego i w miarę swobodnego pozycjonowania Szwajcarii w Europie, a przy tym zachowania tego, co najważniejsze, czyli jej niezależności. Oczywiście można polemizować ze stanowiskiem rządu, dotyczącym faktycznych możliwości oddziaływania na kształt przyszłej UE. Trudno jed- 
nak odmówić wiarygodności przesłanek towarzyszących jego decyzjom i jasno sprecyzowanej, a przy tym odważnej, strategii działania.

Kolejne wydarzenia pokrzyżowały jednak plany rządu i zmusiły go do zredefiniowania dotychczasowej koncepcji. Społeczeństwo odrzuciło bowiem propozycję włączenia Szwajcarii do Europejskiego Obszaru Gospodarczego, negując tym samym jego naturalną konsekwencję, a więc członkostwo w UE. Nowy raport, z 1993 r., dotyczący polityki zagranicznej Szwajcarii w latach 90., stanowił próbę wyznaczenia zmienionego kursu ${ }^{39}$. Przygotowując nową strategię polityczną rząd Szwajcarii określił pięć najważniejszych celów, które należało osiągnąć, aby zagwarantować ochronę interesów państwa, w tym bezpieczeństwo i stabilny wzrost gospodarczy. Wyznaczono także instrumenty, które miały służyć ich osiągnięciu. Część z nich odnosiła się bezpośrednio do współpracy ze Wspólnotą. Władze w Bernie przyjęły bowiem strategię, że niekorzystne wyniki referendum nie muszą oznaczać rezygnacji z integracji, lecz tylko poważnie przesuwają ją w czasie. Realizacja tej koncepcji zakładała zatem rozpoczęcie rozmów w sprawie umów bilateralnych. Szczegółowe informacje dotyczące nowej koncepcji polityki wobec UE odnaleźć można w punkcie dotyczącym wsparcia bezpieczeństwa i pokoju oraz dobrobytu ${ }^{40}$.

Podstawą decyzji rządu była świadomość konieczności podejmowania aktywnych działań Szwajcarii na arenie międzynarodowej, w tym również w ramach międzynarodowych organizacji. Tym samym zerwano ze strategią, determinowaną przez doktrynę Bindschedlera, o czym była mowa w pierwszej części niniejszej pracy ${ }^{41}$. Rząd wychodził z założenia, iż pozycja gospodarcza Szwajcarii, plasująca ją w czołówce państw nie tylko europejskich, lecz również światowych, nie odzwierciedla poziomu aktywności w forach międzynarodowej współpracy. Chodziło tutaj przede wszystkim o te struktury, w ramach których podejmowane są decyzje o zasięgu globalnym, tj. głównie ONZ, ale również NATO i UE. Co ciekawe, o współpracy z tą ostatnią organizacją mówi się nie tylko w kontekście gospodarczym, ale również w kontekście bezpieczeństwa. Jest to dość znamienne, albowiem w przeciwieństwie do poprzedniego raportu rząd jednoznacznie ustosunkowuje się do szerokiego zakresu integracji, w tym również aspektów związanych z neutralnością. Wcześniej kwestię tę pomijano, motywując to głównie trudnym do oszacowania ostatecznym kształtem i rolą Wspólnoty ${ }^{42}$.

W zakresie wspierania dobrobytu raport z roku 1993 kładzie nacisk na integrację europejską. To jej przypisuje się w tym obszarze największe znaczenie. Strategia rządu zakłada zatem, że przystąpienie Szwajcarii do Unii Europejskiej pozostaje celem strategicznym w polityce europejskiej. Tym samym władze

${ }^{39}$ Bericht über die Aussenpolitik der Schweiz in den 90er Jahren vom 29. November 1993, BB1 1994 I 153.

${ }^{40}$ Ibidem, s. 17-29.

${ }^{41}$ Zob. także D. Popławski, Szwajcarska polityka bezpieczeństwa, Warszawa 2007, s. 80.

${ }^{42}$ Bericht über einen Beitritt..., s. 120. 
w Bernie nie odcięly się do końca od założeń zawartych w poprzednim raporcie. Nadały im jedynie nieco lżejszy wydźwięk, głównie poprzez unikanie konkretnych terminów. Rząd wyraża jednak przekonanie, że integracja jest najlepszym krokiem do zabezpieczenia interesów państwa w perspektywie długoterminowej. Wobec odrzucenia wniosku o włączenie Szwajcarii do EOG władze skoncentrowały działania na współpracy na poziomie bilateralnym. Głównym ich celem była minimalizacja negatywnych skutków rezygnacji z EOG, a przy tym umożliwienie stworzenia pozytywnych warunków zewnętrznych oraz wewnętrznych do ewentualnego członkostwa we Wspólnocie. Istotna jest przy tym świadomość, iż w tym kontekście bardzo wiele zależy nie tylko od decyzji samej Szwajcarii, lecz również Unii Europejskiej. Dla władz w Bernie stało się jasne, że przystąpienie do Wspólnoty będzie procesem coraz trudniejszym. Nie tylko ze względu na nastroje społeczne, ale również z uwagi na coraz silniejszą pozycję UE, która z czasem może zacząć dyktować określone warunki. Przyszłość pokazała zresztą, że obawy Szwajcarii były jak najbardziej uzasadnione.

W związku z powyższym władze zdecydowały się na przyjęcie konkretnego planu działań, zakładającego dokonanie przez rząd oraz społeczeństwo oceny nowej strategii politycznej, w tym przede wszystkim opcji powiązań bilateralnych. Miało się to odbyć najpóźniej do końca roku 1999. Na ich podstawie miały być podjęte kolejne kroki mające na celu intensyfikację integracji, tj. włączenie Szwajcarii do EOG lub UE. Kwestia ta uznana została za jeden z najważniejszych priorytetów polityki zagranicznej rządu w latach 90., zwłaszcza że integracja traktowana była nie tylko jako jeden z najistotniejszych gwarantów rozwoju gospodarczego. Stwarzała bowiem również możliwość akcentowania własnego stanowiska i opinii na forum międzynarodowym, na czym Szwajcarii niewątpliwie bardzo zależało.

Motywem przewodnim omawianego raportu pozostaje zatem kwestia aktywnego włączenia Szwajcarii do struktur międzynarodowej współpracy. Wnioski z obserwacji geopolitycznych uwarunkowań wskazywały, iż brak aktywności międzynarodowej przynosi daleko idące konsekwencje, oznaczające zdecydowanie więcej strat niż korzyści. Celem nadrzędnym było więc przede wszystkim zagwarantowanie Szwajcarii pełnoprawnego udziału w tych gremiach, gdzie podejmowane są kluczowe decyzje, a także tam, gdzie interesy kraju nie były do tej pory reprezentowane.

\subsubsection{CZLONKOSTWO W UNII EUROPEJSKIEJ JAKO CEL STRATEGICZNY}

Upadek systemu bipolarnego oznaczał z jednej strony likwidację wielu zagrożeń dla bezpieczeństwa Szwajcarii, ale zarazem stwarzał nowe szanse i wyzwania, którym nie sposób było sprostać samodzielnie. Negacja integracji eu- 
ropejskiej niosłaby za sobą przykre konsekwencje ekonomiczne, polityczne, a wreszcie wizerunkowe. Unia Europejska pozostała więc najważniejszym partnerem, a możliwość nawiązania ścisłych z nią relacji celem strategicznym rządu. Mając w pamięci przykre rezultaty poprzednich głosowań referendalnych podjęto decyzję o zamrożeniu wniosku w sprawie przystąpienia Szwajcarii do Wspólnoty. Co ciekawe, nigdy go zresztą formalnie nie wycofano. Fakt ten był wielokrotnie krytykowany przez SVP, a także inne prawicowe ugrupowania i stowarzyszenia, o czym mowa będzie jeszcze w dalszej części niniejszego rozdziału. Droga bilateralna traktowana była na początku bardziej jako okres przejściowy, który umożliwi zbliżenie z UE i zapewni prawne oraz instytucjonalne podstawy przyszłej integracji ${ }^{43}$. Nastąić to miało zresztą relatywnie szybko.

Warto zauważyć, że wątki poświęcone polityce europejskiej są elementem składowym zupełnie nowej koncepcji polityki zagranicznej, polityki nastawionej na współpracę z innymi podmiotami, i - co ważne - nie tylko w celu osiągnięcia własnych, doraźnych interesów, lecz również stworzenia nowego wizerunku Szwajcarii - państwa aktywnie uczestniczącego w politycznych i gospodarczych przemianach w Europie. Duży nacisk kładło się na wsparcie pokoju i bezpieczeństwa na świecie, pomoc dla państw byłego bloku wschodniego, zwalczanie nierówności społecznych. Nowo określone cele miały charakter całkowicie przełomowy, wyznaczając nowy trend w polityce międzynarodowej Szwajcarii.

Okres negocjacji pierwszego pakietu umów bilateralnych upłynął pod znakiem rosnącego zaufania opinii publicznej do współpracy z UE. Rząd, przy wsparciu środowisk gospodarczych, umiejętnie kierował do społeczeństwa pozytywny przekaz dotyczący przyszłych relacji ze Wspólnotą. Poparcie społeczne dla polityki władz federalnych oscylowało $\mathrm{w}$ granicach nieco ponad $50 \%{ }^{44}$, co uznać należy za bardzo dobry wynik. Był to także okres aktywności ruchów proeuropejskich, których dążeniem było jak najszybsze reaktywowanie wniosku akcesyjnego, złożonego jeszcze w roku $1992^{45}$. Fakt ten był jednym z powodów, dla których rząd zdecydował się na opublikowanie kolejnego raportu, poświęconego tym razem stricte integracji europejskiej - Integrationsberich ${ }^{46}$. Poza tym rok 1999, w którym został on opublikowany, miał znaczenie szczególne, albowiem otwierał nowy rozdział współpracy bilateralnej z UE w siedmiu, kluczowych dla gospodarki, obszarach. Zaprezentowany raport był punktem wyjścia debaty eu-

${ }^{43}$ Tezę tę potwierdza również raport rządowy z roku 1995, który wyznacza współpracy bilateralnej dwa cele: utrzymanie konkurencyjności gospodarki szwajcarskiej oraz ułatwienie włączenia Szwajcarii do struktur europejskich: Zwischenbericht zur europäischen Integrationspolitik der Schweiz vom 29. März 1995, Bern 1995.

${ }^{44} \mathrm{Z}$ przeprowadzonych latem 1998 r. przez Instytut gfs. Bern sondaży wnikało, iż 53\% obywateli popierało lub miało stosunek życzliwy wobec przystąpienia Szwajcarii do UE.

${ }^{45}$ Inicjatywa „Ja zu Europa” (Tak dla Europy), zakładająca wpisanie do konstytucji obowiązku natychmiastowego rozpoczęcia negocjacji w sprawie włączenia Szwajcarii do UE.

${ }^{46}$ Schweiz-Europäische Union: Integrationsbericht 1999 von 3. Februar 1999, BBI 1999 V 3935. 
ropejskiej, której podstawowym celem było stwierdzenie, czy istnieją przesłanki wznowienia rozmów akcesyjnych, czy też nadal ich nie ma. Miał on również skłonić do poważnej dyskusji ogólnospołecznej nad alternatywnymi opcjami współpracy z UE.

Rozważano tutaj trzy główne kierunki. Bilateralizm, przystąpienie do EOG lub Alleingang (,samotny rajd”), a więc dystansowanie się od wszelkich form współpracy międzynarodowej ${ }^{47}$. Raport stanowił także uzupełnienie dość pogłębionych analiz, dotyczących aspektów prawnych i gospodarczych integracji z UE, które powstały na zlecenie Rady Związkowej. Zawierał również wiele informacji na temat bieżącego funkcjonowania Wspólnoty, zwłaszcza po dwukrotnych jej przeobrażeniach instytucjonalnych, wprowadzonych na mocy traktatów z Maastricht i Amsterdamu, a także w perspektywie ostatniego i spodziewanego rozszerzenia $^{48}$. Warto zauważyć, iż dokument charakteryzuje się dość przystępną dla czytelnika formą, ułatwiającą zrozumienie podstawowych zagadnień związanych z funkcjonowaniem UE nawet laikom, nieposiadającym specjalistycznej wiedzy dotyczącej integracji europejskiej. Drugą część raportu wzbogacono o cytaty z wybranych pytań, skierowanych przez obywateli do Biura Integracyjnego, i odpowiedzi na nie. Całość raportu przygotowana została zatem w taki sposób, aby ułatwić mu dotarcie do jak najszerszego grona odbiorców.

Integrationsbericht składa się z dwóch części. Pierwsza z nich zawiera przegląd podstawowych programów oraz polityki Wspólnoty, a także zasad funkcjonowania wspólnotowego rynku, zwłaszcza w kontekście współpracy dwustronnej. Rozpatruje się tutaj wszystkie trzy, wymienione wyżej, scenariusze rozwoju wzajemnych relacji. Druga część poświęcona jest omówieniu uwarunkowań ramowych dla różnych form współpracy, a także ich oddziaływaniu na podstawowe elementy systemu politycznego Szwajcarii. Autorzy raportu poświęcili również nieco miejsca analizie perspektyw rozwoju Unii Europejskiej, przeprowadzonej na podstawie bieżących uwarunkowań i spodziewanych zmian, będących wynikiem wejścia w życie Traktatu Amsterdamskiego.

Nie ulega wątpliwości, że pod wieloma względami raport z roku 1999 nie różni się niczym szczególnym od tego opublikowanego w 1993 r. Zwłaszcza W sferze konceptualnej nie wnosi niczego nowego. W zakresie strategii politycznej wobec UE stanowi potwierdzenie dotychczasowej polityki ${ }^{49}$. Sprowadza się ona do wyczekiwania na lepsze warunki, sprzyjające wznowieniu wniosku akce-

${ }^{47}$ Co zresztą byłoby sprzeczne z założeniami zawartymi w koncepcji politycznej opublikowanej w roku 1993.

${ }^{48}$ W 1995 r. do UE przystąpiły Austria, Szwecja i Finlandia, rozpoczęto również negocjacje akcesyjne z sześcioma nowymi kandydatami.

${ }_{49}$ Do najważniejszych wyznaczników wzajemnych relacji między Szwajcarią a UE rząd zalicza: wsparcie procesów integracyjnych, dążenie do zagwarantowania dostępu do wspólnotowego rynku dla szwajcarskiego eksportu oraz łagodzenie zjawisk dyskryminacji czy chęć zapobieżenia politycznej i kulturowej izolacji kraju; Integrationsbericht..., s. 284. 
syjnego. Wielokrotnie odnaleźć można zwroty świadczące o całkowitym przekonaniu rządu, że właśnie pełna integracja jest najlepszym gwarantem ochrony interesów Szwajcarii. Jednakże ze względu na konieczność poszanowania woli suwerena, władze podjęły decyzję o rozpoczęciu rozmów bilateralnych.

Nowym elementem raportu jest próba wyjaśnienia wątpliwości i kontrowersji na temat relacji dwustronnych z Unią Europejską. Jak wiadomo, dokument opublikowany został niemal bezpośrednio po zakończeniu negocjacji dotyczących pakietu Bilaterale I. Obywatele byli zresztą regularnie i w sposób wyczerpujący informowani o ich przebiegu. Nie uniknięto jednak krytyki. Zdarzały się opinie, zresztą umiejętnie podsycane przez środowiska prawicowo-konserwatywne, że pozycja negocjacyjna Szwajcarii jest relatywnie słaba. Podobne argumenty pojawiają się zresztą także i teraz. Podkreślano, że niewielka Szwajcaria nie jest dla Unii równorzędnym partnerem, co przekłada się na niekorzystne warunki umów bilateralnych. Oczywiście największe obawy wiązano z zasadą swobody przepływu osób, która oznaczała otwarcie rynku pracy dla obcokrajowców.

Stanowisko Rady Związkowej nie jest w tej kwestii jednoznaczne, lecz zostało przedstawione w sposób wyważony, zgodnie z przyjętym charakterem raportu. Władze podkreślają, że dotychczasowe doświadczenia z negocjacji nad umowami bilateralnymi wskazują, iż przyjęta forma współpracy akceptowana jest przez obydwie strony i leży w interesie zarówno Szwajcarii, jak i UE. W związku z powyższym zasadne jest jej kontynuowanie, a więc negocjowanie kolejnych umów. Niezbędne jest jednak, aby zawrzeć je na równych warunkach, gwarantujących ochronę interesów obydwu stron. Za umowami bilateralnymi przemawia również możliwość w miarę swobodnego wyboru obszarów, które wymagają uregulowania, oraz pełna autonomia w zakresie ich późniejszego wdrażania. Ponadto nie wymagają one transponowania acquis communitaire do porządku prawnego Szwajcarii. Podkreśla się także aspekt finansowy. W tym przypadku Szwajcaria zwolniona jest ze składek członkowskich, które oznaczałyby dodatkowe obciążenie dla budżetu ${ }^{50}$.

Oczywiście władze wskazują również na negatywne aspekty współpracy bilateralnej, głównie w perspektywie długoterminowej. Podstawową ich wadą jest konieczność negocjowania poszczególnych umów ze wszystkimi członkami Wspólnoty. W praktyce oznacza to, że każdy obszar tematyczny musi uzyskać akceptację wszystkich państw członkowskich, co nie odbywa się na zasadzie kompromisu, ale znacznie wydłuża proces negocjacji. Wystarczy wspomnieć, że pierwszy pakiet umów negocjowany był przez pięć lat. Ponadto każdorazowa modyfikacja postanowień umowy wymaga wznowienia analogicznej procedury. Oczywiście z uwagi na ten problem umowy bilateralne z zasady mają charakter statyczny. Jednakże część warunków, będących chociażby efektem rozszerzenia

${ }^{50}$ Umowy bilateralne przewidują jedynie niewielkie wpłaty bezpośrednie, które pozwalają na sfinansowanie wspólnych programów, jak np. 7. Program Ramowy w zakresie badań i rozwoju technologicznego $(7 P R)$. 
Wspólnoty, może ulec zmianie. W takiej sytuacji wskazana byłaby możliwość dynamicznego dopasowania przyjętych regulacji do zachodzących zmian. Jest to jednak z oczywistych względów niemożliwe. Władze związkowe przyznają też, iż wybór obszarów tematycznych jest uzależniony od wspólnego stanowiska ogółu państw członkowskich UE. Oznacza to, że nie wszystkie, istotne z punktu widzenia Berna, tematy mogą stać się przedmiotem negocjacji, co potwierdza zresztą praktyka. Jedynie siedem z 16 zaproponowanych przez Szwajcarię tematów uzyskało akceptację Brukseli. W dłuższej perspektywie utrzymanie tej formy relacji przysparzać będzie coraz więcej problemów, a wypracowanie właściwych ram prawnych bądź instytucjonalnych dla kolejnych obszarów tematycznych stanie się niezwykle trudne, przynajmniej na obecnym poziomie integracji. Władze potwierdzają tym samym, iż współpraca bilateralna jest jedynie czasowym rozwiązaniem.

Jak już wcześniej wspomniano, główną intencją rządu było zmotywowanie obywateli do dyskusji nad koncepcją stosunków z UE. Analiza raportu z roku 1999 skłania jednakże do postawienia tezy, że faktycznym celem tej debaty było przekonanie obywateli do poparcia idei włączenia Szwajcarii do struktur UE. Poświęcona jest temu zresztą niemal wprost znaczna część raportu. Odnosi się ona prawie do wszystkich aspektów funkcjonowania państwa w warunkach pełnego członkostwa. Począwszy od prawnych oraz instytucjonalnych, kończąc na tożsamości kulturowej i podstawowych wartościach, takich jak suwerenność i neutralność. Głębsza ich analiza nie jest przedmiotem niniejszego rozdziału. Warto jednak zwrócić uwagę na kilka wyróżnionych w raporcie elementów.

Rząd wskazuje, że przystąpienie do UE skutkować będzie nie tylko określonymi korzyściami dla Szwajcarii, lecz przynieść może również pozytywne efekty dla całej Wspólnoty. Podkreśla się tutaj doświadczenia z funkcjonowania państwa w warunkach dużego zróżnicowania gospodarczego, kulturowego i językowego. Można więc pokusić się o stwierdzenie, że system helwecki przypomina, oczywiście w mniejszej skali, ten, który funkcjonuje lub przynajmniej do którego dąży się w ramach Wspólnoty ${ }^{51}$. Rząd przyznaje oczywiście, że przekonanie o możliwości transponowania doświadczeń Szwajcarii na grunt unijny byłoby pewną naiwnością ${ }^{52}$. Niemniej jednak zachodzące obecnie procesy, polegające na konsolidacji systemów prawnych oraz instytucjonalnych państw wchodzących w skład UE, mogą ulec wzmocnieniu dzięki obecności doświadczonej w tym zakresie Szwajcarii. Jest to szczególnie istotne w kontekście konieczności przeprowadzenia zmian w sposobie funkcjonowania Wspólnoty, szczególnie

${ }^{51}$ Por. G. Kreis, Nach der schweizerischen jetzt die europäische Integration: Zur Idee der schweizerischen Modellhaftigkeit, [w:] T. Cottier, A. Kopse, Der Beitritt der Schweiz zur Europäischen Union - Brennpunkte und Auswirkungen, Zürich 1998; M. Tomczyk, Czy Unia ulegnie szwajcaryzacji?, Portal Spraw Zagranicznych, http://www.psz.pl/Michal-Tomczyk-Czy-Unia-ulegnie-_szwajcaryzacji_(11.11.2010).

${ }^{52}$ Integrations $\bar{b}$ ericht..., s. 318. 
w perspektywie jej kolejnego rozszerzenia. Ponadto, na co również zwraca się uwagę w raporcie, Szwajcaria dysponuje szeregiem sztywnych ram prawnych, zwłaszcza $\mathrm{w}$ zakresie ochrony środowiska, które mogą być punktem odniesienia dla prawodawstwa UE. Nie ulega bowiem wątpliwości, iż duża część regulacji prawnych, obowiązujących w Szwajcarii, jest znacznie bardziej „wyśrubowana" niż w wielu państwach Unii Europejskiej ${ }^{53}$. Prawo wspólnotowe przewiduje, w przypadku pełnego członkostwa, możliwość utrzymania dotychczasowych norm i przepisów, o ile nie zakłócają one zasad funkcjonowania unijnego rynku ${ }^{54}$. Oznacza to w praktyce, że szwajcarskie przepisy dotyczące ochrony środowiska nie mogą ograniczać swobody konkurencji, przykładowo poprzez faworyzowanie rodzimych przedsiębiorstw. Normy środowiskowe możemy zatem zaliczyć do norm z grupy prawodawstwa eurokompatybilnego, a więc takiego, które nie będzie wymagało żadnych zabiegów dostosowawczych. Władze liczą zatem, że w przypadku przystąpienia do UE Szwajcaria nie tylko nie będzie zmuszona do rezygnacji z przepisów związanych z ochroną środowiska, lecz nawet będą one stanowiły wzór dla innych państw. Należy przy tym zauważyć, że kwestie ekologii mają dla Szwajcarów znaczenie priorytetowe.

Ciekawe wnioski płyną również z analizy części dotyczącej wpływu członkostwa na politykę neutralności Szwajcarii. Autorzy raportu wskazują, że obie kwestie nie wykluczają się wzajemnie. Wspólna Polityka Zagraniczna i Bezpieczeństwo UE (WPZiB), przynajmniej w obecnym jej kształcie, nie stanowi problemu i pozwala na swobodną kontynuację zasady bezstronności w sporach i konfliktach międzynarodowych. Zdaniem rządu jakiekolwiek wątpliwości w tej materii mogą pojawić się dopiero w momencie wykrystalizowania struktur UE w zakresie polityki obronnej, co jednakże pozostaje perspektywą bardzo odległą. Władze przyznają jednak, iż w przypadku faktycznego stworzenia tego typu struktur Szwajcaria będzie musiała wziąć pod uwagę możliwość rezygnacji z dotychczasowej strategii bezpieczeństwa, opartej na zbrojnej neutralności, na rzecz kolektywnej obrony w ramach UE. W związku z powyższym rząd przewiduje w najbliższym czasie opracowanie koncepcji reform, pozwalających na poprawę instytucjonalnych zdolności do aktywnego uczestniczenia w WPZiB Unii Europejskiej.

Nieco miejsca poświęca się również aspektom finansowym. Przykładowo po raz pierwszy pojawiają się informacje na temat szacunkowej wysokości składki do budżetu UE. W raporcie mówi się tutaj o sumie rzędu 3,1 - 3,9 mld franków rocznie $^{55}$. Podobne dane opublikowane zostały przez Economiesuisse ${ }^{56}$, o czym w dalszej części rozdziału. Należy zatem przyjąć, że kwotę tę obliczono w sposób

\footnotetext{
${ }^{53}$ Zob. więcej: A. Epiney, H. Pfenniger, Auswirkungen eines Beitritts zur Europäischen Union auf das schweizerische Umweltrecht-Das Problem der Umweltnormung, [w:] T. Cottier, A. Kopse, op. cit.

${ }^{54}$ Zasada ta wprowadzona została na mocy Traktatu z Maastricht.

${ }^{55}$ Integrationsbericht..., s. 399.

${ }^{56}$ Zbliżona kwota zawarta jest w analizie UBS, Alleingang - Bilaterale Verträge - EU Beitritt..., s. 9 .
} 
wiarygodny. Rząd wskazuje jednak na korzyści wynikające z członkostwa, które będą w stanie zrekompensować powyższe obciążenia. Podkreśla się spodziewany wzrost wpływów do budżetu, spowodowany zniesieniem barier w handlu. Szwajcarskie przedsiębiorstwa uzyskają wówczas dostęp do unijnych rynków, co w oczywisty sposób przełoży się na kondycję całej gospodarki. Ponadto wzrost konkurencyjności wymusi podwyższenie jakości oferowanych towarów. Należy również oczekiwać weryfikacji cen, a więc obniżenia ich do poziomu pozwalającego na zachowanie wysokiej atrakcyjności szwajcarskich produktów. Oczywiście trzeba przy tym pamiętać, iż niektóre branże odczuwać mogą negatywne skutki integracji. Zasada swobody konkurencji oznaczać może konieczność likwidacji niektórych instrumentów ochronnych lub dopłat proeksportowych. Podobne efekty przynieść może również przyjęcie unijnej waluty. Krok ten pozwoli, co prawda, na zminimalizowanie ryzyka mechanizmów spekulacyjnych, z którymi rząd musi się co jakiś czas borykać, jednak bezdyskusyjna pozostaje zarazem kwestia utraty samodzielności w zakresie kształtowania polityki monetarnej. Oczywiście najbardziej bolesny może być sam fakt rezygnacji z franka szwajcarskiego, który bez wątpienia stanowi jeden z najważniejszych motorów napędowych tutejszej gospodarki. Obok dolara i euro jest to najbardziej popularna waluta wśród kredytobiorców.

Równie istotną kwestią pozostaje konieczność dostosowania polityki fiskalnej. Przede wszystkim chodzi tutaj o niezbędne podniesienie stawki podatku VAT z obecnych 7,5 do $15 \%$. Niewątpliwie pociągnie to za sobą wyraźny wzrost wpływów do budżetu państwa, oceniany na ok. 15 mld franków rocznie. Niemniej jednak tego rodzaju zabiegi muszą być zrównoważone przez redukcję innych podatków, celem zagwarantowania stabilnego wzrostu gospodarczego. Nieunikniona jest zatem szersza debata dotycząca reformy systemu podatkowego Szwajcarii w perspektywie przystąpienia do UE. Podobny postulat podnoszony jest zresztą przez różne pozarządowe ośrodki opiniotwórcze.

Rząd odnosi się też do ogólnych problemów, z którymi boryka się obecnie Europa. Chodzi o takie zagadnienia, jak zwalczanie zorganizowanej przestępczości, współpraca w zakresie regulacji polityk azylowych lub też promowanie podstawowych wartości związanych z państwem prawa. Autorzy raportu wskazują, że skuteczna polityka w tych obszarach możliwa jest jedynie na szczeblu wspólnotowym. Polityka azylowa jest doskonałym przykładem takiej współpracy, służącej osiągnięciu wymiernych korzyści m.in. w zakresie poprawy bezpieczeństwa państw UE. Jednym z jej istotnych elementów jest bowiem koordynacja pracy organów ścigania. Chodzi tutaj przede wszystkim o kontrole na granicach zewnętrznych UE oraz działalność Europolu ${ }^{57}$. Ponadto członkostwo we Wspólno-

${ }^{57}$ Europejski Urząd Policji (European Police Office) jest europejską agencją policyjną, która ma swoją siedzibę w Hadze. Jej celem jest współpraca w zakresie zwalczania międzynarodowej przestępczości. Europol powstał w roku 1999, na skutek przekształcenia Europol Drugs Unit, istniejącego od $1994 \mathrm{r}$. 
cie mogłoby wzmocnić pozycję Szwajcarii w relacjach z państwami trzecimi. Przykład niekorzystnych relacji z Libią pokazuje, że państwa niedysponujące silnym wsparciem politycznym mogą stać się łatwym obiektem manipulacji i szantażu ${ }^{58}$.

Podsumowując, Integrationsbericht miał być podstawą do merytorycznej dyskusji nad wyborem właściwej polityki wobec Unii Europejskiej. W raporcie próbowano udzielić odpowiedzi na pytanie dotyczące sposobów i kierunków ochrony interesów gospodarczych i politycznych Szwajcarii, a także zapewnienia bezpieczeństwa opartego na nowej koncepcji, przyjętej jeszcze w Raporcie '93. Władze starają się odpowiedzieć na te pytania w sposób dość obiektywny i rzeczowy, jednak po zapoznaniu się z całością trudno oprzeć się wrażeniu, iż decyzja została już podjęta, a raport stanowi jedynie próbę jej legitymizacji.

Inicjatywa Tak dla Europy z roku 2001 zweryfikowała koncepcje rządu, zawarte w Integrationsbericht. Aż 76,8\% obywateli, i wszystkie kantony, opowiedziało się przeciwko natychmiastowemu rozpoczęciu negocjacji akcesyjnych. W tej sytuacji rząd zmuszony był do rezygnacji z możliwości ponownego rozpoczęcia działań na rzecz pełnej integracji. Skoncentrowano się na wypracowaniu jak najlepszych warunków nowych umów, wchodzących w skład drugiego pakietu. Tym razem znacznie szybciej osiągnięto kompromis, pomimo iż umowy wchodzące w jego skład obejmowały znacznie rozleglejszą tematykę współpracy, wybiegającą poza aspekty czysto gospodarcze. Zaledwie po dwóch latach, tj. w roku 2004, od wejścia w życie Bilaterale I, udało się podpisać kolejny pakiet. Po tym okresie nastąpił właściwy moment na dokonanie pewnych podsumowań i wyznaczenie strategii w polityce europejskiej na kolejne lata.

\subsubsection{BILATERALIZM JAKO NAJBARDZIEJ OPTYMALNA FORMA WSPÓŁPRACY Z UNIĄ EUROPEJSKĄ}

W okresie pomiędzy podpisaniem obu pakietów doszło do znaczących zmian na szwajcarskiej scenie politycznej. Przeprowadzone w roku 2003 wybory parlamentarne zakończyły się wygraną konserwatywnej partii ludowej - SVP, należącej do głównych oponentów integracji europejskiej. Ludowcy uzyskali aż dwa miejsca w Radzie Związkowej, co zapewniło im silną pozycję w rządzie. Ponadto tekę ministra spraw zagranicznych objęła Micheline Calmy-Rey, wywodząca się z socjaldemokratów (Sozialdemokratische Partei der Schweiz). Jej kadencja otworzyła nowy rozdział w relacjach między Szwajcarią a UE, ponieważ w odróżnieniu od swojego poprzednika nowa szefowa dyplomacji opowiadała się za większą powściągliwością w stosunkach z UE. Przystąpienie do Wspólnoty utraciło znaczenie celu strategicznego.

Już na początku swojej kadencji nowy rząd opublikował raport, w którym zobowiązał się do przedstawienia w najbliższym czasie obszernej analizy efek-

${ }^{58}$ Zob. Libyen-Krise: ,, Gravierende Defizite” im Krisenmanagement, „,Tagesanzeiger”, 8. Juli 2010; Zum Glück hilft die EU, „Tagesanzeiger”, 22. April 2010. 
tów ewentualnego członkostwa Szwajcarii w UE ${ }^{59}$. W toku politycznych dyskusji podjęto decyzję o rozszerzeniu przedmiotu powyższej analizy. Miała ona zawierać opis wszystkich możliwych form współpracy, które mogły służyć zabezpieczeniu interesów Szwajcarii w relacjach ze Wspólnotą ${ }^{60}$. Jednocześnie zadecydowano, że główne działania rządu będą się koncentrować na ratyfikacji umów bilateralnych, a także na aktywnym zaangażowaniu w ograniczenie społecznych i gospodarczych nierówności w Europie. Istotnym elementem była również chęć przeprowadzenia wstępnych rozmów w sprawie nowych obszarów tematycznych, którymi mogły być objęte kolejne pakiety umów dwustronnych. Rząd postanowił także podtrzymać dość kontrowersyjną decyzję o niewycofywaniu wniosku akcesyjnego. Świadczy to o dużej konsekwencji władz federalnych, które pomimo oczywistego braku społecznego poparcia dla tego typu działań, zdecydowały się kontynuować dotychczasową strategię. Rząd dał tym samym jasny komunikat, iż perspektywa przystąpienia do UE jest nadal aktualna. Pozostawienie wniosku akcesyjnego zapewnia realną furtkę do wznowienia rozmów w dogodnym do tego momencie.

W związku z powyższym, w roku 2006 władze federalne opublikowały obszerny raport dotyczący polityki europejskiej, zatytułowany Europabericht $2006^{61}$. Stanowi on niewątpliwie kontynuację raportu z 1999 r., jednak wzbogacony jest o istotną analizę pierwszych efektów współpracy bilateralnej. Perspektywa siedmiu lat pozwoliła na dokonanie oceny rosnącej współzależności pomiędzy Szwajcarią a Unią Europejską, przede wszystkim w kontekście harmonizacji prawodawstwa, przebiegającej głównie w formie tzw. autonomicznego dopasowania (autonomie Nachvollzug) niezbędnych reform, problemów ujawniających się w toku kształtowania wzajemnych relacji. Autorzy raportu wskazują również na niezwykle istotny aspekt gospodarczych i politycznych przemian w Szwajcarii oraz w ramach UE. W przypadku tej ostatniej analizuje się tutaj przede wszystkim efekty realizacji postanowień Traktatu z Nicei, wprowadzenia wspólnej waluty europejskiej, rozszerzenia Unii na wschód oraz ewolucji Wspólnej Polityki Zagranicznej i Bezpieczeństwa.

Oficjalnym celem raportu jest przedstawienie podstawowych instrumentów współpracy pomiędzy Szwajcarią a EU, przy uwzględnieniu, że relacje te mają charakter dynamiczny ${ }^{62}$. Widzimy zatem kolejną korelację pomiędzy raportem z roku 1999 oraz 2006. Obie analizy miały za zadanie przedstawienie wszystkich opcji współpracy oraz ich oddziaływania na kluczowe obszary życia społeczno-politycznego w Szwajcarii.

Raport z roku 2006 składa się z trzech części. Pierwsza poświęcona jest przedstawieniu celów ogólnych polityki wobec UE. Druga dotyczy analizy aktu-

${ }^{59}$ Bericht über die Legislaturplanung 2003-2007 vom 25. Februar 2004, BB1 20041149.

${ }^{60}$ Decyzja ta podjęta została w ramach specjalnego posiedzenia Rady Związkowej odbytego w dniu 26 października 2005 r., poświęconego tematyce europejskiej.

${ }^{61}$ Europabericht 2006 vom 28. Juni 2006, BB1 20066815.

${ }^{62}$ Ibidem, s. 6826. 
alnego stanu wzajemnych relacji. Zwraca się tu uwagę na rosnącą współzależność pomiędzy Szwajcarią a UE. Trzecia, niezwykle obszerna, to opis wpływu współpracy na podstawowe elementy systemu politycznego i społecznego współczesnej Szwajcarii. Raport uwzględnia w sumie około 20 zagadnień, począwszy od demokracji bezpośredniej i federalizmu na rynku pracy, a na polityce fiskalnej kończąc. Analizuje się je w perspektywie realizacji współpracy na szczeblu bilateralnym, multilateralnym oraz poprzez pełne członkostwo w UE.

Władze związkowe wychodzą z założenia, że polityka Szwajcarii wobec Unii Europejskiej wpisuje się doskonale w szerszą koncepcję polityczną, bazującą na dwóch podstawowych zasadach - zabezpieczenia interesów materialnych i ideowych oraz aktywności na arenie międzynarodowej. Podyktowane jest to przekonaniem, że oba te aspekty są od siebie całkowicie zależne. Zapewnienie stabilnego rozwoju gospodarczego państwa, przy zagwarantowaniu jego suwerenności i bezpieczeństwa, nie jest możliwe bez aktywnej współpracy z innymi państwami lub organizacjami. Zasada ta ma zresztą swoje umocowanie w konstytucji związkowej z roku $1999^{63}$. Realizacja polityki europejskiej jest tym istotniejsza, że umożliwia osiągnięcie pięciu horyzontalnych celów, wyznaczonych przez rząd jeszcze na początku lat $90 .{ }^{64}$ Szwajcarię i Unię Europejską łączy wspólnota tych samych wartości, tj. demokracji, państwa prawa, praw człowieka oraz zrównoważonego rozwoju. Poza tym Szwajcaria odczuwa współodpowiedzialność za stabilny rozwój i bezpieczeństwo w Europie. Polityka europejska traktowana jest zatem w sposób priorytetowy zarówno ze względu na aspekty ekonomiczne, jak $\mathrm{i}$ ideologiczne.

Raport porusza także kwestię współpracy z organizacjami międzynarodowymi. Rząd przyznaje, iż obszar ten do niedawna nie zajmował właściwego miejsca w polityce zagranicznej. Błędy przeszłości wynikały jednak przede wszystkim z niewłaściwego postrzegania własnej roli na arenie międzynarodowej. Zbyt dużą wagę przykładano do kwestii instytucjonalnych, tj. samego faktu przynależności do określonej organizacji (w kontekście doktryny neutralności), a nie zadań i roli, jaką może odgrywać Szwajcaria dzięki aktywności na forum międzynarodowym.

Współpraca bilateralna z Unią Europejską umożliwia punktowe rozwiązanie najbardziej palących problemów we wzajemnych relacjach. Co ważniejsze, władze federalne mogą liczyć na pełne poparcie społeczne dla tego typu działań, o czym świadczą ostatnie głosowania referendalne, dotyczące kwestii europejskich ${ }^{65}$.

${ }^{63}$ Zob. artykuł 54 konstytucji. Rząd federalny jest zobowiązany do zachowania niezależności Szwajcarii oraz jej interesów, a także do łagodzenia niedostatku i ubóstwa na świecie, do przestrzegania praw człowieka i promowania demokracji, pokojowego współistnienia narodów i ochrony naturalnych podstaw egzystencji.

${ }^{64}$ Obszerniej była o nich mowa w pierwszym rozdziale.

${ }^{65}$ Chodzi o głosowania w sprawie rozszerzenie swobody przepływu osób oraz włączenia kraju do układów z Schengen i Dublina. 
Istotnym elementem raportu Europabericht 2006 jest obszerna analiza dostępnych instrumentów budowy relacji z Unią Europejską. Rząd dysponuje tutaj kilkoma możliwościami, które, co wielokrotnie podkreślano, dobierane będą w sposób pragmatyczny. Oznacza to, że podstawową przesłanką, jaką musi spełniać dany instrument, jest jego efektywność. Co ważne, nie wykluczają się one wzajemnie, a więc mogą być stosowane w zależności od wewnętrznych oraz zewnętrznych uwarunkowań, umożliwiających wykorzystanie ich w określonym terminie. Skuteczność tych instrumentów zależy także w dużej mierze od decyzji UE. Rozważa się zatem stosowanie następujących instrumentów:

- dostosowanie prawodawstwa Szwajcarii;

- zarządzanie i aktualizacja istniejących umów;

- negocjacje nowych obszarów tematycznych;

- unia celna;

- poprawa ram instytucjonalnych;

- układ ramowy;

- włączenie do Europejskiego Obszaru Gospodarczego;

- członkostwo w UE.

Możliwość użycia niektórych z nich, jak na przykład układu ramowego, wydaje się nierealna, przede wszystkim ze względu na stanowisko Unii Europejskiej, która już teraz obawia się stworzenia pewnego precedensu, wykorzystywanego ewentualnie przez obecnych lub potencjalnych członków Wspólnoty. Inne z kolei pociągają za sobą niekorzystne konsekwencje, czego dobrym przykładem jest unia celna, wymuszająca stosowanie wyższych taryf w handlu z krajami nienależącymi do UE. Szwajcaria utraciłaby z tego powodu część autonomii w zakresie kreowania własnej polityki gospodarczej. Należy również zauważyć, że pewne instrumenty, jak chociażby dostosowanie prawodawstwa Szwajcarii, nie do końca można uznać za element szerszej strategii politycznej, przynajmniej nie w wymiarze, który pozwoliłby na zaliczenie ich do grona celowych i długofalowych instrumentów polityki europejskiej. Jest to raczej wyraz pragmatyzmu w bieżących relacjach ze Wspólnotą. Harmonizacja prawa nie jest ponadto zabiegiem uniwersalnym, ponieważ nie zawsze w odpowiednim stopniu zabezpiecza interesy Szwajcarii. Dzieje się tak w przypadku polityki fiskalnej i monetarnej, które stanowią o przewadze konkurencyjnej szwajcarskiej gospodarki. Za najbardziej prawdopodobne uznać należałoby aktualizację istniejących umów oraz wypracowanie nowych. W kolejce czekają tu takie tematy, jak polityka energetyczna, opieka zdrowotna czy - bodaj najtrudniejszy obszar - sektor rolniczy.

$\mathrm{Na}$ uwage zasługuja również, przytoczone w raporcie, problemy rozwoju Unii Europejskiej oraz utrzymania jej spójności. Kolejne rozszerzenie Wspólnoty uwidoczniło szereg trudności związanych z procesem integracji. Różnorodność uwarunkowań politycznych oraz gospodarczych poszczególnych państw aspirujących do członkostwa w Unii Europejskiej, skłoniła do zredefiniowania współpracy $w$ ramach UE i stworzenia zróżnicowanych form integracji. Służy to zapew- 
nieniu efektywności funkcjonowania Wspólnoty, a także może się przyczynić do ułatwienia nawiązania współpracy państwom, w przypadku których perspektywa przystąpienia jest zbyt odległa, chociażby ze względu na niemożność sprostania określonym wymogom formalnym (głównie ekonomicznym). Może również dochodzić do sytuacji, w której przyjęta, tradycyjna formuła współpracy, z różnych powodów nie spełnia określonych oczekiwań. Jest to jeden z istotnych powodów, dla którego takie kraje, jak Szwajcaria lub Norwegia do dziś nie podjęły decyzji o przystąpieniu do UE. Niechęć opinii publicznej, wyrażona w sondażach i przeprowadzonych głosowaniach, skutecznie wstrzymuje ośrodki polityczne przed podjęciem tego rodzaju decyzji. Pojawiające się wyzwania i zagrożenia dla sprawnego funkcjonowania Unii Europejskiej dały asumpt do zaproponowania nowych form współpracy:

- modelu Europy o „zmiennej geometrii” (variable Geometrie);

- elastycznej integracji;

- wzmocnionej współpracy.

Mają one nie tylko wprowadzać atrakcyjniejsze formuły integracji, lecz również przeciwdziałać tworzeniu groźnych podziałów wewnątrz UE. Doprowadzenie do wykształcenia $\mathrm{w}$ ramach Wspólnoty tzw. twardego rdzenia, a więc grupy państw silnie ze sobą zintegrowanych, oznaczałoby marginalizację i podporządkowanie pozostałych członków Unii. Sytuacja ta mogłaby doprowadzić w konsekwencji do osłabienia współpracy i pogorszenia efektywności Wspólnoty jako całości. Do tego doszłyby problemy natury instytucjonalnej. Elastyczna integracja oznacza, że nie każde państwo w równym stopniu uczestniczyć musi w politykach wspólnotowych. Z takiej możliwości korzystają chociażby Dania czy Wielka Brytania, które nie zdecydowały się na walutę UE - euro oraz korzystają ze specjalnego statusu w ramach układu z Schengen. Klauzula dotycząca wzmocnionej współpracy pozwala na zwiększenie dynamiki integracji i osiągnięcie wyznaczonych celów w sytuacji, gdy nie są one dostępne dla Unii jako całości $^{66}$. Tego rodzaju współpraca ma charakter otwarty, a jedynym jej warunkiem jest przestrzeganie ogólnie przyjętych zasad, w tym zakazu dyskryminacji, swobody konkurencji oraz spójności terytorialnej, gospodarczej i społecznej UE. Choć do tej pory nie zdecydowano się na wykorzystanie tej klauzuli ${ }^{67}$, stanowi ona atrakcyjną formułę współpracy, która wcześniej czy później może zostać wykorzystana przez członków Wspólnoty ${ }^{68}$. Oczywiście pojawiają się opinie, iż stworzenie różnych modeli integracji może przyczynić się do powstania modelu

${ }^{66}$ Obecne zasady mechanizmu wzmocnionej współpracy określa Traktat z Lizbony, jednak regulacje zawarte były już w art. 20 Traktatu o Unii Europejskiej oraz art. 326-334 Traktatu o funkcjonowaniu Unii Europejskiej.

${ }^{67}$ Stan z lutego $2010 \mathrm{r}$.

${ }^{68}$ Warto zauważyć, iż już teraz tworzą się nieformalne grupy na rzecz osiągania określonych celów, jak na przykład EU-3 (Wielka Brytania, Francja, Niemcy w sprawie Iranu) czy G-5 zajmująca się walką z terroryzmem (Francja, Niemcy, Włochy, Wielka Brytania, Hiszpania). 
Europy „dwóch prędkości”, co odbiłoby się bardzo niekorzystnie na solidarności krajów członkowskich ${ }^{69}$.

Zdaniem rządu Szwajcarii przedstawione powyżej modele integracji z UE stanowią ciekawą propozycję i mogą być wykorzystane w budowaniu przyszłych relacji ze Wspólnotą. Biorąc pod uwagę bieżącą dyskusję nad perspektywą rozszerzenia, w tym również problemem członkostwa takich państw, jak Turcja, oraz propozycje reform instytucjonalnych, wykorzystanie tych rozwiązań staje się wielce prawdopodobne. Szwajcaria odnosi się zatem do rozważanego tematu ze sporą atencją, uznając, iż obecne i przyszłe uwarunkowania dają podstawę do wysunięcia tezy, że zapotrzebowanie na wprowadzenie modelu zróżnicowanej integracji w ramach UE wzrośnie. Bardzo możliwe, że w najbliższej przyszłości również sama UE będzie w stanie zaproponować państwom niebędącym jej członkami inne rozwiązanie niż to, jakim dysponuje obecnie, a więc relacje bilateralne. Istnieje zatem duże prawdopodobieństwo, że wraz z rozwojem Wspólnoty zmieni się nastawienie wobec kontaktów z państwami trzecimi, w tym również ze Szwajcarią.

Powyższe stanowisko należy uznać za niezwykle interesujące. Władze Szwajcarii rozpatrują bowiem możliwość wyboru tzw. trzeciej drogi we współpracy z Unią Europejską. Co ciekawe, przyjmuje się, iż potrzeba wypracowania nowego modelu wzajemnych relacji może płynąć także z samej Brukseli. Oznaczałoby to, że obecny poziom współpracy, oparty na umowach dwustronnych, nie musi być traktowany jako okres przejściowy na drodze do pełnej integracji. Może służyć jako narzędzie zacieśniania wzajemnych relacji, a także sondowania potrzeb i możliwości integracyjnych obu stron. Dzięki temu możliwy byłby wybór jedynie pewnych, określonych płaszczyzn współpracy, tj. wybranych polityk i programów wspólnotowych, a więc tych obszarów, które wymagają uregulowania. Wariant ten byłby bodaj najkorzystniejszy dla władz Szwajcarii, przy założeniu, że nie dyskryminowałby małych krajów i gwarantował sprawiedliwe współuczestniczenie w podejmowaniu decyzji w ramach UE.

Punktem wyjścia debaty nad polityką europejską nie jest więc kwestia przystąpienia do Unii, lecz lepszego doboru instrumentów, zapewniających ochronę interesów Szwajcarii. Zdaniem władz związkowych obecne relacje pozwalają na osiąganie obranych przez siebie celów. Ich kontynuacja będzie jednak przede wszystkim zależała od spełnienia podstawowych uwarunkowań, jakimi są:

- zadowalający poziom oddziaływania na rozwój wzajemnych relacji;

- swoboda w realizacji umów;

- wysoki poziom skuteczności w polityce zagranicznej;

- korzystne uwarunkowania gospodarcze.

Możliwość doboru właściwych instrumentów będzie szczególnie istotna w przypadku zmian uwarunkowań zewnętrznych, na które Szwajcaria nie będzie miała

${ }^{69}$ Według opinii niektórych politologów zagrożenie w postaci stworzenia takiego modelu rozwoju jest znikome. Por. K. Bachmann, Unia Europejska dwóch prędkości jest niemożliwa, „Centrum Stosunków Międzynarodowych” 2004, nr 13. 
wpływu, co zapewne nastąpi w dłuższej perspektywie czasu. Jest to zatem strategia nastawiona na prowadzenie dynamicznych relacji z UE. Relacji, które pozwolą nie tylko na zabezpieczenie interesów państwa, ale dadzą również szanse zaprezentowania nowego wizerunku Szwajcarii. Państwa, które może być ważnym i odpowiedzialnym partnerem dla Unii Europejskiej i które będzie gotowe do wspólnego podejmowania nowych wyzwań, pomimo że nadal nie będzie członkiem Wspólnoty.

W związku z powyższym władze rezygnują z konkretyzowania polityki europejskiej na rzecz określenia jedynie ogólnych ram wspólpracy. Europabericht nakreśla również główne priorytety, którymi będzie się kierował rząd, kształtując politykę wobec UE w najbliższym czasie. Zaliczamy do nich postanowienia, ż $\mathrm{e}^{70}$ :

- zawarte umowy dwustronne muszą być realizowane w sposób możliwie najbardziej efektywny;

- dążyć należy do pogłębienia obecnej współpracy, o ile będzie to właściwe i wykonalne;

- Szwajcaria zapewni swój wkład w likwidowanie gospodarczych i społecznych nierówności w Europie.

Europabericht 2006 był wielokrotnie krytykowany, nie tylko przez ośrodki przeciwne integracji. Zarzucono mu zbytnią asekuracyjność, brak konkretnych propozycji i wizji rozwoju współpracy z UE. Zgadzano się co do punktu, że może on stanowić ważną podstawę do dyskusji nad strategią europejską. Należy jednak zauważyć, że podobnego charakteru dokument opublikowany został już w roku 1999, a Europabericht niewiele różni się pod tym względem od swojego poprzednika. Najbardziej zasadniczą różnicą, na którą trzeba zwrócić uwagę analizując ewolucję koncepcji ośrodków rządowych, jest fakt, iż w raporcie z 2006 r. ostatecznie zrezygnowano z traktowania przystąpienia do UE jako celu długookresowego. Jeszcze do niedawna rząd uznawał przystąpienie do Wspólnoty za docelową formę współpracy oraz taką, która w największym stopniu zabezpiecza interesy Szwajcarii. Europabericht otwiera pod tym względem zdecydowanie nową kartę $w$ relacjach z UE. Rząd rezygnuje z rozpatrywania jej w kategoriach dwubiegunowych, tj. bilateralizmu lub członkostwa. Obserwacja uwarunkowań zewnętrznych, którym podlega również Wspólnota, skłania do rozważenia innych wariantów współpracy, jakie już teraz zaczynają pojawiać się w dyskusjach wokół przyszłości i ewentualnych reform w funkcjonowaniu UE.

Europabericht 2006 był przedostatnim raportem ${ }^{71}$, który w sposób wyłączny i szeroki traktował o polityce Szwajcarii wobec Unii Europejskiej, przedstawia-

\footnotetext{
${ }^{70}$ Informationsblatt Europabericht 2006, EDA/EVD, Bern 2006, s. 13.

${ }^{71}$ We wrześniu 2010 r. opublikowano jeszcze dwa raporty, będące odpowiedzią na interpelacje poselskie - Postulat Markwalder vom 10. Juni 2009 Europapolitik. Evaluation, Prioritäten, Sofortmassnahmen und nächste Integrationsschritt, SR 09.3560 oraz Postulat David vom 19. März 2008 Verhältnis der Schweiz zu den europäischen Agenturen, SR 08.3141. Zob. Bericht des Bundesrates über die Evaluation der schweizerischen Europapolitik, BBI 2010 1419; Bericht des Bundesrates zum Verhältnis der Schweiz zu den europäischen Agenturen, SR 10.088. Oba raporty zostały omówione w rozdziale dotyczącym perspektyw polityki Szwajcarii wobec UE.
} 
jąc oficjalną koncepcję polityczną władz związkowych oraz strategię rozwoju wzajemnych relacji w perspektywie najbliższych lat. Pewne uzupełnienie stanowi Föderalismusbericht 200772, będący odpowiedzią na analizę ekspercką, przygotowaną na zlecenie rządów kantonalnych przez $\mathrm{KdK}^{73}$. Dokument ten był przedmiotem dokładniejszych rozważań w pierwszym rozdziale niniejszej pracy. Warto jedynie przypomnieć, iż kładzie on nacisk na wzmocnienie współpracy w polityce europejskiej pomiędzy władzami związkowymi a kantonalnymi. Postulował również wprowadzenie szeregu instytucjonalnych reform, umożliwiających sprawny przepływ informacji oraz wprowadzających wymóg efektywnych konsultacji, które wzmocnią pozycję kantonów i ich udział w kreowaniu polityki europejskiej.

W tym samym roku Rada Związkowa przedstawiła trzy krótko- i średnioterminowe cele w relacjach z Unią Europejską:

- szybka i sprawna realizacja wszystkich umów dwustronnych z UE;

- dalszy rozwój stosunków z UE poprzez podpisanie dodatkowych umów w nowych obszarach wspólnego zainteresowania;

- umocnienie stosunków z UE.

Ostatnim dokumentem strategicznym, dotyczącym relacji zewnętrznych Związku, w którym również odnaleźć możemy informacje na temat koncepcji polityki rządu wobec Unii Europejskiej, jest Aussenpolitischer Bericht $2009^{74}$ (Raport na temat polityki zagranicznej 2009). Władze związkowe potwierdzają w nim chęć dalszej intensyfikacji współpracy ze Wspólnotą poprzez podpisanie dodatkowych umów. Oczywiście w tych obszarach, które są istotne z punktu widzenia interesów obydwu stron. Dużą wagę przykłada się również do organizowania regularnych spotkań i konsultacji na najwyższym szczeblu, które w oczach władz szwajcarskich stanowią najlepszy instrument budowy zaufania i rozwiązywania ewentualnych problemów w relacjach dwustronnych.

W raporcie pojawia się też koncepcja zawarcia układu ramowego z Unią Europejską, którego podstawowym zadaniem byłaby konsolidacja umów bilateralnych. Rząd ma nadzieję, iż stworzenie sztywniejszych ram formalnoprawnych wpłynie na wzmocnienie relacji z UE. Pomysł ten nie jest niczym nowym i jako taki pojawiał się już wcześniej w wypowiedziach członków Rady Związkowej, m.in. wielokrotnie w wywiadach prowadzonych z szefową szwajcarskiej dyplomacji. Również wcześniejsze dokumenty rządowe zawierają wzmianki o możliwości podpisania układów ramowych ${ }^{75}$. Do tej pory nie padały jednak żadne konkretne deklaracje. Zdecydowanie śmielej wypowiadają się na ten temat parlament

${ }^{72}$ Bericht des Bundesrates zu den Auswirkungen verschiedener europapolitischer Instrumente auf den Föderalismus in der Schweiz, BBl 20075907.

${ }^{73}$ Konferenz der Kantonsregierungen.

${ }^{74}$ Aussenpolitischer Bericht 2009 vom 2 September 2009, BB1 20096291.

${ }^{75}$ Zob. Europabericht 2006..., s. 16, 23. 
oraz ośrodki pozarządowe ${ }^{76}$. Wstrzemięźliwość władz związkowych może być podyktowana brakiem pewności co do podobnych intencji ze strony UE. Raport z 2009 r. odwołuje się co prawda do wcześniejszych wypowiedzi urzędników Unii Europejskiej, jednak na ile reprezentują oni oficjalne stanowisko Unii w tej sprawie nie wiadomo. Niewątpliwie istnieje pewne zainteresowanie wypracowaniem tego typu umowy. Temat ten pojawił się m.in. w trakcie spotkania prezydenta Rady Związkowej, Pascala Couchepina, z szefem Komisji Europejskiej, które odbyło się 15 grudnia $2008 \mathrm{r}^{77}$ Nigdy nie padły jednak żadne konkretne propozycje. Wydaje się zatem, że do momentu wykrystalizowania sytuacji władze Szwajcarii nie będą naciskać na Unię i nie zdecydują się na forsowanie idei układu ramowego. Trudno ocenić faktyczny stopień zainteresowania Brukseli. Nie ulega wątpliwości, że chociażby ze względu na obawę przez stworzeniem kolejnego precedensu tego typu propozycja nie będzie wywoływała entuzjazmu wśród przywódców UE.

Rząd odnosi się w raporcie również do pojawiających się coraz częściej żądań Unii dotyczących przejęcia przez Szwajcarię części acquis communautaire, celem wyeliminowania wielu problemów natury prawnej, które uwidaczniają się w trakcie wdrażania podpisanych już umów. Bruksela uzależnia nawet od tej decyzji możliwość zawarcia kolejnych porozumień oraz grozi wstrzymaniem realizacji dotychczasowych, jeżeli Szwajcaria odmówi podjęcia niezbędnych działań dostosowawczych. Zdaniem rządu tego typu zachowanie godzi jednak w suwerenność Szwajcarii i nie może być przez nią akceptowane. W związku z powyższym podjęto decyzję o wprowadzeniu określonych zasad, które traktowane będą jako przesłanka konieczna do kontynuowania poprawnych relacji na linii Szwajcaria $-\mathrm{UE}^{78}$ :

- Szwajcaria zaakceptuje fakt, iż negocjacje będą oparte na acquis communautaire UE, pod warunkiem pełnego poszanowania dla jej suwerenności;

- przejęcie wspólnotowego dorobku prawnego wymaga zagwarantowania możliwości udziału w procesie decyzyjnym, związanym z zawartymi umowami (tzw. decision shaping), tj. udziału w pracach odpowiednich grup roboczych, komisji (odpowiedzialnych za dalszy rozwój prawodawstwa UE), grup eksperckich;

- dostosowanie do acquis communautaire wymaga odpowiednich okresów przejściowych, uwzględniających specyfikę szwajcarskiego porządku prawnego; - zmiany prawne muszą przebiegać na zasadzie wzajemności.

W przypadku niemożności ujednolicenia prawa Szwajcarii względem acquis communautaire winny być przewidziane mechanizmy kompensacyjne, które jednakże nie mogą wykroczyć poza materię umowy, zachowując odpowiednią

${ }^{76}$ Zob. Bericht der Aussenpolitischen Kommission des Ständerates vom 18. März 2002 über die Optionen der schweizerischen Integrationspolitik, BBl 2002 6326; Bundesbeschluss über die Legislaturplanung 2007-2011 vom 18. September 2008, BB1 2008 8543, s. 6.

${ }^{77}$ Zob. Couchepin räumte nicht alle Zweifel aus, „Tagesanzeiger”, 15. Dezember 2008.

${ }^{78}$ Aussenpolitischer Bericht 2009..., s. 44. 
równowagę. Proporcjonalność tych środków może być sprawdzana na drodze arbitrażu.

W kontekście współpracy bilateralnej rząd potwierdza opinię zawartą w raporcie z 2006 r., uznając, że ta forma relacji w najlepszy sposób zabezpiecza interesy Szwajcarii. Wyniki referendum dotyczące rozszerzenia swobody przepływu osób na Bułgarię i Rumunię, z lutego 2009 r., utwierdziły rząd w przekonaniu o słuszności obranej drogi.

Wydaje się zatem, iż mając tak duże poparcie społeczne rząd nie zdecyduje się na zmianę własnej koncepcji politycznej. Nawet mimo zawartych w powyższych dokumentach propozycji odnośnie do różnych form integracji, należy uznać za mało realną sytuację, w której władze związkowe zrezygnują ze współpracy bilateralnej, zwłaszcza że tego typu decyzja prawdopodobnie napotkałaby opór ze strony parlamentu. Komisja Spraw Zagranicznych Rady Kantonalnej wielokrotnie wypowiadała się pozytywnie o przyjętej formie współpracy z UE77.

Przeglądając wszystkie przedstawione powyżej dokumenty zauważyć można następującą ewolucję koncepcji ośrodków rządowych w kontekście rozwoju relacji ze Wspólnotą. Jeszcze na początku lat 90. można mówić o pewnej determinacji władz związkowych w kwestii przystąpienia do UE. Fakt, iż Unia Europejska stała się najważniejszym partnerem politycznym i gospodarczym Szwajcarii, zwłaszcza po upadku żelaznej kurtyny, zachęcał do podjęcia zdecydowanych kroków na rzecz pełnego włączenia kraju do struktur UE. Nie zmieniła tego nawet nieudana próba włączenia do Europejskiego Obszaru Gospodarczego. Rząd zmienił co prawda taktykę, podejmując współpracę na poziomie bilateralnym, jednak nie zdecydował się na rezygnację z członkostwa. Przystąpienie do UE pozostało celem strategicznym polityki europejskiej, przynajmniej do końca lat 90 . Zmiany na scenie politycznej, w tym przede wszystkim objęcie przez Michelin Calmy-Rey teki ministra spraw zagranicznych oraz wzmocnienie SVP, doprowadziło do korekty strategii politycznej. Wydaje się, że największy wpływ na zmianę koncepcji europejskiej miały pozytywne efekty wdrażania umów bilateralnych oraz przychylne nastroje wśród społeczeństwa. Sondaże przeprowadzone po podpisaniu drugiego pakietu porozumień wskazywały na zdecydowane poparcie takiej formy współpracy przez obywateli oraz relatywnie niewielkie, przynajmniej w porównaniu z wynikami podobnych badań z lat 90., poparcie dla pełnej integracji z UE. Na taką ocenę wpływ miał przede wszystkim brak negatywnych skutków otwarcia szwajcarskiego rynku pracy. Aspekt ten budził zdecydowanie najwięcej wątpliwości. Jako drugi element należałoby wskazać kwestie finansowe, tj. brak dodatkowych obciążeń dla budżetu, oraz pełna suwerenność w zakresie polityki monetarnej i fiskalnej, a także utrzymanie tajemnicy bankowej. Wszystkie te elementy złożyły się na pozytywny odbiór społeczny układów bilateralnych, a przy tym niechęć wobec silniejszej integracji. Budziła ona zbyt wiele kontrowersji. Forsowanie planu budowy innych relacji z UE stało się w tej sytuacji bezzasadne.

${ }^{79}$ Zob. Keine Alternative zum bilateralem Weg, „Neue Zürcher Zeitung”, 12. Januar 2010. 
Raport z 2006 r. wprowadza zupełnie inną kategoryzację celów. Już nie przystąpienie do Wspólnoty, lecz osiągnięcie celów strategicznych, zawartych w $R a$ porcie '93 oraz ochrona interesów Szwajcarii stały się głównymi wyznacznikami polityki europejskiej rządu. Zaproponowano szereg nowych wariantów integracji z UE, traktując je jako instrumenty nowej koncepcji politycznej. Zakładała ona dobór właściwych opcji integracyjnych w zależności od bieżących uwarunkowań zewnętrznych i wewnętrznych. W ten sposób polityka europejska miała uzyskać charakter dynamiczny, dostosowany do zmian zachodzących w Unii Europejskiej (reform instytucjonalnych, rozszerzenia) oraz aktualnej sytuacji politycznej wewnątrz kraju (głównie w odniesieniu do rozważanych reform systemu politycznego oraz nastrojów społecznych).

Obecna polityka rządu wskazuje na chęć kontynuacji współpracy bilateralnej. Oczywiście przy założeniu, iż stanowisko Brukseli w tej sprawie nie ulegnie zmianie. W związku z powyższym rozważa się możliwość podpisania nowych umów, co jest obecnie przedmiotem rozmów dwustronnych. Rząd przyjął jednak kilka podstawowych warunków dalszej współpracy. Przede wszystkim Szwajcaria musi mieć zagwarantowaną możliwość oddziaływania na proces tworzenia podstaw prawnych, związanych z umowami bilateralnymi. Bardzo często mamy bowiem do czynienia $\mathrm{z}$ sytuacją, w której nowo tworzone lub modyfikowane prawo, tj. głównie różnego rodzaju regulacje, ograniczenia, niezwiązane bezpośrednio z przedmiotem umów dwustronnych, w sposób pośredni mają na nie wpływ. Chodzi zatem o to, aby Szwajcaria miała szansę akcentowania własnego stanowiska wobec tego typu ustaw i wpływania w jakiś sposób na ich ostateczny kształt. Ponadto konieczność implikacji wypracowanego na poziomie UE prawa nie powinna naruszać kompetencji organów krajowych oraz musi uwzględniać specyfikę procesu decyzyjnego Szwajcarii, głównie w odniesieniu do mechanizmu demokracji bezpośredniej. Nie ulega wątpliwości, że stanowisko Brukseli będzie w tym względzie dość elastyczne dopóty, dopóki nie będzie to kolidowało $\mathrm{z}$ istotnym interesem UE. W sytuacji, gdy polityka Szwajcarii będzie naruszać podstawowe zasady wspólnego rynku, takie jak np. swoboda konkurencji, należy oczekiwać pewnych nacisków ze strony władz unijnych. Charakterystycznym przykładem jest tutaj spór związany z polityką fiskalną w poszczególnych kantonach. Tego typu sytuacje mogą zaciążyć na przyszłej współpracy pomiędzy Szwajcarią a Unią Europejską. Za wielce prawdopodobne należałoby uznać, że w dłuższej perspektywie Szwajcaria będzie zmuszona ulec naciskom ze strony UE, zwłaszcza że nie może liczyć na wsparcie innych państw i w praktyce dysponuje znacznie słabszą pozycją w ewentualnych negocjacjach. Ponadto trzeba zwrócić uwagę na fakt, że nie dysponuje ona w zasadzie żadną kartą przetargową, która mogłaby w jakiś istotny sposób wpłynąć na stanowisko władz UE.

Władze Szwajcarii stoją na stanowisku, że mocnym argumentem w dyskusji z Unią Europejską jest zaangażowanie ich kraju w realizację wspólnych, europejskich koncepcji politycznych i gospodarczych. Chodzi tutaj przede wszystkim 
o udział w operacjach pokojowych i humanitarnych, w których zaangażowana jest UE oraz o budowę bezpieczeństwa i stabilizacji w Europie. Nie bez znaczenia pozostaje również współpraca gospodarcza. Podkreśla się finansowy wymiar pomocy dla krajów byłego bloku wschodniego. Szwajcaria, pomimo iż nie jest członkiem Wspólnoty, ponosi określone koszty jej rozszerzenia w postaci specjalnie utworzonego funduszu rozwojowego (Erweiterungsbeitrag), zbliżonego celowościowo i funkcjonalnie do funduszy strukturalnych UE. Rząd Szwajcarii próbuje nadać wspólnym relacjom charakter partnerski, który uwzględnia interesy obydwu stron. Trudno jednakże oczekiwać od Unii, aby ta traktowała Szwajcarię jako równoprawnego partnera.

Ostatnim wreszcie warunkiem rządu Szwajcarii jest uniknięcie sytuacji, w której współpraca bilateralna doprowadziłaby do niemal całkowitej integracji z UE, jednakże bez formalnego członkostwa, a co za tym idzie, prawa uczestniczenia w procesie decyzyjnym wewnątrz Wspólnoty. Oznaczałoby to, że Szwajcaria stała się de facto członkiem Unii, niedysponującym jednak tymi samymi prawami co pozostałe państwa. Innymi słowy, współpraca bilateralna musi mieć określone granice. Będzie ona tak długo kontynuowana, jak długo będzie spełniać swoje funkcje i nie wpłynie niekorzystnie na interes gospodarczy czy polityczny Szwajcarii. Zmiana uwarunkowań związanych z funkcjonowaniem Unii Europejskiej lub nasileniem się pewnych nacisków na Szwajcarię doprowadzi do zredefiniowania formy współpracy. Rząd prawdopodobnie zdecyduje się wówczas na podjęcie nowych kroków integracyjnych, łącznie z możliwością przystąpienia do UE. Za najmniej prawdopodobne należałoby uznać zerwanie dotychczasowych układów i stworzenie zupełnie nowych płaszczyzn współpracy w Europie. Należy jednak zauważyć, że koncepcja polityki europejskiej rządu nie koncentruje się wyłącznie na rozwoju jak najlepszych relacji z krajami europejskimi w wymiarze instytucjonalnym. Dla władz szwajcarskich integracja oznacza również rozwijanie dobrych relacji z poszczególnymi państwami starego kontynentu bez względu na ich przynależności do szerszych struktur współpracy multilateralnej. Dlatego też Szwajcaria dąży do utrzymywania bezpośrednich kontaktów ze stolicami państw członkowskich lub sąsiadujących z UE. Ma to na celu stworzenie sieci współpracy, wymianę informacji, a przede wszystkim budowanie pozytywnego wizerunku kraju. Dzięki temu niektóre decyzje Berna mogą znaleźć więcej zrozumienia, co przełoży się zapewne na relacje ze Wspólnotą jako całością. Rozwój bezpośrednich kontaktów z krajami europejskimi umożliwia również kształtowanie współpracy w tych obszarach, które nie są przedmiotem umów bilateralnych z UE. Daje to Szwajcarii większą swobodę w kreowaniu relacji i akcentowaniu własnych interesów.

Mając także na względzie scharakteryzowaną wyżej specyfikę uwarunkowań społeczno-politycznych wolno postawić tezę, która jest jednocześnie odpowiedzią na zadane na wstępie pytanie, że koncepcja polityczna ośrodków rządowych nie może wychodzić poza przyjęte ogólnie ramy, ograniczając się jedynie do pie- 
lęgnacji status quo powiązań bilateralnych. Przystąpienie do Unii Europejskiej, określane w raportach rządowych z roku $1993^{80}$ jako cel strategiczny, ustąpiło, w późniejszych dokumentach, miejsca konieczności kontynuacji obecnego poziomu integracji ze Wspólnotą. Mówi się jedynie o dążeniach do uregulowania kolejnych obszarów tematycznych. Rząd traktuje zatem powiązania bilateralne bardziej jako instrument normalizacji stosunków z UE niż element przybliżający Szwajcarię do członkostwa we Wspólnocie.

\subsection{KONCEPCJE OŚRODKÓW OPINIOTWÓRCZYCH}

Zdecydowana większość ośrodków opiniotwórczych wykazuje pozytywne nastawienie w stosunku do problemu integracji europejskiej. Tendencje, które dominowały jeszcze na początku lat 90., a więc dystansowanie się wobec kwestii integracyjnych, odeszły w zapomnienie. Obecnie najważniejszym zagadnieniem jest nie sam fakt nawiązania ścisłych relacji z państwami europejskimi, bo to wydaje się koniecznością, lecz bardziej forma i charakter tej współpracy. Większość organizacji pozarządowych lub partii politycznych popiera dotychczasową strategię europejską władz federalnych, określając ją jako najbardziej optymalną, uwzględniającą specyfikę i tradycję międzynarodowej aktywności Szwajcarii. Wydaje się zatem, że stanowisko tych ośrodków opiniotwórczych jest zbieżne z prezentowanym przez rząd. Różnice występują jedynie w ocenie dalszych perspektyw współpracy. Podczas gdy rząd obiera strategię wyczekiwania, niektóre organizacje i partie nawołują do podejmowania odważnych kroków integracyjnych. Podstawowym argumentem jest tutaj chęć zintensyfikowania współpracy, a przede wszystkim rozszerzenia jej na kolejne obszary tematyczne. Umowy bilateralne traktowane są jako istotny etap kontaktów w relacjach ze Wspólnotą, jednak ze względu na ich ograniczenia nie mogą stanowić podstawy do dalszej współpracy. Często wykorzystywanym argumentem jest fakt, że wniosek akcesyjny nie został oficjalnie wycofany, a więc nadal istnieje możliwość szybkiego wznowienia negocjacji akcesyjnych. $Z$ tego punktu widzenia rządowe raporty z lat 90., określające przystąpienie do UE jako cel strategiczny, spotykały się $\mathrm{z}$ największym entuzjazmem.

Także ośrodki o bardziej konserwatywnych poglądach, które na kwestie europejskie patrzą z daleko większym dystansem, uznają bilateralizm za najlepszą formę współpracy. Tego zdania jest nawet ludowo-konserwatywna SVP, do niedawna lider wszystkich ugrupowań przeciwnych współpracy z Unią Europejską. Za najważniejszą przyczynę tak dużego poparcia dla obecnej strategii politycznej

${ }^{80}$ Bericht über Aussenpolitik der Schweiz in der 90er Jahren vom 29. November 1993, BB1 1994 I 153, s. 18, a także Bericht über einen Beitritt der Schweiz zur Europäischen Union vom 18. Mai 1992, BBI 1992 III, s. 2. 
rządu uznać należy pozytywne efekty wdrażania umów bilateralnych. Dla takich organizacji jak Economiesuisse dane ekonomiczne stanowią najważniejsze źródło argumentacji w debacie politycznej. Wszystko wskazuje zatem na to, że pozytywne wskaźniki gospodarcze, idące w parze z pozaekonomicznymi korzyściami wynikającymi ze współpracy z Unią Europejską, stanowią o całościowej ocenie układów bilateralnych.

Główną intencją ośrodków mających wpływ na kreowanie opinii publicznej jest przekazanie społeczeństwu możliwie najpełniejszych danych na temat bieżących relacji ze Wspólnotą, a także korzyści i strat wynikających z integracji. Nie ulega wątpliwości, że obecny poziom zaufania wobec Unii Europejskiej związany jest z deficytem informacji. Bardzo często mamy do czynienia z sytuacją, w której znakomita część obywateli ma ogólnie pozytywne nastawienie wobec Wspólnoty, lecz ze względu na brak dostatecznej wiedzy na temat ostatecznych skutków integracji wykazuje dużą powściągliwość. Działalność ośrodków opiniotwórczych koncentruje się zatem na przedstawieniu szerszego spektrum tych relacji. Przede wszystkim starają się one pokazać integrację jako proces wymagający określonych działań dostosowawczych, a więc również pewnych ustępstw na rzecz Wspólnoty. Przeglądając dokumenty, raporty i oficjalne stanowiska ośrodków pozarządowych oraz partii politycznych natrafić możemy na szereg analiz oceniających bieżące i przyszłe skutki integracji z UE. Bazują one często na twardych danych makroekonomicznych, a także doświadczeniach innych państw. Argumenty te najlepiej trafiają bowiem do opinii publicznej, pozwalając stworzyć wiarygodny wizerunek UE. Tym co łączy ośrodki pro- i antyeuropejskie jest poczucie przynależności Szwajcarii do społeczności europejskiej. Oczywiście różnie może być postrzegana jej w owej społeczności rola.

Przyglądając się debacie prowadzonej przez szwajcarskie ośrodki opiniotwórcze można wyodrębnić kilka głównych zagadnień, które stanowią rdzeń dyskusji związanej z polityką europejską. W miarę rozwoju współpracy między UE a Szwajcarią nastąpiły przesunięcia akcentów pomiędzy poszczególnymi tematami. Część z nich zyskała na aktualności, część natomiast przestała odgrywać istotną rolę. Typowym tego przykładem jest problem neutralności, który nie należy obecnie do tematów wiodących. Z kolei kwestia kontynuacji i rozszerzenia zasady swobodnego przepływu osób, podobnie zresztą jak problematyka szwajcarskiego systemu bankowego i podatkowego, należą do najczęściej podnoszonych przez ugrupowania popierające lub przeciwne integracji. Wątki te powracają za każdym razem, kiedy Bruksela wznawia naciski na Szwajcarię. Mianem tematu dyżurnego możemy określić również relacje gospodarcze oraz problem suwerenności decyzyjnej w sprawach legislacyjnych.

Na podstawie analizy materiałów, zamieszczanych w prasie oraz na stronach internetowych ośrodków opowiadających się za integracją z Unią Europejską, dokonać można próby usystematyzowania i wyodrębnienia najważniejszych argumentów ugrupowań proeuropejskich. Poniższa lista przedstawia najistotniejsze z nich: 
- Szwajcaria jest częścią europejskiej cywilizacji, z którą dzieli wspólne korzenie kulturowe, tradycję i historię, podlega zatem tym samym procesom, co inne państwa starego kontynentu, a więc również zjawiskom integracyjnym;

- współpraca z UE nie ogranicza suwerenności Szwajcarii, lecz ją wzmacnia, dzięki możliwości akcentowania własnych interesów i realizacji głównych zadań strategicznych, które ustalone zostały przez władze związkowe;

- integracja zapewnia Szwajcarii możliwość oddziaływania na kluczowe decyzje dotyczące przyszłości Europy;

- integracja europejska umożliwi tworzenie sojuszy i koalicji celem ochrony interesów państw o zbliżonej specyfice oraz uwarunkowaniach gospodarczych i politycznych ${ }^{81}$;

- członkostwo w UE daje obywatelom dodatkowe możliwości rozwoju, chodzi tutaj przede wszystkim o swobodę podróżowania, osiedlania się, podejmowania pracy, studiowania we wszystkich państwach należących do Unii Europejskiej;

- Szwajcaria może zaoferować swój wkład w rozwój UE dzięki dużemu doświadczeniu w zakresie funkcjonowania struktur federacyjnych oraz rozwoju państwowości w warunkach znacznego zróżnicowania kulturowego i językowego;

- aktywny udział w procesach integracyjnych zapewnia Szwajcarii wsparcie ze strony innych państw członkowskich, jest to szczególnie istotne w przypadku prowadzenia polityki wobec państw trzecich, jako członek UE Szwajcaria dysponować będzie lepszą pozycją negocjacyjną;

- współpraca z UE umożliwia Szwajcarii swobodny dostęp do wspólnotowego rynku, wpłynie to pozytywnie na rozwój gospodarczy, stworzy nowe miejsca pracy, wzmocni konkurencyjność szwajcarskich przedsiębiorstw;

- członkostwo w UE wzmacnia bezpieczeństwo Szwajcarii poprzez współdziałanie $\mathrm{z}$ innymi krajami na rzecz zwalczania nowego typu zagrożeń, takich jak terroryzm, przestępczość zorganizowana, nielegalna imigracja, handel narkotykami itp. szczególnie istotny jest tutaj dostęp do cennych baz danych policji, systemów wymiany informacji pomiędzy organami ścigania $\mathrm{z}$ różnych państw; znaczenie Unii Europejskiej rośnie również w kontekście Wspólnej Polityki Zagranicznej i Bezpieczeństwa, zapewniającej istotną przeciwwagę dla Sojuszu Północnoatlantyckiego (NATO), którego Szwajcaria, ze względu na politykę neutralności, nie może być członkiem.

Kiedy na początku lat 90. rząd szwajcarski podjął decyzję o rozpoczęciu rozmów w sprawie włączenia kraju najpierw do EOG, a potem do Wspólnoty Europejskiej, wszystkie ośrodki, które krytykowały politykę władz, uważane były za zachowawcze, oczywiście w rozumieniu negatywnym. Uważano, że tego typu poglądy nie idą w parze ze zmianami na mapie politycznej świata i ograniczają się

${ }^{81}$ Zob. Der EU-Beitritt und die direkte Demokratie der Schweiz, Politische Kommission der Nebs, Thesenpapiere, s. 4. Dokument dostępny na stronie: http://www.europa.ch/index. asp?page=page45 (01.02.2010). 
do wąsko rozumianego poczucia patriotyzmu. Znaczna część obywateli patrzyła na integrację z nadzieją, choć oczywiście również z pewną nieufnością, zwłaszcza W odniesieniu do spraw związanych z suwerennością polityczną i neutralnością Szwajcariii ${ }^{82}$. Rozumiano jednak konieczność wyzbycia się pewnych kompleksów, będących reminiscencją lat wojennych i powojennych, lecz przede wszystkim zdawano sobie sprawę, iż dalsza izolacja państwa może przynieść więcej strat niż korzyści. Wydaje się, że rząd brał pod uwagę zróżnicowane nastroje opinii publicznej, lecz nie docenił wagi sytuacji. Decyzja o natychmiastowym rozpoczęciu rozmów w sprawie włączenia Szwajcarii do Wspólnoty Europejskiej okazała się zbyt dużym zaskoczeniem dla społeczeństwa, które nie było przygotowane na tak odważne kroki. Działania rządu, jako ośrodka kreowania opinii, okazały się niewystarczające, aby przekonać niezbędną większość do poparcia integracji. Wzmocnieniu uległy natomiast ośrodki antyeuropejskie, które zaczęły odgrywać coraz większą rolę na arenie politycznej.

$\mathrm{Z}$ czasem tendencja ta uległa odwróceniu. Efekty wdrażania pakietów bilateralnych były na tyle pomyślne, że większość społeczeństwa coraz pozytywniej oceniała procesy integracyjne, choć wiele nowych problemów, które wypłynęły w toku rozwoju współpracy, stało się przyczynkiem do nasilenia działań ze strony ośrodków krytycznych wobec UE. Należy podkreślić, że ugrupowania proeuropejskie znajdują się w o tyle lepszej sytuacji, że większość mediów, w tym najważniejsze tytuły prasowe, wydaje się sprzyjać tym procesom. Oczywiście oficjalnie takie gazety, jak „Neue Zürcher Zeitung”, „Tagesanzeiger” oraz „Blick” zajmują pozycję neutralną, starając się jedynie relacjonować wydarzenia w sposób obiektywny. Trudno jednak nie zauważyć pewnej tendencyjności w przekazywaniu informacji, wzbogaconych licznymi komentarzami zespołów redakcyjnych. Ponadto najbardziej opiniotwórczy z nich NZZ poświęca sporo miejsca relacjonowaniu spotkań, konferencji czy też innych działań rządu związanych z polityką europejską.

Retoryka ośrodków opiniotwórczych, popierających integrację, oparta jest w głównej mierze na kreowaniu wizerunku Szwajcarii jako kraju silnie zaangażowanego we wspieranie pokoju, wzmacnianie bezpieczeństwa oraz szerzenie demokracji na świecie. Podkreśla się również wysiłki na rzecz wyrównywania różnic społecznych i gospodarczych. Wszystkie te działania zmierzają do uwypuklenia wkładu Szwajcarii w rozwój Europy i jej wspólnych wartości. Nie chodzi więc tutaj o ukazanie zupełnie nowej koncepcji politycznej, będącej wypadkową zmian związanych z upadkiem bloku wschodniego, lecz raczej o naturalną kontynuację działań podejmowanych przynajmniej od zakończenia II wojny światowej. Miały one jedynie nieco inny wymiar i charakter, determinowany przez ówczesną sytuację geopolityczną. Nawiązując do przeszłości wskazuje się na tradycję działań humanitarnych, udział w misjach pokojowych oraz przypomina wszelkie

${ }^{82}$ Przeprowadzone w roku 1988 przez Uniwersytet w Lozannie badania wskazywały, iż zaledwie $24 \%$ obywateli było całkowicie przeciwnych członkostwu w EWG. Dane za M. Schenker, $E G$ als Chance. Die Schweiz am europäischen Scheideweg, Werd Verlag, Zürich 1991, s. 23. 
działania w ramach tzw. dobrych usług, tj. mediacje, pokojowe rozwiązywanie sporów itp. Integracja pozwoli na kontynuowanie tego rodzaju aktywności, która stała się wizytówką Szwajcarii, stanowiąc podstawę jej obecnego wizerunku. Nie można zatem dopuścić do przerwania długiej tradycji tzw. aktywnej neutralności.

Charakterystyczne dla tej grupy ośrodków opiniotwórczych jest również przedstawianie procesu integracji jako naturalnego zjawiska, któremu Szwajcaria podlega już od dłuższego czasu, dostosowując swoje prawodawstwo do prawodawstwa UE w stopniu pozwalającym stwierdzić, że państwo to jest bardziej zintegrowane z Unią niż niejedno państwo członkowskie ${ }^{83}$. Co więcej, eurokompatybilność szwajcarskiego prawodawstwa sprawia, iż integracja będzie procesem łatwym i niewymagającym szczególnego nakładu sił i środków ${ }^{84}$. Szwajcaria jest zatem gotowa na przystąpienie do UE, przynajmniej pod względem instytucjonalnym. Warto w tym miejscu nadmienić, że teza ta jest jednak bardzo często wykorzystywana także przez przeciwników integracji, którzy nieco inaczej interpretują to zjawisko. Autonomiczne dopasowanie (autonomie Nachvollzug) jest, ich zdaniem, procesem zmuszającym Szwajcarię do przejmowania prawa, na którego tworzenie nie ma ona najmniejszego wpływu ${ }^{85}$. Ponadto integracja europejska wymusza na niej przeprowadzenie trudnych reform instytucjonalnych (była o tym już mowa w pierwszym rozdziale). Ugrupowania proeuropejskie podkreślają jednak, że spójność dorobku prawnego pozwala na przeprowadzenie sprawnego procesu integracji i jest kolejnym argumentem przemawiającym za szybkim włączeniem Szwajcarii do struktur UE.

\subsubsection{ORGANIZACJE POZARZĄDOWE WOBEC PROBLEMÓW EUROPEJSKICH}

Do grona ośrodków wspierających wysiłki na rzecz integracji zaliczyć należy w pierwszej kolejności Neue Europäische Bewegung Schweiz (Nebs). Ta pozarządowa organizacja, będąca członkiem międzynarodowej sieci współpracy, w skład której wchodzą takie organizacje, jak Europäische Bewegung (Ruch Europejski) oraz Union der Europäischen Föderalisten (Unia Europejskich Federalistów), powstała w roku 1998. Jej korzenie sięgają jednak znacznie głębiej, albowiem protoplastą dzisiejszej Nebs była Europa-Union ${ }^{86}$, założona w roku 1934.

${ }^{83}$ Zob. wywiad z Josephem Deissem, szefem dyplomacji szwajcarskiej w latach 1999-2002, „Europa.ch. Das Magazin der Neuen Europäischen Bewegung Schweiz” 2008, Nr. 2 (November), s. 5.

${ }^{84}$ Zob. ciekawa analiza zjawiska europeizacji Szwajcarii: W. Linder, Europäisierung der Schweiz, Verschweizerung der EU?, Universitätsverlag, Konstanz 2000.

${ }^{85}$ Por. krytyczny stosunek wobec obecnej formy integracji w wywiadzie „Tagesanzeiger” z Peterem von Mattem: Ich lasse mir mein Land nicht wegnehmen, „Tagesanzeiger”, 31. Dezember 2009.

${ }^{86}$ Europa-Union to pierwsza tego typu organizacja na kontynencie, której celem było doprowadzenie do stworzenia wspólnego państwa, opartego na systemie federacyjnym. Działania te nie spotkały się jednak z dużym poparciem społeczny, dlatego znaczenie Europa-Union, zwłaszcza w okresie zimnej wojny, było niewielkie. 
Za cel stawiała sobie integrację Europy na wzór USA, a więc stworzenie „Stanów Zjednoczonych Europy".

Neue Europäische Bewegung Schweiz powstał z połączenia kilku proeuropejskich ugrupowań. Obecnie liczy około 5000 członków wywodzących się ze środowisk gospodarczych, naukowych i kulturowych. Ma także swoich przedstawicieli w parlamencie związkowym. Nebs wspierany jest również przez młodzieżówkę - Young European Swiss, która dąży do „uwrażliwienia” młodych ludzi na problematykę unijną i szerzenie wśród tej grupy idei integracyjnych.

Podstawowym celem Nebs jest doprowadzenie do włączenia Szwajcarii do struktur unijnych. Wizja tej organizacji zakłada stworzenie silnej, zjednoczonej Europy, której Szwajcaria powinna być integralną częścią. Oficjalne stanowisko Nebs zawarte zostało w dokumentach statutowych, a także licznych publikacjach $^{87}$. Główne działania podejmowane przez tę organizację polegają na przygotowywaniu Szwajcarii do członkostwa w Unii Europejskiej poprzez tworzenie platformy wymiany myśli i informacji, a także na przekonywaniu społeczeństwa do poparcia działań integracyjnych. Podstawową formą przekazu są broszury informacyjne, strona internetowa, własne publikacje. Co pewien czas organizowane są również konferencje i debaty europejskie. Działalność Nebs nie ogranicza się wyłącznie do przekazywania informacji na temat UE, jej funkcjonowania, oddziaływania na kraje członkowskie, lecz obejmuje również poszukiwania rozwiązań problemów integracyjnych. Artykuły prasowe i liczne analizy, przygotowywane przez Nebs, zawierają propozycje konkretnych reform lub instrumentów ochronnych, które mają na celu stworzenie najkorzystniejszych warunków gospodarczych, politycznych i społecznych dla członkostwa Szwajcarii w UE. Członkowie tej organizacji, jako eksperci, biorą także udział w różnego rodzaju spotkaniach, promując reprezentowane przez nią poglądy i proponowane rozwiązania.

Należy zauważyć, iż Neue Europäische Bewegung Schweiz zaliczana jest do grona organizacji pozarządowych. Jego członkowie posiadają jednak szerokie kontakty polityczne zarówno na szczeblach kantonalnych, jak i związkowych. Przewodniczącą stowarzyszenia jest Christa Markwalder, poseł do Rady Narodowej z ramienia FDP (Freisinig-Demokratische Partei Schweiz). Członkami Nebs są zresztą również inni politycy tej partii ${ }^{88}$. Widać zatem wyraźnie, że FDP stanowi polityczne zaplecze organizacji, zapewniając jej duże wsparcie przy wspólnie podejmowanych działaniach.

Stanowisko Neue Europäische Bewegung Schweiz dotyczące polityki europejskiej zawiera się w przekonaniu, że obecna forma współpracy, oparta na umowach dwustronnych, ogranicza w pewien sposób suwerenność Szwajcarii. Staje się ona pasywnym członkiem UE, bez prawa głosu, możliwości współdecydowa-

${ }^{87}$ Zob. „Europa.ch. Das Magazin der Neuen Europäischen Bewegung Schweiz”. Magazyn publikowany jest średnio raz na kwartał, dostępny (w formie pdf) na stronie: http://www.europa.ch/ index.asp?page=menu_site75 (04.02.2010).

${ }^{88}$ Wiceprzewodniczącym Nebs jest Jacques Ducry, poseł do parlamentu kantonu Tessin. 
nia, przy stale rosnących kosztach integracji. Nebs angażuje się zatem w działania mające na celu włączenie Szwajcarii do struktur europejskich, a więc de facto zmiany statusu z członka pasywnego na aktywnego. Tylko dzięki temu możliwe będzie sprostanie nowym wyzwaniom globalizacji. Jako podstawę do dyskusji Nebs wskazuje rządowy Europabericht 2006, pod którego adresem kieruje zresztą wiele słów krytyki ${ }^{89}$. Uznaje jednak, że raport ten jest obecnie jedynym dokumentem traktującym w sposób bardziej wyczerpujący o problemach integracyjnych. Podstawowy zarzut odnosi się zaś do braku propozycji konkretnych działań, które można by podjąć w najbliższym czasie, aby zapewnić Szwajcarii silną pozycję w relacjach ze Wspólnotą. Zdaniem Nebs rząd akceptuje status quo zamiast podejmować konkretne decyzje dotyczące przyszłości państwa. Rozpatruje się tutaj jedynie dwie możliwe drogi - włączenie do UE lub pozostanie poza jej strukturami. Należy zauważyć, że Nebs nie traktuje członkostwa w kategoriach celu strategicznego, tak jak do niedawna rząd, lecz uznaje je za instrument ochrony interesów Szwajcariii ${ }^{90}$. Neue Europäische Bewegung Schweiz zachęca władze związkowe do opracowania i przedstawienia opinii publicznej strategii europejskiej wraz z określeniem narzędzi służących jej realizacji. Strategię tę powinny charakteryzować sztywne ramy czasowe, uwzględniające tzw. kroki milowe, a więc konkretne działania, reformy, uzupełniane przez otwartą debatę publiczną. Ten ostatni element związany jest z potrzebą stworzenia jasnej strategii komunikacji między rządem a społeczeństwem, celem wysłania do opinii publicznej klarownych komunikatów odnośnie do przyjętej koncepcji politycznej. Przyjmuje się, iż Europabericht 2006, mimo obietnic składanych na początku nowej kadencji, nie wskazuje najbardziej optymalnej drogi w relacjach z UE. W związku z powyższym postuluje się, aby do końca obecnej legislatury rząd zrealizował swoje zobowiązania, złożone jeszcze w roku 2003.

Konsekwencją krytyki Nebs był poselski wniosek, złożony przez wspomnianą już Christę Markwalder w czerwcu 2009 r., w sprawie podjęcia przez rząd natychmiastowych działań, mających nakreślić priorytety w polityce europejskiej ${ }^{91}$. Przewodnicząca Nebs postuluje w nim jak najszybsze zdiagnozowanie korzyści i strat związanych z zastosowaniem instrumentów przedstawionych w raporcie z 2006 r., przy uwzględnieniu nowych uwarunkowań funkcjonowania Wspólnoty, tj. rozszerzenia o Bułgarię i Rumunię oraz przyjęcia Traktatu z Lizbony. Jednocześnie rząd powinien opracować katalog konkretnych działań, pozwalających na osiągnięcie celów zawartych w programie Festigung der schweizerischen Stellung

${ }^{89}$ Zob. oficjalne stanowisko wobec rządowego raportu: Fehlende europapolitische Strategie! Stellungnahme der Neuen Europäischen Bewegung Schweiz zum Europabericht 2006. Dokument dostępny na stronie http://www.europa.ch/Files/pdf/pk_stellungnahme.pdf (04.02.2010); C. Markwalder, Der EU-Beitritt aus politischer Sicht und aus Bürgersicht, Pressekonferenz „Europabericht 2006 des Bundesrates", Bern 28. Juni 2006.

${ }^{90}$ Ibidem, s. 2.

${ }^{91}$ Dokładny tekst poselskiego wniosku dostępny jest w bazie parlamentu: http://www.parlament.ch/D/Suche/Seiten/geschaefte.aspx?gesch_id=20093560 (04.02.2010). 
in einer vernetzten Welt (Wzmocnienie pozycji Szwajcarii w świecie), zakładającym przerwanie politycznej izolacji Szwajcarii. Wszystkie te działania pozwolą na określenie ścieżki rozwoju współpracy z UE w kolejnej kadencji parlamentu, przypadającej na lata 2011-2015. Powinny one uwzględniać oczekiwania obywateli oraz odpowiadać gospodarczym i politycznym wyzwaniom.

Nebs wychodzi z założenia, że współpracę bilateralną cechuje duża niestabilność. Umowy mogą podlegać weryfikacji społecznej w drodze referendum, którego wynik pozostaje niepewny i przesądzić może o przyszłości wzajemnej współpracy. Ponadto umowy dwustronne mają charakter statyczny, co nie odpowiada dynamice zmian zachodzących na świecie, którym podlega również Unia Europejska. Wreszcie jako rozwiązanie czasowe nie mogą stanowić podstawy do współpracy ze Wspólnotą, chociażby dlatego, iż nie obejmują wszystkich obszarów tematycznych ${ }^{92}$.

W trakcie parlamentarnej dyskusji nad wnioskiem przewodnicząca Nebs podkreśliła, że w perspektywie zmian zachodzących w Unii należy liczyć się z możliwością wyraźnego obniżenia zainteresowania Wspólnoty wypracowaniem kompromisowych rozwiązań ze Szwajcarią ${ }^{93}$. Bruksela będzie koncentrowała się bardziej na rozwiązaniu wewnętrznych problemów niż na łagodzeniu ewentualnych konfliktów z Bernem. Jej postawa przybierze bardziej roszczeniowy charakter, polegający na przedstawieniu warunków przyjęcia acquis communautaire (głównie ustanowieniu okresów przejściowych na dostosowanie szwajcarskiego prawodawstwa), bez możliwości przeprowadzenia merytorycznej dyskusji.

Kwestia konieczności przejęcia dorobku prawnego Unii Europejskiej stanowi zresztą bardzo istotny element w retoryce Nebs. Autonomiczne dopasowanie (autonomie Nachvollzug) traktowane jest jako przejaw ograniczenia suwerenności Szwajcarii. Zdaniem organizacji przyjęte nazewnictwo w odniesieniu do tego zjawiska nosi znamiona eufemizmu, nieodpowiadającego rzeczywistości. Faktycznie Szwajcaria nie ma bowiem możliwości selekcji prawa, lecz jest zmuszona, na podstawie umów bilateralnych, do ujednolicenia przepisów prawnych na wzór tych, obowiązujących w państwach UE. Ponadto nie ma możliwości oddziaływania na sam proces ustawodawczy, co z kolei kłóci się z zasadą społecznej partycypacji w sprawowaniu władzy.

Koncepcja polityczna Nebs sprowadza się do jednoznacznego postulatu - jak najszybszego wprowadzenia Szwajcarii do Unii Europejskiej. Należy jednak zauważyć, że podstawowe założenia tego ośrodka nie są oparte na całkowitej

${ }^{92}$ Zob. również referat wiceprzewodniczącego Nebsa na temat ekonomicznych problemów współpracy bilateralnej: P. Gasser, Wirtschaftliche Probleme des Bilateralismus, Pressekonferenz „Europabericht 2006 des Bundesrates”, Bern, 28. Juni 2006. Dokument dostępny na stronie: http:// www.europa.ch/index.asp?page=page502 (01.02.2010).

${ }^{93}$ Postulat Markwalder Bär Christa vom 10. Juni 2009 Europapolitik. Evaluation, Prioritäten, Sofortmassnahmen und nächste Integrationsschritt, „Amtliches Bulletin - Die Wortprotokolle von Nationalrat und Ständerat", SR 09.3560. 
negacji układów bilateralnych. Oczywiście wskazuje się na słabości tego rodzaju współpracy, o czym mowa była już wyżej. Unika się jednak wyraźnej polaryzacji tych dwóch wartości. Nie dyskredytuje się umów bilateralnych celem wzmocnienia argumentacji na rzecz pełnej integracji ze Wspólnotą. Zdaniem Nebs umowy dwustronne stanowią ważny element współpracy z Unią Europejską i jako taki stanowią cenny wkład w rozwój wzajemnych relacji, umożliwiający przygotowanie społeczeństwa szwajcarskiego do podjęcia dalszych kroków integracyjnych. Chodzi tutaj bardziej o przekonanie obywateli, że jedyną alternatywą dla układów bilateralnych jest członkostwo w UE. Jeżeli rząd uzna, iż nadszedł czas na zredefiniowanie relacji ze Wspólnotą, do czego zresztą Nebs gorąco namawia, to jedynie owo przystąpienie powinno być traktowane jako realna, a zarazem najbardziej optymalna opcja. Nie rozpatruje się tutaj innych formuł współpracy, jakie zawarte były chociażby w Europabericht 2006. Jest to zatem zasadnicza różnica pomiędzy koncepcją rządową a wizją Nebs, a także innych ośrodków prointegracyjnych.

W stosunku do proponowanego przez rząd porozumienia ramowego z UE Nebs jest dość sceptyczny. Sama propozycja zawarcia tego rodzaju umowy jest akceptowana, jednakże pod warunkiem, że będzie ona miała charakter jedynie techniczny, umożliwiający lepszą koordynację współpracy i kontrolę nad wdrażaniem podpisanych porozumień bilateralnych. Układ ramowy nie może być jednak rozważany w kategoriach docelowej formy współpracy, mogącej zastąpić członkostwo w UE. W praktyce nie przynosi bowiem żadnych korzyści i nie likwiduje najważniejszych problemów, tj. utraty suwerenności czy braku możliwości oddziaływania na decyzje podejmowane w ramach Wspólnoty.

Oczywiście koncepcja prowadzenia aktywnej polityki wobec UE nie jest akceptowana przez wszystkie ośrodki opiniotwórcze. Na przeciwległym biegunie znajduje się populistyczno-konserwatywna Aktion für Unabhängige und Neutrale Schweiz (Akcja na rzecz Niezależnej i Neutralnej Szwajcarii). Z całą pewnością odgrywa ona rolę wiodącego ośrodka wśród wszystkich ugrupowań eurosceptycznych w kraju. Auns powstał jako stowarzyszenie, powołane w roku 1986, przy okazji głosowania w sprawie przystąpienia Szwajcarii do Organizacji Narodów Zjednoczonych. Reprezentuje środowiska prawicowe i ultrakonserwatywne, dążące do zachowania zasady neutralności i niezależności Szwajcarii jako najważniejszych gwarancji jej bezpieczeństwa. Od samego początku funkcjonowania członkowie stowarzyszenia opowiadali się przeciwko wszelkim przejawom politycznej bytności Szwajcarii w ponadnarodowych organizacjach. Oprócz sprzeciwu wobec aktywności w ramach ONZ, odrzucano również włączenie do Europejskiego Obszaru Gospodarczego, układy bilateralne z UE, a także rozszerzenie swobody przepływu osób na nowe państwa UE. Auns włącza się zatem aktywnie we wszelkie inicjatywy mające na celu przeciwstawienie się zjawiskom integracyjnym. $\mathrm{Z}$ niewielkiego ruchu społecznego w ciągu niespełna dwudziestu 
lat stworzono dużą, bo liczącą ok. $38000^{94}$ członków, organizację pełniącą funkcję najważniejszego ośrodka opiniotwórczego szwajcarskich konserwatystów. Auns przypisuje sobie wszelkie zasługi w zakresie ograniczenia proeuropejskiej polityki władz federalnych. Rzekomo to dzięki niej Szwajcaria nie jest jeszcze członkiem Unii Europejskiej ${ }^{95}$.

Czołowym ideologiem Auns jest Christoph Blocher, który w latach 19862003 zajmował stanowisko prezydenta tego stowarzyszenia. Blocher, podobnie jak inni działacze, wywodzi się z ludowo-konserwatywnej SVP (Schweizerische Volks Partei). Auns ma zatem silne zaplecze polityczne, jeszcze mocniejsze od czasu zwycięstwa ludowców w wyborach parlamentarnych w roku 2007. Początkowo aktywnymi członkami stowarzyszenia byli również przedstawiciele innych partii ${ }^{96}$. Radykalizacja postulatów zniechęciła jednak bardziej umiarkowanych polityków. Obecnie szeregi Auns zasilają głównie członkowie SVP.

Zgodnie ze swoim statutem stowarzyszenie działa na rzecz ograniczenia aktywności Szwajcarii na arenie międzynarodowej ${ }^{97}$. Można zatem przyjąć, iż nadrzędnym celem Auns jest kontynuacja doktryny politycznej, opracowanej przez Rudolfa Bindschedlera. Neutralność Szwajcarii pozostaje jedynym sprawdzonym sposobem na zagwarantowanie bezpieczeństwa i stabilizacji państwa. Należy podkreślić, że Auns nie wolno traktować na równi z ugrupowaniami typowo nacjonalistycznymi. Nacisk kładzie się w nim bowiem nie na kwestie narodowościowe - chodzi bardziej o forsowanie określonej koncepcji politycznej i to w odniesieniu przede wszystkim do relacji zewnętrznych.

Od samego początku Auns opowiadał się przeciwko współpracy bilateralnej, choć niektóre jej aspekty oceniane były pozytywnie. Bierze się to z faktu, iż nadrzędnym celem stowarzyszenia jest niedopuszczenie do włączenia Szwajcarii do Unii Europejskiej ${ }^{98}$. Współpraca bilateralna, mimo że traktowana jako pierwszy krok do pełnej integracji, pozwala jednak na zachowanie tych wartości, które uznawane są za kluczowe, a więc demokracji bezpośredniej, federalizmu oraz neutralności. Istotna jest również możliwość podejmowania suwerennych decyzji w zakresie polityki monetarnej i fiskalnej, a także zachowania tajemnicy bankowej. W tym sensie współpraca bilateralna jest dla Auns po prostu „mniejszym złem". Znamienny jest również fakt, iż Auns nie włączył się aktywnie w kampanię na rzecz odrzucenia pierwszego pakietu układów bilateralnych. Spowodowane to było przede wszystkim dwuznacznym zachowaniem ówczesnego przewodniczącego stowarzyszenia, który ze względów politycznych i finanso-

\footnotetext{
${ }^{94}$ Dane za rok 2000.

${ }^{95}$ Zob. www.auns.ch.

${ }^{96}$ Współzałożycielem Auns był m.in. Otto Fischer, wywodzący się FDP (Partia Liberalno-Demokratyczna).

${ }^{97}$ AUNS Statuten vom 6 Mai 2006, s. 2, źródło: http://www.auns.ch/statuten.php (10.11.2012).

${ }^{98}$ Zob. Warum die Schweiz der EU nicht beitreten darf - ein Argumentarium. Dokument dostępny pod adresem: http://www.auns.ch/download/argumentarium_eu.pdf(01.03.2010).
} 
wych zachował $\mathrm{w}$ tej sprawie powściągliwość ${ }^{99}$. Wywołało to zresztą niemałą konsternację wśród członków Auns, choć nie zaważyło w poważnym stopniu na ogólnym wizerunku Christopha Blochera. Decyzja o rezygnacji z udziału w kampanii przeciwko umowom bilateralnym, a dokładnie wprowadzeniu swobody przepływu osób, tłumaczona była oficjalnie tym, że pozwalają one na uniknięcie gorszego scenariusza, czyli członkostwa w UE ${ }^{100}$. Poza tym działalność Auns miała się skupiać wokół ochrony neutralności. Uznano, że umowy bilateralne nie stanowią dla niej zagrożenia.

$\mathrm{Z}$ biegiem lat krytyka wobec tej formy współpracy uległa nasileniu. Twierdzono, że wbrew obietnicom władz federalnych układy bilateralne nie przynoszą żadnych korzyści, a wręcz przeciwnie, uzależniają Szwajcarię coraz bardziej od UE i zmuszają ją do ograniczenia suwerenności decyzyjnej. Oficjalne stanowisko przewodniczącego Auns - Pirmina Schwandera - jest w tym względzie jednoznaczne $^{101}$. Obecnie Auns opowiada się za wypowiedzeniem porozumień bilateralnych. Najostrzej krytykowana jest umowa dotycząca opodatkowania odsetek, zwalczania oszustw finansowych oraz włączenia Szwajcarii do strefy Schengen. Problemy związane z sektorem bankowym traktowane są przez Auns jako efekt złej woli Unii Europejskiej. Uważa się, że Szwajcaria odgrywa tutaj rolę kozła ofiarnego. Wskazuje się na liczne analogie w stosunku do sektorów bankowych Austrii oraz Luksemburga, które z pewnych powodów nie są obiektem podobnej krytyki ze strony Komisji Europejskiej ${ }^{102}$. Równie mocno krytykowane jest porozumienie o swobodzie przepływu osób, uważane za główną przyczynę wzrostu bezrobocia. Ocenia się również, iż sytuację pogarsza wzrost nielegalnej imigracji, której sprzyja m.in. układ z Schengen, ograniczający w poważnym stopniu kontrolę graniczną ${ }^{103}$.

Auns działa na rzecz ograniczenia negatywnych efektów integracji. W sierpniu roku 2009 złożono inicjatywę konstytucyjną, zakładającą obowiązek poddawania pod głosowanie referendalne każdej, istotnej pod względem prawnym i finansowym, umowy międzynarodowej ${ }^{104}$. Ma to na celu zwiększenie społecznej kontroli, a tym samym przeciwdziałanie negatywnym zjawiskom, takim jak marginalizacja praw obywatelskich związanych z demokracją bezpośrednią. Przy-

${ }^{99}$ Zob. więcej T. Oberer, op. cit., s. 18, 42.

${ }^{100}$ Ibidem, s. 19.

${ }^{101}$ P. Schwander, Der Bilaterale Weg ist erschöpft!, Begrüssung und Standortbestimmung vom 25. April 2009.

${ }^{102}$ Der Bundesrat will in die EU, „Presse-Mitteilung der Auns”, 7. Oktober 2009.

${ }^{103}$ R. Golban, Bilaterale Abkommen - eine Sackgasse!, „Auns Klartext. Wer stoppt den IRRWEG?", November 2009, Nr. 133, s. 6.

${ }^{104}$ Zgodnie z przedstawionym przez Auns projektem głosowaniu podlegałyby umowy, które: a) doprowadzają do międzynarodowego ujednolicenia prawa w ważnych dziedzinach, b) obligują Szwajcarię do przejęcia określonych przepisów prawnych, c) wymuszają przekazanie części kompetencji szwajcarskiego wymiaru sprawiedliwości na rzecz międzynarodowej instancji, d) pociągają za sobą jednorazowe wydatki finansowe w kwocie większej niż 1 mld franków. 
jęcie tej inicjatywy oznaczałoby konieczność uzupełnienia art. 140 konstytucji wymogiem przedstawienia społeczeństwu do akceptacji niemal wszystkich umów międzynarodowych, a więc również kolejnych porozumień bilateralnych.

\subsubsection{STANOWISKO ŚRODOWISK GOSPODARCZYCH}

Organizacje gospodarcze należą bez wątpienia do najbardziej aktywnych ośrodków proeuropejskich. Stopień ich oddziaływania na opinię publiczną jest bardzo duży, m.in. z uwagi na fakt, iż reprezentują apolityczny punkt widzenia. Ze względu zatem na brak pewnego rodzaju koniunkturalizmu politycznego, którym skażone są inne, również pozarządowe, ośrodki opiniotwórcze, Economiesuisse cieszy się dużym zaufaniem społecznym. Należy zauważyć, że opinie środowisk gospodarczych w kwestiach integracji europejskiej nie zawsze były jednomyślnie pozytywne. Jeszcze na początku lat 90., a więc w okresie, kiedy poważnie rozważano możliwość włączenia Szwajcarii do Europejskiego Obszaru Gospodarczego, oczekiwania szwajcarskich przedsiębiorstw były zróżnicowane. Wynikało to zapewne z faktu, iż część z nich, zwłaszcza dużych koncernów, od wielu lat była już obecna na zagranicznych rynkach. Takie firmy, jak Nestle lub Novartis traktowały nowe działania integracyjne rządu w sposób raczej ambiwalentny. Z kolei małe i średnie przedsiębiorstwa, dla których korzyści ze swobodnego dostępu do wspólnotowego rynku mogłyby okazać się dużo większe, nie były do końca pewne ostatecznych efektów integracji europejskiej. Jak wskazują badania przeprowadzone w roku 1988 przez IHA-Institut, zaledwie 40\% firm planowało podjęcie konkretnych kroków celem przygotowania do nowych uwarunkowań i możliwości wynikających z ułatwionego dostępu do wspólnotowych rynków ${ }^{105}$. Dopiero z początkiem lat 90 . zaczęło się stopniowo zmieniać nastawienie środowisk gospodarczych. Trzeba jednak zauważyć, że nastroje były nadal powściągliwe. Oficjalne stanowisko dwóch głównych organizacji gospodarczych - Dachverband der Schweizerischer Industrie oraz Arbeitgeberverband, czyli protoplastów dzisiejszego Economiesuisse należałoby uznać za umiarkowanie entuzjastyczne. Były one gotowe poprzeć włączenie Szwajcarii do EOG, ale nie traktowały tego w kategoriach działań niezbędnych. Dominowała wówczas opinia, iż dostęp do wspólnotowego rynku może okazać się korzystny dla szwajcarskich przedsiębiorstw, ale nie jest warunkiem ich przetrwania. Zwłaszcza że pozaekonomiczne skutki takich działań mogłyby okazać się dla Szwajcarii o wiele bardziej dotkliwe i przeważyć ewentualne korzyści gospodarcze ${ }^{106}$. Integrację europejską wiązano z groźbą „satelityzacji” Szwajcarii ${ }^{107}$. Dopiero z czasem nastawienie to uległo

${ }^{105}$ M. Schenker, op. cit., s. 27.

106 Ibidem.

${ }^{107}$ Jednoznacznie za przystąpieniem do EOG oraz EWG opowiedziały się Verein Schweizerischer Maschinenindustrieller (Szwajcarskie Stowarzyszenie Przemysłu Maszynowego) oraz Gruppe der Schweizerischen Bauindustrie (Grupa Budownictwa Szwajcarskiego). 
zmianie i dzisiaj możemy już uznać je za całkowicie pozytywne. Dla sektora małych, średnich i dużych przedsiębiorstw możliwość swobodnego dostępu do unijnych rynków stała się warunkiem koniecznym do dalszego rozwoju. Rząd może liczyć zatem na duże wsparcie ze strony środowisk gospodarczych. Bilaterale I było pierwszym i jak dotąd najbardziej znaczącym pakietem, który umożliwił szwajcarskim firmom intensyfikację działań na europejskich rynkach. Oczywiście oczekują one dalszych kroków w tym kierunku ze strony władz, a lista obszarów, które wymagają uregulowania, jest jeszcze długa.

Również stanowisko związków zawodowych dotyczące kwestii europejskich nie było jednolite. Od samego początku podejmowania prób integracyjnych środowiska reprezentujące szwajcarskich pracobiorców były silnie podzielone. Największy związek zawodowy - Schweizerische Gewerkschaftbundes - ostrzegał swoich członków przed nadmiernym zaufaniem do zjawisk integracyjnych. W wypowiedziach czołowych działaczy związkowych z okresu końca lat 80 . i początku lat 90 . wieku XX odnaleźć możemy sporo słów krytyki odnośnie do efektów włączenia Szwajcarii do EOG ${ }^{108}$. Niewątpliwie największe obawy dotyczyły liberalizacji rynku pracy. Obawiano się napływu taniej siły roboczej, czego konsekwencją miało być zachwianie obowiązujących stawek płacowych, a także wzrost bezrobocia. Oczywiście z tego względu największy niepokój związków zawodowych budziły późniejsze działania władz federalnych zmierzające do wprowadzenia swobody przepływu osób. Dopiero zastosowanie okresów przejściowych wyciszyło nieco emocje związkowców. Należy jednak zauważyć, iż od samego początku wiązano też z integracją pewne nadzieje. Chodziło głównie o wyrównanie praw pracowniczych do poziomu, który obowiązywał w państwach Wspólnoty. Liczono, że dzięki nawiązaniu ścisłej współpracy z Europejskim Związkiem Zawodowym, uda się urzeczywistnić postulaty, których dotąd nie zdołano osiągnąc, a więc wzmocnić pozycję związków zawodowych oraz zagwarantować większą transparentność prawa, pozwalającą na jego lepsze egzekwowanie. Wszystko to miało zostać osiągnięte dzięki włączeniu Szwajcarii do Wspólnoty Europejskiej.

Umowy bilateralne rozwiały część wątpliwości związanych z integracją. Nie pociągnęły one za sobą jednak żadnych działań na rzecz ujednolicenia praw pracowniczych lub wzmocnienia pozycji związków zawodowych. Udało się osiągnąć przede wszystkim wprowadzenie korzystnych okresów przejściowych, które ograniczyły negatywne konsekwencje liberalizacji rynku pracy. Stanowisko związków zawodowych, przychylne polityce władz federalnych i współpracy bilateralnej, może jednak bardzo szybko ulec zmianie. Pogorszenie sytuacji na rynku pracy, przede wszystkim wzrost bezrobocia, łatwo może wzbudzić nastroje rewizjonistyczne. Związki „staną murem” za szwajcarskimi pracownikami.

${ }^{108}$ Wiceprzewodniczący Szwajcarskiego Związku Zawodowego Walter Renschler ostrzegał przed utworzeniem „Europy kupców, kramarzy i kapitalistów” („Europa der Händler, Krämer und Kapitalisten"). 
Z pewnością zmieni się wówczas nastawienie wobec umowy o swobodnym przepływie osób. Większość związkowców będzie domagała się przywrócenia instrumentów ochronnych, być może nawet czasowego zamknięcia szwajcarskiego rynku pracy dla obcokrajowców.

Omawiając stanowisko środowisk gospodarczych nie sposób pominąć wpływowej Economiesuisse, którą z całą pewnością można zaliczyć do ośrodków popierających politykę integracyjną rządu. Jest to największa organizacja gospodarcza w Szwajcarii, zrzeszająca obecnie ok. 30000 przedsiębiorstw, zatrudniających łącznie 1,5 mln osób. Bez wątpienia pełni ona funkcję najważniejszej instytucji reprezentującej interesy środowisk biznesowych. Economiesuisse powstała w roku 2000 w Lozannie, na gruncie istniejących wcześniej stowarzyszeń przemysłowych $^{109}$. Skupia nie tylko pojedyncze firmy, lecz również izby gospodarcze oraz współpracuje ściśle ze Schweizerische Arbeitgeberverband (Stowarzyszeniem Pracodawców Szwajcarskich).

Podstawowym zadaniem Economiesuisse jest tworzenie optymalnych warunków rozwoju dla szwajcarskich przedsiębiorstw, m.in. poprzez wywieranie nacisku na ośrodki decyzyjne. Organizacja ta ma niezliczone kontakty na wszystkich szczeblach administracji centralnej i kantonalnej oraz w parlamentach. Reprezentuje również interesy przedsiębiorców w trakcie konsultacji społecznych prowadzonych w ramach nowych propozycji legislacyjnych. Jest więc instytucją lobbingu politycznego, aktywnie działającą na rzecz wzmocnienia konkurencyjności szwajcarskich przedsiębiorstw ${ }^{110}$. Główny nacisk kładzie się tutaj na politykę finansową, podatkową, a także edukację oraz ochronę środowiska. Istotnym elementem działalności Economiesuisse jest ocena bieżącej polityki rządu, w tym m.in. wobec partnerów zewnętrznych. Relacje z Unią Europejską, przede wszystkim w aspekcie gospodarczym, budzą więc szczególne zainteresowanie. Economiesuisse działa na rzecz stworzenia jak najlepszych warunków wzajemnej współpracy, reprezentując interesy firm, które zrzesza, oraz opracowując propozycje nowych rozwiązań gospodarczych. Szeroko komentuje przy tym dotychczasowe działania władz federalnych, zwłaszcza w kontekście podpisywania i wdrażania umów bilateralnych z UE.

Dla środowisk gospodarczych korzyści płynące ze współpracy ze Wspólnotą są niepodważalne. Trzeba pamiętać, że to właśnie względy gospodarcze były podstawowym czynnikiem determinującym działania władz szwajcarskich. Pierwszy pakiet porozumień miał przecież stanowić uzupełnienie układu o wolnym handlu z EWG. Nic więc dziwnego, że szwajcarskie przedsiębiorstwa patrzyły z nadzieją na umowy bilateralne.

${ }^{109}$ Schweizerische Handels- und Industrieverein oraz Gesellschaft zur Förderung der schweizerischen Wirtschaft.

${ }^{110}$ Economiesuisse ma również swoje biuro w Brukseli, gdzie wspiera działania szwajcarskiej misji przy UE, a także lobbuje w Komisji Europejskiej na rzecz szwajcarskich przedsiębiorstw. Jest też członkiem Konfederacji Europejskiego Biznesu - Businesseurope (zwanej dawniej UNICE). 
Całkowita ocena dotychczasowych relacji z Unią Europejską jest zbieżna z opinią Nebs. Oczywiście największy nacisk kładzie się tutaj na aspekty ekonomiczne, a więc korzyści płynące z likwidacji barier w handlu, stworzenie nowych ram współpracy w branżach nieobjętych dotąd żadnymi regulacjami, mobilność pracowników itp. Zawarcie porozumień bilateralnych było, zdaniem Economiesuisse, najważniejszym krokiem w budowie właściwych relacji z UE. Dotychczasowe doświadczenia z wdrażania umów oceniane są pozytywnie. Ich znaczenie rośnie wraz z rozwojem Unii Europejskiej. Rozszerzenie z roku 2004 oraz 2007 zapewniło Szwajcarii dostęp do kolejnych, prężnie rozwijających się rynków. Należy zauważyć, że państwa byłego bloku wschodniego są niezwykle cennym partnerem gospodarczym ze względu na wyższe, w porównaniu z państwami starej piętnastki, zapotrzebowanie na nowe usługi i produkty wysokiej jakości ${ }^{111}$. Szwajcaria ma tutaj do zaoferowania ogromne doświadczenie oraz cenny know-how. Nie bez znaczenia jest również dostęp do siły roboczej, zwłaszcza tej wysoko wykwalifikowanej ${ }^{12}$.

W ocenie Economiesuisse dalsza współpraca z UE powinna uwzględniać jej specyfikę. Wspólnota nie jest tworem idealnym, w związku z czym dręczy ją wiele problemów natury instytucjonalnej. Istotne jest również duże zróżnicowanie pod względem rozwoju między Europą wschodnią a zachodnią. Należy zatem szukać takich płaszczyzn współpracy, które, biorąc pod uwagę powyższe problemy, będą w stanie w maksymalnym stopniu zabezpieczyć interesy gospodarcze Szwajcarii. Economiesuisse rozważa tutaj pięć scenariuszy rozwoju współpracy, z których jeden wskazywany jest jako najbardziej optymalny ${ }^{113}$.

W przeciwieństwie do stanowiska reprezentowanego przez Neue Europäische Bewegung Schweiz członkostwo w UE jest postrzegane jako korzystny, ale nie optymalny sposób na zapewnienie właściwych ram wzajemnych relacji. Zdaniem Economiesuisse układy bilateralne pozwoliły na wyeliminowanie najważniejszych barier, co sprawia, iż przystąpienie do Wspólnoty nie przyniosłoby obecnie tak dużych korzyści, jak jeszcze przed dziesięcioma laty ${ }^{114}$. Oczywiście dzięki temu możliwa będzie dalsza eliminacja czynników utrudniających rozwój współpracy gospodarczej - głównie dzięki bezwarunkowemu dostępowi do wspólnotowego rynku. Pozytywnie jest również oceniany aspekt polityczny, tj. możliwość bezpośredniego uczestniczenia w formułowaniu polityk UE. Podkreśla się tutaj konieczność poszukiwania sojuszy lub koalicji w ramach przyszłej Wspólnoty celem wzmocnienia własnej pozycji, a tym samym eksponowania swoich interesów. W opinii Economiesuisse należy się również liczyć z ograniczeniami dwóch naj-

${ }^{111}$ Według danych OECD w latach 1995-2005 średni wzrost PKB krajów, które przystąpiły do UE w roku 2004 był prawie trzykrotnie wyższy niż w Szwajcarii.

112 Zob. Neue Art von Zuwanderung, „Standpunkt der Wirtschaft”, 21. Oktober 2008, s. 11.

113 Europapolitik: Erfolg durch Pragmatismus, Positionspapier der Economiesuisse, Zürich 2006, s. 8.

${ }^{114}$ Ibidem 
ważniejszych filarów systemu politycznego Szwajcarii, czyli federalizmu i demokracji bezpośredniej. Oznacza to, że przystąpienie do Unii Europejskiej implikuje przeprowadzenie określonych reform dostosowawczych. Prawo UE i specyfika procesu decyzyjnego w ramach Wspólnoty nie przewidują takich uprawnień, jakimi dysponuje obecnie społeczeństwo szwajcarskie. W tym punkcie stanowisko Economiesuisse jest zatem zbieżne z koncepcjami innych ośrodków kreowania opinii, nieco sceptyczniej nastawionych wobec członkostwa niż Nebs.

Tym, na co szczególnie zwracają uwagę środowiska gospodarcze, są kwestie finansowe, przede wszystkim obciążenia dla budżetu, spowodowane koniecznością przekazywania składek członkowskich do Brukseli. Szwajcaria byłaby tutaj zapewne płatnikiem netto. Dodatkowe straty wynikałyby z rezygnacji ze szwajcarskiej waluty na rzecz euro ${ }^{115}$ - nie tylko w sensie czysto ekonomicznym, lecz również politycznym, tj. utraty zdolności kreowania własnej polityki monetarnej, która zależeć będzie od decyzji Europejskiego Banku Centralnego. Na obecną atrakcyjność Szwajcarii, jako miejsca lokowania inwestycji, składają się m.in. korzystne stopy procentowe. Utrata własnej waluty obniży konkurencyjność szwajcarskiej gospodarki i wpłynie niekorzystnie na jej przyszły rozwój. Economiesuisse zwraca również uwagę na konieczność podwyższenia stawki podatku VAT, z dzisiejszych 7,5 na 15\%. Unia wymaga unifikacji polityk fiskalnych z uwagi na chęć stworzenia jednolitych warunków podatkowych na całym wspólnotowym rynku. Ma to na celu wykreowanie odpowiednich warunków swobody konkurencji i równych szans rozwoju dla wszystkich państw UE. Podobną politykę stosuje także wobec sfery socjalnej oraz rynku pracy. Zdaniem Economiesuisse wprowadzenie tego typu regulacji odbije się niekorzystnie na szwajcarskich pracodawcach oraz pracownikach ${ }^{116}$.

Przystąpienie do Unii Europejskiej traktowane jest przez środowiska gospodarcze jako jedna z możliwych opcji integracyjnych, niosących jednakże ze sobą zbyt dużo negatywnych konsekwencji. Poza opisanymi powyżej zwraca się również uwagę na problem kierunków rozwoju gospodarczego Wspólnoty. Wyróżnia się tutaj dwa modele. Pierwszy z nich zakłada stworzenie jednolitego rynku, opartego na regułach pełnej liberalizacji handlu, drugi oparty jest na zasadzie państwa socjalnego, a więc o rozbudowanych instrumentach ingerencji i kontroli rozwoju rynków. Obecnie nie jest przesądzone, w jakim kierunku Unia będzie się rozwijać. Trudno zatem ocenić, który z wariantów może okazać się korzystniejszy dla Szwajcarii. Z tego względu Economiesuisse opowiada się za rozwiązaniami bilateralnymi, gdyż umożliwiają one elastyczniejsze reagowanie na zachodzące w UE zmiany.

${ }^{115}$ Według szacunków Economiesuisse straty te, w postaci zmniejszenia dochodów Banku Narodowego, wynikającego ze sprzedaży franka szwajcarskiego, sięgałyby rocznie ok. 1 mld franków. Należy zauważyć, że szwajcarska waluta należy obecnie do grona pięciu najpopularniejszych walut na świecie.

${ }^{116}$ Ibidem, s. 10. 
Drugim scenariuszem rozpatrywanym przez środowiska gospodarcze jest opcja elastycznej integracji, nazywana również członkostwem „light”. Jest to model zaproponowany przez władze federalne w raporcie z roku 2006. Economiesuisse ocenia jednak ten wariant współpracy jako mało realny, choć główne jego założenie, polegające na transponowaniu jedynie części kompetencji na rzecz ponadnarodowej organizacji, wydaje się słuszne. Prawdopodobnie państwa UE nie będą gotowe na tego typu ustępstwa. Równie sceptycznie oceniana jest kolejna forma współpracy - przystąpienie do Europejskiego Obszaru Gospodarczego. W opinii Economiesuisse opcja ta uległa z czasem dezaktualizacji. Dziś EOG nie może w żadnym stopniu zabezpieczyć interesów gospodarczych Szwajcarii, tak jak to mogło się stać jeszcze kilka lat temu. Wpływ na to mają przede wszystkim umowy bilateralne, które pozwoliły na wyeliminowanie najpilniejszych problemów. W tej sytuacji członkostwo EOG może oznaczać dla Szwajcarii jedynie konieczność przyjęcia tych regulacji, które nie przyniosą jej żadnych korzyści, a mogą tylko odbić się negatywnie na konkurencyjności szwajcarskiej gospodarki. Podobnie oceniana jest propozycja zawarcia unii celnej. Również ten wariant stracił na aktualności, ponieważ większość korzyści dla przedsiębiorstw płynie z eliminacji formalności celnych i wzmocnienia ochrony prawnej w handlu. Natomiast bariery pozataryfowe nie są przedmiotem regulacji $\mathrm{w}$ ramach unii celnej. Dodatkowo wymusza ona stosowanie wyższych stawek celnych w handlu z państwami trzecimi, co odbije się niekorzystnie na poziomie cen i kosztów oraz konkurencyjności produktów niektórych branż ${ }^{117}$.

Za zdecydowanie najbardziej optymalną opcję uważa się kontynuację powiązań bilateralnych. Należy jednak podkreślić, że dotychczasowe doświadczenia i tu nie skłaniają do jednoznacznej oceny. Środowiska gospodarcze wielokrotnie wskazywały na negatywne aspekty tego rodzaju rozwiązań. Chodzi tutaj przede wszystkim o kwestie polityczne, podkreślane zarówno przez władze federalne, jak i Nebs. Umowy bilateralne, zdaniem Economiesuisse, cechuje duża niestabilność. Ze względu na klauzulę gilotyny istnieje ciągłe zagrożenie zerwaniem zawartych i skutecznie wdrażanych umów. Niewiadomy pozostaje również ostateczny kierunek dalszego rozwoju Unii. Nie ulega wątpliwości, iż z czasem Bruksela będzie wykazywać coraz mniej zrozumienia dla problemów sygnalizowanych przez Szwajcarię, a co za tym idzie, chęć rozwiązywania ich drogą kompromisu i specjalnie negocjowanych umów prawdopodobnie będzie niewielka. Ponadto należy zauważyć, że publikowane przez Economiesuisse raporty i analizy wskazywały też na możliwość negatywnego oddziaływania porozumień bilateralnych, zwłaszcza dotyczących obszarów bankowych i podatkowych ${ }^{118}$. Mówiono o koniecz-

117 Przeciętna stawka celna na produkty przemysłowe eksportowane z krajów UE wynosi 4,1\%, podczas gdy w Szwajcarii sięga ona poziomu 2,3\%.

${ }^{118}$ Zob. Bilaterale II: Dossier Zinsbesteuerung. Die Interessen des Finanzplatzes gewahrt, „Economiesuisse Dossierpolitik”, 27. September 2004, Nr. 35/1. 
ności budowy tego typu relacji, lecz nie za wszelką cenę $e^{119}$. Dla szwajcarskich przedsiębiorstw umowy bilateralne stanowią jednak sprawdzoną formę współpracy, pozwalającą na pragmatyczne podejście do podstawowych problemów, jakie napotykają w relacjach z UE. Nic więc dziwnego, że Economiesuisse jest w sposób szczególny zaangażowana we wszelkie kampanie polityczne, związane z głosowaniami referendalnymi w sprawie umów bilateralnych. Środki finansowe przeznaczone na wsparcie tego rodzaju działań znacznie przewyższają możliwości innych ośrodków opiniotwórczych, zwłaszcza tych przeciwnych współpracy z UE ${ }^{120}$.

Economiesuisse działa również na rzecz uregulowania kolejnych obszarów współpracy z UE, mając przy tym świadomość, że systemowe rozwiązania, na wzór pakietów Bilaterale I lub Bilaterale II, są mało realne. Chodzi jednak o to, aby doprowadzić do zawarcia porozumień ułatwiających współpracę gospodarczą w kolejnych, kluczowych sektorach, jak energetyka czy rolnictwo. Dzięki temu można by nadać relacjom z UE wspomniany już, bardziej pragmatyczny charakter, który umożliwi większą kontrolę nad działaniami rządu i zarazem nie ograniczy suwerenności Szwajcarii, zmuszając ją do rezygnacji z części swoich kompetencji w zakresie prowadzenia polityk wewnętrznych i zewnętrznych.

$* * *$

Koncepcja polityki Szwajcarii wobec Unii Europejskiej sprowadza się zatem do poszukiwania złotego środka. $Z$ jednej strony odrzuca się powrót do izolacjonizmu (wyłączając skrajne ugrupowania), z drugiej niechętnie spogląda się na ideę pełnej integracji. Takie stanowisko podzielają zarówno ośrodki decyzyjne, jak i pozarządowe. Z przeprowadzonej powyżej analizy można wyciągnąć kilka interesujących wniosków. Po pierwsze, koncepcja budowania określonych relacji z UE wykazuje cechy dynamiczne, tj. podlega okresowej weryfikacji i zmianom, będącym efektem konkretnych doświadczeń. Są one uwarunkowane głownie czynnikami obiektywnymi - ekonomicznymi i politycznymi. Te pierwsze należy rozumieć jako potrzebę zacieśniania współpracy gospodarczej, która umożliwi eliminację wybranych barier w handlu. Drugie odnoszą się do poprawy wizerunku Szwajcarii jako państwa zaangażowanego w rozwój Europy, a także ogólnego przeświadczenia o konieczności włączenia się w procesy integracyjne, a więc stworzenia należytych więzi politycznych, społecznych i kulturowych. W zależności od tego, w jakim stopniu potrzeby te są zaspokojone, wzmaga się lub słabnie chęć do integracji z UE. Można zatem pokusić się o stwierdzenie, iż dominuje tutaj podejście pragmatyczne. Po drugie, zauważyć możemy pewną tendencję ewolucyjną tych koncepcji - od zaangażowania i entuzjazmu, w kierun-

${ }^{119}$ Standortbestimmung zur schweizerischen Integrationspolitik, Economiesuisse Positionspapier, Zürich 2002, s. 5.

${ }^{120}$ Szczególną aktywność wykazywano przy okazji głosowań nad rozszerzeniem swobody przepływu osób na nowe kraje członkowskie UE. 
ku większego zdystansowania, a nawet sceptycyzmu wobec idei integracyjnych. Po trzecie, ośrodki proeuropejskie wyraźnie dominują nad eurosceptycznymi, są liczniejsze, dysponują większymi środkami finansowymi oraz poparciem wpływowych środowisk gospodarczych, stąd też wynika rosnące, choć powoli, poparcie społeczne dla tego rodzaju koncepcji. Po czwarte, stanowisko ośrodków decyzyjnych jest silnie motywowane przez opinię publiczną. Rząd modyfikuje własne koncepcje w zależności od faktycznych możliwości ich realizacji. Wreszcie zarówno w obozie eurosceptyków, jak i euroentuzjastów, nie ma konsensusu co do właściwego kształtu relacji z Unią Europejską. 


\section{ROZDZIAL III \\ REALIZACJA POLITYKI SZWAJCARII WOBEC UNII EUROPEJSKIEJ}

Praktyka polityczna pozostaje wypadkową myśli i uwarunkowań, którym poświęcone były dwa poprzednie rozdziały. Jest odzwierciedleniem faktycznych możliwości funkcjonowania państwa w stosunkach międzynarodowych, stanowiąc tym samym najważniejszy element analizy polityki zagranicznej owego państwa. Niniejszy rozdział analizuje ewolucję działań rządu Szwajcarii wobec zjawisk integracyjnych w Europie. Za cezurę czasową przyjęto tutaj początek lat 60. ubiegłego wieku, kiedy to rząd Szwajcarii zaczął przejawiać większe zainteresowanie procesem integracyjnym, choć zasadniczy nacisk położono na okres od początku lat 90 . XX w. Od tego momentu mamy do czynienia z wyraźną intensyfikacją współpracy ze Wspólnotą. W dalszej części tekstu uwagę poświęcono podstawom normatywnym, a więc ramom prawnym i instytucjonalnym bieżącej polityki wobec UE. Na końcu przeanalizowane zostały dość dokładnie poszczególne porozumienia dwustronne. Należy nadmienić, że w przypadku Szwajcarii zasięg merytoryczny umów motywowany jest przede wszystkim aspektami ekonomicznymi, tj. potrzebą zacieśnienia współpracy gospodarczej z państwami UE. Działania integracyjne w innych obszarach, takich jak bezpieczeństwo, edukacja, wymiar sprawiedliwości czy też relacji z państwami trzecimi mają znaczenie drugorzędne i są bardziej pochodną realizacji współpracy na płaszczyźnie ekonomicznej. Dobrym tego przykładem jest koordynacja działania organów ścigania, będąca konsekwencją otwarcia granic w ramach realizacji zasady czterech swobód - osób, kapitału, towaru i usług (nie wszystkie zostały wprowadzone w pełnym zakresie). $\mathrm{Z}$ tego względu zrezygnowano z próby wyodrębnienia płaszczyzn współpracy na rzecz omówienia poszczególnych umów będących podstawą normatywną polityki Szwajcarii wobec UE.

\subsection{EWOLUCJA POLITYKI SZWAJCARII W STOSUNKU DO UNII EUROPEJSKIEJ}

\subsubsection{SZWAJCARIA W OBLICZU ZJAWISK INTEGRACYJNYCH W EUROPIE}

Szwajcaria bierze udział w procesie integracji europejskiej, w różnym wymiarze, począwszy od lat 60 . ubiegłego wieku. Wcześniejsze przejawy dążeń 
integracyjnych, jak chociażby Rada Europy, traktowane były przez rząd tego kraju z dużym sceptycyzmem, a idea stworzenia stanów zjednoczonych Europy, lansowana m.in. przez Winstona Churchilla w latach powojennych, zdawała się stanowić dodatkowy argument dla przeciwników integracji. Wyjątek stanowiła jedynie Organizacja Europejskiej Współpracy Gospodarczej ${ }^{1}$ (OEEC), do której Szwajcaria włączyła się od samego początku jej funkcjonowania. Podłożem decyzji była jednakże głównie chęć podreperowania wizerunku państwa, nadszarpniętego prowadzoną w trakcie II wojny światowej, dość kontrowersyjną, polityką oraz dążenie do zagwarantowania korzystnych kontaktów gospodarczych ${ }^{2}$. Rząd Szwajcarii zaangażował się również w działalność Europejskiej Unii Płatniczej, mając nadzieję na wzmocnienie pozycji własnej waluty. Należy bowiem pamiętać, że w tamtym okresie frank szwajcarski był jedyną wymienialną europejską walutą. Istotnym elementem było również dobitne manifestowanie własnych sympatii politycznych czy też bardziej ideologicznych, tj. opowiedzenie się po stronie Zachodu w dobie zimnowojennego konfliktu na linii Wschód-Zachód. Od samego początku szwajcarscy politycy jasno deklarowali ideę „bilateralizmu”, jako zdecydowanie bardziej korzystnej formy współpracy międzynarodowej niż umowy multilateralne. Jak zauważają jednak Hug, Gees i Dannecker, w rzeczywistości negocjacje multilateralne prowadzone były przez szwajcarską dyplomację znacznie częściej ${ }^{3}$. Chodziło zatem bardziej o poszukiwanie właściwej drogi prowadzącej do zoptymalizowania kontaktów gospodarczych z innymi państwa$\mathrm{mi}^{4}$. W konsekwencji doprowadziło to również do swoistej erozji dotychczasowej doktryny neutralności, którą zastąpiono zasadą militarnej bezstronności oraz politycznej i gospodarczej solidarności z Zachodem ${ }^{5}$. Legła ona zresztą u podstaw, wspomnianej już w pierwszym rozdziale niniejszej monografii, powojennej doktryny neutralności, autorstwa Rudolfa Bindschedlera.

Dzięki aktywności w ramach Europejskiej Unii Płatniczej Szwajcaria zagwarantowała sobie korzystne warunki handlowe nie tylko w Europie, lecz również z państwami afrykańskimi, azjatyckimi oraz Oceanii. Nie dziwi zatem fakt, że rząd Szwajcarii nie był zainteresowany współpracą w ramach Układu Ogólnego w sprawie Ceł i Handlu (GATT) oraz Międzynarodowego Funduszu Walutowego uznając, że organizacje te, stworzone pod dyktando USA, nie będą w wystarcza-

${ }^{1}$ Rząd w Bernie wynegocjował tzw. szwajcarską klauzulę (Swiss clause), która umożliwiała podejmowanie wiążących decyzji w ramach OEEC, pomimo wstrzymującego głosu Szwajcarii. Miało to na celu zagwarantowanie zasady bezstronności kraju neutralnego.

${ }^{2}$ Zob. więcej D. Popławski, Szwajcarska polityka bezpieczeństwa, Warszawa 2007, s. 91.

3 P. Hug, T. Gees, K. Dannecker, Die Aussenpolitik der Schweiz im kurzen 20. Jahrhundert. Antibolschewismus, Deutschlandpolitik und organisierte Weltmarktintegration - Segmentierte Praxis und öffentliches Ritual, Nationales Forschungsprogramm 42: „Grundlagen und Möglichkeiten der Schweizerischen Aussenpolitik”, Synthesis, Bern 2000, s. 18.

${ }^{4}$ Opinię tą podziela również D. Popławski, Szwajcarska polityka ..., s. 92.

${ }^{5}$ P. Hug, T. Gees, K. Dannecker, op. cit., s. 19. 
jącym stopniu zabezpieczać jej interesów ${ }^{6}$. Równie sceptycznie odnoszono się do idei Europejskiej Wspólnoty Węgla i Stali. Kwestie zaopatrywania w surowce rozwiązywano skutecznie w ramach OEEC. Część dostaw, np. węgla, zagwarantowana była także na mocy odpowiednich porozumień z rządem polskim ${ }^{7}$. Sytuacja uległa zmianie wraz z rozwiązaniem Europejskiej Unii Płatniczej w roku 1958, czego konsekwencją była utrata dotychczasowej pozycji szwajcarskiej waluty. Coraz częściej borykano się również z przejawami dyskryminacji ze strony rosnącej w siłę EWG.

W reakcji na pogarszającą się pozycję gospodarczą rząd w Bernie zajął się pomysłem stworzenia strefy wolnego handlu w Europie. Jego ucieleśnieniem miało być Europejskie Stowarzyszenie Wolnego Handlu. EFTA stała się dla Szwajcarii, obok OECD, najważniejszym organem multilateralnej współpracy gospodarczej, tym bardziej że współpraca oparta wyłącznie na liberalizacji handlu w pełni odpowiadała doktrynie politycznej i gospodarczej Szwajcarii ${ }^{8}$. Dość szybko okazało się jednak, że koncepcja utworzenia przeciwwagi dla EWG nie znajduje równie silnego poparcia ze strony pozostałych członków EFTA. Dyplomacja Austrii dążyła do nawiązania ścisłych stosunków pomiędzy Wspólnotą a Stowarzyszeniem, z kolei Wielka Brytania, Dania, Irlandia i Norwegia złożyły oddzielne wnioski akcesyjne do EWG. W tej sytuacji stało się jasne, że Szwajcaria musi szukać zbliżenia z państwami o zbliżonych uwarunkowaniach polityczno-gospodarczych. Nawiązano zatem współpracę z Austrią i Szwecją celem koordynacji działań asocjacyjnych z EWG. Rząd Szwajcarii wyszedł z założenia, iż jedynie dzieki temu może liczyć na uwzględnienie przez EWG przedstawionych zastrzeżeń wynikających ze statusu neutralności wszystkich trzech państw. Ostatecznie nie doszło do formalnych negocjacji w tej sprawie. Wniosek stowarzyszeniowy rozpatrywany był w powiązaniu z wnioskiem akcesyjnym Wielkiej Brytanii. Sprzeciw gen. Charlesa de Gaulle'a w tej sprawie odsunął na dalszy plan również kwestie dotyczące państw neutralnych.

Zamrożenie wniosku asocjacyjnego nie wyeliminowało przedmiotowej sprawy z dyskusji publicznej. Społeczeństwo coraz częściej obawiało się groźby międzynarodowej izolacji. Powołane na początku lat 60. grupy robocze, mające na celu wyjaśnienie wszystkich kwestii związanych z ewentualnym przystąpieniem do EWG, kontynuowały swoją działalność. Należy jednak zaznaczyć, że rząd nie informował w wyczerpującym stopniu opinii publicznej o faktycznych działaniach na międzynarodowej scenie politycznej. Dyplomacja szwajcarska była

${ }^{6}$ Szwajcaria przystąpiła do GATT ostatecznie w roku 1959, a do Międzynarodowego Funduszu Walutowego w roku 1992.

${ }^{7}$ Porozumienia te dotyczyły dostaw węgla jako rekompensaty za część nacjonalizowanych kopalni, będących niegdyś własnością obecnych obywateli Szwajcarii.

${ }^{8}$ EFTA była inicjatywą brytyjską, choć często przedstawianą jako własną przez ówczesnego dyrektora Wydziału Handlowego Federacji Szwajcarskiej - Hansa Schaffnera, późniejszego członka Rady Związkowej. 
bowiem obecna w tamtym okresie na wszystkich ważniejszych forach multilateralnej współpracy. Władze starały się jednak o zachowanie wizerunku państwa zdystansowanego i niezaangażowanego w sprawy międzynarodowe 9 .

Nie zmieniało to faktu, iż rosnąca pozycja EWG, idąca w parze ze stopniowo słabnącym znaczeniem EFTA, wpływała coraz gorzej na interesy gospodarcze Szwajcarii, tym bardziej że pozostałe państwa neutralne, pomimo wcześniejszych wspólnych ustaleń, zaczęły realizować własną politykę wobec Wspólnoty. W tej sytuacji najlepszym rozwiązaniem okazał się układ o wolnym handlu towarami przemysłowymi, który wszedł w życie w roku 1973, a więc wkrótce po rozszerzeniu EWG o Wielką Brytanię, Irlandię oraz Danię. Analogiczny układ podpisały wówczas wszystkie państwa neutralne należące do EFTA, z tą jedynie różnicą, że Szwajcaria nie podpisała klauzuli rozwojowej, oznaczającej możliwość rozciągnięcia liberalizacji handlu na dalsze obszary. Społeczeństwo przyjęło taką politykę rządu z największą aprobatą, o czym świadczyć może wynik referendum, w którym za porozumieniem opowiedziało się $72,5 \%$ obywateli.

Układ o wolnym handlu stanowił podstawę pragmatycznej polityki Szwajcarii wobec EWG, która kontynuowana była w takim kształcie aż do lat 90 . W tym czasie podpisano ponad 130 umów bilateralnych, będących uzupełnieniem układu z roku 1973. Dzięki temu Szwajcaria miała zagwarantowany dostęp do obszernego rynku państw należących do Wspólnoty, który bardzo szybko stał się najważniejszym rynkiem zbytu dla szwajcarskich przedsiębiorstw. Co równie istotne, relacje te nie zaburzały doktryny państwa neutralnego. Dzięki temu interesy gospodarcze i polityczne Szwajcarii nie godziły w jej wizerunek międzynarodowy. Pewnego rodzaju konformizm zaowocował jednak brakiem określonych strategii politycznych wobec integrującej się Europy. Jak podkreślają P. Hug, T. Gees i K. Dannecker, każdy z departamentów (szwajcarski odpowiednik ministerstwa), w ramach swoich kompetencji prowadził osobną politykę, wbrew obiegowej opinii opartą w dużej mierze na aktywności na forach współpracy multilateralnej. Odbywało się to bez jakichkolwiek działań koordynacyjnych ze strony rządu bądź też prób formułowania szerszej strategii ${ }^{10}$. Co więcej, im bardziej działania poszczególnych departamentów były od siebie oderwane, tym mniejsze było poczucie konieczności informowania Rady Związkowej czy opinii publicznej o prowadzonej polityce.

Zapotrzebowanie informacyjne, dotyczące polityki rządu w kwestiach europejskich, zaczęło narastać dopiero po podpisaniu w roku 1986 jednolitego aktu europejskiego rozszerzającego kompetencje EWG. Oczywiście koncepcja stworzenia wspólnego rynku nie wywołała szczególnego entuzjazmu w Szwajcarii. Władze podchodziły do tego pomysłu sceptycznie, tym bardziej że pozytywne wskaźniki gospodarcze zdawały się potwierdzać słuszność dotychczasowej polityki. Rząd w Bernie podejmował jedynie działania zmierzające do zwiększenia

\footnotetext{
${ }^{9}$ P. Hug, T. Gees, K. Dannecker, op. cit., s. 23.

${ }^{10}$ Ibidem, s. 24.
} 
kompatybilności prawodawstwa Szwajcarii ze wspólnotowym, poprzez wspomniany już wcześniej proces tzw. autonomicznego dostosowania (autonome Nachvollzug $)^{11}$. Miało to na celu wyeliminowanie ewentualnych barier w dostępie do wspólnotowego rynku. W drodze wewnętrznego dyskursu politycznego rząd podją jednak decyzję o zmianie dotychczasowego kursu, o czym sygnalizował po raz pierwszy w raporcie z roku $1988^{12}$. Ostatecznie zdecydowano się na złożenie wniosku w sprawie włączenia Szwajcarii do Europejskiego Obszaru Gospodarczego, co od samego początku traktowano jako przystanek na drodze do pełnej integracji ze Wspólnotą ${ }^{13}$.

Z perspektywy czasu widać wyraźnie błędy popełnione przez rząd Szwajcarii w tamtym okresie. Przede wszystkim przesłano opinii publicznej jasny komunikat dotyczący celu strategicznego, jakim jest członkostwo w UE. Społeczeństwo nie było zaś przygotowane na tego rodzaju decyzje, zwłaszcza że dotychczasowa polityka bilateralna zdawała się odpowiadać potrzebom szwajcarskiej gospodarki. Ponadto wniosek nie zawierał zastrzeżeń dotyczących neutralności, czego nie omieszkała uczynić nieco wcześniej Austria ${ }^{14}$. Wydaje się, iż oba te argumenty miały decydujące znaczenia dla przebiegu referendum w sprawie EOG, które przeprowadzono w grudniu roku 1992. Przy rekordowo wysokiej frekwencji, sięgającej 78,3\%, przeciwko włączeniu Szwajcarii do EOG zagłosowało 50,3\% uprawnionych, przy zdecydowanej „negatywnej” przewadze 14 kantonów i 4 półkantonów ${ }^{15}$. Nie ulega wątpliwości, że wynik referendum był sporym zaskoczeniem dla kół rządzących. Z przeprowadzonych nieco wcześniej sondaży wynikało bowiem, iż większość społeczeństwa popiera ideę integracji. Za przyjęciem porozumienia opowiedziały się również obie izby parlamentu - Rada Narodowa („za” 62\%) oraz Rada Kantonów (,za” 85\%). Społeczeństwo okazało się jednak zdecydowanie bardziej podzielone. Sceptycy obawiali się przede wszystkim utraty suwerenności oraz odejścia od zasad neutralności. Nie bez znaczenia były również kwestie materialne, w tym przede wszystkim obawa przed koniecznością otwarcia rodzimego rynku pracy i masowego napływu obcokrajowców.

Odrzucenie wniosku o przystąpienie do EOG wzmocniło ugrupowania konserwatywne, które zyskały wśród obywateli wielu nowych zwolenników. Świadomość szerokiego poparcia dla reprezentowanych poglądów sprzyjała ich rozwojowi i dawała asumpt do śmielszych i energiczniejszych działań (w tym m.in. antyunijnych kampanii). Z biegiem czasu takie partie, jak ludowo-konserwatywna

${ }^{11}$ Zob. T. Cottier, D. Dzamko, E. Evtimov, Die eurokompatible Auslegung es schweizerischen Rechts, [w:] A. Epiney, S. Theuerkauf, F. Riviere, Schweizerische Jahrbuch für Europarecht, Annuaire Suisse de Droit europeen 2003, Bern 2004, s. 360-369.

${ }^{12}$ Zob. rozdział II niniejszej pracy.

${ }^{13}$ Wniosek złożono 20 maja 1992 r.

${ }^{14}$ Austria złożyła wniosek roku 1989.

${ }^{15}$ Rząd zdecydował się na poddanie tej kwestii pod referendum obligatoryjne, a więc wymagające podwójnej większości głosów - obywateli i kantonów. 
SVP, zyskiwały coraz większy wpływ na kształtowanie kierunków działań politycznych państwa na następne lata, zwłaszcza po wygranych w roku 2003 wyborach, dzięki którym formacja ta uzyskała dodatkowe miejsce w siedmioosobowej Radzie Związkowej.

\subsubsection{NOWA POLITYKA WOBEC UNII EUROPEJSKIEJ}

W sytuacji braku poparcia społecznego dla szerszej integracji z UE, rząd Szwajcarii podjął decyzję o wejściu na drogę bilateralną, nastąpiło otwarcie nowego rozdziału w relacjach ze Wspólnotą. Poniższa tabela (tab. 3.1) przedstawia najważniejsze etapy rozwoju nowej polityki Szwajcarii wobec Unii Europejskiej.

Nie ulega wątpliwości, że nowa polityka rządu zyskała znacznie większe poparcie społeczne, o czym świadczą chociażby wyniki przeprowadzanych sondaży nastrojów opinii publicznej oraz rezultaty kolejnych głosowań referendalnych. Nadrzędnym celem Rady Związkowej było zagwarantowanie korzystnych warunków rozwoju gospodarczego przy zachowaniu większości kompetencji decyzyjnych. Najbardziej optymalnym wyjściem było zatem podpisanie kolejnych umów bilateralnych, które charakteryzuje kilka istotnych cech. Po pierwsze, nie prowadzą do stworzenia organizacji o charakterze ponadnarodowym, w ramach której Szwajcaria utraciłaby cześć swoich suwerennych kompetencji na rzecz innego podmiotu. Po drugie, umożliwiają uniknięcie konieczności transponowania pewnych, nie zawsze pozytywnie ocenianych, rozwiązań prawnych do własnego porządku prawnego. Wreszcie oddalają możliwość kontrolowania określonych obszarów, głównie gospodarczych, przez ponadnarodowy organ. Droga bilateralna oznaczała jednym słowem kontynuowanie sprawdzonych i mających szerokie poparcie społeczne metod, wzorowanych na umowach o wolnym handlu $\mathrm{z}$ roku $1972^{16}$.

Powolne przyzwyczajanie i zaznajamianie społeczeństwa szwajcarskiego ze Wspólnotą okazało się skutecznym i jak najbardziej słusznym rozwiązaniem. Oczywiście stopień poparcia nie uległ drastycznemu wzrostowi, ale proeuropejski trend nabierał coraz większych rumieńców. Jak zwykle nie obyło się przy tym bez tradycyjnego już podziału na bardziej otwartą na integrację, francuskojęzyczną część państwa i nastawione konserwatywnie niemieckie kantony. Powoli jednak tendencja ta zaczęła ulegać zatarciu. Pewne różnice światopoglądowe dawało się coraz częściej zauważyć pomiędzy obszarami bardziej zurbanizowanymi a terenami wiejskimi. Mieszkańcy tych ostatnich wykazywali znacznie większy sceptycyzm wobec dążeń integracyjnych. Niemniej jednak poparcie społeczne stopniowo rosło, co zachęcało rząd do dalszych działań.

${ }^{16}$ Poparcie dla tego rodzaju porozumień wynosiło wówczas $72,5 \%$, Europapolitik der Schweiz: Die bilateralne Abkommen, Integrationsbüro EDA/EVD, Bern 2007, s. 1. 
Najważniejsze etapy w relacjach z Unią Europejską

\begin{tabular}{|c|c|}
\hline Data & Wydarzenie \\
\hline 1 & 2 \\
\hline 13.01.1993 & $\begin{array}{l}\text { Komunikat Rady Związkowej dotyczący rezygnacji z rozpoczęcia negocjacji } \\
\text { akcesyjnych z UE }\end{array}$ \\
\hline 05.02 .1993 & $\begin{array}{l}\text { Przedstawienie stronie unijnej propozycji nawiązania współpracy bilateralnej } \\
\text { w } 15 \text { obszarach tematycznych }\end{array}$ \\
\hline 12.12.1994 & $\begin{array}{l}\text { Rozpoczęcie negocjacji dotyczących pierwszego pakietu umów bilateralnych. } \\
\text { Ostatecznie podjęto decyzję o nawiązaniu współpracy w siedmiu obszarach }\end{array}$ \\
\hline 11.12 .1998 & $\begin{array}{l}\text { Zakończenie negocjacji w sprawie pierwszego pakietu umów bilateralnych, tzw. } \\
\text { Bilaterale I }\end{array}$ \\
\hline 21.06 .1999 & Uroczyste podpisanie pakietu Bilaterale I w Luksemburgu \\
\hline 08.10 .1999 & Przyjęcie przez parlament szwajcarski propozycji umów z UE \\
\hline 21.05.2000 & $\begin{array}{l}\text { Referendum w sprawie Bilaterale I. Wniosek poparło } 67,2 \% \text {, przeciwnych było } \\
32,8 \% \text {; frekwencja sięgnęła } 48 \%\end{array}$ \\
\hline 05.07 .2001 & $\begin{array}{l}\text { Rozpoczęcie negocjacji z UE w czterech nowych obszarach tematycznych: zwal- } \\
\text { czanie oszustw, przetworzone produkty rolne, ochrona środowiska, statystyka }\end{array}$ \\
\hline 01.06 .2002 & Wejście w życie pierwszego pakietu umów - Bilaterale I \\
\hline 17.06.2002 & $\begin{array}{l}\text { Rozpoczęcie negocjacji z UE w sześciu kolejnych obszarach tematycznych: } \\
\text { opodatkowanie odsetek, Schengen/Dublin, usługi, media, edukacja, statystyka, } \\
\text { emerytury i renty (likwidacja podwójnego opodatkowania) }\end{array}$ \\
\hline 16.07.2003 & $\begin{array}{l}\text { Rozpoczęcie negocjacji w kwestii rozszerzenia swobody przepływu osób na } \\
\text { dziesięć nowych państw członkowskich UE }\end{array}$ \\
\hline 01.05 .2004 & $\begin{array}{l}\text { Podjęcie decyzji o rozszerzeniu zakresu umów bilateralnych na nowe państwa } \\
\text { członkowskie UE, z wyjątkiem umowy dotyczącej swobody przepływu osób, } \\
\text { która miała być przedmiotem oddzielnych negocjacji }\end{array}$ \\
\hline 25.06.2004 & $\begin{array}{l}\text { Parafowanie umowy w sprawie drugiego pakietu umów bilateralnych - tzw. } \\
\text { Bilaterale II }\end{array}$ \\
\hline 26.10 .2004 & $\begin{array}{l}\text { Podpisanie pakietu Bilaterale II w Luksemburgu, w tym protokołu w sprawie } \\
\text { rozszerzenia swobody przepływu osób na nowe kraje członkowskie UE }\end{array}$ \\
\hline 17.12 .2004 & $\begin{array}{l}\text { Zatwierdzenie przez parlament szwajcarski pakietu Bilaterale II oraz propozycji } \\
\text { rozszerzenia swobody przepływu osób na nowe kraje członkowskie UE }\end{array}$ \\
\hline 05.06 .2005 & $\begin{array}{l}\text { Referendum w sprawie Schengen/Dublin. Wniosek poparło } 54,6 \% \text {, przeciwnych } \\
\text { było } 45,4 \% \text {; frekwencja sięgnęła } 56 \%\end{array}$ \\
\hline 25.09.2005 & $\begin{array}{l}\text { Referendum w sprawie rozszerzenia przepływu osób na nowe kraje członkow- } \\
\text { skie UE. Za wnioskiem opowiedziało się } 56 \% \text { uprawnionych, przeciwnych było } \\
44 \% \text {; frekwencja wyniosła } 53,8 \%\end{array}$ \\
\hline 26.10.2005 & $\begin{array}{l}\text { Rada Związkowa wyraża zgodę na otwarcie przedstawicielstwa Komisji Euro- } \\
\text { pejskiej w Bernie }\end{array}$ \\
\hline 27.02.2006 & $\begin{array}{l}\text { Podpisanie w Brukseli memorandum w sprawie szwajcarskiego wkładu na rzecz } \\
\text { rozszerzenia Unii Europejskiej (tzw. Memorandum of Understanding) }\end{array}$ \\
\hline
\end{tabular}


Tabela 3.1 (cd.)

\begin{tabular}{|c|l|}
\hline 1 & \multicolumn{1}{|c|}{2} \\
\hline 26.11 .2006 & $\begin{array}{l}\text { Przyjęcie memorandum w referendum: 53,4\% opowiedziało się za, przeciwnych } \\
\text { było 46,6\%, frekwencja wyniosła 44,3\% }\end{array}$ \\
\hline 25.06 .2007 & Podpisanie umowy w sprawie udziału Szwajcarii w 7. Programie Ramowym UE \\
\hline 10.07 .2007 & $\begin{array}{l}\text { Rozpoczęcie negocjacji w kwestii rozszerzenia swobody przepływu osób na } \\
\text { Bułgarię i Rumunię }\end{array}$ \\
\hline 12.12 .2008 & Wejście w życie układu Schengen/Dublin \\
\hline 08.02 .2009 & $\begin{array}{l}\text { Referendum w sprawie rozszerzenia swobody przepływu osób na Bułgarię } \\
\text { i Rumunię. Za rozszerzeniem opowiedziało się 59,6\%, przeciwnych było 40,4\%. } \\
\text { Frekwencja wyniosła 50,9\% }\end{array}$ \\
\hline
\end{tabular}

Źródło: dane według Integrationsbüro EDA/EVD.

Już w lutym roku 1993 zaproponowano UE podjęcie rozmów w 15 obszarach tematycznych. Należy w tym miejscu podkreślić, że z inicjatywą nawiązania współpracy bilateralnej wyszła Szwajcaria. Początkowo stanowisko Unii Europejskiej było raczej niechętne. Uważano tego typu formę współpracy za przestarzałą, nieodpowiadającą nowym wyzwaniom globalizacyjnym ${ }^{17}$. Ostatecznie Rada UE ustosunkowała się jednak przychylnie do propozycji Szwajcarii, zatwierdzając siedem obszarów negocjacyjnych dotyczących swobodnego przepływu osób, badań, transportu lotniczego i powietrznego, rolnictwa, handlu oraz zamówień publicznych ${ }^{18}$. Niezwykle istotnym, z punktu widzenia Unii, czynnikiem warunkującym zgodę na przystąpienie do negocjacji była konieczność powiązania wszystkich umów w jeden pakiet. Unia Europejska chciała w ten sposób uniknąć możliwości odrzucenia przez społeczeństwo szwajcarskie któregoś z porozumień. Rezygnacja z jednej umowy oznaczałaby bowiem, zgodnie z tzw. zasadą gilotyny, unieważnienie pozostałych. Zasada ta miała przede wszystkim uchronić najbardziej kontrowersyjne porozumienie, dotyczące swobodnego przepływu osób. Punkt ten stał się piętą achillesową całego pakietu porozumień, najchętniej wykorzystywanym w prowadzonej przez ugrupowania prawicowe kampanii antyunijnej ${ }^{19}$. Zrealizowane w tym samym czasie badania wskazywały ciągły wzrost poparcia dla działań rządu, sięgającego w drugiej połowie lat 90 . ok. $60 \%{ }^{20}$. Podobne nastroje panowały wśród obywateli państw Wspólnoty, którzy obok Norwegii najchętniej widzieliby w Unii właśnie Szwajcarię ${ }^{21}$.

${ }^{17}$ G. Kreis, Ein langer Weg in Etappen, [w:] G. Kreis (red.), Schweiz-Europa: wie weiter? Kontrollierte Personenfreizügigkeit, Verlag Neue Zürcher Zeitung, Zürich 2009, s. 22.

${ }^{18}$ Bruksela zgodziła się na negocjowanie 7 z 15 zaproponowanych przez Berno obszarów.

${ }^{19}$ Zob. L. Goetschel, Die Einführung der Personenfreizügigkeit durch die Schweiz. Eine demokratisch legitimierte Revolution, [w:] G. Kreis (red.), op. cit., s. 136-139.

${ }^{20}$ D. Popławski, Perspektywy przystapienia Szwajcarii do Unii Europejskiej, [w:] P. Łaciński (red.), Dylematy rozszerzenia Unii Europejskiej, Warszawa 2006, s. 177.

${ }^{21}$ L. Goetschel, Aussenpolitik im Wandel, Synthese des NFP 42, Bern 2000, s. 26. 
Oficjalne negocjacje rozpoczęły się w grudniu 1994 r. Jak już wcześniej wspomniano, Szwajcarii zależało przede wszystkim na wypracowaniu takiego kształtu umowy, który nie wymagałby transponowania aquis communitaire do szwajcarskiego porządku prawnego. Postulat ten nie był jednak możliwy do spełnienia w stu procentach. Unia Europejska dała jasno do zrozumienia, że umowy bilateralne muszą być oparte na prawie unijnym, które z kolei jest efektem wieloletnich negocjacji pomiędzy poszczególnymi państwami członkowskimi, a więc z zasady nie jest możliwe wprowadzenie do niego jakichkolwiek zmian. Szwajcaria musiała zatem siłą rzeczy dostosować się do wymogów stawianych przez Unię. Mogła jedynie liczyć na wynegocjowanie najkorzystniejszych możliwych okresów przejściowych. Było to szczególnie istotne w przypadku umowy o swobodzie przepływu osób. Na korzyść Szwajcarii przemawiał jedynie fakt, iż prawodawstwo szwajcarskie od dłuższego czasu poddawane było analizie pod kątem zgodności z prawem unijnym. Dzięki samodzielnie wypracowanym przez lata procesom dostosowawczym, w momencie rozpoczęcia negocjacji z UE, relatywnie niewielka część przepisów wymagała ujednolicenia z prawem wspólnotowym. Dzięki temu, przynajmniej teoretycznie, kompetencje decyzyjne w zakresie stanowienia autonomicznego prawa zostały zachowane. W odniesieniu do niemal wszystkich umów obowiązywała zatem zasada równoważności przepisów prawnych. Jak zauważa E. Honegger, formalna niezależność była jednak pozorna ${ }^{22}$. Biorąc pod uwagę zawartość merytoryczną, mieliśmy do czynienia z faktycznym transponowaniem przepisów prawnych UE do porządku prawnego Szwajcarii. Istotne jest również, że w przypadku jakichkolwiek zmian prawnych Unii Europejskiej, Szwajcaria nie ma praktycznie żadnej możliwości wpływu na wynikające $z$ tego faktu korekty w umowach dwustronnych. Przyznano jej jedynie prawo do uczestniczenia $\mathrm{w}$ posiedzeniach kilku komisji ${ }^{23}$, jednakże tylko z głosem o charakterze konsultacyjnym. Ponadto, z uwagi na fakt, że decyzje podejmowane przez powyższe komisje mają wyłącznie charakter doradczy wobec posiedzeń Komisji Europejskiej, faktyczny wpływ na stanowienie prawa UE pozostaje marginalny.

Kolejnym przedmiotem negocjacji z UE była kwestia nadzorowania umów, szczególnie w aspekcie zmian prawnych. Chodziło tutaj o to, aby stworzyć ciało, którego zadaniem będzie kontrola właściwego wdrażania zawartych porozumień. Przyjęto jednakże wymóg, iż organ ten nie może mieć charakteru ponadnarodowego, gdyż oznaczałoby to w praktyce oddanie części kompetencji decyzyj-

${ }^{22}$ Zob. E. Honegger, Die Gemischten Ausschüsse in den Sektoriellen Abkommen zwischen der Schweiz und der EG, IDHEAP, Chavannes-Lausanne 2004, s. 40-42.

${ }^{23}$ Umowy przewidują możliwość uczestniczenia przedstawicieli strony szwajcarskiej w Komisji ds. programów badawczych UE, Komisji Administracyjnej ds. zabezpieczenia społecznego pracowników migrujących, w posiedzeniach Grupy Koordynacyjnej ds. wzajemnego uznawania dyplomów wyższych uczelni, w Komitecie Doradczym ds. stosowania zasad konkurencji w transporcie lotniczym. 
nych. Ustalono zatem, że będą się tym zajmować tzw. komisje mieszane, złożone z przedstawicieli UE oraz Szwajcarii, których rola ograniczać się będzie do bieżącego przeglądu prawodawstwa, wzajemnej wymiany informacji oraz wprowadzenia drobnych modyfikacji w umowach ${ }^{24}$. Przekształcenia te nie mogły jednakże dotyczyć zasadniczych aspektów merytorycznych, lecz tylko niezbędnych zmian w załącznikach do poszczególnych porozumień. W przypadku konieczności przeprowadzenia poważniejszych modyfikacji ustalono, że zwoływane będą oddzielne spotkania dwustronne.

Powyższe ustalenia pozostają bez większego znaczenia dla UE, która dysponuje $\mathrm{w}$ zasadzie pełną swobodą $\mathrm{w}$ zakresie stanowienia prawa wspólnotowego, będącego, jak już wcześniej wspomniano, wyznacznikiem treści umów bilateralnych. Inaczej wygląda sytuacja w przypadku Szwajcarii. Ponieważ w jej interesie leży, aby wszelkie modyfikacje w krajowym porząaku prawnym były zgodne z wykładnią prawa wspólnotowego (celem uniknięcia ewentualnych trudności w realizacji postanowień umów dwustronnych) każda, nawet drobna poprawka w tych umowach, może pociągać za sobą konieczność zmiany prawa na poziomie federalnym. Mając na względzie ograniczenia wynikające $\mathrm{z}$ uzależnienia procesu decyzyjnego od demokracji bezpośredniej w Szwajcarii, określone umową relacje dwustronne z UE mogą być oceniane jako niesprawiedliwe ${ }^{25}$.

W trakcie rozmów z UE doszło w Szwajcarii do wydarzeń, które zaciążyły na atmosferze, jaka towarzyszyła negocjacjom. Jeszcze w lutym 1994 r. społeczeństwo szwajcarskie przyjęło w referendum inicjatywę dotyczącą ochrony obszarów alpejskich (tzw. Alpen-initiative). Przewidywała ona ograniczenia w ruchu drogowym oraz przeniesienie części transportu kołowego na tory kolejowe ${ }^{26}$. Decyzja ta wywołała sporą konsternację w Komisji Europejskiej, zdaniem której nowa poprawka konstytucyjna jest niezgodna z zasadami przyjętymi przez kraje UE. Podobną reakcję wywołało odrzucenie, w czerwcu roku 1994, propozycji wprowadzenia ułatwień $\mathrm{w}$ zakresie naturalizacji młodych emigrantów, a także rozluźnienia przepisów dotyczących nabywania ziemi przez obcokrajowców. Jak zauważa G. Kreis atmosferze, w której prowadzone były negocjacje, nie sprzyjały podnoszone, szczególnie w latach 1996-1998, zarzuty dotyczące polityki Szwajcarii w trakcie II wojny światowej, podobnie jak występowania w niej rzekomych postaw nacjonalistycznych ${ }^{27}$.

${ }^{24}$ Wyjątek stanowią komisje nadzorujące układy dotyczące badań naukowych (funkcje te przejęly organy powstałe na mocy podpisanego jeszcze w 1986 r. porozumienia o współpracy naukowej), opodatkowania lokat bankowych i podwójnego opodatkowania dochodów obywateli unijnych (funkcje kontrolne sprawują tutaj poszczególne rządy, za porozumieniem stron) oraz rolnictwa (ustanowiono w tym zakresie dwie oddzielne komisje: jedna ds. ogólnych oraz druga odpowiedzialna wyłącznie za sprawy weterynaryjne).

${ }^{25}$ Por. B. Spinner, Rechtliche Grundlagen und Grenzen für bilaterale Abkommen, [w:] D. Felder, Ch. Kaddous, Accords bilatéraux Suisse - UE, Bilaterale Abkommen Schweiz - EU, Dossiers de droit européen no $8 D$. (ed.), Basel-Genf-München-Brüssel 2001, s. 13-20.

${ }^{26}$ Art. 84 konstytucji Szwajcarii.

${ }^{27}$ G. Kreis, op. cit. 
Negocjacje z UE nie należały zatem do najłatwiejszych, zwłaszcza że w takich obszarach, jak swobodny przepływ osób czy transport lądowy obie strony zgłaszały sporo zastrzeżeń. Pewien przełom nastąpił w roku 1996. Jego efektem było przyjęcie rozwiązań w dwóch, najbardziej wrażliwych tematach. Ustalono, że w zakresie swobody przepływu osób oraz transportu obowiązywać będą korzystne dla Szwajcarii okresy przejściowe. W przypadku tego pierwszego zagadnienia chodziło przede wszystkim o zastosowanie instrumentów ochronnych, które przeciwdziałałyby negatywnym skutkom otwarcia rynku pracy dla obcokrajowców. Problemem była kwestia ubezpieczeń i zasiłków dla osób bezrobotnych, a także przeciwdziałanie zjawiskom tzw. turystyki zarobkowej. Ustalono również regulacje związane z podejmowaniem pracy przez osoby zamieszkujące tereny przygraniczne. Miało to nie tylko wymierne znaczenie w zakresie przeciwdziałania bezrobociu i ochrony przed dumpingiem socjalnym, lecz również odbierało przeciwnikom integracji dość istotny argument w dyskusji. Ponadto niektóre instrumenty ochronne nie zostały wprowadzone na zasadzie wzajemności, tj. nie obowiązywały obywateli Szwajcarii, którzy chcieliby podjąć pracę na terenie państw UE. Warto zauważyć, że wszelkie ograniczenia dla obywateli UE zostały zniesione dopiero po upływie 12 lat (licząc łącznie z klauzulą ochronną, pozwalającą na ponowne wprowadzenie ograniczeń w zakresie podejmowania pracy przez obcokrajowców, jeżeli wzrost ich liczby w danym roku będzie wyższy niż 10\% w stosunku do średniej z trzech ostatnich lat). W przypadku obywateli Szwajcarii okres ten wynosi zaledwie dwa lata. Zagwarantowano sobie również pewną furtkę, umożliwiającą rezygnację z umowy dotyczącej swobody przepływu osób. Zgodnie z ustaleniami rząd Szwajcarii był zobligowany do zakomunikowania Unii Europejskiej chęci lub odmowy przedłużenia umowy na kolejne lata do końca czerwca 2009 r. Miało to na celu przede wszystkim uspokojenie opinii publicznej, przez danie jej do zrozumienia, że wyrażenie zgody na podpisanie pierwszego pakietu porozumień nie oznacza utraty kontroli nad rozwojem współpracy w przyszłości. Biorąc jednak pod uwagę obowiązywanie wspomnianej już zasady gilotyny, podjecie takiej decyzji wiązałoby się z daleko idącymi konsekwencjami. Jak pokazują wyniki kolejnych głosowań z roku 2005 oraz 2009 społeczeństwo wykazuje w takich przypadkach daleko idący pragmatyzm, który stoi jednak w sprzeczności z zasadą swobodnego wyboru.

Od samego początku rząd w Bernie musiał się również liczyć z faktem, iż statyczne w zamierzeniu umowy wykazują wiele cech dynamicznych. Odnosi się to zwłaszcza do kwestii swobody przepływu osób. Było bowiem do przewidzenia, że dalsze rozszerzenia Unii wymuszą na Szwajcarii objęcie nowych członków Wspólnoty tymi samymi regulacjami. W przeciwnym razie doprowadzono by do stworzenia dwóch kategorii państw członkowskich, co z pewnością zostałoby uznane za swoistą dyskryminację. Fakt ten mógłby być z kolei podstawą do jednostronnego wypowiedzenia umów przez Brukselę. 
Widać zatem, że UE postawiła Szwajcarię w sytuacji bez wyjścia. Rząd musiał robić wszystko, aby kwestia rozszerzenia swobody nie była przedmiotem targów wewnątrzpolitycznych, a przede wszystkim, by nie zagroziła funkcjonowaniu pozostałych umów. Sprawa otwarcia rynku pracy dla obcokrajowców traktowana jest zresztą przez przeciwników integracji jako bomba z opóźnionym zapłonem. Trudno bowiem określić długofalowe skutki takiej decyzji, biorąc pod uwagę chociażby fakt, iż kwestia rozszerzenia UE na nowe państwa podejmowana jest w okresie, w którym trudno o faktyczną i miarodajną tego ocenę. W przypadku ,starych” państw UE mamy do czynienia $\mathrm{z}$ istotnie wyższym wskaźnikiem zamożności i relatywnie niższym poziomem bezrobocia ${ }^{28}$. Należy zatem spodziewać się znacznie większego zainteresowania podjęciem pracy w Szwajcarii wśród obywateli nowych państw członkowskich UE. Na obiektywną ocenę oddziaływania swobody przepływu osób na szwajcarską gospodarkę trzeba zatem poczekać do momentu zniesienia wszystkich instrumentów ochronnych, co nastąpi w roku 2014, a w przypadku Bułgarii i Rumunii w 2019 r. (włączając klauzulę ochronną)29.

Ostatecznie negocjacje zakończono w grudniu 1998 r. W lutym następnego roku umowy parafowano, a oficjalne ich podpisanie nastąpiło 21 czerwca w Luksemburgu. Sygnatariuszami po stronie Szwajcarii byli członkowie rządu - Pascal Couchepin oraz Joseph Deiss. Projekt pierwszego pakietu - Bilaterale I - poddano następnie pod głosowanie w parlamencie. Obie izby przyjęły wnioski znakomitą większością głosów ${ }^{30}$. Zgodnie z obowiązującym w Szwajcarii procesem decyzyjnym, każda nowa uchwała parlamentu może być poddana pod głosowanie fakultatywne. Tak też się stało i w tym przypadku. Komitet złożony z przedstawicieli Lega dei Ticinesi oraz Schweizer Demokraten zebrał wymagane 50000 podpisów pod wnioskiem dotyczącym referendum ${ }^{31}$. Zostało ono przeprowadzone 21 maja 2000 r. Był to pierwszy, od czasów niechlubnego głosowania w sprawie EOG, test na poparcie nowej polityki europejskiej rządu. Obawy związane z wynikiem referendum okazały się niepotrzebne. Wniosek przyjęto większością 67,2\% głosów ${ }^{32}$. Widać było wyraźnie, że polityka władz Szwajcarii uzyskała duże poparcie społeczne, pomimo dość aktywnych działań ze strony ugrupowań konserwatywnych, operujących populistycznymi hasłami, związa-

${ }^{28}$ Pewne zawirowania w tej kwestii wywołało spowolnienie gospodarcze z roku 2008.

${ }^{29}$ Personenfreizügigkeit: Informationsblatt, Integrationsbüro EDA/EVD, Bern 2009, s. 2.

${ }^{30}$ W Radzie Narodowej stosunkiem głosów 183 do 11, a w Radzie Kantonów jednomyślnie.

31 Wniosek dotyczył umowy o swobodzie przepływu osób, jednakże ze względu na obowiązywanie klauzuli gilotyny rząd zmuszony był poddać pod głosowanie cały pakiet. Zebranie 50000 podpisów okazało się dość trudne. Zajmowały się tym m.in. specjalnie wynajęte do tego firmy.

${ }^{32}$ Zdaniem niektórych politologów na wynik referendum miało także wpływ przyzwyczajenie obywateli do tematu integracji. Propozycja włączenia Szwajcarii do EOG była dla wielu ogromnym zaskoczeniem. Po ośmiu latach od tego wydarzenia zmieniła się świadomość, a także poziom wiedzy obywateli dotyczący korzyści wynikających z integracji i ewentualnych negatywnych skutków izolacji. Zob. G. Kreis, op. cit., s. 33. 
nymi przede wszystkim z kontrowersyjną umową dotyczącą swobody przepływu osób. Koła prawicowe, w tym głównie SVP, snuły wizje zalewu szwajcarskiego rynku pracy przez przybyszów ze Wschodu, których pobyt oznaczać miał także wzrost przestępczości oraz znaczne obciążenie budżetu państwa, spowodowane zwiększeniem wydatków socjalnych. Podkreślano pojawiające się coraz częściej problemy z asymilacją emigrantów, których źródła upatrywano przede wszystkim w nastawieniu samych obcokrajowców. Retoryce tej sprzyjały pogarszające się wyniki gospodarcze państwa, związane z ogólnoświatową tendencją, która dotknęła oczywiście nie tylko Szwajcarię. Przeważająca część społeczeństwa najwyraźniej nie podzielała tych obaw. Na wynik głosowania wpłynęły zapewne również aktywne działania ze strony środowisk gospodarczych. Jeszcze w okresie kampanii dotyczącej EOG przedsiębiorcy podkreślali potrzebę otwarcia rynku pracy dla wykwalifikowanej kadry, której braki gospodarka szwajcarska coraz bardziej odczuwała. Argumentowano, iż początkowe wydatki, związane z wdrażaniem umów bilateralnych, mogą co prawda spowodować dodatkowe obciążenia dla budżetu, szacowane wstępnie na 800 mln franków, wyliczono jednak, że w ciągu następnych dziesięciu lat należy oczekiwać pobudzenia gospodarki, co skutkować będzie wzrostem PKB i dodatkowymi wpływami do budżetu na poziomie 8 mld franków ${ }^{33}$.

Pozytywny wynik referendum umożliwił władzom ratyfikowanie umowy, co nastąpiło 16 października 2000 r. Od tego momentu nastąpił niemal dwuletni okres wyczekiwania, związany z koniecznością ratyfikowania umowy przez wszystkie państwa członkowskie UE. Ponieważ kilka z nich zasygnalizowało problemy i poprosiło o nieco więcej czasu, całość wydłużyła się do wiosny roku 2002. Ostatecznie umowy weszły w życie z dniem 1 czerwca 2002 r.

Rząd oceniał podpisany pakiet niezwykle pozytywnie. Podkreślano gospodarcze i politycznie znaczenie zawartych porozumień, eliminujących przede wszystkich groźbę izolacji Szwajcarii oraz stwarzających korzystne warunki dalszej, stopniowej integracji ${ }^{34}$. Przystąpienie Szwajcarii do UE, w dłuższej perspektywie, nie zostało bowiem w oficjalnych komunikatach odrzucone. Szczególny nacisk kładziono jednak na korzyści ekonomiczne, wynikające ze wzajemnej współpracy, gdyż te, z oczywistych względów, były najbardziej popularne, a zarazem najmniej podważalne. Publikowane w rządowych sprawozdaniach dane zdają się potwierdzać ten pogląd ${ }^{35}$. Z punktu widzenia Szwajcarii szczególnie korzystnym aspektem podpisanych porozumień była możliwość kontynuowania własnej polityki monetarnej i fiskalnej. Utrzymanie na niskim poziomie podatków oraz korzystnego kursu franka umożliwiało zwiększenie konkurencyjności na rynku europejskim, co zresztą, w późniejszym okresie, stanie się punktem zapalnym w sporze pomiędzy UE a Szwajcarią.

${ }^{33}$ G. Kreis, op. cit., s. 30.

${ }^{34}$ Zob. Schweiz-Europäischen Union: Integrationsbericht 1999, dostępny na stronie www. europa.admin.ch.

${ }^{35}$ Europapolitik der Schweiz: Die bilaterale Abkommen..., s. 6. 
Jeszcze przed wejściem w życie nowych porozumień rząd w sprawozdaniu politycznym za rok 2000 potwierdzał dalsze dążenia Szwajcarii do pełnej integracji ze Wspólnotą ${ }^{36}$. Unikano konkretnych ram czasowych, ale przedstawiono kryteria, warunkujące przystąpienie do UE. Były nimi pozytywne efekty wdrażania dotychczasowych umów oraz pełne poparcie społeczne i zgoda wewnątrzpolityczna na dalszą integrację. Na te pierwsze nie trzeba było długo czekać, ale konsensus polityczny okazał się o wiele trudniejszy do osiągnięcia. Kontrowersje i spory wokół współpracy bilateralnej z Unią nie cichły, a zdobycie silniejszej pozycji w Radzie Związkowej przez prawicową i konserwatywną SVP sprzyjało ich nasileniu.

Środowiska popierające integrację również nie pozostawały bierne. Pozytywny wynik głosowania w sprawie Bilaterale I zachęcił ugrupowania proeuropejskie do podjęcia aktywniejszych działań na rzecz jak najszybszej integracji ze Wspólnotą. Ugrupowania skupione wokół Nowego Europejskiego Ruchu Szwajcarii (Neue Europäische Bewegung Schweiz) ${ }^{37}$ wystąpiły z propozycją uchwalenia poprawki konstytucyjnej, zobowiązującej rząd do natychmiastowego rozpoczęcia negocjacji akcesyjnych z UE. Inicjatywa Tak dla Europy została poddana pod głosowanie w kwietniu $2001 \mathrm{r}$. Wynik okazał się dla jej pomysłodawców dotkliwą porażką. Prawie $77 \%$ głosujących uznało, że podjęcie rozmów w sprawie akcesji do UE jest zdecydowanie przedwczesne. Negatywnie ustosunkowali się do tego nie tylko zagorzali przeciwnicy integracji, ale również osoby określające siebie jako otwarte, ale obawiające się ostatecznego związania ze Wspólnotą, przynajmniej w ciągu najbliższych kilku lat. Większość społeczeństwa akceptuje integrację, ale tylko na poziomie gospodarczym, który nie wymaga drastycznych ingerencji w dotychczasowy stan prawny Szwajcarii. Wszelkie modyfikacje nie są mile widziane, a utrzymanie status quo w tym przypadku traktowane jest najczęściej w kategoriach interesu państwowego.

Współpracę z Brukselą systematycznie kontynuowano. Jeszcze w podpisanych w roku1999 Bilaterale I obie strony deklarowały chęć dalszej intensyfikacji działań na rzecz integracji i rozwiązania kolejnych spornych kwestii w kontaktach dwustronnych. W praktyce jednak Bruksela okazała nieco więcej sceptycyzmu wobec powiązań sektorowych, zarzucając Szwajcarii unikanie mniej korzystnych dla niej regulacji, głównie w sferze podatkowej. Przystąpienie do dalszych rozmów uzależniano od zgody władz w Bernie na objęcie Szwajcarii systemem unijnego opodatkowania odsetek od lokat bankowych (dyrektywa oszczędnościowa) oraz podjęcia zdecydowanych działań na rzecz zwalczania oszustw podatkowych. Ten ostatni punkt obejmował również tajemnicę bankowąą ${ }^{38}$.

${ }^{36}$ Zob. Aussenpolitischer Bericht 2000 vom 15. November 2000, BBI 2001261.

${ }^{37}$ Zob. www.europa.ch.

${ }^{38}$ Zob. T. Gisselbrecht, Besteuerung von Zinserträgen in der Europäischen Union. Abschied vom Schweizerischen Bankgeheimnis?, „Baslerschriften zur europeischen Integration” 2000, Nr. 50, źródło: www.europa.unibas.ch. 
W odpowiedzi na stanowisko UE władze Szwajcarii sformułowały własne warunki. Domagano się rozszerzenia negocjacji również na inne, istotne dla Szwajcarii, obszary, nakreślone wstępnie jeszcze w trakcie rozmów nad Bilaterale I. Chodziło tutaj o współpracę w zakresie polityki azylowej, migracyjnej i bezpieczeństwa w ramach układów Schengen/Dublin. Rząd zabiegał również o gwarancje dotyczące utrzymania tradycji tajemnicy bankowej oraz równoczesnego prowadzenia negocjacji we wszystkich spornych kwestiach i ich późniejszego wdrażania, przy rezygnacji jednakże z niewygodnej ,zasady gilotyny”.

Po kilkukrotnej wymianie not rozpoczęto, trwające od czerwca 2002 r., negocjacje w dziesięciu obszarach tworzących wspólnie pakiet Bilaterale II. W trakcie rozmów napotkano szczególnie wiele trudności w zakresie liberalizacji rynku usług. Obie strony postanowiły czasowo zawiesić negocjacje w tej sprawie i odłożyć je na później. Dosyć szybko udało się za to osiągnąć konsensus w pozostałych obszarach. Ostatnie sporne kwestie rozwiązano przy okazji szczytu Szwajcaria-Unia Europejska w maju roku 2004. Całość porozumień, pod nazwą Bilaterale II, podpisano w październiku tego samego roku w Luksemburgu. W przeciwieństwie do wcześniejszych porozumień poruszono o wiele więcej zagadnień, wybiegających znacznie dalej poza zwykłe porozumienia o charakterze gospodarczym. Bilaterale II były zatem wyraźnie śmielszym krokiem we wzajemnych stosunkach pomiędzy Bernem a Brukselą. Obie strony wydawały się zadowolone z kształtu osiągniętego porozumienia. Ostateczny sukces zależał jednak od przyzwolenia szwajcarskiego społeczeństwa, które na drodze fakultatywnego referendum mogło odrzucić wypracowane umowy. W konsekwencji pod głosowanie poddano jedynie porozumienie dotyczące współpracy w ramach Schengen/Dublin ${ }^{39}$. Na decyzję o przeprowadzeniu referendum w tej sprawie wpływ mieli przede wszystkim ludowcy, których hasła nawołujące do utrzymania pełnej neutralności i zaostrzenia polityki imigracyjnej trafiały na coraz podatniejszy grunt. Potwierdzeniem tego poparcia był doskonały wynik wyborczy z roku 2003. Ludowcy zdobyli wówczas aż dwa miejsca (kosztem CVP) w siedmioosobowej Radzie Związkowej, przełamując tym samym ustanowioną w roku 1959, tzw. magiczną formułę, według której dysponowali w niej tylko jednym miejscem. Ostatecznie jednak niewielką przewagą głosów $(54,6 \%)$ społeczeństwo opowiedziało się za przyjęciem pakietu Bilaterale $I I^{40}$. Umowy ratyfikowano 20 marca $2006 \mathrm{r}$.

W przeciwieństwie do układów z Bilaterale I, nowo podpisane porozumienia wchodziły w życie w różnym czasie. Począwszy od marca roku 2005 stopniowo wdrażano kolejne regulacje, zwlekając jedynie z układem Schengen/Dublin

${ }^{39}$ Zgodnie $\mathrm{z}$ art. 140 Konstytucji Związkowej żaden z układów wchodzących w skład $\mathrm{Bi}$ laterale II nie podlegał obligatoryjnemu głosowaniu, ponieważ nie spełniał kryteriów organizacji ponadnarodowej ani nie był układem zbiorowego bezpieczeństwa.

${ }^{40}$ Zob. Bundesratsbeschluss über das Ergebnis der Volksabstimmung vom 5. Juni 2005, źródło: www.europa.admin.ch. 
oraz dotyczącym zwalczania oszustw. Wymagały one bowiem głębszej analizy dotychczasowych przygotowań Szwajcarii do ich pełnego wdrożenia.

Jeszcze w trakcie negocjacji nad pakietem Bilaterale II obie strony musiały również podjąć problem spodziewanego rozszerzenia Unii o dziesięć nowych państw. Zgodnie z przyjętymi już w pakiecie Bilaterale I ustaleniami Szwajcaria była zobligowana do objęcia nowych państw członkowskich tymi samymi regulacjami. Także i tym razem najwięcej kłopotu przysparzała umowa dotycząca swobody przepływu osób. Podjęto decyzję, że kwestia rozszerzenia ujęta zostanie w protokole dodatkowym, który miał być następnie zatwierdzony przez parlament Szwajcarii i ewentualnie poddany pod głosowanie w referendum. Rozmowy w tej sprawie rozpoczęły się w lipcu 2003 r. UE zależało na uregulowaniu wszystkich kwestii do czasu kolejnego rozszerzenia Wspólnoty, tj. do maja roku 2004. Ostatecznie protokół dodatkowy podpisano w październiku jako uzupełnienie dossier pierwszego pakietu porozumień ${ }^{41}$. Od tego momentu nastąpił proces wewnątrzpolitycznego dyskursu, prowadzonego na forum parlamentu oraz $\mathrm{w}$ debacie publicznej. Jego kulminacją było referendum, przeprowadzone dzięki zebraniu wymaganej liczby podpisów przez ugrupowania prawicowe - SVP (szczycące się dostarczeniem ponad połowy podpisów), Szwajcarskich Demokratów, Lega dei Ticinesi oraz stowarzyszenia Auns (Aktion für unabhängige und neutrale Schweiz $)^{42}$. Referendum przeprowadzono we wrześniu 2005 r., a więc kilka miesięcy po głosowaniu w sprawie umowy Schengen/Dublin ${ }^{43}$. Zakończyło się wynikiem pozytywnym. Przy frekwencji wynoszącej 53,8\%, za opowiedziało się $56 \%{ }^{44}$.

Głosowania w sprawach Schengen/Dublin oraz swobody przepływu osób, choć zakończone powodzeniem, nie należy traktować jako wyrazu społecznego poparcia dla integracji. Oczywiście rząd traktował wyniki kolejnych głosowań jako legitymizację własnych działań. Należy jednak zauważyć, że w tych dwóch głosowaniach obywatele opowiedzieli się nie tyle za Unią, której ocena pozostawała sprawą drugorzędną, ile bardziej chodziło tutaj o zajęcie stanowiska wobec przyszłego rozwoju gospodarczego Szwajcarii. Podobnie rzecz się miała z polityką azylową, bezpieczeństwem oraz podstawowymi zagadnieniami związanymi z otwarciem kraju na szerszą, międzynarodową współpracę. Wielu komentatorów podkreśla, że głównym przedmiotem debaty w kampanii przedreferendalnej były sprawy gospodarcze - dostęp do środkowoeuropejskich rynków, możliwość pozyskania wykwalifikowanych pracowników. Otwarcie

${ }^{41}$ Botschaft zur Genehmigung des Protokolls zum Freizügigkeitsabkommen zwischen der Schweiz und EG vom 1. Oktober 2004, BBI Nr. 44, s. 5891-5930.

${ }^{42} \mathrm{~W}$ sumie zebrano 93000 podpisów (wymagane 50000 ).

${ }^{43}$ Decyzją rządu protokół dodatkowy zostały poddany pod głosowanie łącznie z instrumentami ochronnymi dotyczącymi płacowego i socjalnego dumpingu. Miało to na celu zmniejszenie prawdopodobieństwa jego odrzucenia w referendum.

${ }^{44}$ Szczegółowe informacje na temat wyników głosowania dostępne są na stronie: http://www. admin.ch/ch/d/pore/va/20050925/index.html (10.03.2008). 
rodzimego rynku pracy łączono oczywiście z szerszym efektem społecznym, tj. zwiększeniem migracji zarobkowej, bezrobociem, dumpingiem socjalnym, problemami asymilacyjnymi. Nie bez znaczenia pozostawały również różnice kulturowe wynikające przede wszystkim z relatywnie niskiego poziomu wiedzy na temat mieszkańców Europy Środkowowschodniej. Głównie jednak skupiano się na aspektach ekonomicznych, które zresztą okazały się najbardziej przekonującymi argumentami.

Należy zauważyć, że wśród zwolenników rozszerzenia byli też politycy SVP, łącznie z Chrostophem Blocherem, który piastując wówczas stanowisko ministerialne był niejako zmuszony do podzielania proeuropejskiej linii rządu. Rada Związkowa określiła protokół dodatkowy jako konsekwentną realizację polityki imigracyjnej, pozytywnie oceniając przy tym możliwości integracyjne obywateli nowych państw UE ${ }^{45}$. Oczywiście zdawano sobie sprawę, iż postawa Blochera była $\mathrm{w}$ tym czasie wynikiem chłodnej kalkulacji i nie do końca pozostawała $\mathrm{w}$ zgodzie z jego prawdziwymi intencjami. Można jednak spotkać się z opinią, że właśnie dzięki obecności Blochera w rządzie i niejako wymuszonemu poparciu dla współpracy bilateralnej protokół dotyczący swobodnego przepływu osób został przyjęty w referendum ${ }^{46}$. Kwestia współpracy z Unią Europejską pozostawała na uboczu debaty politycznej. Wskazywano jedynie, że wyrażenie zgody na rozszerzenie swobody przepływu osób na kraje, które przystąpiły do UE w roku 2004, oznaczać będzie konieczność podjęcia analogicznej decyzji wobec kolejnych państw, które już teraz aspirują do członkostwa we Wspólnocie. Perspektywa przystąpienia państw o zdecydowanie niższym poziomie zamożności, jak Bułgaria, Rumunia czy Turcja, z oczywistych względów wywoływała wiele obaw.

Od momentu rozpoczęcia negocjacji nad porozumieniami bilateralnymi UE nie ukrywała, iż ma nadzieję, że rząd Szwajcarii zgodzi się na współfinansowanie wydatków związanych z kolejnym rozszerzeniem Unii. Oczywiście najlepszym wariantem, z punktu widzenia UE, byłaby pełna integracja Szwajcarii ze Wspólnotą. Państwo to stałoby się wówczas najpewniej płatnikiem netto. Ten wariant był jednak w najbliższym czasie raczej mało realny.

Coraz częściej pojawiające się głosy krytyki wobec polityki Szwajcarii, nastawionej na czerpanie korzyści z integracji europejskiej, przy jednoczesnym unikaniu związanych z nią kosztów sprawily, że rząd Szwajcarii podjął decyzję o wyasygnowaniu dodatkowych środków na wsparcie polityki spójności UE. Odpowiednie porozumienie $\mathrm{w}$ tej sprawie podpisane zostało $\mathrm{w}$ lutym roku $2006^{47}$. Zgodnie z nim Szwajcaria przeznaczyć miała w ciągu pięciu lat jeden miliard

${ }^{45}$ Erläuterungen des Bundesrates. Volksabstimmung vom 25 September 2005. Źródło: http:// www.admin.ch/ch/d//pore/va//20050925/explic/index.html (22.07.2010), a także Pressekonferenz des Bundesrates vom 04.07.2005, źródło: www.europa.admin.ch.

${ }^{46}$ Zob. wywiad z Wernerem Seiztem dla radia DRS 1 z 3 czerwca 2008 r.

${ }^{47}$ Pełny tekst umowy (Memorandum of Understanding) dostępny jest na stronie: www. bundesgesetzost.admin.ch. 
franków na rzecz rozwoju nowych członków Unii Europejskiej ${ }^{48}$. Wsparcie miało być udzielane w postaci dofinansowania konkretnych projektów, dotyczących m.in. rozbudowy infrastruktury, ochrony środowiska, rozwoju gospodarczego i społecznego ${ }^{49}$. Rząd Szwajcarii podkreślał, że tego rodzaju zobowiązania zwiększają wiarygodność jego państwa w Europie i przyczyniają się do dalszego rozwoju współpracy z UE, ale przede wszystkim stanowią naturalną kontynuację tradycji wspierania państw byłego bloku wschodniego, zapoczątkowaną jeszcze w roku $1990^{50}$.

Korzyści płynące z tego rodzaju wsparcia wydają się niepodważalne. Wkład Szwajcarii, choć na pierwszy rzut oka duży, wypada raczej blado. Norwegia, której liczba ludności nie przekracza 4,5 miliona, przeznacza o ok. $60 \%$ więcej pieniędzy na dofinansowanie biedniejszych państw niż Szwajcaria ${ }^{51}$, tym bardziej że faktycznie poniesione koszty, dzięki odpowiednim modyfikacjom budżetowym, nie obciążają szwajcarskiego podatnika ${ }^{52}$. Ponadto, wkład Szwajcarii stanowi zaledwie $0,5 \%$ całości środków przeznaczanych na dofinansowanie słabiej rozwiniętych regionów. Decyzja rządu Szwajcarii, choć biorąc pod uwagę powyższe czynniki raczej symboliczna, ma ogromne znaczenie gospodarcze i pozytywnie wpływa na wizerunek państwa. Szwajcaria staje się bowiem równoprawnym partnerem Unii, który podobnie jak inne państwa ponosi niemałe koszty związane z rozwojem Europy. Posunięcie to miało na celu skłonienie Brukseli do większego uwzględniania interesów Szwajcarii i odebranie jej istotnej karty przetargowej przy kolejnych negocjacjach. Jednocześnie, dzięki bezpośredniemu wsparciu konkretnych projektów, Szwajcaria gwarantuje sobie dostęp do nowych rynków na równoprawnych zasadach. Wraz z rozwojem gospodarczym nowych członków Unii i naturalnym zwiększeniem zapotrzebowania na różnego rodzaju towary, państwa te dążyć będą do zacieśniania powiązań gospodarczych, także z przedsiębiorstwami szwajcarskimi. Przełoży się to na zwiększenie obrotów handlowych i stworzenie kolejnych miejsc pracy. W samym tylko roku 2005 obroty handlowe

${ }^{48}$ Podział środków pomiędzy poszczególnymi państwami uzależniony jest od liczby ludności i dochodu na jednego mieszkańca. Według przyjętego kryterium najwięcej, bo ok. $49 \%$ całej sumy przypadnie Polsce. Odpowiednie porozumienie w tej sprawie zostało podpisane z rządem polskim w grudniu 2007 r. Przewiduje ono wsparcie finansowe dla projektów z zakresu: poprawy bezpieczeństwa (ochrona granic, przeciwdziałanie zorganizowanej przestępczości, zwalczanie korupcji itp.), infrastruktury i ochrony środowiska, wsparcia prywatnej przedsiębiorczości, współpracy naukowej.

${ }^{49}$ Wszystkie projekty mają być zrealizowane w ciągu dziesięciu lat.

${ }^{50}$ Zob. Medienmitteilung vom 26. November 2006, Integrationsbüro EDA/EVD, źródło: www. bundesgesetzost.admin.ch.

${ }^{51}$ Zob. Norweski Mechanizm Finansowy, www.eog.gov.pl.

${ }^{52}$ Środki pochodzą z dwóch źródeł: dochodów z opodatkowania odsetek, które są konsekwencją umowy Bilaterale II, wymuszonej na Szwajcarii przez Unię (zapewniają one 40\% całościowego wkładu) oraz z cięć w ramach istniejących już środków pomocowych dla krajów rozwijających się (stanowiących pozostałe $60 \%$ ). 
z nowymi państwami Unii wyniosły 1,4 mld franków ${ }^{53}$. Wiele firm wzięło bezpośredni udział w realizacji projektów dofinansowanych przez rząd Szwajcarii. Zwiększenie zatrudnienia i poziomu życia w krajach będących beneficjentami unijnych funduszy ograniczy jednocześnie zjawisko emigracji zarobkowej, którego najbardziej obawia się znaczna część społeczeństwa szwajcarskiego.

Przytoczone argumenty zdawały się docierać do opinii publicznej, czego dowodem może być pozytywny wynik referendum we wrześniu roku 2006. Nieco ponad 53\% obywateli opowiedziało się za przyjęciem nowej ustawy, dotyczącej współpracy z państwami Europy Wschodniej, będącej podstawą prawną do przeznaczenia dodatkowych środków na wsparcie nowych członków Unii. Zapewniono tym samym dalszy rozwój stosunków bilateralnych pomiędzy Unią Europejską a Szwajcarią.

Po zakończeniu najtrudniejszego etapu negocjacji z UE, Rada Związkowa opracowała sprawozdanie $\mathrm{z}$ dotychczasowej polityki europejskiej. Analizy i wnioski przedstawione zostały w dokumencie opublikowanym w roku 2006 pod nazwą Europabericht $2006^{54}$. Potwierdzono w nim dążenia Szwajcarii do aktywnego udziału w budowie silnej i zrównoważonej gospodarczo Europy. W interesie wszystkich państw europejskich, w tym również Szwajcarii, leży intensyfikacja integracji. Dotychczasowa polityka, nastawiona na współpracę sektorową, przynosi dobre efekty, ale nie wyklucza możliwości pełnego członkostwa. Negatywny wynik referendum w sprawie EOG nie przekreślił zatem szans na ostateczną integrację, lecz zawiesił ją w czasie, a pozytywne efekty współpracy bilateralnej umożliwią jej kontynuację.

Rządowy raport z roku 2006 wskazywał również kierunki dalszego rozwoju współpracy, określając dziedziny, w ramach których powinny być kontynuowane rozmowy. Wymienia się tutaj politykę energetyczną, edukację, zdrowie, rolnictwo oraz prace nad programem Galileo ${ }^{55}$. Kolejne etapy współpracy wydają się zatem coraz trudniejsze. Rząd w pierwszej kolejności zamierza dokonać weryfikacji obecnego poziomu integracji. Może bowiem zachodzić sytuacja, w której efektywna implementacja regulacji prawnych nie będzie możliwa bez wprowadzenia istotnych zmian w dotychczasowych relacjach wzajemnych. Nowe obszary negocjacyjne mogą być sprawdzianem skuteczności drogi bilateralnej i odpowiedzią na pytanie o sens jej kontynuowania.

Rząd w Bernie podsumował dotychczasowe relacje z UE wskazując na korzyści i zagrożenia wynikające z tego typu współpracy. Przekonywał, iż obrany

${ }^{53}$ Die Volkswirtschaft. Das Magazin für Wirtschaftspolitik, November 2006, s. 58, źródło: www.dievolkswirtschaft.ch.

${ }^{54}$ Zob. więcej w rozdziale II niniejszej monografii.

${ }^{55}$ Europejski system nawigacji satelitarnej, którego budowa ma się zakończyć w roku 2012. Ma on na celu stworzenie alternatywy wobec amerykańskich i rosyjskich systemów, ale w przeciwieństwie do nich nie będzie nadzorowany przez instytucje wojskowe. Szczegółowe informacje dostępne są na stronach Komisji Europejskiej: http://ec.europa.eu. 
kierunek przynosi nie tylko doraźne korzyści, ale jest procesem długofalowym, polegającym na zrównoważonym rozwoju Europy, stwarzającym szanse dla mniej zamożnych państw, a obowiązkiem Szwajcarii jest aktywny w nim udział. Szwajcaria pozostaje otwarta na współpracę, pomimo coraz głośniej wyrażanych opinii ze strony pewnych środowisk, dążących do ograniczenia tego procesu. Jest to dosyć ważne, albowiem analiza aktualnej sytuacji na scenie politycznej kraju i wyniki niektórych głosowań referendalnych ${ }^{56}$ i parlamentarnych ${ }^{57}$ mogły wywierać na zagranicznych partnerach wprost odwrotne wrażenie.

Nastroje społeczne nie były tak optymistyczne. Znaczna część obywateli wykazywała spory sceptycyzm wobec współpracy z Unią Europejską. Nie był on tak silny jak jeszcze na początku lat 90., lecz wciąż zniechęcał ośrodki decyzyjne do podejmowania śmielszych kroków integracyjnych. W rok po podpisaniu przez rząd drugiego pakietu porozumień i tuż po głosowaniu referendalnym przeprowadzono w Szwajcarii obszerne badania, w ramach projektu Europa-Barometer ${ }^{58}$, odnoszące się do postrzegania polityki europejskiej, współpracy z UE oraz jej perspektyw. Wyniki pokazały, iż społeczeństwo, pomimo wielu pozytywnych sygnałów, jest nadal wyraźnie podzielone i nieufnie nastawione do dalszej współpracy z UE. Badania przeprowadzone zostały tuż po dwóch głosowaniach dotyczących przystąpienia Szwajcarii do konwencji Schengen/Dublin oraz rozszerzenia umowy o swobodzie przepływu osób na nowe państwa unijne. W obu przypadkach społeczeństwo opowiedziało się za przyjęciem układów, co świadczyć mogło o pełnej akceptacji współpracy z UE, przynajmniej na poziomie bilateralnym. Wyniki ankiet są zatem tym bardziej zaskakujące. Jedynie około $30 \%$ ankietowanych opowiedziało się za podtrzymaniem dotychczasowej drogi bilateralnej. Jeszcze mniej, bo $25 \%$, wykazało poparcie dla całkowitej integracji z UE. Z kolei 18\% respondentów było zdecydowanie przeciwnych intensyfikacji współpracy ponad obecny poziom. Część osób uważała ponadto, że należałoby ograniczyć integrację jedynie do członkostwa w EWG. Z dalszych analiz wynika, iż gdyby w roku 2005 miało odbyć się referendum w sprawie przystąpienia do UE, jedynie 37\% jego uczestników opowiedziałoby się za. Przeciwnych byłoby aż 54\% obywateli. Nawet jeżeli do grona zwolenników dołączyliby niezdecydowani, stanowiący 9\%, nie dałoby to większości gwarantującej sukces w referendum akcesyjnym. Pomimo dość dużego sceptycyzmu, 81\% respondentów opowiedziała się za otwarciem Szwajcarii na współpracę z innymi państwami o mniejszym lub większym stopniu intensyfikacji. Jedynie $6 \%$ było zdania, że

${ }^{56} \mathrm{~W}$ wyniku przeprowadzonego we wrześniu roku 2006 referendum zaostrzona została polityka azylowa, szczegółowe informacje dostępne są pod adresem: http://www.admin.ch/ch/d/ ff/2006/9455.pdf (10.03.2008).

${ }^{57} \mathrm{~W}$ październikowych wyborach parlamentarnych w roku 2007 największą liczbę mandatów uzyskała prawicowa SVP, przeciwna integracji z UE.

${ }^{58}$ Wyniki badań omówione zostały dokładniej w pracy: C. Longchamp, Offen auf die Zukunft zugehen. Hauptergebnisse aus dem neuesten Bericht zum Europa-Barometer Schweiz, Winter 2005, Bern 2005. 
ich państwo powinno dążyć do zwiększenia izolacjonizmu. Relatywnie niewielka jest natomiast liczba osób, która przewidywała przystąpienie Szwajcarii do UE w ciągu najbliższych 10 lat. Za tą opcją opowiedziało się 45\% respondentów. Przeciwnego zdania było $48 \%$ ankietowanych. Ciekawostką jest, że według przeprowadzonych badań około 22\% obywateli Szwajcarii uważa, że do roku 2015 Unia Europejska w ogóle przestanie funkcjonować 59 .

Z powyższych analiz wynika, że społeczeństwo, choć nastawione wobec Wspólnoty raczej pozytywnie, nie widzi możliwości przystąpienia do Unii czy intensyfikacji współpracy w najbliższym czasie. Słuszna zatem wydaje się opinia, iż chęć integracji z Unią jest bardziej wyrazem woli elit politycznych (i to też nie wszystkich opcji) niż dążeń społeczeństwa. Dla większości Szwajcarów Unia nie jest uniwersalnym panaceum na wszelkie problemy rozwijającej się Europy. Z drugiej strony społeczeństwo szwajcarskie wydaje się być świadome konieczności nawiązania ściślejszych kontaktów z tak ważnym partnerem, jakim jest Unia Europejska.

Pomimo przejściowych trudności, o których mowa będzie jeszcze poniżej, współpraca pomiędzy Szwajcarią a Unią Europejską układała się pomyślnie. Rok 2009 miał okazać się kluczowy dla dalszego rozwoju relacji. Zgodnie z zawartym w roku 1999 porozumieniem rząd Szwajcarii był zobligowany do przedstawienia, do końca maja 2009 r., swojego stanowiska odnośnie do przedłużenia obowiązywania umowy o swobodnym przepływie osób na kolejne lata. Uzyskanie społecznego przyzwolenia w postaci pomyślnego wyniku referendum nie było rzeczą oczywistą, zwłaszcza że sprawę kontynuacji umowy powiązano z kwestią rozszerzenia jej obowiązywania na dwa nowe kraje członkowskie UE - Bułgarię i Rumunię. Sprawę pogarszał fakt, że rok 2009 był okresem odczuwalnej stagnacji gospodarczej, spowodowanej ogólnoświatowym kryzysem. Perspektywa otwarcia rynku pracy dla obywateli najuboższych państw EU nie mogła wywołać entuzjazmu wśród Szwajcarów, szczególnie że poziom bezrobocia po raz pierwszy od dłuższego czasu wyraźnie wzrósł.

Władze federalne czekało zatem ogromne wyzwanie - przekonanie opinii publicznej do zagłosowania za rozszerzeniem umowy o swobodzie przepływu osób w wyjątkowo niekorzystnym gospodarczo okresie. Decyzja obywateli oznaczała przecież być albo nie być dla współpracy bilateralnej z UE. W tej sytuacji zdecydowano się na pewien wybieg, który miał decydujące znaczenia dla tego, jak się później okazało, decydującego testu na popularność polityki rządu Szwajcarii wobec Wspólnoty.

Z przeprowadzonych wcześniej sondaży, a także obserwacji politycznego dyskursu wynikało, że współpraca bilateralna jako taka cieszyła się sporym poparciem społecznym. Żadne z ugrupowań parlamentarnych czy też innych ruchów politycznych nie podważało do tej pory zasadności jej kontynuowania.

${ }^{59}$ Podobna liczba ankietowanych uważała, iż Unia Europejska przekształci się w federację. 
Spór dotyczył zazwyczaj stopnia integracji, jej perspektyw, pozycji politycznej Szwajcarii w jednoczącej się Europie. Również w przypadku głosowania z roku 2009, głównym przedmiotem sporu była nie tyle kontynuacja umowy o swobodzie przepływu osób, ile bardziej jej rozszerzenie na nowe państwa członkowskie UE. Władze federalne postanowiły zatem zwiększyć szanse na pozytywny wynik referendum poprzez powiązanie obu kwestii, stawiając obywatelom pytanie w sprawie przedłużenia obowiązywania umowy wraz z jej jednoczesnym rozszerzeniem na Bułgarię i Rumunię. Liczono, że obywatele będą w tej sytuacji kierowali się przede wszystkim pragmatyzmem. Decyzję władz silnie skrytykowały środowiska antyeuropejskie, $w$ tym przede wszystkim Auns oraz SVP. Domagano się rozdzielenia tych zagadnień $\mathrm{w}$ celu poddania ich pod dwa oddzielne głosowania. Uważano, że w interesie Szwajcarii jest zakomunikowanie stronie unijnej zgody na kontynuację swobody przepływu osób, z wyłączeniem jednak Bułgarii i Rumunii ${ }^{60}$. Ostatecznie nie udało się storpedować decyzji rządu i uchwała parlamentu, łącząca kwestię kontynuacji i rozszerzenia swobody przepływu osób, trafiła pod głosowanie fakultatywne ${ }^{61}$.

Po podjęciu decyzji w sprawie przeprowadzenia referendum rozgorzała gorąca dyskusja nad zasadnością rozszerzenia swobody przepływu osób na Bułgarię i Rumunię. W porównaniu z podobnymi debatami w przeszłości, obóz eurosceptyków wyraźnie zmalał, ograniczając się do SVP, choć, co ważne, w toku dyskusji widoczne były pewne pęknięcia w łonie tej partii oraz w kilku mniejszych ugrupowaniach, jak Lega dei Ticinesi czy Schweizer Demokraten. Zdecydowana większość organizacji lub związków, reprezentujących główne grupy interesów w sferze gospodarczej i społecznej, jeszcze na etapie dyskusji przedparlamentarnej zdecydowanie opowiedziała się za przyjęciem uchwały ${ }^{62}$. Dla ludowców sprawa była o tyle istotna, że stanowiła kolejną szansę na spowolnienie procesu integracji Szwajcarii z UE, tym bardziej że rozpatrywane zagadnienie, przynajmniej w części, zdecydowanie ułatwiało prowadzenie skutecznej agitacji politycznej. Już nie kwestia swobody przepływu osób, lecz jej rozszerzenia stanowiła doskonałe pole do politycznego dyskursu i szansę na powiększenie grona zwolenników swych poglądów.

Referendum w sprawie rozszerzenia swobody przepływu osób traktowane było zatem jako barometr poparcia, a tym samym wskaźnik popularności głoszonych przez SVP haseł. Niekorzystny wynik głosowania oznaczałby dla partii

${ }^{60}$ Zob. Personenfreizuegigkeit mit der ganzen EU, „Neue Zürcher Zeitung”, 28. November 2008.

${ }^{61}$ Sytuacja ta nie zniechęciła eurosceptycznych ugrupowań, które w niedługim czasie zebrały wymaganą prawnie liczbę podpisów, niezbędną do przeprowadzenia w tej sprawie fakultatywnego referendum. W skład komitetu zbierającego podpisy wchodziły również inne ugrupowania: Lega dei Ticinesi, Young4Fun, Schweizer Demokraten oraz Pressec lub Schweiz.

${ }^{62}$ Weiterführung des Abkommens über die Freizügigkeit. Vernehmlassungsergebnisse. Źródło: http://www.bfm.admin.ch/content/dam/data/pressemitteilung/2008/2008-03-14/ve-ber-weiterfuehrung-d.pdf (26.07.2010). 
nie tylko dotkliwą porażkę, zmuszającą do zrewidowania obranej jakiś czas temu strategii, ale przede wszystkim mógłby potencjalnie doprowadzić do kolejnych rozłamów wewnętrznych i dalszego jej osłabiania. Nic więc dziwnego, że kampania przedreferendalna traktowana była przez SVP priorytetowo.

Głosowanie odbyło się w lutym 2009 r. Dzięki m.in. dobrze przeprowadzonej rządowej kampanii zakończyło się sukcesem dla wszystkich ugrupowań popierających dalszą współpracę ze Wspólnotą. Frekwencję wynoszącą 51\% należy uznać za dość wysoką, a odsetek głosów na „tak”, wynoszący prawie $60 \%$, mógł być zaskoczeniem dla obu obozów - przeciwników, jak i zwolenników integracji. Obawa, iż co prawda przejściowy, ale trudny dla gospodarki Szwajcarii okres, może zaważyć na ostatecznym kształcie przyszłych relacji z UE, okazała się zbyteczna. Wyniki referendum pokazały, że społeczeństwo dokonało słusznego wyboru pomiędzy przejściowymi, koniunkturalnymi problemami a trwałą, politycznie i gospodarczo, priorytetową współpracą ze Wspólnotą. Świadczy to dobitnie o jego politycznej dojrzałości. Decyzja ta była również wyrazem słabej podatności na populistyczne wpływy, m.in. ze strony SVP.

Referendum dotyczące rozszerzenia swobody przepływu osób na Bułgarię i Rumunię było nie tylko istotnym elementem polityki Szwajcarii, wynikającym z międzynarodowych zobowiązań, lecz zarazem niezwykle cennym barometrem społecznych lęków, podziałów, a także aspiracji i oczekiwań wobec rządu. Jak wynika z przeprowadzonych przed głosowaniem badan, większość obywateli była bardzo dobrze poinformowana co do przedmiotu referendum, a zarazem jego wpływu na dalsze relacje z UE. Świadczy o tym fakt, iż ponad połowa osób biorących udział w głosowaniu miała w pełni ukształtowaną opinię jeszcze przed rozpoczęciem oficjalnej kampanii informacyjnej ${ }^{63}$. Podobnie jak w przypadku wcześniejszych głosowań, również i tym razem wyniki referendum potwierdziły tkwiące w społeczeństwie szwajcarskim podziały. Większą otwartość i akceptację wobec działań rządu prezentuje dobrze wykształcona, zamożna część społeczeństwa, pochodząca zazwyczaj z aglomeracji miejskich. Ludność wiejska jest w tym względzie zdecydowanie bardziej sceptyczna, choć od czasu poprzednich głosowań proporcje te uległy pewnej zmianie na korzyść postaw proeuropejskich. Co ciekawe, status materialny odgrywa stopniowo coraz mniejszą rolę. Poparcie dla swobody przepływu osób i jej rozszerzenia na nowe kraje członkowskie UE deklarowały zarówno osoby czynne zawodowo, jak i bezrobotni. Oczywiście odsetek poparcia w przypadku tej drugiej grupy był nieco mniejszy. Jest to być może przyczyna, dla której wpływ spowolnienia gospodarczego nie miał tak istotnego znaczenia dla końcowych rezultatów głosowania.

Pozostaje jednak jeszcze problem wyraźnej odrębności włoskojęzycznej części Szwajcarii. W kantonie Tessin liczba osób opowiadająca się przeciw rozsze-

${ }^{63}$ Zob. więcej H. Hirter, W. Linder, Analyse der eidgenössischen Abstimmung vom 8. Februar 2009. Forschung für Politik, Kommunikation und Gesellschaft. Institut für Politikwissenschaft, Bern 2009. 
rzeniu sięgnęła aż 66\%. Przypadek tego kantonu jest jednak szczególny. Należy bowiem, oceniając źródła tak negatywnego wyniku, wziąć pod uwagę szerszy kontekst, a przede wszystkim geograficzne uwarunkowania, czyli bezpośrednie sąsiedztwo Włoch, będące prawdziwym sednem problemu. W porównaniu z innymi kantonami, których obywatele w większości opowiedzieli się przeciwko kontynuacji swobody przepływu osób, wynik referendum nie był podyktowany obawą przed otwarciem rodzimego rynku pracy, lecz raczej był sprzeciwem wobec nieudolnych działań rządu. Od momentu wejścia w życie porozumień bilateralnych z UE strona włoska nie wywiązuje się ze wzajemnych zobowiązań, przede wszystkim w zakresie likwidacji barier administracyjnych i innego typu form dyskryminacji osób oraz przedsiębiorstw, które chcą rozpocząć działalność na terenie Włoch. Od pewnego czasu prowadzone są ze stroną włoską stosowne rozmowy, ale nie przynoszą one oczekiwanych rezultatów. Sytuację pogarsza coraz wyższe bezrobocie, sięgające już ponad 5\%. Nic więc dziwnego, iż poziom poparcia dla współpracy bilateralnej należy tu do najniższych w całej Szwajcarii. Przypadek Tessinu jest zatem wyraźnym sygnałem dla władz w Bernie, że polityka europejska wymaga szczególnej uwagi i problemowego podejścia, przy uwzględnieniu wielu istotnych, choć często pomijanych, czynników. Rozwiązania systemowe, nieuwzględniające lokalnej specyfiki i problemów, bywają często nieskuteczne.

Wynik referendum w sprawie kontynuacji swobody przepływu osób oraz jej rozszerzenia na Bułgarię i Rumunię pokazały, że społeczeństwo Szwajcarskie, pomimo coraz większej otwartości, nie jest jeszcze gotowe na kolejny poziom integracji z UE. W porównaniu z poprzednimi tego typu głosowaniami, poparcie dla drogi bilateralnej wzrosło, choć nadal nie przekracza bariery $60 \%$. Poziom ten świadczyć może o silnie zakorzenionych obawach czy wątpliwościach związanych z pełnoprawnym członkostwem we Wspólnocie. Warto zauważyć, że główną tego przyczyną są względy ekonomiczne, związane z zagrożeniem miejsc pracy lub wzrostem obciążeń socjalnych. Istotne są również aspekty społeczne, takie jak problemy asymilacyjne cudzoziemców czy potencjalny wzrost przestępczości. Kwestie związane z poczuciem tożsamości narodowej lub roli Szwajcarii w integrującej się Europie pozostają, przynajmniej dla przeciętnego Szwajcara, drugorzędne.

Współpraca Szwajcarii z UE w pierwszej dekadzie wieku XXI przebiegała niemal bezproblemowo. Umowy dwustronne $\mathrm{z}$ drugiego pakietu wdrażane były stopniowo, zgodnie z przyjętym harmonogramem. Na pozytywne efekty tych działań nie trzeba było długo czekać. Gospodarka rozwijała się, nie licząc ogólnoświatowej recesji z lat 2008-2010, bardzo dobrze. Poparcie społeczne dla tego typu współpracy systematycznie rosło, czego doskonałym potwierdzeniem są kolejne wyniki głosowań referendalnych dotyczących spraw europejskich. Łącznie suweren wypowiedział się w tej sprawie już sześć razy. Perspektywy dla rozwoju powiązań bilateralnych uznawano za obiecujące, choć już na tym etapie wskazywano na kilka spornych obszarów, które mogą zaważyć na kształcie przyszłych relacji. 
We wrześniu roku 2005 Komisja Europejska przesłała Radzie Związkowej oficjalne stanowisko dotyczące polityki fiskalnej praktykowanej w niektórych kantonach, która, jej zdaniem, narusza obowiązującą w Unii zasadę swobody konkurencji ${ }^{4}$. Zarzucono Szwajcarii, iż ta nie stosuje się do regulacji zawartych w Układzie o Wolnym Handlu z roku 1972. Według Komisji przyjęty w Szwajcarii system podatkowy pozostawia kantonom duży zakres autonomii w zakresie kreowania własnej polityki fiskalnej, stwarzając im tym samym warunki do nieuczciwej konkurencji. Wiele firm z obszaru Wspólnoty przenosi swoje siedziby do Szwajcarii, unikając tym samym wyższych podatków, obowiązujących w kraju pochodzenia. Sytuacja ta z oczywistych względów krytykowana jest przez państwa UE, które coraz częściej pozbawiane są w ten sposób części dochodów budżetowych. Korzystają na tym z kolei szwajcarskie kantony, które celem przyciągnięcia kapitału uatrakcyjniają co pewien czas warunki prowadzenia biznesu na swoim obszarze, głównie poprzez bardzo korzystne stawki podatkowe.

Od samego początku rząd w Bernie dawał wyraźnie do zrozumienia, że nie zgadza się z punktem widzenia władz UE i jej interpretacją prawa, podkreślając że nie pójdzie w tej sprawie na żadne ustępstwa. Rada Związkowa stoi twardo przy swoim stanowisku, zwłaszcza że gra toczy się o wysoką stawkę. Jeżeli władze Szwajcarii spełniłyby żądania wysuwane przez Unię, poważnie nadwerężyłyby wizerunek państwa jako raju podatkowego dla zagranicznych podmiotów gospodarczych, które zdecydowały się ulokować tutaj swój kapitał. Liczbę takich firm ocenia się na około $20000^{65}$. Zdaniem władz w Bernie regulacje systemu podatkowego wybiegają poza zakres przedmiotowy układu z roku 1972, ponieważ dotyczy on wyłącznie swobody handlu określonymi grupami towarów, a nie harmonizacji zasad swobody konkurencji. Ponadto Szwajcaria, nie będąca członkiem Unii, nie jest zobowiązana do przestrzegania zasad obowiązujących na jednolitym rynku wewnętrznym Wspólnoty ${ }^{66}$. Rząd w Bernie dysponuje zatem mocnymi argumentami, które UE jest bardzo trudno obalić. Istotą konfliktu jest fakt, że z punktu widzenia Wspólnoty Szwajcaria korzysta do woli ze swobodnego dostępu do unijnego rynku, nie respektując zarazem zasad na nim obowiązujących. Komentatorzy podkreślają, iż być może problem ten udałoby się wspólnie rozwiązać, gdyby Bruksela wykazała więcej zrozumienia, a przede wszystkim konsultowała wszystkie sporne kwestie na bieżąco. Sygnalizowałaby tym samym chęć znalezienia kompromisu pomiędzy interesem Szwajcarii i UE. Gdy, jeszcze w latach 80., opracowywano zasady opodatkowania odsetek bankowych, dążąc do ustalenia jednolitego pułapu podatkowego, który przeciwdziałałby odpływowi kapitału z państw Unii Europejskiej, zaproszono do rozmów Szwajcarię. Nego-

${ }^{64}$ Obecny system pozwala poszczególnym kantonom na ustanawianie własnych progów podatkowych. Służy to zwiększaniu atrakcyjności kantonu i przyciaganiu kapitału, w tym również zagranicznego.

${ }^{65}$ Schlechter Stil der EU, „Neue Zürcher Zeitung”, 14. Februar 2007.

${ }^{66}$ Dotyczy to zasad jednolitego rynku, zawartych w Traktacie Wspólnoty Europejskiej z roku 1992. 
cjacje trwały dość długo, ale ostatecznie uległa ona Unii, podpisując w roku 2003 odpowiednie porozumienie. Można zatem przypuszczać, iż gdyby UE w sprawie podatków (przy opracowywaniu Code of Conduct), zastosowała analogiczną strategię, konflikt byłby już dawno zażegnany. Tymczasem zarzuty wysuwane obecnie pod adresem rządu w Bernie odbierane są jako przejaw złego stylu i braku szacunku wobec partnera gospodarczego ${ }^{67}$. Wątpliwe jest, czy Szwajcarzy zaakceptują żądania Unii, zwłaszcza że polityka fiskalna jest dla większości z nich jednym $\mathrm{z}$ atrybutów suwerennego państwa.

Zatwierdzenie kontynuacji i rozszerzenia umowy dotyczącej swobody przepływu osób było ostatnim, niezwykle co prawda istotnym, krokiem w polityce Szwajcarii wobec UE. Obecnie obie strony prowadzą rozmowy dotyczące kolejnych obszarów tematycznych. Cyklicznie organizowane są spotkania robocze, mające na celu bieżącą weryfikację współpracy oraz rozwiązywanie pojawiających się co pewien czas problemów. Na jednym z takich spotkań, które odbyło się w lipcu roku 2010, podjęto decyzję o powołaniu specjalnej grupy roboczej, której zadaniem będzie analiza bieżących aspektów współpracy, w tym również przedstawienie możliwych wariantów rozwiązań kwestii spornych, przykładowo w zakresie polityki fiskalnej ${ }^{68}$.

\subsection{PODSTAWY NORMATYWNE}

\subsubsection{CHARAKTER UMÓW}

Omawiając podstawy normatywne polityki Szwajcarii wobec UE należy zaznaczyć, iż pakiety umów z 1999 oraz 2004 r. stanowią uzupełnienie szerokiej gamy porozumień podpisywanych ze Wspólnotą, począwszy od roku 1972 (łącznie zawarto ponad sto umów). Ze względu jednak na przyjętą w niniejszej pracy cezurę czasową nie będą one przedmiotem oddzielnej analizy. Trzeba przy tym podkreślić, że zgodnie z regulacjami zawartymi w umowach bilateralnych mają one pierwszeństwo przed wcześniej zawartymi porozumieniami ${ }^{69}$. Istotne jest również to, że umowy bilateralne z UE wyznaczają także ramy współpracy z państwami trzecimi. Przykładowo w treści porozumienia dotyczącego rolnictwa obie strony zobowiązują się do stosowania podobnych regulacji również wobec innych partnerów.

Zgodnie z art. 54 Konstytucji Związkowej realizacja polityki zagranicznej, w tym również podpisywanie umów międzynarodowych, należy do kompetencji

${ }^{67}$ Schlechter Stil der EU...

${ }^{68}$ Komunikat prasowy: Gemeinsame Arbeitsgruppe Schweiz-EU soll institutionelle Fragen behandeln, źródło: http://www.news.admin.ch/message/?lang=de\&msg-id=34349 (26.07.2010).

${ }^{69}$ D. Thürer, R.H. Weber, R. Zäch, Bilaterale Verträge Schweiz - EG. Ein Handbuch, Schulthess Verlag, Zürich 2002, s. 26. 
władz federalnych. Nadaje jej to wyłączne prawo do negocjowania treści poszczególnych porozumień i podejmowania decyzji odnośnie do praw i obowiązków strony szwajcarskiej wobec partnera umowy. Dotyczy to również tych obszarów, które kompetencyjnie, jak np. ochrona zdrowia lub edukacja, leżą w gestii kantonów. Mają one jedynie prawo, o czym była mowa dokładniej w rozdziale pierwszym, do wyrażania własnych opinii w sprawach będących przedmiotem danej umowy. Stanowisko kantonów nie jest jednak dla władz federalnych wiążące. Również w dalszym etapie procesu decyzyjnego rola Rady Związkowej pozostaje kluczowa. Rząd podpisuje oraz ratyfikuje umowy międzynarodowe. Ma, co prawda, obowiązek przedstawienia ich parlamentowi do zatwierdzenia, ten jednak nie ma prawnej możliwości ingerowania $\mathrm{w}$ treść danej umowy ${ }^{70}$. Może ją jedynie odrzucić, co jednakże w praktyce zdarza się niezwykle rzadko.

Umowy międzynarodowe są następnie przedmiotem głosowania w referendum obligatoryjnym (jeżeli dotyczą przystąpienia Szwajcarii do organizacji ponadnarodowej lub zbiorowego bezpieczeństwa) bądź fakultatywnym. W przypadku umów bilateralnych jest to zawsze głosowanie fakultatywne. Umowy z obu pakietów - Bilaterale I oraz Bilaterale II mogły być przedmiotem głosowania. Jedynym warunkiem było zebranie 50000 podpisów pod stosownym wnioskiem. $\mathrm{W}$ praktyce skorzystano z tego przywileju jedynie dwukrotnie ${ }^{71}$.

Wszystkie wypracowane i podpisane umowy z obu pakietów możemy podzielić na trzy kategorie. Pięć porozumień dotyczących transportu lądowego, przepływu osób, handlu produktami rolnymi, przetargów publicznych oraz wzajemnego uznawania ocen zgodności to umowy w sprawie liberalizacji handlu. Można je porównać z zawartym w roku 1972 Uktadem o Wolnym Handlu z EWG. Opierają się one na zasadzie ekwiwalencji przepisów prawnych, obowiązujących w Szwajcarii oraz w państwach Unii Europejskiej ${ }^{72}$. Umowa dotycząca transportu lotniczego jest z kolei umową quasi integracyjną, ponieważ przewiduje funkcjonowanie wspólnych organów nadzorujących oraz odpowiedzialnych za dalszą ewolucję podstaw prawnych. W przeciwieństwie do wcześniejszych porozumień zakłada ona rozszerzenie obowiązywania prawa wspólnotowego również na Szwajcarię $^{73}$. Z kolei umowa dotycząca badań jest typową umową o współpracy, zakładającą udział Szwajcarii we wspólnych projektach badawczych UE pod warunkiem partycypacji w ich kosztach. Należy jednak zauważyć, iż partnerzy Unii Europejskiej nie mają prawa do współdecydowania w zakresie aspektów finansowych i merytorycznych programu ${ }^{74}$. Podobny charakter mają umowy z zakresu

\footnotetext{
${ }^{70}$ Patrz art. 166 oraz 184 konstytucji Szwajcarii.

${ }^{71}$ Nie licząc protokołu dodatkowego dotyczącego swobody przepływu osób.

${ }^{72}$ T. Cottier, R. Liechti, Die Beziehungen der Schweiz zur Europäischen Union: Eine kurze Geschichte differenzieller und schrittweiser Integration, „Basler Schriften zur europäischen Integration" 2006, Nr. 81, s. 12.

${ }^{73}$ Łącznie z kompetencjami Europejskiego Trybunału Sprawiedliwości; zob. B. Spinner, op. cit., s. 15 .

${ }^{74}$ Szwajcaria brała udział w 6. oraz 7. Programie Ramowym UE.
} 
współpracy w dziedzinie bezpieczeństwa, zwalczania oszustw podatkowych oraz koordynacji polityki azylowej - Schengen/Dublin.

Porozumienia bilateralne regulują, jak sama nazwa wskazuje, współpracę dwustronną pomiędzy Unią Europejską a Szwajcarią. Należy jednak zauważyć, że są wśród nich pewne wyjątki. Chodzi mianowicie o umowę dotyczącą swobodnego przepływu osób oraz współpracy naukowej. W przypadku tej ostatniej stroną umowy jest również Europejska Agencja Atomowa. Z kolei umowa o swobodnym przepływie osób dotyczyła tych obszarów, które kompetencyjnie leżą w gestii poszczególnych państw członkowskich. W związku z powyższym każde $\mathrm{z}$ nich oddzielnie ratyfikowało umowę $\mathrm{w}$ tej sprawie. Biorąc zatem pod uwagę powyższe uwarunkowania, te dwa porozumienia mają charakter multilateralny, a nie bilateralny.

\subsubsection{UWARUNKOWANIA PRAWNE}

Jednym z podstawowych założen, jakie przyświecało władzom związkowym, było podpisanie porozumień w kształcie, który nie będzie wymagał transponowania prawa wspólnotowego do szwajcarskiego porządku prawnego. Abstrahując od pozornych lub faktycznych uwarunkowań, które udało się zagwarantować Szwajcarom w zawartych umowach (mowa była o tym w pierwszej części niniejszego rozdziału), są one z zasady bezpośrednio stosowalne. Oznacza to, że przynajmniej teoretycznie obywateli Szwajcarii obowiązują prawa i obowiązki zawarte w treści umowy i na nią mogą się też powoływać w przypadku ewentualnych sporów prawnych (tzw. self-executing treaties) ${ }^{75}$. Jedynym wymogiem, który warunkuje uzyskanie mocy prawnej, jest publikacja umowy w „Federalnym Dzienniku Ustaw". W praktyce władze związkowe pozostawiają sobie jednak pewien margines bezpieczeństwa, który ma na celu uniknięcie kłopotliwej interpretacji prawa przez krajowe sądy. Za bezpośrednio stosowalne uznaje się zatem te postanowienia, które pozostają w bezpośrednim związku z przedmiotem oraz celem umowy a sformułowane są w sposób niepozostawiający żadnych wątpliwości. Przykładowo, przepisy zawarte w umowie dotyczącej swobody przepływu osób czy transportu lądowego spełniają te kryteria, natomiast klauzula ewolucyjna już nie ${ }^{76}$.

W razie złożenia skargi przez osoby fizyczne lub prawne szwajcarskie sądy, na poziomie kantonalnym bądź federalnym, mają prawo do rozstrzygania sporu według własnej interpretacji prawnej umowy. Jedynie w przypadku porozumienia dotyczącego swobody przepływu osób są zobowiązane do uwzględniania wy-

${ }^{75}$ Por. H. Durić, Die freihandelsabkommen EG-Schweiz - Die rechtliche Problematik, Freiburg 1998, s. 197; P.E. Holzer, Die Ermittlung der innerstaatlichen Anwendbarkeit völkerrechtlicher Vertragsbestimmungen, Zürich 1998, s. 72-74; D. Schindler, Die Schweiz und das Völkerrecht, [w:] A. Riklin, H. Haug, R. Probst, Neues Handbuch der schweizerischen Aussenpolitik, Bern 1992, s. 112.

${ }^{76}$ D. Thürer, R.H. Weber, R. Zäch, op. cit., s. 25, por. Botschaft zur Genehmigung der sektoriellen Abkommen ..., s. 6437. 
kładni Europejskiego Trybunału Sprawiedliwości. W tej sytuacji nie ma jednak możliwości zwrócenia się do Trybunału z pytaniem prejudycjalnym, dotyczącym wykładni przepisu prawa wspólnotowego. Także obywatele szwajcarscy nie mogą bezpośrednio odwoływać się do tej instytucji.

Porozumieniom bilateralnym przyświeca także zasada równoważności przepisów prawnych ${ }^{77}$. Odnosi się to głównie to umów dotyczących liberalizacji handlu. Oznacza to, że, przynajmniej teoretycznie, prawodawstwo Szwajcarii zachowało autonomię i nie musi być dostosowane do przepisów UE (tzn. dosłownie identyczne). Istotne jest jedynie zachowanie ogólnego celu danej regulacji prawnej oraz przestrzeganie zasad obowiązujących na wspólnotowym rynku. Innymi słowy ustawodawca szwajcarski tworząc krajowe prawa musi się wzorować na prawie UE, lecz nie jest zobowiązany do jego bezpośredniego transponowania (de facto proces ten zachodził w Szwajcarii jeszcze na długo przed podpisaniem umów bilateralnych ${ }^{78}$ ). W przypadku zaistnienia jakichkolwiek różnic czy też potrzeb zmiany przepisów prawnych, każda ze stron jest zobligowana do poinformowania partnera w ustalonym trybie - za pośrednictwem komisji mieszanych, o których mowa będzie jeszcze poniżej.

Zakres terytorialny porozumień bilateralnych dotyczy oczywiście wszystkich państw UE oraz Szwajcarii. W przypadku rozszerzenia Wspólnoty wszystkimi regulacjami obejmowani są automatycznie nowi członkowie Unii Europejskiej. Także i tu wyjątkiem jest umowa o swobodzie przepływu osób, która wymaga przeprowadzenia oddzielnych negocjacji. Doszło do tego w momentach rozszerzenia UE w 2004 oraz 2007 r. Szwajcaria wynegocjowała wówczas odrębne okresy przejściowe oraz kontyngenty ilościowe dla obywateli tych państw. Za każdym razem umowy te muszą być również ratyfikowane przez wszystkie strony. Mowa będzie o tym w dalszej części niniejszego rozdziału.

Większość umów bilateralnych również została zawarta na czas nieokreślony, chyba że któraś ze stron podejmie decyzje o ich wypowiedzeniu ${ }^{79}$. W takim przypadku porozumienia tracą ważność po upływie sześciu miesięcy. Jedynie umowę dotyczącą swobodnego przypływu osób zawarto początkowo na okres siedmiu lat ${ }^{80}$. Jednakże po podjęciu decyzji, w lutym roku 2009, odnoszącej się do kontynuacji i rozszerzenia na nowe państwa członkowskie UE, okres jej obowiązywania jest obecnie bezterminowy. Pozostałe umowy zawarte zostały na dany okres programowania. Dotyczy to przykładowo udziału Szwajcarii w projektach

77 W przypadku umowy dotyczącej zamówień publicznych równoważność przepisów prawnych wynika z ustaleń zawartych w ramach Światowej Organizacji Handlu.

${ }^{78}$ Zob. Botschaft zur Genehmigung der sektoriellen Abkommen ..., s. 6158.

${ }^{79}$ M. Vahl, N. Grolimund, Integration ohne Mitgliedschaft: die bilateralen Verträge der Schweiz mit der Europäischen Gemeinschaft, Schulthess, Zürich 2007, s. 52. Jak zauważa D. Thürer, poszczególne państwa członkowskie Unii Europejskiej nie mają prawa do wypowiedzenia umowy indywidualnie. Jest to możliwe jedynie wspólnie, na poziomie UE. D. Thürer, R.H. Weber, R. Zäch, op. cit., s. 29.

${ }^{80}$ Botschaft zur Genehmigung der sektoriellen Abkommen ..., s. 6313. 
badawczych $\mathrm{UE}^{81}$ lub w programie MEDIA. Ustalono również, że porozumienie o opodatkowaniu odsetek od lokat bankowych będzie podlegać ewentualnej rewizji w roku 2013.

Umowy Bilaterale I zostały także związane tzw. klauzulą gilotyny, zgodnie z którą wypowiedzenie jednej z nich powoduje anulowanie wszystkich pozostałych $^{82}$. Konsekwencją tej klauzuli jest fakt poddania całego pakietu pod głosowanie oraz wejście $\mathrm{w}$ życie wszystkich porozumień w tym samym momencie, tj. w czerwcu 2002 r. Wyjątek stanowi umowa o współpracy badawczej. Jej wygaśnięcie, będące konsekwencją zakończenia danego okresu programowania, nie pociąga za sobą anulowania pozostałych umów bilateralnych ${ }^{83}$. Drugi pakiet $-B i$ laterale II nie jest już obwarowany takimi zastrzeżeniami. Należy jednak zauważyć, iż w przeciwieństwie do Bilaterale I z roku 1999 jego nadrzędnym celem nie jest eliminacja barier handlowych i harmonizacja przepisów prawnych. Umowy bilateralne podpisane w roku 2004 mają inny charakter i cel, a więc także okres obowiązywania poszczególnych porozumień pozostaje odmienny.

Warto również dodać, że umowy bilateralne mają moc wiążącą, m.in. ze względu na ich bezpośrednią stosowalność, we wszystkich oficjalnych językach Unii Europejskiej (w tym automatycznie również w trzech oficjalnych językach Szwajcarii). W przypadku problemów interpretacyjnych wymagane jest porównanie wszystkich wersji. Oczywiście dopuszcza się drobne rozbieżności, wynikające z różnic językowych. Niemniej jednak podtrzymany musi być zasadniczy cel umowy (zgodnie $\mathrm{z}$ art. 31 Konwencji wiedeńskiej o prawie traktatów) ${ }^{84}$.

\subsubsection{UWARUNKOWANIA INSTYTUCJONALNE}

Intencją władz Szwajcarii, jeszcze na etapie negocjacji z UE, było zachowanie jak największej autonomiczności w zakresie nie tylko stanowienia prawa, lecz również jego wdrażania. Chodziło o to, aby jak najwięcej kompetencji pozostało w gestii władz związkowych, ewentualnie kantonalnych. Zawarcie porozumień bilateralnych $\mathrm{w}$ innym kształcie pociągałoby za sobą konieczność przeniesienia części kompetencji na ponadnarodowy organ. Konstytucja wymaga wówczas przeprowadzenia referendum obligatoryjnego ${ }^{85}$, a - jak pokazuje praktyka - osiągnięcie tzw. podwójnej większości obywateli i kantonów jest niezwykle trudne.

W związku z powyższym przyjęto zasadę, że za właściwe wdrażanie porozumień odpowiedzialne będą krajowe instytucje - władze związkowe, kantonalne

${ }^{81}$ Okres programowania 7. Programu Ramowego przypada na lata 2007-2013. Po tej dacie ewentualna kontynuacja będzie przedmiotem osobnych negocjacji.

${ }_{82}$ Zob. Schweiz-Europäische Union: Integrationsbericht 1999 vom 3. Februar 1999..., s. 290-291.

${ }^{83}$ Botschaft zur Genehmigung der sektoriellen Abkommen ..., s. 6156.

${ }^{84}$ Ibidem, s. 6160.

${ }^{85}$ Art. 140 konstytucji Szwajcarii. 
oraz sądy. Mają one za zadanie wykorzystanie wszelkich środków, które zagwarantują osiągniecie celu określanego w umowach bilateralnych. Wyjątek stanowią jedynie umowy dotyczące zamówień publicznych oraz transportu lotniczego. W pierwszym przypadku obie strony są zobowiązane do powołania specjalnych organów nadzoru ${ }^{86}$, natomiast w drugim szwajcarskie linie lotnicze podporządkowane są częściowo organom $\mathrm{UE}^{87}$.

Ponieważ większość umów bilateralnych ma charakter dynamiczny, związany chociażby z cyklicznymi modyfikacjami krajowych przepisów prawnych, podstawowym wyzwaniem $w$ kontekście ich prawidłowego funkcjonowania jest bieżące dostosowywanie do zaistniałych zmian. Od czasu podpisania pierwszego pakietu porozumień w roku 1999 wprowadzono szereg nowych rozwiązań oraz regulacji. Rzutują one oczywiście na treść porozumień bilateralnych, które w związku z powyższym muszą podlegać bieżącej aktualizacji. Z uwagi na fakt, że każda ze stron umowy podejmuje samodzielne decyzje w zakresie stanowienia prawa, niezbędne było powołanie organu, który zająłby się monitorowaniem i wymianą informacji. W tym celu, w trakcie negocjacji nad pierwszym pakietem porozumień, podjęto decyzję o ustanowieniu specjalnych komisji mieszanych, złożonych z przedstawicieli Unii Europejskiej oraz Szwajcarii. Ich zadaniem jest kontrola zgodności przepisów krajowych z zawartymi porozumieniami.

Według wstępnych założeń, każdej umowie bilateralnej powinna być przyporządkowana jedna komisja. Jednak w przypadku porozumienia dotyczącego rolnictwa powołano dwie komisje (oddzielną ds. weterynaryjnych), w efekcie czego w ramach pakietu Bilaterale I funkcjonuje osiem komisji ${ }^{88}$. Ponadto liczbie porozumień bilateralnych, podpisanych w roku 2004, nie odpowiada liczba komisji. Nie utworzono bowiem komisji zajmującej się opodatkowaniem odsetek oraz ds. emerytur i rent.

\section{Komisje mieszane, powołane w ramach umów bilateralnych z roku 1999:}

Komisja ds. badań naukowych;

Komisja mieszana ds. zamówień publicznych;

${ }^{86}$ Każda strona umowy ma obowiązek powołania niezależnych organów, których zadaniem jest notyfikowanie wszelkich nieprawidłowości związanych z wdrażaniem danego porozumienia. Muszą mieć również możliwość zastosowania odpowiednich sankcji. W przypadku państw UE funkcję tę może pełnić Komisja Europejska. W Szwajcarii powierzono to zadanie istniejącej już Komisji ds. monitorowania i wdrażania zobowiązań międzynarodowych Szwajcarii w dziedzinie zamówień publicznych. Jest ona organem wspólnym władz związkowych i kantonalnych, została jedynie wyposażona w dodatkowe kompetencje.

${ }^{87}$ D. Thürer, R.H. Weber, R. Zäch, op. cit., s. 41.

${ }^{88} \mathrm{~W}$ przypadku umowy dotyczącej badań nie powoływano nowej komisji. Jej zadania przejęła istniejąca już komisja, która utworzona została w roku 1986, przy okazji zawarcia umowy na temat współpracy naukowo-technicznej. Z kolei komisja ds. transportu lotniczego zajmuje się również umową tranzytową, zawartą ze Wspólnotą w 1992 r. 
Komisja mieszana ds. wzajemnego uznawania oceny zgodności;

Komisja mieszana ds. rolnictwa;

Komisja weterynaryjna;

Komisja ds. transportu lotniczego;

Komisja mieszana ds. transportu lądowego;

Komisja mieszana ds. swobody przepływu osób.

\section{Komisje mieszane, powołane w ramach umów bilateralnych z roku $2004^{89}$ :}

Komisja mieszana ds. ochrony środowiska;

Komisja mieszana ds. współpracy w dziedzinie statystyki;

Wspólna komisja ds. zarządzania umową stowarzyszeniową Dublin;

Wspólna komisja ds. zarządzania umową stowarzyszeniową Schengen;

Komisja mieszana ds. zwalczania oszustw podatkowych;

Komisja mieszana ds. udziału Szwajcarii w programie MEDIA.

Spotkania komisji mieszanych odbywają się cyklicznie, w zależności od potrzeb, nie rzadziej jednak niż raz do roku. W skład takiej komisji wchodzi od czterech do ośmiu przedstawicieli każdej ze stron. Zależy to głównie od rodzaju izłożoności problemu, który jest przedmiotem spotkania ${ }^{90}$. Szwajcarię reprezentują $\mathrm{z}$ reguły przedstawiciele Biura Integracyjnego EDA/EVD, urzędnicy ministerialni oraz przedstawiciele jej misji w Brukseli. Jeżeli sprawa dotyczy kompetencji kantonów, przedstawiciel KdK również uczestniczy w spotkaniu. Wszelkie decyzje podejmowane są jednogłośnie, a każda ze stron dysponuje jednym głosem, bez względu na liczbę przedstawicieli. Dotyczy to również komisji zajmującej się porozumieniem w sprawie swobodnego przepływu osób, która, jak już wcześniej wspomniano, ma charakter multilateralny. Zatem jego stroną są wszystkie państwa Unii Europejskiej. Mają one prawo do posiadania swojego przedstawiciela w komisji, jednakże ci nie dysponują oddzielnym głosem. Przewodniczy obradom każda ze stron przemiennie ${ }^{11}$. W ramach każdej komisji powoływane mogą być oddzielne grupy robocze, złożone z ekspertów danej dziedziny, którzy wspierają merytorycznie jej prace. W przypadku niektórych komisji tego typu grupy eksperckie funkcjonują stale. Dotyczy to przykładowo komisji ds. rolnictwa ${ }^{92}$.

Podstawowym zadaniem powyższych ciał jest troska o właściwe wdrażanie umów dwustronnych. Chodzi tutaj głównie o wymianę informacji, konsultacje,

\footnotetext{
${ }^{89}$ Źródło: Integrationsbüro EDA/EVD. http://www.europa.admin.ch/dokumentation/00438/ 00465/index.html?lang=de (29.07.2010).

${ }^{90}$ Stronę unijną reprezentują zazwyczaj członkowie Komisji Europejskiej, w tym przedstawiciel Generalnej Dyrekcji ds. Polityki Zewnętrznej Unii Europejskiej.

${ }^{91} \mathrm{~W}$ przypadku komisji ds. swobody przepływu osób przewodnictwo strony unijnej przejmuje państwo pełniące w danym półroczu prezydencję. Zob. także więcej E. Honegger, op. cit., s. 65-66.

${ }^{92}$ Grupa robocza ds. ochrony roślin, grupa robocza ds. nasion, grupa robocza ds. pasz dla zwierząt, grupa robocza ds. produktów winiarskich.
} 
wydawanie zaleceń, podejmowanie określonych w umowie decyzji, rozstrzyganie sporów, rozwój stosunków dwustronnych ${ }^{93}$. W praktyce sprowadza się to najczęściej do monitorowania stanu prawnego Wspólnoty i podejmowania stosownych decyzji. Zazwyczaj komisje mają do czynienia z trzema sytuacjami ${ }^{94}$ :

- nowy akt prawny nie wpływa na treść danej umowy bilateralnej;

- nowy akt wpływa na umowę, ale zmiany możliwe są do pogodzenia $\mathrm{z}$ istniejącymi regulacjami;

- umowa bilateralna wymaga dostosowania do nowego aktu prawnego.

W tym ostatnim przypadku komisja podejmuje czynności, w ramach własnych kompetencji, które zapewnią właściwe wykonywanie postanowień umowy. Najczęściej sprowadza się to do naniesienia poprawek do załączników danego porozumienia, są to więc raczej drobne zmiany techniczne. Ewentualnie zapada decyzja o czasowym zawieszeniu wykonywania niektórych przepisów. Jeżeli umowa wymaga poważniejszych modyfikacji bądź też w poważnym stopniu koliduje z krajowym prawodawstwem, stosowny wniosek w tej sprawie przesyłany jest do władz związkowych. Za koordynację tych działań odpowiedzialne jest Biuro Integracyjne oraz przewodniczący szwajcarskiej delegacji. Projekt zmian w umowie, który zostaje wypracowany w trakcie obrad komisji mieszanej, jest konsultowany przez każdą ze stron wewnętrznie. W przypadku Szwajcarii propozycja tekstu trafia do Federalnego Urzędu Sprawiedliwości oraz Dyrektoriatu Prawa Międzynarodowego, gdzie sprawdzany jest pod względem zgodności z prawem krajowym. Konsultowany jest również z różnymi grupami interesu. Po pozytywnym zaopiniowaniu przekazywany jest ostatecznie do Rady Związkowej, która upoważnia delegację Szwajcarii do zatwierdzenia projektu zmian w umowie. Zazwyczaj nie jest wymagana zgoda parlamentu. Wszystkie decyzje komisji, w tym zmiany w umowach bilateralnych, są następnie publikowane w „Federalnym Dzienniku Ustaw"95.

Powyższy tryb prac komisji należy ocenić jako sprawny, choć dość powolny. Mają na to wpływ zarówno specyfika procesu decyzyjnego w Szwajcarii, jak i tryb pracy komisji. Każda nowa propozycja zmian nie jest bowiem na bieżąco konsultowana, lecz zawieszona do czasu zwołania kolejnego posiedzenia. Ma to oczywiście większe znaczenie w przypadku szczególnie dynamicznych porozumień. Jak zauważają M. Vahl i N. Grolimund należy do nich umowa w sprawie transportu lotniczego oraz lądowego ${ }^{96}$. Przepisy unijne dotyczące tego obszaru ulegają dość częstym zmianom. Na tym tle pojawia się zresztą sporo niezgodności, o czym mowa będzie w dalszej części rozdziału. Autorzy oceniają zatem, że cały proces przystosowania umowy do nowego prawa może trwać nawet półtora

${ }^{93}$ D. Thürer, R.H. Weber, R. Zäch, op. cit., s. 51.

${ }^{94}$ M. Vahl, N. Grolimund, op. cit., s. 54.

${ }^{95}$ Zob. Beschlüsse der Gemischten Ausschüsse, źródło: http://www.admin.ch/ch/d/eur/gemaus. html (29.07.2010).

${ }^{96}$ M. Vahl, N. Grolimund, op. cit., s. 58. 
roku. Trzeba więc spodziewać się znacznego obniżenia wydajności powyższego procesu $\mathrm{w}$ momencie wejścia $\mathrm{w}$ życie wszystkich umów $\mathrm{z}$ drugiego pakietu.

Każda ze stron ma również prawo do zgłoszenia wniosku o zastosowanie określonych instrumentów ochronnych, jeżeli wykonywanie postanowień danej umowy jest $\mathrm{z}$ jakiegoś powodu szkodliwe. Zadaniem komisji jest wówczas ustalenie, w ciągu trzech miesięcy, sposobu rozwiązania danego problemu. Wypada jednak zaznaczyć, że tego typu środki nie mogą być wprowadzane na stałe. Zadania komisji związane z czasowym wprowadzaniem instrumentów ochronnych są konsekwencją zmieniających się uwarunkowań gospodarczych lub społecznych. Może się bowiem zdarzyć, że ze względu na trudną sytuację ekonomiczną strona wnioskuje o czasowe zamknięcie rodzimego rynku pracy dla obcokrajowców ${ }^{97}$.

Istotną funkcją komisji mieszanych jest również rozstrzyganie sporów pomiędzy stronami umowy. W takim przypadku zadaniem tego gremium jest wspólne wypracowanie rozwiązań, które pozwolą na wyeliminowanie problemów związanych z prawidłowym funkcjonowaniem porozumień. Jak sądzi T. Jaag, członkowie komisji są związani określonymi instrukcjami rządowymi, a więc nie ma ona charakteru niezależnego organu mediacyjnego ${ }^{98}$. Chodzi tu bardziej o zastosowanie dyplomatycznych mechanizmów rozwiązywania sporów. Ponieważ tego typu rozwiązania mogą być niewystarczające i nie doprowadzą do znalezienia konsensusu, każda ze stron ma prawo do zastosowania określonych retorsji, zgodnych z prawem międzynarodowym. W ostateczności przewiduje się jednostronne wypowiedzenie umowy, co w przypadku pakietu Bilaterale I oznacza automatyczne anulowanie wszystkich porozumień.

M. Vahl i N. Grolimund zauważają jednak, że w ciągu prawie czterech lat od momentu wejścia w życie pierwszego pakietu porozumień nie zanotowano większych problemów związanych z wdrażaniem umów bilateralnych ${ }^{99}$. Do tej pory nie zaszła konieczność uruchomienia oficjalnej procedury rozwiązywania sporów. Wszelkie niezgodności czy problemy eliminowano w trybie roboczym, w trakcie kolejnych posiedzeń komisji mieszanych. Autorzy podają jednak w wątpliwość faktyczną zdolność tego gremium do rozwiązywania sporów. Uznają bowiem za mało prawdopodobną możliwość, aby spór został zażegnany przez te same osoby, które przecież jeszcze jakiś czas temu nie mogły osiągnąć konsensusu w przedmiotowej kwestii. Należałoby zatem powierzyć tego typu zadanie innemu gremium. Nie zmienia to faktu, że komisje mieszane pełnią, jak na razie, funkcję jedynej platformy rozwiązywania ewentualnych sporów. Nie przewidziano bowiem możliwości zaskarżenia jednej ze stron umowy do niezależnej instancji w sprawie pogwałcenia postanowień zawartego porozumienia. Wyjątek stanowi umowa dotycząca transportu lotniczego. Obszar ten, z uwagi na swoją specyfikę, podlega

${ }^{97} \mathrm{~W}$ przypadku umowy dotyczącej swobodnego przepływu osób przewidziane są z góry określone instrumenty ochronne.

${ }^{98}$ D. Thürer, R.H. Weber, R. Zäch, op. cit., s. 57.

${ }^{99}$ M. Vahl, N. Grolimund, op. cit., s. 64. 
organom wspólnotowym i również wszelkie spory w jego zakresie rozstrzygane są przez Trybunał.

Niektóre umowy, jak np. ta, dotycząca rolnictwa, przewidują wyposażenie komisji mieszanych $\mathrm{w}$ dodatkowe zadania, związane $\mathrm{z}$ rozwojem dwustronnych relacji. Zapis ten odnaleźć można w klauzuli ewolucyjnej, zawartej w pewnych porozumieniach. $\mathrm{W}$ takim przypadku każda ze stron ma prawo do przedstawienia wniosku, wraz z uzasadnieniem, w sprawie zmian bądź rewizji danej umowy. Mogą mieć one charakter horyzontalny, a więc prowadzić do poszerzenia umowy o nieporuszane dotąd kwestie, lub wertykalny, dotyczący zmian albo rozbudowy obszarów objętych już określonymi regulacjami. Odbywa się to za pośrednictwem komisji mieszanej, która zgodnie ze swoimi kompetencjami podejmuje negocjacje w tej sprawie. Ich wyniki podlegają następnie zatwierdzeniu i ratyfikowaniu przez każdą ze stron, zgodnie $\mathrm{z}$ obowiązującymi $\mathrm{w}$ danym kraju procedurami. Jak zauważają D. Thürer i C. Hillemanns, umieszczenie w umowach bilateralnych klauzuli ewolucyjnej było częścią strategii negocjacyjnej rządu Szwajcarii ${ }^{100}$. Chodziło o uzyskanie lepszej kontroli nad całym procesem włączenia kraju do części wspólnotowego rynku poprzez podzielenie całego procesu na dwa etapy. Pierwszy z nich zakłada podpisanie porozumień w określonym, bezpiecznym z punktu widzenia interesów Szwajcarii kształcie, oczywiście przy zachowaniu zasady paralelizmu w zakresie wdrażania wszystkich umów, a więc „Związując” je w jeden pakiet. Drugiemu etapowi służą klauzule ewolucyjne, których zadaniem jest zagwarantowanie kontynuacji czy też rozszerzenia współpracy zgodnie z przyjętymi wcześniej założeniami. Innymi słowy dalsza liberalizacja współpracy gospodarczej ma przebiegać według określonego harmonogramu.

\subsubsection{PRAKTYKA I OCENA PODSTAW NORMATYWNYCH}

Jednym z podstawowych zarzutów związanych z funkcjonowaniem porozumień bilateralnych jest brak ich transparentności zarówno na poziomie instytucjonalnym, rozumianym jako przejrzystość zakresu prac komisji mieszanych, jak i prawnym, czyli dotyczącym swobodnego dostępu do aktów prawnych będących efektem prac tychże komisji. Spowodowane jest to kilkoma czynnikami, które jednakże, co istotne, nie są przejawem złych intencji ze strony władz szwajcarskich lub unijnych. Po pierwsze różna jest natura poszczególnych komisji, związana z przedmiotem jej prac, składem oraz specyfiką funkcjonowania. Zgodnie z postanowieniami porozumień bilateralnych każda komisja samodzielnie określa tryb swojej pracy oraz zasady funkcjonowania ${ }^{101}$. Może się składać $\mathrm{z}$ różnej liczby przedstawicieli każdej ze stron, którzy każdorazowo pochodzą z innych resortów. Komisje nie mają zatem charakteru scentralizowanego. Konsekwencją tego

\footnotetext{
${ }^{100}$ D. Thürer, R.H. Weber, R. Zäch, op. cit., s. 35.

${ }^{101}$ Czasami informacje te publikowane są na stronach internetowych władz federalnych.
} 
jest różne podejście odnośnie do zasięgu i znaczenia prawa wspólnotowego dla umów dwustronnych. Do tego należy dodać relatywnie mały poziom wiedzy dotyczącej przebiegu prac tego gremium z uwagi na fakt, że protokoły ze spotkań nie są upubliczniane ${ }^{102}$. Po każdym posiedzeniu komisji organizowana jest jedynie konferencja prasowa, a na stronach internetowych zamieszczany zostaje krótki komunikat dotyczący aktualnego przedmiotu rozmów dwustronnych ${ }^{103}$. Nie odnajdziemy w nim jednak sprawozdania z przebiegu spotkania czy informacji na temat stanowiska stron wobec przedmiotowej kwestii. Wszystko to sprawia, że - jak zauważają M. Vahl i N. Grolimund - komisje żyją często własnym życiem, a ich prace $\mathrm{w}$ niewielkim stopniu kontrolowane są przez władze związkowe, a tym bardziej przez opinię publiczną ${ }^{104}$. Ta ostatnia boryka się zresztą z problemem utrudnionego dostępu do aktualnych danych odnoszących się do prawodawstwa UE. Efekty prac komisji są co prawda publikowane, trudniej natomiast odnaleźć rozporządzenia, na które się powołują $\mathrm{w}$ przypadku wprowadzania modyfikacji $\mathrm{w}$ umowach ${ }^{105}$. Analogicznie ma się rzecz w przypadku nowelizacji krajowych przepisów prawnych, będących konsekwencją zmian w prawodawstwie wspólnotowym.

Główny przepływ informacji pomiędzy ośrodkami sprawowania władzy a opinią publiczną odbywa się za pośrednictwem trzech organów. Na najwyższym poziomie politycznym sytuuje się Kancelaria Związkowa. Pełni ona funkcję głównego ośrodka koordynacyjnego w zakresie przetwarzania i publikowania informacji urzędowych. Nowe projekty ustaw zamieszczane są w Urzędowym Zbiorze Prawa Federalnego (Amtlichen Sammlung des Bundesrechts) i Systematycznym Zbiorze Prawa Federalnego (Systematischen Sammlung des Bundesrechts) ${ }^{106}$. Drugim organem przepływu informacji jest Biuro Integracyjne (Integrations Büro), nie tylko koordynujące politykę europejską, lecz również gromadzące wszelkie informacje z nią związane. Wreszcie są to poszczególne resorty, które zajmują się danym obszarem tematycznym. Na ich stronach również można odnaleźć aktualne dane dotyczace współpracy bilateralnej z Unią Europejską.

Przeprowadzona w roku 2004 nowelizacja przepisów dotyczących publikowania informacji urzędowych sprawiła, iż obowiązkowi upublicznienia podlegają jedynie umowy międzynarodowe o istotnym znaczeniu prawnym (a więc ustanawiające nowe zobowiązania) ${ }^{107}$. Decyzje, które nie niosą za sobą poważnych konsekwencji

${ }^{102} \mathrm{~W}$ przypadku instytucji prawa międzynarodowego protokoły ze spotkań nie są upubliczniane.

${ }^{103}$ Informacje takie publikowane są na stronie władz federalnych www.admin.ch/ch/d/eur/ lub Biura Integracyjnego www.europa.admin.ch.

${ }^{104}$ M. Vahl, N. Grolimund, op. cit., s. 68.

${ }^{105}$ Od momentu podjęcia decyzji przez komisję mieszaną do czasu jej opublikowania może minąć nawet rok. Zob. ibidem, s. 71.

${ }^{106}$ Oba zbiory dostepne sa w Internecie. Por. http://www.admin.ch/ch/d/sr/sr.html oraz http:// www.admin.ch/ch/d/as/index.html (02.08.2010).

${ }^{107}$ Zob. art 3. Bundesgesetz vom 18. Juni über die Sammlungen des Bundesrechtes und das Bundesblatt (Publikationsgesetz). Źródło: http://www.admin.ch/ch/d/sr/170_512/index.html (02.08.2010). 
prawnych, a do takich najczęściej zaliczamy postanowienia komisji mieszanych, są publikowane tylko w formie komunikatu w Urzędowym Zbiorze Prawa Federalnego.

Przejrzysty dostęp do materiałów związanych z funkcjonowaniem ośrodków władzy, ma w przypadku Szwajcarii wyjątkowo istotne znaczenie. Oceniając zatem aspekty instytucjonalne i prawne porozumień bilateralnych warto zwrócić uwagę również na ten czynnik. Oczywiście ma on charakter subiektywny, albowiem z punktu widzenia efektywności czy też funkcjonalności umów sam poziom ich transparentności nie ma większego znaczenia, zwłaszcza że akurat ten element polityki Szwajcarii nie podlega społecznej weryfikacji na drodze referendum. W tym przypadku mamy do czynienia bardziej z problemem postrzegania czy też oceny współpracy bilateralnej z UE przez społeczeństwo. M. Vahl i N. Grolimund uważają, że obywatel, mając ograniczony dostęp do informacji związanych z bieżącymi aspektami porozumień bilateralnych, może odnieść wrażenie, iż współpraca ta ma charakter raczej statyczny ${ }^{108}$. Oznacza to, że nie wymaga od Szwajcarii żadnych szczególnych zabiegów, chociażby na płaszczyźnie legislacyjnej. Faktycznie jednak mamy do czynienia z sytuacją wprost odwrotną. Umowy bilateralne wymuszają na Szwajcarii ciągły proces dostosowawczy, który, co warte podkreślenia, przebiega zawsze jednokierunkowo. Choć protokoły czy dokładne sprawozdania z przebiegu spotkań komisji mieszanych nie są dostępne, nie ulega wątpliwości, że modyfikacje w treści porozumień są efektem zmian przepisów UE. Jedyne na co może liczyć w takim przypadku strona szwajcarska, to jak najkorzystniejsze okresy przejściowe. Umowy bilateralne mają zatem charakter dynamiczny i taka jest również polityka Szwajcarii wobec Unii Europejskiej. Oczywiście stopień tej dynamiki nie jest identyczny w każdym obszarze. Współpraca w zakresie transportu lądowego czy lotniczego jest zdecydowanie bardziej podatna na różnego typu modyfikacje niż porozumienia w sprawie opodatkowania odsetek od lokat bankowych. Umowy bilateralne oceniamy jednak jako pewną całość.

Władzom Szwajcarii udało się osiągnąć zachowanie autonomiczności w zakresie wdrażania umów. Dzięki temu najważniejsze kompetencje, dotyczące realizacji porozumień, pozostały w jej gestii, a nie ponadnarodowego organu. Gwarantuje to władzom większą kontrolę nad rozwojem relacji z UE i eliminuje automatyzację niektórych procesów. Proces integracyjny zdaje się zatem mieć charakter w pełni świadomy. Choć, jak wykazano powyżej, pod wieloma względami jest to autonomia iluzoryczna, niemniej jednak sprawdza się i spełnia oczekiwania społeczne oraz polityczne. Wydaje się również, że przynajmniej na tym etapie jest to rozwiązanie najlepsze z możliwych. Paradoksalnie, być może właśnie ta ograniczona transparentność całego procesu wpływa korzystnie na poziom zadowolenia obywateli z obecnej formy współpracy z UE, zwłaszcza że nie są oni świadomi faktycznych uwarunkowań współpracy bilateralnej, szczególnie w kontekście procesów adaptacyjnych.

${ }^{108}$ M. Vahl, N. Grolimund, op. cit., s. 72. 


\subsection{UMOWY BILATERALNE}

Polityka Szwajcarii konsekwentnie realizowana najpierw wobec EWG, a potem Unii Europejskiej zaowocowała ponad setką różnego rodzaju porozumień bilateralnych. Poniżej omówione zostaną jedynie te porozumienia, które weszły w skład pakietów Bilaterale I oraz Bilaterale II, najważniejsze z punktu widzenia tematyki niniejszego opracowania. Na wstępie należy wyraźnie zaznaczyć występującą miedzy nimi różnicę. Pierwszy z nich ma charakter bardziej gospodarczy i w zamierzeniu ma ułatwiać, głównie poprzez eliminację barier w handlu, współpracę gospodarczą pomiędzy Szwajcarią a państwami Unii Europejskiej. Z kolei drugi ma na celu harmonizację obszarów jak do tej pory nieuregulowanych, a dotyczących niezwykle istotnych zagadnień, takich jak bezpieczeństwo, polityka azylowa czy ochrona środowiska. Pakiet Bilaterale II zdecydowanie rozszerza współpracę, lecz - co warte podkreślenia - czyni ją o wiele bardziej złożoną. Ponadto dotyka bardzo wrażliwych zagadnień, związanych z polityką fiskalną oraz sektorem bankowym. Na tym tle pojawia się pomiędzy obydwoma stronami coraz więcej spięć, które jak na razie trudno jest załagodzić.

Zważywszy na złożoność poszczególnych porozumień, na uwagę zasługują również dwie umowy wchodzące w skład Bilaterale I. Są to porozumienia dotyczące swobody przepływu osób oraz harmonizujące przepisy w zakresie transportu lądowego i lotniczego. Pierwsze z nich określane było mianem „pięty achillesowej" całego pakietu, największym zagrożeniem i główną przyczyną ewentualnego zerwania współpracy. Przez początkowe siedem lat obowiązywania umowy miało kluczowe znaczenie dla pomyślności dalszej współpracy. Jako punkt kulminacyjny należy traktować referendum z 8 lutego 2009 r., w którym obywatele opowiedzieli się za kontynuacją umowy i otwarciem rynku pracy dla obywateli Bułgarii oraz Rumunii. Oczywiście w przypadku kolejnego rozszerzenia UE może zostać złożony wniosek w sprawie przeprowadzenia kolejnego referendum, a wówczas powtórnie dalsza współpraca mogłaby być zagrożona. Biorąc jednakże pod uwagę doświadczenia z poprzednich głosowań, z roku 2005 oraz 2009, można uznać taką możliwość za mało prawdopodobną, tym bardziej że nawet kryzys gospodarczy z lat 2008-2010 nie wpłynął negatywnie na wynik głosowania. $Z$ kolei umowa w sprawie transportu wykazuje wiele cech dynamicznych, które mogą w pewnym momencie zostać zakwestionowane przez stronę szwajcarską. Położenie Szwajcarii sprawia, iż kraj ten traktowany jest jako jeden z najważniejszych korytarzy tranzytowych. Nie dziwią zatem zabiegi Unii na rzecz harmonizacji, a więc w praktyce poluzowania przepisów dotyczących transportu kołowego na terytorium Szwajcarii. Pamiętając jednak o ogromnej wadze, jaką przykładają Szwajcarzy do ochrony środowiska, a zwłaszcza terenów alpejskich, widzimy, że polityka UE wyraźnie nie idzie w parze ze stanowiskiem władz Szwajcarii i tamtejszej opinii publicznej. 
Umowy bilateralne

\begin{tabular}{|c|c|}
\hline Umowa & Przelomowe daty \\
\hline \multicolumn{2}{|l|}{ BILATERALE I } \\
\hline Swoboda przepływu osób & $\begin{array}{l}\text { Podpisanie: } 21 \text { czerwca } 1999 \text { r. } \\
\text { Wejście w życie: } 1 \text { czerwca } 2002 \text { r. }\end{array}$ \\
\hline Bariery techniczne w handlu & $\begin{array}{l}\text { Podpisanie: } 21 \text { czerwca } 1999 \text { r. } \\
\text { Wejście w życie: } 1 \text { czerwca } 2002 \text { r. }\end{array}$ \\
\hline Zamówienia publiczne & $\begin{array}{l}\text { Podpisanie: } 21 \text { czerwca } 1999 \text { r. } \\
\text { Wejście w życie: } 1 \text { czerwca } 2002 \text { r. }\end{array}$ \\
\hline Badania & $\begin{array}{l}\text { Podpisanie: } 21 \text { czerwca } 1999 \text { r. } \\
\text { Wejście w życie: } 1 \text { czerwca } 2002 \text { r. }\end{array}$ \\
\hline Transport lądowy & $\begin{array}{l}\text { Podpisanie: } 21 \text { czerwca } 1999 \text { r. } \\
\text { Wejście w życie: } 1 \text { czerwca } 2002 \text { r. }\end{array}$ \\
\hline Transport lotniczy & $\begin{array}{l}\text { Podpisanie: } 21 \text { czerwca } 1999 \text { r. } \\
\text { Wejście w życie: } 1 \text { czerwca } 2002 \text { r. }\end{array}$ \\
\hline Rolnictwo & $\begin{array}{l}\text { Podpisanie: } 21 \text { czerwca } 1999 \text { r. } \\
\text { Wejście w życie: } 1 \text { czerwca } 2002 \text { r. }\end{array}$ \\
\hline \multicolumn{2}{|l|}{ BILATERALE II } \\
\hline Schengen & $\begin{array}{l}\text { Podpisanie: } 26 \text { października } 2004 \text { r. } \\
\text { Wejście w życie: } 1 \text { marca } 2008 \text { r. (kontrole na lotniskach dla } \\
\text { lotów w strefie Schengen zostały zniesione } 29 \text { marca } 2009 \text { r.) }\end{array}$ \\
\hline Dublin & $\begin{array}{l}\text { Podpisanie: } 26 \text { października } 2004 \text { r. } \\
\text { Wejście w życie: } 1 \text { marca } 2008 \text { r. }\end{array}$ \\
\hline Przetworzone produkty rolne & $\begin{array}{l}\text { Podpisanie: } 26 \text { października } 2004 \text { r. } \\
\text { Wejście w życie: } 30 \text { marca } 2005 \text { r. }\end{array}$ \\
\hline Statystyka & $\begin{array}{l}\text { Podpisanie: } 26 \text { października } 2004 \text { r. } \\
\text { Wejście w życie: } 1 \text { stycznia } 2007 \text { r. }\end{array}$ \\
\hline Ochrona środowiska & $\begin{array}{l}\text { Podpisanie: } 26 \text { października } 2004 \text { r. } \\
\text { Wejście w życie: } 1 \text { kwietnia } 2006 \text { r. }\end{array}$ \\
\hline MEDIA & $\begin{array}{l}\text { Podpisanie: } 26 \text { października } 2004 \text { r. } \\
\text { Wejście w życie: } 1 \text { sierpnia } 2010 \text { r. }\end{array}$ \\
\hline Emerytury i renty & $\begin{array}{l}\text { Podpisanie: } 26 \text { października } 2004 \text { r. } \\
\text { Wejście w życie: } 31 \text { maja } 2005 \text { r. }\end{array}$ \\
\hline Zwalczanie oszustw & $\begin{array}{l}\text { Podpisanie: } 26 \text { października } 2004 \text { r. } \\
\text { Wejście w życie: - }\end{array}$ \\
\hline Opodatkowanie odsetek & $\begin{array}{l}\text { Podpisanie: } 26 \text { października } 2004 \text { r. } \\
\text { Wejście w życie: } 1 \text { lipca } 2005 \text { r. }\end{array}$ \\
\hline Edukacja, kształcenie, młodzież & $\begin{array}{l}\text { Podpisanie: } 15 \text { lutego } 2010 \mathrm{r} . \\
\text { Wejście w życie: } 1 \text { marca } 2011 \text { r. }\end{array}$ \\
\hline
\end{tabular}

Źródło: Integrationsbüro EDA/EVD, stan z 3.08.2011 r. 
Priorytetem w polityce władz wobec UE jest obecnie konsekwentne realizowanie postanowień porozumień, doprowadzenie do wejścia w życie wszystkich umów, ich bieżąca aktualizacja, a także negocjowanie kolejnych obszarów. Już teraz prowadzone są rozmowy m.in. w sprawie polityki energetycznej (głównie liberalizacji rynku) czy handlu produktami rolnymi oraz spożywczymi. Sporym wyzwaniem jest również sektor ochrony zdrowia. Należy jednak zauważyć, że na tym etapie najbardziej pilne obszary współpracy zostały uregulowane.

Poniżej omówione zostaną kolejne porozumienia, co ma na celu przedstawienie wszystkich płaszczyzn współpracy. Pozwoli to również na scharakteryzowanie polityki Szwajcarii wobec Unii Europejskiej w poszczególnych obszarach tematycznych. Wart podkreślenia jest fakt, iż z zaproponowanych przez rząd szwajcarski w roku 1993 zagadnień, obecnie wszystkie zostały objęte dwustronnymi porozumieniami. Oznacza to, że pomimo początkowego sprzeciwu ze strony UE (wyrażono zgodę na negocjowanie tylko siedmiu z 16 zaproponowanych przez Szwajcarię obszarów) oraz nieufności czy nawet niechęci znacznej części społeczeństwa szwajcarskiego, polityka władz Szwajcarii była konsekwentnie realizowana. Częściowa integracja stała się faktem.

\section{SWOBODA PRZEPŁYWU OSÓB (PERSONENFREIZÜGIGKEIT)}

Powyższa umowa jest jednym z elementów jednolitego rynku Unii Europejskiej, które tworzą zasady czterech swobód. Poza przepływem osób zaliczamy do nich również swobodę przepływu kapitału, towaru i usług. Głównym celem przedmiotowej umowy jest zagwarantowanie Szwajcarii dostępu do wspólnotowego rynku. Ocenia się, że obecnie ok. 400000 Szwajcarów żyje i pracuje w państwach UE. I choć nie należy zapominać, że zamysłem stworzenia wspólnego rynku jest zagwarantowanie wszystkim stronom obopólnych korzyści, wynikających ze swobody osiedlania się i podejmowania pracy, umowa ta oceniana jest głównie przez pryzmat ewentualnych strat wynikających z otwarcia rynku pracy w Szwajcarii dla obcokrajowców. Biorąc pod uwagę potencjał ludnościowy oraz ekonomiczny można przyjąć, że większe konsekwencje wynikające z zawarcia tego typu porozumienia poniesie Szwajcaria. Trzeba jednakże zaznaczyć, iż liczba obcokrajowców w tym państwie oscyluje w granicach $21 \%{ }^{109}$ i nie jest to liczba będąca efektem porozumień zawartych z UE w ciągu kilku ostatnich lat. Szwajcaria od dawna uzależniona była od zagranicznej siły roboczej. Oczywiście liczba obcokrajowców ulegała zmianom na przestrzeni lat. Zdecydowanie najniższy ich odsetek odnotowano tuż po zakończeniu II wojny światowej. Wynosił on wówczas niecałe $5 \%$. Z biegiem lat gospodarka szwajcarska coraz szybciej się rozwijała. Ponieważ rodzimy rynek nie pokrywał zapotrzebowania, pracowników zaczęto szukać także za granicą. Dzięki podpisanym z Włochami i Hiszpanią, w latach 60.

${ }^{109}$ Według danych Urzędu ds. Migracji z końca kwietnia 2010 r. wskaźnik ten wynosi 21,8\%. 
i 70. XX w., umowom dwustronnym w sprawie zatrudnienia, coraz więcej emigrantów podejmowało pracę w Szwajcarii. Dla rządów państw borykających się z wysokim poziomem bezrobocia był to szczególnie korzystny układ. Oczywiście w zamierzeniu władz Szwajcarii pobyt takich pracowników miał mieć charakter jedynie czasowy. Po latach okazało się jednak, że emigranci niechętnie powracają do swoich ojczyzn ${ }^{110}$. Władze podejmowały próby wydalenia takich osób, co jednak zakończyło się najwyżej częściowym sukcesem ${ }^{111}$. Z czasem coraz więcej obcokrajowców, znęconych atrakcyjnymi warunkami płacowymi oraz wysokim poziomem życia, przybywało do Szwajcariii ${ }^{112}$. Do tego dodać należy również sporą grupę uciekinierów politycznych z bloku wschodniego, którzy właśnie w Szwajcarii starali się o azyl. Pod koniec lat 70. obcokrajowcy stanowili nieco ponad $17 \%$ ogólnej liczby mieszkańców ${ }^{113}$. Wydarzenia związane z rozpadem ZSRR, wojną domową w byłej Jugosławii przyczyniły się do zwiększenia odsetka osób obcego pochodzenia. Pod koniec lat 90 . XX w. liczba ta po raz pierwszy sięgnęła $20 \%$. Widać zatem wyraźnie, że nowa polityka władz Szwajcarii wobec UE nie wpłynęła w sposób znaczący na zwiększenie liczby obcokrajowców. Mamy tutaj raczej do czynienia ze zmianami o charakterze strukturalnym, tj. pewnymi przesunięciami w liczbie osób pochodzących z państw UE w stosunku do pozostałych.

Tabela 3.3

Obcokrajowcy w Szwajcarii

\begin{tabular}{|l|c|c|}
\hline \multirow{2}{*}{\multicolumn{1}{|c|}{ Obcokrajowcy }} & \multicolumn{2}{|c|}{ Stan } \\
\cline { 2 - 3 } & liczba & w \% \\
\hline UE 27 / EFTA w tym: & 1076540 & 63,6 \\
\hline UE 15 / EFTA & 1036832 & 61,3 \\
\hline UE 10 (rozszerzenie 2004 r.) & 32091 & 1,9 \\
\hline UE 2 (rozszerzenie 2007 r.) & 7617 & 0,5 \\
\hline Pozostałe kraje & 616028 & 36,4 \\
\hline
\end{tabular}

Źródło: Bundesamt für Migration (04.2010 r.).

${ }^{110} \mathrm{Na}$ tle problemów asymilacyjnych dochodziło do coraz większych napięć społecznych. Sytuację wykorzystywały ugrupowania prawicowe, które swoją pozycję polityczną zdobyły dzięki nierzadko radykalnym hasłom skierowanym przeciwko emigrantom. Por. T. Buomberger, Kampf gegen unerwünschte Fremde. Von James Schwarzenbach bis Christoph Blocher, Zürich 2004; I. Drews, Schweizer erwache!, Frauenfeld 2005.

${ }^{111}$ Zob. T. Kästli, Selbsbezogenheit und Offenheit. Die Schweiz in der Welt des 20. Jahrhunderts, NZZ Libro, Zürich 2005, s. 435-436.

${ }^{112}$ Było to również możliwe dzięki programowi łączenia rodzin.

${ }^{113}$ Zob. J. Zieliński, Wielokulturowość Szwajcarii na rozdrożu, Wydawnictwo Uniwersytetu Jagiellońskiego, Kraków 2009, s. 84-96. 
Inicjatywa zawarcia porozumienia $\mathrm{w}$ sprawie swobody przepływu osób pojawiła się jeszcze na etapie negocjacji dotyczących włączenia Szwajcarii do Europejskiego Obszaru Gospodarczego. Otwarcie rynku pracy miało mieć charakter raczej bezwarunkowy, nie przewidywano wówczas, poza krótkimi okresami przejściowymi, zastosowania żadnych dodatkowych instrumentów ochronnych ${ }^{114}$. Obawa przed gwałtownym wzrostem bezrobocia była zresztą jedną z przyczyn odrzucenia wniosku w referendum. W związku z powyższym rząd, w swoim sprawozdaniu z 26 listopada 1996 r., wyraźnie podkreślił, iż zawarcie porozumienia w sprawie swobody przepływu osób z UE wymaga zastosowania specjalnych regulacji.

Były one jednym z najważniejszych elementów rokowań z Unią Europejską, dotyczących pierwszego pakietu porozumień. Ostatecznie udało się wynegocjować wprowadzenie zasady wspólnego rynku etapami wraz z zastosowaniem specjalnych instrumentów ochronnych ${ }^{115}$. Dzięki temu obywatele Unii Europejskiej oraz Szwajcarii mają możliwość osiedlania się i podejmowania pracy w dowolnie wybranym przez siebie kraju. Porozumienia o swobodzie przepływu osób dopełniają umowy w sprawie wzajemnego uznania dyplomów ${ }^{116}$ oraz koordynacji systemów ubezpieczenia społecznego.

Początkowo polityka władz Szwajcarii zmierzała do wprowadzenia na stałe kontyngentów ilościowych, a więc ustanowienia jedynie częściowej swobody, tak aby zagwarantować ochronę rodzimego rynku. Unia Europejska nie podzielała jednak tego stanowiska, albowiem byłoby to sprzeczne z zasadami traktatu ustanawiającego Wspólnotę Europejską, a więc również wspólnotowego rynku. Ostatecznie uzgodniono wprowadzenie kontyngentów ilościowych, ale obowiązujących jedynie przez pierwsze pięć lat ${ }^{117}$. W tym okresie stałe pozwolenie na pracę mogło otrzymać maksymalnie 15000 osób, a czasowe, tj. od czterech do 12 miesięcy, nie więcej niż 115 500. Od momentu wejścia w życie pierwszego pakietu aż do czerwca roku 2007 obywatele tzw. starej Unii oraz Malty i Cypru mieli więc możliwość podjęcia pracy w Szwajcarii w ograniczonej liczbie. Po tym okresie kontyngenty zostały zniesione. Pozostawiono jedynie możliwość ich powtórnego wprowadzenia w przypadku, gdyby liczba obcokrajowców gwałtownie

${ }^{114}$ Przewidziano jedynie zastosowanie tzw. kolektywnej klauzuli ochronnej, która oznaczała możliwość podjęcia przez Wspólnotę retorsji w stosunku do wszystkich krajów EFTA, bez możliwości skierowania ich tylko do wybranego państwa.

${ }^{115}$ Zob. więcej nt. umowy dotyczącej swobody przepływu osób w opracowaniu D.W. Grossen, C. de Coulon, Bilaterales Abkommen über die Freizügigkeit zwischen der Schweiz und der Europäischen Gemeinschaft und Ihren Mitgliedstaaten, [w:] D. Thürer, R.H. Weber, W. Portmann, A. Kellerhals, Bilaterale Verträge I \& II Schweiz - EU. Handbuch, Schulthess, Zürich 2007, s. 135-143.

116 Dotyczy wyłącznie zawodów, których wykonywanie wymaga posiadania określonego dyplomu, np. lekarz, pielęgniarka, dentysta, farmaceuta.

${ }^{117}$ Kontyngenty nie obowiązywały mieszkańców stref przygranicznych, którzy mogli dowolnie przekraczać granicę i pracować w Szwajcarii, pod warunkiem, że przynajmniej raz w tygodniu wracają do kraju pochodzenia. 
wzrosła. Zapis ten zawarto w tzw. klauzuli ochronnej ${ }^{118}$. Dodatkowo, przez pierwsze dwa lata funkcjonowania umowy, obowiązywała zasada pierwszeństwa obywateli Szwajcarii na rynku pracy (priorytet narodowy). Oznacza ona, że przedsiębiorca, aby zatrudnić osobę z innego państwa, musi wykazać, iż nie może znaleźć osoby o wymaganych kwalifikacjach wśród rodaków. Ponadto rząd ma możliwość zastosowania dodatkowych instrumentów ochronnych w postaci obowiązku stosowania jednakowych warunków płacowych. Ma to na celu przeciwdziałanie zjawisku dumpingu, co pozwoli na utrzymanie wynagrodzeń na dotychczasowym poziomie. Zapis ten miał szczególne znaczenie w okresie rozszerzania Wspólnoty i konieczności objęcia swobodą także obywateli państw o zdecydowanie niższym poziomie zamożności.

Umowę w powyższym kształcie zawarto początkowo na siedem lat, z możliwością jej przedłużenia na czas nieokreślony. Podobne regulacje zastosowane zostały również wobec nowych państw Unii Europejskiej, co ujęto w oddzielnych protokołach dodatkowych, które weszły w życie kolejno w roku 2006 oraz 2009. Generalne uwarunkowania dla nowych członków UE pozostały takie same. Wydłużono jednak zasadę priorytetu narodowego oraz zaostrzono kontrolę wynagrodzenia i warunków pracy ${ }^{119}$. Także same kontyngenty ilościowe zwiększane są stopniowo, z początkowych 1700 osób, w latach 2006/2007, do 3000 w latach 2010/2011. Dla obywateli Bułgarii i Rumunii wprowadzono najdłuższe, bo trwające siedem lat, okresy przejściowe. Przewidziano również zdecydowanie mniejszą liczbę pozwoleń na pobyt stały (1207 osób) i czasowy (11 664 osób).

Umowa dotycząca swobodnego przepływu osób ma istotne znaczenie dla gospodarki Szwajcarii. Polityka władz w tym zakresie zmierzała do ułatwienia możliwości podejmowania pracy w państwach UE oraz stopniowego otwarcia szwajcarskiego rynku dla obcokrajowców ${ }^{120}$. Należy podkreślić, że przez lata Szwajcaria wypracowała własne sposoby na pozyskanie niezbędnych pracowników, na długo przed podpisaniem stosownej umowy z Unią Europejską. Jest to zresztą jeden z argumentów przeciwników współpracy bilateralnej. Tym razem chodziło jednak o stworzenie dogodnych warunków także dla obywateli Szwajcarii. Dotyczy to nie tylko osób, które chcą podjąć pracę w państwach należących do Unii, ale również przypadków, gdy szwajcarskie przedsiębiorstwa otrzymują zlecenia za granicą i, aby je wykonać, muszą wysyłać tam swoich pracowników. Dawniej wymagało to przebrnięcia przez czasochłonne procedury urzędowe. Po

${ }^{118}$ Dla obywateli starej piętnastki oraz dla państw, które przystąpiły do UE w roku 2004 klauzula obowiązuje do roku 2014. W przypadku Bułgarii i Rumunii okres ten wydłużono do 2019 r. Klauzula zakłada, że w przypadku zwiększenia liczby obcokrajowców w danym roku o więcej niż $10 \%$ w porównaniu ze średnią z trzech ostatnich lat, wprowadzone zostaną ograniczenia. Nie mogą one funkcjonować dłużej niż przez 2 lata.

119 Zwiększono częstotliwość kontroli o 20\%, ułatwiono dostęp do informacji dotyczących warunków płacowych poprzez stworzenie platformy internetowej (www.entsendung.ch), ulepszono system wymiany informacji pomiędzy władzami a organami kontrolnymi.

${ }^{120}$ Botschaft zur Genehmigung der sektoriellen Abkommen ..., s. 6128. 
otwarciu unijnych rynków bariery biurokratyczne zostały praktycznie wyeliminowane. Sytuacja ta wpływa pozytywnie na wzrost konkurencyjności szwajcarskich firm, co pozwala im w konsekwencji na tworzenie nowych miejsc pracy.

$\mathrm{Z}$ drugiej strony przedsiębiorcy mają również możliwość rekrutacji nowych pracowników, o których ze względu na zmiany demograficzne coraz trudniej w Szwajcarii. Ocenia się, że obecnie prawie 25\% zatrudnionych w Szwajcarii to obcokrajowy. W przypadku stanowisk kierowniczych liczba ta sięga nawet $40 \%$. Według rządowych wyliczeń, dzięki wprowadzeniu swobody przepływu osób produkt krajowy brutto wzrósł o 1\%, co odpowiada ok. 40-50 miliardom franków $^{121}$. Z kolei zastosowanie instrumentów ochronnych zapobiegło dumpingowi płacowemu. Przeciwnie, w ciągu ostatnich trzech lat wynagrodzenie w zawodach najsłabiej opłacanych, a więc tych najbardziej wrażliwych, wyraźnie wzrosło ${ }^{122}$. W porównaniu zatem $\mathrm{z}$ okresem sprzed podpisania porozumień bilateralnych władze Szwajcarii dysponują lepszymi instrumentami kontroli napływu cudzoziemców. Pozwala to na zagwarantowanie gospodarce dopływu siły roboczej w niezbędnym wymiarze. Oczywiście trudno przewidzieć, w jakim kierunku rozwinie się sytuacja po zniesieniu wszystkich barier, jednak trzeba pamiętać, że w dużym stopniu rynek reguluje się sam, co pokazuje chociażby przykład Wielkiej Brytanii. Podaż pracowników wzrasta wraz z rozwojem gospodarki i zwiększeniem popytu na rynku, a maleje przy spadku koniunktury i braku stabilności rynku pracy ${ }^{123}$. Oczywiście nie oznacza to, iż w przypadku Szwajcarii sytuacja potoczy się w sposób analogiczny. Niemniej jednak właśnie na ten rodzaj samoregulacji rynku liczy rząd tego kraju.

\section{BARIERY TECHNICZNE W HANDLU (TECHNISCHE HANDELSHEMMNISSE)}

Pojęcie „bariery techniczne” zostało wprowadzone do obiegu pojęciowego w trakcie kolejnej rundy negocjacyjnej GATT (Układ Ogólny w sprawie Taryf Celnych i Handlu) i oznacza ograniczenia pozataryfowe w handlu międzynarodowym. W rozumieniu prawa federalnego z roku 1995 jako bariery techniczne traktuje się $e^{124}$ :

- odmienne przepisy i normy techniczne;

- różne zastosowanie tychże przepisów i norm;

- nieuznanie przepisów, ocen zgodności, homologacji.

Umowa dotycząca barier technicznych w handlu nawiązuje do unijnej zasady wzajemnego uznawania produktów, będącej wynikiem orzeczenia Trybunału

${ }^{121}$ Die Bilateralen Abkommen Schweiz - Europäischen Union, Integrationsbüro EDA/EVD, November 2009, s. 25.

${ }^{122}$ Schweizerische Lohnstrukturerhebung, Bundesamt für Statistik, November 2007, s. 6-7.

${ }^{123}$ Zob. Braucht die Schweiz Personenfreizügigkeit?, „Neue Zürcher Zeitung”, 16. Januar 2009.

${ }^{124}$ Art. 3 Bundesgesetz über die technischen Handelshemmnisse (THG) vom 6. Oktober 1995 (Stand am 1. Juli 2010), AS 1996/1725, SR-946.51, s. 2. 
Europejskiego w tzw. sprawie Cassis de Dijon (sprawa 120/78). Zgodnie z nim towar legalnie wyprodukowany i wprowadzony do obrotu w jednym państwie UE powinien być dopuszczony na rynki pozostałych państw członkowskich ${ }^{125}$.

Do czasu wejścia w życie powyższej umowy każdy szwajcarski produkt, eksportowany na rynki Wspólnoty, musiał być uprzednio skontrolowany przez organ certyfikujący pod względem zgodności z przepisami UE ${ }^{126}$. Była to procedura czasochłonna i kosztowna, która ograniczała możliwości eksportowe szwajcarskich przedsiębiorstw. Nic więc dziwnego, iż harmonizacja przepisów była dla władz związkowych jednym z priorytetów. Co prawda umowa o wolnym handlu z EWG z 1972 r. znosiła znaczną część barier, lecz dotyczyła wyłącznie tych o charakterze taryfowym, jak cła lub podatki. Nie odnosiła się natomiast do pozostałych. Także porozumienie w ramach Światowej Organizacji Handlu przewiduje wzajemną wymianę informacji odnośnie do krajowych przepisów technicznych, ale nie wymaga, aby były one identyczne we wszystkich państwach będących sygnatariuszami umowy. Co więcej, każde państwo ma prawo do ustanawiania własnych procedur w zakresie ocen zgodności.

W związku z powyższym Rada Związkowa, w ramach programu rewitalizacji, przyjęła nową strategię, zakładającą dostosowanie przepisów krajowych do obowiązujących na terenie Wspólnoty. Jej efektem było wprowadzenie nowej ustawy dotyczącej barier technicznych, która weszła w życie 1 lipca 1996 r. ${ }^{127}$ Od tego momentu krajowe przepisy były na bieżąco aktualizowane pod kątem wspólnotowym, celem minimalizacji barier w handlu ${ }^{128}$. Dzięki temu towary szwajcarskie były produkowane według norm zgodnych z unijnymi, co znacznie ułatwiało eksport na rynki wspólnotowe.

Zjawisko autonomicznego dopasowania nie rozwiązywało jednak wszystkich problemów. Procedury oceny zgodności były nadal nieuznawane przez państwa Unii Europejskiej. Rząd Szwajcarii zdecydował się zatem rozwiązać tę kwestię na drodze dwustronnego porozumienia. Jak czytamy w sprawozdaniu władz związkowych z roku 1999, nie chodziło jednak o realizację zasady Cassis de Dijon, albowiem ta wymagałaby zastosowania rozwiązań o charakterze instytucjonalnym, przykładowo wspólnych organów jurysdykcyjnych, co wykraczało poza możli-

${ }^{125}$ Umowa zawarta pomiędzy Szwajcarią a Unią Europejską nie zakłada jednak automatycznego uznawania produktów. Przedmiotem porozumienia jest harmonizacja ocen zgodności, która możliwa jest jedynie dzięki temu, że szwajcarskie przepisy dopuszczające produkt do obrotu handlowego są kompatybilne z unijnymi.

${ }^{126}$ Por. T. Bruha, Normen und Standards im Warenverkehr mit Drittstaaten, [w:] M. Hilf, C. Tomuschat, EG und Drittstaatsbeziehungen nach 1992: Referate der Jahrestagung des Arbeitskreises Europäische Integration in Bonn vom 15. bis 17. November 1990, Baden-Baden 1991, s. 83-109.

${ }^{127}$ Bundesgesetz über die technischen Handelshemmnisse...

${ }^{128} \mathrm{Z}$ wyjątkiem przypadków, w których pewne odchylenia są uzasadnione, jak na przykład w zakresie ochrony zdrowia, konsumentów i środowiska naturalnego. Botschaft zur Genehmigung der sektoriellen Abkommen..., s. 6212. 
wości porozumień bilateralnych ${ }^{129}$. Tego typu rozwiązania mogłyby mieć zastosowanie w razie włączenia Szwajcarii do Europejskiego Obszaru Gospodarczego. Polityka rządu zmierzała jedynie do uznania przez państwa UE szwajcarskich ocen zgodności, co eliminowałoby ostatnią przeszkodę w dostępie do wspólnotowego rynku. Negocjacje w tej sprawie nie były długie, głównie dzięki temu, że Szwajcaria we własnym zakresie uruchomiła wspomniany już proces dostosowywania krajowych przepisów.

Umowa, która weszła w skład pierwszego pakietu porozumień, opiera się zatem na zasadzie wzajemnego uznania ocen zgodności. Przewiduje ona w tym względzie dwie możliwości ${ }^{130}$ :

- Jeżeli przepisy dotyczące danej kategorii produktów zostaną uznane za równoważne, wówczas ocena zgodności przeprowadzona przez organ kontrolny w Szwajcarii lub w jednym z państw UE jest automatycznie uznawana przez wszystkie strony. Oznacza to, że produkt nie musi być poddawany powtórnej kontroli przed wprowadzeniem na rynek wspólnotowy.

- Jeżeli przepisy nie są uznawane za równoważne, wówczas dany produkt musi przejść dwie kontrole, według prawa Szwajcarii oraz UE. Dopuszczalne jest jednak, aby obie procedury zostały przeprowadzone przez jeden organ kontrolny, mający swoją siedzibę w Szwajcarii lub w jednym z państw Unii Europejskiej.

Nie wszystkie grupy produktów zostały objęte umową, co wcale nie oznacza, że w przyszłości nie może być ona rozszerzona ${ }^{131}$. Jedynym warunkiem jest uznanie kompatybilność przepisów. Jeśli wymóg ten zostanie spełniony przez Szwajcarię, kolejne produkty będą mogły być objęte wspólnymi procedurami ocen zgodności. Nastąpiło to już w odniesieniu do materiałów budowlanych, które włączone zostały do umowy w marcu 2008 r. ${ }^{132}$

Dzięki harmonizacji przepisów technicznych władze Szwajcarii zagwarantowały rodzimym przedsiębiorstwom dostęp do ogromnego rynku, liczącego niemal 450 mln konsumentów. Eksport stał się łatwiejszy i tańszy, co w konsekwencji doprowadziło do zwiększenia produkcji i wzmocnienia pozycji szwajcarskich produktów na zagranicznych rynkach ${ }^{133}$. Ułatwiony import z państw UE umożliwił z kolei poszerzenie asortymentu oferowanego szwajcarskim konsumentom, co zwiększyło konkurencję, a w konsekwencji wpłynęło na obniżenie cen niektórych produktów.

${ }^{129}$ Ibidem.

${ }^{130}$ Die Bilateralen Abkommen Schweiz - Europäischen Union..., November 2009, s. 27-28.

131 Postanowieniami umowy nie są objęte środki ochrony roślin oraz niektóre kosmetyki, produkty chemiczne czy spożywcze. Dzieje się tak, ponieważ część produktów, np. spożywczych, nie podlega ocenom zgodności lub też pomiędzy przepisami szwajcarskimi a unijnymi występują zbyt duże różnice.

${ }^{132} \mathrm{~W}$ tym przypadku szwajcarskie przepisy wymagały ujednolicenia na poziomie federalnym, ponieważ wcześniej każdy kanton dysponował oddzielnymi przepisami.

133 Ocenia się, że harmonizacja ocen zgodności pozwoliła szwajcarskim firmom na zaoszczędzenie rocznie od 200 do $500 \mathrm{mln}$ franków. Zob. Bilaterale Abkommen Schweiz - EU, Integrationsbüro EDA/EVD, August 2009, s. 14. 


\section{ZAMÓWIENIA PUBLICZNE (ÖFFENTLICHES BESCHAFFUNGSWESEN)}

Podstawowym celem powyższej umowy jest rozszerzenie czy też uzupełnienie postanowień porozumienia zawartego w ramach Światowej Organizacji Handlu w dniu 15 kwietnia 1994 r. (Government Procerement Agreement). Zgodnie z przyjętymi regulacjami wszyscy sygnatariusze, w tym również Szwajcaria, zobowiązani są do przeprowadzania otwartych przetargów na określone towary i usługi. Regulacjami tymi objęte są podmioty publiczne na poziomie federalnym oraz kantonalnym i jedynie powyżej określonej kwoty.

Za punkt wyjścia negocjacji w dziedzinie zamówień publicznych należy przyjąć wymianę not pomiędzy Szwajcarią a Komisją Europejską z marca oraz maja roku 1994. Obie strony potwierdziły w nich gotowość do zawarcia dwustronnego porozumienia gwarantującego liberalizację rynku na poziomie obowiązującym w ramach Europejskiego Obszaru Gospodarczego ${ }^{134}$. Pierwsza runda negocjacyjna rozpoczęła się w lutym roku 1995. Największe różnice w stanowiskach obu stron zaznaczyły się w kwestii zakresu obowiązywania zasady niedyskryminacji oraz pozycji i roli niezależnego organu kontrolnego, którego zadaniem jest nadzorowanie wykonywania postanowień umowy. Ostatecznie kompromis udało się osiągnąć w marcu 1997 r. Warto zaznaczyć, że w negocjacjach czynny udział wzięli także przedstawiciele władz kantonalnych, tj. eksperci powołani przez Konferencję rządów kantonalnych (Konferenz der Kantonsregerungen $)^{135}$.

Umowa bilateralna, zawarta pomiędzy Szwajcarią a Unią Europejską, w dziedzinie zamówień publicznych ma na celu wspieranie zasad transparentności i konkurencyjności w dostępie do wspólnego rynku. Porozumienie rozszerza zakres podmiotów, które przy organizowaniu przetargów na dostawę określonych produktów lub usług muszą wyłonić wykonawcę zgodnie z zasadami zamówień publicznych. Od wejścia w życie powyższej umowy nowymi regulacjami objęte są nie tylko podmioty publiczne, lecz również prywatne, które ze względu na rodzaj oferowanych usług bądź towarów zajmują pozycję monopolistyczną. Do takich zalicza się przykładowo przedsiębiorstwa komunikacji zbiorowej (pociągi, autobusy, linie lotnicze), energetyczne czy zakłady wodno-kanalizacyjne. Ponadto procedurami wydatkowania środków publicznych objęte są również gminy oraz okręgi. Przyjęto, że wszystkie zamówienia muszą być udzielane w zgodzie z trzema głównymi zasadami:

- transparentności;

- równego traktowania wszystkich oferentów (bez względu na kraj pochodzenia);

- możliwości odwołania się od decyzji dotyczących wyłonienia wykonawcy.

${ }^{134}$ G. Biaggini, Das Abkommen über bestimmte Aspekte des öffentlichen Beschaffungswesens, [w:] D. Thürer, R.H. Weber, W. Portmann, A. Kellerhals, op. cit., s. 653.

${ }^{135}$ Botschaft zur Genehmigung der sektoriellen Abkommen..., s. 6145. 
Powyższe zasady odnoszą się jedynie do zamówień przekraczających określone wartości. Przykładowo, w przypadku robót budowlanych kwota ta wynosi $10 \mathrm{mln}$ franków, towarów i usług 250000 (na poziomie federalnym) lub 380000 (na poziomie gminy bądź kantonu) ${ }^{136}$. Uzgodniono również, że w przypadku zamówień o niższej wartości obie strony będą co prawda przestrzegały zasad niedyskryminacji, jednakże nie obowiązują wówczas żadne procedury odwoławcze ${ }^{137}$. Mamy tutaj do czynienia zatem z tzw. gentleman's agreement.

Nad właściwą realizacją postanowień umowy czuwają niezależne komisje, powoływane oddzielnie przez każdą ze stron ${ }^{138}$. W przypadku UE rolę tę odgrywa Komisja Europejska, po stronie Szwajcarii Komisja ds. wdrażania i monitorowania międzynarodowych zobowiązań tego państwa w dziedzinie zamówień publicznych (KBBK) ${ }^{139}$. Umowa przewiduje ponadto wzajemną wymianę informacji na temat przetargów oraz istotnych przepisów prawnych, a także dostępu do odpowiednich baz danych ${ }^{140}$.

Umowa dotycząca zamówień publicznych nie była nigdy traktowana jako wyjątkowo ważny element pakietu Bilaterale I. Nie ulega wątpliwość, że wartość przetargów organizowanych przez pomioty publiczne jest ogromna. Tylko w państwach UE, według szacunkowych wyliczeń, sięga ona 750 miliardów euro rocznie, co stanowi ok. $11 \% \mathrm{PKB}^{141}$. Ocenia się, że w niektórych państwach ponad 30\% przetargów odbywa się zgodnie z procedurami wydatkowania środków publicznych $^{142}$. W przypadku Szwajcarii łączna kwota zamówień publicznych przekroczyła w roku 2004 33,5 mld franków szwajcarskich ${ }^{143}$. Dzięki umowie bilateralnej przedsiębiorstwa mają ułatwiony dostęp do międzynarodowych przetargów, co wpływa na wzrost konkurencyjności i stabilizację cen. Rząd Szwajcarii podkreślał ponadto, że ma nadzieję na bardziej ekonomiczne wykorzystanie środków publicznych. Należy jednak zauważyć, iż znaczenie tej umowy jest w praktyce zdecydowanie mniejsze. Krajowe przedsiębiorstwa dysponują bowiem istotną przewagą w postaci chociażby lepszej znajomości lokalnych rynków. Dzięki temu

${ }^{136}$ Bilaterale Abkommen Schweiz - EU..., s. 16.

${ }^{137}$ Botschaft zur Genehmigung der sektoriellen Abkommen ..., s. 6147.

${ }^{138}$ Zob. art. 8 Abkommen zwischen der Schweizerischen Eidgenossenschaft und der Europäischen Gemeinschaft über bestimmte Aspekte des öffentlichen Beschaffungswesens, AS 2002/1951, SR-0.172.052.68, s. 8 .

${ }^{139}$ Komisja składa się z równej liczby przedstawicieli Związku oraz kantonów i powiązana jest z SECO. KBBK ma za zadanie spójną realizację międzynarodowych zobowiązań Szwajcarii w dziedzinie zamówień publicznych na wszystkich szczeblach administracji. Przyjmuje skargi dotyczące stosowania umowy i ma możliwość samodzielnie zainicjować taki proces. W niektórych przypadkach ma prawo do wydawania zaleceń.

${ }^{140}$ Botschaft zur Genehmigung der sektoriellen Abkommen... Informacje na temat przetargów w Szwajcarii dostępne są na stronie www.simap.ch, w Unii Europejskiej na stronie http://simap. eu.int.

${ }^{141}$ Botschaft zur Genehmigung der sektoriellen Abkommen ..., s. 6148.

${ }^{142}$ G. Biaggini, op. cit., s. 658.

${ }^{143}$ Die Bilateralen Abkommen Schweiz - Europäischen Union..., s. 30. 
mają większą wiedzę na temat prowadzonych przetargów oraz mogą przygotować korzystniejszą ofertę.

\section{BADANIA (FORSCHUNG)}

Umowa w sprawie współpracy naukowo-technicznej pomiędzy Szwajcarią a Unią Europejską została zawarta pierwotnie w roku 1999. Od tego momentu była już dwukrotnie odnawiana, ponieważ w przeciwieństwie do innych porozumień, zawieranych w ramach pakietów Bilaterale $I$ oraz II, okres obowiązywania determinowany jest przez czas trwania bieżącego programu UE. Umowa dotyczy udziału Szwajcarii w Programie Ramowym UE w zakresie badań i rozwoju technologicznego, będącym podstawowym instrumentem realizacji strategii lizbońskiej oraz największym mechanizmem finansowania i kształtowania badań naukowych na poziomie europejskim ${ }^{144}$. Ponieważ czas trwania programu oraz jego budżet są zmienne, umowa w sprawie partycypacji Szwajcarii musi być każdorazowo odnawiana. Ostatnia, dotycząca 7. Programu Ramowego UE na lata 2007-2013, zawarta została w czerwcu roku 2007 i weszła w życie w lutym 2008 r. $^{145}$

Polityka Szwajcarii zakładała rozszerzenie współpracy w dziedzinie badań naukowych, zapoczątkowanej w roku $1986^{146}$. Ograniczała się ona do organizowania regularnych spotkań oraz wymiany informacji. Nic więc dziwnego, że zapotrzebowania w tym obszarze były znacznie większe. Parlament Szwajcarii po raz pierwszy podjął decyzję o współfinansowaniu programu UE w roku $1992^{147}$. Uruchomienie pierwszego kredytu związane było ze spodziewanym włączeniem Szwajcarii do EOG. Jednak po fiasku w referendum zdecydowano się na kontynuację współpracy w ramach umowy bilateralnej.

Pierwsza runda negocjacyjna zakładała udział Szwajcarii w 5. Programie Ramowym, przewidzianym na lata 1998-2002. Związanie umowy klauzulą gilotyny pokrzyżowało jednak plany rządu, gdyż odłożyło w czasie wejście w życie całego pakietu. Udział w 5. Programie Ramowym nie był tym samym możliwy. W tej sytuacji konieczne było negocjowanie udziału Szwajcarii w kolejnym okresie programowania. Rząd przystąpił do negocjacji po zatwierdzeniu przez parlament, w czerwcu roku 2002, kredytu na sfinansowanie szwajcarskie-

${ }^{144}$ Źródło: http://www.kpk.gov.pl/7pr/podstawy/cele_i_budzet.html (09.08.2010 r.).

145 Abkommen über wissenschaftlich-technische Zusammenarbeit zwischen der Schweizerischen Eidgenossenschaft einerseits und der Europäischen Gemeinschaft und der Europäischen Atomgemeinschaft andererseits, AS 2008/3237, SR-0.420.513.1.

146 Zob. Rahmenabkommen über wissenschaftlich-technische Zusammenarbeit zwischen der Schweizerischen Eidgenossenschaft und den Europäischen Gemeinschaften, AS 1987/1389, SR0.420 .518 .

147 Zob. Bundesbeschluss über die Finanzierung der Beteiligung der Schweiz an den Forschungs- und Bildungsprogrammen der Europäischen Gemeinschaften 1993-1996 vom 18. Dezember 1992, BBI 1993 I, s. 29. 
go wkładu w 6. Programie Ramowym ${ }^{148}$. Treść porozumienia została zaakceptowana w lipcu 2003 r. Dzięki temu Szwajcaria mogła już wziąć czynny udział w programie przewidzianym na lata 2003-2006 ${ }^{149}$. Finansowy wymiar partycypacji wyliczany jest na podstawie skonsolidowanych danych dotyczących PKB Szwajcarii i UE. Odpowiada on 2,8\% całkowitego budżetu programu.

Po wygaśnięciu 6. $P R \mathrm{w}$ grudniu roku 2006 rząd Szwajcarii, analogicznie do wcześniejszych doświadczeń, przystąpił do renegocjowania kolejnego porozumienia. Zostało ono zawarte na podobnych warunkach. Wzmocniono jedynie aspekty finansowego zabezpieczenia $\mathrm{w}$ przypadku zerwania umowy przez jedną ze stron oraz uzupełniono współpracę o tzw. Wspólne Inicjatywy Technologiczne (JTI), zakładające nawiązanie partnerstwa publiczno-prywatnego w celu sfinansowania badań wymagających długoterminowego finansowania ${ }^{150}$.

Uczestnictwo Szwajcarii w 7. Programie Ramowym, przewidzianym na lata 2007-2013, umożliwia uczelniom, ośrodkom naukowo-badawczym, a także firmom i osobom fizycznym dostęp do największego w Europie mechanizmu wspierania i finansowania badań, na poziomie równym z państwami Unii Europejskiej. Oznacza to możliwość nie tylko wzięcia udziału w wybranym projekcie badawczym, ale również jego inicjowanie i koordynację. Jedyną konieczną do spełnienia przesłanką jest znalezienie przynajmniej dwóch partnerów w krajach UE lub EFTA (bądź Izraela). Ponadto Szwajcaria ma zagwarantowany dostęp do wyników badań pozostałych projektów, co nie było możliwe przed zawarciem umowy dwustronnej. W okresie 2007-2013 przeznaczono na programy w sumie 54,6 mld euro, tzn. ok. $60 \%$ więcej niż w przypadku poprzedniego okresu. Istotne jest również, że w bieżącym programie szczególny nacisk kładzie się na rozwój technologii informacyjnych oraz komunikacyjnych, a także ochrony zdrowia, energetyki, nanotechnologii i ochrony środowiska, a więc obszary, w których Szwajcaria ma szczególne osiągnięcia ${ }^{151}$.

Niewątpliwym atutem Programu Ramowego UE jest efekt wzmocnionej współpracy ośrodków naukowych z biznesem. Ułatwia to w znacznym stopniu późniejszą komercjalizację wyników badań. Ocenia się, że prawie jedna trzecia projektów, w których brali udział Szwajcarzy, opierała się na współpracy uczelni wyższych z firmami ${ }^{152}$. W przypadku 6. $P R$ prawie jedna czwarta środków, tj. 203 mln franków, trafiła do szwajcarskich przedsiębiorstw.

${ }^{148}$ Zob. Bundesbeschluss über die Finanzierung der Beteiligung der Schweiz an den Programmen der EU im Bereich der Forschung, der technologischen Entwicklung und der Demonstration in den Jahren 2003-2006 vom 6. Juni 2002, BBI 2002 Nr. 30, s. 5246.

${ }^{149}$ Umowa weszła w życie przed zatwierdzeniem jej przez parlament. Rząd skorzystał ze swoich kompetencji, zawartych w art. 184 konstytucji związkowej.

${ }^{150}$ Tego rodzaju badania mogą być współfinansowane przez podmioty prywatne oraz pożyczki i gwarancje z Europejskiego Banku Inwestycyjnego.

${ }^{151}$ Die Bilateralen Abkommen Schweiz - Europäischen Union..., s. 32.

${ }^{152}$ Ibidem. 


\section{ROLNICTWO (LANDWIRTSCHAFT)}

Sektor rolny jest jednym z trudniejszych obszarów wzajemnej współpracy. Politykę Szwajcarii w tym zakresie możemy więc określić jako wyjątkowo ostrożną. Związane jest to przede wszystkim ze specyficznymi warunkami naturalnymi, które sprawiają, że produkcja rolna, bez odpowiednich dopłat państwowych, byłaby nieopłacalna. Otwarcie szwajcarskiego rynku na produkty z państw UE, które cechuje zazwyczaj niższa cena, poważnie zagroziłoby funkcjonowaniu wielu gospodarstw rolnych. Dlatego też władze związkowe nie wyraziły zgody na objęcie postanowieniami układu o wolnym handlu z EWG również sektora rolnego. Także w ramach GATT zniesiono jedynie cła na wybrane grupy produktów, ustanawiając przy tym kontyngenty ilościowe w taki sposób, aby móc ochronić szczególnie wrażliwe towary. Z drugiej strony rynek wewnętrzny nie jest na tyle chłonny, aby móc sprostać podaży, stąd też potrzeba zwrócenia się ku zagranicznym rynkom.

Od wielu lat rząd podejmował starania na rzecz ułatwienia szwajcarskim rolnikom sprzedaży swoich produktów za granicą. Odnosi się to przede wszystkim do mleka i jego przetworów, tj. głównie serów, które stały się marką rozpoznawalną na całym świecie. Nieprzetworzone produkty rolne nie są wystarczająco atrakcyjne na zagranicznych rynkach, przeważnie ze względu na wysoką cenę. Polityka władz zmierzała zatem do nawiązania dobrych kontaktów handlowych z państwami EWG, do których trafiała większość eksportu, jednakże z zastrzeżeniem zachowania własnej polityki rolnej i ominięcia całkowitej liberalizacji handlu w tym sektorze.

W trakcie negocjacji nad pierwszym pakietem porozumień bilateralnych import produktów rolnych z państw UE dwukrotnie przewyższał eksport, co świadczy o zdecydowanie większym znaczeniu rynku szwajcarskiego dla producentów unijnych niż odwrotnie. Nie zmienia to jednak faktu, że prawie $60 \%$ szwajcarskiego eksportu trafia do państw należących do Unii Europejskiej, głównie Niemiec, Francji i Włoch ${ }^{153}$. Na tamtejsze rynki eksportuje się zwłaszcza sery i czekoladę oraz w mniejszych ilościach żywe rośliny, suszone warzywa, przyprawy, sosy i oleje roślinne. Do Szwajcarii importuje się z kolei przede wszystkim te towary, które nie mogą być tu produkowane ze względu na uwarunkowania klimatyczne lub też takie, które są po prostu tańsze. Należą do nich przykładowo mięso, kawa, herbata, wino, ryby i owoce morza ${ }^{154}$.

Unia Europejska dążyła do zniesienia lub ewentualnie znacznego obniżenia barier taryfowych i pozataryfowych w handlu produktami rolnymi, co doprowadziłoby do stworzenia podstaw do liberalizacji rynku (idea wolnego handlu ze Szwajcarią miała być początkowo realizowana w ramach Europejskiego Obszaru

${ }^{153}$ R. Senti, Abkommen über den Handel mit landwirtschaftlichen Erzeugnissen, [w:] D. Thürer, R.H. Weber, W. Portmann, A. Kellerhals, op. cit., s. 733.

${ }^{154}$ Ibidem. 
Gospodarczego). Uważano również, że należy wyeliminować dopłaty eksportowe, celem zachowania zasad swobodnej konkurencji. Postulaty UE początkowo nie wywołały entuzjazmu w Szwajcarii, jednak ze względu na planowaną reformę rolną, zakładającą m.in. utrzymanie stałych wielkości produkcji, przystano na propozycję Brukseli. Rząd Szwajcarii liczył, że nowe porozumienie zagwarantuje rodzimym producentom również dostęp do unijnego rynku. Przewidywano zatem stopniową liberalizację handlu, zgodną z regułami obowiązującymi w ramach Światowej Organizacji Handlu, a zarazem idącą w parze z planowanymi reformami.

Umowa dotycząca handlu produktami rolnymi ${ }^{155}$ odnosi się do dwóch wymiarów - ilościowego oraz jakościowego. Pierwszy z nich zakłada stopniową eliminację barier taryfowych, tj. kontyngentów i ceł na wybrane grupy produktów ${ }^{156}$. Z punktu widzenia Szwajcarii najważniejszym elementem tego porozumienia jest handel serami, który od roku 2007 nie podległa już żadnym obostrzeniom. Drugi dotyka barier pozataryfowych, do których zaliczamy omawiane już wcześniej normy techniczne i sanitarne. Uległy one ujednoliceniu w stosunku do takich produktów, jak pasze, nasiona, wyroby spirytusowe, produkty ekologiczne.

Ponadto $\mathrm{w}$ umowie zawarto specjalny załącznik określający współpracę w dziedzinie weterynarii. Przyjęto w nim równoważność przepisów odnoszących się do wszystkich produktów pochodzenia zwierzęcego. Oznacza to, iż przykładowo sery, jaja, miód i wędliny mogą być eksportowane do państw Unii Europejskiej bez uzyskania specjalnej certyfikacji ${ }^{157}$.

W trakcie negocjacji nad umową obie strony uzgodniły, że podejmą w przyszłości działania zmierzające do uregulowania kwestii ochrony marek i produktów regionalnych. W październiku roku 2007 rozpoczęto negocjacje w tej sprawie. $\mathrm{W}$ efekcie zawarto dodatkowe porozumienie w kwestii oznaczeń pochodzenia geograficznego produktów rolnych ${ }^{158}$. Dotyczy ono wyrobów wytwarzanych na określonym obszarze i w tradycyjny sposób. Szwajcaria zabiegała o takie porozumienie przede wszystkim ze względu na marki serów regionalnych, których wolumen eksportu jest z roku na rok coraz większy ${ }^{159}$. Umowa opiera się na ustawodawstwie unijnym, stosowanym od roku 1992.

Wartość eksportu produktów rolnych do państw Unii Europejskiej wyniosła w roku 2008 4,9 mld franków. Osiągnięcie takiego wyniku zapewne nie byłoby możliwe bez częściowej liberalizacji rynku. Największym zainteresowaniem wśród europejskich konsumentów cieszą się sery szwajcarskie, stanowiące główną część eksportu. Ocenia się również, iż prawie jedna czwarta produkowanego

155 Zob. Abkommen vom 21. Juni 1999 zwischen der Schweizerischen Eidgenossenschaft und der Europäischen Gemeinschaft über den Handel mit landwirtschaftlichen Erzeugnissen, AS 2002/2147, SR-0.916.026.81.

${ }^{156}$ Owoce, warzywa, wołowina, wieprzowina, kwiaty, wina.

${ }^{157}$ Pod warunkiem, że prawo UE nie przewiduje szczególnych odstępstw. Od 1 stycznia 2009 r. zniesiono wszystkie kontrole weterynaryjne na granicach.

${ }^{158}$ Porozumienie zostało parafowane w kwietniu $2009 \mathrm{r}$.

${ }^{159} \mathrm{~W}$ latach 2005-2007 eksport zwiększał się rokrocznie o 7\%. 
w Szwajcarii mleka trafia na rynek unijny. Z drugiej strony, ze względu na wzrost importu, rośnie również konkurencja dla szwajcarskiego rolnictwa. Na razie dotyczy to tylko pewnej grupy produktów, które i tak ze względu na uwarunkowania naturalne produkowane są w Szwajcarii w niewielkich ilościach. Umowa o handlu produktami rolnymi była jednak tylko pierwszym etapem całego procesu. Dalsze kroki podjęto w ramach pakietu Bilaterale II, o którym mowa będzie poniżej.

\section{TRANSPORT DROGOWY (LANDVERKEHR)}

Umowa dotycząca transportu towarowego i pasażerskiego w ruchu kolejowym i drogowym ${ }^{160}$ należała do najtrudniejszych tematów w negocjacjach nad pakietem Bilaterale I. Rozmowy w tej sprawie trwały wyjątkowo długo, bo od końca 1994 do grudnia 1998 r. Główny problem polegał na tym, iż w przeciwieństwie do pozostałych umów, zasadniczym celem tego porozumienia nie było ujednolicenie przepisów Szwajcarii i UE, lecz ogólna harmonizacja polityki transportowej. Chodziło o określenie wspólnych celów i instrumentów, które miały służyć ich osiągnięciu. Rząd Szwajcarii promował pod tym względem strategię odciążenia dróg tranzytowych (zwłaszcza na terenach alpejskich) poprzez przeniesienie transportu na tory kolejowe ${ }^{161}$. Z kolei Unia Europejska dążyła do wprowadzenia swobodnego transportu drogowego przez terytorium Szwajcarii. Państwa UE kierowały się tu zresztą różnymi pobudkami. Podczas gdy Austrii i Francji zależało głównie na zniesieniu limitów obciążenia samochodów ciężarowych, wynoszącego w Szwajcarii 28 ton $^{162}$, Niemcom oraz Włochom chodziło przede wszystkim o obniżenie kosztów związanych z tranzytem przez Alpy ${ }^{163}$.

Do czasu zawarcia nowej umowy obowiązywało w relacjach dwustronnych porozumienie tranzytowe dotyczące ruchu drogowego i kolejowego, które zawarto w roku 1992 na okres 12 lat. Wprowadzało ono pewne ułatwienia, jednak nie rozwiązywało podstawowej kwestii związanej z odmiennymi koncepcjami rozwoju tego sektora. Sytuację pogorszyło przyjęcie w Szwajcarii nowej poprawki do konstytucji (tzw. Alpenschutzinitiative), mającej na celu ochronę terenów alpejskich poprzez ograniczenie ruchu kołowego. Oznaczało to, że realizacja przez Szwajcarię polityki UE byłaby sprzeczna z postanowieniami konstytucyjnymi.

Negocjacje dotyczące umowy podzielić można na dwa etapy. Rząd Szwajcarii był gotowy zrezygnować z limitów dotyczących masy pojazdu, pod warunkiem jednakże przyjęcia nowych regulacji fiskalnych. Pierwszy etap negocjacji

160 Abkommen vom 21. Juni 1999 zwischen der Schweizerischen Eidgenossenschaft und der Europäischen Gemeinschaft über den Güter- und Personenverkehr auf Schiene und Strasse, AS 2002/2649, SR-0.740.72.

${ }^{161}$ R.H. Weber, M. Friendli, Abkommen über den Güter- und Personenverkehr auf Schiene und Strasse, [w:] D. Thürer, R.H. Weber, W. Portmann, A. Kellerhals, op.cit., s. 408.

${ }^{162}$ Limit ten w państwach UE wynosi $40 \mathrm{t}$.

${ }^{163}$ Ibidem. 
zakończono zawarciem tzw. kompromisu z Kloten (Klotener Kompromiss), który uznawany jest często za przejaw europeizacji polityki Szwajcarii oraz helwetyzacji polityki UE w zakresie transportu drogowego ${ }^{164}$. Obie strony ustaliły, że limity zostaną zrównane z obowiązującymi na terenie Unii Europejskiej (a więc maksymalnie 40 ton). W ramach rekompensaty UE zgodziła się na wprowadzenie nowych stawek tranzytowych, które obowiązywać będą od momentu zniesienia limitów, tj. od roku 2005. Są one formą dodatkowego opodatkowania firm transportowych, które mają nakłonić je do przeniesienia części transportu na tory kolejowe. Opłaty obliczane są w zależności od masy pojazdu, przebytej odległości i emisji szkodliwych substancji ${ }^{165}$. Drugi etap zakończył się po przyjęciu nowej ustawy federalnej, dotyczącej budowy i finansowania infrastruktury drogowej ${ }^{166}$ oraz zatwierdzeniu w referendum taryf tranzytowych ${ }^{167}$. Ostateczny kompromis zawarto 12 grudnia $1998 \mathrm{r}$.

Umowa harmonizuje również przepisy i normy, umożliwiając tym samym liberalizację rynku dla usług transportowych, w tym także kolei. Ujednolicono m.in. standardy techniczne dopuszczające pojazdy do ruchu czy wymagania stawiane kierowcom samochodów ciężarowych. Dla przedsiębiorstw zajmujących się transportem kolejowym lub kombinowanym (samochody ciężarowe oraz kontenery ładowane na pociągi) oznacza to możliwość korzystania z infrastruktury kolejowej, tj. szyn i sieci trakcyjnej. Umowa nie dotyczy jedynie liberalizacji pasażerskiego transportu kolejowego. Większość biurokratycznych barier została zniesiona. Dzięki temu szwajcarskie przedsiębiorstwa mają swobodny dostęp do ogromnego rynku UE, gdzie mogą bez większych przeszkód oferować własne usługi.

Powyższe porozumienie jest doskonałym przykładem obrazującym potencjał negocjacyjny obydwu stron oraz możliwości osiągnięcia kompromisu, nawet w przypadku zupełnie odmiennych stanowisk. Rząd Szwajcarii, idąc na pewien kompromis, przekonał UE do konieczności wprowadzenia nowej strategii w zakresie transportu kołowego, której celem nadrzędnym jest ochrona środowiska naturalnego. Jeden z jej elementów polega na rozbudowie infrastruktury w postaci nowych linii kolejowych oraz dodatkowych tuneli, umożliwiających tranzyt omijający szczególnie cenne ekologicznie obszary ${ }^{168}$. Koszty związane z ich budową pokrywane są częściowo z wprowadzonych opłat ${ }^{169}$.

${ }^{164}$ Ibidem, s. 413.

${ }^{165}$ Średnia stawka w roku 2009 wynosiła 325 franków za każde 300 km przejechanych przez pojazd o masie 40 ton.

166 Bundesbeschluss über Bau und Finanzierung von Infrastrukturvorhaben des öffentlichen Verkehrs vom 20. März 1998, AS 1999-4045.

${ }^{167}$ Bundesgesetz vom 19. Dezember 1997 über eine leistungsabhängige Schwerverkehrsabgabe (Schwerverkehrsabgabegesetz, SVAG), AS 2000/98, SR-641.81.

${ }^{168}$ Lötchbergtunnel został otwarty w roku 2007, Gotthard-Basistunnel, liczący ponad $57 \mathrm{~km}$, ma być oddany w roku 2017. Jego budowa została zatwierdzona przez społeczeństwo 29 listopada 1998 r. w referendum. Są one częścią ogromnego projektu zakładającego stworzenie nowych połączeń tranzytowych - NEAT.

${ }^{169}$ Wpływy z opłat w roku 2008 wyniosły 1441 mln franków. Dwie trzecie z tej kwoty przeznaczane jest na finansowanie nowych projektów infrastrukturalnych. 


\section{TRANSPORT LOTNICZY (LUFTVERKEHR)}

Znamienną cechą umowy dotyczącej transportu lotniczego jest fakt, iż w przeciwieństwie do pozostałych porozumień Szwajcaria przejęła w niej znaczną część prawa wspólnotowego. Oznacza to, że w tym obszarze warunki współpracy pomiędzy Szwajcarią a Unią Europejską są niemal identyczne jak w przypadku pełnego członkostwa. Różnica polega jedynie na tym, że wprowadzenie przepisów, prowadzących do liberalizacji rynku, przebiega etapami.

Ruch powietrzny w Unii Europejskiej jest obecnie zliberalizowany. Działania, które były podejmowane od roku 1987 doprowadziły do poważnych zmian na rynku przewoźników pasażerskich. Ujednolicono taryfy, otwarto przestrzeń powietrzną, rozpoczęto proces tworzenia tzw. Jednolitej Europejskiej Przestrzeni Powietrznej (Single European Sky), która ma doprowadzić do stworzenia wspólnego systemu zarządzania ruchem lotniczym w ramach i poza UE. Szwajcaria przez lata wyłączona była z tego procesu, co poważnie zagroziło funkcjonowaniu krajowych przewoźników. Szwajcarskie przedsiębiorstwa nie miały swobodnego dostępu do rynku unijnego. Konieczność spełnienia szeregu biurokratycznych wymogów uniemożliwiała ekspansję i oferowanie konkurencyjnych oraz elastycznych usług, skierowanych na potrzeby danego rynku. Przystąpienie do negocjacji z UE nad umową regulującą współpracę w zakresie transportu lotniczego motywowane było właśnie m.in. próbą naprawy trudnej sytuacji finansowej największego szwajcarskiego przewoźnika - Swissair.

Efektem wejścia w życie umowy ${ }^{170}$ jest przede wszystkim wzajemne otwarcie rynków. Dzięki ustanowieniu zakazu dyskryminacji ze względu na państwo pochodzenia wszyscy przewoźnicy mogą świadczyć swoje usługi we wszystkich państwach Unii Europejskiej, a także w Szwajcarii i Norwegii. Na straży przestrzegania zasad uczciwej konkurencji stoi Europejski Trybunał Sprawiedliwości. Podlegają jej również, z małymi wyjątkami, szwajcarskie przedsiębiorstwa ${ }^{171}$. Jest to więc jedyny przypadek, w którym umowy bilateralne doprowadziły do przeniesienia części kompetencji na rzecz ponadnarodowej instytucji. Pomiędzy Szwajcarią a Unią Europejską wprowadzona została swoboda inwestowania i prowadzenia biznesu, która oznacza w praktyce, że przykładowo przejęcie pakietu większościowego spółki funkcjonującej na terenie UE przez kapitał szwajcarski nie pociąga za sobą utraty jej dotychczasowych praw, wynikających z terytorialnej przynależności. Jako jedną z przyczyn upadku linii Swissair wskazuje się nieobowiązywanie takich reguł w przeszłości. Od momentu wejścia w życie umowy podstawową przesłanką podjęcia działalności na zagranicznych rynkach jest zapotrzebowanie klientów na świad-

170 Abkommen vom 21. Juni 1999 zwischen der Schweizerischen Eidgenossenschaft und der Europäischen Gemeinschaft über den Luftverkehr vom 21. Juni 1999, AS 2001/1705, SR0.748.127.192.68.

${ }^{171}$ ETS nie jest instytucją właściwą do rozstrzygania sporów dotyczących pomocy publicznej oraz ograniczeń wynikających z przepisów ochrony środowiska. 
czenie określonych usług. Dotyczy to małego i dużego przewozu kabotażowego ${ }^{172}$. Szwajcarscy przewoźnicy mogą zatem obsługiwać połączenia w państwach UE.

Dzięki umowie Szwajcaria ma także swojego przedstawiciela w Europejskiej Agencji Bezpieczeństwa Lotniczego, której zadaniem jest utrzymanie wysokiego poziomu bezpieczeństwa lotnictwa cywilnego oraz ochrony środowiska naturalnego. Agencja zajmuje się certyfikacją produktów aeronautycznych, wspiera Komisję Europejską w wydawaniu rozporządzeń dotyczących ruchu lotniczego.

Oczywiście nowe regulacje uwolniły rynek, powodując wzrost konkurencji i pojawienie się tzw. tanich przewoźników, oferujących loty w najniższych cenach. Integracja doprowadziła także do procesów, które nie były brane pod uwagę w trakcie negocjacji nad pierwszym pakietem umów. Okazało się bowiem, że dwie największe linie lotnicze, mające swoje siedziby na terenie Szwajcarii, są w rękach zagranicznego kapitału. Przedsiębiorstwo lotnicze Swiss, powstałe w wyniku przejęcia majątku Swissair, pozostaje obecnie w rękach niemieckiej Lufthansy, natomiast Easy Jet (Schweiz) jest spółką córką linii lotniczej, mającej swoją główną siedzibę w Wielkiej Brytanii.

Konsolidacja przedsiębiorstw lotniczych jest jednak zjawiskiem naturalnym, które wcześniej czy później musiałoby objąć swoim zasięgiem również Szwajcarię. Jest to cena, jaką trzeba zapłacić za proces uwolnienia rynku, który ma przecież w pierwszej kolejności przynieść korzyść konsumentom.

\section{SCHENGEN/DUBLIN}

Umowy dotyczące współpracy policji i wymiaru sprawiedliwości (Schengen) oraz koordynacji polityki azylowej (Dublin) związane są z szeroko pojętym obszarem odnoszącym się do bezpieczeństwa. Warto więc przeanalizować je wspólnie. Obie umowy weszły w skład pakietu Bilaterale II, a z inicjatywą ich zawarcia wyszedł rząd szwajcarski.

Jeszcze na początku lat 90. powołano specjalną grupę ekspercką (Grenzpolizeiliche Personenkontrolle - EGPK), której zadaniem było przeanalizowanie funkcjonowania kontroli granicznych w perspektywie rozwoju Układu z Schengen oraz oczekiwanego włączenia Szwajcarii do Europejskiego Obszaru Gospodarczego. Już wcześniej zawarte zostały oddzielne umowy dwustronne z sąsiednimi państwami w sprawie współpracy służb celnych i policji, jednak funkcjonowanie strefy Schengen stworzyło podstawy do zredefiniowania dotychczasowej polityki w zakresie bezpieczeństwa. W raporcie końcowym EGPK, przedstawionym w roku 1993, uznano, że przystąpienie do układu z Schengen, z punktu widzenia interesu Szwajcarii, jest najbardziej optymalnym posunięciem ${ }^{173}$.

172 Przewozy wykonywane przez przedsiębiorstwo zarejestrowane na terenie innego państwa. Mały kabotaż dotyczy przewozów wewnątrz danego kraju, duży obejmuje kilka państw.

${ }^{173}$ Botschaft zur Genehmigung der bilateralen Abkommen zwischen der Schweiz und der Europäischen Union, einschliesslich der Erlasse zur Umsetzung der Abkommen (Bilaterale II) vom 1. Oktober 2004..., s. 6063. 
W tej sytuacji Rada Związkowa podjęła decyzję o wypracowaniu nowych rozwiązań w zakresie bezpieczeństwa poprzez umowy dwustronne, gdyż klimat polityczny panujący po zawieszeniu kwestii członkostwa Szwajcarii w EOG sprzyjał jedynie takiemu posunięciu. Skupiono się zatem na pogłębieniu współpracy służb granicznych oraz policji, a także uproszczeniu kontroli na granicach. Treść poszczególnych umów, zawieranych zresztą w różnych terminach, była w wielu przypadkach odmienna ${ }^{174}$. Generalnie jednak nie udało się osiągnąć najważniejszego celu, jakim było przynajmniej częściowe włączenie Szwajcarii do strefy Schengen, chociażby poprzez dostęp do bazy wizowej czy do systemu wymiany informacji SIS. Duże wsparcie uzyskano ze strony Niemiec, które w trakcie swojego przewodnictwa próbowały przekonać pozostałe państwa do stopniowego wprowadzenia Szwajcarii do wspomnianej strefy. Warto w tym miejscu zauważyć, że Szwajcarii od samego początku nie zależało na przystąpieniu do układu w pełnym wymiarze, albowiem rząd w Bernie zastrzegał sobie możliwość utrzymania kontroli granicznych ${ }^{175}$. Komitet Wykonawczy Schengen ustosunkował się jednak negatywnie do tego rodzaju propozycji, uznając, iż rozszerzenie strefy o państwo niebędące członkiem UE nie jest możliwe ze względów instytucjonalno-prawnych. Stwierdzono mianowicie, że dorobek prawny układu jest integralną częścią pierwszego i trzeciego filaru Unii Europejskiej.

Również przystąpienie do konwencji dublińskiej okazało się dla Szwajcarii problematyczne. UE przedstawiła co prawda wszystkim państwom EFTA propozycję wypracowania na bazie porozumienia z Dublina oddzielnych umów, jednak spotkało się to ze sprzeciwem ze strony niektórych członków Unii Europejskiej. Państwa te wstrzymywały ostateczną decyzję do czasu zakończenia rozmów w sprawie pakietu Bilaterale I.

Dopiero w roku 2001 rząd Szwajcarii, wykorzystując fakt rozpoczęcia negocjacji dotyczących zwalczania nadużyć finansowych oraz opodatkowania odsetek, wchodzących w skład Bilaterale II, zaproponował Komisji Europejskiej powrót do tematyki Schengen i Dublina. Rada Związkowa postanowiła zresztą wykorzystać równolegle prowadzone rozmowy jako kartę przetargową, uzależniając wspólne rozwiązania dotyczące sektora bankowego od nawiązania ścisłej współ-

${ }^{174}$ Por. Botschaft zum Abkommen zwischen dem Schweizerischen Bundesrat und der Regierung der Republik Ungarn über die Zusammenarbeit bei der Bekämpfung der Kriminalität vom 23. August 2000, BBI 2000 4927; Botschaft über verschiedene Vereinbarungen mit Deutschland sowie mit Österreich und dem Fürstentum Liechtenstein über polizeiliche und justitielle Zusammenarbeit vom 24. November 1999, BBI 2000 862; Botschaft über verschiedene bilaterale Abkommen über die polizeiliche und justizielle Zusammenarbeit mit Frankreich und Italien sowie zur Änderung des Bundesgesetzes über Aufenthalt und Niederlassung der Ausländer vom 14. Dezember 1998, BBI 19991485.

${ }^{175}$ Chodziło o tzw. Schengen light, polegający na zagwarantowaniu dostępu do baz danych SIS, jednakże bez wprowadzenia swobody przepływu osób wewnątrz strefy Schengen, a więc zniesienia kontroli granicznych. 
pracy $\mathrm{w}$ dziedzinie bezpieczeństwa ${ }^{176}$. UE jasno dawała jednak do zrozumienia, iż nie ma zgody na przyjęcie przez Szwajcarię okrojonego pakietu Schengen. Oficjalne rozmowy rozpoczęto ostatecznie w lipcu 2002 r. i w ciągu następnych dwóch lat udało się osiągnąć kompromis we wszystkich spornych kwestiach.

Od tego momentu rozpoczął się w Szwajcarii długi proces legislacyjny, którego punktem kulminacyjnym było przeprowadzenie referendum w roku 2005. Formalnie pytanie referendalne dotyczyło jedynie realizacji porozumienia w sprawie Schengen/Dublin, jednak faktycznie nadano mu szersze znaczenie. Ostatecznie wniosek poparło 54,6\% głosujących, przyznając tym samym symboliczną legitymizację polityce bilateralnej rządu ${ }^{177}$.

Oficjalne włączenie Szwajcarii do strefy Schengen poprzedzone zostało przyjęciem odpowiednich aktów prawnych, umożliwiających uruchomienie szeregu działań stanowiących uzupełnienie całego pakietu. Chodziło m.in. o wprowadzenie nowych dokumentów z danymi biometrycznymi, przyjęcie kodeksu granicznego Schengen (określającego zasady kontroli granicznej osób), udział w agencji FRONTEX, wprowadzenie systemu informacyjnego Schengen SIS, uproszczenie procedur wymiany informacji pomiędzy organami ścigania, przyjęcie polityki UE w sprawie nabywania i posiadania broni czy uruchomienie systemu informacji wizowej (VIS $)^{178}$. Wejście w życie porozumienia nastąpiło formalnie dopiero w marcu 2008 r., choć tak naprawdę ostatnie procedury dostosowawcze, dotyczące chociażby odprawy granicznej na lotniskach, zakończono rok później.

Umowy odnoszące się do układu z Schengen oraz Dublina wzorowane były na konwencji, którą zawarła Wspólnota z Norwegią oraz Islandią w roku $19999^{179}$. Szwajcarii udało się jednak wynegocjować zmiany w kilku istotnych punktach. Ze względu na brak w niniejszym opracowaniu miejsca na omówienie szczegółowo wszystkich regulacji związanych z pakietem Schengen/Dublin, warto zwrócić uwagę choć na elementy wyróżniające ${ }^{180}$.

${ }^{176}$ Por. C. Schoch, Schweiz hält an parallelem Abschluss fest, [w:] Weiter auf dem bilateralem Weg, NZZ-Focus, November 2005, Nr. 27, s. 17-18.

177 Informacje dot. referendum dostępne na stronie: http://www.europa.admin.ch/dokumentation/00438/00545/00547/index.html?lang=de (23.08.2010); zob. także analizę instytutu Gfs. Bern: I. Engeli, A. Tresch, Analyse der eidgenössischen Abstimmungen vom 5. Juni 2005, Juli 2005, Publikation Nr. 87.

${ }^{178}$ Pełna lista aktów legislacyjnych związanych z umową Schengen/Dublin dostępna pod adresem: http://www.admin.ch/ch/d/eur/008.004.000.000.000.000.html (24.08.2010).

179 Abkommen vom 26. Oktober 2004 zwischen der Schweizerischen Eidgenossenschaft, der Europäischen Union und der Europäischen Gemeinschaft über die Assoziierung dieses Staates bei der Umsetzung, Anwendung und Entwicklung des Schengen-Besitzstands, AS 2008/481, SR-0.362.31; Abkommen vom 26. Oktober 2004 zwischen der Schweizerischen Eidgenossenschaft und der Europäischen Gemeinschaft über die Kriterien und Verfahren zur Bestimmung des zuständigen Staates für die Prüfung eines in einem Mitgliedstaat oder in der Schweiz gestellten Asylantrags, AS 2008/515, SR-0.142.392.68.

${ }^{180}$ Zob. więcej Botschaft zur Genehmigung der bilateralen Abkommen zwischen der Schweiz und der Europäischen Union, einschliesslich der Erlasse zur Umsetzung der Abkommen (Bilaterale II) vom 1. Oktober $2004 \ldots$, s. 6072-6124. 
Jak już wcześniej wspomniano, Szwajcarii zależało na utrzymaniu kontroli granicznych i ten postulat udało się rządowi zrealizować. Argumentów w negocjacjach dostarczał fakt, iż kraj niebędący członkiem Europejskiego Obszaru Gospodarczego nie wchodzi w skład unii celnej, a więc ma prawo do przeprowadzania procedur związanych z odprawą celną na granicach. Ponadto służby graniczne zachowują prawo do przeprowadzenia w jej ramach kontroli paszportowej. Mamy więc tutaj do czynienia z odstępstwem od podstawowego celu układu z Schengen, jakim jest swobodny przepływ osób w obrębie całej strefy. W porównaniu z Norwegią i Islandią rząd Szwajcarii wynegocjował znacznie dłuższe okresy przejściowe na podjęcie właściwych środków dostosowawczych (instytucjonalnych oraz prawnych). Argumentowano, że specyfika procesu decyzyjnego, łącznie $\mathrm{z}$ uwzględnieniem instrumentów demokracji bezpośredniej, wymaga więcej czasu. Maksymalnie przyznano Szwajcarii okres dwóch lat (Norwegia - sześć miesięcy, Islandia - cztery tygodnie). Również w zakresie dalszego rozwoju dorobku prawnego strona szwajcarska dysponuje dużym zakresem autonomii - ma możliwość swobodnego decydowania, jakiego rodzaju akty włączy do krajowego prawodawstwa. W praktyce dowolność ta może zostać ograniczona, albowiem odstąpienie od nowych postanowień legislacyjnych, realizowanych w ramach układu z Schengen, może skutkować całkowitym rozwiązaniem umowy ${ }^{181}$. Szwajcaria zastrzegła jedynie, że powyższe konsekwencje nie mogą dotyczyć aktów, które stoją w sprzeczności z podstawowymi filarami ustroju Szwajcarii, tj. demokracją bezpośrednią, neutralnością i federalizmem. Oczywiście Szwajcaria, jako państwo stowarzyszone, ma prawo do udziału w posiedzeniach komitetów Schengen/ Dublin $^{182}$, które mają bezpośredni wpływ na podejmowanie określonych decyzji prawnych z zakresu obu układów, jednak bez prawa głosu. Rząd podkreśla jednak, iż sama obecność szwajcarskich ekspertów jest istotna z punktu widzenia wymiany informacji i prezentowania własnego stanowiska. Oznacza to przynajmniej teoretyczną możliwość współkształtowania wielu ważnych, z punktu widzenia Szwajcarii, decyzji ${ }^{183}$.

Warto również wspomnieć o kwestii zakupu i przetrzymywania broni. Układ z Schengen wprowadza dość szczegółowe przepisy na temat posiadania, transportu i obrotu bronią palną i amunicją. Obawiano się, że wprowadzenie takich regulacji spotka się z silnym protestem społecznym. Należy tu bowiem nadmienić, iż prawo szwajcarskie dopuszcza posiadanie określonego rodzaju broni przez każdego obywatela (chodzi o broń myśliwską oraz związaną ze służbą wojskową). Jest to uwarunkowane czynnikami historycznymi. Przyjęto zatem, że przepisy zawarte w układzie z Schengen nie będą obejmowały krajowego rejestru broni.

${ }^{181}$ Zob. art. 7 umowy dotyczącej Schengen.

${ }^{182}$ Szwajcaria bierze udział w spotkaniach ponad 12 grup roboczych w zakresie wiz, azylu, współpracy policji, systemu SIS itp.

${ }^{183}$ Botschaft zur Genehmigung der bilateralen Abkommen zwischen der Schweiz und der Europäischen Union, einschliesslich der Erlasse zur Umsetzung der Abkommen (Bilaterale II) vom 1. Oktober 2004..., s. 6178-6179. 
Umowa stowarzyszeniowa z konwencjami Schengen oraz Dublin jest istotnym elementem budowy bezpieczeństwa państwa. Rząd zrealizował tym samym zapowiedzi zawarte $\mathrm{w}$ sprawozdaniu dotyczącym polityki integracyjnej z roku 1999 (Integrationsbericht) oraz polityki zagranicznej z roku 2000 (Aussenpolitischer Bericht). Nie ulega wątpliwości, że wprowadzony system współpracy policji i wymiaru sprawiedliwości oraz koordynacja polityki azylowej odciąża krajowe organy. Pełny dostęp do bazy danych Schengen SIS ułatwia organom ścigania pracę, dzięki czemu walka z przestępczością, pomimo formalnego zniesienia kontroli granicznych, jest znacznie łatwiejsza. Również funkcjonujący, dzięki konwencji dublińskiej, system Eurodac pozwala na ograniczenie nadużyć azylowych. Chodzi tutaj o oszustwa polegające na składaniu wniosków w kilku państwach członkowskich jednocześnie. Szwajcaria, chociażby z uwagi na poziom zamożności i dość długą tradycję udzielania schronienia obywatelom innych państw, borykała się z rosnącą liczbą nielegalnych emigrantów. W samym tylko pierwszym półroczu roku 2009 dzięki bazie Eurodac udało się wykryć blisko 3500 nadużyć.

Umowa Schengen/Dublin oznacza również nawiązanie ścisłej współpracy pomiędzy Szwajcarią a Unią Europejską w obszarach pozagospodarczych. Warto jednak zauważyć, iż likwidacja czy też uproszczenie kontroli granicznych oraz wprowadzenie wizy Schengen także na terytorium Szwajcarii wpływa korzystnie na rozwój turystyki ${ }^{184}$.

\section{STATYSTYKA (STATISTIK)}

Ujednolicenie systemu opracowywania danych statystycznych usprawnia wzajemny przepływ informacji i ułatwia współpracę w tych obszarach, w których utrzymywane są ścisłe kontakty. Szwajcaria od lat 80. XX w. uczestniczyła w programach Europejskiego Urzędu Statystycznego. Jej przedstawiciele zasiadali w gremiach eksperckich, jednak bez możliwości prawa głosu ${ }^{185}$. Przyglądano się pracy Eurostatu, a zebrane doświadczenie wykorzystywano na gruncie krajowym. Federalny Urząd Statystyczny przyjmował wzorce unijne, stosując podobną metodologię zbierania i opracowywania danych. Mimo to nadal występowały spore dysproporcje w zakresie pozyskiwania informacji, ich jakości oraz ewaluacji. Z tego powodu Szwajcaria bardzo często była krytykowana w corocznych raportach Międzynarodowego Funduszu Walutowego ${ }^{186}$.

Rząd Szwajcarii postulował rozwiązanie tej kwestii jeszcze przed przystąpieniem do pierwszej rundy negocjacyjnej w sprawie pakietu Bilaterale I. Statystyka

${ }^{184}$ Por. interpelacja poselska Bezzola Duri: Auswirkungen des Schengener Abkommens auf den Schweizer Tourismus, źródło: http://www.parlament.ch/d/suche/seiten/geschaefte.aspx?gesch_ id=19971172 (26.08.2010).

${ }^{185}$ Szwajcaria nie miała również możliwości zasiadania w komisjach podejmujących strategiczne decyzje, np. zajmujących się projektami nowych norm europejskich dotyczących statystyki.

${ }^{186}$ A. Bürgi-Schmelz, G. Gamez, Rahmenbedingungen unter Bedeutung des Statistikabkommens, [w:] D. Thürer, R.H. Weber, W. Portmann, A. Kellerhals, op. cit., s. 817. 
nie znalazła się jednak na liście tematów zaakceptowanych przez Unię Europejską. Uznano za to, że należy do obszarów priorytetowych, co znalazło swój wyraz w Akcie końcowym pierwszego pakietu.

Przed przystąpieniem do negocjacji powołano specjalną grupę ekspercką pod przewodnictwem Federalnego Urzędu Statystycznego, która miała za zadanie zbadać krajowe przepisy i normy dotyczące statystki pod względem ich zgodności z unijnymi. Na tej podstawie określono potencjalny nakład środków (finansowych oraz personalnych), pozwalających na harmonizację systemów. Dzięki temu łatwiej można było określić wzajemne oczekiwania w tym obszarze. Jednym z postulatów delegacji szwajcarskiej było zagwarantowanie korzystnego okresu przejściowego na zreformowanie Federalnego Urzędu Statystycznego tak, aby jego funkcjonowanie umożliwiało harmonijną współpracę z Eurostatem.

Umowa o współpracy w dziedzinie statystyki stała się częścią pakietu Bilaterale II ${ }^{187}$ i weszła w życie z dniem 1 stycznia 2007 r. Dzięki niej Szwajcaria uzyskała dostęp do ogromnego banku danych Eurostatu, który gromadzi informacje przesyłane przez krajowe urzędy statystyczne wszystkich państw Unii Europejskiej oraz Norwegii, Islandii i Lichtensteinu. Jednolita metodologia opracowywania informacji oraz wyczerpujące analizy i komentarze dają możliwość pozyskania cennej wiedzy, będącej podstawą do podejmowania ważnych decyzji politycznych. Między innymi na podstawie danych Eurostatu kształtowana jest polityka dotycząca bezpieczeństwa, ochrony środowiska, opieki socjalnej. Oceniana jest też sytuacja na rynku pracy (poziom wynagrodzeń, koszty pracy, struktura bezrobocia, itp.) pod kątem zastosowania właściwych instrumentów przeciwdziałających bezrobociu. Oczywiście korzyści są obustronne, albowiem również Szwajcaria jest zobowiązywana do przesyłania, opracowanych według wspólnej metodologii, informacji do Eurostatu ${ }^{188}$. Są one następnie publikowane w rocznikach statystycznych. Bardzo często podkreśla się, że publikacje Eurostatu wpływają na międzynarodową percepcję Szwajcarii, chociażby jako stabilnego i godnego zaufania partnera gospodarczego ${ }^{189}$. Korzyści ze współpracy bilateralnej czerpią również szwajcarskie instytucje naukowe i Federalny Urząd Statystyczny, które mogą brać udział w międzynarodowych projektach badawczych. Ponadto rząd w Bernie ma możliwość wysyłania swoich przedstawicieli do udziału w specjalnych komisjach, których zadaniem jest doradzanie Komisji Europejskiej w sprawie opracowywania nowych programów oraz regulacji prawnych z zakresu statystyki. Szwajcaria nie ma w takich gremiach prawa głosu.

187 Abkommen vom 26. Oktober 2004 zwischen der Schweizerischen Eidgenossenschaft und der Europäischen Gemeinschaft über die Zusammenarbeit im Bereich der Statistik, AS 2006/5933, SR-0.431.026.81.

${ }^{188}$ Szwajcaria została włączona w Europejski System Statystyczny, obejmujący Eurostat oraz krajowe organy, które odpowiedzialne są za tworzenie i rozpowszechnianie statystyki europejskiej. Finansowy wkład Szwajcarii wynosi 5,5 mln franków rocznie.

${ }^{189}$ Die Bilateralen Abkommen Schweiz - Europäischen Union ..., s. 53. 


\section{MEDIA}

Umowa odnosząca się do współpracy z Unią Europejską w dziedzinie kinematografii i sztuki audiowizualnej dotyczy udziału Szwajcarii w programie MEDIA, skierowanym do niezależnych producentów, dystrybutorów, organizatorów festiwali filmowych i targów branżowych, a także szkół filmowych i centrów szkoleniowych. Jego celem jest wspieranie europejskiej kinematografii i ochrona europejskiego dziedzictwa audiowizualnego. Program MEDIA jest głównym filarem polityki UE w tym zakresie, realizowanym z powodzeniem od roku 1991. W tym czasie tysiące projektów dotyczących promocji festiwali i kinematografii europejskiej, dystrybucji oraz szkoleń otrzymało wsparcie ze środków unijnych. Budżet programu ustalany jest na dany okres programowania, wynoszący od 5 do 7 lat. Program Media na lata 20072013 dysponuje największymi dotychczas środkami, o łącznej kwocie $755 \mathrm{mln}$ euro.

Szwajcaria, jako pierwsze państwo spoza UE, miała możliwość uczestniczenia w tym programie dzięki zawarciu w roku 1992 prowizorycznej umowy, która miała obowiązywać $\mathrm{w}$ okresie przejściowym, tj. do momentu spodziewanego przystąpienia do EOG. Odrzucenie wniosku w referendum pociągnęło za sobą poważne konsekwencje. Wiele projektów upadło z uwagi na brak możliwości uzyskania niezbędnego wsparcia. Federalny Urząd ds. Kultury zastosował co prawda środki zastępcze w postaci zwiększenia budżetu, z którego wypłacane były dotacje. Działania te okazały się jednak niewystarczające, ponieważ poza aspektami finansowymi pojawily się problemy związane $\mathrm{z}$ tworzeniem stabilnego partnerstwa międzynarodowego. Niemożność uczestniczenia w programie MEDIA zmniejszyła zainteresowanie europejskich partnerów Szwajcarią.

Branża filmowa naciskała na rząd, aby ten podjął stosowne rozmowy z Unią Europejską. Władze szwajcarskie zdecydowały się zatem na rozwiązanie problemu na drodze bilateralnej. Nieformalne rozmowy w tej sprawie rozpoczęto już w listopadzie roku 2001, czyli jeszcze przed wejściem w życie pakietu Bilaterale $I$, który pierwotnie miał również obejmować współpracę w ramach programu MEDIA ${ }^{190}$. Obie strony doszły dość szybko do porozumienia. Sporne kwestie wynikły jedynie na gruncie harmonizacji prawa telewizyjnego. $\mathrm{Z}$ tego powodu zresztą umowa była nowelizowana w roku 2007 i do momentu wejścia w życie, co nastąiło w sierpniu 2010 r., funkcjonowała jedynie prowizorycznie. Problemy wynikały z dwóch przyczyn. Po pierwsze, Komisja Europejska uznała, iż prawo Szwajcarii mało precyzyjnie określa obowiązek faworyzowania dzieł europejskich i produkcji niezależnych. Zobowiązano zatem to państwo do wprowadzenia takich samych kryteriów, jakie obowiązują w Unii Europejskiej. Pod drugie, Komisja domagała się ujednolicenia stanowisk dotyczących Układu Ogólnego w sprawie handlu ustugami (GATS/WTO) w ramach toczącej się Rundy Doha ${ }^{191}$. Był to warunek konieczny do udziału w programie MEDIA.

\footnotetext{
${ }^{190}$ Ostatecznie kwestię tę poruszono jedynie w akcie końcowym pakietu Bilaterale I.

${ }^{191}$ Różnica dotyczyła rozbieżności stanowisk wobec klauzuli najwyższego uprzywilejowania, która kłóciła się z zasadą utrzymania różnorodności kulturowej popieranej przez UE.
} 
Umowa weszła pierwotnie w życie w kwietniu roku 2006, jednak rok później dokonano jej nowelizacji pod kątem przygotowania do współpracy w ramach okresu programowego 2007-2013. Nowa wersja umowy nie została jednak zaakceptowana przez parlament, z uwagi na wątpliwości odnoszące się do konieczności ujednolicenia szwajcarskiego prawa z unijną dyrektywą w sprawie audiowizualnych usług medialnych (2007/65/WE). Spór dotyczył nowych zasad określania jurysdykcji, albowiem dyrektywa oparta jest na tzw. zasadzie państwa pochodzenia. Oznacza ona, że nadawca podlega przepisom państwa, z którego pochodzi, a nie państwa odbioru ${ }^{192}$. Stosowanie zasady ,telewizji bez granic" zostało zakwestionowane ze względu na kolizję z prawem krajowym. Chodziło o sytuacje, w których zagraniczny nadawca będzie miał np. prawo do nadawania reklam napojów alkoholowych, na co pozwalają mu przepisy państwa pochodzenia, a co stoi w sprzeczności z prawem szwajcarskim. W wyniku dodatkowych negocjacji przyznano Szwajcarii możliwość odstąpienia od zasad narzuconych przez dyrektywę w przypadku ochrony zdrowia publicznego oraz małoletnich przed treściami szkodliwymi. Dzięki temu utrzymano w mocy zakaz nadawania reklam o treści politycznej i religijnej, a także promujących napoje alkoholowe ${ }^{193}$. Nowe zmiany zostały zaakceptowane przez parlament Szwajcarii w czerwcu roku 2009.

Decyzja parlamentu przypieczętowała formalnie udział Szwajcarii w programie MEDIA 2007. Kinematografia szwajcarska ma obecnie zagwarantowany dostęp do wszystkich form wsparcia, na równi z państwami Unii Europejskiej. Możliwe jest zatem otrzymanie dotacji na takie projekty, jak promocja festiwali, organizacja międzynarodowych programów szkoleniowych, wdrażanie nowych technologii, promocja i dystrybucja filmów, opracowanie scenariuszy filmowych. Szwajcaria przeznacza rocznie na udział w programie 10,5 mln franków, co stanowi niewielki procent całkowitego budżetu, jaki jest do rozdysponowania ${ }^{194}$. W roku 2006 twórcy szwajcarscy uzyskali wsparcie rzędu 1,25 mln franków, przy czym należy pamiętać, że każdy projekt finansowany jest z programu MEDIA w 50\%.

Dotychczasowe doświadczenia pokazują, iż udział Szwajcarii w programie MEDIA przynosi wiele korzyści zarówno branży filmowej, jak i samej publiczności. Znacznie więcej dzieł europejskiej kinematografii ma szansę zaistnieć na szerokim ekranie. Przez lata wspomniana branża była na starym kontynencie zdominowana przez amerykańskie superprodukcje. Dzięki programowi MEDIA wiele filmów, których realizacja nie była dotąd możliwa lub których właściwa promocja znacznie przewyższała możliwości finansowe, otrzymuje cenne wsparcie. Sprzyja to również integracji europejskiej branży filmowej. Wiele tytułów powstaje w ramach międzynarodowej koprodukcji, której efektem jest silna promocja filmu

${ }_{192}$ M. Pęk, Nowe podejście regulacyjne do usług audiowizualnych $w$ prawie wspólnotowym - $w$ świetle zmian wprowadzonych dyrektywa o audiowizualnych ustugach medialnych, „Analiza Biura KRRiTv" 2007, nr 6, s. 12.

${ }^{193} \mathrm{Z}$ wyjątkiem piwa i wina.

${ }^{194}$ Bilaterale Abkommen Schweiz - EU..., s. 36. 
w kilku państwach. Szwajcaria aktywnie korzysta z tego rodzaju wsparcia. Prawie $65 \%$ wniosków otrzymało dofinansowanie z budżetu programu MEDIA. Pod tym względem szwajcarscy twórcy plasują się na wyższej pozycji niż ich koledzy w Holandii, Danii czy Belgii ${ }^{195}$. Efektem wszystkich tych działań jest poszerzenie repertuaru w kinach, co w konsekwencji oznacza korzyści dla europejskiej publiczności

\section{EMERYTURY I RENTY}

Umowa dotycząca opodatkowania rent i emerytur ${ }^{196}$ swoim zasięgiem obejmuje zaledwie ok. 50 osób, zatem jej znaczenie w ramach całego pakietu Bilaterale II jest zdecydowanie najmniejsze ${ }^{197}$. Inicjatywa zawarcia takiego porozumienia wyszła ze strony władz UE, chcących zadbać o zniesienie podwójnego opodatkowania świadczeń otrzymywanych przez byłych pracowników instytucji europejskich, którzy będąc na rencie lub emeryturze postanowili zamieszkać w Szwajcarii.

Do czasu wejścia w życie niniejszej umowy świadczenia tych osób podlegały podwójnemu opodatkowaniu. Pobierany był zatem podatek z tytułu świadczeń emerytalnych oraz dodatkowy podatek dochodowy, ściągany przez szwajcarskie urzędy (na poziomie gminy, kantonu i federacji). Problem ten przez lata nie doczekał się uregulowania, choć obie strony potwierdzały wielokrotnie potrzebę jego rozwiązania ${ }^{198}$. Unia Europejska odwoływała się w swoim stanowisku do umowy o podwójnym opodatkowaniu, zawartej pomiędzy Szwajcarią a wszystkimi państwami UE, z wyjątkiem Cypru i Malty. Przewiduje ona, że świadczenia emerytalne wszystkich pracowników państwowych podlegają opodatkowaniu tylko przez państwo dłużnika, bez względu na miejsce zamieszkania. Wyjątek dotyczy jedynie tych osób, które dodatkowo posiadają obywatelstwo państwa zamieszkania. W takich przypadkach osoby te podlegają również miejscowej ordynacji podatkowej. Władze Szwajcarii uznały jednak taką interpretację zapisów umowy za zbyt szeroką, wskazując, że świadczenie pracy na rzecz ponadnarodowej instytucji, za jaką uważa się Unię Europejską, nie jest porównywalne z pracą na rzecz jednego z państw członkowskich, będących stroną umowy ${ }^{199}$.

${ }^{195}$ Die Bilateralen Abkommen Schweiz - Europäischen Union..., s. 57.

${ }^{196}$ Abkommen vom 26. Oktober 2004 zwischen dem Schweizerischen Bundesrat und der Kommission der Europäischen Gemeinschaften zur Vermeidung der Doppelbesteuerung von in der Schweiz ansässigen ehemaligen Beamten der Organe und Agenturen der Europäischen Gemeinschaften, AS 2005/2187, SR-0.672.962.81.

${ }^{197}$ Ibidem, s. 61.

${ }^{198} \mathrm{~W}$ akcie końcowym umowy o swobodnym przepływie osób zawarto deklarację poszukiwania rozwiązań dotyczących podwójnego opodatkowania. Zob. Abkommen vom 21. Juni 1999 zwischen der Schweizerischen Eidgenossenschaft einerseits und der Europäischen Gemeinschaft und ihren Mitgliedstaaten andererseits über die Freizügigkeit, AS 2002/1529, SR-0.142.112.681, s. 108.

199 T. Baumgartner, Besteuerung von Ruhegehältern, [w:] D. Thürer, R.H. Weber, W. Portmann, A. Kellerhals, op. cit., s. 896. 
Szwajcaria wyraziła zatem gotowość do podpisania oddzielnego porozumienia w tej sprawie. Początkowo zakładano częściowe zniesienie podatków poprzez podpisanie wspólnego porozumienia lub też zawarcie go osobno z każdym państwem Unii Europejskiej. Ostatecznie jednak Szwajcaria zgodziła się na zniesienie całości opodatkowania, przy zastrzeżeniu, iż umową nie będą objęte dochody uzyskane $\mathrm{z}$ innych źródeł niż z tytułu pracy w instytucjach UE ${ }^{200}$. Dotyczy to także osób posiadających obywatelstwo Szwajcarii.

Umowa weszła w życie 31 maja 2005 r. i jej postanowieniami objęte są jedynie świadczenia wypłacane od 1 stycznia 2006 r. Rząd szacuje straty wynikające ze zniesienia opodatkowania na nieco ponad milion franków rocznie (licząc łączne wpływy na poziomie gminy, kantonu i związku), co jest kwotą niewielką i nieobciążającą dodatkowo budżetu państwa. Oczywiście władze mają świadomość prawdopodobnego zwiększenia w przyszłości liczby osób, które będą zainteresowane pobytem na terenie Szwajcarii, zwłaszcza po podpisaniu przedmiotowego porozumienia. Nie uważa się jednak, aby wzrost ten miał mieć znaczące konsekwencje $\mathrm{e}^{201}$.

\section{OCHRONA ŚRODOWISKA}

Ekologia odgrywa szczególną rolę w polityce wewnętrznej i zewnętrznej Szwajcarii. Przepisy dotyczące ochrony środowiska należą do najbardziej restrykcyjnych w Europie. Bardzo często stanowią one wzór dla aktów legislacyjnych wydawanych na poziomie UE. Dorobek prawny w tym obszarze nie odbiega od standardów Unii Europejskiej, osobne regulacje w postaci wspólnych porozumień nie były zatem przez długi czas konieczne.

Pod koniec roku 1993 weszło w życie rozporządzenie Rady EWG (1210/1990) ustanawiające Europejską Agencję Środowiska, która zajmuje się szeroko pojętym monitorowaniem stanu środowiska naturalnego. Tworzą ją wszystkie państwa UE, które po przystąpieniu do Wspólnoty stają się automatycznie członkami Agencji i mają swoich przedstawicieli w jej zarządzie. Do podstawowych zadań tej instytucji należy dostarczanie wszystkim zainteresowanym stronom (instytucjom UE, ośrodkom akademickim, instytucjom pozarządowym, biznesowym) informacji dotyczacych środowiska naturalnego. Dane te opracowywane są przez poszczególne państwa członkowskie, a następnie przesyłane do Agencji, której główna siedziba mieści się w Kopenhadze. Na podstawie zebranych danych opracowywane są opinie, analizy i wytyczne, wykorzystywane m.in. przez Komisję

${ }^{200}$ Jako instytucje UE traktuje się Parlament Europejski, Komisję Europejską, Radę Unii Europejskiej, Europejski Trybunał Sprawiedliwości, a także Europejski Bank Inwestycyjny, Europejski Bank Centralny oraz Europejski Fundusz Inwestycyjny.

${ }^{201}$ Botschaft zur Genehmigung der bilateralen Abkommen zwischen der Schweiz und der Europäischen Union, einschliesslich der Erlasse zur Umsetzung der Abkommen (Bilaterale II) vom 1. Oktober 2004..., s. 6224. 
Europejską. Agencja oferuje zatem merytoryczne wsparcie, mając dzięki temu wymierny wpływ na podejmowane w ramach Wspólnoty decyzje odnoszące się do ochrony środowiska i jego poprawy. Właściwej realizacji powyższych zadań służy Europejska Sieć Informacji i Obserwacji Środowiska (EIONET), która powołana została na mocy wspomnianego już wcześniej rozporządzenia.

Szwajcaria współpracowała z Agencją od samego początku jej istnienia, ale były to kontakty o charakterze nieformalnym, opartym na współpracy w ramach konkretnych projektów i wyłącznie na poziomie naukowo-technicznym ${ }^{202}$. Wymiana informacji przyczyniła się jednak do stopniowej harmonizacji danych dotyczących ochrony środowiska. Ponadto w roku 2002 Szwajcaria uzyskała status obserwatora, co uprawniało ją do posiadania stałych przedstawicieli w Agencji. Ciągły kontakt o charakterze formalnym bądź nieformalnym ułatwił negocjacje w sprawie podpisania oficjalnego porozumienia o współpracy. Rozmowy rozpoczęły się w lipcu 2001 r. jednocześnie w trzech obszarach tematycznych. Obok ochrony środowiska również zwalczania oszustw podatkowych, a także przetworzonych produktów rolnych ${ }^{203}$. Po trzech rundach negocjacyjnych kompromis osiągnięto ostatecznie w lipcu $2004 \mathrm{r}$.

Umowa nadaje Szwajcarii prawo do uczestniczenia we wszystkich pracach Europejskiej Agencji Środowiska oraz EIONET-u ${ }^{204}$. Państwo to ma swojego przedstawiciela w zarządzie, który ma możliwość przedstawiania stanowiska rządu szwajcarskiego w danej kwestii, jednakże bez prawa głosu, gdyż ten przysługuje jedynie państwom członkowskim UE. $Z$ uwagi jednak na fakt, że decyzje dotyczące wyboru dyrektora wykonawczego oraz wyznaczenia członków komitetu naukowego zapadają jednogłośnie, ograniczenia wynikające ze statusu Szwajcarii nie mają szczególnego znaczenia ${ }^{205}$. O wiele ważniejszy jest dostęp do ogromnej bazy danych sieci EIONET. Funkcję krajowego punktu kontaktowego pełni Federalny Urząd ds. Środowiska, którego zadaniem jest koordynacja współpracy w ramach Agencji. Polega ona m.in. na gromadzeniu i wymianie informacji, a także na realizacji międzynarodowych projektów badawczych. Zebrane dane publikowane są następnie na stronach internetowych oraz w periodykach. Szwajcarscy eksperci biorą udział w pracach pięciu europejskich centrów tematycznych (również należących do sieci EIONET): woda, powietrze i zmiany klimatu, różnorodność bio-

${ }^{202}$ Ibidem, s. 6044. Szwajcaria była m.in. miejscem spotkań Grupy Doradczej ds. Informatyki i Telekomunikacji.

${ }^{203}$ Oficjalny wniosek dotyczący przystąpienia Szwajcarii do Europejskiej Agencji Środowiska rząd tego kraju przedłożył unijnemu komisarzowi ds. środowiska jeszcze w październiku $1994 \mathrm{r}$. Decyzja $\mathrm{w}$ tej sprawie została jednak zawieszona $\mathrm{z}$ uwagi na brak jasnych procedur odnośnie do współpracy z państwem trzecim oraz ostatecznego statusu Szwajcarii.

${ }^{204}$ Abkommen vom 26. Oktober 2004 zwischen der Schweizerischen Eidgenossenschaft und der Europäischen Gemeinschaft über die Beteiligung der Schweiz an der Europäischen Umweltagentur und dem Europäischen Umweltinformations- und Umweltbeobachtungsnetz (EIONET), AS 2006/1111, SR-0.814.092.681.

${ }^{205}$ Ibidem, s. 6046. 
logiczna, zarządzanie zasobami i odpadami, wykorzystanie wody i gruntu. Budżet Europejskiej Agencji Środowiska finansowany jest ze składek państw członkowskich oraz tych, które - tak jak Szwajcaria - zawarły z UE stosowne porozumienie ${ }^{206}$. W roku 2008 wkład Szwajcarii wyniósł 2,1 mln franków. Część środków wraca do niej w postaci dofinansowania konkretnych projektów lub przetargów organizowanych przez Agencję. Wnioski w tej sprawie składać mogą instytucje oraz organizacje pozarządowe.

Nawet najsurowsze normy, dotyczące ochrony środowiska, nie będą skuteczne, jeżeli działania podejmowane są w pojedynkę. Współpraca w ramach Agencji oraz EIONET-u gwarantuje Szwajcarii możliwość współkształtowania polityki na poziomie europejskim. Efekty takiej współpracy są dzięki temu znacznie bardziej odczuwalne. Na lata 2009-2013 przewidziano cztery obszary, wokół których koncentrować się będą działania Agencji:

- ochrona środowiska (jakość powietrza, emisja zanieczyszczeń, różnorodność biologiczna, emisja gazów cieplarnianych, woda);

- tematy horyzontalne (wpływ zmian klimatu, wrażliwość i adaptacja ekosystemów, środowisko naturalne i zdrowie, środowisko morskie, zrównoważona konsumpcja, produkcja i odpady, rolnictwo i zagospodarowanie przestrzenne lasu, energetyka, transport);

- zintegrowana ocena oddziaływania na środowisko;

- informacja i komunikacja.

\section{OPODATKOWANIE ODSETEK BANKOWYCH}

Z inicjatywą zawarcia umowy mającej na celu harmonizację jednego z elementów polityki fiskalnej (tzw. dyrektywy oszczędnościowej) wyszła Unia Europejska. Szwajcaria podchodziła do tej propozycji dość ostrożnie, albowiem traktowała ją jako wstęp do zniesienia tajemnicy bankowej. Obawy te należy zresztą uznać za jak najbardziej uzasadnione, zważywszy na decyzje podejmowane wewnątrz Unii Europejskiej. Ta ostatnia uznała jednak zawarcie wspomnianej umowy za warunek sine qua non rozpoczęcia negocjacji w sprawie pakietu Bilaterale II. Szwajcaria była zatem niejako zmuszona do podjęcia rozmów dotyczących wprowadzenia dodatkowego opodatkowania odsetek od lokat bankowych. Rząd miał przy tym świadomość, iż niewątpliwym kosztem zawarcia kompromisu, nawet uwzględniającego możliwość zachowania tajemnicy bankowej, będzie utrata znaczenia Szwajcarii jako atrakcyjnego miejsca do lokowania kapitału. Była to jednak cena, jaką należało zapłacić za podpisanie porozumień w innych obszarach i na, być może, korzystniejszych warunkach.

Wprowadzenie zasady swobody przepływu kapitału w państwach należących do Wspólnoty pociągało za sobą ryzyko jego nierównomiernej kumulacji. Było to

${ }^{206}$ Agencja liczy obecnie 32 członków. Oprócz państw UE tworzą ją Islandia, Norwegia, Lichtenstein, Turcja i Szwajcaria. 
możliwe, ponieważ poszczególne państwa UE mogą prowadzić autonomiczną politykę fiskalną. Liberalizacja rynku spowodowała zjawisko swoistej konkurencyjności podatkowej pomiędzy państwami, które ze względu na obowiązujące progi podatkowe stawały się mniej lub bardziej atrakcyjnym miejscem do lokowania pieniędzy. Bezpośrednią tego konsekwencją był odpływ kapitału z niektórych państw, a co za tym idzie zmniejszone wpływy do budżetu, wynikające $z$ niskiej ściągalności podatków w pozostałych państwach. Wytworzył się zatem mechanizm sprzyjający nadużyciom i zakłócający sprawne funkcjonowanie wspólnotowego rynku.

Władze UE postanowiły ukrócić ten proceder. W maju roku 1998 Komisja Europejska przedłożyła pierwszy projekt nowego rozporządzenia dotyczącego zagwarantowania minimum skutecznego opodatkowania dochodów z oszczędności w ramach Wspólnoty (tzw. dyrektywa oszczędnościowa) 207 . Zaproponowano przy tym dwie drogi rozwiązania przedmiotowego problemu - poprzez wprowadzenie jednolitego opodatkowania dochodów od lokat bankowych (według jednakowych stawek) we wszystkich państwach UE lub ustanowienie tzw. systemu automatycznej wymiany informacji. Zakładał on wzajemny przepływ danych dotyczących stanu kont, umożliwiający odpowiednim organom ściągnięcie należnej kwoty podatkowej. W ten sposób, przykładowo obywatel Niemiec, który postanowi otworzyć konto w Belgii, będzie musiał liczyć się z koniecznością uiszczenia podatku od zysków, wynikających z oprocentowania, ponieważ banki i inne instytucje finansowe będą miały obowiązek udostępnienia niemieckiemu fiskusowi niezbędnych danych. Lokowanie kapitału w kraju innym niż kraj pochodzenia podatnika przestanie być wówczas atrakcyjne.

Początkowo dopuszczano możliwość wprowadzenia obu systemów, w zależności od decyzji danego państwa UE ${ }^{208}$. Okres przejściowy miał jednak potrwać maksymalnie siedem lat. Po tym czasie wszystkie państwa byłyby zobowiązane do wprowadzenia automatycznej wymiany informacji. W toku dalszych rozmów, m.in. trwających jednocześnie negocjacji ze Szwajcarią, ustalono, że decyzja odnosząca się do formy współpracy, gwarantującej skuteczne opodatkowanie dochodów, zależeć będzie od kształtu porozumienia z państwami trzecimi ${ }^{209}$. Oprócz Szwajcarii zaliczano do nich Andorę, Monako, Lichtenstein, San Marino oraz USA. Uznano bowiem, że wprowadzenie nowej polityki w ramach UE nie będzie skuteczne, jeżeli wspólnym systemem nie zostaną objęte państwa o szczególnie atrakcyjnych warunkach lokowania kapitału ${ }^{210}$.

${ }^{207}$ Zob. B. Patterson, Steuerkoordinierung in der EU: der neueste Stand, Generaldirektion Wissenschaft des Europäisches Parlaments, ECON 128, PE 312.788, s. 7-8.

${ }^{208}$ Przeciwko automatycznej wymianie informacji opowiedziały się Austria, Belgia i Luksemburg.

${ }^{209}$ Dyrektywa Rady 2003/48/WE z 3 czerwca 2003 r. w sprawie opodatkowania dochodów $\mathrm{z}$ oszczędności $\mathrm{w}$ formie wypłacanych odsetek.

${ }^{210}$ Odwoływano się tutaj do porozumienia zawieranego w ramach OECD, dotyczącego wymiany informacji w sprawach podatkowych. Szwajcaria nie brała udziału w pracach nad projektem takiego porozumienia, gdyż z punktu widzenia jej rządu automatyczna wymiana informacji oznaczać będzie zniesienie tajemnicy bankowej. 
Mając na względzie nową linię polityczną przyjętą przez Unię Europejską, rząd Szwajcarii postanowił we własnym zakresie przeanalizować techniczne możliwości wprowadzenia analogicznego systemu opodatkowania. W marcu $2000 \mathrm{r}$. powołano do życia grupę roboczą (pod przewodnictwem Federalnego Urzędu Podatkowego), której zadaniem było przeprowadzenie studium wykonalności. Miała ona ustalić, czy zastosowanie nowego systemu podatkowego jest możliwe bez ujawnienia tajemnicy bankowej. Wnioski z analizy, opublikowane w lutym 2001 r., okazały się pozytywne ${ }^{211}$.

Jeszcze w kwietniu tego roku rozpoczęto z UE wstępne rozmowy. Na początku Szwajcaria postawiła jednak dwa warunki. Po pierwsze, zgoda na wprowadzenie opodatkowania odsetek nie może uwzględniać automatycznej wymiany informacji (nawet przy zachowaniu okresu przejściowego), jako że ta zagroziłaby funkcjonowaniu pryncypialnej zasady tajemnicy bankowej, od której Szwajcarzy w żadnym wypadku nie chcieli odstąpić. Po drugie, rozpoczęcie rozmów dotyczących opodatkowania odsetek uzależniano od podjęcia innych tematów w ramach pakietu Bilaterale II. Oczywiście rząd szwajcarski oczekiwał również ze strony UE rychłego wprowadzenia podobnych instrumentów we wszystkich państwach członkowskich.

Konsensus osiągnięto wiosną roku 2004, co umożliwiało wejście w życie porozumienia od stycznia 2005 r. Ze względu jednak na wewnętrzne procesy legislacyjne, strona szwajcarska poprosiła o przesunięcie tego terminu na czerwiec ${ }^{212}$. Zawarte porozumienie przewidywało ustanowienie środków równoważnych z tymi, jakie zostały określone w dyrektywie Rady 2003/48/WE z dnia 3 czerwca 2003 r. w sprawie opodatkowania odsetek bankowych ${ }^{213}$. Zakładają one, że:

- następuje wprowadzenie 15\% stawki podatkowej od odsetek, naliczanych przez bank lub inną instytucję finansową, obowiązującej przez pierwsze trzy lata od momentu wejścia umowy w życie. Po tym okresie stawka wzrośnie do $20 \%$, a od lipca 2011 r. do $35 \%$;

- 75\% dochodu z opodatkowania trafia do kraju, z którym związany jest podatnik, pozostała część zasila budżet Związku (90\%) i kantonu (10\%);

- podatnik ma prawo do dobrowolnego złożenia oświadczenia w sprawie wysokości dochodów pochodzących z odsetek. Informacja ta, za pośrednictwem Federalnego Urzędu Podatkowego, trafia do właściwych organów państwa, z którym związany jest podatnik;

${ }^{211}$ Botschaft zur Genehmigung der bilateralen Abkommen zwischen der Schweiz und der Europäischen Union, einschliesslich der Erlasse zur Umsetzung der Abkommen (Bilaterale II) vom 1. Oktober 2004..., s. 6205.

${ }^{212}$ Konieczne było przyjęcie dodatkowej ustawy federalnej: Bundesgesetz vom 17. Dezember 2004 zum Zinsbesteuerungsabkommen mit der Europäischen Gemeinschaft (Zinsbesteuerungsgesetz, ZBstG), AS 2005/2558, SR-641.91.

213 Abkommen vom 26. Oktober 2004 zwischen der Schweizerischen Eidgenossenschaft und der Europäischen Gemeinschaft über Regelungen, die den in der Richtlinie 2003/48/EG des Rates im Bereich der Besteuerung von Zinserträgen festgelegten Regelungen gleichwertig sind, AS 2005/2571, SR-0.641.926.81. 
- strony zobowiązują się do udzielenia wzajemnej pomocy w przypadku oszustw podatkowych lub innych przestępstw (związanych z zakresem umowy). Osobne regulacje w tej sprawie są przedmiotem oddzielnych umów dwustronnych, dotyczących podwójnego opodatkowania, zawieranych ze wszystkimi państwami UE;

- prowadzone będą wzajemne konsultacje, celem stwierdzenia, czy w świetle rozwoju sytuacji międzynarodowej wprowadzenie ewentualnych poprawek do umowy jest konieczne;

- Unia Europejska będzie prowadzić rozmowy dotyczące opodatkowania odsetek bankowych także z państwami trzecimi.

Szwajcaria zabiegała również, aby powyższymi regulacjami objęte były jedynie osoby fizyczne. Dzięki temu międzynarodowe przedsiębiorstwa, działające na jej terytorium, zwolnione były z opodatkowania wypłat dywidend, odsetek i należności licencyjnych. Dotyczy to przede wszystkim spółek zależnych, mających swoje siedziby w różnych państwach Wspólnoty oraz w Szwajcarii214. Jest to cenny argument $w$ staraniach o przyciągnięcie do kraju nowych inwestycji i zatrzymanie już zrealizowanych.

Największym osiągnięciem rządu Szwajcarii podczas negocjacji w sprawie opodatkowania odsetek było zagwarantowanie tajemnicy bankowej. W przyszłości stanowisko Brukseli może jednak w tym punkcie ulec zmianie i wówczas presja ze strony władz UE w kierunku wprowadzenia zasady automatycznej wymiany informacji znacząco wzrośnie. Należy jednak oczekiwać, że przynajmniej tak długo, jak podobne regulacje obowiązywać będą również Belgię, Austrię i Luksemburg, Unia Europejska nie będzie wywierać na Szwajcarię szczególnego nacisku. Nie zmienia to faktu, iż szwajcarski sektor bankowy budzi nadal wiele kontrowersji w relacjach wzajemnych. Szwajcaria, ze względu na specyfikę usług bankowych, krytykowana jest za tworzenie raju podatkowego. Umowa dotycząca opodatkowania odsetek jest więc kolejną próbą łagodzenia napięcia. Rząd liczył, że porozumienie skłoni Unię do zmiany stanowiska. Częściowo rzeczywiście udało się ten cel osiągnąć. Nie sposób także pominąć pobocznej korzyści, wynikającej z zagwarantowania dodatkowych wpływów do budżetu. W roku 2008 dochody z tego tytułu wyniosły 184,7 mln franków ${ }^{215}$. Znaczna część tej kwoty przeznaczona została na wsparcie polityki spójności UE, co niewątpliwie dodatkowo poprawiło wizerunek Szwajcarii.

\section{ZWALCZANIE NADUŻYĆ FINANSOWYCH}

Straty wynikające z unikania podatków pośrednich, jak chociażby VAT czy akcyzy, liczone są w Unii Europejskiej na dziesiątki miliardów euro. Szczególnie

${ }^{214}$ Postulat Szwajcarii opierał się na Dyrektywie Rady z dnia 23 lipca 1990 roku w sprawie wspólnego systemu opodatkowania stosowanego $w$ przypadku spótek dominujacych i spótek zależnych różnych Państw Członkowskich (90/435/EWG).

${ }^{215}$ Die Bilateralen Abkommen Schweiz - Europäischen Union..., s. 46. 
uciążliwym problemem jest przemyt papierosów lub alkoholu. Groźnym zjawiskiem jest także wyłudzanie subwencji eksportowych, m.in. poprzez organizowanie fikcyjnych transportów. Państwa unijne od lat walczą z tym procederem, jednak skala nadużyć nadal pozostaje ogromna.

Współpraca pomiędzy UE a Szwajcarią w zakresie zwalczania nadużyć finansowych rozpoczęła się na długo przed zawarciem umów bilateralnych ${ }^{216}$, ale nie przebiegała bezproblemowo. Po pierwsze, dotychczasowe umowy nie przewidywały możliwości zastosowania nadzwyczajnych środków (np. przeszukanie) na prośbę organu administracyjnego. Było to możliwe jedynie po decyzji organów sądowych. Po drugie, pomoc sądowa oferowana była tylko pod warunkiem zaistnienia określonych, trudnych do spełnienia, przesłanek. W efekcie współpraca nie była wystarczająco efektywna i nie spełniała oczekiwań żadnej ze stron, zwłaszcza że przez Szwajcarię, ze względu na położenie geograficzne, przechodziło wiele szlaków przemytniczych. Zawarcie dwustronnego porozumienia, mającego na celu zwalczanie tego typu nadużyć, było niezwykle ważne z punktu widzenia UE, głównie ze względów finansowych. Z kolei w interesie Szwajcarii leżało ukrócenie przemytniczych procederów na swoim terenie, gdyż pogarszały one reputację kraju i stawiały go w niekorzystnym świetle. Równie istotne były względy bezpieczeństwa.

W literaturze przedmiotu można spotkać się z opinią, iż bezpośrednią przyczyną nawiązania ściślejszej współpracy pomiędzy UE a Szwajcarią w omawianym obszarze był problem przemytu papierosów ${ }^{217}$. Nie mniejsze straty przynosił jednak również proceder związany z wyłudzaniem podatku VAT. Ocenia się, że rocznie wpływy do budżetu $\mathrm{z}$ tego tytułu były mniejsze o 60-70 miliardów euro, w skali całej $\mathrm{UE}^{218}$. Polegał on na przesyłaniu za granicę prawdziwego lub fikcyjnego towaru, za który następnie firma otrzymywała zwrot podatku VAT. Z kolei inne przedsiębiorstwa, które były zaangażowane w całą tę transakcję i na nich spoczywał obowiązek uiszczenia odpowiednich opłat, nagle znikały z rynku ${ }^{219}$.

W roku 1997 Parlament Europejski opublikował sprawozdanie, w którym mocno krytykował dotychczasową współpracę w zakresie zwalczania nadużyć finansowych, proponując jednocześnie wypracowanie nowego porozumienia, mającego na celu wzmocnienie współdziałania w zakresie stosowania procedur sądowych i administracyjnych pomiędzy UE a Szwajcarią. Pierwszym krokiem było przeprowadzenie rozmów eksperckich, które rozpoczęły się w roku 1999.

${ }^{216}$ W. Wohlers, Betrugsbekämpfung, [w:] D. Thürer, R.H. Weber, W. Portmann, A. Kellerhals, op. cit., s. 985. Zobowiązania do wzajemnej pomocy w sprawach celnych zawarte były w protokole dodatkowym z 19 grudnia 1996 r., stanowiącym uzupełnienie umowy o wolnym handlu z EWG $\mathrm{z}$ roku 1972; zob. Botschaft zur Genehmigung der bilateralen Abkommen zwischen der Schweiz und der Europäischen Union, einschliesslich der Erlasse zur Umsetzung der Abkommen (Bilaterale II) vom 1. Oktober 2004..., s. 6185-6186.

${ }^{217}$ W. Wohlers, op. cit.

${ }^{218}$ Ibidem, s. 986.

${ }^{219}$ Ibidem. 
Obie strony potwierdziły gotowość do zawarcia dwustronnego porozumienia. Oficjalne negocjacje w tej sprawie podjęto latem roku 2001 i potrwały one do maja 2004 r. ${ }^{220}$ Generalną intencją Unii Europejskiej było zagwarantowanie własnym organom administracyjnym i sądowym takich samych praw w zakresie zwalczania nadużyć finansowych, jakie przysługiwały ich szwajcarskim odpowiednikom. Nie chodziło oczywiście o przejęcie ich kompetencji, lecz o zniesienie formalności i ułatwienie procedur ścigania przestępstw, pozwalających na skrócenie całego procesu i znaczne podniesienie skuteczności działania odpowiednich organów (celnych, sądowych i skarbowych).

Umowa, która weszła w skład pakietu Bilaterale II, wzmacnia zatem współpracę w obszarach administracyjnych i sądowych. Jej celem jest zwalczanie nadużyć finansowych ${ }^{221}$. Współpraca ta obejmuje wyłącznie wykroczenia dotyczące podatków pośrednich. Wszystkie pozostałe, jak podatek dochodowy od osób fizycznych lub prawnych, nie są objęte postanowieniami umowy. Obie strony zobowiązały się zresztą, że informacje uzyskane w ramach pomocy sądowej lub administracyjnej nie będą wykorzystywane do prowadzenia spraw odnoszących się do podatków bezpośrednich.

Warto zauważyć, że niniejsze porozumienie ma charakter raczej jednostronny. Współpraca w tym obszarze wynika przede wszystkim z nałożenia na Szwajcarię szeregu zobowiązań, czym różni się od typowych porozumień bilateralnych. Przed zawarciem porozumienia pomoc prawna i administracyjna udzielana była organom UE fakultatywnie, a każde wykroczenie traktowano indywidualnie. Obecnie organy Szwajcarii mają obowiązek udzielenia takiej pomocy, a jej dokładny wymiar określony został treścią zawartego porozumienia. Przykładowo zastosowanie środków bezpośrednich, takich jak rewizje, zajęcie majątku lub kontrola rachunków bankowych, możliwe jest tylko wówczas, gdy dany czyn podlega karze także w państwie, które zwróciło się o pomoc. Ustalono również, że wszczęcie odpowiednich procedur przez stronę szwajcarską nastąpi w przypadku przestępstw podatkowych przekraczających wartość 25000 euro lub przemytu towaru o wartości nie mniejszej niż 100000 euro $^{222}$. O pomoc mogą się zwrócić nie tylko organy sądowe, lecz również administracyjne, co ułatwia współpracę organom celnym i podatkowym ${ }^{223}$. Urzędnicy państwa wnioskującego o udzielenie pomocy mogą osobiście uczestniczyć w pracach określonych organów (mają

${ }^{220}$ Botschaft zur Genehmigung der bilateralen Abkommen zwischen der Schweiz und der Europäischen Union, einschliesslich der Erlasse zur Umsetzung der Abkommen (Bilaterale II) vom 1. Oktober $2004 \ldots$, s. 6184.

${ }^{221}$ Abkommen vom 26. Oktober 2004 über die Zusammenarbeit zwischen der Schweizerischen Eidgenossenschaft einerseits und der Europäischen Gemeinschaft und ihren Mitgliedstaaten andererseits zur Bekämpfung von Betrug und sonstigen rechtswidrigen Handlungen, die ihre finanziellen Interessen beeinträchtigen, AS 2009/1299, SR-0.351.926.81.

${ }^{222}$ Die Bilateralen Abkommen Schweiz - Europäischen Union..., s. 48.

${ }^{223} \mathrm{~W}$ przypadku zastosowania niektórych środków, jak np. przeszukanie, nadal konieczny jest nakaz sądowy. 
również prawo do wglądu w te same dokumenty), jednak prowadzenie całego dochodzenia powierzone zostaje zawsze organom Szwajcarii ${ }^{224}$.

Intensyfikacja współpracy pomiędzy Unią Europejską a Szwajcarią wpisuje się w realizację inicjatywy parlamentarnej z roku 2001, postulującej wyeliminowanie luk prawnych, które sprzyjają rozwojowi przemytu towarów i związanych $\mathrm{z}$ tym nadużyć finansowych ${ }^{225}$. Chodziło w szczególności o wprowadzenie zmian w krajowym kodeksie karnym, ale modyfikacjom miała podlegać również ustawa federalna dotycząca międzynarodowej pomocy w sprawach karnych. Umowa bilateralna z UE jest więc elementem realizacji tego ostatniego postulatu.

Jako kraj niebędący członkiem Unii Europejskiej, a jednocześnie położony w samym centrum Europy, Szwajcaria jest wyjątkowo narażona na działanie zorganizowanych grup przestępczych. Dzięki współpracy ze Wspólnotą udało się wzmocnić kontrolę na granicach (umowa Schengen/Dublin) oraz usprawnić procedury w zakresie międzynarodowej pomocy prawnej i sądowej.

\section{PRZETWORZONE PRODUKTY ROLNE}

Podpisana w roku 1972 umowa o wolnym handlu z EWG dzieliła wszystkie towary będące przedmiotem obrotu na trzy kategorie - przemysłowe, rolne oraz uzyskane w wyniku przetworzenia podstawowych produktów rolnych. Handel pierwszą grupą tych towarów został zliberalizowany w wyniku stopniowego zniesienia barier celnych. Produkty rolne nie były objęte postanowieniami umowy z 1972 r. Dopiero porozumienie bilateralne z roku 1999 wprowadziło nowe zasady wymiany handlowej pomiędzy Szwajcarią a państwami UE. Była o tym mowa w części omawiającej współpracę w obszarze rolnictwa. Natomiast przetworzone produkty rolne podlegały specjalnym regulacjom, zawartym $\mathrm{w}$ protokole $\mathrm{nr}$ 2 umowy z roku $1972^{226}$. Stanowią one grupę produktów pośrednich pomiędzy towarami przemysłowymi, nieobjętymi obostrzeniami w handlu, a rolnymi, które są chronione za pomocą instrumentów taryfowych i pozataryfowych ${ }^{227}$. Nieco upraszczając, przetworzone produkty rolne traktowane są jako towar zawierający niejako obydwa elementy, a więc wymagają zastosowania osobnych regulacji. Wspomniany protokół do umowy z EWG przewidywał częściowe zniesienie ceł oraz wprowadzenie środków kompensacyjnych w stosunku do produktów rolnych, takich jak mąka, masło, tłuszcz roślinny itp. Polegały one na przyznawaniu

${ }^{224}$ Art. 16 Botschaft zur Genehmigung der bilateralen Abkommen zwischen der Schweiz und der Europäischen Union, einschliesslich der Erlasse zur Umsetzung der Abkommen (Bilaterale II) vom 1. Oktober 2004..., s. 6192.

225 Ibidem, s. 6204; Vorschlag zu gesetzlichen Änderungen zur wirksameren Bekämpfung des Schmuggels und des organisierten Wirtschaftsverbrechens (Pedrina), $00.447 \mathrm{n} \mathrm{Pa.Iv.}$

${ }^{226}$ Protokoll Nr. 2 vom 22. Juli 1972 zum Freihandelsabkommen zwischen der Schweizerischen Eidgenossenschaft und der Europäischen Wirtschaftsgemeinschaft, AS 1972/3163, SR-0.632.401.2.

${ }^{227}$ Do tej grupy produktów zaliczamy np. czekoladę, ciastka, pieczywo, cukierki, zupy, sosy, makarony, kawę rozpuszczalną, lody. 
refundacji wywozowych oraz zwrocie, umorzeniu lub zwolnieniu z opłat celnych. Przy ustalaniu wysokości tych środków brano pod uwagę stosunek cen na surowce rolne na rynku krajowym i zagranicznym. Chodziło o to, aby z jednej strony utrzymać konkurencyjność produktów szwajcarskich, które ze względu na wyższe ceny surowców wyjściowych nie są atrakcyjne cenowo na rynkach unijnych, z drugiej zaś strony utrzymanie barier celnych chroniło rynek w Szwajcarii.

Zawarte w protokole nr 2 regulacje okazały się niewystarczające i w praktyce powodowały wiele zakłóceń $\mathrm{w}$ handlu. $\mathrm{W}$ latach 80 . podjęto pierwsze próby naprawy tej sytuacji (tzw. Deklaracja Luksemburska), co znalazło swoje odzwierciedlenie w protokole $\mathrm{nr} 3$, będącym częścią umowy dotyczącej EOG ${ }^{228}$. Ostatecznie Szwajcaria nie przystapiła do Europejskiego Obszaru Gospodarczego, a zatem kwestia handlu przetworzonymi produktami rolnymi została zawieszona. Rząd Szwajcarii czynił wielokrotnie próby włączenia tego tematu do negocjacji nad pierwszym pakietem umów bilateralnych, jednak UE nie wyraziła na to zgody. W rezultacie jedynie w akcie końcowym zawarto deklarację wznowienia negocjacji w dziedzinach będących przedmiotem wspólnego zainteresowania, takich jak aktualizacja protokołu nr 2 do umowy o wolnym handlu z roku 1972.

Oficjalne rozmowy w tej sprawie rozpoczęto zatem tuż po podpisaniu pakietu Bilaterale I, tj. w lipcu 2001 r. Rząd Szwajcarii odwoływał się w swoim stanowisku do regulacji zawartych we wspomnianym już protokole $\mathrm{nr} 3$. Chodziło więc głównie o uproszczenie systemu kompensacji cen, rozszerzenie listy produktów oraz częściowe zniesienie barier celnych. Obie strony doszły dość szybko do porozumienia, albowiem ostateczny tekst umowy został zaakceptowany w listopadzie roku $2002^{229}$.

Nowa umowa wprowadza kilka zmian w dotychczasowych zasadach han$\mathrm{dlu}^{230}$. Przede wszystkim znacznemu obniżeniu uległy opłaty celne, związane z importem towarów do Szwajcarii z państw UE, a także inny jest sposób ich naliczania (w zależności od składu towarów i różnic w cenie). Ponadto obniżono poziom refundacji przy eksporcie szwajcarskich produktów na rynki unijne, a całkowicie zniesiono go w przypadku wywozu z UE do Szwajcarii. System kompensacji cen uległ znacznemu uproszczeniu. Ceny na poszczególne surowce rolne określa się w ramach komisji mieszanych. Każda ze stron ma obowiązek przekazywania do komisji przynajmniej raz w roku informacji dotyczących średnich stawek cen surowców rolnych obowiązujących na krajowych rynkach. Bierze się zatem pod uwagę jedynie wewnętrzne ceny odniesienia w ramach Wspól-

${ }^{228}$ Botschaft zur Genehmigung der bilateralen Abkommen zwischen der Schweiz und der Europäischen Union, einschliesslich der Erlasse zur Umsetzung der Abkommen (Bilaterale II) vom 1. Oktober 2004..., s. 6034.

${ }^{229}$ Tekst dostępny także w polskiej wersji językowej na stronach Agencji Rynku Rolnego: http://www.arr.gov.pl/showdoc.php?inoId=3439 (20.09.2010).

${ }^{230}$ Abkommen vom 26. Oktober 2004 zwischen der Schweizerischen Eidgenossenschaft und der Europäischen Gemeinschaft zur Änderung des Abkommens zwischen der Schweizerischen Eidgenossenschaft und der Europäischen Wirtschaftsgemeinschaft vom 22. Juli 1972 in Bezug auf die Bestimmungen über landwirtschaftliche Verarbeitungserzeugnisse, AS 2005/1533, SR-0.632.401.23. 
noty oraz w Szwajcarii, dzięki czemu różnice są znacznie mniejsze niż przedtem, gdy porównywało się stawki na rynkach światowych. Postęp technologiczny wymusił również uzupełnienie listy produktów objętych postanowieniami umowy. Przedmiotem handlu są bowiem produkty, które jeszcze niedawno w ogóle nie były dostępne na rynkach.

Niniejsza umowa ma szczególne znaczenie dla szwajcarskiego sektora spożywczego, zatrudniającego 34000 osób i eksportującego na zagraniczne rynki towar o wartości 3,4 mld franków ${ }^{231}$. Bez możliwości sprzedaży produktów za granicą utrzymanie tak wysokiego zatrudnienia i produkcji nie byłoby możliwe. Według Eurostatu wartość eksportu produktów, uwzględnionych w protokole nr 2 umowy z 1972 r., do państw UE w latach 1999-2001 wynosiła średnio ok. 1 mld franków rocznie. Po wejściu w życie nowego porozumienia, a więc od 30 marca 2005 r., notuje się wzrost każdego roku średnio o ok. 16\%. Ogromne korzyści czerpią również szwajcarscy rolnicy. Firmy z branży spożywczej należą bowiem do największych odbiorców ich produktów. Przykładowo, prawie połowa produkowanego w Szwajcarii mleka trafia do firm zajmujących się jego przetwórstwem. Rządowi Szwajcarii udało się zatem utrzymać podstawowe instrumenty proeksportowe, a jednocześnie zachować najważniejsze środki ochronne dla rodzimego rynku.

\section{EDUKACJA, SZKOLENIE, MŁODZIEŻ}

Rozmowy w sprawie włączenia Szwajcarii do unijnego programu wspierania kształcenia rozpoczęły się oficjalnie w kwietniu 2008 r., a więc kilka lat po podpisaniu drugiego pakietu porozumień. Zawarta w roku 2010 umowa nie jest więc częścią Bilaterale II, choć stanowi kontynuację polityki bilateralnej władz Szwajcarii. Z tego względu warto poświęcić jej nieco uwagi.

Szwajcaria uczestniczyła w unijnych programach edukacyjnych od początku lat 90. XX w. Była to jednak współpraca nieformalna, bazująca na udziale w konkretnych projektach i realizowana w ramach porozumienia zawartego z wybraną instytucją w jednym z państw UE lub koordynującą dany projekt na poziomie europejskim. Przykładowo, szwajcarskie uczelnie wyższe brały udział w programie „Erasmus”, dotyczącym wymiany studenckiej. Rząd szwajcarski, jeszcze w trakcie negocjacji nad pakietem Bilaterale II, wyraził chęć nawiązania współpracy o charakterze formalnym ${ }^{232}$. Podjęto zatem rozmowy dwustronne, mające na celu określenie wymiaru udziału Szwajcarii w programach UE związanych z kształceniem i szkoleniem młodzieży na lata 2007-2013. Strategia rządu opierała się na zagwarantowaniu ${ }^{233}$ :

${ }^{231}$ Die Bilateralen Abkommen Schweiz - Europäischen Union..., s. 50.

${ }^{232}$ Podobne deklaracje zawarte były w Akcie końcowym pakietu Bilaterale I.

${ }^{233}$ Botschaft und Entwurf der Bundesbeschlüsse zur Genehmigung des Abkommens über die Teilnahme der Schweiz am EU-Programm ,Jugend in Aktion” und am EU-Aktionsprogramm im Bereich des lebenslangen Lernens (2007-2013) sowie zur Finanzierung der Teilnahme (2011-2013) vom 2. September 2009, BBI 2009 Nr. 39, s. 6263. 
- udziału Szwajcarii w programach „Młodzież w działaniu” oraz dotyczących kształcenia ustawicznego ${ }^{234}$;

- równego dostępu do unijnych środków wsparcia dla szwajcarskich uczestników programu;

- udziału swojego przedstawiciela w gremiach programu, na równi z krajami EOG/EFTA;

- partycypacji finansowej adekwatnej do wymiaru współpracy.

Unia Europejska postulowała z kolei związanie umowy klauzulą gilotyny, a zatem uzależnienie jej od umowy dotyczącej swobody przepływu osób. Domagano się również podjęcia przez Szwajcarię zobowiązania do automatycznego przyjęcia w przyszłości acquis UE. W tej pierwszej sprawie osiągnięto kompromis zakładający objęcie umowy specjalną klauzulą, ale dopiero po zakończeniu pierwszego okresu programowania. Z kolei w drugiej kwestii rząd Szwajcarii stanowczo odrzucał możliwość transponowania regulacji prawnych UE, argumentując, że wszelkie zmiany, wzorem pozostałych umów bilateralnych, powinny być każdorazowo konsultowane w ramach komisji mieszanych. Ustalono zresztą, iż rolę tę przejmie komisja zajmująca się umową o swobodzie przepływu osób. Ostatecznie umowa parafowana została w sierpniu 2009 r., a jej oficjalne podpisanie nastąpiło w lutym roku $2010 \mathrm{w}$ Brukseli ${ }^{235}$.

Rządowi udało się osiągnąć właściwie wszystkie zakładane na początku negocjacji cele. Zagwarantowano sobie m.in. stałe miejsce, jednakże bez prawa głosu, w komitetach programowych. Dzięki temu Szwajcaria ma dostęp do wszelkich informacji oraz może wpływać na kształt i zawartość merytoryczną programów ${ }^{236}$. Wkład finansowy na lata 2007-2013 ustalono na kwotę $75 \mathrm{mln}$ franków, co stanowi niewielką cześć całkowitego budżetu, wynoszącego ok. 8 mld euro.

Nad właściwą realizacją umowy po stronie Szwajcarii czuwa niezależna instytucja, wyłoniona w drodze konkursu ${ }^{237}$. Chodziło tutaj o zachowanie pełnej transparentności programu. Ponadto opierano się na założeniu, że rezygnacja z centralnego zarządzania programem przyniesie lepsze efekty ${ }^{238}$. Wyznaczona instytucja jest odpowiedzialna za właściwy przepływ informacji, nawiązywanie międzynarodowych kontaktów oraz wspieranie, pod względem merytorycznym, prac komitetu programowego. Oprócz tego pełni ona funkcję instytucji pośredniczącej, przyjmującej i kontrolującej wnioski, a także przeprowadzającej audyty i opracowującej raporty dotyczące realizacji projektu, które są regularnie przesyłane do Brukseli ${ }^{239}$.

${ }^{234}$ Erasmus, Leonardo da Vinci, Comenius, Grundtvig.

${ }^{235}$ Bundesrat Didier Burkhalter unterzeichnet das Bildungsabkommen zwischen der Schweiz und der EU, Medienmitteilung EDI, 15.02.2010, źródło: www.europa.admin.ch.

${ }^{236}$ Die Bilateralen Abkommen Schweiz - Europäischen Union..., s. 60.

${ }^{237}$ Umowa przewiduje, iż opieka nad programem musi być powierzona niezależnej, pozaministerialnej instytucji. W drodze przeprowadzonego przetargu zadanie to powierzono fundacji „ch Stiftung für eidgenössische Zusammenarbeit der Kantone”. Zob. www.chstiftung.ch.

${ }^{238}$ Botschaft und Entwurf der Bundesbeschlüsse zur Genehmigung des Abkommens..., s. 6264.

${ }^{239}$ Zob. więcej ibidem, s. 6264-6265. 
Przedmiotowe porozumienie można potraktować jako pewne uzupełnienie umowy odnoszącej się do udziału Szwajcarii w 7. Programie Ramowym UE. Tym razem jednak podjęto próbę skoordynowania polityki edukacyjnej w znacznie szerszym znaczeniu. Jej podstawowym założeniem jest wspieranie kształcenia ustawicznego. Szwajcarzy, na równi z obywatelami UE, mają zapewniony dostęp do szerokiej gamy projektów, mających na celu rozwój osobisty, wzmacnianie kompetencji i doświadczenia, a także nawiązywanie międzynarodowych kontaktów. Korzyści wynikające z tego rodzaju współpracy są obustronne. Dla Unii Europejskiej Szwajcaria jest partnerem cennym, chociażby ze względu na wysoki poziom edukacji czy współczynnik internacjonalizacji przedsiębiorstw, a także interesującym z uwagi na wielokulturowość. Z kolei Szwajcaria ma możliwość współkształtowania polityki edukacyjnej na poziomie europejskim, dzięki czemu ma szansę wykorzystania w pełni własnego potencjału naukowego i gospodarczego.

$$
* * *
$$

Nowy etap w polityce Szwajcarii wobec Unii Europejskiej został zapoczątkowany w momencie przełomowym dla Europy, a mianowicie po upadku żelaznej kurtyny i rozpoczęciu intensywnych procesów integracyjnych. Rząd Szwajcarii postanowił aktywnie w nich uczestniczyć, pomimo że oficjalnie Szwajcaria nadal była państwem neutralnym. Głównym motywem działań były aspekty gospodarcze. Zawarty w roku 1972 układ o wolnym handlu z EWG okazał się niewystarczającym narzędziem budowy relacji gospodarczych z państwami należącymi do Wspólnoty. Odpowiedzią na tę sytuację miało być włączenie do Europejskiego Obszaru Gospodarczego. Pomysł ten nie spotkał się jednak z aprobatą obywateli. Rząd zmuszony został do poszukiwania nowych rozwiązań. Okazały się nimi umowy bilateralne.

Po ponad dekadzie od podpisania pierwszego pakietu porozumień dotychczasowy bilans zysków i strat należy oceniać pozytywnie. Większość problemów $\mathrm{w}$ relacjach gospodarczych $\mathrm{z}$ państwami UE udało się rozwiązać. Okupione to było pewnymi wyrzeczeniami, jednak wydaje się, iż zyski dalece przewyższają straty. Zliberalizowano handel w wielu istotnych sektorach, umożliwiono Szwajcarii udział w ważnych programach unijnych, dotyczących współpracy badawczej lub wsparcia sztuki audiowizualnej. Dzięki włączeniu do strefy Schengen/Dublin wymiernie poprawiono bezpieczeństwo państwa. Wzrósł poziom wykrywania przestępczości oraz nadużyć finansowych, wzmocniono szczelność granic, poprawiono efektywność polityki azylowej. Dzięki wsparciu polityki spójności UE Szwajcaria poprawiła swój wizerunek, a przyjęcie tzw. dyrektywy oszczędnościowej pozwoliło na złagodzenie oskarżeń kierowanych pod adresem szwajcarskiego sektora bankowego, co nie znaczy, że na tym polu pomiędzy Bernem a Brukselą nie dochodzi nadal do wielu spięć. Utrzymano jednak tajemnicę bankową, co niewątpliwie należy zaliczyć do sukcesów szwajcarskiej dyplomacji. Nawet otwar- 
cie rynków pracy, pomimo wielu obaw i kontrowersji, okazuje się mieć zbawienny wpływ na gospodarkę. Przynajmniej dopóty, dopóki obowiązują instrumenty ochronne. Być może po okresie przejściowym sytuacja ulegnie zmianie. Przy tym wszystkim udało się zachować to, co najcenniejsze - suwerenność, neutralność, poszanowanie dla szwajcarskiej demokracji i dla ustroju federalnego.

Pozostaje tylko pytanie, na jak długo? Już teraz pojawiają się wątpliwości co do faktycznego wymiaru procesów legislacyjnych w obszarach będących przedmiotem współpracy z Unią Europejską. Zjawisko autonomicznego dopasowania nie jest do końca tak autonomiczne, jak się powszechnie uważa. Wiele nowych aktów prawnych jest przyjmowanych w Szwajcarii niejako pod przymusem. Wynika to ze specyfiki umów bilateralnych, które opierają się na prawie wspólnotowym. $\mathrm{Z}$ tego względu z zasady nie podlegają negocjacjom i wymagają dostosowania prawodawstwa Szwajcarii. Można zatem śmiało powiedzieć, że relacje pomiędzy Szwajcarią a Unią Europejską mają charakter asymetryczny. Do tego dochodzi problem braku odpowiedniej przejrzystości tej współpracy, zwłaszcza na poziomie legislacyjnym i instytucjonalnym. Powołane do życia komisje mieszane zdają się nie spełniać wszystkich stawianych im wymogów. Brakuje gremium pełniącego funkcje koordynujące i nadającego współpracy wizję klarowną i długofalową. Problemem pozostaje również niska decyzyjność, a właściwie jej brak w ramach UE. Szwajcaria może brać udział w posiedzeniach wielu komisji eksperckich, niestety bez prawa głosu. Nie ma zatem wpływu na podejmowane $\mathrm{w}$ ramach Wspólnoty decyzje. $\mathrm{Z}$ jednej strony wydaje się to oczywiste. Trudno, aby państwo niebędące członkiem Unii współdecydowało o kierunkach jej rozwoju. Przy powszechnej świadomości rosnącego uzależnienia Szwajcarii od Wspólnoty współpraca bilateralna, przynajmniej w obecnym kształcie, słusznie wywołuje jednak coraz więcej kontrowersji.

Analiza realizacji polityki wobec UE pozwala na zweryfikowanie kilku postawionych na wstępie hipotez badawczych. Po pierwsze, widać wyraźnie, iż nowy rozdział w stosunkach z Unią Europejską motywowany był w pierwszej kolejności czynnikami gospodarczymi. Okazało się bowiem, że zjawiska integracyjne doprowadziły do wzmocnienia znaczenia EWG, a potem UE. Wspólnota stała się głównym animatorem życia polityczno-gospodarczego w Europie. W konsekwencji osłabieniu uległa EFTA, z którą Szwajcaria wiązała początkowo spore nadzieje. Strefa wolnego handlu, z uwagi na swój charakter, miała być doskonałą formą współpracy, zwłaszcza dla państw neutralnych. Tak się jednak nie stało, albowiem potrzeby integracyjne wybiegały poza obszary czysto gospodarcze. Zaczęto poszukiwać nowych form współpracy także na innych płaszczyznach. Wobec słabnącej roli EFTA w Europie Szwajcaria była zmuszona do zwrócenia się ku Wspólnocie, zwłaszcza że większość państw, które do niedawna były częścią strefy wolnego handlu, również wybrała tę formę współpracy.

Po drugie, Unia Europejska nie stanowi gwarancji gospodarczego lub politycznego rozwoju Szwajcarii, choć bezapelacyjnie jest obecnie jej najważ- 
niejszym partnerem handlowym. Fakt ten sprawil, że relacje dwustronne mają charakter bardziej pragmatyczny, ograniczający się do regulowania współpracy jedynie $\mathrm{w}$ wybranych obszarach, a nie do pełnej integracji. Z przytoczonych w niniejszym rozdziale danych widać wyraźnie, że polityka Szwajcarii niemal całkowicie zabezpiecza dziś jej interesy gospodarcze i polityczne. Nie ma zatem poważnych przesłanek do rozpoczęcia rozmów akcesyjnych. 


\section{ROZDZIAL IV \\ OCENA I PERSPEKTYWY POLITYKI SZWAJCARII WOBEC UNII EUROPEJSKIEJ}

Niniejszy rozdział stanowi próbę bilansu dotychczasowej polityki rządu Szwajcarii wobec UE. Pod uwagę wzięto tutaj dwie płaszczyzny funkcjonowania państwa w stosunkach międzynarodowych - polityczną oraz ekonomiczną. Ma to na celu przedstawienie obiektywnego obrazu bieżących relacji, zmierzającego do odpowiedzi na pytanie - czy dotychczasowa polityka jest efektem z góry przemyślanej strategii, czy też wynika z konieczności przystosowania się do zachodzących zmian geopolitycznych? W rozdziale dokonano też próby nakreślenia perspektyw dalszej współpracy. Pod uwagę wzięto tutaj trzy, najbardziej prawdopodobne, scenariusze: kontynuację polityki bilateralnej, przystąpienie do Unii Europejskiej oraz alternatywne formy integracji. Każdy z wariantów został przeanalizowany pod kątem możliwych implikacji politycznych oraz ekonomicznych, a także prawdopodobieństwa jego realizacji.

\subsection{OCENA POLITYKI SZWAJCARII WOBEC UNII EUROPEJSKIEJ}

Strategia polityczna rządu Szwajcarii wobec Unii Europejskiej zakładała osiągnięcie dwóch celów. Po pierwsze, wypracowanie korzystnych warunków do rozwoju współpracy gospodarczej, głównie poprzez zagwarantowanie dostępu do wspólnotowego rynku. Po drugie, uzyskanie możliwości współdecydowania w szeroko pojętych kwestiach europejskich, a więc w praktyce przeciwdziałanie izolacjonizmowi. To ostatnie zjawisko niewątpliwie stawało się coraz bardziej realne, zwłaszcza po fiasku w głosowaniach w sprawie Europejskiego Obszaru Gospodarczego oraz znacznym rozluźnieniu współpracy w ramach EFTA.

Polityka oparta na relacjach bilateralnych była wówczas jedynym, możliwym z punktu widzenia głównie uwarunkowań wewnątrzpolitycznych, wyjściem, tym bardziej że Unia Europejska była zdecydowana na stworzenie takiego precedensu w zakresie współpracy z państwem trzecim. Należy to zresztą uznać za pewien ewenement w polityce Wspólnoty. Wobec żadnego innego państwa nie zdecydowano się na podjęcie podobnej strategii. Oczywiście można w tym miejscu pokusić się o drobne dywagacje, dotyczące przyczyn wspomnianej postawy ze 
strony UE. Za wielce prawdopodobną należy uznać tezę, według której współpracę bilateralną należałoby traktować jako wstęp do pełnej integracji, a więc swego rodzaju poczekalnię, pozwalającą na częściowe ujednolicenie prawne i instytucjonalne pod kątem przyszłego członkostwa we Wspólnocie. Etap ten byłby wówczas traktowany jako okres pozwalający na wyciągnięcie pierwszych wniosków z tak prowadzonej współpracy. Już teraz zauważyć można coraz większe zniecierpliwienie władz UE zaistniałą sytuacją. Objawia się to chociażby w postaci rosnącej presji na Szwajcarię, związanej z jej sektorem bankowym czy systemem podatkowym. Naciski te nasiliły się szczególnie z nastaniem kryzysu gospodarczego z roku 2008. Różnego rodzaju napięcia i wzajemne pretensje zauważyć można nawet wśród członków Wspólnoty, co znacznie zresztą osłabia jej wewnętrzną spójność. Nic więc dziwnego, że mamy do czynienia z pogorszeniem relacji również wobec partnerów zewnętrznych. Z kolei elity polityczne w Szwajcarii w zdecydowanej większości zdają się popierać kontynuację polityki bilateralnej, mając przy tym świadomość jej wielu negatywnych konsekwencji, o których szerzej będzie jeszcze mowa. Chęć przystąpienia do UE, a więc wariant współpracy chyba najbardziej odpowiadający władzom w Brukseli, wykazuje niewielka część szwajcarskich komentatorów politycznych i tamtejszych środowisk gospodarczych. W przypadku tych ostatnich warto zwrócić uwagę na brak konsensusu, co może być o tyle zastanawiające, że to właśnie gospodarka zdaje się w największym stopniu korzystać ze współpracy z Unią Europejską. Najczęściej można jednak spotkać się z opinią, że obecne uwarunkowania ekonomiczne, mając na uwadze przede wszystkim skutki światowego kryzysu i sposoby radzenia sobie z nim w strefie euro, nie przemawiają za włączeniem Szwajcarii do UE¹. Dodatkowo przytacza się tutaj wiele istotnych argumentów, jak chociażby konieczność podniesienia podatku VAT z obecnych 7 do $15 \%$, wprowadzenie automatycznej wymiany informacji dotyczących kont bankowych czy wreszcie ujednolicenie kantonalnych podatków.

Wychodząc z takiego założenia warto przeanalizować dotychczasowe doświadczenia wynikające ze współpracy z UE, jak również dokonać próby oceny polityki Szwajcarii wobec Wspólnoty w ciągu minionych, blisko dwóch, dekad. Poniższa analiza składać się będzie z dwóch części. W pierwszej przedstawione zostaną efekty dotychczasowej współpracy w postaci konkretnych danych ekonomicznych. Należy zauważyć, iż umowy z pierwszego pakietu regulują współpracę w wielu istotnych obszarach gospodarki szwajcarskiej. Ważne są tutaj zatem dane odnoszące się do wymiany handlowej, będącej efektem zniesienia znakomitej części barier celnych (zarówno taryfowych, jak i pozataryfowych), struktury zatrudnienia, na którą wpływ ma wprowadzenie swobody przepływu osób czy też liberalizacji rynku transportowego. Ocena skutków wprowadzenia drugiego pakietu będzie możliwa z kolei po przeanalizowaniu danych dotyczących zwalczania przestępczości zorganizowanej, wykrywania nadużyć podatkowych czy przeciwdziałania nielegalnej imigracji. Istotne będą również miękkie wskaźniki,

${ }^{1}$ Por. Nachdenken über den EWR, „Neue Zürcher Zeitung”, 29. Juli 2010. 
związane z udziałem szwajcarskich jednostek naukowych lub innych podmiotów w międzynarodowych projektach, finansowanych ze źródeł unijnych. Warto też zwrócić uwagę na zaoferowane przez rząd Szwajcarii wsparcie polityki spójności UE. Chodzi tutaj przede wszystkim o jej wymiar finansowy, tj. bilans zysków i strat $\mathrm{w}$ postaci wydatków budżetowych oraz dodatkowych impulsów dla rozwoju gospodarki, będących efektem zjawiska tzw. otwartych drzwi.

Oceniając politykę zagraniczną państwa należy wziąć pod uwagę nie tylko aspekty ekonomiczne, ale również polityczne. Interesujące jest zatem, w jakim stopniu realizowana koncepcja doprowadziła do ewentualnego wzrostu lub obniżenia pozycji państwa na arenie międzynarodowej? W jaki sposób zmienił się, i czy w ogóle, sposób postrzegania go przez inne podmioty? Ciekawy wydaje się być również apekt rozwoju i ewentualnej deformacji wewnętrznej sceny politycznej, będącej następstwem wprowadzenia problemu integracji z UE do debaty publicznej. W jakim stopniu zatem polityka europejska mogła wpłynąc na wzmocnienie bądź osłabienie określonych ugrupowań politycznych? Wreszcie, czy może ona skutkować zmianami ustrojowymi bądź instytucjonalnymi w bliższej lub dalszej perspektywie? Nierozerwalnie wiąże się to również z pojęciem świadomości politycznej i kulturowej. Istotne jest zatem przeanalizowanie ewentualnych zmian w nastawieniu opinii publicznej do problemu europejskiego, jak również przyszłości Szwajcarii i jej roli w perspektywie procesów globalizacyjnych i integracyjnych.

\subsubsection{EKONOMICZNY WYMIAR POLITYKI WOBEC UNII EUROPEJSKIEJ}

Pod względem gospodarczym Unia Europejska jest bez wątpienia najważniejszym partnerem Szwajcarii. Wynika to przede wszystkim z uwarunkowań geograficznych, ale również historycznych i kulturowych. Rząd Szwajcarii nieustannie podejmuje próby zdywersyfikowania kontaktów gospodarczych, kierując swą uwagę na Stany Zjednoczone oraz rynki wschodzące, należące do tzw. grupy BRIC (Brazylia, Rosja, Indie, Chiny)2 ${ }^{2}$ Z uwagi na chłonność tamtejszych rynków i ogromne zapotrzebowanie na wysoko wyspecjalizowane produkty oraz know how, jaki ma do zaoferowania Szwajcaria, kierunki te wydają się bardzo obiecujące. Rząd dążył zatem do zawarcia z tymi państwami korzystnych umów dwustronnych, opierających się głównie na zniesieniu barier celnych oraz włączeniu się w fora międzynarodowej współpracy, ukierunkowanej na rynki azjatyckie, jak APEC (Asia Pacific Economic Cooperation), ASEM (Asia Europa Meeting) czy ASEAN (Association of Southeast Asian Nation) ${ }^{3}$. Bardzo szybko natrafiono jednak na pewne problemy związane z relatywnie niską atrakcyjnością rynku

\footnotetext{
${ }^{2} \mathrm{Na}$ temat znaczenia rynków BRIC dla Szwajcarii zob. Bericht des Bundesrates zur Aussenwirtschaftspolitik 2006, Staatssekretariat für Wirtschaft SECO, Bern 2007, s. 9-29.

${ }^{3}$ Próby włączenia Szwajcarii do prac tych organizacji w 1989, 1996 oraz 1997 r. zakończyły się fiaskiem.
} 
szwajcarskiego dla tak potężnych partnerów, jak Rosja czy Chiny. Nie oznacza to oczywiście, że wzajemne relacje nie ulegają korzystnym zmianom ${ }^{4}$. Niemniej jednak pozycja negocjacyjna Szwajcarii byłaby zapewne silniejsza, gdyby występowała ona jako członek Unii Europejskiej.

Władze w Bernie skoncentrowały się w tej sytuacji na intensyfikacji kontaktów dwustronnych z państwami europejskimi. Można zatem obecnie wskazać na trzy podstawowe filary strategii gospodarczej władz Szwajcarii. Poza zaangażowaniem w ramach Światowej Organizacji Handlu i rozwojem dwustronnych układów handlowych z państwami trzecimi, główną osią tej polityki jest współpraca gospodarcza z UE5. Sama idea uregulowania wielu istotnych obszarów współpracy gospodarczej spotkała się od samego początku z ogromnym poparciem przedsiębiorców oraz znakomitej większości środowisk opiniotwórczych. Nie brakowało oczywiście głosów krytycznych, ale te odnosiły się głównie do wprowadzenia swobody przepływu osób i zawarcia porozumienia w sprawie liberalizacji usług transportowych. Obawiano się wzrostu nielegalnej imigracji, znacznego pogorszenia warunków na rynku pracy, tj. wzrostu bezrobocia i dumpingu płacowego, a także w przypadku tej drugiej umowy, pogorszenia stanu dróg i zanieczyszczenia środowiska naturalnego, spowodowanego drastycznym zwiększeniem tranzytu przez terytorium Szwajcarii.

Już rok po wejściu w życie pierwszego pakietu porozumień Biuro Integracyjne opublikowało pierwsze sprawozdanie nt. bilansu umów bilateralnych ${ }^{6}$. Należy je traktować z pewnym dystansem, chociażby z uwagi na fakt, iż w dość ograniczonym stopniu „podparte” jest solidną bazą danych statystycznych. Jednak pierwsze doświadczenia były niewątpliwie niezwykle obiecujące. Uznano wówczas, że realizacja porozumień nie przysparza większych problemów, a współpraca na linii rząd - kantony odbywa się pomyślnie. Odnotowano niewielki wzrost napływu obcokrajowców, choć dodać należy, że przez pierwsze pięć lat obowiązywały kontyngenty ilościowe, które znacznie ograniczały swobodę osiedlania się w Szwajcarii. Część środowisk gospodarczych krytykowała nawet zbyt restrykcyjne ograniczenia możliwości zatrudniania obcokrajowców, domagając się zwiększenia kontyngentów i uproszczenia procedur administracyjnych. Szczególnie krytycznie wypowiadały się o tym związki rolników, cierpiące na niedobór siły roboczej ${ }^{7}$. Zapotrzebowanie rynku okazało się więc znacznie większe niż początkowo sądzono, a obawy związane ze wzrostem bezrobocia stały się, przynajmniej w początkowym okresie, zupełnie bezpodstawne. Pozytywnie oceniano

${ }^{4}$ Por. 60-Jahr-Jubiläum der diplomatische Beziehungen Schweiz-China, Medienmitteilung EDA, 13.09.2010 r.

${ }^{5}$ A. Brunetti, U. Bucher, Die Bilateralen I aus wirtschaftlichen Sicht, „Die Volkswirtschaft. Das Magazin für Wirtschaftspolitik”, 01.11.2008, s. 4.

${ }^{6}$ Monitoring. Bilaterale Abkommen I Schweiz - EU: Erste Erfahrungen ein Jahr nach Inkrafttreten, Integratonsbüro EDA/EVD, Bern, den 27. Mai 2003.

${ }^{7}$ Ibidem, s. 4. 
również instrumenty ochronne przeciwdziałające zjawisku dumpingu socjalnego, choć odpowiednie mechanizmy nie były wdrażane w równym stopniu przez wszystkie kantony. Zdecydowanie najszybciej proces ten przebiegał w kantonach granicznych, takich jak Tessin czy Genewa.

W pierwszym roku od momentu wejścia w życie porozumień odnotowano również drobne zmiany w obszarze transportu drogowego. Trudno jednak mówić tutaj o jego ograniczeniu, lecz bardziej o spowolnieniu tempa wzrostu z 10 do $2 \%$ rocznie. Zauważono jednak pozytywny trend zmierzający w kierunku zmniejszenia liczby przejazdów tranzytowych przez tereny alpejskie, co było efektem podniesienia dopuszczalnego limitu obciążenia pojazdów ${ }^{8}$. $Z$ drugiej strony przedstawiciele branży transportowej krytykowali wprowadzenie dodatkowych obciążeń fiskalnych, związanych z zastosowaniem nowych taryf tranzytowych ${ }^{9}$.

$\mathrm{Na}$ bardziej miarodajną analizę bilansu zysków i strat pozwalają dane za lata 2007 oraz 2008. Opublikowano wówczas kilka interesujących raportów zarówno rządowych, jak i niezależnych ośrodków opiniotwórczych. Dane te świadczą o postępującym rozwoju współpracy gospodarczej, objawiającej się chociażby w rosnących obrotach handlowych pomiędzy Szwajcarią a państwami UE. Średni roczny wzrost wynosi $6 \%$. W przypadku nowych członków Wspólnoty tempo wzrostu jest jeszcze większe, bo sięga 13, a nawet 15\% (Bułgaria i Rumunia). Obecnie 2/3 całkowitego wolumenu eksportu, o łącznej wartości 132 mld franków, trafia na rynki UE, z kolei import z tego kierunku pokrywa $4 / 5$ całości ( 156 mld franków $)^{10}$. Wartość inwestycji bezpośrednich Szwajcarii w UE oscyluje w granicach 290 mld franków, co przekłada się m.in. na ok. 900000 miejsc pracy stworzonych przez szwajcarskie przedsiębiorstwa w krajach Wspólnoty. Z kolei ponad 70\% bezpośrednich inwestycji zagranicznych trafia do Szwajcarii właśniez państw UE. W samym tylko roku 2007 ich wartość przekroczyła 270 mld franków ${ }^{11}$. Współpraca ta przekłada się na wzrost zatrudnienia w Szwajcarii, rokrocznie o ok. 2,1\% (nie licząc spowolnienia gospodarczego wywołanego ogólnoświatowym kryzysem z roku 2008).

Jeżeli wziąć pod uwagę dane z poszczególnych sektorów gospodarki, widać wyraźnie, iż dotychczasowy bilans współpracy również wykazuje pozytywne trendy. We wszystkich obszarach tematycznych, które stały się przedmiotem umów dwustronnych, rząd Szwajcarii może poszczycić się dobrymi lub bardzo dobrymi osiągnięciami. Otwarcie rynku pracy dla obcokrajowców nie pociągnęło za sobą żadnych negatywnych implikacji. Napływ cudzoziemców odbywa się w sposób kontrolowany, choć przyznać należy, że od czasu zniesienia kontyngentów ilościowych zainteresowanie podjęciem pracy w Szwajcarii wyraźnie

${ }^{8}$ Spadek o $9 \%$ w porównaniu z corocznym wzrostem o prawie $8 \%$.

${ }^{9}$ Dodatkowe wpływy do budżetu z tego tytułu w samym tylko 2002 r. wyniosły $882 \mathrm{mln}$ franków.

${ }^{10}$ Dane za rok 2008.

${ }^{11}$ Dane według zestawienia zawartego w opracowaniu Die Bilateralen Abkommen SchweizEuropäischen Union, Integrationsbüro EDA/EVD, November 2009, s. 11. 
wzrosło. Spośród tzw. starych państw UE najwyższy wskaźnik notuje się tu wśród obywateli Niemiec, których liczba w ciągu ostatnich pięciu lat wzrosła prawie dwukrotnie. Jak dotąd nie stanowią oni najliczniejszej grupy obcokrajowców, ale różnica $\mathrm{w}$ stosunku do obywateli Włoch, którzy od lat zajmują tę pozycję, jest niewielka. Jeżeli obecne tempo zostanie utrzymane, już wkrótce Niemcy będą stanowić najliczniejszą grupę cudzoziemców w Szwajcarii. Przyczyn tej sytuacji należy doszukiwać się w braku barier językowych oraz zbliżonej mentalności i stosunku do pracy, co sprawia, iż obywatele Niemiec postrzegani są jako cenni pracownicy. Instrumenty ochronne, przeciwdziałające dumpingowi płacowemu, zdają się funkcjonować poprawnie ${ }^{12}$. Władze dość aktywnie próbują zapobiec ewentualnym nadużyciom. W samym tylko roku 2008 liczbę przeprowadzonych kontroli zwiększono o $30 \%{ }^{13}$.

Tabela 3.4

Mieszkańcy według narodowości, dane w tysiącach

\begin{tabular}{|l|r|r|r|r|r|}
\hline \multirow{2}{*}{ Wyszczególnienie } & \multicolumn{5}{|c|}{ Rok } \\
\cline { 2 - 6 } & 2005 & 2006 & 2007 & 2008 & 2009 \\
\hline $\begin{array}{l}\text { UE 27/EFTA } \\
\text { w tym: }\end{array}$ & 903,5 & 923,8 & 971,9 & 1037,1 & 1077,6 \\
\hline Niemcy & 158,7 & 173,9 & 203,2 & 234,6 & 251,9 \\
\hline Francja & 70,9 & 73,5 & 79,3 & 87,4 & 92,5 \\
\hline Włochy & 297,9 & 293,3 & 291,2 & 291,6 & 290,6 \\
\hline Austria & 33,1 & 33,2 & 34,2 & 35,7 & 36,7 \\
\hline Portugalia & 167,9 & 174,2 & 183,0 & 196,8 & 206,0 \\
\hline Hiszpania & 72,2 & 69,1 & 65,9 & 65,2 & 65,0 \\
\hline
\end{tabular}

Źródło: dane według Bundesamt für Statistik.

Na takuzależnioną od obcej siły roboczej gospodarkę, zjakąmamy doczynienia w Szwajcarii, liberalizacja rynku pracy miała bardzo pozytywny wpływ ${ }^{14}$. Ocenia się, że to właśnie wprowadzeniu swobody przepływu osób państwo to zawdzięcza obecne tempo rozwoju gospodarczego ${ }^{15}$. Średnio co czwarta pracująca tu oso-

${ }^{12}$ Por. Bericht über die Umsetzung der Flankierenden Massnahmen zur Freizügigkeit im Personenverkehr, 1. Januar bis 31. Dezember 2008, SECO, 23. April 2009.

${ }^{13}$ Die Bilateralen Abkommen Schweiz - Europäischen Union..., s. 24.

${ }^{14}$ Według raportu OECD wysoki poziom wzrostu gospodarczego w latach 1982-2005 byłby niemożliwy bez napływu obcokrajowców. Patrz Economic Survey of Switzerland. Policy Brief OECD, November 2007. Por. Arbeit und Erwerb: Panorama, Bundesamt für Statistik, Februar 2010, s. 2.

${ }^{15}$ Według danych Avenir Suisse dzięki otwarciu rynku pracy dla obcokrajowców średni wzrost PKB wynosi $1 \%$, co przekłada się na 4-5 mld franków. 
ba to obcokrajowiec. W niektórych sektorach, w tym również na stanowiskach kierowniczych lub wśród pracowników akademickich, odsetek ten sięga nawet 40-50\% ${ }^{16}$. Interesującym trendem jest również fakt, że wśród cudzoziemców coraz więcej osób dysponuje wysokimi kwalifikacjami zawodowymi ${ }^{17}$. Według danych SECO w grupie osób, które osiedliły się w Szwajcarii w latach 1997-2007, prawie połowa miała wyższe wykształcenie, a aż $81 \%$ wykształcenie na poziomie szkoły średniej ${ }^{18}$. Pozwala to na zwiększenie produkcyjności i budowanie gospodarki opartej na wiedzy. Ma również pozytywny wpływ na strukturę zarobkową. Nowa emigracja przyczynia się do ograniczenia różnic płacowych pomiędzy nisko a wysoko opłacanymi zawodami. W ciągu ostatnich dziesięciu lat odnotowuje się wzrost zarobków osób o niskich kwalifikacjach przy jednoczesnym zahamowaniu tendencji wzrostowych w stosunku do osób wysoko wykwalifikowanych ${ }^{19}$. Część ekonomistów uważa, że stopa bezrobocia byłaby mniejsza, gdyby utrzymano wcześniejsze ograniczenia ${ }^{20}$. Należy jednak zauważyć, iż poziom bezrobocia w Szwajcarii, pomimo to należy do najniższych w Europie. W drugim kwartale $2010 \mathrm{r}$. wynosił on $3,6 \%$ co, biorąc pod uwagę negatywne tendencje na rynkach światowych i ogromne bezrobocie w niektórych z państw strefy euro, jest wynikiem imponującym ${ }^{21}$.

Nie bez znaczenia jest również kwestia integracji społecznej. Ta przebiega dość sprawnie, chociażby ze względu na fakt, że najwięcej obcokrajowców, bo ok. 70\%, którzy podejmują pracę i osiedlają się na terytorium Szwajcarii, pochodzi z państw UE, głównie geograficznych sąsiadów, czyli z Niemiec i Włoch, w mniejszym stopniu Francji. Nie ma więc przepaści pod względem mentalnym czy kulturowym. Mniejszości te dość łatwo ulegają asymilacji.

Kwestią otwartą pozostaje wpływ zawarcia umowy dwustronnej z UE w sprawie swobodnego przepływu osób w dłuższym okresie. Należy zauważyć, że ograniczenia ilościowe nadal obowiązują część państw Unii. Na wiarygodne dane będzie trzeba więc jeszcze poczekać. Wiadomo natomiast, iż do pewnego stopnia rynek reguluje się sam. Wzrost imigracji zarobkowej będzie trwał dopóty, dopóki gospodarka będzie kontynuować tendencje wzrostowe. Po drugie, rząd Szwajcarii ma do dyspozycji dodatkowe instrumenty ochronne, o których mowa była już w poprzednim rozdziale. Pozwalają one na ponowne wprowadzenie ogra-

${ }^{16}$ Die Neue Zuwanderung, „Die Volkswirtschaft. Das Magazin für Wirtschaftspolitik”, 01.11.2008, s. 15 .

${ }^{17}$ Zob. art. na temat wysoko wykwalifikowanych emigrantów z Niemiec: Kluge Köpfe, gratis importiert. Wo Liege das Problem?, „Tagesanzeiger”, 30. Januar 2010.

${ }^{18}$ Mehr Zuwanderung und Wachstum dank Personenfreizügigkeit, Medienmitteilung Staatssekretariat für Wirtschaft, 02.07.2009.

${ }^{19}$ Ibidem.

${ }^{20}$ Por. Personenfreizügigkeit: Auswirkungen auf den Arbeitsmarkt und das Wirtschaftswachstum, „Die Volkswirtschaft. Das Magazin für Wirtschaftspolitik”, 01.11.2008, s. 11.

${ }^{21}$ Arbeitslosenquote in der Schweiz verharrt auf 3,6 Prozent, „Tagesanzeiger”, 7. September 2010. 
niczeń ilościowych w przypadku gwałtownego napływu obcokrajowców. Oczywiście trzeba pamiętać, że mogą być one wprowadzone jedynie czasowo.

Część społeczeństwa szwajcarskiego, głównie osoby skupione wokół ugrupowań prawicowych, jest zdania, że pozytywne doświadczenia z otwarcia rynku pracy dla obywateli starej Unii nie oznaczają wcale, iż podobny proces będzie zachodził także w przypadku nowych państw UE. Kraje takie, jak Bułgaria czy Rumunia cechuje zdecydowanie niższy poziom życia i wysoki współczynnik bezrobocia. Obywatele tych państw odznaczają się zatem zdecydowanie wyższym potencjałem migracyjnym. Trudno więc przewidzieć, jak będą wyglądały zmiany sytuacji na rynku pracy w Szwajcarii po zakończeniu okresów przejściowych. Trzeba jednak mieć na uwadze fakt, o czym wspomina zresztą również Rolf Weder, iż podobne obawy pojawiły się w momencie rozszerzenia Unii W roku $2004^{22}$. Spodziewano się dość znacznego strumienia emigracyjnego z nowych państw UE. Jak do tej pory do zjawiska takiego nie doszło, choć oczywiście powinniśmy uwzględnić przy tym regulacyjne właściwości wprowadzonych instrumentów ochronnych. Ponadto takie państwa, jak Szwajcaria, chociażby ze względów językowych, nie stanowiły tak atrakcyjnych kierunków emigracyjnych jak np. Wielka Brytania. Wydaje się, że wśród krajów niemieckojęzycznych znacznie większym powodzeniem będą cieszyć się Niemcy, ewentualnie Austria. Jak do tej pory liczba emigrantów z Polski w ciągu dziesięciu lat uległa co prawda podwojeniu, ale nadal jest to stosunkowo niewielka, w porównaniu z populacją całego kraju, grupa ok. 10000 osób.

Już teraz można natomiast wskazać na kilka negatywnych aspektów polityki wobec UE. Oczywiście mają one charakter poboczny, a więc nie mogą znacząco wpływać na całościową ocenę, niemniej jednak warte są odnotowania. Otóż zwiększenie populacji migrantów może doprowadzić do wystąpienia problemów mieszkaniowych, a co za tym idzie wzrostu cen na rynkach. Rząd musi się liczyć również z dodatkowymi obciążeniami komunikacyjnymi, które w przypadku tak małego kraju staną się dość szybko zauważalne i trudne do przezwyciężenia. Nie bez znaczenia jest także poczucie wyobcowania spowodowane rosnąca liczbą obcokrajowców. Problem ten często podnoszony jest w debacie publicznej. Ważne jest jednak, że zjawisko starzenia się społeczeństwa, które staje się szczególnie dotkliwe dla państw zachodniej Europy, wymusza na Szwajcarii otwarcie rynku pracy dla obcokrajowców. Najprawdopodobniej polityka rządu będzie zmierzała do utrzymania możliwie najdalej posuniętej kontroli tego procesu, tak aby był to przede wszystkim wzrost jakościowy, a nie ilościowy. Kwestią dyskusyjną jest jednak, na ile proces ten jest sterowalny.

Dopełniając obrazu całości należy też wspomnieć o otwarciu rynków UE dla obywateli Szwajcarii, którzy po zakończeniu znacznie krótszych okresów przejściowych mają możliwość osiedlania się i podejmowania pracy za granicą.

${ }^{22}$ R. Weder, Hohe Integration ohne Beitritt, [w:] G. Kreis (red.), Schweiz - Europa: wie weiter? Kontrollierte Personenfreizügigkeit, Verlag Neue Zürcher Zeitung, Zürich 2009, s. 128. 
Z punktu widzenia gospodarki szwajcarskiej bądź jej rynku pracy jest to zjawisko również korzystne, choć oczywiście poziom emigracji zarobkowej jest nieporównywalnie mniejszy w stosunku do imigracji.

Gospodarka szwajcarska wyraźnie skorzystała z zawartych porozumień. Od momentu wejścia $\mathrm{w}$ życie pierwszego pakietu wymiana handlowa $\mathrm{z}$ państwami UE sukcesywnie wzrasta. Zniesienie barier pozataryfowych spowodowało, że obecne uwarunkowania eksportowe mogą być porównywalne z tymi, jakie obowiązywałyby w przypadku włączenia Szwajcarii do EOG. Ograniczenie kosztów związanych z certyfikacją produktów podniosło atrakcyjność szwajcarskich towarów na europejskich rynkach ${ }^{23}$. Od tego momentu eksport wyraźnie wzrósł, osiągając w roku 2006 wartość 47 mld franków. Analizy wykazały, że największy wzrost odnotowano w produktach, które objęte zostały dwustronną umową w sprawie wzajemnego uznania ocen zgodności, a więc kryteriów dopuszczających dany towar do obrotu handlowego ${ }^{24}$. Była o tym mowa dokładniej w rozdziale trzecim. Najwięcej korzyści czerpią zatem branże wysoko wyspecjalizowane, jak farmaceutyka, teleinformatyka czy produkcja aparatów medycznych. Jeżeli wziąć pod uwagę specyfikę gospodarki szwajcarskiej, widać wyraźnie, że przedmiotowa umowa należy zdecydowanie do najistotniejszych. Uproszczenie procedur certyfikujących przyczyniło się także do wzrostu importu z państw UE. Podkreśla się jednakże, iż proces ten skutkować będzie przede wszystkim zwiększeniem konkurencyjności zagranicznych produktów na szwajcarskim rynku, a co za tym idzie również obniżeniem cen. Warto też dodać, że umowa oznacza dodatkowe dochody dla szwajcarskich instytucji certyfikujących, nie tylko ze względu na rodzimych producentów, lecz także tych z państw Unii Europejskiej lub krajów trzecich.

Wyraźny wzrost eksportu odnotowuje się również w branży spożywczej, szczególnie produktów rolnych, które objęte zostały umową dwustronną z roku 1999. Od momentu jej wejścia w życie wartość eksportu uległa podwojeniu, z 2,3 do 4,6 mld franków w roku $2007^{25}$. W tym samym czasie import wzrósł o $40 \%$, czego efektem było m.in. obniżenie cen na rynku szwajcarskim. Liberalizacja handlu w tym sektorze jest procesem długotrwałym i trudnym pod względem ekonomicznym oraz społecznym. Niezwykle korzystnym posunięciem było wynegocjowanie zniesienia barier celnych w handlu serami. Jedynie przez dwa pierwsze lata zanotowano lekki spadek eksportu w tej grupie produktów. Część ekonomistów podkreśla jednak, iż miało to związek z ówczesną sytuacją na rynku

\footnotetext{
${ }^{23}$ Ocenia się, że koszty certyfikacji wynoszą średnio od 0,5 do $1 \%$ wartości każdego produktu. Oznacza to, że rocznie gospodarka szwajcarska może zaoszczędzić z tego tytułu od 250 do $500 \mathrm{mln}$ franków.

${ }^{24}$ Dane według Das Abkommen über die gegenseitige Anerkennung von Konformitätsbewertungen, „Die Volkswirtschaft. Das Magazin für Wirtschaftspolitik”, 01.11.2008, s. 35.

${ }^{25}$ Bilaterale Öffnung der Landwirtschaft gegenüber der EU erfolgreich, „Die Volkswirtschaft. Das Magazin für Wirtschaftspolitik”, 01.11.2008, s. 21.
} 
krajowym i wprowadzaną akurat reformą rolną ${ }^{26}$. Po tym okresie wartość eksportu rosła średnio o 7\% rocznie. W roku 2007 osiągnęła ona $440 \mathrm{mln}$ franków ${ }^{27}$.

Podobne trendy wzrostowe odnotowuje się $\mathrm{w}$ grupie przetworzonych produktów rolnych. Liberalizacja handlu poprzez częściowe lub całkowite zniesienie ceł oraz subwencji proeksportowych pozwoliła na zwiększenie obrotów handlowych. Te z kolei przyczyniły się do obniżenia cen produktów spożywczych na rynku szwajcarskim. Wypada przy tym podkreślić, że te należą do najwyższych w Europie. Rząd Szwajcarii zdaje sobie sprawę z niskiej konkurencyjności szwajcarskiego rolnictwa. Wdrażana stopniowo reforma ma na celu ograniczenie liczby małych powierzchniowo gospodarstw rolnych, które nie są w stanie konkurować z zagranicznymi producentami. Dopóki ten proces nie zostanie zakończony, władze najpewniej nie zdecydują się na całkowitą liberalizację handlu w omawianym sektorze. Niemniej jednak rozmowy w tej sprawie są już prowadzone ${ }^{28}$, zwłaszcza że dodatkową presję wywiera na Szwajcarię Światowa Organizacja Handlu.

Obiecujące dane z roku 2003, dotyczące efektów umowy w sprawie transportu lądowego, pozostały pozytywne również w dalszym okresie. Analizując podstawowe informacje statystyczne widać wyraźnie, że rządowi udało się osiągnąć podstawowy cel, jaki stawiał sobie jeszcze przy stole negocjacyjnym z UE, a więc odciążenie dróg tranzytowych przez Alpy. Warto zresztą przypomnieć, iż postulat ten był elementem realizacji zapisów konstytucyjnych, nakładających na rząd obowiązek podejmowania działań na rzecz zmniejszenia ruchu kołowego na terenach szczególnie cennych pod względem przyrodniczym. Wprowadzenie dodatkowych opłat tranzytowych, przy jednoczesnym podwyższeniu dopuszczalnego obciążenia pojazdów sprawiło, że ruch samochodów ciężarowych zmniejszył się w roku 2007 o $10 \%$, w porównaniu z tym samym okresem sprzed siedmiu lat. Co ciekawe, w tym samym czasie łączna masa przewożonych towarów wzrosła z 29,6 do 39,5 mln ton ${ }^{29}$. Jednocześnie odnotowano wzrost transportu kolejowego o $23 \%$. Pomimo wielu obaw i czarnych scenariuszy, zakładających ogromne zanieczyszczenie środowiska, efekty zawartej umowy są wprost odwrotne. Ocenia się, iż bez wprowadzenia nowych regulacji w samym tylko roku 2006 na drogach znalazłoby się o ok. 400000 pojazdów ciężarowych więcej ${ }^{30}$. Wpływy z opłat tranzytowych zasiliły budżety kantonów i federacji w kwocie ponad 4 mld franków, licząc pierwsze sześć lat od momentu ich wprowadzenia ${ }^{31}$. Umożliwiło to re-

${ }^{26}$ Ibidem.

${ }^{27}$ Bilaterale Abkommen mit der EU: eine Schweizer Erfolgsgeschichte, Dossierpolitik Economiesuisse, 29. September 2008, Nr. 20, s. 3.

${ }^{28} \mathrm{~W}$ marcu roku 2008 rząd podjął decyzję o rozpoczęciu negocjacji z UE.

${ }^{29}$ Volkswirtschaftliche und soziale Auswirkungen des Landverkehrsabkommens, „Die Volkswirtschaft. Das Magazin für Wirtschaftspolitik”, 01.11.2008, s. 30.

${ }^{30}$ M. Ambühl, Zwischenbilanz Bilaterale I Schweiz - EU. Sprechnotiz, EDA, 3. November 2008, s. 2.

${ }^{31}$ Bilaterale Abkommen mit der EU: eine Schweizer Erfolgsgeschichte..., s. 4. Zob. także Informationsblatt Landverkehr, Integrationsbüro EDA/EVD, 2008. 
alizację wielu inwestycji infrastrukturalnych, w tym ogromnego projektu budowy nowych dróg tranzytowych przez terytorium Szwajcarii. Istotny jest również fakt, że nowe opłaty, których wysokość uzależniona jest od poziomu emisyjności spalin, przyczyniły się do znacznego unowocześnienia floty pojazdów ciężarowych, jeżdżących po tamtejszych drogach. Umowa otworzyła zarazem drzwi na rynki europejskie, umożliwiając szwajcarskim przewoźnikom swobodne konkurowanie z podmiotami z Unii Europejskiej.

Zawarcie umowy w sprawie ruchu lotniczego zapewniło szwajcarskim przewoźnikom swobodny dostęp do europejskiego rynku. Było to szczególnie istotne po wyraźnym spowolnieniu dynamiki rozwoju tej branży w latach 2001-2002. Obecnie ok. $80 \%$ ruchu powietrznego odbywa się pomiędzy tym krajem a państwami UE ${ }^{32}$. Szwajcarscy przewoźnicy mogą konkurować z innymi firmami z państw UE na równych zasadach. Co więcej, dzięki przeniesieniu części kompetencji na ponadnarodowy organ, jakim jest Europejski Trybunał Sprawiedliwości, także ewentualne spory są rozstrzygane w sposób niezależny. Jak dotąd Szwajcaria raz skorzystała z tej możliwości. Chodziło o spór dotyczący ograniczenia lotów nad południową częścią Niemiec ${ }^{33}$. Szwajcaria odwoływała się w tej sprawie od decyzji Komisji Europejskiej, która podtrzymała rozporządzenie Niemiec. Szwajcarski wniosek, który trafił w roku 2003 do ETS, został oddalony ${ }^{34}$. Dzięki umowie Szwajcaria została włączona do systemu zarządzania przestrzenią powietrzną - Single European Sky (Jednolita Europejska Przestrzeń Powietrzna). Projekt ma za zadanie zwiększenie płynności i bezpieczeństwa transportu lotniczego. Z punktu widzenia Szwajcarii istotne jest również, że wprowadzenie systemu zarządzania przyczyni się do ograniczenia negatywnego wpływu ruchu powietrznego na środowisko naturalne ${ }^{35}$. Integracja branży lotniczej oznacza dla pasażerów większy wybór pomiędzy przewoźnikami, uelastycznienie taryf, a więc również obniżenie kosztów podróży. Włączenie Szwajcarii do EASA (Europejska Agencja Bezpieczeństwa Transportu Lotniczego) wpływa na poprawę bezpieczeństwa i eliminuje podwójne kontrole na lotniskach.

Pozytywne zmiany zauważyć można również w zakresie poprawy bezpieczeństwa w ruchu granicznym oraz polityki azylowej, dzięki włączeniu Szwajcarii do układu z Schengen i Dublina. Z uwagi na fakt, że wejście w życie powyższych umów wymagało podjęcia szeregu procedur dostosowawczych po stronie Szwaj-

${ }^{32}$ Wirkungsanalyse des bilateralen Abkommens über den Luftverkehr, „Die Volkswirtschaft. Das Magazin für Wirtschaftspolitik", 01.11.2008, s. 31.

${ }^{33}$ Mieszkańcy niemieckich gmin przygranicznych protestowali przeciwko zwiększeniu hałasu spowodowanego ustaleniem ścieżki podejścia do lotniska w Zurychu od strony północnej, czyli m.in nad terenem Niemiec.

${ }^{34}$ Zob. więcej Schweiz und Deutschland streiten vor EU-Gericht um Fluglärm, „Tagesanzeiger”, 9. September 2010; Süddeutschland fordert weitere Begrenzung der Nordanflüge, „Tagesanzeiger”, 9. September 2010; Noch ein Irrtum wäre einer zu viel, „Tagesanzeiger”, 10. September 2010.

${ }^{35}$ Według danych Komisji Europejskiej wprowadzenie systemu ograniczy zanieczyszczenie o $10 \%$ do roku 2020. 
carii, doświadczenia wynikające chociażby z dostępu do bazy SIS są relatywnie niewielkie, choć niezwykle obiecujące. $Z$ komunikatów rządowych wynika, że liczba tzw. trafień znacznie przekroczyła oczekiwania. Świadczy to oczywiście o dużej skuteczności systemu informacyjnego, ale też o skali problemu, z jakim Szwajcaria była i jest konfrontowana. W ciągu jedynie pierwszych stu dni operacyjnego funkcjonowania bazy SIS wykryto ponad dwa tysiące wykroczeńn ${ }^{36}$. Również w zakresie polityki azylowej rząd może pochwalić się sporymi osiągnięciami. Od momentu wejścia w życie umowy, tj. grudnia 2008 r., do końca marca roku 2009 oddalono 997 wniosków, uznając, iż winny być one rozpatrywane w innym państwie ${ }^{37}$. Bardzo często osoby ubiegające się o azyl składają wnioski w kilku państwach, aby zwiększyć szanse przyznania statusu uchodźca. Według wstępnych założeń ocenia się, że włączenie Szwajcarii do konwencji z Dublina przyczyni się do ograniczenia liczby rozpatrywanych wniosków minimum o ok. $20 \%{ }^{38}$.

Granicę Szwajcarii przekracza dziennie ok. 700000 osób i ok. 320000 pojazdów. Będąc w strefie Schengen staje się ona ważnym elementem całego systemu budowy bezpieczeństwa europejskiego. Przestępczość nie zna granic, a więc współpraca policji i wymiaru sprawiedliwości jest niezwykle istotna. Bardzo często podkreśla się również, że zniesienie kontroli granicznych oraz wprowadzenie jednej wizy dla całego obszaru Schengen, poza wymiarem bezpieczeństwa wpływa na rozwój turystyki. Sektor ten jest zaś jednym z najważniejszych motorów napędowych całej gospodarki. Korzyści dla Szwajcarii, wynikające z włączenia do strefy Schengen, wydają się więc podwójne.

Warto również wspomnieć o umowie w sprawie udziału Szwajcarii w 6. oraz 7. Programie Ramowym UE. Dzięki niej szwajcarskie ośrodki naukowo-badawcze mają możliwość uzyskania niezwykle cennego wsparcia finansowego na realizację własnych projektów. Należy zauważyć, że Szwajcaria, w ramach programu, otrzymuje więcej pieniędzy niż wpłaca do unijnej kasy. Jest to oczywiście zasługa przede wszystkim prężnych ośrodków, które zabiegają aktywnie o dotację z UE. W przypadku 6. Programu Ramowego wkład szwajcarski opiewał na kwotę $780 \mathrm{mln}$ franków, natomiast nieco więcej, bo $793 \mathrm{mln}$, wróciło do Szwajcarii $\mathrm{w}$ formie dotacji ${ }^{39}$. Jest to bardzo dobry wynik. Największa część tych środków trafia do uczelni wyższych, głównie politechnik. Ważne jednak, iż program UE jest podstawowym narzędziem realizacji strategii lizbońskiej, a więc budowy społeczeństwa opartego na wiedzy. Wiele projektów realizuje się we współpracy pomiędzy ośrodkami naukowymi a biznesem, dlatego część środków trafia także do sektora małych i średnich przedsiębiorstw. W minionym okresie programowania ok. $14 \%$ całkowitej puli środków przeznaczonych zostało na wsparcie takich

${ }^{36}$ Grüezi in ,,Schengen-Land”, Medienmitteilung EFD, 27.03.2009.

${ }^{37}$ Dublin-Abkommen: Positive Bilanz für die Schweiz, Medienmitteilung BFM, 07.04.2009.

${ }^{38}$ Europabrevier Schweiz - EU..., s. 32. Dokument dostępny na stronie www.europabrevier.ch.

${ }^{39}$ Das bilaterale Forschungsabkommen: Vollbeteiligung der Schweiz am europäischen Forschungsraum, „Die Volkswirtschaft. Das Magazin für Wirtschaftspolitik”, 01.11.2008, s. 26. 
projektów ${ }^{40}$. Według analizy przedstawionej przez Sekretariat ds. Edukacji i Badań Naukowych przekłada się to na konkretne miejsca pracy oraz innowacyjne produkty i usługi. Biorąc pod uwagę obszary badań, które najczęściej otrzymują dofinansowanie, na pierwszym miejscu znajdują się technologie informatyczne, a na następnych bioinżynieria i medycyna.

W połowie roku 2010 rząd opublikował pierwsze dane dotyczące udziału w 7. Programie Ramowym ${ }^{41}$. Wynika z nich, że poziom zwrotu nakładów finansowych jest jeszcze większy niż w poprzednim okresie programowania. Do tej pory udało się pozyskać 561,8 miliona franków, co stanowi jak na razie ok. 4\% wszystkich przyznanych dotacji ${ }^{42}$. Jeżeli porównamy to ze szwajcarskim wkładem finansowym, wynoszącym $2,5 \%$ całego budżetu programu, wynik ten okazuje się imponujący.

Udział Szwajcarii w Programie Ramowym UE jest tym ważniejszy, że nie tylko umożliwia realizację wielu ważnych projektów badawczych, nierzadko dających impuls do rozwoju gospodarki, ale również stwarza szansę na nawiązanie międzynarodowej sieci współpracy pomiędzy ośrodkami naukowymi w Europie $^{43}$. Partnerami $\mathrm{w}$ projektach są najczęściej podmioty $\mathrm{z}$ państw ościennych Szwajcarii, a także z Wielkiej Brytanii. Ponadto Szwajcaria bierze udział w wielu gremiach, pełniących istotne funkcje doradcze wobec Komisji Europejskiej. Daje to możliwości pośredniego, bo bez prawa głosu, wpływania lub bardziej lobbowania w sprawie kierunków rozwoju i współkształtowania kolejnych programów badawczych. Chodzi tu głównie o coroczne ustalanie harmonogramu konkursów, ich budżetu, najważniejszych wytycznych itp. Szwajcaria ma także zagwarantowany swobodny dostęp do wyników badań innych projektów, realizowanych $\mathrm{z}$ przedmiotowego programu.

Widać wyraźnie, że umowy bilateralne pozytywnie wpływają na rozwój gospodarki szwajcarskiej. Wszędzie tam, gdzie wzajemna współpraca uregulowana jest dwustronnymi porozumieniami, notuje się pozytywne trendy, począwszy od sytuacji na rynku pracy, po rozwój badawczo-naukowy. Jeżeli przyjąć, że polityka rządu jest wynikiem realizacji dwóch podstawowych zadań - przeciwdziałania izolacji państwa oraz zabezpieczenia interesów gospodarczych, to można wysunąć wniosek, iż przynajmniej ten drugi cel udało się osiągnąć. Oczywiście część aspektów współpracy, jak chociażby sprawę opodatkowania odsetek, można uznać za niezbyt korzystne. Niewątpliwie ten element obniżył atrakcyjność Szwajcarii jako miejsca lokowania kapitału. Należy jednak zaznaczyć, że z dru-

${ }^{40}$ Ibidem, s. 25.

${ }^{41}$ Beteiligung der Schweiz am 7. Europäischen Forschungsrahmenprogramm, Zwischenbilanz 2007-2009, Staatssekretariat für Bildung und Forschung, Bern 2010.

42 Starke Schweizer Position im 7. Forschungsrahmenprogramm der EU, Medienmitteilung SBF, 24.06.2010.

${ }^{43}$ Według danych opublikowanych przez Sekretariat ds. Edukacji i Badań Naukowych, aż 71\% beneficjentów 5. i 6. Programu Ramowego uważało, iż ich projekt nie zostałby zrealizowany bez wsparcia ze strony UE. 
giej strony przyczynił się do poprawy jej wizerunku, a także oddalenia części zarzutów dotyczących rzekomego sprzyjania finansowym nadużyciom. Umowa ta, jak również decyzja o współfinansowaniu unijnej polityki spójności, jest ceną, jaką musiała zapłacić Szwajcaria za korzystne dla niej rozwiązania w innych obszarach.

Kwestia roli tego państwa w integrującej się Europie pozostaje sprawą dyskusyjną. Z jednej strony Szwajcaria nie jest już samotną wyspą, albowiem stopień integracji, zwłaszcza jak na kraj niebędący członkiem UE, jest bardzo wysoki. $\mathrm{Z}$ drugiej, faktyczny brak możliwości współdecydowania w wielu istotnych aspektach współpracy siłą rzeczy przesuwa Szwajcarię do rangi partnera drugiej kategorii. Biorąc pod uwagę wyłącznie gospodarczy wymiar takiej integracji, należy przyjąć, że polityka bilateralna jest rozwiązaniem korzystnym. Poza relatywnie niewielkimi wydatkami związanymi z partycypacją w polityce spójności UE, budżet państwa nie jest obciążony żadnymi znaczącymi kosztami. Przeciwnie, rozwój gospodarczy, wzrost obrotów handlowych, polepszenie sytuacji na rynku pracy sprawiają, że budżet państwa jest $\mathrm{w}$ dobrej, a nawet bardzo dobrej kondycji, biorąc pod uwagę gospodarki Unii Europejskiej. Nawet wspomniane już wprowadzenie podatku dochodowego od lokat bankowych przynosi budżetowi państwa dodatkowe dochody, które choć po części kompensują ewentualne straty wynikające z obniżenia atrakcyjności finansowej.

Nie do przecenienia jest również zjawisko internacjonalizacji gospodarczej, zwłaszcza dla tak uzależnionej od współpracy międzynarodowej gospodarki, jak szwajcarska. Z opracowanych przez Rolfa Wedera danych wynika, że współczynnik internacjonalizacji, mierzony stosunkiem zagranicznych obrotów handlowych do PKB, jest w przypadku Szwajcarii dość wysoki ${ }^{44}$. Wynosi on $79 \%$ przy średniej unijnej sięgającej 59\%. Przy porównywaniu tych danych trzeba mieć na uwadze fakt, iż współczynnik ten w dużym stopniu zależy od wielkości rynku wewnętrznego. Im jest on większy, tym mniejszy będzie stopień umiędzynarodowienia. Można więc przyjąć, iż internacjonalizacja gospodarki Szwajcarii jest niejako naturalnym zjawiskiem. Weder podaje jednak inne jeszcze interesujące wskaźniki. Okazuje się, że również pod względem wymiany czynników produkcji, jak kapitał czy praca, Szwajcaria znajduje się w czołówce na tle innych państw europejskich, prześcigając m.in. Szwecję oraz Austrię. Rynek pracy wykazuje szczególnie duży stopień umiędzynarodowienia. Jedynie Luksemburg może poszczycić się tu wyższym współczynnikiem, ale wynika on z wyjątkowej specyfiki tego niewielkiego państwa.

Dane, jakie przytacza Weder, pochodzą z roku 2007. Można zatem uznać, że przynajmniej po części są one efektem prowadzonej przez rząd polityki otwarcia na międzynarodową współpracę gospodarczą, w tym również z Unią Europejską. Umowy bilateralne bez wątpienia okazały się dla szwajcarskiej gospodarki dużo korzystniejsze niż pozostawanie przy poprzednim poziomie współpracy z UE. Specyfika tych porozumień umożliwia Szwajcarii utrzymywanie korzystnych relacji gospodarczych z państwami trzecimi, co nie byłoby realne w takim samym

${ }^{44}$ R. Weder, op. cit., s. 109. 
wymiarze w przypadku przystąpienia do Wspólnoty. Wymaga ona bowiem od wszystkich członków koordynacji polityki celnej wobec zewnętrznych partnerów. Jest to tym bardziej cenne w dobie kryzysu, kiedy dywersyfikacja powiązań gospodarczych staje się jednym z bardziej skutecznych sposobów na walkę z recesją. Obecnie państwa azjatyckie pozostają wyjątkowo atrakcyjnymi partnerami dla Szwajcarii. Przystąpienie do Unii Europejskiej mogłoby ograniczyć swobodę w zakresie kreowania własnej polityki gospodarczej wobec tych państw.

Podejmując próbę wskazania negatywnych aspektów powiązań bilateralnych, należy z kolei zwrócić uwagę na kwestie związane z dynamiką ich rozwoju. Warunki, w jakich podpisywano porozumienia w roku 1999, uległy wyraźnym zmianom na przestrzeni dziesięciu następnych lat. Przede wszystkim znacznemu poszerzeniu uległa Unia Europejska. Oczywiście z jednej strony była to bardzo korzystna zmiana, ponieważ umożliwiła Szwajcarii dostęp do dynamiczniej rozwijających się rynków niż w państwach starej piętnastki. Nowe kraje UE cechuje duży potencjał rozwojowy, chłonne rynki oraz zapotrzebowanie na know how i wysoko wyspecjalizowane produkty, czyli dokładnie to, co ma do zaoferowania Szwajcaria. Konstrukcja Szwajcarskiego Programu Wspótpracy, skierowanego do nowych członków Unii Europejskiej, dodatkowo ułatwia nawiązywanie cennych kontaktów handlowych. Poza tym, dzięki zawartej umowie bilateralnej szwajcarskie firmy mogą bez żadnych przeszkód startować w przetargach publicznych na terenie Wspólnoty. Tych, ze względu na szeroki strumień funduszy UE skierowanych do jej nowych członków, w ostatnim czasie nie brakuje. Zaledwie w ciągu trzech pierwszych lat zakontraktowano 756 mln franków, co stanowi ok. 80\% całkowitego budżetu Szwajcarskiego Programu Wspótpracy ${ }^{45}$. Z drugiej strony zwiększenie liczby członków UE utrudnia negocjacje i osiąganie kompromisu na wielu płaszczyznach współpracy, w tym m.in. w komisjach mieszanych, które zajmują się przecież bieżącą koordynacją umów dwustronnych. Tym samym perspektywa zawarcia kolejnych porozumień staje się coraz bardziej mglista. Można zatem przyjąć, iż biorąc pod uwagę jedynie wymiar gospodarczy, rozszerzenie Unii przyczyniło się do wzmocnienia znaczenia umów bilateralnych. Stworzone zostały ramy prawne dla wspólpracy z tą częścią Europy, która do tej pory, z uwagi na uwarunkowania polityczne, była najsłabiej rozwinięta. Rozszerzenie Wspólnoty może jednak zmusić obie strony do przeprowadzenia istotnych zmian we wzajemnych relacjach. Dotychczasowa współpraca może okazać się bardziej skomplikowana i nieefektywna, a więc konieczne będzie poszukiwanie nowych rozwiązań.

\subsubsection{POLITYCZNY WYMIAR WSPÓEPRACY}

Współpraca bilateralna, jako taka, nie pociąga za sobą bezpośrednich konsekwencji politycznych. Był to zresztą warunek sine qua non wyboru takiej polityki

${ }^{45}$ Der Schweizer Beitrag an die erweiterte Europäische Union: eine Zwischenbilanz, Medienmitteilung EDA/EVD [Bern], 19. November 2010. 
wobec UE. Uznano, że po odrzuceniu wniosku w sprawie EOG jedyną możliwą drogą będzie próba intensyfikacji powiązań gospodarczych, przy jednoczesnym utrzymywaniu możliwie luźnych relacji na płaszczyźnie politycznej. Związane to było zresztą z doktryną neutralności i suwerennością państwa, traktowaną jako wartość nadrzędna. Uważano zatem, że rozwój współpracy gospodarczej musi być kontynuowany w oderwaniu od sfery politycznej. Jednakże w dobie coraz wyraźniej rysujących się zjawisk globalizacyjnych oba te elementy stają się nierozłączne. Gospodarka i polityka wzajemnie się przenikają i uzupełniają. Próba prowadzenia odpolitycznionych relacji gospodarczych musi zakończyć się zatem niepowodzeniem.

Politykę Szwajcarii wobec Unii Europejskiej, przynajmniej z założenia, można nazwać polityką gospodarczą, bo taki jest charakter umów bilateralnych, szczególnie tych, które wchodzą w skład pierwszego pakietu. Nacechowana jest ona jednak przy tym dość poważnymi konsekwencjami politycznymi, choć przyznać należy, iż mają one charakter raczej pośredni. Warto przytoczyć tutaj kilka argumentów.

Otóż nie ulega wątpliwości, że nowa polityka władz Szwajcarii wobec Wspólnoty wywołała ogromną dyskusję nad rolą państwa na arenie międzynarodowej, nad współczesnym obliczem neutralności, przyszłością demokracji bezpośredniej oraz federalizmu, z perspektywy pogłębiającej się integracji lub nawet ewentualnego członkostwa w UE. W literaturze odnaleźć można liczne opracowania na ten temat ${ }^{46}$. Część politologów podkreśla, że na tym tle doszło do kryzysu władzy wykonawczej. Rada Związkowa w dotychczasowym kształcie nie jest w stanie sprostać nowym wyzwaniom politycznym, związanym z procesami integracyjnymi. Oczywiście to nie polityka europejska jest bezpośrednią przyczyną tych problemów. Pojawiały się one w debacie publicznej już znacznie wcześniej. Można jednak zaryzykować stwierdzenie, że współpraca bilateralna znacznie je uwydatniła. Mamy tutaj zatem do czynienia nie tylko z problematyką internacjonalizacji szwajcarskiej polityki, lecz również z towarzyszącymi jej konsekwencjami o charakterze wewnątrzpolitycznym. $Z$ wielu względów te ostatnie wydają się nawet dominować w debacie publicznej.

Część polityków, jak chociażby Christoph Blocher (SVP), jest zdania, że przyszłość stosunków pomiędzy Szwajcarią a Unią Europejską musi być ograniczona do powiązań na poziomie bilateralnym. Tę formę uważają za jedyną, która może zagwarantować zachowanie pełnej suwerenności i neutralności państwa. Często stosuje się nawet określenie „,pragmatyczny bilateralizm”47. Biorąc

${ }^{46}$ Patrz rozdział pierwszy, a także opracowania: J. Blatter, Horizontalföderalismus und Schweizer Demokratie, „Swiss Political Science Review”2010, vol. 16 (2), s. 247-277; J. Papadopolous, Europeanisation? Two Logics of Change of Policy-making Patterns in Switzerland, „Journal of Comparative Policy Analysis" 2008, vol. 10 (3), s. 255-278.

${ }^{47}$ B. Steppacher, Naher fremder Nachbar Schweiz: Szenarien der Schweizpolitik der Europäischen Union, [w:] F. Breuss, T. Cottier, P.C. Müller-Graf, Die Schweiz im Europäischen Integrationsprozess, Baden-Baden 2008, s. 144. 
jednakże pod uwagę obecną pozycję Szwajcarii, która pozbawiona jest przecież prawa głosu w najważniejszych gremiach UE, jej rola ogranicza się jedynie do biernej realizacji postanowień zapadających w Brukseli. Wystarczy wspomnieć tutaj o kwestii rozszerzenia Wspólnoty, która niejako wymusiła na Szwajcarii objęcie zasadą swobody przepływu osób także nowych państw członkowskich. W tej sprawie rząd Szwajcarii praktycznie nie miał nic do powiedzenia. Oczywiście teoretycznie suweren mógł odrzucić taki wniosek w referendum, cena jaką jednak należałoby za to zapłacić była zbyt wysoka. Również bieżąca realizacja umów dwustronnych, wymuszająca na Szwajcarii przyjmowanie unijnego prawa, jest kolejnym przykładem dowodzącym asymetryczności w relacjach dwustronnych $^{48}$. Także i w tym przypadku, przynajmniej teoretycznie, rząd Szwajcarii dysponuje autonomią w zakresie stanowienia prawa. Odmowa przyjęcia nowych regulacji prawnych uniemożliwia jednak w praktyce właściwe wykonywanie postanowień zawartych umów. Dążąc zatem do zachowania pełnej suwerenności państwa, której gwarantem mają być umowy bilateralne, politycy, w tym również rząd, przyzwalają de facto na jej znaczne ograniczenie. Niektórzy badacze określają wręcz taką formę relacji mianem neokolonializmu ${ }^{49}$.

Ocena znaczenia politycznego powiązań bilateralnych uzależniona jest w dużej mierze od charakteru integracji. Polityka Wspólnoty może mieć bowiem charakter wertykalny - opierający się na asymetrycznych relacjach w stosunkach wewnętrznych, gdzie silniejsze państwa narzucają słabszym swoją wolę, a także horyzontalny, polegający na wypracowaniu wspólnych strategii na zasadzie konsensusu oraz koordynacji różnych obszarów funkcjonowania państwa ${ }^{50}$. Jeżeli przyjąć ten drugi wariant, to wówczas pozycja Szwajcarii byłaby relatywnie wysoka. Sandra Lavenex zauważa, że od pewnego czasu mamy do czynienia ze zjawiskiem decentralizacji władzy w UE, polegającym na powoływaniu różnych gremiów - komitetów lub komisji, które pełnią funkcje doradcze w stosunku do Komisji Europejskiej ${ }^{51}$. Ta nadal dysponuje kompetencjami decyzyjnymi, jednak konsensus osiągnięty w ramach wspomnianych gremiów ma decydujące znaczenie. W tej sytuacji Szwajcaria, choć pozbawiona możliwości formalnego współdecydowania, jest w stanie, poprzez swoich ekspertów, wpływać pośrednio na kształt podejmowanych decyzji. Mają oni bowiem prawo do przedstawiania opinii w imieniu rządu. Pozycja Szwajcarii będzie zatem tym silniejsza, im większe będą możliwości przekazywania własnego stanowiska za pośrednictwem swoich przedstawicieli. Zdaniem Lavenex wariant taki jest możliwy, jednak zależy on

${ }^{48}$ Por. J. Gabriel, S. Hedinger, Aussen- und Sicherheitspolitik, [w:] U. Klöti (red.), Handbuch der Schweizer Politik, NZZ Verlag, Zürich 2002, s. 707.

${ }^{49}$ Por. A. Tovias, Exploring the „Pros” and „Cons" of Swiss and Norwegian Models of Relations with the European Union: What Can Israel Learn from the Experiences of These Two Countries?, „Cooperation and Conflict” 2006, No 41, s. 203-222.

${ }^{50} \mathrm{~S}$. Lavenex, Switzerland's Flexible Integration in the EU: A Conceptual Framework, „Swiss Political Science Review" 2009, No 15 (4), s. 9.

${ }^{51}$ Ibidem, s. 7. 
w głównej mierze od stopnia upolitycznienia powoływanych gremiów, a także od przedmiotu danej debaty. Nie należy mieć bowiem złudzeń co do tego, że stanowisko Szwajcarii będzie zawsze brane pod uwagę. Może zdarzyć się tak raczej w przypadku tych spraw, w których dysponuje ona istotną kartą przetargową, tj. wsparciem finansowym.

Jak dowodzi zatem Lavenex, polityka bilateralna zostawia Szwajcarii pewną furtkę w zakresie oddziaływania na proces decyzyjny w ramach Wspólnoty. Ma to jednak charakter bardzo ograniczony. Wydaje się mimo wszystko, iż droga bilateralna była najbardziej optymalnym wyjściem, biorąc pod uwagę nastroje opinii publicznej po referendum z roku 1992, tym bardziej że decyzja ta wpłynęła pozytywnie na sposób postrzegania Szwajcarii w Europie i na świecie. Spośród dwóch najbardziej realnych możliwości, jakimi dysponował wówczas rząd - umowy bilateralne lub izolacjonizm, ten ostatni wariant byłby zapewne zdecydowanie najmniej korzystny. Szwajcaria pokazała więc, że jest wiarygodnym i otwartym na współpracę partnerem, nawet jeżeli uwarunkowania wewnętrzne nie są ku temu szczególnie sprzyjające.

Droga bilateralna wpłynęła również na zmianę nastawienia opinii publicznej wobec problemu integracji europejskiej. Na początku lat 90 . XX w. przeważały opinie negatywne. Obywatele nie tylko nie widzieli potrzeby otwarcia nowego etapu w relacjach z UE, lecz wprost budziła ona w nich spore obawy. Jak zwykle były one związane z utratą suwerenności oraz poważnym naruszeniem doktryny neutralności. Do tego dochodziło poczucie wyjątkowości własnego państwa, określanego mianem „Sonderfall Schweiz”. Zdaniem J.M. Gabriela pojęcie to ma dwa znaczenia - introwertyczne oraz ekstrawertyczne ${ }^{52}$. Pierwsze oznacza dążenie do alienacji, dystansowania się od polityki międzynarodowej, również zachowanie neutralności. Natomiast drugie to chęć promowania czy też ciągłego podkreślania szczególnej roli, jaką odgrywa Szwajcaria w kontekście tzw. dobrych usług. Ponadto Szwajcarzy czują się dumni z własnej państwowości, wypracowanej w drodze społecznego kompromisu - było to rzeczywiście niezwykle trudne, biorąc pod uwagę zróżnicowanie kulturowe, językowe i gospodarcze poszczególnych kantonów. Jednym ze źródeł sukcesu było podejmowanie wszystkich decyzji zgodnie z zasadą kolegialności. Stąd też duża niechęć do centralizacji władzy. Można zatem przyjąć, iż jednym z powodów, dla których Szwajcarzy niezbyt entuzjastycznie traktuja zjawisko integracji europejskiej jest fakt, że obecna forma funkcjonowania Unii Europejskiej zakłada transponowanie wielu kompetencji na rzecz centralnego ośrodka w Brukseli.

Droga bilateralna nie wywoływała takich emocji. Była akceptowana przez ponad połowę obywateli. Wynikało to przede wszystkim z braku poważniejszych zobowiązań o charakterze politycznym, choć przyznać należało, że wobec przedłużających się rozmów z UE nastawienie obywateli stawało się coraz bardziej

${ }^{52}$ J.M. Gabriel, Switzerland and the European Union, Center for International Studies, Beiträge Nr. 33, Dezember 2000, s. 9. 
sceptyczne. Z sondażu przeprowadzonego przez instytut Gfs Bern wynika, że w kwietniu 2003 r. jedynie nieco ponad 30\% ankietowanych była za kontynuacją polityki bilateralnej ${ }^{53}$. Aż $27 \%$ było jej zdecydowanie przeciwnych. To duży spadek, jeżeli wziąć pod uwagę wyniki referendum z roku 2000, dotyczącego pierwszego pakietu porozumień. Wniosek poparło wówczas 57\% głosujących. Jeszcze większy sceptycyzm przejawiano wobec propozycji włączenia Szwajcarii do UE, o czym świadczy nieudana próba przeforsowania inicjatywy „Tak dla Europy". Sytuacji nie zmieniły również kolejne głosowania w sprawach europejskich. Kończyły się one wynikiem pozytywnym, ale nigdy nie wiązały się z szerszą percepcją problemu integracji z Unią Europejską. Odnosiły się wyłącznie do konkretnych zagadnień, które były akurat przedmiotem głosowania, tj. rozszerzenia swobody przepływu osób na nowe państwa członkowskie bądź wyrażenia zgody na współfinansowanie unijnej polityki spójności. Ogólne nastawienie społeczeństwa do problemu europejskiego pozostało nadal sceptyczne. Co ciekawe, tendencje te zauważyć można zarówno wśród starszego, jak i młodszego pokolenia, często niezależnie od pochodzenia czy poziomu wykształcenia.

Powstaje zatem pytanie, czy nowa polityka wobec Unii Europejskiej przyczyniła się do zmian światopoglądowych oraz dotyczących stosunku wobec własnej historii i świadomości kulturowej Szwajcarów? Niezwykle interesujący jest fakt, że Szwajcaria jako państwo leżące w samym sercu Europy zawsze pozostawała w opozycji wobec wszystkich dominujących tendencji politycznych lub ideologicznych. Herbert Lüthy określa nawet jej historię mianem antytezy ${ }^{54}$. Szwajcaria była zatem zawsze antymonarchistyczna, antyimperialistyczna, antyfaszystowska, antykomunistyczna, antytotalitarna itd. ${ }^{55}$ Patrząc wstecz należy uznać, że była to droga słuszna. Pozwalała ona na zachowanie jedności państwa i względnej niezależności, choć oczywiście niekiedy dochodziło do kryzysów wywoływanych różnymi uwarunkowaniami (wojny domowe, okres napoleoński, światowe konflikty). Neutralizm w stosunkach zewnętrznych został ugruntowany w efekcie doświadczeń wojen światowych i okresu zimnej wojny. W świadomości obywateli rosło przekonanie, iż izolacjonizm jest najlepszym gwarantem suwerenności państwa. W obliczu zjawisk integracyjnych w Europie okazało się jednak, że niezależność staje się coraz bardziej złudna. Polityka państwa jest coraz silniej uzależniona od czynników zewnętrznych, a postawa neutralna, paradoksalnie, ogranicza jego suwerenność. $Z$ czasem neutralność zaczęto traktować przedmiotowo, jako doraźny sposób na usprawiedliwienie tych czy innych zachowań na arenie międzynarodowej. Odnosi się to również do polityki wobec Unii Europejskiej. Względy światopoglądowe zeszły zatem na dalszy plan. Z drugiej strony, wart

${ }^{53}$ A. Hollmann, Die Schweizer und Europa, Nomos Verlagegesellschaft, Baden-Baden 2005, s. 42.

${ }^{54}$ H. Lüthy, Die Schweiz als Antithese, Verlag der Arche, Zürich 1969.

${ }^{55} \mathrm{~A}$. Riklin, Isolierte Schweiz. Eine europa- und innenpolitische Lagebeurteilung, „Swiss Political Science Review"1995, vol. 1 (2-3), s. 13. 
zastanowienia jest fakt, że tkwiąca w społeczeństwie niechęć do pełnej integracji z Unią Europejską nie może być uwarunkowana wyłącznie względami ekonomicznymi. Biorąc bowiem pod uwagę aspekty gospodarcze, korzyści wynikające z integracji europejskiej, o czym świadczą przytaczane wyżej dane oraz raporty niezależnych ośrodków opiniotwórczych, wydają się niepodważalne. Potwierdzają to również prognozy ekonomiczne. Naturalną konsekwencją współpracy bilateralnej powinno być zatem członkostwo w UE. Pomimo to poczucie odrębności nadal tkwi głęboko w świadomości społecznej.

Nastroje obywateli związane z problematyką europejską doskonale odzwierciedlają zmiany, jakie zaszły na scenie politycznej Szwajcarii w ciągu ostatnich dwudziestu lat. Przez ponad czterdzieści lat (1959-2003) podział miejsc w Radzie Związkowej przebiegał zgodnie z zasadą tzw. magicznej formuły, wedle której trzy najsilniejsze partie obsadzały po dwa miejsca w siedmioosobowym rządzie. Ludowcy (SVP) dysponowali zaś tylko jednym miejscem. Sytuacja uległa zmianie w momencie, gdy problematyka polityki europejskiej coraz częściej zaczęła pojawiać się w debacie publicznej. Ludowcy, którzy opowiadali się przeciwko integracji ze Wspólnotą, występowali w opozycji wobec politycznych aspiracji rządu i zjednywali sobie tym coraz liczniejszą rzeszę obywateli o konserwatywnych poglądach w zakresie polityki zagranicznej. Z czasem popularność SVP znacznie wzrosła, czego efektem były doskonałe wyniki w wyborach parlamentarnych. W roku 2003 nastąpił moment przełomowy dla tego ugrupowania. Dzięki uzyskaniu większości miejsc w parlamencie zdołało ono przejąć, kosztem CVP, dodatkowe miejsce w Radzie Związkowej.

Można zatem wysunąc tezę, iż jedną z konsekwencji nowej polityki wobec UE były zmiany na szwajcarskiej scenie politycznej. Oczywiście popularność SVP była wynikiem popularności szerszego programu politycznego. Problematyka europejska wzbudziła jednak sporo emocji oraz kontrowersji i zmobilizowała tę część społeczeństwa, która wykazywała najbardziej krytyczną postawę wobec integracji europejskiej. Ludowcy doskonale wykorzystali te nastroje, doprowadzając do wzmocnienia swojej pozycji. W oficjalnych dokumentach programowych lub przemówieniach czołowych działaczy tego ugrupowania można spotkać się z tezą, że to właśnie dzięki SVP Szwajcaria nie jest jeszcze członkiem Unii Europejskiej.

Specyfika funkcjonowania rządu uniemożliwia zdominowanie Rady przez jedno z ugrupowań. Polityka wobec Unii Europejskiej musiała więc nadal być konsekwencją wypracowanego kompromisu pomiędzy poszczególnymi partiami. To oznaczało, że nieco zdystansowana, ale nadal otwarta na współpracę strategia będzie kontynuowana. Zmiany dotyczące podziału miejsc w parlamencie nie pociągnęły więc za sobą diametralnych zmian w sensie politycznym. Wzmocnienie ugrupowania będącego w opozycji do dotychczasowej polityki europejskiej rządu, przyczyniło się jednak do spowolnienia pewnych procesów, co zresztą legitymizowane było przez większość społeczeństwa szwajcarskiego. Zauważyć moż- 
na również, że polityka europejska na pewien czas zniknęła z debaty publicznej. Preferowano postawę bierną, na zasadzie „czekaj i patrz”. To z kolei wzmocniło ugrupowania eurosceptyczne, albowiem część osób, która była do tej pory niezdecydowana, odczuwała coraz większy deficyt informacyjny, skutkujący wzrostem nieufności wobec Unii Europejskiej.

\subsection{PERSPEKTYWY POLITYKI SZWAJCARII WOBEC UNII EUROPEJSKIEJ}

Wydaje się, że po blisko dekadzie prowadzenia wobec Unii Europejskiej polityki opartej na umowach bilateralnych nie należy oczekiwać nagłego zwrotu. Ogólny konsensus co do słuszności obranej drogi nie zachęca do zmian, a raczej do cementowania takich relacji tak długo, jak to tylko będzie możliwe. Opinia publiczna w zdecydowanej większości popiera politykę rządu i nie widzi potrzeby głębszej integracji. Również elity polityczne oraz czołowe ośrodki opiniotwórcze są zdania, że bilateralizm najlepiej zabezpiecza interesy Szwajcarii i zmiany w bliskiej perspektywie po prostu nie miałyby sensu. Nie przemawiają za tym ani względy gospodarcze, ani polityczne, choć te ostatnie, o czym mowa była szerzej w poprzednich rozdziałach, niezmiennie wywołują sporo kontrowersji, zwłaszcza w kontekście asymetryczności w relacjach pomiędzy UE a Szwajcarią. Stosunek do problematyki europejskiej najlepiej obrazują wypowiedzi szefowej dyplomacji Szwajcarii. Zdaniem Micheline Calmy-Rey podstawowym problemem polityki wobec Wspólnoty nie jest wybór pomiędzy członkostwem a bilateralizmem, lecz wybór najlepszych instrumentów ochrony interesów Szwajcariii ${ }^{56}$. Polityka wobec Unii Europejskiej ma więc charakter pragmatyczny, w mniejszym stopniu podyktowana jest względami ideologicznymi, dążeniem do integracji czy chęcią budowy wspólnej Europy. Jeżeli przyjęta strategia gwarantuje Szwajcarii rozwój gospodarczy, a jednocześnie nie narzuca zbyt wielu trudnych do zaakceptowania zobowiązań, to jest ona właściwa. W wywiadzie udzielonym „Neue Zürcher Zeitung" w styczniu 2008 r., Micheline Calmy-Rey wyraziła chęć rozszerzenia dotychczasowej współpracy o kolejne sporne obszary, podkreślając, że z punktu widzenia interesu Szwajcarii nie można pozwolić sobie na jakikolwiek przestój w tym względzie. Rozwijająca się Europa wymusza poszukiwanie nowych form współdziałania. Jeżeli Szwajcaria pozostanie bierna, nie zaznaczy swojego stanowiska oraz nie przedstawi propozycji co do kształtu wzajemnych relacji, Bruksela zapewne zacznie dyktować warunki. Konieczne jest zatem, zdaniem Calmy-Rey, zaproponowanie w najbliższym czasie kolejnych tematów negocjacyjnych, pod warunkiem oczywiście, że dotychczasowe porozumienia będą w pełni zabezpieczone.

${ }^{56}$ EU-Politik: Die Zukunft der Schweiz ist bilateral, „Neue Zürcher Zeitung”, 22. August 2010. 
Okazuje się jednak, że kontynuacja tej drogi może wcale nie być taka prosta. Pojawia się bowiem coraz więcej problemów, niejasności i wzajemnych pretensji. Należy podkreślić, iż nie chodzi tutaj wyłącznie o problem występowania lub braku chęci do utrzymywania relacji na obecnym poziomie. Kwestia wzajemnych stosunków jest o wiele bardziej złożona. Wyznaczają ją m.in. uwarunkowania wewnętrzne, głównie związane ze specyfiką ustroju politycznego Szwajcarii, zjawiska globalizacji, reformy instytucjonalne w Unii Europejskiej, kryzysy gospodarcze. Obie strony chcą współpracy, ale opartej na własnych warunkach, a ich ogólne podejście wydaje się coraz bardziej roszczeniowe, nie tak entuzjastyczne i optymistyczne, jak jeszcze na początku lat 90.

Umowy bilateralne, zwłaszcza pierwszy pakiet, zostały zawarte z uwagi na specyficzną sytuację tamtego okresu. Poszukiwano wówczas rozwiązań, które będą umożliwiały nawiązanie współpracy w wersji „light” ${ }^{27}$. Obecnie pomysł ten nie wywołuje już takiego entuzjazmu. Późniejsze, jak i obecne negocjacje o wiele silniej obciążone są partykularnymi interesami poszczególnych państw, a jest ich, jak wiadomo, znacznie więcej niż jeszcze dziesięć lat temu. Obszary, które mogłyby być przedmiotem negocjacji, traktowane są często w sposób instrumentalny, na zasadzie „,coś za coś” 58 - ustępstwa w jednym obszarze kosztem zysków w innych. Współpraca na takich zasadach jest tym trudniejsza, że kolejne tematy negocjacyjne są coraz bardziej skomplikowane. Wymagają często dużych nakładów finansowych i osiągnięcia szerokiego konsensusu społecznego, co bywa niekiedy bardzo trudne. Do tego dochodzą problemy związane z bieżącą realizacją zawartych już porozumień. Coraz częściej mówi się tutaj o konieczności wprowadzenia pewnych zmian, powołania nowych organów kontrolnych, których zadaniem byłoby usprawnienie współpracy, ale również zagwarantowanie większego poszanowania dla suwerenności Szwajcarii. Równie istotne jest stworzenie bardziej przejrzystego systemu prac komisji mieszanych oraz lepszej koordynacji działań. Postuluje się utworzenie w tym celu dodatkowego ciała na szczeblu ministerialnym.

Wielu problemów przysparza też dynamika rozwoju Unii Europejskiej, jej niedawne oraz przyszłe rozszerzenia, które niosą ze sobą daleko idące konsekwencje także dla Szwajcarii - nie zawsze przy tym w znaczeniu pozytywnym. W ciągu najbliższych kilku lat należy więc oczekiwać pewnych zmian w relacjach dwustronnych. Jaki będą one miał ostateczny wymiar, pozostaje kwestią do dyskusji.

Można pokusić się o stworzenie kilku scenariuszy rozwoju dalszej polityki Szwajcarii wobec UE. Analizując bieżące uwarunkowania i doświadczenia, a także oceniając dotychczasową strategię polityczną rządu, można na tej podstawie wyodrębnić trzy główne jej kierunki: kontynuację polityki bilateralnej, przystąpienie do Unii Europejskiej bądź zawarcie czegoś na kształt umowy ra-

${ }^{57}$ M. Vahl, N. Grolimund, Integration ohne Mitgliedschaft: die bilateralen Verträge der Schweiz mit der Europäischen Gemeinschaft, Schulthess, Zürich 2007, s. 113.

${ }^{58}$ Ibidem, s. 128. 
mowej lub stowarzyszeniowej. Za najmniej prawdopodobne wypada natomiast uznać zerwanie współpracy i powrót do izolacjonizmu, a także przyłączenie się do Europejskiego Obszaru Gospodarczego, jednakże bez przystąpienia do UE. Spośród wymienionych trzech głównych scenariuszy szczególnie realne wydają się kontynuacja polityki bilateralnej albo przystąpienie do UE. Trudno jednak dokładnie przewidzieć posunięcia rządu w ciągu kilku najbliższych lat, zwłaszcza że w dużym stopniu będą one zależeć on polityki Unii wobec Szwajcarii. Warto zatem przeanalizować pokrótce wszystkie opcje, opierając się na przekazach medialnych, oficjalnych stanowiskach, a także opiniach politologicznych.

\subsubsection{KONTYNUACJA POLITYKI BILATERALNEJ}

Jak już wcześniej wspomniano, zawarte w 1999 oraz 2000 r. umowy nie mają charakteru statycznego, a więc kontynuowanie polityki bilateralnej oznacza nie tylko dążenie do uregulowania kolejnych obszarów tematycznych za pomocą dwustronnych porozumień, ale również bieżącą ewaluację już obowiązujących. Ponieważ część umów związana jest ze sobą w sposób formalnoprawny (klauzula gilotyny), a inne tylko w sposób dorozumiany, zawieszenie bądź zerwanie współpracy w jednym obszarze może zaważyć na przyszłości pozostałych. Obie strony muszą zatem zabiegać o to, aby współpraca ta układała się możliwie bez przeszkód, co nie jest jednak wcale takie proste. Osobną kwestią pozostaje natomiast próba uregulowania innych obszarów. Rozmowy dwustronne w tej kwestii prowadzone są już od pewnego czasu.

Pozytywny wynik referendum w sprawie kontynuacji i rozszerzenia swobody przepływu osób na nowe państwa członkowskie UE, tj. Bułgarię i Rumunię, z lutego 2009 r., oznaczał oddalenie największego zagrożenia dla współpracy na poziomie bilateralnym. Nie zmienia to jednak faktu, że w przypadku kolejnego rozszerzenia Szwajcarzy najprawdopodobniej znowu będą musieli ustosunkować się do tej propozycji w referendum. Wówczas kontynuacja polityki bilateralnej ponownie stanie pod znakiem zapytania. W kolejce czekają bowiem państwa, których członkostwo w UE może wywołać wiele kontrowersji. Prawdopodobnie Szwajcarzy nie będą entuzjastycznie nastawienie wobec perspektywy otwarcia rynku pracy dla obywateli takich państw, jak Turcja, Macedonia lub Albania, tym bardziej że, jak pokazuje praktyka, perspektywa otwarcia szwajcarskiego rynku pracy, w sytuacji pogłębiającego się kryzysu europejskiego, staje się bardzo kusząca. Imigracja zarobkowa do Szwajcarii osiągnęła w kwietniu 2012 r. poziom uzasadniający ponowne wprowadzenie przez rząd kontyngentów ilościowych wobec nowych państw UE ${ }^{59}$. Nie omieszkano skorzystać z tego instrumentu, ograniczając, począwszy od maja 2012 r., liczbę wydawanych pozwoleń na pobyt

${ }^{59}$ Odnotowano prawie trzykrotny wzrost wydawanych pozwoleń na pobyt czasowy i stały. Kontyngentami objęte zostały Estonia, Litwa, Łotwa, Polska, Słowacja, Słowenia, Czechy, Węgry. 
zarobkowy w Szwajcarii trwający dłużej niż jeden rok $^{60}$. Decyzja ta wywołała co prawda falę krytyki ze strony państw UE, wiadomo jednak, że warunki zawartej w 1999 r. umowy pozostawiają rządowi szwajcarskiemu pełna swobodę w tym względzie, przynajmniej do roku 2014, czyli do końca obowiązywania klauzuli ochronnej. Trudno przewidzieć dalszy rozwój sytuacji gospodarczej w Europie i na świecie. Sądząc jednak po negatywnych nastrojach na rynkach i przedłużającym się kryzysie w strefie euro, nie należy spodziewać się szybko szczególnej poprawy. Wiadomo na pewno, że Szwajcarię czeka kolejne głosowanie w sprawie rozszerzenia swobody przepływu osób na Chorwację, stojącą u progu akcesji do UE. Można zatem oczekiwać kolejnej debaty społecznej, ponownie wystawiającej na próbę słuszność obranej formy integracji z UE.

Rząd Szwajcarii będzie również musiał przystąpić wkrótce do negocjowania warunków udziału kraju w programach MEDIA oraz w 8. Programie Ramowym. Wydaje się, że współpraca w tym obszarze nie jest zagrożona. Dotychczasowe doświadczenia są bardzo pozytywne, a możliwość zasilenia budżetów obu programów przez Szwajcarię jest cenna z punktu widzenia UE.

Osobną kwestią pozostaje jednak problem koordynacji prac komisji mieszanych, a także usprawnienie procesu przekazywania informacji na zewnątrz. W tym zakresie proponuje się stworzenie dodatkowego ciała, które pełniłoby funkcję centralnego sekretariatu ${ }^{61}$. Miałby on działać w ramach Kancelarii Związkowej lub Biura Integracyjnego. Gromadziłby informacje, spływające z poszczególnych komisji, a następnie publikował je w oficjalnych komunikatach lub na stronie internetowej. W ramach tej propozycji postuluje się również udostępnienie opinii publicznej danych na temat podstaw prawnych, tj. określonych dyrektyw UE oraz rozporządzeń dla podejmowanych w ramach komisji decyzji. Chodzi o to, aby proces transponowania prawa UE był bardziej przejrzysty. Być może obecnie rząd świadomie unika odpowiedzi na pytanie, w jakiej formie przebiega owa współpraca i czy rzeczywiście suwerenność Szwajcarii w tym obszarze pozostaje kwestią dyskusyjną. Wiadomo, iż coraz częściej pojawiają się głosy krytyczne.

Przeciwnicy takiego rozwiązania są jednak zdania, że stworzenie dodatkowej instytucji w ramach istniejących organów administracyjnych zwiększyłoby jedynie i tak już zbyt rozbudowaną biurokrację. Postuluje się raczej usprawnienie przepływu informacji poprzez nałożenie na komisje obowiązku załączania listy aktów prawnych UE, które stanowią podstawę określonych decyzji. Umożliwiłoby to uzyskanie wiedzy na temat podstawowych celów, jakie kryją się za nowymi przepisami. Mogłyby one również stanowić podstawę ewentualnych sporów sądowych.

Jak już wcześniej wspomniano, od pewnego czasu rząd Szwajcarii prowadzi ze stroną unijną rozmowy w kolejnych obszarach tematycznych. Negocjacje nie

${ }^{60}$ Freizügigkeitsabkommen Schweiz - EU: Anrufung der Ventilklausel gegenüber den Staaten $\operatorname{der} E U-8$, Medienmitteilung EDA/EVD [Bern], 18.04.2012.

${ }^{61}$ M. Vahl, N. Grolimund, op. cit., 
są jednak prowadzone w sposób pakietowy, tzn. nie zmierzają do zawarcia pakietu Bilaterale III (choć nie brakuje zwolenników także i takiego rozwiązania). Obie strony uważają, że taka forma negocjacji znacznie wydłuża cały proces i utrudnia osiągnięcie kompromisu ${ }^{62}$. Często dochodzi bowiem do sytuacji, w której współpraca w ramach jednego obszaru rzutuje na inny, często zupełnie z nim niepowiązany. Podjęto zatem decyzję, aby traktować poszczególne tematy w sposób samodzielny. Część z nich jest przedmiotem rozmów zgodnie z ustaleniami końcowego aktu pakietu Bilaterale II, inne są efektem propozycji, którą Komisja Europejska złożyła Szwajcarii z uwagi na toczące się akurat procesy legislacyjne w ramach UE.

W listopadzie roku 2008 rozpoczęto negocjacje w dziedzinie rolnictwa, żywności, a także ochrony zdrowia. Ich celem ma być otwarcie rynku dla całego „łańcucha rolno-spożywczego”, jak również wzmocnienie współpracy w zakresie bezpieczeństwa żywności i produktów spożywczych ${ }^{63}$. Rozmowy w tej sprawie należą zapewne do najtrudniejszych, głównie z uwagi na specyfikę sektora rolnego w Szwajcarii. Otwarcie rynku dla produktów rolno-spożywczych z UE, z reguły o wiele tańszych, mogłoby wpłynąć bardzo niekorzystnie na kondycję szwajcarskich producentów. Ponieważ wszystkie te tematy ściśle się ze sobą łączą, Rada Związkowa postanowiła przyjąć wspólny mandat negocjacyjny i rozpocząć rozmowy z UE jednocześnie we wszystkich obszarach. Koordynacją zajmuje się Biuro Integracyjne.

Liberalizacja rynku rolnego stanowi uzupełnienie omawianych już w rozdziale III umów z zakresu rolnictwa oraz przetworzonych produktów rolnych. Jest również konsekwencją postanowień rundy Doha, w ramach posiedzeń Światowej Organizacji Handlu. Rząd traktuje tę umowę także jako element wdrażanej konsekwentnie reformy tego sektora. Liberalizacja przewiduje całkowite zniesienie ceł oraz barier pozataryfowych, a także wszelkich instrumentów proeksportowych, takich jak dopłaty lub subwencje. W celu zniwelowania negatywnych skutków otwarcia rynku powołano do życia specjalną grupę roboczą, która miała za zadanie stworzyć instrumenty, jakie pozwoliłyby na wzmocnienie konkurencyjności produktów szwajcarskich na zagranicznych rynkach ${ }^{64}$. Chodzi tu głównie o podkreślenie ich jakości i stworzenie wspólnej, rozpoznawalnej za granicą marki. Postuluje się również organizację systemu wsparcia dla rodzimych producentów, który umożliwi rozwój sektora, zwiększenie jego efektywności oraz budowę silnej pozycji wobec zagranicznej konkurencji. Wyniki prac tej grupy przedstawiono w lipcu roku $2009^{65}$.

${ }^{62}$ Ibidem, s. 112.

${ }^{63}$ Zob. Verhandlungen über Landwirtschaft, Lebensmittelsicherheit, Produktsicherheit und öffentliche Gesundheit, Integrationsbüro EDA/EVD, Oktober 2009.

${ }^{64}$ Freihandel mit der EU im Agrar- und Lebensmittelbereich: Arbeitsgruppe Begleitmassnahmen bestimmt, Medienmitteilung Generalsekretariat GS-EVD, 8. April 2008.

${ }^{65}$ Begleitmassnahmen zu einem Freihandelsabkommen im Agrar- und Lebensmittelbereich. Bericht der AG Begleitmassnahmen zuhanden des Eidgenössischen Volkswirtschaftsdepartements, Juli 2009. 
Umowa dotycząca bezpieczeństwa żywności i produktów przewiduje z kolei współpracę z Europejskim Urzędem ds. Bezpieczeństwa Żywności (EFSA), a także włączenie Szwajcarii do Systemu Wczesnego Ostrzegania w Zakresie Żywności i Środków Żywienia Zwierząt (RASFF) oraz do systemu szybkiego informowania RAPEX.

Rząd Szwajcarii zmierza również do uregulowania współpracy w dziedzinie ochrony zdrowia, która obecnie funkcjonuje w bardzo ograniczonym wymiarze. Dzięki negocjowanej aktualnie umowie ma się to zmienić. Przede wszystkim krajowe organy mają nawiązać współpracę z Europejskim Centrum ds. Zapobiegania i Kontroli Chorób (ECDC), z siedzibą w Sztokholmie. Szwajcaria zamierza też wziąć udział we wspólnotowym programie działań na rzecz ochrony zdrowia, który jak dotąd przewidziany jest na lata 2008-2013, ale najprawdopodobniej będzie przedłużony na kolejny okres. Jego celem jest wparcie działań profilaktycznych i zdrowotnych ${ }^{66}$.

Rozpoczęte w roku 2008 negocjacje mają potrwać do końca roku 2011. Są to oczywiście wstępne założenia, które przewidują również prawdopodobny termin wejścia w życie powyższych umów na połowę roku 2014.

Od listopada roku 2007 prowadzone są również negocjacje dotyczące sektora energetycznego ${ }^{67}$. Z propozycją zawarcia porozumienia wyszła tu UE. Jego głównym celem jest zabezpieczenie dostaw energii elektrycznej poprzez stworzenie jednolitego rynku europejskiego ${ }^{68}$. Ma to być możliwe dzięki harmonizacji norm bezpieczeństwa oraz eliminacji barier $\mathrm{w}$ handlu transgranicznym. Jednym $\mathrm{z}$ elementów tego procesu będzie oddzielenie usług produkcji od usług dystrybucji, które zgodnie z nowymi regulacjami UE nie będą mogły być świadczone przez jedną firmę. Stworzony zostanie również niezależny organ regulacyjny, który ma zastąpić jego odpowiedniki na poziomach krajowych. Pojawiła się propozycja, aby szwajcarski rynek energii podlegał regulacjom właściwej Agencji UE z siedzibą w Ljubljanie ${ }^{69}$. Dzięki temu rozpocznie się swobodny handel energią na terenie Unii Europejskiej i Szwajcarii. Umowa ma zarazem regulować kwestię obrotu tzw. energią zieloną, a więc produkowaną z odnawialnych źródeł. Chodzi tu głównie o wzajemne uznawanie świadectw pochodzenia. Szwajcaria, która produkuje ponad 50\% energii z OZE, może dzięki tej umowie sprzedawać jej część za granicą, co dzieje się już teraz. Szwajcaria zarabia rocznie na handlu zieloną energią, głównie z Włochami i Francją, ok. miliard franków ${ }^{70}$. Umowa z UE ułatwi dostęp do unijnych rynków i dodatkowo wzmocni pozycję Szwajcarii.

${ }^{66}$ Decyzja nr 1350/2007/WE Parlamentu Europejskiego i Rady z dnia 23 października 2007 r., „Dziennik Urzędowy Unii Europejskiej” 2007, L 301/3.

${ }^{67}$ Verhandlungen Schweiz-EU im Strombereich gestartet, Medienmitteilung Bundesamt für Energie, 08.11.2007.

${ }^{68}$ Stworzenie jednolitego rynku energii pozwoli na uniknięcie tzw. Blackoutów, czyli przerw w dostawach energii elektrycznej spowodowanych awarią lub przeciążeniem sieci.

${ }^{69}$ Agencja ds. Współpracy Organów Regulacji Energetyki (ACER).

${ }^{70}$ Strom, Integrationsbüro EDA/EVD, Februar 2010, s. 2. 
Uzupełnieniem współpracy w sektorze energetycznym ma być porozumienie w sprawie handlu emisjami. Pierwsze rozmowy w tej kwestii rozpoczęły się w 2008 r., a pod koniec następnego roku rząd Szwajcarii podjął decyzję o rozpoczęciu oficjalnych negocjacji ${ }^{71}$. Dzięki umowie Szwajcaria będzie objęta europejskim systemem handlu prawami do emisji gazów cieplarnianych, który ma przyczynić się do ochrony środowiska naturalnego i przeciwdziałania niekorzystnym zmianom klimatycznym ${ }^{72}$. Dla szwajcarskich przedsiębiorstw oznaczać to będzie możliwość korzystania z unijnego rynku, a więc zakupu lub sprzedaży praw do emisji na równych zasadach. System handlu emisjami funkcjonuje w Szwajcarii od 2008 r. Krajowy rynek jest jednak niewielki, co znacznie podnosi koszty świadectw i - co za tym idzie - utrudnia realizację zobowiązań emisyjnych. Dostęp do rynku UE otwiera nowe perspektywy dla szwajcarskich przedsiębiorstw.

Ponieważ negocjacje dotyczące sektora energetycznego są najbardziej zaawansowane, obie strony traktują ten obszar jako swoisty poligon doświadczalny. Przyjęte regulacje i rozwiązania dotyczą przede wszystkim problemów natury instytucjonalnej, mają służyć jako wzorzec dla innych płaszczyzn współpracy ${ }^{73}$. Rząd w Bernie przedstawił nawet, aczkolwiek bez uprzedniej konsultacji ze stroną unijną, pakiet rozwiązań instytucjonalnych dla tego obszaru. Niestety nie wszystkie propozycje znalazły zrozumienie w UE.

We wrześniu roku 2010 rozpoczęły się również negocjacje w sprawie udziału Szwajcarii w programie budowy systemu nawigacji satelitarnej Galileo. Ma być on przeciwwagą dla amerykańskiego GPS-u, jednak w przeciwieństwie do niego kontrolę nad europejskim systemem sprawować będą organy cywilne, a nie wojskowe. Galileo był projektem lansowanym od połowy lat 90., początkowo przez Unię Europejską i Europejską Agencję Kosmiczną (ESA) ${ }^{74}$. Szwajcaria, z uwagi na swoje członkostwo w ESA, współpracowała przy jego tworzeniu. Po przejęciu projektu przez UE, Bruksela zaproponowała Szwajcarii zawarcie nowego porozumienia, zapewniającego kontynuację współpracy. Celem rządu Szwajcarii jest zagwarantowanie udziału w budowie systemu na równych zasadach, tj. z prawem do współdecydowania oraz swobodnym dostępem do know-how. System Galileo może stanowić doskonałą podstawę do rozwoju szwajcarskiego przemysłu lotniczego oraz sektora usługowego ${ }^{75}$.

Dwa kolejne obszary są na razie przedmiotem wstępnych rozmów. Pierwszy z nich dotyczy współpracy w ramach Europejskiej Agencji Obrony. Jej działania

${ }^{71}$ Bundesrat erteilt Verhandlungsmandat für Verknüpfung mit EU-Emissionshandel, Medienmitteilung UVEK, 16.12.2009.

${ }^{72}$ Zob. Emissionshandel, Integrationsbüro EDA/EVD, Februar 2010.

${ }^{73}$ Takie wnioski płyną ze spotkania Eveline Widmer-Schlumpf z Jose Manuelem Barosso, do którego doszło w Brukseli, w marcu 2012 r. Zob. C. Blumer, Der Freund der Schweiz, „Tagesanzeiger”, 20 März 2012.

${ }^{74}$ Satellitennavigationsprogramme Galileo und EGNOS: Start der bilateralen Verhandlungen über Kooperation $C H-E U$, Medienmitteilung Bundesamt für Strassen ASTRA, 21.09.2010.

${ }^{75}$ Zob. Satellitennavigation (Galileo und EGNOS), Integrationsbüro EDA/EVD, September 2010. 
obejmują wspieranie prac badawczo-rozwojowych, a także promowanie międzynarodowej współpracy zbrojeniowej w Europie. Dodatkowym celem Agencji jest harmonizacja przepisów i zasad produkcji i sprzedaży broni oraz sprzętu wojskowego. Szwajcaria współpracowała z Agencją już wcześniej. Była to jednak współpraca o charakterze doraźnym, przy wybranych projektach i po zawarciu stosownego porozumienia. Nowa umowa gwarantowałaby możliwość stałej wymiany informacji i udziału w różnych projektach, w zależności od potrzeb i bez konieczności każdorazowego formalizowania poczynań. Agencja spełnia także funkcję platformy wymiany doświadczeń i wiedzy. Dla szwajcarskiego przemysłu zbrojeniowego będzie to oznaczać możliwość zawierania cennych kontaktów i realizacji wspólnych projektów z partnerami z UE. Rząd ma przy tym nadzieję, iż nawiązanie ściślejszej współpracy w tym obszarze pozwoli na obniżenie wysokich kosztów prowadzenia własnych projektów badawczo-rozwojowych, zwłaszcza że w dziedzinie zbrojeń są one szczególnie kosztochłonne ${ }^{76}$.

Drugi obszar związany jest z rozporządzeniem Parlamentu Europejskiego i Rady na temat bezpiecznego stosowania chemikaliów. Weszło ono w życie w czerwcu 2007 r. i jak dotąd obowiązuje na obszarze Unii Europejskiej, a także Norwegii, Islandii i Lichtensteinu. Rozporządzenie ma docelowo ułatwić obrót substancjami chemicznymi, zapewnić bezpieczeństwo w zakresie ich transportu i przechowywania. Nowe przepisy UE utrudniają jednak wymianę handlową ze Szwajcarią, gdyż nie są kompatybilne z obowiązującymi na jej terenie regulacjami. Co więcej, znaczna część szwajcarskich eksporterów, przed wejściem w życie nowego rozporządzenia, jedynie w niewielkim stopniu lub w ogóle nie miała styczności z prawodawstwem UE w dziedzinie chemikaliów ${ }^{77}$. Obie strony postanowiły zatem powrócić do stołu negocjacyjnego. W ramach działań doraźnych rząd szwajcarski powołał do życia specjalne biuro informacyjne, którego zadaniem jest udzielanie pomocy szwajcarskim przedsiębiorcom. Docelowo umowa ma umożliwić zniesienie pozataryfowych barier w handlu. Obecnie ok. $60 \%$ tego typu towarów, produkowanych w Szwajcarii, trafia na rynek UE. Rząd będzie się zatem starał, aby handel w tym obszarze uległ jak najszybszej liberalizacji ${ }^{78}$.

Cieniem na współpracy bilateralnej kładą się natomiast problem polityki fiskalnej oraz harmonizacji rynku usług. Osiągniecie kompromisu w tych dwóch obszarach jest niezwykle trudne. W przypadku liberalizacji rynku usług rozmowy prowadzone były jeszcze przy okazji drugiego pakietu umów bilateralnych. Podstawowy spór dotyczył zakresu owej liberalizacji. Szwajcaria stała na stanowisku, że jedynie wybrane branże powinny być objęte umową. Uważano, że zniesienie

${ }^{76}$ Europäische Verteidigungsagentur (EVA): Bundesrat verabschiedet Verhandlungsmandat, Medienmitteilung VBS, 17.12.2009. Zob. więcej Technische Zusammenarbeit mit der Europäischen Verteidigungsagentur, Integrationsbüro EDA/EVD, Februar 2010.

${ }^{77}$ EG-Chemikalienverordnung REACH: Handlungsbedarf für die Schweiz, Medienmitteilung Staatssekretariat für Wirtschaft, 29.10.2008.

${ }^{78}$ Zob. REACH, Integrationsbüro EDA/EVD, Februar 2010. 
wszelkich obostrzeń może negatywnie wpłynąć na rynek pracy. Komisja Europejska nalegała jednak, aby nie ograniczać zakresu umowy, albowiem traktowano ją jako element unijnej strategii jednolitego rynku, zakładającej zarówno swobodny przepływ kapitału, towarów, jak i usług oraz osób. Rozbieżności były zbyt duże, dlatego negocjacje zawieszono. Obie strony obiecały powrócić do tematu w późniejszym terminie, na co się jednak do tej pory nie zdecydowano.

$\mathrm{Z}$ podobnym impasem mamy do czynienia $\mathrm{w}$ przypadku sporu dotyczącego polityki fiskalnej poszczególnych kantonów. Organizowane cyklicznie spotkania robocze pomiędzy przedstawicielami Szwajcarii oraz Komisji Europejskiej nie przyniosły do tej pory żadnego konkretnego rezultatu. Służyły głównie prezentowaniu stanowisk i wymianie opinii ${ }^{79}$. Spór, choć ma znacznie szersze podłoże, zogniskowany jest wokół różnej interpretacji umowy o wolnym handlu z roku 1972. Rząd Szwajcarii odpiera zarzuty Komisji Europejskiej przedstawiając własną wykładnię w sposób wiarygodny i trudny do podważenia. Obie strony są zdeterminowane, a zatem osiągnięcie kompromisu w najbliższym czasie nie będzie łatwe. Ludowcy wysunęli nawet postulat powiązania kwestii podatkowych z wyrażeniem zgody na rozszerzenie i kontynuację swobody przepływu osób. Propozycja miała jednak wyraźnie populistyczne zabarwienie i nie została wykorzystana przez rząd ${ }^{80}$. Należy podkreślić, że kwestia autonomii podatkowej kantonów, poza aspektami ekonomicznymi, ma też istotne znaczenie polityczne. Zarzuty wysuwane przez Komisję Europejską są bowiem sprzeczne z elementarnymi zasadami systemu ustrojowego Szwajcarii, w którym poszczególne jednostki składowe federacji dysponują sporą niezależnością, m.in. w zakresie polityki fiskalnej ${ }^{81}$. Trudno oczekiwać od władz związkowych, aby próbowały wpływać na zachowanie kantonów w tych obszarach, które leżą przecież w ich wyłącznych kompetencjach, tym bardziej że inicjatywa ta nie byłaby efektem wewnętrznej dyskusji czy też elementem szerszej reformy finansów Szwajcarii, lecz postulatem inspirowanym przez inne państwa.

Co przyniesie zatem najbliższa przyszłość? Sądząc po prowadzonych obecnie negocjacjach, polityka Szwajcarii będzie zmierzała do utrzymania bieżącego poziomu współpracy z UE, przynajmniej w ciągu kolejnych kilku lat. Rząd opublikował już wstępny harmonogram wejścia $\mathrm{w}$ życie negocjowanych aktualnie umów. Ponadto we wrześniu 2010 r. Rada Związkowa przyjęła nowe sprawozdanie dotyczące polityki europejskiej, w którym podtrzymuje opinię, iż bilateralizm stanowi najbardziej optymalny instrument ochrony interesów Szwajcariii ${ }^{82}$. Rząd

${ }^{79}$ Dialog Steuerkontroverse: Drittes Treffen mit der EU-Kommission, Medienmitteilung EFD, 08.04.2008.

${ }^{80}$ Personenfreizügigkeit und Steuerstreit verknüpfen, „Neue Zürcher Zeitung”, 27. Februar 2008.

${ }^{81}$ Zob. Warum die materielle Steuerharmonisierung kein Rezept für die Schweiz ist. Referat Bundesrat Hans-Rudolf Merz an der Bundessteuerkonferenz, Bern, 11.05.2006.

${ }^{82}$ Bericht des Bundesrates über die Evaluation der schweizerischen Europapolitik vom 17. September 2010, BBI 2010/1419. 
przyznaje też, że współpraca bilateralna jest obecnie znacznie trudniejsza. Wynika to ze wzrostu liczby państw członkowskich oraz coraz większej determinacji Unii, aby istniejące i przyszłe umowy bazowały wyłącznie na prawie wspólnotowym. Szwajcaria niechętnie zgadza się na taki warunek, gdyż to de facto eliminuje możliwość jakichkolwiek negocjacji i deprecjonuje jej pozycję w relacjach dwustronnych. Rząd przyjął zatem kilka wytycznych, które muszą być spełnione, aby współpraca bilateralna była z powodzeniem kontynuowana ${ }^{83}$.

Po pierwsze, zagwarantowana musi być suwerenność Szwajcarii, m.in. w zakresie prawidłowego przebiegu procesu decyzyjnego. Wykluczono zatem możliwość automatycznego transponowania unijnego prawa do szwajcarskiego porządku prawnego. Po drugie, należy usprawnić mechanizmy rozwoju i wdrażania umów. Po trzecie, zachowana musi być równowaga interesów obu stron, w szczególności poprzez zagwarantowanie swobodnego dostępu do rynków. Po czwarte, Szwajcaria ma mieć zapewnione prawo do nieskrępowanej polityki względem UE oraz pozostałych państw. Chodzi tutaj zatem o utrzymanie politycznej, gospodarczej i społecznej niezależności, która ma być również elementem budowy zrównoważonego rozwoju w Europie.

Sądząc po deklaracjach rządu odnośnie do kontynuacji polityki bilateralnej, można przyjąć, iż obecne relacje spełniają powyższe oczekiwania, choć wiele punktów wymaga jeszcze dopracowania. Istnieje pewien rozdźwięk pomiędzy formalnym stanowiskiem władz związkowych a opinią niezależnych ośrodków odnoszącą się do faktycznego wymiaru tej współpracy, a zwłaszcza pozycji Szwajcarii i problemów, jakich zaistnienie przewiduje się w bliższej perspektywie. Nie ulega jednak wątpliwości, że bilateralizm, który początkowo traktowany był jako okres przejściowy na drodze ku pełnej integracji, stał się obecnie podstawą wzajemnych relacji, choć obie strony zapewne nie przewidywały takiego scenariusza.

Kiedy na początku lat 90 . podjęto decyzję o zawarciu kilku porozumień o charakterze gospodarczym, nie przypuszczano, iż w ciągu najbliższych dziesięciu lat stosunki pomiędzy Szwajcarią a Unią Europejską przybiorą wymiar bezprecedensowy. Jeśli zatem nie nastąpią diametralne zmiany nastrojów w Unii Europejskiej, taki model współpracy będzie kontynuowany. Problemem dla Brukseli może być chociażby sytuacja, w której casus Szwajcarii stałby się wzorem dla innych, obecnych lub potencjalnych członków Unii. Bilateralizm w stosunkach ze Szwajcarią mógłby też wywołać nastroje rewizjonistyczne wewnątrz Wspólnoty i zagrozić jej jedności. Z drugiej strony, przypadek Szwajcarii, jeżeli okaże się efektywny dla obu stron, może być z powodzeniem stosowany również wobec państw trzecich, takich jak Rosja, Turcja lub Izrael. Według niektórych opinii bilateralizm w stosunkach ze Szwajcarią jest jednak jedynie efektem jej wyjątko-

${ }^{83}$ Bundesrat setzt im Verhältnis zur EU auf Kontinuität und führt den bilateralen Weg fort, Medienmitteilung Integrationsbüro EDA/EVD, 19.08.2010: Rada Związkowa potwierdziła swoje stanowisko w oficjalnym komunikacie z 15 czerwca 2012 r., podkreślając dodatkowo konieczność powołania niezależnego od UE organu kontrolnego, nadzorującego właściwe wdrażanie umów, zob. Institutionelle Fragen, Integrationsbüro EDA/EVD, August 2012. 
wego położenia w samym środku Europy ${ }^{84}$. Wobec innych partnerów taka forma współpracy nie będzie wykorzystywana.

\subsubsection{PRZYSTĄPIENIE DO UNII EUROPEJSKIEJ}

Biorąc pod uwagę oficjalne komunikaty rządowe dotyczące polityki europejskiej oraz analizując wypowiedzi szefowej dyplomacji Szwajcarii, należałoby przyjąć, iż przystąpienie do Unii Europejskiej jest zdecydowanie mniej prawdopodobnym scenariuszem niż kontynuacja współpracy na poziomie bilateralnym. Warto jednakże przyjrzeć się bliżej również i tej opcji, chociażby z uwagi na fakt, że obecna polityka Szwajcarii determinowana jest także określonym stanowiskiem Unii Europejskiej. Być może presja ze strony Wspólnoty będzie na tyle duża, że członkostwo okaże się dla Szwajcarii w dłuższej perspektywie nieuniknione.

\subsubsection{WYMIAR POLITYCZNY}

Analizując konsekwencje przystąpienia do Unii Europejskiej należy brać pod uwagę zarówno aspekty polityczne, jak i gospodarcze. W przypadku tych pierwszych możemy mówić o pozytywnych implikacjach dla Szwajcarii, w postaci chociażby wzmocnionego oddziaływania na proces decyzyjny w ramach Wspólnoty. Rząd Szwajcarii wielokrotnie podkreślał, że bilateralizm może, paradoksalnie, doprowadzić do osobliwej formy integracji, niemal nieodbiegającej od pełnego członkostwa, pozbawionego jednakże możliwości współdecydowania $^{85}$. Taka sytuacja byłaby dla kraju najbardziej niekorzystna. Jako pełnoprawny członek UE będzie miała możliwość nie tylko wyrażania własnych opinii, za pośrednictwem różnego rodzaju gremiów (co dzieje się do pewnego stopnia już teraz), lecz również aktywnego uczestniczenia w procesie legislacyjnym. Wielkość Szwajcarii nie zapewnia jej, co prawda, istotnej pozycji wśród pozostałych członków Wspólnoty, szczególnie w aspekcie nowego sposobu głosowania w Radzie UE, przyjętego w traktacie z Lizbony, który nie sprzyja małym państwom ${ }^{86}$. Jednak dzięki odpowiednim i korzystnym sojuszom wymiar oddziaływania może być znacznie większy. Potwierdza to chociażby przypadek Austrii i Luksemburga, które umiejętnie wykorzystują dostępne środki i metody dla osiągania własnych celów i ochrony interesów. Szwajcaria, podobnie jak wspomniane państwa, będzie miała możliwość wyznaczenia swojego przedstawiciela w Komisji Europejskiej (co prawda w formie rotacyjnej) oraz w Sekretariacie Generalnym Rady.

${ }^{84}$ T. Cottier, R. Liechti, Die Beziehungen der Schweiz zur Europäischen Union: Eine kurze Geschichte diff erenzieller und schrittweiser Integration, „Basler Schriften zur europäischen Integration" 2006, Nr. 81, s. 31.

${ }^{85}$ Aussenpolitischer Bericht 2009 vom 2. September 2009, BB1 2009/6291, s. 6337.

${ }^{86}$ Szwajcaria będzie dysponowała 10 głosami w Radzie. Z kolei w Parlamencie Europejskim będzie mogło zasiąść maksymalnie 20 posłów z tego kraju. 
Ponadto członkostwo zapewni jej możliwość obsadzenia stanowiska w służbach dyplomatycznych UE. Warto także wspomnieć, że od momentu przystąpienia do UE jednym z sędziów Europejskiego Trybunału Sprawiedliwości będzie mógł być Szwajcar. Oczywiście kwestia ta ma znaczenie raczej symboliczne, albowiem na decyzje ETS w żaden sposób nie wpływają stanowiska państw członkowskich. Całość uzupełnia niepodważalna korzyść w postaci sprawniejszej wymiany informacji i akcentowania własnego stanowiska w kluczowych dla Szwajcarii obszarach. Argument ten pojawia się zdecydowanie najczęściej w dyskursie politycznym lub politologicznym, dotyczącym przyszłości relacji z Unią Europejską.

$\mathrm{Z}$ drugiej strony mamy tutaj do czynienia $\mathrm{z}$ ogromnym problemem natury legislacyjnej, związanym z koniecznością przyjęcia całego dorobku prawnego Wspólnoty. Oczywiście, jak wykazano w poprzednich rozdziałach, prawodawstwo szwajcarskie jest w przeważającej części eurokompatybilne. Nie zmienia to jednak faktu, że w świetle obowiązującego procesu decyzyjnego i podziału kompetencyjnego w ramach federacji szwajcarskiej, kwestia implementowania dynamicznie rozwijającego się prawa UE powoduje sporo komplikacji ${ }^{87}$, tym bardziej że niektóre akty prawne, jak np. rozporządzenia, są bezpośrednio stosowalne, co eliminuje praktycznie możliwość oddziaływania obywateli na kształt ustaw ${ }^{88}$. Podobnie rzecz wygląda w przypadku podstawowych praw obywatelskich, związanych z demokracją bezpośrednią, takich jak referendum lub inicjatywa. Nie ulega wątpliwości, iż wnioski w sprawie głosowań referendalnych będą mogły dotyczyć wyłącznie, o ile w ogóle, jedynie krajowych przepisów wykonawczych. $\mathrm{W}$ przypadku nieimplementowania unijnych dyrektyw w wyznaczonym terminie Szwajcaria będzie musiała liczyć się z zaskarżeniem jej do Europejskiego Trybunału Sprawiedliwości. Ograniczona zostanie również możliwość zgłaszania inicjatyw konstytucyjnych. Może bowiem dojść do sytuacji, w której wniosek okaże się niezgodny z prawem UE. Dlatego szczególnie aktualne i pilne wydają się postulaty przeprowadzenia głębokich reform instytucjonalnych, obejmujących m.in. kwestie podziału kompetencji pomiędzy związkiem i kantonami, a także funkcjonowania demokracji bezpośredniej. Bardzo często podnosi się tutaj sprawę konieczności zawarcia porozumienia ramowego pomiędzy władzami związkowymi a kantonami w celu usprawnienia współpracy i przepływu informacji w ramach polityki europejskiej ${ }^{89}$.

Ponadto członkostwo we Wspólnocie oznacza konieczność przyjęcia polityk UE w wielu wrażliwych obszarach, takich jak chociażby polityka migracyjna, rol-

${ }^{87}$ Problem ten był przedmiotem analizy w pierwszym rozdziale niniejszej pracy. Zob. także Europabericht 2006 vom 28. Juni 2006, BB1 2006 6815, s. 6944.

${ }^{88}$ Implementowanie rozporządzeń będzie najprawdopodobniej wymagało zastosowania specjalnych procedur legislacyjnych, bazujących przykładowo na tzw. klauzuli pilności, upoważniających parlament do wydawania dekretów bez referendum. Więcej na ten temat: W. Linder, Demokracja Szwajcarska..., s. 185-187.

${ }^{89}$ Umowa ta miałaby również przewidywać powołanie specjalnego organu, mającego koordynować współpracę. Zob. Bericht des Bundesrates über die Evaluation ..., s. 84. 
na, podatkowa, w tym również w aspekcie relacji z państwami trzecimi. Kwestie te będą musiały zostać uregulowane jeszcze na etapie negocjacji akcesyjnych, chyba że Unia wyrazi zgodę na pewne ustępstwa lub korzystne okresy przejściowe.

Przyjęcie polityki UE będzie wiązało się z koniecznością przeniesienia części kompetencji na rzecz ponadnarodowego organu. Tym samym obniżona zostanie suwerenność państwa w niektórych dziedzinach. Odnosi się to szczególnie do polityki monetarnej i walutowej, o ile oczywiście Szwajcaria zgodzi się na rezygnację z franka szwajcarskiego na rzecz euro. Jak wiadomo, niektóre państwa UE nie przystąpiły do unii walutowej, jednak prawdopodobieństwo wyboru tej drogi oceniane jest raczej sceptycznie. Rząd szwajcarski będzie miał co najwyżej możliwość opóźnienia momentu przyjęcia wspólnej waluty. Jeżeli do tego ostatecznie dojdzie, Szwajcarski Bank Narodowy utraci część kompetencji na rzecz Europejskiego Banku Centralnego ${ }^{90}$. Od tego momentu polityka monetarna będzie dyktowana interesami całej strefy euro. Wykluczone będą chociażby samodzielne interwencje banków narodowych. Ograniczone zostaną również kompetencje kantonów w zakresie kreowania własnej polityki fiskalnej. Od dłuższego czasu sprawa ta pozostaje w centrum zainteresowania władz w Brukseli. Weryfikacji UE podlegać będą także instrumenty związane z pomocą publiczną. Rząd Szwajcarii będzie musiał zwrócić się do Komisji Europejskiej z prośbą o zatwierdzenie ewentualnych planów pomocowych, mających na celu np. ożywienie gospodarki w czasach kryzysu.

Realizacja polityki unijnej odnosi się nie tylko do kwestii bezpośrednio związanych z rozwojem gospodarczym, ale również do obszarów polityki społecznej czy ochrony środowiska. Państwa członkowskie są zobowiązane do uwzględniania tzw. celów strategicznych przyjętych przez Unię Europejską. Mimo że większość z nich ma charakter raczej ogólnikowy i pozostają na ogół zbieżne z wartościami przyjętymi przez rząd Szwajcarii, należy się liczyć z koniecznością dostosowania niektórych przepisów prawnych. Punktem odniesienia będą także orzeczenia Europejskiego Trybunału Sprawiedliwości. Biorąc to wszystko pod uwagę, ostateczne konsekwencje realizacji wymienionych polityk dla szwajcarskiej gospodarki są na tym etapie trudne do przewidzenia ${ }^{91}$.

Obecnie coraz rzadziej podnosi się problem wieczystej neutralności, która zgodnie z tradycyjną wykładnią uniemożliwia przystąpienie do ponadnarodowej organizacji o charakterze politycznym, jaką bez wątpienia jest Unia Europejska. Raport z roku $1993^{92}$ zmienił co prawda miejsce i znaczenie neutralności w polityce zagranicznej Związku, jednakże trudno jest obecnie jednoznacznie określić, na ile stanowi ona przeszkodę w pełnej integracji. Bez wątpienia efektem przyję-

${ }^{90} \mathrm{~W}$ przypadku włączenia do strefy euro Szwajcarski Bank Narodowy będzie również zobligowany do przekazania EBC kwoty prawie dwóch miliardów franków na rzecz unijnej rezerwy walutowej.

${ }^{91} \mathrm{Na}$ temat oddziaływania członkostwa w UE na politykę socjalną Szwajcarii zob. także $E u$ ropabericht 2006..., s. 6947.

${ }_{92}$ Bericht über die Aussenpolitik der Schweiz in der 90er Jahren vom 29. November 1993... 
cia nowej strategii politycznej było przesunięcie punktu ciężkości polityki zagranicznej na inne obszary działań, takie jak wspieranie światowego pokoju, praw człowieka, demokracji i zasad państwa prawa. Wiązało się to również z poluzowaniem polityki gospodarczej, szczególnie w dziedzinie integracji europejskiej.

Biorąc pod uwagę doświadczenia innych państw neutralnych, jak chociażby Austrii, status ten, przynajmniej teoretycznie, nie powinien stanowić problemu, zwłaszcza jeżeli we wniosku akcesyjnym znajdą się stosowne zastrzeżenia (na taki krok zdecydował się właśnie rząd austriacki). Pozostaje jednak kwestia udziału Szwajcarii we Wspólnej Polityce Zagranicznej i Bezpieczeństwa UE (WPZiB). Mamy tu do czynienia $\mathrm{z}$ dwojakim problemem. Z jednej strony aktywny udział w kreowaniu relacji zewnętrznych Unii ma istotne zalety, jak chociażby możliwość oddziaływania na podejmowane decyzje i zajmowane przez UE stanowiska wobec kluczowych zagadnień stosunków międzynarodowych. $Z$ drugiej nie należy zapominać, że członkostwo może ograniczać swobodę działania w niektórych, bardzo istotnych obszarach funkcjonowania państwa, dotykających jego partykularnych interesów. Doświadczenie pokazuje, że realizacja wspólnej polityki w takim przypadku jest niezwykle trudna. Bardzo dobrym tego przykładem może być chociażby bezpieczeństwo energetyczne.

Osobnym zagadnieniem jest udział w akcjach o charakterze wojskowym, nawet jeżeli ma on wymiar wyłącznie humanitarny lub związany jest z działaniami typu peace-keeping. Do tej pory szukano rozwiązań w postaci tzw. podwójnej strategii, w myśl której państwo neutralne deklarowało ogólne poparcie dla działań w ramach WPZiB, choć samo wstrzymywało się od konkretnych deklaracji. Ograniczały się one jedynie do zgody na tranzyt wojskowych transportów i udostępnienie przestrzeni powietrznej ${ }^{93}$. Pewne zmiany w tym względzie przyniosła decyzja Rady Europejskiej z Kolonii z 2-4 czerwca 1999 r. Uznano wówczas oficjalnie, że członkostwo w Unii nie kłóci się z neutralnością i nie wymaga jej ograniczania ${ }^{94}$. Zapis ten, ze względu na brak precyzji, pozostawiał szeroki margines interpretacji i nie rozwiał całkowicie wątpliwości związanych ze współdziałaniem państwa neutralnego w ramach WPZiB. Rząd odniósł się do tego problemuw sprawozdaniu dotyczącym polityki europejskiej, które opublikowane zostało w roku 2006. Stwierdza w nim, iż w świetle aktualnego wymiaru WPZiB status neutralności, przy zachowaniu drobnych zastrzeżeń związanych z udziałem w akcjach militarnych, stosowaniem sankcji lub wspólnej obrony, nie stanowi przeszkody na drodze do członkostwa w UE. Zaznaczono jednak, że sytuacja może ulec zmianie w przypadku podpisania projektowanego już wówczas traktatu ustanawiającego konstytucje dla UE95.

${ }^{93}$ Problem neutralności omawiany jest szerzej również w rządowym sprawozdaniu: Europabericht 2006..., s. 6979-6981.

${ }^{94}$ Zob. więcej D. Popławski, Neutralność jako podstawa zinstytucjonalizowanej wspótpracy wielostronnej w Europie, [w:] S. Parzymies, R. Zięba (red.), Instytucjonalizacja wspótpracy międzynarodowej w Europie, Warszawa 2004.

${ }^{95}$ Europabericht 2006..., s. 6980-6981. 
Traktat Lizboński wprowadził sporo modyfikacji w obszarze WPZiB, jednak zasadniczy charakter współpracy został zachowany. Nadal dopuszcza możliwość odstąpienia przez dane państwo od niektórych działań. W traktacie zapisana jest, co prawda, zasada solidarnej pomocy, ale odnosi się ona głównie do katastrof naturalnych lub zamachów terrorystycznych ${ }^{96}$. W pozostałych przypadkach państwo neutralne ma możliwość ograniczenia udzielanej pomocy do działań humanitarnych bądź stricte dyplomatycznych, tj. mediacji, rozwiązywania sporów. Ewentualny udział w misjach pokojowych może być również uzależniony od wydania odpowiedniej rezolucji ONZ. Z kolei zasada wspólnej obrony wymaga jednomyślnej zgody wszystkich członków UE. Warunkiem podjęcia takiej decyzji przez Szwajcarię byłoby przeprowadzenie referendum w tej sprawie ${ }^{97}$. Jak wiadomo, państwo neutralne winno utrzymywać bezstronność w konflikcie międzynarodowym, trudno jednak przewidzieć, jak zagłosują obywatele w sytuacji bezpośredniego zagrożenia bezpieczeństwa. Należy wziąć pod uwagę również presję polityczną ze strony innych państw w przypadku niezaangażowania Szwajcarii w ewentualny konflikt. Są to jednak rozważania na wysokim poziomie abstrakcyjności.

Powyższe zasady wynikają przede wszystkim z założenia, że podstawowym gwarantem bezpieczeństwa w Europie pozostaje NATO, a nie Unia Europejska. We wspomnianym już sprawozdaniu z sierpnia 2010 r. rząd jednoznacznie podkreśla, że nowe zapisy dotyczące WPZiB nie stanowią przeszkody dla państw neutralnych ${ }^{98}$. Niemniej jednak proponuje się, aby w przypadku przystąpienia do Unii Europejskiej złożyć dodatkową deklarację neutralności, która precyzowałaby zakres zobowiązań Szwajcarii w ramach WPZiB ${ }^{99}$. Chodzi tutaj o jednoznaczne nakreślenie jej stanowiska wobec zagadnień związanych z bezpieczeństwem UE. Miałoby to wzmocnić wizerunek Szwajcarii jako partnera, przede wszystkim przewidywalnego, a jednocześnie usprawiedliwić określone postawy i działania w przyszłości. Taka deklaracja byłaby również cennym kontrargumentem dla przeciwników integracji. Inną propozycją jest zawarcie osobnej umowy dwustronnej miedzy Szwajcarią a Unią Europejską, która gwarantowałaby poszanowanie statusu neutralności tego państwa ${ }^{100}$. W przeszłości taki dokument podpisany został przez Irlandię, w przededniu referendum w sprawie Traktatu Lizbońskiego.

Można zatem skonstatować, iż obszar bezpieczeństwa nie stanowi formalnej przeszkody dla członkostwa Szwajcarii w UE, tym bardziej że istniejące regulacje dopuszczają spory margines swobody dla państw, które ze względu na swój status nie mogą lub nie chcą wyrazić zgody na bezwarunkowy udział w WPZiB. Kwestia ta jest zresztą elementem szerszej dyskusji nad formą integracji związanej z koncepcjami Europy tzw. różnych prędkości, zmiennej geometrii lub a la carte.

${ }^{96}$ Chyba że za przeprowadzenie zamachu odpowiedzialne będzie konkretne państwo. W takim przypadku możemy mieć do czynienia z typowym konfliktem międzypaństwowym.

${ }^{97}$ Zgodnie z postanowieniem konstytucji art. 140 ust. 1.

${ }^{98}$ Bericht des Bundesrates über die Evaluation..., s. 7.

${ }^{99}$ Ibidem, s. 89.

${ }^{100}$ Ibidem. 
Od tego, jaki kierunek rozwoju przyjmie w przyszłości UE, zależeć będzie wymiar funkcjonowania $w$ jej ramach państw neutralnych. Jeżeli poziom integracji zostanie wzmocniony na tyle, iż państwa członkowskie będą mogły prowadzić własną politykę w skrajnie ograniczonym zakresie, Szwajcaria będzie zmuszona, o czym wspomina się również w rządowym raporcie ${ }^{101}$, do redefinicji własnej strategii politycznej. Wówczas konieczna będzie odpowiedź na pytanie, jakie formy budowy bezpieczeństwa państwa są najwłaściwsze - neutralność czy integracja.

\subsubsection{WYMIAR EKONOMICZNY}

Przystąpienie do Unii Europejskiej z pewnością będzie odczuwalne również w wymiarze ekonomicznym. Trudno obecnie określić dokładne konsekwencje integracji, ponieważ w dużym stopniu będą one uzależnione od kondycji całej unijnej gospodarki. Kryzys gospodarczy, który rozpoczął się w roku 2008 pokazał jak silne są współzależności pomiędzy poszczególnymi członkami UE. Biorąc jednakże pod uwagę obecny poziom integracji i obszary, które już są lub w niedalekiej przyszłości zostaną uregulowane na drodze umów bilateralnych, wydaje się, iż za przystąpieniem do UE nie będą przemawiały argumenty ekonomiczne. Szczególnie że - jak pokazuje praktyka - członkostwo w UE nie stanowi dla Szwajcarii gwarancji jej ekonomicznego rozwoju.

Konsekwencje przystąpienia do Unii Europejskiej będą odczuwalne zarówno na poziomie czysto gospodarczym, jak i finansowo-bankowym. Warto w pierwszej kolejności przyjrzeć się efektom związanym z włączeniem Szwajcarii do wspólnotowego rynku. Umowy bilateralne już teraz umożliwiają swobodny handel niektórymi grupami towarów (głównie przemysłowymi) oraz zapewniają obywatelom możliwość osiedlania się i podejmowania pracy na terenie państw UE. Bez wątpienia jednak sporo barier taryfowych i pozataryfowych, zwłaszcza w obszarze rolno-spożywczym, nadal utrudnia wzajemną wymianę handlową. Ponadto do tej pory nie udało się osiągnąć kompromisu w sprawie wprowadzenia swobody przepływu usług. Pozostaje oczywiście pytanie, na ile całkowite otwarcie rynków byłoby korzystne dla szwajcarskiej gospodarki. Nie ulega wątpliwości, że niektóre branże muszą być objęte określonymi instrumentami ochronnymi. W przeciwnym razie nie byłyby w stanie sprostać zagranicznej konkurencji. Ponadto przystąpienie do UE wymusi na Szwajcarii ujednolicenie polityki gospodarczej wobec państw trzecich. Może to oznaczać utrudnienia w handlu z partnerami nienależącymi do Unii.

Całościowa analiza bilansu zysków i strat wypada jednak korzystnie. Według analiz przeprowadzonych przez UBS w roku 2000, w ciągu trzech pierwszych lat po przystąpieniu do UE należy spodziewać się delikatnego spowolnienia gospodarczego $^{102}$. Jednakże w dłuższej perspektywie gospodarka powinna rozwijać się

${ }^{101}$ Ibidem.

${ }^{102}$ Alleingang - Bilaterale Verträge - EU-Beitritt. Implikationen für die Schweizer Wirtschaft und den Finanzplatz Schweiz, „UBS Group Economic Research Studies”, April 2000, s. 8. 
szybciej niż w przypadku kontynuacji współpracy na poziomie bilateralnym, a to głównie za sprawą deregulacji rynków. Nie wszystkie branże w równym stopniu odczują konsekwencje integracji. Wpływał będzie na to stopień uzależnienia od popytu wewnętrznego oraz instrumenty ochronne, jak cła lub dopłaty eksportowe. Biorąc jednak pod uwagę fakt, że gospodarka Szwajcarii jest w znacznym stopniu uzależniona od eksportu, niewiele branż odczuje negatywne konsekwencje przystąpienia do Unii Europejskiej. Zdecydowanie największym przegranym będzie sektor rolno-spożywczy, który najboleśniej odczuje zniesienie dopłat eksportowych i ceł importowych. Jak już wcześniej wspomniano, rząd od pewnego czasu wdraża reformę rolną mającą zmienić charakter gospodarstw wiejskich, m.in. zakłada się likwidację małych, nierentownych gospodarstw na rzecz większych, a przez to bardziej wydajnych i konkurencyjnych. Być może do czasu przystąpienia do UE będzie widać już pierwsze, wymierne efekty tych działań, dzięki czemu rolnicy szwajcarscy będą lepiej przygotowani na unijną konkurencję. Do grupy tzw. wygranych możemy z kolei zaliczyć branżę maszynową i motoryzacyjną, tekstylną oraz zegarmistrzowską ${ }^{103}$. Także sektor bankowy powinien skorzystać z integracji rynków, aczkolwiek kwestia tajemnicy bankowej może być źródłem wielu problemów ${ }^{104}$. Integracja nie będzie miała również większego znaczenia dla dużych koncernów, które od lat obecne są na zagranicznych rynkach i doskonale radzą sobie $\mathrm{z}$ istniejącymi obecnie barierami.

Członkostwo w Unii Europejskiej przyniesie spore zmiany w sektorze finansowym. Przede wszystkim rząd Szwajcarii będzie zmuszony do wyrównania poziomu stóp procentowych, co oznacza w praktyce ich podniesienie. Może to skutkować spadkiem inwestycji krajowych i zagranicznych, z uwagi na wzrost kosztów kredytu. Tym samym zmniejszy się również atrakcyjność franka szwajcarskiego dla kredytobiorców. W związku z tym należy się spodziewać czasowego spowolnienia dynamiki wzrostu gospodarczego.

$\mathrm{Na}$ koniec warto wspomnieć o bezpośrednich konsekwencjach integracji dla budżetu państwa. Od momentu przystąpienia do UE Szwajcaria stanie się płatnikiem netto. Corocznie będzie zmuszona wpłacać do unijnej kasy ok. 3,5 mld franków. Całkowite koszty członkostwa, uwzględniające m.in. wydatki związane $\mathrm{z}$ wdrażaniem unijnego prawodawstwa, zniesienie ceł, realizację programów i polityk UE oraz inne wydatki administracyjne, mogą wynieść nawet nieco ponad 5 mld franków. Część tej kwoty zostanie zrekompensowana w postaci dodatkowych wpływów budżetowych z tytułu wyższej stawki VAT. Zostanie ona podwyższona $z$ obecnych 7,5 do $15 \%$. Trudno jednak przewidzieć dziś ostateczny bilans zysków i strat związanych ze zmianą stawek podatkowych.

${ }^{103}$ Pełna lista zob. ibidem, s. 17

${ }^{104}$ Autorzy raportu UBS wskazują jednak, iż podobny system tajemnicy bankowej funkcjonuje w Austrii i Luksemburgu. Sugeruje się zatem, że obecne naciski Komisji Europejskiej na Szwajcarię są pewnego rodzaju demagogią. 


\subsubsection{ALTERNATYWNE FORMY INTEGRACJI}

W oficjalnych dokumentach rządowych, jak i literaturze przedmiotu, odnaleźć można propozycje wypracowania z Unią Europejską czegoś na kształt umowy ramowej lub stowarzyszeniowej ${ }^{105}$. Wielokrotnie sprawą tą zajmował się również parlament szwajcarski ${ }^{106}$. Posłowie z różnych opcji politycznych nieraz występowali z interpelacjami dotyczącymi zbadania celowości i wykonalności umowy ramowej ${ }^{107}$. Nie spotkały się one jednak z konkretną odpowiedzią ze strony rządu, choć potwierdzano potrzebę sporządzenia osobnego sprawozdania w tej sprawie. Entuzjastą podpisania takiego porozumienia była m.in. szefowa szwajcarskiej dyplomacji - Micheline Calmy-Rey. Według niej dokument ten nadawałby współpracy bilateralnej konkretne ramy prawne ${ }^{108}$. Miałby więc charakter umowy horyzontalnej, ułatwiającej sprawne zarządzanie istniejącymi porozumieniami. Kładłby zarazem nacisk na ustanowienia stałego dialogu pomiędzy Szwajcarią a UE, który sprzyjałby płynnej wymianie informacji oraz zrozumieniu interesów i potrzeb drugiej strony.

Z umową ramową najczęściej wiąże się propozycję powołania centralnej instytucji koordynującej, która miałaby uporządkować i zharmonizować prace poszczególnych komisji mieszanych. Takie gremium, aby spełniało swoją funkcję, powinno składać się z przedstawicieli wyższego szczebla administracji państwowej (ministrów oraz komisarzy europejskich), wspieranych przez ekspertów z danej dziedziny i przedstawicieli środowisk pozarządowych (związki zawodowe, izby przemysłowo-handlowe). Pojawiał się również pomysł stworzenia osobnego ciała, w pełni niezależnego i odpolitycznionego, dla rozstrzygania sporów pomiędzy stronami.

W sprawie umowy ramowej stanowisko zajęła również Konferencja Rządów Kantonalnych $(\mathrm{KdK})$. Zdaniem kantonów podstawowym celem takiego dokumentu powinno być klarowne uregulowanie kwestii transponowania prawa UE, a także zinstytucjonalizowania dialogu politycznego. KdK jest nawet zdania, że negocjacje dotyczące umowy ramowej powinny mieć pierwszeństwo w stosunku do nowych umów bilateralnych ${ }^{109}$, pod warunkiem jednakże przeprowadzenia najpierw reform wewnętrznych, tj. konsolidacji federacyjnej organizacji państwa.

${ }^{105}$ Zob. Europabericht 2006..., s. 6830, 6837; Aussenpolitischen Bericht vom 2. September 2009, BBI 2009/6333.

${ }^{106}$ Zob. sprawozdanie komisji spraw zagranicznych rady kantonalnej: Bericht der APK des Ständerates vom 18. März 2002 über die Optionen der schweizerischen Integrationspolitik, BBI 2002/1905, s. 6326.

107 Zob. Interpellation Polla Barbara vom 21. Juni 2002. Verbesserung der Beziehungen Schweiz/EU, „Amtliches Bulletin der Bundesversammlung”, 02.3374; Postulat Stähelin Philipp, Rahmenvertrag zwischen der Schweiz und der EU vom 5. Oktober 2005, „Amtliches Bulletin der Bundesversammlung”, 05.3564; Interpellation Fehr Hans-Jürg. Wie weiter mit der EU?, 18. März 2009, „Amtliches Bulletin der Bundesversammlung”, 09.3172; Interpellation Riklin Kathy. Rahmenabkommen mit der EU versus EWR, „Amtliches Bulletin der Bundesversammlung”, 10.3211.

${ }^{108}$ Funkcję umowy ramowej mogłaby spełniać umowa o wolnym handlu z roku 1972, jednak nie uwzględnia ona stałego, politycznego dialogu, o który najbardziej tutaj chodzi.

${ }^{109}$ Bericht des Bundesrates über die Evaluation..., s. 70. 
Obecnie koncepcję zawarcia umowy ramowej możemy uznać za raczej mało realną. Dla Szwajcarii oznaczałoby to de facto włączenie do Europejskiego Obszaru Gospodarczego (EOG) w wersji light, czyli bez wprowadzenia swobody przepływu usług, ale już z koniecznością podporządkowania się ponadnarodowym organom, które byłyby władne rozstrzygać w przypadku ewentualnych sporów pomiędzy stronami. Ponadto Unia Europejska wielokrotnie wyrażała zainteresowanie podpisaniem takiego dokumentu. Nie podjęto jednak żadnych konkretnych decyzji ${ }^{110}$. Ponadto KE wysyła, jak na razie jasne, sygnały, iż nie ma miejsca na tworzenie kolejnych precedensów dla Szwajcarii. Już obecne relacje stanowią szczególny przypadek w stosunkach Unii z krajami trzecimi. Władze w Brukseli obawiają się, że mogłoby to wywołać postawy rewizjonistyczne wśród obecnych członków Wspólnoty, a także państw, które do niej aspirują.

Pojawia się również pomysł zawiązania unii celnej, ewentualnie powrotu do koncepcji włączenia Szwajcarii do Europejskiego Obszaru Gospodarczego. Wydaje się jednak, że obie propozycje nie znajdują obecnie zainteresowania żadnej ze stron ${ }^{111}$, tym bardziej że Unia Europejska ma już za sobą negatywne doświadczenia z próby wprowadzenia unii celnej z Turcją ${ }^{112}$.

Podsumowując, jak na razie nie należy spodziewać się przełomowych decyzji w tym względzie, chociażby z uwagi na czekające Szwajcarię w najbliższych latach dość wrażliwe społecznie głosowania, które mogą bezpośrednio lub pośrednio wpływać na relacje ze Wspólnotą. Chodzi tu m.in. o rozszerzenie swobody przepływu osób na Chorwację (referendum możliwe w połowie 2014 r.), inicjatywę konstytucyjną Ecopop (dotyczącą redukcji imigracji niemal do zera), decyzję w sprawie wyasygnowania dodatkowych środków na wsparcie unijnej polityki spójności czy wreszcie wybory parlamentarne w $2015 \mathrm{r}$. Sprawy te mogą ograniczyć chęć rządu szwajcarskiego do podejmowania odważniejszych decyzji w relacjach z UE.

W świetle prac nad Traktatem Lizbońskim pojawiło się sporo wątpliwości dotyczących kształtu i kierunków rozwoju Unii Europejskiej w najbliższej przyszłości. Spór dotyczy przede wszystkim stopnia integracji, szczególnie w obszarze WPZiB. Coraz realniejsze wydają się zatem postulaty usankcjonowania rozwiązań bardziej elastycznych, a więc takich, które będą, po pierwsze, umożliwiały rezygnację z transponowania części dorobku prawnego Wspólnoty,

${ }^{110}$ Stanowisko w tej sprawie zajął między innymi Parlament Europejski, zob. Rezolucja Parlamentu Europejskiego z dnia 7 września 2010 r. w sprawie EOG i Szwajcarii: Przeszkody w petnej realizacji rynku wewnętrznego, INI/2009/2176.

${ }^{111}$ Propozycji włączenia Szwajcarii do EOG sprzeciwia się m.in. KdK. Zob. Europapolitische Standortbestimmung der Kantonsregierungen vom 25. Juni 2010, s. 1, dokument dostępny pod adresem: http://www.kdk.ch/int/kdk/de/mm.ParagraphContainerList.ParagraphContainer0.ParagraphList.0026.File.pdf/20100625.pdf (04.11.2010).

${ }^{112}$ M. Vahl, N. Grolimund, op. cit., s. 127. 
a po drugie, zachowanie większej suwerenności względem UE. Konsekwencją tego będzie najprawdopodobniej wykrystalizowanie Europy dwóch prędkości. Warto zresztą zauważyć, że Traktat Lizboński już teraz przewiduje możliwość zawarcia tzw. wzmocnionej współpracy w wybranych obszarach pomiędzy minimum dziewięcioma członkami UE. Szwajcaria może zatem wykorzystać ten moment, aby zaproponować Unii alternatywną formę integracji, przewidującą przede wszystkim luźniejsze formy współdziałania w obszarach szczególnie wrażliwych. Chodziłoby tutaj zatem o stworzenie czegoś pośredniego pomiędzy klasycznym członkostwem a typowymi umowami dotyczącymi współpracy międzypaństwowej.

Z punktu widzenia Szwajcarii możliwość wynegocjowania innych warunków członkostwa wydaje się wyjątkowo atrakcyjna. Pomijając aspekty WPZiB, które były już wcześniej omawiane, warto wspomnieć chociażby o polityce fiskalnej, monetarnej, socjalnej czy o ochronie środowiska. We wszystkich tych obszarach Szwajcarii będzie zależało na zachowaniu większej niezależności. Wiadomo, iż w zakresie podatków pośrednich (wspomnianego już podatku VAT) pole manewru jest niewielkie, choć niektóre państwa stosują pewne wybiegi techniczne, aby utrzymać niższe opodatkowanie wybranych grup produktów. Nadal dyskusyjna jest sprawa dyrektywy oszczędnościowej UE, która przewiduje automatyczną wymianę informacji o kontach cudzoziemców.

Na poziomie bilateralnym udało się wypracować dość atrakcyjne warunki, które jednakże w przypadku przystąpienia do Unii będą najprawdopodobniej renegocjowane ${ }^{113}$. Dobrym tego przykładem jest kwestia podatków kantonalnych. Szwajcarii zarzuca się działanie niezgodne z zasadą swobodnej konkurencji. Jak na razie rząd szwajcarski umiejętnie odpiera zarzuty Brukseli. Sprawa zapewne byłaby jednym z głównych tematów przy okazji negocjacji akcesyjnych. Interesująca jest również problematyka wprowadzenia unijnej waluty, wiążącej się nierozerwalnie z wprowadzeniem wspólnej polityki monetarnej. Jak wiadomo, nie we wszystkich państwach UE obowiązuje euro. Część z nich, tak jak Wielka Brytania i Dania, świadomie odmówiły przyjęcia wspólnej waluty. W przypadku pozostałych państw przesądziły względy obiektywne, związane z koniecznością spełnienia tzw. kryteriów konwergencji. Szwajcaria bez problemów spełnia wszelkie wymagania niezbędne, aby wprowadzić euro. Wydaje się jednak, iż władze szwajcarskie najchętniej nie rezygnowałyby z rodzimej waluty, zwłaszcza, że to jej m.in. gospodarka zawdzięcza swój rozwój. Niezbyt entuzjastycznie odnosi się też do konieczności ograniczenia kompetencji Banku Narodowego, o czym była już mowa wcześniej. W zakresie polityki socjalnej Szwajcaria może liczyć na specjalne regulacje dotyczące Karty Praw Podstawowych, o ile nie będą one bezpośrednio związane z realizacją umowy o swobodzie przepływu osób.

${ }^{113}$ Austria i Luksemburg wynegocjowały korzystne okresy przejściowe na wdrażanie dyrektywy oszczędnościowej. 
Pozytywna ocena dotychczasowych relacji pomiędzy Unią Europejską a Szwajcarią świadczy o słuszności wyboru drogi bilateralnej. Rząd w Bernie oficjalnie obstaje przy jej kontynuacji, dlatego nie należy się spodziewać, aby w najbliższym czasie zaszły większe zmiany. Wszystkie przedstawione wyżej scenariusze rozwoju polityki Szwajcarii wobec UE można uznać za z pewnością realne, jednak nie należy zapominać, że to, która opcja ostatecznie zostanie wybrana, zależy w dużej mierze od stanowiska Unii Europejskiej. Ta, jak na razie, nie wywiera szczególnego nacisku na Szwajcarię, choć w ostatnim czasie można zauważyć pewne zniecierpliwienie ze strony przedstawicieli UE ${ }^{114}$. Należy jednak zauważyć, że Wspólnota przeżywa obecnie kryzys gospodarczy i tożsamościowy. W kolejce do członkostwa czekają takie państwa, jak Turcja, Macedonia czy Albania $^{115}$, a więc kraje o zróżnicowanym poziomie rozwoju gospodarczego i relatywnie niższym poziomie stabilności politycznej. Najbliższe rozszerzenie Unii będzie zatem ogromnym wyzwaniem. Może nie dotyczy to tylko Islandii, która jako członek Europejskiego Obszaru Gospodarczego oraz strefy Schengen znajduje się w lepszej sytuacji. Wysiłki UE będą zatem koncentrowały się na współpracy z obecnymi kandydatami, a kwestia ewentualnego przystąpienia do niej Szwajcarii siłą rzeczy zostanie odsunięta w czasie.

${ }^{114}$ Zob. wystąpienie wiceprzewodniczącej Komisji Europejskiej Viviane Reding, Die Zeit des bilateralen Weges ist vorbei, „Neue Zürcher Zeitung”, 12. November 2010.

${ }^{115}$ Do krajów kandydujących zaliczamy Chorwację, Byłą Jugosłowiańską Republikę Macedonii, Albanię, Bośnię i Hercegowinę, Czarnogórę, Serbię, Kosowo w rozumieniu rezolucji Rady Bezpieczeństwa Narodów Zjednoczonych nr 1244 oraz Turcję. Raport Komisji Europejskiej z listopada 2010 r. na temat rozszerzenia nie porusza kwestii współpracy ze Szwajcarią. 



\section{ZAKOŃCZENIE}

Polityka Szwajcarii wobec UE jest przede wszystkim elementem nowej strategii w budowaniu relacji zewnętrznych zarówno wobec pojedynczych państw, jak i międzynarodowych organizacji. W przypadku tych ostatnich zauważyć możemy powolne odejście od dualistycznej koncepcji podziału na organizacje o charakterze technicznym i politycznym, sprowadzającej się do negacji współpracy wychodzącej poza sferę stricte gospodarczą. Innymi słowy poluzowaniu uległa restrykcyjna wykładnia doktryny neutralności, obowiązująca w zasadzie do początku lat 90. ubiegłego wieku. Upadek systemu bipolarnego wymusił rewizję przyjętej strategii politycznej, czego bezpośrednim efektem było zwrócenie się Szwajcarii ku forom międzynarodowej współpracy, których do niedawna zdecydowanie unikano.

Nowa polityka zagraniczna uwarunkowana jest szeregiem czynników wewnętrznych i zewnętrznych, jednakże ich analiza skłania do konkluzji, iż to właśnie te pierwsze w szczególny sposób wpływają na realizację określonej koncepcji politycznej rządu Szwajcarii. Nakreślone na początku lat 90. strategie zostały dość szybko zweryfikowane, głównie za sprawą instrumentów demokracji bezpośredniej. Odrzucenie wniosku w kwestii włączenia Szwajcarii do Europejskiego Obszaru Gospodarczego oddaliło perspektywę przystąpienia do Unii Europejskiej. Od tego momentu, bez wątpienia przełomowego, polityka rządu wobec Wspólnoty siłą rzeczy stała się bardziej asekuracyjna i jakby celowo niedookreślona. Musiała bowiem w pierwszej kolejności uwzględniać nastroje opinii publicznej, dalece bardziej sceptycznie nastawionej do zacieśnienia współpracy z UE. Możemy zatem tutaj wyodrębnić trzy zasadnicze etapy w określaniu polityki wobec Wspólnoty. Pierwszy to wizja szybkiej integracji, obowiązująca od końca lat 80. do czasu głosowania w sprawie EOG, kiedy rząd żywił przekonanie, że społeczeństwo podziela w tej sprawie wizję elit politycznych. Drugi opiera się na idei określenia członkostwa w UE jako celu strategicznego. Integracja miała być wówczas jedynie odsunięta w czasie, ale pozostała nadal celem polityki europejskiej. Trzeci etap uległ wykrystalizowaniu w pierwszej dekadzie wieku XXI, głównie za sprawą, nieoczekiwanego przez żadną ze stron, wymiaru i znaczenia umów bilateralnych. Okazało się wówczas, że bilateralizm, uznawany początkowo za etap przejściowy, doprowadził do stworzenia precedensu w relacjach Unii z państwem trzecim, który - jak do tej pory, mimo drobnych „zgrzytów” - spełnia oczekiwania i zaspokaja potrzeby obu partnerów. Przyjęta przez rząd koncepcja współpracy z Unią Europejską miała więc charakter dynamiczny. 
Wyłania się nam zatem obraz polityki, która była bardziej wyrazem woli elit politycznych niż społeczeństwa, wyraźnie niegotowego na tak radykalny zwrot w polityce zagranicznej. Hołubiona do niedawna bezstronność, granicząca z izolacjonizmem, stała się nagle tylko jednym z elementów koncepcji bezpieczeństwa i budowy relacji zewnętrznych. Obywatele wyraźnie nie utożsamiali się z takim wizerunkiem państwa, czego wyraz dali we wspomnianym już referendum.

Równie istotnym czynnikiem wewnętrznym, wpływającym na kształt polityki zagranicznej, jest kwestia instytucjonalnej gotowości Szwajcarii do zacieśnienia współpracy ze Wspólnotą. Polityka europejska, w nowym wymiarze, uwidoczniła problemy związane $\mathrm{z}$ funkcjonowaniem ośrodków decyzyjnych, w tym również w relacjach pomiędzy władzami federalnymi a kantonalnymi. Okazało się, że zarówno na obecnym poziomie współpracy z UE, jak i w przypadku pełnej integracji, mamy do czynienia ze sporem kompetencyjnym. Kantony, odpowiedzialne za realizację polityki rządu, nie dysponują realnymi instrumentami oddziaływania na jej kształt. Konstytucja z roku 1999 formalnie wzmocniła pozycję kantonów. Nie przyznaje im jednak żadnych realnych kompetencji, ograniczając je jedynie do możliwości wyrażania własnego, lecz pozbawionego charakteru wiążącego, stanowiska. Jest to tym istotniejsze, iż umowy bilateralne nie mają tak statycznego charakteru jak początkowo sądzono. Wymagają bowiem ciągłego dostosowywania do dynamicznie rozwijającego się prawa wspólnotowego.

Także i w tym obszarze pojawia się ponownie kwestia demokracji bezpośredniej, dla której, w perspektywie ścisłej integracji ze Wspólnotą, najprawdopodobniej nie będzie już miejsca, przynajmniej w dotychczasowym wymiarze. Problem ten pojawia się zwłaszcza w przypadku konieczności transponowania prawa UE. Wówczas, charakterystyczny dla procesu decyzyjnego w Szwajcarii, etap tzw. konsultacji społecznych zostanie zmarginalizowany, o ile w ogóle nie zlikwidowany. Nie ulega zatem wątpliwości, że funkcjonowanie demokracji bezpośredniej ma ogromny wpływ na kształt obecnych relacji z UE, a jej znaczenie rośnie wprost proporcjonalnie do stopnia integracji. Należy podkreślić, że z jednej strony umożliwia obywatelom większe oddziaływanie na politykę rządu, z drugiej stanowić może istotne narządzie w rękach przeciwników integracji. Obecnie niemal każde nowe prawo lub umowa międzynarodowa, dzięki zebraniu odpowiedniej liczby podpisów, mogą zostać odrzucone przez społeczeństwo. Demokracja bezpośrednia spełnia więc funkcję barometru nastrojów społecznych, determinującego politykę rządu w sprawach europejskich.

W tej sytuacji władze Szwajcarii będą zmuszone do przeprowadzenia istotnych reform instytucjonalnych - przede wszystkim powinny rozwiązać kwestie kompetencyjne, wprowadzając takie rozgraniczenie władzy, które pozwoli utrzymać kantonom realny wpływ na politykę rządu federalnego. Niezbędne będzie również usprawnienie procesu decyzyjnego, głównie w perspektywie ewentualnego członkostwa w UE. Można zatem skonstatować, że podstawową determi- 
nantą polityki Szwajcarii są, obok neutralności, zasadnicze atrybuty ustroju politycznego, tj. federalizm i demokracja bezpośrednia.

Charakterystyczną cechą polityki Szwajcarii wobec Unii jest z kolei fakt, że od dawna nie budzi ona większych kontrowersji w odniesieniu do najważniejszego założenia, jakim jest konieczność nawiązania ściślejszych relacji. Tutaj stanowisko obywateli, jak i szeroko rozumianych elit politycznych, pozostaje zbieżne. Różnice widoczne są jedynie w doborze właściwych instrumentów budowy tej współpracy. Właśnie ów dobór instrumentów jest obecnie kluczowym elementem w strategii politycznej rządu, co świadczy przede wszystkim o pragmatycznym charakterze polityki wobec UE. Dyplomacja Szwajcarii stawia sobie za cel ochronę interesów gospodarczych i politycznych w sposób, który okaże się nie tylko skuteczny, ale również nie wywoła negatywnych reakcji ze strony opinii publicznej. Stąd wniosek, iż obecna polityka nie jest efektem określonej przez rząd i w dużym stopniu niezależnej strategii, lecz bardziej wynikiem społecznego kompromisu.

Aktualne sondaże wskazują, że poparcie dla włączenia Szwajcarii do Unii Europejskiej nadal nie jest wysokie. Także wśród środowisk, które określają się mianem euroentuzjastycznych, idea przystąpienia do UE nie znajduje jednakowo dużego poparcia. Częściej mówi się o szukaniu nowych rozwiązań w stosunkach dwustronnych, ewentualnie o rozszerzeniu współpracy na poziomie bilateralnym. Należy podkreślić, że dotychczasowych głosów dotyczących spraw europejskich nie można traktować jako barometru nastrojów społecznych wobec idei pełnej integracji. Do tej pory przeprowadzono bowiem w sumie aż pięć głosowań w tej sprawie, jednakże tylko jedno z nich (,Tak dla Europy”) dotyczyło stricte kwestii przystąpienia do UE. Warto przypomnieć, że wynik okazał się w tym przypadku dużym zaskoczeniem dla euroentuzjastów. Prawie $77 \%$ głosujących uznało, że podjęcie rozmów w sprawie akcesji do UE jest zdecydowanie przedwczesne. Wszystkie pozostałe referenda dotyczyły bieżących spraw, związanych z wdrażaniem umów bilateralnych, które - jak wiadomo - cieszą się ogólnym poparciem obywateli. Ocenia się, że gdyby obecnie przeprowadzono głosowanie w sprawie przystąpienia Szwajcarii do UE, wynik także byłby negatywny. Prawdopodobieństwo uzyskania podwójnej większości głosów (obywateli i kantonów) jest więc zbyt małe, aby rząd zdecydował się na „odmrożenie” wniosku akcesyjnego i ponowne przystąpienie do rozmów. Co ciekawe, krytyczną postawę wobec pełnej integracji ze Wspólnotą wykazują osoby pochodzące z różnych środowisk, o zróżnicowanym statusie materialnym i pochodzeniu. Zatarciu uległ typowy podział na konserwatywne kantony niemieckojęzyczne oraz otwarte na współpracę francuskojęzyczne. Podobne tendencje zauważyć można w przypadku terenów wiejskich oraz zurbanizowanych. Także młode pokolenia nie są tak entuzjastycznie nastawione wobec idei włączenia Szwajcarii do UE jak niegdyś. Widać zatem wyraźnie, że brak zdecydowanych działań rządu federalnego na rzecz włączenia do Wspólnoty wynika w dużym stopniu z niskiego poziomu poparcia społecznego. 
Pragmatyczna polityka władz Szwajcarii w stosunku do Unii Europejskiej przynosi zadowalające efekty. Gospodarka kraju rozwija się, rosną obroty handlowe z państwami UE, bezrobocie utrzymuje się na bezpiecznym poziomie, pomimo zapaści na wielu europejskich rynkach. Umowy bilateralne, podpisane w 1999 oraz 2004 r. stały się skutecznym narzędziem w budowie właściwych relacji gospodarczych. Ściślejsza integracja nie miałaby więc większego znaczenia - to co udało się osiągnąć na obecnym poziomie, zabezpiecza najważniejsze interesy ekonomiczne. Rozpoczęto proces włączania Szwajcarii do wspólnotowego rynku. Realizacja zasady swobodnego przepływu osób nie napotyka na razie większych trudności, pomimo wielu obaw związanych z tzw. zasadą gilotyny, choć, zdaniem obserwatorów, to właśnie ona w dużym stopniu zaważyła na decyzji w sprawie otwarcia rynków pracy dla obywateli Bułgarii i Rumunii. Warto podkreślić, że wprowadzenie swobody przepływu osób nie było inicjatywą rządu Szwajcarii, lecz propozycją Komisji Europejskiej, będącą efektem doświadczeń w budowaniu współpracy wewnątrz Wspólnoty. Można zatem mówić o rozwiązaniu systemowym, stosowanym wobec wszystkich państw aspirujących do członkostwa w Unii Europejskiej. Umowy bilateralne stanowią bazę do dalszej integracji. Z powyższych uwag wolno zatem wysnuć wniosek, że zastosowana wobec Berna taktyka jest celowym posunięciem, mającym doprowadzić w konsekwencji do włączenia Szwajcarii w struktury UE. Z punktu widzenia Brukseli poszerzenie Wspólnoty o kraj z tak silną gospodarką i niezwykle stabilną politycznie strukturą państwową byłoby działaniem zapewne bardzo korzystnym.

W efekcie powstaje pytanie, jaki kierunek w polityce Szwajcarii wobec UE zostanie obrany w najbliższych latach? Oficjalne stanowisko rządu w tej sprawie, opublikowane w roku 2010, nie pozostawia co do tego wątpliwości. Bilateralizm określany jest ciągle jako najbardziej optymalny instrument w budowie wzajemnych relacji. Rząd obiecuje zakończenie trwających negocjacji oraz rozpoczęcie kolejnych, w kluczowych dla dwustronnych stosunków obszarach. W kolejce czekają chociażby sektor energetyczny oraz rolny. Coraz częściej mówi się także o potrzebie realizacji kolejnego elementu wspólnotowego rynku - swobodnego przepływu usług. Bilateralizm ogranicza również konieczność współfinansowania programów unijnych. Poza niemal niezauważalnym dla budżetu Szwajcarii wkładem w postaci dofinansowania niektórych projektów w państwach Europy Środkowowschodniej Berno nie ponosi w zasadzie żadnych kosztów związanych z funkcjonowaniem Unii. Umowy dwustronne, w przeciwieństwie do pełnego członkostwa, nie pociągają zatem za sobą poważniejszych zobowiązań.

Z drugiej strony cieniem na wzajemnych relacjach odbija się kwestia kantonalnej polityki fiskalnej oraz systemu bankowego. Presja ze strony Komisji Europejskiej w tych dwóch obszarach nie maleje. Wręcz przeciwnie, część przedstawicieli gremiów unijnych uznaje je za argumenty przemawiające za wyczerpaniem się formuły współpracy bilateralnej i za koniecznością poszukiwania nowych rozwiązań. Najczęściej pada w tym miejscu propozycja powrotu do rozmów akcesyjnych. 
Rząd Szwajcarii nie jest jednak skłonny do podejmowania tego typu decyzji, przyjmując na razie strategię wyczekiwania. Prawdopodobnie potrwa ona dopóty, dopóki Unia nie zacznie stawiać zbyt wygórowanych żądań względem Szwajcarii, które sprawią, iż kontynuacja współpracy na obecnym poziomie okaże się niewygodna. Na korzyść utrzymania dotychczasowych rozwiązań przemawia jedynie fakt, że Wspólnota przeżywa obecnie kryzys gospodarczy i tożsamościowy. Traktat Lizboński wprowadził wiele istotnych zmian, głównie w kwestiach instytucjonalnych. Unia uzyskała podmiotowość międzynarodową, zmienił się system liczenia głosów w Radzie. Miną jednak lata, zanim wszystkie te zmiany wejdą w życie i będą realnie odczuwalne. Ponadto istotnym punktem dyskusji nad przyszłością Wspólnoty jest sprawa jej kolejnego rozszerzenia. Chęć włączenia do Unii zgłosiły takie kraje, jak Turcja, Macedonia czy Albania - państwa o zróżnicowanym poziomie rozwoju gospodarczego i relatywnie niższym poziomie stabilności politycznej. Najbliższe rozszerzenie jest zatem dla Unii ogromnym wyzwaniem. Naturalną tego konsekwencją będzie koncentracja uwagi władz unijnych na tym problemie, a kwestia ewentualnego przystąpienia Szwajcarii do UE siłą rzeczy zostanie odsunięta w czasie.

Warto podkreślić przewijający się w różnych analizach politologicznych argument o braku instytucjonalnej oraz mentalnej gotowości Szwajcarii do członkostwa w UE. Szczególne cechy ustrojowe tego kraju sprawiają, że integracja nastręcza wielu problemów natury instytucjonalnej, zwłaszcza w kwestiach podziału władzy oraz procesu decyzyjnego. Demokracja bezpośrednia, będąca niemal symbolem państwowości Szwajcarii, w perspektywie integracji wydaje się anachroniczna i nie przystająca do warunków, w jakich obecnie musi funkcjonować państwo. Wszystko wskazuje na to, że integracja europejska, bez względu na jej ostateczny kształt, będzie prowadziła do jednoczenia Europy, a państwa uczestniczące w tym procesie będą zmuszone do ustąpienia części swojej suwerenności. Będzie to oznaczało konieczność rezygnacji z niektórych kompetencji decyzyjnych na rzecz ponadnarodowego organu. W tej sytuacji tradycyjne dla Szwajcarii formy sprawowania władzy zostaną podważone lub w dużym stopniu ograniczone.

Na płaszczyźnie światopoglądowej społeczeństwo szwajcarskie również nie jest gotowe na pełną integrację. Przede wszystkim brakuje na to ogólnospołecznej zgody. Zgody, która ma kluczowe znaczenie w państwie konsensualnym.

Można zatem postawić tezę, że integracja europejska od samego początku nie mogła być celem samym w sobie. Szwajcarii, jako państwu neutralnemu, chodziło bardziej o przystosowanie się do nowych uwarunkowań geopolitycznych, będących efektem upadku bloku wschodniego i zjawisk integracyjnych zachodzących w Europie. Od zakończenia II wojny światowej polityka Szwajcarii w kwestiach europejskich dyktowana była przede wszystkim względami ekonomicznymi. Wszystkie wcześniejsze formy współpracy europejskiej, jak chociażby EFTA, miały służyć właśnie zagwarantowaniu najbardziej optymalnych warunków do 
rozwoju gospodarczego. Kwestie polityczne bądź ideologiczne, jak chociażby walka z komunizmem, były zepchnięte na dalszy plan. Tego wymagała doktryna Bindschedlera i tego także domagali się obywatele. Podobna strategia przyjęta została również wobec Unii Europejskiej, której istnienia nie można było negować. Rosnące znaczenie Wspólnoty, przy jednoczesnym osłabieniu EFTA, oznaczało konieczność określenia nowych ram współpracy i choć koncepcje dotyczące budowania określonych relacji ulegały na przestrzeni lat zmianom, jedna rzecz pozostała niezmienna. Szwajcaria zawsze kierowała się dwoma nadrzędnymi zasadami - bezstronnością oraz pragmatyzmem. W dobie zjawisk globalizacyjnych i zanikania tradycyjnych zagrożeń w postaci konfliktu międzynarodowego, neutralność przestaje jednak spełniać swoje funkcje, staje się bardziej ciężarem niż skutecznym instrumentem budowy bezpieczeństwa państwa. Pozostaje zatem pragmatyzm i to on jest kluczem do zrozumienia współczesnej polityki zagranicznej Szwajcarii, w tym również wobec Unii Europejskiej. 


\section{BIBLIOGRAFIA}

\section{DOKUMENTY}

60-Jahr-Jubiläum der diplomatische Beziehungen Schweiz-China, Medienmitteilung EDA, 13.09.2010.

Abkommen über wissenschaftlich-technische Zusammenarbeit zwischen der Schweizerischen Eidgenossenschaft einerseits und der Europäischen Gemeinschaft und der Europäischen Atomgemeinschaft andererseits, AS 2008/3237, SR-0.420.513.1.

Abkommen vom 21. Juni 1999 zwischen der Schweizerischen Eidgenossenschaft einerseits und der Europäischen Gemeinschaft und ihren Mitgliedstaaten andererseits über die Freizügigkeit, AS 2002/1529, SR-0.142.112.681.

Abkommen vom 21. Juni 1999 zwischen der Schweizerischen Eidgenossenschaft und der Europäischen Gemeinschaft über den Güter- und Personenverkehr auf Schiene und Strasse, AS 2002/2649, SR-0.740.72.

Abkommen vom 21. Juni 1999 zwischen der Schweizerischen Eidgenossenschaft und der Europäischen Gemeinschaft über den Handel mit landwirtschaftlichen Erzeugnissen, AS 2002/2147, SR-0.916.026.81.

Abkommen vom 21. Juni 1999 zwischen der Schweizerischen Eidgenossenschaft und der Europäischen Gemeinschaft über den Luftverkehr vom 21. Juni 1999, AS 2001/1705, SR-0.748 .127 .192 .68 .

Abkommen vom 26. Oktober 2004 über die Zusammenarbeit zwischen der Schweizerischen Eidgenossenschaft einerseits und der Europäischen Gemeinschaft und ihren Mitgliedstaaten andererseits zur Bekämpfung von Betrug und sonstigen rechtswidrigen Handlungen, die ihre finanziellen Interessen beeinträchtigen, AS 2009/1299, SR-0.351.926.81.

Abkommen vom 26. Oktober 2004 zwischen dem Schweizerischen Bundesrat und der Kommission der Europäischen Gemeinschaften zur Vermeidung der Doppelbesteuerung von in der Schweiz ansässigen ehemaligen Beamten der Organe und Agenturen der Europäischen Gemeinschaften, AS 2005/2187, SR-0.672.962.81.

Abkommen vom 26. Oktober 2004 zwischen der Schweizerischen Eidgenossenschaft, der Europäischen Union und der Europäischen Gemeinschaft über die Assoziierung dieses Staates bei der Umsetzung, Anwendung und Entwicklung des Schengen-Besitzstands, AS 2008/481, SR-0.362 .31 .

Abkommen vom 26. Oktober 2004 zwischen der Schweizerischen Eidgenossenschaft und der Europäischen Gemeinschaft über die Beteiligung der Schweiz an der Europäischen Umweltagentur und dem Europäischen Umweltinformations- und Umweltbeobachtungsnetz (EIONET), AS 2006/1111, SR-0.814.092.681.

Abkommen vom 26. Oktober 2004 zwischen der Schweizerischen Eidgenossenschaft und der Europäischen Gemeinschaft über die Kriterien und Verfahren zur Bestimmung des zuständigen Staates für die Prüfung eines in einem Mitgliedstaat oder in der Schweiz gestellten Asylantrags, AS 2008/515, SR-0.142.392.68. 
Abkommen vom 26. Oktober 2004 zwischen der Schweizerischen Eidgenossenschaft und der Europäischen Gemeinschaft über die Zusammenarbeit im Bereich der Statistik, AS 2006/5933, SR-0.431.026.81.

Abkommen vom 26. Oktober 2004 zwischen der Schweizerischen Eidgenossenschaft und der Europäischen Gemeinschaft über Regelungen, die den in der Richtlinie 2003/48/EG des Rates im Bereich der Besteuerung von Zinserträgen festgelegten Regelungen gleichwertig sind, AS 2005/2571, SR-0.641.926.81.

Abkommen vom 26. Oktober 2004 zwischen der Schweizerischen Eidgenossenschaft und der Europäischen Gemeinschaft zur Änderung des Abkommens zwischen der Schweizerischen Eidgenossenschaft und der Europäischen Wirtschaftsgemeinschaft vom 22. Juli 1972 in Bezug auf die Bestimmungen über landwirtschaftliche Verarbeitungserzeugnisse, AS 2005/1533, SR-0.632.401.23.

Abkommen zwischen der Schweizerischen Eidgenossenschaft und der Europäischen Gemeinschaft über bestimmte Aspekte des öffentlichen Beschaffungswesens, AS 2002/1951, SR-0.172 .052 .68 .

Ambühl M., Schweizerische Europapolitik als Teil der Aussenpolitik. Referat von Staatssekräter, Generalversammlung der Schweizerischen Gesellschaft, Bern, 16. Juni 2005.

Ambühl M., Zwischenbilanz Bilaterale I Schweiz-EU. Sprechnotiz, EDA, 3. November 2008.

Aussenpolitischer Bericht 2000 vom 15. November 2000, BBI 2001261.

Aussenpolitischer Bericht 2009 vom 2. September 2009, BBI 20096291.

Arbeit und Erwerb: Panorama, Bundesamt für Statistik, Februar 2010.

Änderungen im Ausländergesetz (Indirekter Gegenvorschlag zur Ausschaffungsinitiative). Stellungnahme der Schweizerischen Flüchtlingshilfe, Bern 2009.

Begleitmassnahmen zu einem Freihandelsabkommen im Agrar- und Lebensmittelbereich. Bericht $\operatorname{der} A G$ Begleitmassnahmen zuhanden des Eidgenössischen Volkswirtschaftsdepartements, Juli 2009, http://www.blw.admin.ch.

Bericht der APK des Ständerates vom 18. März 2002 über die Optionen der schweizerischen Integrationspolitik, BBI 2002/1905.

Bericht des Bundesrates über die Evaluation der schweizerischen Europapolitik, BBI 2010/1419.

Bericht des Bundesrates zu den Auswirkungen verschiedener europapolitischer Instrumente auf den Föderalismus in der Schweiz, BBI 20075907.

Bericht des Bundesrates zum Verhältnis der Schweiz zu den europäischen Agenturen, SR 10.088.

Bericht des Bundesrates zur Aussenwirtschaftspolitik 2006, Staatssekretariat für Wirtschaft SECO, Bern 2007.

Bericht über die Aussenpolitik der Schweiz in der 90er Jahren vom 29 November 1993, BBI 1994 I 153.

Bericht über die Legislaturplanung 2003-2007 vom 25. Februar 2004, BBI 20041149.

Bericht über die Stellung der Schweiz im Integrationsprozess, BBI 1988.

Bericht über die Umsetzung der Flankierenden Massnahmen zur Freizügigkeit im Personenverkehr, 1. Januar bis 31. Dezember 2008, SECO, 23. April 2009.

Bericht über einen Beitritt der Schweiz zur Europäischen Gemeinschaft, BBI 1992 III 1185.

Bericht über einen Beitritt der Schweiz zur Europäischen Union vom 18. Mai 1992, BBI 1992 III.

Bericht vom 24. August 1988 über die Stellung der Schweiz im europäischen Integrationsprozess, BBI 1988 III 370.

Beschlüsse der Gemischten Ausschüsse, źródło: http://www.admin.ch (29.07.2010).

Beteiligung der Schweiz am 7. Europäischen Forschungsrahmenprogramm, Zwischenbilanz 20072009, Staatssekretariat für Bildung und Forschung, Bern 2010.

Bezzola D., Dringliche Einfache Anfrage Auswirkungen des Schengener Abkommens auf den Schweizer Tourismus, „Amtliches Bulletin” 1997, Nr. 97.1172. 
Botschaft des Bundesrates zur Genehmigung der sektoriellen Abkommen zwischen der Schweiz und der EG, Bern 1999, BBI, Nr. 34.

Botschaft und Entwurf der Bundesbeschlüsse zur Genehmigung des Abkommens über die Teilnahme der Schweiz am EU-Programm ,Jugend in Aktion” und am EU-Aktionsprogramm im Bereich des lebenslangen Lernens (2007-2013) sowie zur Finanzierung der Teilnahme (2011-2013) vom 2. September 2009, BBI 2009, Nr. 39.

Botschaft über verschiedene bilaterale Abkommen über die polizeiliche und justizielle Zusammenarbeit mit Frankreich und Italien sowie zur Änderung des Bundesgesetzes über Aufenthalt und Niederlassung der Ausländer vom 14. Dezember 1998, BBI 1999, 1485.

Botschaft über verschiedene Vereinbarungen mit Deutschland sowie mit Österreich und dem Fürstentum Liechtenstein über polizeiliche und justitielle Zusammenarbeit vom 24. November 1999, BBI 2000862.

Botschaft zum Abkommen zwischen dem Schweizerischen Bundesrat und der Regierung der Republik Ungarn über die Zusammenarbeit bei der Bekämpfung der Kriminalität vom 23. August 2000, BBI 20004927.

Botschaft zur Genehmigung der bilateralen Abkommen zwischen der Schweiz und der Europäischen Union vom 1. Oktober 2004, BBI 2004, Nr. 44.

Botschaft zur Genehmigung des Abkommens über den Europäischen Wirtschaftsraum vom 18. Mai 1992, Bern 1992.

Botschaft zur Genehmigung des Protokolls zum Freizügigkeitsabkommen zwischen der Schweiz und EG vom 1. Oktober 2004, BBI 2004, Nr. 44.

Bundesbeschluss über Bau und Finanzierung von Infrastrukturvorhaben des öffentlichen Verkehrs vom 20. März 1998, AS 1999-4045.

Bundesbeschluss über die Finanzierung der Beteiligung der Schweiz an den Forschungs- und Bildungsprogrammen der Europäischen Gemeinschaften 1993-1996 vom 18. Dezember 1992, BBI 1993 I.

Bundesbeschluss über die Finanzierung der Beteiligung der Schweiz an den Programmen der EU im Bereich der Forschung, der technologischen Entwicklung und der Demonstration in den Jahren 2003-2006 vom 6. Juni 2002, BBI 200230.

Bundesbeschluss über die Legislaturplanung 2007-2011 vom 18. September 2008, BB1 20088543.

Bundesgesetz über die technischen Handelshemmnisse (THG) vom 6. Oktober 1995 (Stand am 1. Juli 2010), AS 1996/1725, SR-946.51.

Bundesgesetz über die Zusammenarbeit mit den Staaten Osteuropas vom 24. März 2006, AS 2007 2387.

Bundesgesetz vom 17. Dezember 2004 zum Zinsbesteuerungsabkommen mit der Europäischen Gemeinschaft (Zinsbesteuerungsgesetz, ZBstG), AS 2005/2558, SR-641.91.

Bundesgesetz vom 18. Juni 2004 über die Sammlungen des Bundesrechtes und das Bundesblatt, źródło: http://www.admin.ch/ch/d/sr/170_512/index.html.

Bundesgesetz vom 19. Dezember 1997 über eine leistungsabhängige Schwerverkehrsabgabe (Schwerverkehrsabgabegesetz, SVAG), AS 2000/98, SR-641.81.

Bundesrat beantragt Genehmigung des EU/Abkommens über Zollerleichterungen und Zollsicherheit, Medienmitteilung EDA, 27.11.2009.

Bundesrat beantragt Genehmigung eines bilateralen Bildungsabkommens mit der EU, Medienmitteilung EDA/EVD, 02.09.2008.

Bundesrat beschliesst Unterzeichnung des angepassten Güterverkehrsabkommens Schweiz - EU, Medienmitteilung EFD, 13.05.2008.

Bundesrat Didier Burkhalter unterzeichnet das Bildungsabkommen zwischen der Schweiz und der EU, Medienmitteilung EDI, 15.02.2010, źródło: www.europa.admin.ch.

Bundesrat erteilt Verhandlungsmandat für Verknüpfung mit EU-Emissionshandel, Medienmitteilung UVEK, 16.12.2009. 
Bundesrat setzt im Verhältnis zur EU auf Kontinuität und führt den bilateralen Weg fort, Medienmitteilung Integrationsbüro EDA/EVD, 19.08.2010.

Bundesratsbeschluss über das Ergebnis der Volksabstimmung vom 5. Juni 2005, źródło: www.europa.admin.ch.

Bundesverfassung der Schweizerische Eidgenossenschaft vom 18. April 1999, SR 101.

Busch R., Zusammenarbeit gegen Fiskaldelikte, Integrationsbüro EDA/EVD, 2009, Nr. II, s. 4.

Der Bundesrat will in die EU, Presse-Mitteilung der Auns, 7. Oktober 2009.

Der EU-Beitritt und die direkte Demokratie der Schweiz, Politische Kommission der Nebs, Thesenpapiere, źródło http://www.europa.ch/Files/pdf/gp_direkte_demokratie.pdf.

Der Schweizer Beitrag an die erweiterte Europäische Union: eine Zwischenbilanz, Miedienmitteilung EDA/EVD, Bern, 19. November 2010.

Dialog Steuerkontroverse: Drittes Treffen mit der EU-Kommission, Medienmitteilung EFD, 08.04.2008.

Die Bilaterale Abkommen Schweiz - EU, Integrationsbüro EDA/EVD, August 2009.

Die Bilateralen Abkommen Schweiz - Europäischen Union, Integrationsbüro EDA/EVD, November 2009.

Die Schweiz und die EU treffen sich im Europäischen Forschungsraum, Medienmitteilung SBF, 11.09.2009.

Diplomatische Dokumente der Schweiz (DoDiS), Schweizerisches Bundesarchiv, Bern (CH-BAR), źródło: www.dodis.ch.

Dublin-Abkommen: Positive Bilanz für die Schweiz, Medienmitteilung BFM, 07.04.2009.

Dyrektywa Rady z dnia 23 lipca 1990 roku w sprawie wspólnego systemu opodatkowania stosowanego w przypadku spółek dominujących i spółek zależnych różnych Państw Członkowskich, 90/435/EWG.

Dyrektywa Rady z dnia 3 czerwca 2003 r. w sprawie opodatkowania dochodów z oszczędności $w$ formie wyplacanych odsetek, 2003/48/WE.

EG-Chemikalienverordnung REACH: Handlungsbedarf für die Schweiz, Medienmitteilung Staatssekretariat für Wirtschaft, 29.10.2008.

Eidgenössische Volksinitiative „Für die Stärkung der Volksrechte in der Aussenpolitik (Staatsverträge vors Volk!)”, Bekanntmachung der Departemente und der Ämter, BBI 20092139.

Emissionshandel, Integrationsbüro EDA/EVD, Februar 2010.

Erläuterungen des Bundesrates. Volksabstimmung vom 25. September 2005, źródło: http://www. admin.ch.

Erläuterung zu den Bilateralen Abkommen II, Konferenz der Kantonsregierungen, 2004.

Erweiterungsbeitrag, Integrationsbüro EDA/EVD, August 2007.

Europabericht 2006 vom 28. Juni 2006, BB1 20066815.

Europapolitik der Schweiz: Die bilaterale Abkommen, Integrationsbüro EDA/EVD, Bern 2007.

Europapolitik: Erfolg durch Pragmatismus, Positionspapier der Economiesuisse, Zürich 2006.

Europapolitische Standortbestimmung der Kantonsregierungen vom 25. Juni 2010, http://www.kdk.ch.

Europäische Verteidigungsagentur (EVA): Bundesrat verabschiedet Verhandlungsmandat, Medienmitteilung VBS, 17.12.2009.

Fehr Hans-Jürg, Interpellation vom 18. März 2009: Wie weiter mit der EU?, „Amtliches Bulletin der Bundesversammlung", 09.3172.

Fehlende europapolitische Strategie! Stellungnahme der Neuen Europäischen Bewegung Schweiz zum Europabericht 2006, http://www.europa.ch/Files/pdf/pk_stellungnahme.pdf.

Föderalismusbericht, Integrationsbüro EDA/EVD, Juni 2007.

Freihandel mit der EU im Agrar- und Lebensmittelbereich: Arbeitsgruppe Begleitmassnahmen bestimmt, Medienmitteilung Generalsekretariat GS-EVD, 8. April 2008.

Freihandelsabkommen: Schweiz erfolgreich, Medienmitteilung SECO, 14.01.2009. 
Gasser P., Wirtschaftliche Probleme des Bilateralismus, Pressekonferenz „Europabericht 2006 des Bundesrates", Bern, 28. Juni 2006.

Gemeinsame Arbeitsgruppe Schweiz - EU soll institutionelle Fragen behandeln, Medienmitteilung $\mathrm{EDA} / \mathrm{EVD}$, źródło: http://www.news.admin.ch.

Golban R., Bilaterale Abkommen - eine Sackgasse!, Auns Klartext. Wer stoppt den IRRWEG?, November 2009, Nr. 133.

Grüezi in ,Schengen-Land”, Medienmitteilung EFD, 27.03.2009.

Im Kern der Schweizer Europapolitik, Integrationsbüro EDA/EVD, August 2009.

Informationsblatt Europabericht 2006, EDA/EVD, Bern 2006.

Informationsblatt Landverkehr, Integrationsbüro EDA/EVD, 2008.

Letzter Schritt der Schengen-Assoziierung: Neues Kontrollregime an den Schweizer Flughäfen, Medienmitteilung EJPD, 27.03.2009.

Leuthard D., Die wirtschaftliche Positionierung der Schweiz in Europa und in der Welt, EVD, Bern 4. Mai 2007.

Markwalder C., Der EU-Beitritt aus politischer Sicht und aus Bürgersicht, Pressekonferenz „Europabericht 2006 des Bundesrates", Bern, 28. Juni 2006.

Medienmitteilung vom 26. November 2006, Integrationsbüro EDA/EVD, źródło: www.bundesgesetzost.admin.ch.

Mehr Zuwanderung und Wachstum dank Personenfreizügigkeit, Medienmitteilung Staatssekretariat für Wirtschaft, 02.07.2009.

Monitoring. Bilaterale Abkommen I Schweiz - EU: Erste Erfahrungen ein Jahr nach Inkrafttreten, Integratonsbüro EDA/EVD, Bern, den 27. Mai 2003.

Müller W., Anfrage: Welche Aussenpolitik braucht die Schweiz?, „Amtliches Bulletin der Bundesversammlung" 2009, 09.1051.

Neue Art von Zuwanderung, Standpunkt der Wirtschaft, 21. Oktober 2008.

Organisationsverordnung für das Eidgenössische Departement für auswärtige Angelegenheiten vom 29. März 2000, źródło: http://www.admin.ch/ch/d/sr/1/a172_211_1.html.

Patterson B., Steuerkoordinierung in der EU: der neueste Stand, Generaldirektion Wissenschaft des Europäisches Parlaments, ECON 128, PE 312.788/2008.

Pressekonferenz des Bundesrates vom 04.07.2005, źródło: www.europa.admin.ch.

Personenfreizügigkeit: Informationsblatt, Integrationsbüro EDA/EVD, Bern 2009.

Polla B., Interpellation vom 21. Juni 2002. Verbesserung der Beziehungen Schweiz/EU, „Amtliches Bulletin der Bundesversammlung" 2002, 02.3374.

Postulat David Eugen vom 19. März 2008 Verhältnis der Schweiz zu den europäischen Agenturen, SR 08.3141/2008.

Postulat Markwalder Bär Christa vom 10. Juni 2009 Europapolitik. Evaluation, Prioritäten, Sofortmassnahmen und nächste Integrationsschritt, „Amtliches Bulletin - Die Wortprotokolle von Nationalrat und Ständerat", SR 09.3560.

Postulat Stähelin Philipp, Rahmenvertrag zwischen der Schweiz und der EU vom 5. Oktober 2005, Amtliches Bulletin der Bundesversammlung, 05.3564.

Protokoll Nr. 2 vom 22. Juli 1972 zum Freihandelsabkommen zwischen der Schweizerischen Eidgenossenschaft und der Europäischen Wirtschaftsgemeinschaft, AS 1972/3163, SR-0.632.401.2.

Rahmenabkommen über wissenschaftlich-technische Zusammenarbeit zwischen der Schweizerischen Eidgenossenschaft und den Europäischen Gemeinschaften, AS 1987/1389, SR-0.420 .518 .

REACH, Integrationsbüro EDA/EVD, Februar 2010.

Reymond A., Interpellation vom 20.03.2009: Rahmenabkommen mit der EU zur Stärkung des Automatismus?, „Amtliches Bulletin der Bundesversammlung” 2009, 09.3249. 
Rezolucja Parlamentu Europejskiego z dnia 7 września 2010 r.w sprawie EOG i Szwajcarii: Przeszkody w petnej realizacji rynku wewnętrznego, INI/2009/2176.

Riklin K., Interpellation vom 18 März 2010: Rahmenabkommen mit der EU versus EWR, „Amtliches Bulletin der Bundesversammlung" 2010, 10.3211.

Satellitennavigation (Galileo und EGNOS), Integrationsbüro EDA/EVD, September 2010.

Satellitennavigationsprogramme Galileo und EGNOS: Start der bilateralen Verhandlungen über Kooperation $C H-E U$, Medienmitteilung Bundesamt für Strassen ASTRA, 21.09.2010.

Schwander P., Der Bilaterale Weg ist erschöpft!, Begrüssung und Standortbestimmung vom 25. April 2009.

Schweiz-Europäische Union: Integrationsbericht 1999 von 3. Februar 1999, BBI 1999 V 3935.

Schweizerische Lohnstrukturerhebung, Bundesamt für Statistik, November 2007.

Standortbestimmung zur schweizerischen Integrationspolitik, Economiesuisse Positionspapier, Zürich 2002.

Starke Schweizer Position im 7. Forschungsrahmenprogramm der EU, Medienmitteilung SBF, 24.06.2010.

Steuerkontroverse, Medienmitteilung, Integrationsbüro EDA/EVD, 2007.

Strom, Integrationsbüro EDA/EVD, Februar 2010.

Technische Gespräche über ein Bildungsabkommen zwischen der Schweiz und der EU, Medienmitteilung SBF, 11.02.2009.

Technische Zusammenarbeit mit der Europäischen Verteidigungsagentur, Integrationsbüro EDA/ EVD, Februar 2010.

Verhandlungen Schweiz-EU im Agrar-, Lebensmittel und Gesundheitsbereich: Dritte Verhandlungsrunde, Medienmitteilung Mission der Schweiz bei der EU, 03.06.2009.

Verhandlungen Schweiz-EU im Strombereich gestartet, Medienmitteilung Bundesamt für Energie, 08.11.2007.

Verhandlungen Schweiz-EU über den Marktzugang für Agrarprodukte, Medienmitteilung SECO, 21.10.2009.

Verhandlungen über Landwirtschaft, Lebensmittelsicherheit, Produktsicherheit und öffentliche Gesundheit, Integrationsbüro EDA/EVD, Oktober 2009.

Verwaltungspraxis der Bundesbehörden, Bundeskanzlei, $69 / 75$ (2005).

Volksabstimmung vom 8. Februar 2009. Erläuterungen des Bundesrates, Bundeskanzlei (Hsg.) 2008, źródło: www.parlament.ch.

Vorschlag zu gesetzlichen Änderungen zur wirksameren Bekämpfung des Schmuggels und des organisierten Wirtschaftsverbrechens, Parlamentarische Initiative Pedrina F., 00.447 n Pa.Iv./2000, źródło: http://www.parlament.ch.

Vortrag von Bundesrat Hans-Rudolf Merz. Internationale Herausforderung für die Finanzplatz Schweiz, Botschaftkonferenz-Atelier, EFD, 27. August 2008.

Warum die materielle Steuerharmonisierung kein Rezept für die Schweiz ist. Referat Bundesrat Hans-Rudolf Merz an der Bundessteuerkonferenz, Bern, 11.05.2006.

Warum die Schweiz der EU nicht beitreten darf - ein Argumentarium, źródło: http://www.auns.ch.

Weiterführung des Abkommens über die Freizügigkeit. Vernehmlassungsergebnisse von 23. Januar 2008, źródło: http://www.bfm.admin.ch.

Weiterentwicklung der Abkommen, Medienmitteilung Integrationsbüro EDA/EVD 2008, źródło: http://www.europa.admin.ch.

Zusatzprotokoll Personenfreizügigkeitsabkommen, Konferenz der Kantonsregierungen, 2004.

Zwischenbericht zur europäischen Integrationspolitik der Schweiz vom 29. März 1995, Bern 1995. 


\section{OPRACOWANIA}

Alleingang - Bilaterale Verträge - EU Beitritt. Implikationen für die Schweizer Wirtschaft und den Finanzplatz Schweiz, „UBS Group Economic Research Studies”, April 2000.

Ambühl M.A., Europa-Diskussion - ein Beitrag zur Sachlichkeit, Europäische Bewegung Schweiz, Bern 1996.

Andrzejewski P., Neutralność w polityce zagranicznej Finlandii i Szwecji, Państwowe Wydawnictwo Naukowe, Warszawa 1988.

Arbeitslosenquote in der Schweiz verharrt auf 3,6 Prozent, „Tagesanzeiger”, 7. September 2010.

Arendt M., Lamprecht M., Stamm H., Die Wahrnehmung der Schweiz durch Ausland, Nationales Forschungsprogramm 42: „Grundlagen und Möglichkeiten der schweizerischen Aussenpolitik", Synthesis, Bern 2000.

Asylgesuche im Ausland stoppen, „Neue Zürcher Zeitung”, 3. September 2009.

Aubert J.F., Mitwirkung der Kantone an der europäischen Politik im Falle eines Beitritts der Schweizerischen Eidgenossenschaft zur Europäischen Union, [w:] Hrg. Konferenz der Kantonsregierung, Die Kantone vor der Herausforderung eines EU-Beitritts, Bericht der Arbeitsgruppe „Europa-Reformen der Kantone”, Zürich 2001.

Aubert J.F., Parlament a Zgromadzenie Federalne, [w:] Parlament Szwajcarii, Wydawnictwo Sejmowe, Warszawa 2000.

Auch EU macht Druck gegen Bankgeheimnis, „Neue Zürcher Zeitung”, 10. Februar 2009.

Auer A., Neue Partnerschaft im schweizerischen Bundesstaat, [w:] Die Schweiz, „Neue Helvetische Gesellschaft" 1997/1998.

Bachmann K., Unia Europejska dwóch prędkości jest niemożliwa, „Raporty i Analizy” 2004, nr 13.

Barblan P., Koeller A., Wie weiter in der Schweizer Europapolitik?, Forum Helveticum, Lenzburg 2001.

Barz A., Der Mythos der Neutralität. Zu den Wechselwirkungen zwischen Anspruch und Wirklichkeit des politischen Konzeptes. Reihe Politikwissenschaft, Pfaffenweiler 1991.

Bei den Jungen wächst die Skepsis gegenüber der EU, „20Minuten”, 13 Mai 2009.

Benesch S., Das Freizügigkeitsabkommen zwischen der Schweiz und der Europäischen Gemeinschaft, Mohr Siebeck, Tübingen 2007.

Bernauer T., Bruno S., Moser P., Ruloff D., Schnur A., Globaler Wandel und Schweizerische Aussenpolitik. Informationsbeschaffung und Entscheidungsfindung, Nationales Forschungsprogramm 42: „Grundlagen und Möglichkeiten der schweizerischen Aussenpolitik Aussenpolitik", Synthesis, Bern 1999.

Bieber R., Kahil B., Poralla S., Differenzierte Integration in Europa - Handlungsspielräume für die Schweiz? Rechtwissenschaftliche Perspektive, Nationales Forschungsprogramm 42: „Grundlagen und Möglichkeiten der schweizerischen Aussenpolitik”, Synthesis, Bern 1999.

Bilaterale II: Dossier Zinsbesteuerung. Die Interessen des Finanzplatzes gewahrt, „Economiesuisse Dossierpolitik", 27. September 2004, Nr. 35 (1).

Bilaterale Abkommen mit der EU: eine Schweizer Erfolgsgeschichte, „Economiesuisse Dossierpolitik", 29. September 2008.

Bilaterale Öffnung der Landwirtschaft gegenüber der EU erfolgreich, „Die Volkswirtschaft. Das Magazin für Wirtschaftspolitik", 01.11.2008.

Bindschedler R., Zum Primat der Aussenpolitik, [w:] V. Altermatt, J. Garamvölgyi (red.), Innen und Aussenpolitik, Bern 1980.

Blatter J., Horizontalföderalismus und Schweizer Demokratie, „Swiss Political Science Review” 2010, vol. 16 (2).

Bolliger Ch., Rielle Y., Handbuch der eidgenössischen Volksabstimmungen 1848 bis 2007, Haupt Verlag, Bern 2010. 
Bonfadelli H., Blum R., Helvetisches Stiefkind: die Rolle der Massenmedien bei der Vermittlung schweizerischer Aussenpolitik, Nationales Forschungsprogramm 42: „Grundlagen und Möglichkeiten der schweizerischen Aussenpolitik”, Synthesis, Bern 2000.

Bonjour E., Schweizerische Neutralität. Kurzfassung, Basel 1978.

Borner S., Brunetti A., Straubhaar T., Schweiz AG. Vom Sonderfall zum Sanierungsfall?, Verlag Neue Zürcher Zeitung, Zürich 1990.

Bösch L., Mitwirkung der Kantone in der Europapolitik: Strategie und Standortbestimmung, [w:] P. Barblan, A. Koeller, R. Oppenheim, Die Stellung der Schweiz in Europa, Forum Helveticum, Menziken 2007.

Braucht die Schweiz Personenfreizügigkeit?, „Neue Zürcher Zeitung”, 16. Januar 2009.

Breuss F., Cottier T., Müller-Graf P.C., Die Schweiz im Europäischen Integrationsprozess, Baden-Baden 2008.

Bruha T., Normen und Standards im Warenverkehr mit Drittstaaten, [w:] M. Hilf, C. Tomuschat, EG und Drittstaatsbeziehungen nach 1992: Referate der Jahrestagung des Arbeitskreises Europäische Integration in Bonn vom 15. bis 17. November 1990, Baden-Baden 1991.

Brunetti A., Bucher U., Die Bilateralen I aus wirtschaftlichen Sicht, „Die Volkswirtschaft. Das Magazin für Wirtschaftspolitik", 01.11.2008.

Brunetti A., Jaggi M., Weder R., Öffnung der Schweiz: Verteilungswirkungen, Kompensation und mögliche Strategien, Nationales Forschungsprogramm 42: „Grundlagen und Möglichkeiten der schweizerischen Aussenpolitik", Synthesis, Bern 1999.

Buomberger T., Kampf gegen unerwünschte Fremde. Von James Schwarzenbach bis Christoph Blocher, Zürich 2004.

Bütler C., Schweizer Europapolitik der 90er Jahre im Spiegel der Parteien und Medien, Zürich 2003.

Cottier T., Dzamko D., Evtimov E., Die eurokompatible Auslegung es schweizerischen Rechts, [w:] A. Epiney, S. Theuerkauf, F. Riviere, Schweizerische Jahrbuch für Europarecht, Annuaire Suisse de Droit europeen 2003, Bern 2004.

Cottier T., Liechti R., Die Beziehungen der Schweiz zur Europäischen Union: Eine kurze Geschichte differenzieller und schrittweiser Integration, „Basler Schriften zur europäischen Integration” Nr. 81, 2006.

Cottier T., Liechti-McKee R., Die Schweiz und Europa, Hochschulverlag AG an der ETH, Zürich 2010.

Couchepin räumte nicht alle Zweifel aus, „Tagesanzeiger”, 15. Dezember 2008.

Das Abkommen über die gegenseitige Anerkennung von Konformitätsbewertungen, „Die Volkswirtschaft. Das Magazin für Wirtschaftspolitik”, 01.11.2008.

Das Informationsbulletin Suisseurope, Integrationsbüro EDA/EVD, 2008-2011.

Das Tessin schert aus, „Neue Zürcher Zeitung”, 9. Februar 2009.

Das Tessin - wegen Italien ein Sonderfall, „Neue Zürcher Zeitung”, 10. Februar 2009.

Däniken F., Neutralitätspraxis der Schweiz - aktuelle Aspekte Bericht der interdepartementalen Arbeitsgruppe vom 30. August 2000, źródło www.eda.admin.ch.

Der Kampf um die Schweizer Europapolitik ist neu lanciert, „Neue Zürcher Zeitung”, 20. Januar 2008.

Der Steuerstreit mit der EU wird bald konkret, „Neue Zürcher Zeitung”, 22 Januar 2008.

Die Kantone vor der Harausforderung eines EU-Beitritts, Bericht der Arbeitsgruppe „Europa-Reformen der Kantone”, Zürich 2001.

Die Neue Zuwanderung, „Die Volkswirtschaft. Das Magazin für Wirtschaftspolitik”, 01.11.2008.

Die Neutralität bringt uns einen Mehrwert, „Tagesanzeiger”, 14. Januar 2005.

Die Neutralität ist ein Vorteil für uns, „Neue Zürcher Zeitung”, 5. Oktober 2003.

Die Volkswirtschaft. Das Magazin für Wirtschaftspolitik, November 2006, źródło: http://www.dievolkswirtschaft.ch. 
Die Volkswirtschaft. Das Magazin für Wirtschaftspolitik, November 2008, źródło: http://www.dievolkswirtschaft.ch.

Die Zeit des bilateralen Weges ist vorbei, „Neue Zürcher Zeitung”, 12. November 2010.

Drews I., Schweizer erwache!, Frauenfeld 2005.

Durić H., Die freihandelsabkommen EG-Schweiz - Die rechtliche Problematik, 3. Auflage, Freiburg 1998.

EU-Beitritt nicht realistisch, „Neue Zürcher Zeitung”, 9. März 2011.

Economic Survey of Switzerland. Policy Brief OECD, November 2007.

Ein europäischer Raum für Menschen, Forschung und Wirtschaft - sieben Zugänge zum Binnenmarkt der EU, „Neue Zürcher Zeitung”, 5. Dezember 2008.

Eine neue Vision für das Verhältnis zur EU, „Neue Zürcher Zeitung”, 20. Januar 2008.

Ein Nein zur Personenfreizügigkeit wäre Gift für die Wirtschaft, „Neue Zürcher Zeitung”, 23. August 2005.

Engeli I., Tresch A., Analyse der eidgenössischen Abstimmungen vom 5. Juni 2005, Juli 2005, Publikation Nr. 87.

Entspanntere Stimmung im ländlichen Raum, „Die Neue Zürcher Zeitung”, 10. Februar 2009.

Epiney A., Pfenniger H., Auswirkungen eines Beitritts zur Europäischen Union auf das schweizerische Umweltrecht - Das Problem der Umweltnormung, [w:] T. Cottier, A. Kopse, Der Beitritt der Schweiz zur Europäischen Union - Brennpunkte und Auswirkungen, Zürich 1998.

Ernst A., Vielsprachigkeit, Öffentlichkeit und politische Integration: schweizerische Erfahrungen und europäische Perspektiven, „Swiss Political Science Review” 1998, vol. 4 (4).

Europa.ch. Das Magazin der Neuen Europäischen Bewegung Schweiz, 2008, Nr. 2 (November).

EU-Politik: Die Zukunft der Schweiz ist bilateral, „Neue Zürcher Zeitung”, 22. August 2010.

Fahrni D., Schweizer Geschichte, Zürich 1984.

Freiburghaus D., Föderalismus, de quois's a git-il? Grundlagen und Reformbestrebungen im schweizerischen Föderalismus, [w:] P. Barblan, A. Koeller, R. Oppenheim, Die Stellung der Schweiz in Europa, Forum Helveticum, Menziken 2007.

Freiburghaus D., Königsweg oder Sackgasse?: sechzig Jahre schweizerische Europapolitik, Neue Zürcher Zeitung Verlag, Zürich 2009.

Frik S., Ist die schweizerische Sicherheitspolitik europafähig? Die Neutralität im Lichte der Entwicklungen der ESVP?, Zürich 2000.

Gabriel J.M., Neutralität für den Notfall. Der Bericht des Bundesrates zur Aussenpolitik der Schweiz in den 90er Jahren, ,Swiss Political Science Review” 1995, vol. 1 (2-3).

Gabriel J.M., Sackgasse Neutralität, Hochschulverlag, Zürich 1997.

Gabriel J.M., Schweizer Neutralität im Wandel - Hin zur EG, Frauenfeld 1990.

Gabriel J.M., Schweizerische Europapolitik: Zukunftsszenarien, Institut für Politikwissenschaft, St. Gallen 1990.

Gabriel J.M., Switzerland and the European Union, Center for International Studies, Beiträge Nr. 33, Dezember 2000.

Gabriel J.M., Fanzun J.A., Swiss Foreign Policy: An Overview, Center for International Studies, Beiträge Nr. 43, Zürich 2003.

Gabriel J., Hedinger S., Aussen- und Sicherheitspolitik, [w:] U. Klöti (red.), Handbuch der Schweizer Politik, NZZ Verlag, Zürich 2002.

Gees T., Die Schweiz im Europäisierungsprozess, Chronos, Zürich 2006.

Gehler M., Steininger S. (red.), Die Neutralen und die europäischen Integration 1945-1995, Institut für die Zeitgeschichte der Universität Innsbruck, Arbeitskreis Europäische Integration, Historische Forschungen, Veröffentlichungen 3, Wien-Köln-Weimar 2000.

Gemperle R. (red.), Weiter auf dem bilateralen Weg, NZZ-Focus Nr. 27, Zürich 2005.

Germann R.E., Die bilateralen Verhandlungen mit der EU und die Steuerung der direkten Demokratie, „Swiss Political Science Review” 1995, vol. 1 (2-3). 
Germann R.E., Die Europatauglichkeit der direktdemokratischen Institutionen der Schweiz, „Schweizerisches Jahrbuch für Politische Wissenschaft” 1991.

Germann R.E., Staatsreform. Der Übergang zur Konkurrenzdemokratie, Haupt Verlag, Bern 1994.

Gisselbrecht T., Besteuerung von Zinserträgen in der Europäischen Union. Abschied vom Schweizerischen Bankgeheimnis?, „Baslerschriften zur Europäischen Integration” 2000, Nr. 50.

Glatz H., Moser H. (red.), Herausforderung Binnenmarkt. Kopfüber in die EG?, Wien 1985.

Goetschel L., Aussenpolitik im Wandel. Synthese des NFP 42, Bern 2000.

Goetschel L., Die Einführung der Personenfreizügigkeit durch die Schweiz. Eine demokratisch legitimierte Revolution, [w:] G. Kreis (red.), Schweiz - Europa: wie weiter? Kontrollierte Personenfreizügigkeit, Verlag Neue Zürcher Zeitung, Zürich 2009.

Goetschel L., Die Entwicklung der Neutralität und die schweizerischen Integrationspolitik, [w:] M. Gehler, R. Steininger (red.), Die Neutralen und die europäische Integration 1945-1995, Institut für die Zeitgeschichte der Universität Innsbruck, Arbeitskreis Europäische Integration, Historische Forschungen, Veröffentlichung 3, Wien-Köln-Weimar 2000.

Goetschel L., Die Schweizer Neutralität: Beibehalten, umgestalten oder doch abschaffen?, Werd Verlag, Zürich 2007.

Goetschel L., Wie Aussenpolitik zunehmend politisch wird, „Rote Revue. Zeitschrift für Politik, Wirtschaft und Kultur" 2007, Nr. 4.

Goetschel L., Zwischen Effizienz und Akzeptanz. Die Information der Schweizer Behörden im Hinblick auf die Volksabstimmung über den EWR-Vertrag vom 6. Dezember 1992, Haupt Verlag, Bern 1994.

Goetschel L., Bernath M., Schwarz D., Schweizerische Aussenpolitik. Grundlagen und Möglichkeiten, Verlag Neue Zürcher Zeitung, Zürich 2002.

Gruner E., Hertig H., Das Stimmbürger und neue Politik, Haupt Verlag, Bern 1983.

Hagemann M., Die europäische Wirtschaftsintegration und die Neutralität und Souveränität der Schweiz, „Schriftenreihe des Instituts für Internationales Recht und Internationale Beziehungen der Universität Basel" 1957, Nr. 12.

Haliżak E., Kuźniar R., Stosunki międzynarodowe. Geneza, struktura, dynamika, Wydawnictwo Uniwersytetu Warszawskiego, Warszawa 2001.

Hänni P., Kantone und Aussenpolitik, Nationales Forschungsprogramm 42: „Grundlagen und Möglichkeiten der schweizerischen Aussenpolitik", Synthesis, Bern 2000.

Hänni P., Schweizerischer Föderalismus und europäische Integration, Schulthess, Zürich 2000.

Hertig H.P., Volksabstimmungen, [w:] Handbuch Politisches System der Schweiz, Band II, Bern 1984.

Hirschi Ch., Serdült U., Widmer T., Schweizerische Aussenpolitik im Wandel: Internationalisierung, Globalisierung und Multilateralisierung, „Swiss Political Science Review” 1999, vol. 5 (1).

Hirter H., Analyse der eidgenössischen Abstimmungen vom 21. Mai 2000, VOX Nr. 70, Gfs - Forschungsinstitut und Institut für Politikwissenschaft Universität Bern, Bern 2000.

Hirter H., Linder W., Analyse der eidgenössischen Abstimmung vom 8. Februar 2009. Forschung für Politik, Kommunikation und Gesellschaft. Institut für Politikwissenschaft, Bern 2009.

Hollmann A., Die Schweizer und Europa, Nomos Verlagegesellschaft, Baden-Baden 2005.

Holzer P.E., Die Ermittlung der innerstaatlichen Anwendbarkeit völkerrechtlicher Vertragsbestimmungen, Zürich 1998.

Honegger E., Die Gemischten Ausschüsse In den Sektoriellen Abkommen zwischen der Schweiz und der EG, IDHEAP, Chavannes-Lausanne 2004.

Hug P., Gees T., Dannecker K., Die Aussenpolitik der Schweiz im kurzen 20. Jahrhundert. Antibolschewismus, Deutschlandpolitik und organisierte Weltmarktintegration - Segmentierte Praxis und öffentliches Ritual, Nationales Forschungsprogramm 42: „Grundlagen und Möglichkeiten der Schweizerischen Aussepolitik", Synthesis, Bern 2000. 
Ich bin erschrocken darüber, was ich in der Schweiz erlebt habe, „Tagesanzeiger”, 3. März 2010. Ich lasse mir mein Land nicht wegnehmen, „Tagesanzeiger”, 31. Dezember 2009.

In der Efta ist die Schweiz bald sehr alleine, „Tagesanzeiger”, 17. Juli 2009.

Jaeger F., Der schweizerische Königsweg. Bilateral kooperieren - global öffnen, Verlag Rüegger, Zürich 2006.

Kampagnen-Vielfalt zur Personenfreizügigkeit, „Neue Zürcher Zeitung”, 14. Januar 2009.

Kaufmann B., Kreis G., Gross A., Direkte Demokratie und europäischen Integration. Die Handlungsspielräume der Schweiz, „Baslerschriften zur europäischen Integration” [Europainstitut der Universität Basel, Basel], 2005, Nr. 75.

Kästli T., Selbsbezogenheit und Offenheit. Die Schweiz in der Welt des 20. Jahrhunderts, NZZ Libro, Zürich 2005.

Keine Alternative zum bilateralem Weg, „Neue Zürcher Zeitung”, 12. Januar 2010.

Kellenberger J., Der politische und wirtschaftliche Stellenwert der sieben bilateralen sektorellen Abkommen, [w:] D. Felder, Ch. Kaddous (red.), Bilaterale Abkommen Schweiz - EU (Erste Analysen), Basel 2001.

Klöti U., Serdült U., Widmer T., Aussenpolitik von innen: Entscheidungsprozesse der schweizerischen Aussenpolitik in den achtziger und neunziger Jahren, Nationales Forschungsprogramm 42: „Grundlagen und Möglichkeiten der schweizerischen Aussenpolitik Aussenpolitik”, Synthesis, Bern 2000.

Kluge Köpfe, gratis importiert. Wo Liege das Problem?, „Tagesanzeiger”, 30. Januar 2010.

Kociubiński K., Systemy polityczne Austrii, Niemiec i Szwajcarii, Wrocław 2003.

Kölz A., Neuere schweizerische Verfassungsgeschichte, Stämpfli, Bern 1992.

Kreis G., Der lange Weg des Staatsvertragsreferendum. Schweizerische Aussenpolitik zwischen indirekter und direkter Demokratie, „Baslerschriften zur europäischen Integration” [Europa Institut der Universität Basel, Basel], 1995, Nr. 12.

Kreis G., Ein langer Weg in Etappen, [w:] G. Kreis (red.), Schweiz - Europa: wie weiter? Kontrollierte Personenfreizügigkeit, Verlag Neue Zürcher Zeitung, Zürich 2009.

Kreis G., Nach der schweizerischen jetzt die europäische Integration: Zur Idee der schweizerischen Modellhaftigkeit, [w:] T. Cottier, A. Kopse, Der Beitritt der Schweiz zur Europäischen Union - Brennpunkte und Auswirkungen, Zürich 1998.

Kriesi H., Sciarini P., Marquis L., Démocratie directe et politique extérieure: étude de la formation des attitudes en votation populaire, Bern 2000.

Kukułka J., Zięba R., Polityka zagraniczna państwa, Wydawnictwo Uniwersytetu Warszawskiego, Warszawa 1992.

Kux S., Zwischen Isolation und autonomer Anpassung: Die Schweiz im integrationspolitischen Abseits?, ZEI Disscusion Paper of the Center for European Integration Studies C3/1998, Rheinische Friedrich Wilhelms-Universität, Bonn 1998.

Kużelewska E., Norweskie i szwajcarskie „nie” dla integracji europejskiej, „Studia Europejskie” 2003, $\mathrm{nr} 3$.

Lavenex S., Switzerland's Flexible Integration in the EU: A Conceptual Framework, „Swiss Political Science Review" 2009, vol. 15 (4).

Libyen-Krise: ,, Gravierende Defizite” im Krisenmanagement, „Tagesanzeiger”, 8. Juli 2010.

Linder W., Demokracja szwajcarska. Rozwiąywanie konfliktów w spoleczeństwie wielokulturowym, Wydawnictwo Wyższej Szkoły Pedagogicznej, Rzeszów 1996.

Linder W., Europäisierung der Schweiz, Verschweizerung der EU?, Universitätsverlag, Konstanz 2000.

Linder W., Schweizerische Demokratie: Institutionen - Prozesse - Perspektive, Bern 1999.

Longchamp C., Offen auf die Zukunft zugehen. Hauptergebnisse aus dem neuesten Bericht zum Europa-Barometer Schweiz, Winter 2005, Bern 2005. 
Longchamp C., Die Stärkung des bilateralen Weges. Hauptergebnisse aus dem neuesten Bericht zum Europa-Barometer Schweiz, Winter 2004, Bern 2004.

Luif P., EFTA-Staaten und Europäische Union-Neutralität und GASP im Einklang, [w:] E. Regelsberger (red.), Die gemeinsame Aussenpolitik und Sicherheitspolitik der Europäischen Union. Profilsuche mit Hindernissen, Institut für Europäische Politik, Bonn 1993.

Lüthi R., Die Legislativkommissionen der Schweizerischen Bundesversammlung: Institutionelle Veränderung und das Verhalten von Parlamentsmitgliedern, Paul Haupt Verlag, Bern 1997.

Lüthy H., Die Schweiz als Antithese, Verlag der Arche, Zürich 1969.

Lutz Ch., Schlange L.E., Szenarien der Schweizer Europapolitik, Nationales Forschungsprogramm 42: „Grundlagen und Möglichkeiten der schweizerischen Aussenpolitik”, Synthesis, Bern 1998.

Mayrzedt H., Binswanger H. Ch. (red.), Die Neutralität in der europäischen Integration, Wien 1970.

Möckli D., Schweizer Europapolitik: wie tragfähig ist der Bilateralismus?, CSS Analysen zur Sicherheitspolitik Nr. 37, Juli 2008.

Moeli J.B., Die Kompetenzen der schweizerischen Bundesversammlung in den auswärtigen Angelegenheiten, St. Gallen 1990.

Müller E., Schweizer Europapolitik am Scheideweg, Zürich 1995.

Münger B., Die Konferenz der Kantonsregierungen, [w:] D. Freiburghaus, Die Kantone und Europa, Bern 1994.

Nachdenken über den EWR, „Neue Zürcher Zeitung”, 29. Juli 2010.

Neuhold H.P. (red.), The European Neutrals in the 1990s. New Challenges and Opportunities, Boulder-San Francisco-Oxford-Wien 1987.

Neutralität bedeutet nicht, möglichst ruhig zu bleiben, „Basler Zeitung”, 28./29. August 2004, Nr. 201.

Noch ein Irrtum wäre einer zu viel, „Tagesanzeiger”, 10. September 2010.

Notter M., Der Europäische Integrationsprozess aus Sicht der Kantone, http://www.kdk.ch.

Oberer T., Die innenpolitische Genehmigung der bilateralen Verträge Schweiz-UE: Wende oder Ausnahmen bei Aussenpolitischen Vorlagen?, Baslerschriften zur europäischen Integration $\mathrm{Nr}$. 52/53, Basel 2001.

Papadopolous J., Europeanisation? Two Logics of Change of Policy-making Patterns in Switzerland, „Journal of Comparative Policy Analysis” 2008, vol. 10 (3).

Personenfreizügigkeit: Auswirkungen auf den Arbeitsmarkt und das Wirtschaftswachstum, „Die Volkswirtschaft. Das Magazin für Wirtschaftspolitik”, 01.11.2008.

Personenfreizügigkeit mit der ganzen EU, „Neue Zürcher Zeitung”, 28. November 2008.

Personenfreizügigkeit und Steuerstreit verknüpfen, „Neue Zürcher Zeitung”, 27. Februar 2008.

Pęk M., Nowe podejście regulacyjne do ustug audiowizualnych w prawie wspólnotowym - w świetle zmian wprowadzonych dyrektywa o audiowizualnych ustugach medialnych, „Analiza Biura KRRiTv" 2007, nr 6.

Popławski D., Austriacka polityka neutralności 1955-1995, Warszawa 1995.

Popławski D., Droga neutralnych państw EFTA do Unii Europejskiej, „Zeszyty Naukowe WSC” 2005, nr 10.

Popławski D., Neutralność i polityka neutralności, [w:] Historia. Polityka. Stosunki Międzynarodowe. Księga Jubileuszowa na 65-lecie Profesora Józefa Kukutki, Warszawa 1999.

Popławski D., Neutralność jako podstawa zinstytucjonalizowanej wspótpracy wielostronnej w Europie, [w:] S. Parzymies, R. Zięba (red.), Instytucjonalizacja wspótpracy międzynarodowej w Europie, Warszawa 2004.

Popławski D., Państwa mniejsze a demokracja w stosunkach międzynarodowych, [w:] E. Haliżak, D. Popławski (red.), Demokracja w stosunkach międzynarodowych, Warszawa 1997.

Popławski D., Perspektywy przystapienia Szwajcarii do Unii Europejskiej, [w:] P. Łaciński (red.), Dylematy rozszerzenia Unii Europejskiej, Warszawa 2006. 
Popławski D., Szwajcarska polityka bezpieczeństwa, Warszawa 2007.

Porębski A., Wielokulturowość Szwajcarii na rozdrożu, Wydawnictwo Uniwersytetu Jagiellońskiego, Kraków 2009.

Probst R., Die Schweiz und die ,guten Dienste”, [w:] A. Riklin, H. Haug, R. Probst, Neues Handbuch der schweizerischen Aussenpolitik, Haupt Verlag, Bern-Stuttgart-Wien 1992.

Reber A.F., Der Weg zur Zauberformel, Lang-Bern 1976.

Riklin A., Grundlegung der schweizerischen Aussenpolitik, Bern-Stuttgart 1975.

Riklin A., Isolierte Schweiz. Eine europa- und innenpolitische Lagebeurteilung, „Swiss Political Science Review" 1994, vol. 1 (2-3).

Riklin A., Haug H., Probst R., Neues Handbuch der schweizerischen Aussenpolitik, Verlag Paul Haupt, Bern 1992.

Rosenau J.N., The Scientific Study of Foreign Policy, Nicholas Pub Co., London 1980.

Rotter M., Dauernde Neutralität, Berlin 1981.

Rüegg E., Regierbarkeit durch Konkordanz?, Zürich 1985.

Schenker M., EG als Chance. Die Schweiz am europäischen Scheideweg, Werd Verlag, Zürich 1991.

Schindler D., Dokumente zur schweizerischen Neutralität seit 1945: Geschichte und Stellungnahme der schweizerische Neutralität seit 1945-1983, Bern-Stuttgart 1984.

Schindler D., Die Schweiz und das Völkerrecht, [w:] A. Riklin, H. Haug, R. Probst, Neues Handbuch der schweizerischen Aussenpolitik, Bern 1992.

Schlechter Stil der EU, „Neue Zürcher Zeitung”, 14. Februar 2007.

Schneider G., Hess C., Die innenpolitische Manipulation der Aussenpolitik: Die Logik von Ratifikationsdebatten in der direkten Demokratie, „Swiss Political Science Review” 1994, vol. 1 (2-3).

Schoch C., Langwieriger Weg zu bilateralen Verhandlungen, [w:] Die bilateralen Verträge: eine neue Qualität in den Beziehungen Schweiz-EU, NZZ-Focus Nr. 7, 2000.

Schoch C., Schweiz hält an parallelem Abschluss fest, [w:] Weiter auf dem bilateralem Weg, „NZZ-Focus", November 2005, Nr. 27.

Schulte C., Direkte Demokratie und Aussenpolitik in der Schweiz, Mensch und Buch Verlag, Berlin 2006.

Schweitzer M., Dauernde Neutralität und europäische Integration, Wien 1977.

Schweitzer R.J., Brunner S.C., Die Mitwirkung der Bundesländer an EU-Vorhaben in der Bundesrepublik Deutschland und in Österreich, Schweizer Schriften zur Europäischen Integration Nr. 14, Bern und Zürich 1998.

Schweiz und Deutschland streiten vor EU-Gericht um Fluglärm, „Tagesanzeiger”, 9. September 2010.

Sciarini P., La formulation de la decision, [w:] U. Klöti, Handbuch der Schweizer Politik, Verlag NZZ, Zürich 1999.

Siegwart K., Die Kantone und die Europapolitik des Bundes, Universitätsverlag, Freiburg 1997.

Sigg O., Instytucje polityczne Szwajcarii, Warszawa 1990.

Spinner B., Rechtliche Grundlagen und Grenzen für bilaterale Abkommen, [w:] D. Felder, Ch. Kaddous, Accords bilatéraux Suisse - UE, Bilaterale Abkommen Schweiz - EU, Dossiers de droit européen no 8D. (ed.), Basel-Genf-München-Brüssel 2001.

Steiner J., Continental Integration and Swiss Federalism: a New Openness to Europe?, [w:] H. Lazar, H. Telford, R.L. Watts, The Impact of Global and Regional Integration on Federal Systems, McGill-Queen's University Press, Montreal 2003.

Steiner J., Demokracje europejskie, WSP, Rzeszów 1993.

Steuerstreit: , Ja, aber” von EU-Experten zu Schweizer Vorschlägen, „Tagesanzeiger”, 15. September 2009.

Sturny T., Mitwirkungsrechte der Kantone an der Aussenpolitik des Bundes, Universitätsverlag, Freiburg 1998. 
Süddeutschland fordert weitere Begrenzung der Nordanflüge, „Tagesanzeiger”, 9. September 2010. Sutor J., Państwa neutralne i niezaangażowane, Warszawa 1972.

Thürer D., Aussenpolitische Aspekte der künftigen Beziehung zur Europäischen Gemeinschaft, [w:] A. Riklin, H. Haug, R. Probst, Neues Handbuch der schweizerischen Aussenpolitik, Verlag Paul Haupt, Bern 1992.

Thürer D., Weber R.H., Portmann W., Kellerhals A., Bilaterale Verträge I \& II Schweiz - EU. Handbuch, Schulthess, Zürich 2007.

Thürer D., Weber R.H., Zäch R., Bilaterale Verträge Schweiz - EG. Ein Handbuch, Schulthess Verlag, Zürich 2002.

Tomczyk M., Czy Unia ulegnie szwajcaryzacji?, Portal Spraw Zagranicznych, 13.11.2010, http:// www.psz.pl/Michal-Tomczyk-Czy-Unia-ulegnie-_szwajcaryzacji_

Tomczyk M., Dlaczego Szwajcarzy zagłosowali za zakazem budowy minaretów?, „Kurier Dyplomatyczny” 2009, nr 1, listopad-grudzień 2009.

Tornay B., Renfer I., Auer A., Die Kantone zwischen EU-Beitritt und bilateralen Weg: Direkte Demokratie, Mitwirkung an der Europapolitik und Umsetzung, [w:] Konferenz der Kantonsregierungen (Hrsg.) Zwischen EU-Beitritt und bilateralem Weg: Überlegungen und Reformbedarf aus kantonaler Sicht, Schulthess-Zurich-Basel-Genf 2006.

Tovias A., Exploring the „Pros” and „Cons” of Swiss and Norwegian Models of Relations with the European Union: What Can Israel Learn from the Experiences of These Two Countries?, „Cooperation and Conflict” 2006, No 41. Źródło: http://cac.sagepub.com/content/41/2/203.

Trachsler D., Gute Dienste - Mythen, Fakten, Perspektiven, „Bulletin der schweizerischen Sicherheitspolitik" 2004.

Trechsel A., Sciarini P., Direct Democracy in Switzerland: Do elites matter?, „European Journal of Political Research", January 1998, vol. 33, No 1.

Tscharner B., Die Entwicklung der Beziehungen zwischen der Schweiz und der Europäischen Gemeinschaft, [w:] A. Riklin, H. Haug, R. Probst, Neues Handbuch der schweizerischen Aussenpolitik, Bern 1992.

Vahl M., Grolimund N., Integration ohne Mitgliedschaft: die bilateralen Verträge der Schweiz mit der Europäischen Gemeinschaft, Schulthess, Zürich 2007.

Volkswirtschaftliche und soziale Auswirkungen des Landverkehrsabkommens, „Die Volkswirtschaft. Das Magazin für Wirtschaftspolitik", 01.11.2008.

Vollbeteiligung der Schweiz am europäischen Forschungsraum, „Die Volkswirtschaft. Das Magazin für Wirtschaftspolitik", 01.11.2008.

Weder R., Hohe Integration ohne Beitritt, [w:] G. Kreis (red.), Schweiz - Europa: wie weiter? Kontrollierte Personenfreizügigkeit, Verlag Neue Zürcher Zeitung, Zürich 2009.

Wie schlecht ist dieser Bundesrat wirklich?, „Tagesanzeiger”, 5 Mai 2009.

Wildhaber L., Aussenpolitische Kompetenzordnung im schweizerischen Bundesstaat, [w:] A. Riklin, H. Haug, R. Probst, Neues Handbuch der schweizerischen Aussenpolitik, Verlag Paul Haupt, Bern 1992.

Wilson H.R., Neutrality as a Foreign Policy, Philadelphia 1974.

Wir lösen Steuerstreit, „St. Galler Tagblatt”, 9. Februar 2009.

Wirkungsanalyse des bilateralen Abkommens über den Luftverkehr, „Die Volkswirtschaft. Das Magazin für Wirtschaftspolitik”, 01.11.2008.

Wir sind keine Insel in der EU, „Focus” 2003, Nr. 42.

Wir tun viel. Das muss die EU anerkennen, „Sonntagszeitung”, 28. September 2003.

Wojtowicz J., Historia Szwajcarii, Wrocław 1976.

Zum Glück hilft die EU, „Tagesanzeiger”, 22. April 2010. 


\section{INDEKS OSOBOWY}

Indeks zawiera nazwiska występujące zarówno w tekście, jak i w adnotacjach. Dążono do przytaczania imion i nazwisk w wersji oryginalnej.

\author{
Altermatt Urs 261 \\ Ambühl Max A. 261 \\ Ambühl Michael A. 216, 256 \\ Andrzejewski Piotr 17, 87, 261 \\ Arendt Michal 261 \\ Aubert Jean François 38-42, 261 \\ Auer Andreas 35, 36, 42, 261, 268 \\ Bachmann Klaus 102, 261 \\ Barblan Paolo 32, 46, 261-263 \\ Barosso Jose Manuel 233 \\ Barz Andreas 261 \\ Baumgartner T. 191 \\ Benesch Sebastian 261 \\ Bernath Magdalena 10, 26, 28, 31, 49, 59, 264 \\ Bernauer Thomas 10, 21, 60, 261 \\ Bezzola Duri 187, 256 \\ Biaggini Giovanni 174, 175 \\ Bieber Roland 261 \\ Bindschedler Rudolf 18, 19, 22, 24, 89, 118, \\ 129, 252, 261 \\ Binswanger Hans Christoph 266 \\ Blatter Joachim 222, 261 \\ Blocher Christoph 53, 76-78, 118, 119, 144, \\ $168,222,262$ \\ Blum Roger 64, 262 \\ Blumer C. 233 \\ Bolliger Christian 261 \\ Bonfadelli Heinz 64, 262 \\ Bonjour Edgar 262 \\ Borner Silvio 21, 262 \\ Bösch Lorenz 32, 262 \\ Breuss Fritz 222, 262 \\ Bruha Thomas 172, 262 \\ Brunetti Aymo 21, 51, 210, 262 \\ Brunner Stephen C. 38, 267
}

Bruno Stefano 10, 21, 60, 261

Bucher Urs 210, 262

Buomberger Thomas 168, 262

Bürgi-Schmelz Adelheid 187

Burkhalter Didier 63, 203, 255

Busch R. 258

Bütler C. 262

Calmy-Rey Micheline 43, 63, 64, 97, 106, 227, 244

Church Clive H. 10

Churchill Winston 129

Cottier Thomas 10, 94, 95, 132, 154, 222, 237, 262, 263, 265

Couchepin Pascal 105, 139

Coulon Claire de 169

Däniken Franz von 262

Dannecker Katja 129, 131, 264

David Eugen 103, 259

Deiss Joseph 63, 113, 139

Drews Isabel 168, 263

Ducry Jacques 114

Durić Hans-Peter 155, 263

Dzamko Daniel 132, 262

Engeli Isabelle 185, 263

Epiney Astrid 95, 132, 262, 263

Ernst Andreas 263

Evtimov Erik 132, 262

Fahrni Dieter 263

Fanzun Jon A. 22, 263

Fehr Hans-Jürg 244, 258

Felder Daniel 137, 265, 267

Fischer Otto 118 
Freiburghaus Dieter 33, 46, 263, 266

Friendli M. 180

Frik Silvan 263

Gabriel Jürg Martin 10, 22, 223, 224, 263

Gamez Gabriel 187

Garamvölgyi Judit 261

Gasser Philip 116, 259

Gaulle Charles de 130

Gees Thomas 129, 131, 263, 264

Gehler Michael 263, 264

Gemperle Reinhold 263

Germann Reimund E. 33, 50, 52, 263, 264

Gisselbrecht Thomas 141, 264

Glatz Hans 264

Goetschel Laurent 10, 20, 26, 28, 31, 49, 52, 59, 135, 264

Golban Radu-Eugen 119, 259

Grolimund Nina 156, 160, 161, 163, 164, 228, $230,245,268$

Gross Andreas 33, 265

Grossen Dieter W. 169

Gruner Erich 51, 79, 264

Hagemann Max 264

Haliżak Edward 14, 262, 266

Hänni Peter 264

Haug Hans 10, 18, 24, 26, 29, 155, 267, 268

Haupt Paul (Verlag) 28, 266-268

Hedinger Sandra 223, 263

Hertig Hans Peter 51, 54, 79, 264

Hess Cyrill 53, 267

Hilf Meinhard 172, 262

Hillemanns Carolin 162

Hirschi Christian 264

Hirter Hans 84, 150, 264

Hollmann Anna 225, 264

Holzer Patrick Edgar 155, 264

Honegger Edith 136, 159, 264

Hug Peter 129, 131, 264

Jaag Tobias 161

Jaeger Franz 265

Jaggi Markus 51, 262

Kaddous Christine 137, 265, 267

Kahil Bettina 261

Kästli Tobias 168, 265

Kaufmann Bruno 33, 265
Kellenberger Jakob 265

Kellerhals Andreas 169, 174, 178, 180, 187, 191, 198, 268

Klöti Ulrich 57, 79, 223, 263, 265, 267

Kociubiński Krzysztof 265

Koeller Arnold 32, 46, 261-263

Kölz Alfred 47, 265

Kopse Alwin R. 10, 94, 95, 263, 265

Kreis Georg 33, 94, 135, 137, 139, 140, 214, 264, 265, 268

Kriesi Hanspeter 53, 265

Kukułka Józef 13, 15, 16, 19, 71, 72, 265, 266

Kux Stephan 55, 265

Kuźniar Roman 14, 264

Kużelewska Elżbieta 265

Lamprecht Markus 261

Lavenex Sandra 223, 224, 265

Lazar Harvey 37, 267

Leuthard Doris 259

Liechti McKee Rachel zob. Liechti Rachel

Liechti Rachel 154, 237, 262

Linder Wolf 28, 31, 40, 45, 48, 54, 80, 113, 150, 238, 264, 265

Longchamp Claude 78, 81, 147, 265, 266

Luif Paul 266

Lüthi Ruth 28, 266

Lüthy Herbert 225, 266

Lutz Christian 266

Laciński Piotr 135, 266

Markwalder Bär Christa 103, 114-116, 259

Marquis Lionel 53, 265

Matt Peter von 113

Mayrzedt Hans 266

Merz Hans-Rudolf 235, 260

Möckli Daniel 266

Moeli J. B. 266

Moser Hans 264

Moser Peter 10, 21, 60, 261

Müller Erich 266

Müller Walter 259

Müller-Graf Peter Christian 222, 262

Münger Bernhard 33, 266

Neuhold Hans Peter (Hanspeter) 266

Notter Marcel 266 
Oberer Thomas 73, 79, 83, 119, 266

Oppenheim Roy 32, 46, 262, 263

Papadopolous Yannis 222, 266

Parzymies Stanisław 240, 266

Patterson B. 195, 259

Petitpierre Max 18, 19

Pęk Małgorzata 190, 266

Pfenniger Hanspeter 95, 263

Pietraś Marek 11

Polla Barbara 244, 259

Popławski Dariusz 10, 11, 19, 23, 28, 33, 87, 89, $129,135,240,266,267$

Poralla Sonja 261

Porębski Andrzej 68, 168, 267

Portmann Wolfgang 169, 174, 178, 180, 187, 191, 198, 268

Probst Raymond 10, 18, 24, 26, 29, 155, 267, 268

Reber Arthur Fritz 66, 267

Reding Viviane 246

Regelsberger E. 266

Renfer Irene 35, 36, 268

Renschler Walter 121

Reymond André 259

Rielle Yvan 261

Riklin Alois 10, 18, 23, 24, 26, 29, 155, 225, 267, 268

Riklin Kathy 244, 260

Rivière Florence 132, 262

Rosenau James N. 15, 267

Rotter Manfred 267

Rüegg Erwin 66, 267

Ruloff Dieter 10, 21, 60, 261

Schaffner Hans 130

Schenker Mark 25, 112, 120, 267

Schindler Dietrich 18, 155, 267

Schlange Lutz E. 266

Schneider Gerald 53, 267

Schnur Aviva 10, 21, 60, 261

Schoch Claudia 185, 267

Schulte Christian 267

Schwander Pirmin 119, 260

Schwarz Daniel 10, 26, 28, 31, 49, 59, 264

Schwarzenbach James 168, 262
Schweitzer Michael 267

Schweitzer Rainer J. 38, 265

Sciarini Pascal 53, 78, 79, 265, 267, 268

Seitz Werner 144

Senti Richard 178

Serdült Uwe 57, 264, 265

Siegwart Karine 267

Sigg Oswald 267

Spinner Bruno 137, 154, 267

Stähelin Philipp 244, 259

Stamm Hanspeter 261

Steiner Jürg 37, 47, 267

Steininger Rolf 263, 264

Steppacher B. 222

Straubhaar Thomas 21, 262

Sturny Thiemo 267

Sutor Julian 266

Telford Hamisch 37, 267

Theuerkauf Sarah 132, 262

Thürer Daniel 26, 153, 155, 156, 158, 160-162, $169,174,178,180,187,191,198,268$

Tomczyk Michał 78, 94, 268

Tomuschat Christoph 172, 262

Tornay Benedicte 35, 36, 268

Tovias Alfred 223, 268

Trachsler Daniel 18, 268

Trechsler Alexander 78, 268

Tresch Anke 185, 263

Tscharner Benedikt von 268

Vahl Marius 156, 160, 161, 163, 164, 228, 230, 245, 268

Watts Ronald L. 37, 267

Weber Reif H. 153, 155, 156, 158, 160-162, $169,174,178,180,187,191,198,268$

Weder Rolf 51, 214, 220, 262, 268

Widmer Thomas 57, 264, 265

Widmer-Schlumpf Eveline 75, 233

Wildhaber Luzius 29, 268

Wilson Hugh Robert 268

Wohlers Wolfgang 198

Wojtowicz Jerzy 268

Zäch Roger 153, 155, 156, 158, 160-162, 268

Zięba Ryszard 13, 15, 72, 240, 265, 266 